


\section{$P_{2}-M 365$}

HARVARD UNIVERSITY.

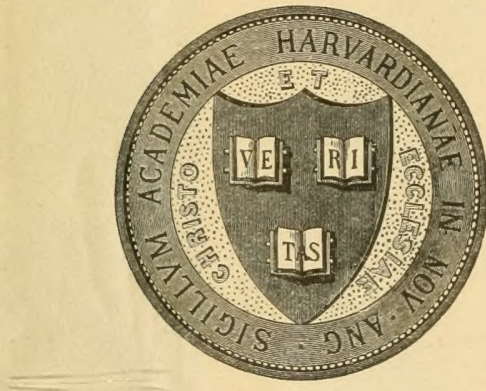

LIBRARY

OF THE

MUSEUM OF COMPARATIVE ZOÖLOGY

58,233

GIFT OF

Lonis Agasiz Shaw.

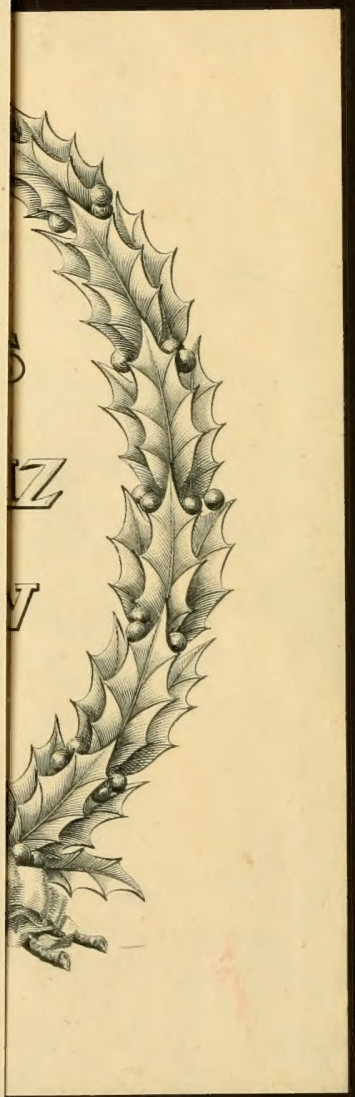
cember 17.1921. 
$w^{m}$

$=$ 
DEC $\quad 17 \quad 1921$ 



\title{
THE EARTH
}

\section{MODIFIED BY HUMAN ACTION}

\author{
A LAST REVISION OF "MAN AND NATURE"
}

BY

GEORGE P. MARSH

\begin{abstract}
"Not all the winds, and storms, and earthquakes, and seas, and seasons of the world have done so much to revolutionize the earth as MAN, the power of an endless life, has done since the day he came forth upon it, and received dominion over it."-H. BusHNeLL, Sermon on the Ponoer of an Endless Life.
\end{abstract}

\author{
NEW YORK
}

OHARLES SCRIBNER'S SONS 
Entered, according to Act of Congress, in the year 1864, by CHARLES SCRIBNER, In the Clerk's Office of the District Court of the United States for the Southern District of New York.

\section{¿UPYHIGT, 1874, BX}

SCRIBNER, ARMSTRONG \& CO.

Copyraht, 1884, BY

CHARLES SCRIBNER'S SONS. 


\section{CONTENTS.}

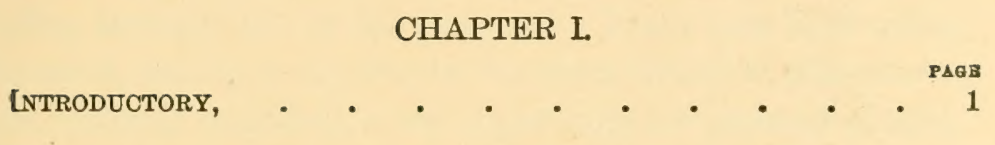

CHAPTER II.

Transfier, Modification, and Extirpation of Vegetable and

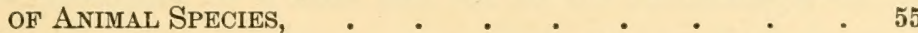

CHAPTER III.

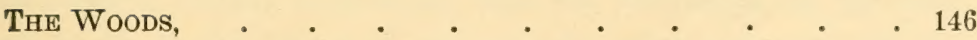

CHAPTER IV.

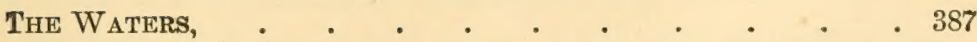

CHAPTER V.

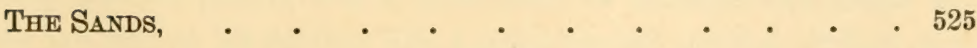

CHAPTER VI.

Great Projects of Physical Change Accomplished or ProPOSED BY MAN, • • • • • • • • • 584 



\section{PUBLISHERS' NOTE.}

Tне profound interest felt in his subject by the author of this work, induced him to devote to a careful revision of it all that portion of the last year of his life which his official duties and his failing strength left at his command. Every new book within his reach, bearing in any way on the topics treated in this volume, was faithfully consulted, every opportunity for personal observation conscientiously seized; and, although neither leisure nor bealth permitted so full a use of these works, nor so frequent recourse to the great book of Nature, as was desired, yet, whenever a new argument or a new fact led to the modification of a previously expressed opinion, such modification has been frankly made.

On the whole, however, it will be seen that the author's general conclusions remain unchanged, and his conviction of the vital importance to the future of our race of a wiser economy, on the part of the present and rising generation, in the use of Nature's gifts, was only deepened and strengthened by the study and observation of every additional year of his life.

The hope of impressing, in some degree, this conviction upon the minds of those in whose hands the practical value of his suggestions lies, was the inspiring motive of the work in its beginning, and the motive which continued to animate the writer to the last day of his earthly life, a considerable portion of that day being devoted by him to the completion of this revision. 



\section{PREFACE TO THE FIRST EDITION.}

THE object of the present volume is : to indicate the character and, approximately, the extent of the changes produced by human action in the physical conditions of the globe we inhabit; to point out the dangers of imprudence and the necessity of caution in all operations which, on a large scale, interfere with the spontaneous arrangements of the organic or the inorganic world; to suggest the possibility and the importance of the restoration of disturbed harmonies and the material improvement of waste and exhausted regions; and, incidentally, to illustrate the doctrine that man is, in both kind and degree, a power of a higher order than any of the other forms of animated life, which, like him, are nourished at the table of bounteous nature.

In the rudest stages of life man depends upon spontaneous animal and vegetable growth for food and clothing, and his consumption of such products consequently diminishes the numerical abundance of the species which serve his uses. At more advanced periods, he protects and propagates certain esculent vegetables and certain fowls and quadrupeds, and, at the same time, he wars upon rival organisms which prey upon these objects of his care or obstruct the increase of their numbers. Hence the action of man upon the organic world tends to derange its original balances, and while it reduces the numbers of some species, or even extirpates them altogether, it multiplies other forms of animal and vegetable life.

The extension of agricultural and pastoral industry involves 
an enlargement of the sphere of man's domain, by encroachment upon the forests which once covered the greater part of the earth's surface otherwise adapted to his occupation. The felling of the woods has been attended with momentous consequences to the drainage of the soil, to the external configuration of its surface, and probably also to local climate; and the importance of human life as a transforming power is, perhaps, more clearly demonstrable in the influence man has thus exerted upon superficial geography than in any other result of his material effort.

Lands won from the woods must be both drained and irrigated; river-banks and maritime coasts must be secured by means of artificial bulwarks against inundation by inland and by ocean floods; and the needs of commerce require the improvement of natural and the construction of artificial channels of navigation. Thus man is compelled to extend over the unstable waters the empire he had already founded upon the solid land.

The upheaval of the bed of seas and the movements of water and of wind expose vast deposits of sand, which occupy space required for the convenience of man, and often, by the drifting of their particles, overwhelm the fields of human industry with invasions as disastrous as the incursions of the ocean. On the other hand, on many coasts, sand-hills both protect the shores from erosion by the waves and currents, and shelter valuable grounds from blasting sea-winds. Man, therefore, must sometimes resist, sometimes promote, the formation and growth of dunes, and subject the barren and flying sands to the same obedience to his will to which he has reduced other forms of terrestrial surface.

Besides these old and comparatively familiar methods of material improvement, modern ambition aspires to yet grander achievements in the conquest of physical nature, and projects are meditated which quite eclipse the boldest enterprises hitherto undertaken for the modification of geographical surface.

The natural character of the various fields where human industry has effected revolutions so important, and where the multi- 
plying population and the impoverished resources of the globe demand new triumphs of mind over matter, suggests a corresponding division of the general subject, and I have conformed the distribution of the several topics to the chronological succession in which man must be supposed to have extended his sway over the different provinces of his material kingdom. I have, then, in the introductory chapter, stated, in a comprehensive way, the general effects and the prospective consequences of human action upon the earth's surface and the life which peoples it. This chapter is followed by four others in which $I$ have traced the history of man's industry as exerted upon Animal and Vegetable Life, upon the Woods, upon the Waters, and upon the Sands; and to these I have added a concluding chapter upon Great Projects of Physical Change accomplished or proposed by Man.

It is perhaps superfluous to add, what indeed sufficiently appears upon every page of the volume, that I address myself not to professed physicists, but to the general intelligence of observing and thinking men; and that my purpose is rather to make practical suggestions than to indulge in theoretical speculations more properly suited to a different class from that for which I write.

December 1, 1863. 



\section{PREFACE TO THE EDITION OF 1874.}

Is preparing for the press an Italian translation of this work, published at Florence in 1870, I made numerous corrections in the statement of both facts and opinions; I incorporated into the text and introduced in notes a large amount of new data and other illustrative matter; I attempted to improve the method by differently arranging many of the minor subdivisions of the chapters; and I suppressed a few passages which seemed to me superfluous.

In the present edition, which is based on the Italian translation, I have made many further corrections and changes of arrangement of the original matter; I have rewritten a considera ble portion of the work, and have made, in the text and in notes, numerous and important additions, founded partly on observa tions of my own, partly on those of other students of Physical Geography, and though my general conclusions remain substantially the same as those I first announced, yet I think I may claim to have given greater completeness and a more consequent and logical form to the whole argument.

Since the publication of the original edition, Mr. Elisee Reclus, in the second volume of his admirable work, La Terre (Paris, 1868), lately made accessible to English-reading students, has treated, in a general way, the subject I have undertaken to discuss. He has, however, occupied himself with the conservative and restorative, rather than with the destructive, effects of human industry, and he has drawn an attractive and encouraging picture 
of the ameliorating influences of the action of man, and of the compensations by which he, consciously or unconsciously, makes amends for the deterioration which he has produced in the medium he inhabits. The labors of Mr. Reclus, therefore, though aiming at a much higher and wider scope than I have had in view, are, in this particular point, a complement to my own. I earnestly recommend the work of this able writer to the attention of my readers.

RoMre, May 1, 1873.

GEORGE P. MARSH. 


\section{BIBLIOGRAPHICAL LIST}

\section{OF WORKS CONSULTED IN THE PREPARATION OF THIS VOLUME.}

About, Edmond: Le Progrès. Paris, 1864. 1 vol. 87o.

Ackerhof. Die Nutzung der Teiche und Gewässer. Quedlinburg, 1869. 1 vol. 8vo.

Allen, Captain. The Dead Sea a New Route to India. 2 vols. 12mo. London, 1855.

Amari. Storia dei Musulmani in Sicilia. Florence, 1854. 4 vols. 8vo.

American Naturalist.

Amersfoordt, J. P. Het Haarlemmermeer, Oorsprong, Geschiedenis, Droog making. Haarlem, 185\%. 8vo.

Andresen, O. O. Om Klitformationem og Klittens Behandling og Bestyrelse. Kjöbenhavn, 1861. 8vo.

Annali di Agricoltura, Industria e Commercio. Pubblicati per cura del Ministero d'Agricoltura, Industria e Commercio. Fasc $\mathrm{i}-\mathrm{\nabla}$. Torino, 1862-'3. 8 ro.

Annales Forestières. Various years.

Annales du Géni Civil, 1863.

Arago, $F$. Extracts from, in Becquerel, Des Climats.

Arriani, Opera. Lipsiæ, 1856.2 vols. $12 \mathrm{mo}$.

Asbjörnsen, P. Chr. Om Skovene og om et ordnet Skovbrug i Norge. Chris tiania, 1855. 12mo. Torv og Torvdrift, Christiania, 1868.

Ascham, Roger. Toxophilus. In complete edition. London, 1865. 3 vols. 8vo. (4 parts).

Aus der Natur. Die neuesten Entdeckungen auf dem Gebiete der Naturwissenschaften. Leipzig, various years, 20 vols. 8 vo.

Avé-Lallemant, $K$. C. B. Die Benutzung der Palmen am Amazonenstrom in der Oekonomie der Indier. Hamburg, 1861. $18 \mathrm{mo}$.

Aymard. Irrigations du Midi de l'Europe. Paris, 1864. 1 vol. 8vo.

Babinet. Etudes et Lectures sur les Sciences d'Observation. Paris, 1855-1863 7 rols. $18 \mathrm{mo}$.

Baer, von. Kaspische Studien. St. Petersburg, 1855-1859. 8vo.

Barth, Heinrich. Wanderungen durch die Kustenlïnder des Mittelmeeres. V i. Berlin, 1849. $8 \mathrm{vo}$.

Barth, J. B. Om Skovene i deres Forhold til Nationalœconomien. Christiania, 1857. 8vo.

Baude, J. J. Les Côtes de la Manche, Revue des Deux Mondes, 15 Janvier, 1859. 


\section{xiv BIBLIOGRAPHICAL LIST OF WORES CONSULTED.}

Baumgarten. Notice sur les Ririères de la Lombardie; in Annales des Ponts et Chaussées, 1817, 1er sémestre, pp. 129-199.

Bazelaire. Traité de Reboisement. Paris, 1863. 1 vol 8vo.

Biale, L. S. Disease Germs, their Supposed Nature.-Disease Germs, their

Real Nature. London, 1870.

Beckwith, Lieut. Report in Pacific Railroad Report, vol. ii.

Beoquerel. Des Climats et de l'Influence qu'exercent les Sols boisés et non. boisés. Paris, 1853 . 8vo.

— Éléments de Physique Terrestre et de MEétéorologie. Paris, 1847. 8vo. Bilgrand. De l'Intluence des Forêts sur l'écoulement des Eaux Pluviales; in Annales des Ponts et Chaussées, 1854, 1er sémestre, pp. 1, 27.

Berenger, A. de. Saggio Storico della Legislazione Veneta Forestale. Venezia, 1863. 1 vol. 4 to.

Berg, Eilmund ron. Das Verdrängen der Laubwälder im Nördlichen Deutschlande durch die Fichte und die Kiefer. Darmstadt, 1844. 8vo.

Berghaus. Geographisches Jahrbuch. Various years.

Bergsōe, A. F. Greve Ch. Ditler Frederik Reventlors Virksomhed som Kongens Embedsmand og Statens Borger. Kjöbenhavn, 1837. 2 vols. 8 vo.

Berlepsch, $H$. Die Alpen in Tatur-und Lebensbildern. Leipzig, 1862. 8vo. Bianchi, Celestino. Compendio di Geografia Fisica Speciale d'Italia. Ap. pendice alla traduzione Italiana della Georg.-Fisica di Maria Somerville. Firenze, 1861. (2d vol. of translation.)

Bigelore, John. Les États Unis d'Amérique en 1863. Paris, 1863. 8vo. Blake, Wm. P. Reports in Pacific Railroad Report, vols. ii. and $\nabla$.

Blanqui. Mémoire sur les Populations des Hautes Alpes; in MIémoires de l'Académie des Sciences Morales et Politiques, 1843.

- Voyage en Bulgarie. Paris, 1843. $12 \mathrm{mo.}$

— Précis Élementaire d'Économie Politique, suivi du Résumé de l'Histoire du Commerce et de l'Industrie. Paris, 185\%. $12 \mathrm{mo}$.

Blomquist. Catalogue Special d'Objets Forestiers. 1882.

Boccardo, Gerolomo. Dizionario dell' Economia Politica. Torino, 1863. 8 vols.

Boitel, Amédée. Mise en valeur des Terres paurres par le Pin Maritime. 2d edition. Paris, 1857. 870.

Bollettino Consolare, 1862.

Bolletino della Soc. Geog. Ital.

Bonnemìre, Eugène. Histoire des Paysans depuis la fin du Moyen Age jusqu’à nos jours. Paris, 1856. 2 vols. 8 ro.

Böttger, C. Das Mittelmeer. Leipzig, 1859.

Boussingault, J. B. Economie Rurale considerée dans ses Rapports avec la Chimie, la Physique, et la ILétéorologie. 2d edition. Paris, 1851. a vols. 8vo.

Brandis, Dr. On the Distribution of Forests in India, 1872.

Brémontier, N. T. Mémoire sur les Dunes; in Annales des Ponts et Chaus. sées, 1833, 1er sémestre, pp. 145, 223.

Brincken, J. von den. Ansichten über die Bewaldung der Steppen des Euro pæischen Russland. Braunschweig, 1854. 4to. 
Browne. Trees of America. New York, 1857. 1 vol. small 4to. Illustrated. Burnes. Journal in Bokhara. 2 vols.

Bryant. Forest Trees. 1871.

Büttner, J. G. Zur Physikalischen Geographie; in Berghaus, Geographisches Jahrbuch, No. iv., 1852, pp. 9-19.

Caimi, Pietro. Cenni sulla Importanza e Coltura dei Boschi. Milano, 1857. 8vo. Cuntegril, and others. Extracts in Comptes Rendus à l'Académie des Sciences. Paris, 1861.

Curtier. .rref Récit., etc., reprint from ed. 1545. Paris, 1863.

Castellani. Dell' immediata influenza delle Selve sul corso delle acque. Torino, 1818, 1819. 2 vols. 4 to.

Census of the United States for 1860. Preliminary Report on. Washington, 1862. 8vo.

Census of the United States for 1870 .

- Preliminary Reports on, for 1880-1882.

Cerini, Giuseppe. Dell' Impianto e Conservazione dei Boschi. Milano, 1844. 8 vo.

Cezanne. Additional volume to Surell's Etude sur les Torrents des Hautes Alpes. Paris, 1872.

Ohampion, Maurice. Les Inondations en France depuis le VIme Siècle jusqu'd nos jours. Paris, 1858, 1862. Vols. i.-iv. 8vo.

Ohateauvieux, F. Lullin de. Lettres sur l'Italie. Seconde edition. Genève, 1834. 8vo.

Ohevandier. Extracts in Comptes Rendus à l'Académie des Sciences. JuilletDecembre, 1844. Paris.

Cicero. De Officiis. Epist. ad Diversos Opera. Ex ed. Oliveti et Ernesti, Recensit Johanes Carey London, 1820. 12 vols. $12 \mathrm{mo.}$

Clavé, Jules. Etudes sur l'Économie Forestière. Paris, 1862. 12mo.

- La Forêt de Fontainebleau; Revue des Deux Mondes, 1 Mai, 1863.

Cleghorn. Memoir on the Timber procured from the Indus, etc. Madras, 1867.

- Forests and Gardens of South India. London, 1861. 1 vol. $12 \mathrm{mo.}$ Illustrated.

Clot, Bey. Aperçu sur l'Egypt. Bruxelles, 1840. 2 vols. 8ro.

Ooaz. Die Hochwasser in 1868 im Bundnerischen Rheingebiet.

Cooper, J. G. The Forests and Trees of Northern America; in Report of the Commissioners of Patents for the year 1860, pp. 416, 445.

Cotta, Bernhard. Deutschlands Boden. Leipzig, 1858. 2 vols. 8vo.

- Vorwort zu Paramelle's Quellenkunde. See Paramelle.

Die Alpen. Leipzig, 1851. 8vo.

Coultas, Harland. What may be Learned from \& Tree. New York, 1860. 8 vo.

Courier, Paul-Louis. CEuvres Completes. Bruxelles, $1833 . \quad 8$ ro.

Courval, Vicomte de. Taille et Conduite des Arbres Forestieres, etc. Paria, 1864. 1 vol. 8vo.

Dana, James D. Manual of Geology. Philadelphia, 1863. 8ro.

Daroin, Charles. Origin of Species. etc. N. Y., 1860. 1 vol. $12 \mathrm{mo.}$

- Earth Worms. 1881. 
Daubeney. Trees and Shrubs of the Ancients. Oxford and London, 1865. 1 vol. 8vo.

Delamarre, $L$. G. Historique de la Création d'une Richesse Millionaire par la culture des Pins. Paris, 1827. 8vo.

$D^{\prime} H e ́ r i c o u r t, A$. $F$. Les Inondations et le livre de M. Vallès; Annales Forestières, December, $185 \%$, pp. 310,321 . Paris.

Della Marmora, Alfonsa. Voyage en Sardaigne. Torino, 1865.

Del Noce. Trattato delle Macchie e Foreste di Toscana. Firenze, 1857.

Delpino. Pensieri sulla Biologia Vegetale, utc. Ulteriori Osservazioni, etc., in parts. Milan, 1868-9.

Des Cars, Comte A. L'Élagage des Arbres. Paris, 1872. 1 vol. 8vo.

Desor. Sahara und Atlas, 1865. La Forêt Vierge et le Sahara. 1879.

Diggelen, B. P. G. van. Groote Werken in Nederland. Zwolle, 1855. 8vo.

Diodorus Siculus. Bibliotheca Historica, ed. Weisseling, Heyne, etc. 1793. 11 vols. 8vo.

Dorotea. Sommario storico dell' Alieutica.

Dugdale. History of Embankment and Drainage. 2d ed. 1772.

Dumas, M. J. La Science des Fontaines. 2me édition, Paris, 1857. $8 \mathrm{vo.}$

Dumont, Aristide. Des Travaux Publics dans leurs Rapports avec l'Agriculture. Paris, 1847. 8vo.

Duponchel. Traité d'Fydraulique et de Géologie Agricoles. Paris, 1868. 1 vol. 8vo.

Doight, Timothy. Travels in New England and New York. New Haven, 1821. 4 vols. 8 vo.

Ebbermayer. Die Physikalische Einwirkungen des Waldes. Aschaffenburg, 1873. 1 vol. 8vo.

Einerson, George B. A Report on the Trees and Shrubs growing naturally in Massachusetts. Boston, 1850. 8 ro.

Emory, Wm. H., Col. Report of Commissioners of the United States and Mexican Boundary Survey, vol. i., 1857.

Escourrou-Mitiago, A. L'Italie à propos de l'Exposition Universelle de Paris. Paris, 1856. 8vo.

Evelyn, John. Silva; or, a Discourse of Forest Trees. With Notes by A. Hunter. York, 1786. 2 vols. 4to.

Terra, a Philosophical Discourse of Earth. York, 1786. 4to, in vol. ii. of Silva.

Fazio degli Uberti. Dittamondo. Ed. Milano, 1827. 1 vol. small $8 \mathrm{vo.}$

Féraud-Giraud, L. J. $D$. Police des Bois, Défrichements et Reboisements Commentaire pratique sur les lois promulguées en 1859 et 1860 . Paris, 1861. 8vo.

Fierrara, Francesco. Descrizione dell' Etna. Palermo, 1818. 8vo.

Feuillide, $O$, de. L'Algérie Française. Paris, 1856. 8vo.

Frgari Bey. Studi Scientifici sull' Egitto. Lucca, 1864. 2 vols. 8ro.

Figuier, Louis. L'Année Scientifique et Industrielle. Paris, 1862-'3, 1879. $12 \mathrm{mo}$.

Finnboga Saga hins rama. Kaupmannatöfn, 1812. 4to.

Foissac, $P$. Meteorologie mit Rücksicht auf die Lehre vom Kosmos, Deutsch von A. H. Emsmann. Leipzig, 1859. 8vo. 
Forchiammer, G. Geognostische Studien am Meeres-Ufer ; in Leonhard und Bronn's Neues Jahrbuch für Mineralogie, Geognosie, Geologrie, etc. Jahrgang, 1841, pp 1-38.

Fossombroni, Fittorio. Memorie Idraulico-Storiche sopra la Val-di-Chiani. Montepulciano, 3za edizione, 1835. 8vo.

Fraas, C. Klima und Pflanzenwelt in der Zeit. Laudshut, 184\%. 8vo.

Frescobaldi. Viaggio in Terra Santa in 1470.

Frisi, Prolo. Del Modo di regolare i Fiumi e i Torrenti. Lucca, 1762. 4 to.

Friis. Lappisk Mythologi. Christiania, 1871. 1 vol. $16 \mathrm{mo.}$

Fuller, Thomas. The History of the Worthies of England. London, 1662. Folio.

Gallenga, Antonio. Country Life in Piedmont. London, 1858. 1 vol. 8vo.

Gilliss, J. M., Cupt. United States Naval Astronomical Expedition to the Southern Hemisphere. Washington, 1855. 2 vols. 4to.

Giorgini. Paper by ; in Salvagrnoli-Marchetti, Rapporto sul Bonificamento delle Maremme, App. v.

Girarl et Parent-Duchatelet. Rapport sur les Puits forés dits Artésiens; Annales des Ponts et Chaussées, 1833, 2me sémestre, 313-344.

Graham, J. D., Lieut.-Col. A Lunar Tidal Wave in the North American Lakes demonstrated. Cambridge, 1861. 8vo pamphlet. Also in vol. xiv. Proc. Am. Ass. for Adv. of Science for 1860.

Gray, Asa. First Lessons in Botany, etc. How Plants Grow.

Grigor. Arboriculture; or, a Practical Treatise, etc. Edinburgh, 1868.1 vol. 8 vo.

Guyot. Physical Geography. London, 1873. 1 vol. 4to.

Guerzoni, G. Ceuni Storici sulle condizioni Fissco-economiche dell' Agro Romano.

Hakluyt, Richard. The Principal Navigations, Voyages, etc., of the English Nation. London, 1598-'9. 3 vols. folio.

Harrison, W. An Historicall Description of the Iland of Britaine ; in Holins. hed's Chronicles. Reprint of 1807 , vol. $i$.

Harrisse, H. Fernand Colomb. Sa Vie et ses Euvres. Paris, 1873.

Hartig. Ueber den Wachsthumsgang und Ertrag der Buche, Eiche und Kiefer, 1869.

Hartwig, G. Das Leben des Meeres. Frankfurt, 1857. 8vo.

- Die Gehölzzucht. Berlin, 1876. 1 vol. 8vo. Illustrated.

Haxthausen, August von Transkaukasia. Leipzig, 1856. 2 vols. 8vo.

Hay, Drummond. Morocco.

Hayden. Preliminary Report on Survey of Wyoming.

Hehn. Kultur Pflanzen und Thiere in ihrem Uebergang aus Asien. Berlin, 1874. 1 vol. $8 \mathrm{vo}$.

Henry, Prof. Joseph. Paper on Meteorology in its connection with Agricul ture; in United States Patent Office Report for 1857. pp. 419-550.

Herodotus ex adit. Jac. Gron., etc. Glasgow, 1761. 9 vols. 8 vo.

Hertz, Henrik. Kong René's Datter. Kiobenhavn, 1874. 1 vol. $12 \mathrm{mo.}$

Homes, H. A. Paper on Water Supply of Constantinople. Albany, 1872.

Hull. Oorsprong der Hollandische Duinen. 


\section{XViii BIBLIOGRAPHICAL LIST OF WORKS CONSULTED.}

Humboldt, Alexander von. Ansichten der Natur, Dritte Ausgabe, Stuttgar und Tübingen, 1849. 2 vols. $12 \mathrm{mo}$.

Hummel, Karl. Physische Geographie. Graz, 1855. 8vo.

Humphreys and Abbott. The Mississippi.

Hunter, A. Notes to Evelyn, Silva, and Terra. York, 1786. See Evelyn.

Italia, L' Sotto l'Aspetto Fisico, etc. Very extensive series, extending to 1882.

Jacini, Stefano. La Proprietì Fondiaria e le Popolazioni agricole in Lombardia. Milano e Verona, 185\%. 8vo.

Johnstmp. On Fugtighedens Bevœgelse i den naturligi Jordbund. Kjöbenhavn, 1866.

Joincille. Histoire de Saint-Louis. Nouvelle Collection des Mémoires pour servir à l'Histoire de France, par Michaud et Poujoulat. Tome i. Paris, 1836. 8vo.

Josselyn, John. New England Rarities. London, 1672. $12 \mathrm{mo.}$

Knorr, E. A. Studien über die Buchen-Wirthschaft. Nordhausen, 1863. 8vo.

Koderle. Grundsütze der Künstlichen Düngung im Forstculturwesen. Wien, 1865. 1 vol. 8vo. Wood-cuts.

Kohl, J. G. Alpenreisen. Dresden und Leipzig, 1849. 3 vols. 8vo.

Die Marschen und Inseln der Herzogthümer Schleswig und Holstein. Dresden und Leipzig, 1846. 3 vols. 8vo.

Kramer, Gustav. Der Fuciner-See. Berlin, 1839. 4to.

Krause, G. C. A. Der Dünenbau auf den Ostsee-Küsten West-Preussens. 1850. 8vo.

Krecke: Het Klimat van Nederland. Haarlem, 1861. 1 vol. 8vo.

Kromer, Alfred von. Egypten, Forschungen über Land und Volk. Leipzig, 1863. 2 vols. 8 vo.

Kriegk, G. L. Schriften zur allgemeinen Erdkunde. Leipzig, 1840. 8vo.

Ladoncette J. C. F. Histoire, Topographie, Antiquités, Usages, Dialectes des Hautes Alpes. Seconde édition, 1834. 1 vol. 8vo, and Atlas.

Lastadius, Lars Levi. Om Möjligheten och Fördelen af allmänna Uppodlingar i Lappmarken. Stockholm, 1824. $12 \mathrm{mo}$.

Lastadius, Petrus. Journal för första året af hans Tjenstģöring såsom Missionaire i Lappmarken. Stockholm, 1831. 8vo.

- Fortsïttning af Journalen öf ver Missions-Resor i Lappmarken. Stockholm, 1833. 8vo.

Lambert. Eucalyptus Culture. Paris, 1873.

Lampridius. Vita Elagabali in Script. Hist., August.

Landgrebe, Georg. Naturgeschichte der Vulcane. Gotha, 1855. 2 vols. 8vo. Lendonnüre. Histoire Notable de la Floride. Reprint, Paris, 1853.

Laura. Secondo, Le Risaije. Torino, 1869. 1 vol. 8vo.

Laurent, Ch. Mémoires sur le Sahara Oriental au point de vue des Puits Artésiens. Paris, 1859. 8vo pamphlet. Also, in Mém. de la Soc. des Ingénieurs Civils, and the Bulletin de la Soc. Géologique de France.

Laval. MIémoire sur les Dunes du Golfe de Gascogne; in Annales des Ponts et Chaussées, 1847, 2me sémestre, pp. 218-268.

Lavaleye. Affaissement du Sol et envasement des Fleuves. 
Lavergne, M. L. de. Économie Rurale de la France, depuis 1789. 2me édition, Paris, 1861. $12 \mathrm{mo}$.

Le Alpi che cingono l'Italia. Parte 1er, vol. 1er. Torino, 1845. 8 vo.

Lefort. Notice sur les travaux de Fixation des Dunes; in Annales des Ponts et Chaussées, 1831, 2me sémestre, pp. 320-332.

Lenormant. Note relative ì l'Execution d'un Puits Artésien en Egypte sous la XVIIIme Dynastie; Académie des Inscriptions et Belles-Lettres, 12 Novembre, 185 .

Leonhard und Bronn. Jahrbuch. Various years.

Liber Llbus: The White Book of the City of London. London, 1861. 4to. Liebig. Modern Agriculture.

Licingstone, Dr. Dacid. Missionary Travels and Researches in South Africa. 1857.

Loftus, W. $K$. Travels and Researches in Chaldæa and Susiana. New York, 1857. 8 vo.

Lombardini. Cenni Idrografi sulla Lombardia ; Intorno al Sistema Idraulico del Pô; epitomized by Baumgarten in Annales des Ponts et Chaussées. 1847, 1er sémestre, pp. 129, 199 ; and in Dumont, Des Travaux Publies, pp. 268, 335 .

- Sui progetti intesi ad estendere l'irrigazione della Pianura del Pô. Politecnico. Gennajo, 1863, pp. 5-50.

Lorentz. Cours Élémentaire de Culture des Bois, complété et publié par A. Parade. 4me édition. Paris et Nancy, 1860. 8vo. Latest edition, 1878.

Lyell, Sir Charles. The Geological Evidence of the Antiquity of Man. London, 1863. 8vo. Principles of Geology. New York, 1862. 8vo.

Mangon, Hervé. Sur l'Emploi des Eaux dans les Irrigations. Paris, 1869.

Mantegazza. Rio de la Plata e Teneriffa. Milano, 1867. 1 vol. 8ro.

Manteuffel. L'Art de Planter. Translation by Stumper. 1868.

Mardigny, M. de. Mémoire sur les Inondations des Rivières de l'Ardèche. Paris, 1860. 8vo.

Marschand, A. Ueber die Entwaldung der Gebirge. Bern, 18t9. 12mo pamphlet.

Martineau. Endeavors after the Christian Life. Boston, 1858.

Martins. Revue des Deux Mondes, Avril, 1863.

Maury, L. F. Alfred. Histoire des grandes Forêts de la Gaule et de l'Ancienne France. Paris, 1867. 1 vol. 8vo.

Maury, M. F. The Physical Geography of the Sea. Tenth edition. London, 1861. 8ro.

Medlicatt, Dr. Observations of, quoted from London Athenæum, 1863.

Meguscher, Francesco. Memorie sulla migliore maniera per rimettere i Boschi della Lombardia, etc. Milano, 1859. 8vo.

Kejdell, Th. Om Foranstaltninger til Behandling af Norges Skove. Christiania, 1858. 8vo.

Mella. Delle Inondazioni del Mella nella notte del 14 al 15 Agosto, 1850. Brescia, 1851. 8vo.

ATenagiana. Ed. 1715. 4 vols. $12 \mathrm{mo.}$

Mengotti. Comptes rendus de l'Académie des Science, 1866.

Merk. Waarenlexikon, 1870. 


\section{$\mathrm{XX}$

Messedaglia. Annalisi dell' opera di Champion.

Meyer, J. Physik der Schweiz. Leipzig, 1854. 8vo.

Michelet, J. L'Insecte, 4me edition. Paris, 1860. $12 \mathrm{mo}$.

L'Oiseau, 7me edition. Paris, 1861. $12 \mathrm{mo.}$

Milton and Cheadle. North-West Passage by Land. London, 1865. 1 vol. 8 ro.

Moncrieff, Scott. Irrigation in Southern Europe. With maps, diagrams, and Appendix. London, 1868. 1 vol. 8vo.

Monestier-Savignat, $A$. Étude sur les Phénomènes, l'Aménagement et la Législation des Eaux au point de vue des Inondations. Paris, 1858. 8vo.

Montluisant. Note sur les Desséchements, les Endiguements et les Irrigations ; in Annales des Ponts et Chaussées, 1833, 2me sémestre, pp. 281-294.

Moreau de Jonnès. État Économique et Social de la France. Paris, 1870. 1 vol. 8vo.

Morell. Scientific Guide to Switzerland.

Morgan, L. H. The American Beaver and his Works. Phila., 1868.

Morozzi, Ferdinando. Dello Stato Antico e MLderno del Fiume Arno. Firenze, 1762. 4to.

Mossman. Origin of the Seasons. Edinburgh, 1869. 1 vol. 8vo. With maps and diagrams.

Mouchot. La Chaleur solaire et ses applications industrielles. Paris, 1869. 1 vol. 8vo. Illustrated.

Nangis, Guillaume de. Extracts from, in Nouvelle Collection des Mémoires pour servir par Michaud et Poujoulat. Vol. i. Paris, 1836.

Nanquette, Henri. Cours d'Aménagement des Forêts. Paris et Nancy, 1860. 8vo.

Naumann. Geognosie.

Nature, - to 1882 .

Negri. Idea su una Legge in Materia de Acqua.

Newberry, Dr. Report in Pacific Railroad Report, vol. vi.

Niebelunge-Lied, Der. Abdruck der Handschrift von Joseph von Lassberg. Leipzig, 1840. Folio.

Niel. L'Agriculture des Etats Sardes. Turin, 1857. 8vo.

Nutzhorn. Skov og Land, Kjöbenhavn, 1873.

Olmated. A Journey in the Seaboard Slave States, 1863. Our Slave States. 3 vols. 8vo.

Orosius. King Arthur's translation.

Pacific Railroad Report. Reports of Explorations and Surveys for a Railroad

Route to the Pacific. Washington, various years. 12 vols. 4 to.

Paifer. Ein Wunderbarer Traum die Fruchtbarkeit durch willkürlichen Regen zu befördern. Metz, 1814.

Palissy, Bernard. CEuvres Completes, avec des Notes, etc., par Paul-Antoine Cap. Paris, 1844. $12 \mathrm{mo.}$

Pantaleone, Dr. D. Important Article in Lo Sperimentale. 1870.

Parade, A. See Lorentz.

Paramelle, Abbé. Quellenkunde, Lehre von der Bildung und Auffindung det

Quellen ; mit einem Vorwort von B. Cotta. Leipzig, 1856. $12 \mathrm{mo.}$

Pareto, Raffaele. Relazione, etc., etc., della Campagna di Roma. 
Parish, Dr. Life of Dr. Eleazer Wheelock. 8vo.

Parliamentary Reports.

Parry, O. O. Report in United States and Mexican Boundary Survey, vol. i. Parthey, G. Wanderungen durch Sicilien und die Levante. Berlin, 1834 a vols. $12 \mathrm{mo}$.

Paston. L'Aménagement des Forêts, 1867.

Peretti. Le Serate del Villaggio.

Petermann. Mittheilungen, to 1882.

Pettenkofer. Articles in Süd-Deutsche Presse, 1809.

Phipson. Utilization of Minute Life. London, 1864. 1 vol. 8vo.

Pigorini. Articles in the Nuova Antologia.

Piper, R. U. The Trees of America. Boston, 1858, Nos. i.-iv. 4to.

Pitre. Usi Popolari Siciliani. Palermo, 1871-1880.

Plinii, Historia Naturalis, ed. Hardouin. Paris, 1723. 3 vols. folio.

Politecnico, various years, to 1882.

Ponz, Antonio. Viage de España. Madrid, 1788, etc. 18 vols. $12 \mathrm{mo.}$

Powers. War and the Weather; or, the Artificial Production of Rain. Chicago, 1871.

Prayer-Frowd. Six Months in California.

Preyer. Der Kampf um das Dasein. Leipzig, 1870. Pam.

Quarterly Journal of Science. Various years.

Quatrefages, $A$. de. Souvenirs d'un Naturaliste. Paris, 1854. 2 vols. $12 \mathrm{mo}$.

L'Espèce humaine, 2d ed. Paris, 1877. 1 vol. 8vo.

Raymond. Mineral Statistics West of the Rocky Mountains. 1870.

Reclus, Élisée. Le Littoral de la France; Revue des Deux Mondes, 15 Decembre, 1862.

Rentzsch, Hermann. Der Wald im Haushalt der Natur und der Volkswirthschaft. Leipzig, 1862. 8vo.

Reports of Agricultural Societies of different Countries for various years.

Reports of Dep. Ag. for various years.

Reports on Forest Conservancy. London. 4 vols. folio, from 1862 to "r1.

Revue des Deux Mondes, for various years.

Revue des Eaux et des Forêts.

Ribbe, Charles de. La Provence au point de vue des Bois, des Torrents et des Inondations. Paris, 1857. 8vo.

Ridolfi, Cosimo. Lezioni Orali. Firenze, 1862. 2 vols. 8vo.

Risler. Articles in Archives des Sciences.

(Bibliothèque Universelle de Genève), 1869, '70, '71.

Ritter, Carl. Einleitung zur allgemeinen vergleichenden Geographie. Berlin, 1852. 8vo.

Die Erdkunde im Verhültniss zur Natur und zur Geschichte des Menschen. Berlin, various years. 19 vols. 8vo.

Rivista Forestale del Regno d'Italia. Various years.

Robinson, Dr. Biblical Researches. 3 vols. 1856.

Rosa, G. Le Condizioni de' boschi, de' fiumi e de' torrenti nella provincia di Bergamo. Politecnico, Dicembre, 1861, pp. 606, 621.

- Studii sui Boschi. Politecnico, Maggio, 1862, pp. 232, 238.

Rossmïssler, C. A. Der Wald. Leipzig und Heidelberg, 1863. 8vo. 


\section{xxii BIBLIOGRAPHICAL LIST OF WORKS CONSULTED.}

Roth, J. Der Vesur und die Umgebung von Neapel. Berlin, 185\%. 8vo.

Rotrou, Léon de. Prosciugamento del Lago Fucino, 1871.

Rozet, II. Mroyens de forcer les Torrents des Montagnes de rendre une partio du sol qu'ils ravagent. Paris, 1856. 8vo pamphlet.

Salvagnoti-Yrarchetti, Antonio. Memorie Economico-Statistiche sulle MIaremme Toscane. Firenze, 1846. 8vo.

- Raccolta di Documenti sul Bonificamento delle Maremme Toscane. Firenze, 1861. 8vo.

- _ Rapporto sul Bonificamento delle Maremme Toscane. Firenze, 1859. 8 ro.

- Rapporto sulle Operazioni Idrauliche ed Economiche eseguite nel 1859-60 nelle Maremme Toscane. Firenze, 1860. 8vo.

Samanos. Traité de la Culture du Pin Maritime.

Sand, George. Un Hiver au Midi de l'Europe. Bruxelles, 1841. 2 vols. $16 \mathrm{mo}$.

Sandys, George. A Relation of a Journey begun An. Dom. 1610. London, 1627. Folio.

Schacht, H. Les Arbres, Études sur leur Structure et leur Végétation, traduit par E. Morren. Bruxelles et Leipzig, 1862. 8vo.

Schleiden, M. J. Die Landenge von Suês. Leipzig, 1858. 8 vo.

- Die Pflanze und ihr Leben. Leipzig, 1848. 8vo.

Schomann. Geologische Wanderung durch die Preussichen Ost-See Provinzen. Berlin, 1869.

Schroeder (van der Kolk). Het Verschil tusschen den Psychischen Aanleg van het Dier en van den Mensch. Ziel en Ligchaam, etc. Utrecht, 1864. 2 vols. 8vo.

Schübeler. Die Pflanzenwelt Norwegens. Christiania, 1870.

Schubert, W. von. Resa genom Sverige, Norrige, Lappland, etc. Stockholm, 1823. 3 vols. 8 vo.

Scrope. Volcanoes. French Translation. Paris, 1864. 1 vol. small 8vo.

Selmi. Il Miasma Palustre. Padua, 1870.

Seneca, L. A. Opera Omnia quæ supersunt, ex rec. Ruhkopf. Aug. Taurinorum, 1831. 6 vols. 8 vo.

Siemoni. Manuale dell' Arte Forestale. Milano, 1872. 1 vol. 8vo.

Simonde, J. E. L. Tableau de l'Agriculture Toscane. Genève, 1801. 8vo.

Smith, Baird. Italian Irrigation. Edinburgh and London, 1855. 2 vols. 8vo.

Smith, John. Historie of Virginia. London, 1624. Folio.

Simith, Dr. William. A Dictionary of the Bible. London, 1860. 3 vols. 8vo.

- A Dictionary of Greek and Roman Geography. London, 1854, 1857 2 vols. 8 vo.

Somerville, Mary. Physical Geography. Fifth edition. London, 1862. 12mo

Smithsonian Reports, Monographs, etc., to 1882.

Sonklar. Die Oetzthaler Gebirgsgruppe. Gotha, 1861. 1 vol. folio.

Spenser. Faëry Queene.

Spon. Dictionary of Engineering.

Springer, John S. Forest-Life and Forest-Trees. New York, 1851. 12mo. 
Btanley, Dr. Lectures on the History of the Jewish Church. London, 1863 $8 \mathrm{vo}$.

Staring, W. $H$. De Bodem van Nederland. Haarlem, 1850. 2 vols. 8vo.

- Voormaals en Thans. Haarlem, 1858. 8vo.

Stevens, Gov. Report in Pacific Railroad Report, vol. xii.

Stoppani. Corso di Geologia. Milan, 1871-5. 3 vols. 8vo.

Strabo. Ed. Casaubon.

Strcin, Lieut. I. C. Darien Exploring Expedition, by J. T. Headley, in Harper's Magazine. New York, March, April, and May, 1855.

Streffleur, V. Ueber die Natur und die Wirkungen der Wildbäche. Sitz. Ber. der MI. N. W. Classe der Kaiserl. Akad. der Wis. February, 1852, viii., p. 248.

Ström, Is.’. Om Skogarnas Värd och Skötsel. Upsala, 1853. Pamphlet.

Surell, Alexandre. Étude sur les Torrents des Hautes Alpes. Paris, 1844. 4to.

Tagliasecchi. Notizie, etc., dei Canali dell' Alta Lombardia. 1871.

Tartini, Ferdinando. Memorie sul Bonificamento delle Maremme Toscane. Firenze, 1838. Folio.

Tennant, Sir Emerson. Natural History of Ceylon, etc. London, 1861. 1 vol. 8vo.

Thomas and Baldroin. Gazetteer. Philadelphia, 1855. 1 vol. 8ro.

Thomassy. Essaie sur l'Hydrologie.

Thompson, Z. History of Vermont, Natural, Civil, and Statistical. Burlington,. 1842 . 8 vo.

- Appendix to History of Vermont. Burlington, 1853. 8vo.

Thoreau. Excursions. The Maine Woods. Boston, 1863-64.

Titcomb, Timothy. Lessons in Life. New York, 1861. 12mo.

Torrelli. Progetto di legge ecc.

Treadioell, $D r$. Observations of, quoted from Report of Commissioner of Patents.

Troy, Paul. Étude sur le Reboisement des Montagnes. Paris et Toulouse, 1861. 8vo pamphlet.

Tschudi, Friedrich von. Ueber die Landwirthschaftliche Bedeutung der Vögel. St. Gallen, 1854. $12 \mathrm{mo.}$

Tschudi, J. J. von. Travels in Peru. New York, 1848. 8ro.

Tyndall, John. Fragments of Science. 3d edition. 1871.

Ure's Dictionary of Arts, MIanufactures, and Mines. London, 186\%. 3 vols. 8 vo.

Valles, M. $F$. Etudes sur les Inondations, leurs causes et leurs effets. Paris, 1857. 8vo.

Valcasor, Johann Weichard. Die Ehre des Herzogthums Crain. Laybach, 1689. 4 vols. folio.

Van Lennep. Extracts from Journal of, in the MIissionary Herald.

Tansleb. Nouvelle Relation, su forme de Journal, d'un Voyage fait in Egypte en 1672, 1673. Paris, 167\%. 1 vol. small 4 to.

Vaupell, Chr. Bögens Indvandring i de Danske Skove. Kjöbenhavn, 1857 8 ro.

— Da Nordsjællandske Skovmoser. Kjöbenhavn, 1851. 4to pamphlet. 


\section{XXiv BIBLIOGRAPHICAL LIST OF WORKS CONSULTED.}

Tenema, G. A. Over het Dalen van de Noordelijke Kuststreken van ons Land. Groningen, 1854. 8vo.

Tibraye. Com, to French Academy.

Vigan. Études sur les Irrigation des Pyrénées Orientales. Paris, 1867. 1 vol. 8vo.

Filla, Antonio Giovanni Batt. Necessità dei Boschi nella Lombardia. Milano, 1850. 4to.

Villani, Giovanni. Cronica. Ed. Magheri. Florence, 1823. 8 vols. 8 vo.

Viollet, J. B. Théorie des Puits Artésiens. Paris, 1840. 8vo.

Viollet le Duc. Le Massif du Mont Blanc. Paris, 1876. 1 vol. 8vo.

Vogt, Carl. Nützliche und Schädliche Thiere. Leipzig, 1864. 1 vol. 8vo. Illustrated.

Walker, Capt. Campbell. Reports on Forest Management. London, 1873.

Waltershausen, W. Sartorius von. Ueber den Sicilianischen Ackerbau. Göttingen, 1863.

Webster, Noah. A Collection of Papers on Political, Literary, and Moral Subjects. New York, 1843. 8vo.

Wessely, Joseph. Die Oesterreichischen Alpenländer und ihre Forste. Wien, 1853. 2 vols. 8vo. Das Karstgebiet, etc. 1 vol. 8vo. 1876.

Wetzstein, J. G. Reisebericht über Hauran und die Trachonen. Berlin, 1860. 8 vo.

Wild, Albert. Die Niederlande. Leipzig, 1862. 2 vols. 8vo.

Wilhelm, Gustav. Der Boden und das Wasser. Wien, 1861. 8vo.

Wilkinson. Hand-Book for Travellers in Egypt.

Williams, Dr. History of Vermont. 2 vols. 8vo.

Winkler. Zand en Duinen. Dockum, 1865. 1 vol. 8vo.

Wittioer, W. C. Die Physikalische Geographie. Leipzig, 1855. $8 \mathrm{vo.}$

Wulfsberg. Norges Verstandskilder.

Young, Arthur. Voyages en France, pendant les années 1787, 1788, 1789, précédée d'une introduction par Lavergne. Paris, 1860. 2 vols. $12 \mathrm{mo.}$

- Voyages en Italie et en Espagne, pendant les années 1787, 1789. Paris, 1860. 1 vol. $12 \mathrm{mo}$.

Yule, Col. H. Mission to the Court of Ava. London, 1857. 1 vol. folio. Illustrated. 


\title{
THE EARTH
}

\section{AS MODIFIED BY HUMAN ACTION.}

\section{CHAPTER I.}

\author{
INTRODUCTORY.
}

Natural Advantages of the Territory of the Roman Empire.-Physical Decay of that Territory.-Causes of the Decay.-Reaction of Man on Nature.Observation of Nature.-Uncertainty of Our Historical Knowledge of Ancient Climates.-Uucertainty of MIodern Meteorology.- Stability of Nature.-Formation of Bogs.-Natural Conditions Favorable to Geographical Change.-Destructiveness of Man.-Human and Brute Action Compared.-Limits of Human Power.-Importance of Physical Conservation and Restoration.-Uncertainty as to Effects of Human Action.

\section{Natural Advantages of the Territory of the Roman Empire.}

THE Roman Empire, at the period of its greatest expansion, comprised the regions of the earth most distinguished by a happy combination of physical conditions. The provinces bordering on the principal and the secondary basins of the Mediterranean enjoyed, in healthfulness and equability of climate, in fertility of soil, in variety of vegetable and mineral products, and in natural facilities for the transportation and distribution of exchangeable commodities, advantages which have not been possessed in an equal degree by any territory of like extent in the Old World or the New. The abundance of the land and of the waters adequately supplied every material want, ministered liberally to every sensuous enjoyment. Gold and silver, indeed, were not found in the profusion which has proved so baneful to the industry of lands richer in veins of the precious metals; but mines and river beds yielded them in the spare measure most favorable to stability of value in the medium of exchange, and, consequently, to the regularity of commercial transactions. The ornaments of the barbaric 
pride of the East, the pearl, the ruby, the sapplire, and the dia* mond-though not unknown to the luxury of a people whose conquests and whose wealth commanded whatever the habitable world could contribute to augment the material splendor of their social life-were scarcely native to the territory of the empire; but the comparative rarity of these gems in Europe at somewhat earlier periods, was, perhaps, the very circumstance that led the cunning artists of classic antiquity to enrich softer stones with engraving's that invest the common onyx and cornelian with a worth surpassing, in cultivated eyes, the lustre of the most brilliant oriental jewels.

Of these manifold blessings the temperature of the air, the distribution of the rains, the relative disposition of land and water, the plenty of the sea, the composition of the soil, and the raw material of the primitive arts, were wholly gratuitous gifts. Yet the spontaneous nature of Europe, of Western Asia, of Libya, neither fed nor clothed the civilized inhabitants of those provinces. The luxuriant harvests of cereals that waved on every field from the shores of the Rhine to the banks of the Nile, the vines that festooned the hillsides of Syria, of Italy and of Greece, the olives of Spain, the fruits of the gardens of the Hesperides, the domestic quadrupeds and fowls known in ancient rural husbandry - all these were original products of foreign climes, naturalized in new homes, and gradnally ennobled by the art of man, while centuries of persevering labor were expelling the wild vegetation, and fitting the earth for the production of more generous growths. Every loaf was eaten in the sweat of the brow. All must be earned by toil. But toil was nowhere else rewarded by so generous wages; for nowhere would a given amount of intelligent labor produce so abundant, and, at the same time, so varied returns of the good things of material existence.

\section{Plysical Decay of the Territory of the Roman Empire.}

If we compare the present physical condition of the countries of which I an speaking, with the descriptions that ancient his. torians and geographers have given of their fertility and general capability of ministering to human uses, we shall find that more than one-half their whole extent-not excluding the provinces 
most celehrated for the profusion and variety of their spontane. ous and their cultivated products, and for the wealth and social advancement of their inhabitants-is either deserted by civilized man and surrendered to hopeless desolation, or at least greatly reduced in both productiveness and population. Vast forests have disappeared from mountain spurs and ridges; the vegetalble earth aceumulated beneath the trees by the decay of leaves and of fallen trunks, the soil of the alpine pastures which skirted and indented the woods, and the mould of the upland fields, are washed away; meadows, once fertilized by irrigation, are waste and unproductive, because the cisterns and reservoirs that supplied the ancient canals are broken, or the springs that fed them dried up; rivers famous in history and song have shrunk to humble brooklets; the willows that ornamented and protected the banks of the lesser watercourses are gone, and the rivulets have ceased to exist as perennial currents, because the little water that finds its way into their old channels is evaporated by the droughts of summer, or absorbed by the parched earth before it reaches the lowlands; the beds of the brooks have widened into broad expanses of pebbles and gravel, over which, though in the hot season passed dryshod, in winter sealike torrents thunder; the entrances of navigable streams are obstructed by sandbars; and harbors, once marts of an extensive commerce, are shoaled by the deposits of the rivers at whose mouths they lie; the elevation of the beds of estuaries, and the consequently diminished velocity and increased lateral spread of the streams which flow into them, have converted thousands of leagnes of shallow sea and fertile lowland into unproductive and miasmatic morasses.

Besides the direct testimony of history to the ancient fertility of the now exhausted regions to which I refer-Northern Africa, the greater Arabian peninsula, Syria, Mesopotamia, Armenia and many other provinces of Asia Minor, Greece, Sicily, and parts of even Italy and Spain - the multitude and extent of yet remaining architectural ruins, and of decayed works of internal improrement, show that at former epochs a dense population inlabited those now lonely districts. Such a population could have been sustained only by a productiveness of soil of which we at present discover but slender traces; and the abundance derived from that fertility serves to explain how large armies, like those of the an. 
cient Persians, and of the Crusaders and the Tartars in later ages, could, without an organized commissariat, secure adequate sup. plies in long marches through territories which, in our times, would scarcely afford forage for a single regiment.

It appears, then, that the fairest and fruitfulest provinces of the Roman Empire, precisely that portion of terrestrial surface, in short, which, about the commencement of the Christian era, was endowed with the greatest superiority of soil, climate and position, which had been carried to the highest pitch of physical improvement, and which thus combined the natural and artificial conditions best fitting it for the habitation and enjoyment of a dense and highly refined and cultivated population, are now completely exhansted of their fertility, or so diminished in productiveness, as, with the exception of a few favored oases that have escaped the general ruin, to be no longer capable of affording sustenance to civilized man. If to this realm of desolation we add the now wasted and solitary soils of Persia and the remoter East that once fed their millions with milk and honey, we shall see that a territory larger than all Europe, the abundance of which sustained in bygone centuries a population scarcely inferior to that of the whole Christian world at the present day, has been entively withdrawn from human use, or, at best, is thinly inhabited by tribes too few in numbers, too poor in superfluous products, and too little advanced in culture and the social arts, to contribute anything to the general moral or material interests of the great commonwealth of man.

\section{Caruses of this Decay.}

The decay of these once flourishing countries is partly due, no doubt, to that class of geological causes whose action we can neither resist nor guide, and partly also to the direct violence of hostile human force; but it is, in a far greater proportion, either the result of man's ignorant disregard of the laws of nature, or an incidental consequence of war and of civil and ecclesiastical tyranny and misrule. Next to ignorance of these laws, the primitive source, the causa causarum, of the acts and neglects which have blasted with sterility and physical decrepitude the noblest half of the empire of the Cæsars, is, first, the brutal and exhausting des- 
potism which Rome herself exercised over her conquered kingdoms and even over her Italian territory; then, the host of temporal and spiritual tyrannies which she left as her dying eurse to all her wide dominion, and which, in some form of violence or of fraud, still brood over almost every soil subdued by the Roman legions.* Man cannot struggle at once agaiust human op-

* In the Middle Ages, feudalism, and a nominal Christianity whose corruptions had converted the most beneficent of religions into the most baneful of superstitions, perpetuated every abuse of Roman tyranny, and added new oppressions and new methods of extortion to those invented by older despotisms. The burdens in question fell most heavily on the provinces that had been longest colonized by the Latin race, and these are the portions of Europe which have suffered the greatest physical degradation. "Feudalism," says Blanqui, "was a concentration of scourges. The peasant, stripped of the inheritance of his fathers, became the property of inflexible, ignorant, indolent masters; he was obliged to travel fifty leagues with their carts whenever they required it; he labored for them three days in the week, and surrendered to them half the product of his earnings during the other three; without their consent he could not change his residence, or marry. And why, indeed, should he wish to marry, when he could scarcely save enough to maintain himself ?. The Abbot Alcuin had twenty thousand slaves, called serfs, who were forever attached to the soil. This is the great cause of the rapid depopulation observed in the Middle Ages, and of the prodigious multitude of monasteries which sprang up on every side. It was doubtless a relief to such miserable men to find in the cloisters a retreat from oppression; but the human race never suffered a more cruel outrage, industry never received a wound better calculated to plunge the world again into the darkness of the rudest antiquity. It suffices to say that the prediction of the approaching end of the world, industriously spread by the rapacious monks at this time, was received without terror."-Résumé de l'Histoire du Commerce, p. 156. See also MICHILET, Histoire de France, Vol. V., pp. 216, $21 \%$.

The abbey of Saint-Germain-des-Pris, which in the time of Charlemagne had possessed a million of acres, was, down to the Revolution, still so wealthy that the personal income of the abbot was 300,000 livres. The abbey of SaintDenis was nearly as rich as that of Saint-Germain-des-Prés.-Laverane, Économie Rurale de la France, p. 104.

Paul Louis Courier quotes from La Bruyère the following striking picture of the condition of the French peasantry in his time: "One sees certain dark, livid, naked, sunburnt, wild animais, male and female, scattered over the country and attached to the soil, which they root and turn over with indomitable perseverance. They have, as it were, an articulate voice, and when they rise to their feet, they show a human face. They are, in fact, men; they creep at night into dens, where they live on black bread, water, and roots. They spare other men the labor of ploughing, sowing and harvesting, and therefore deserve some small share of the bread they have grown." "These are his own words," adds Courier, "and he is speaking of the fortunate peas- 
pression and the destructive forces of inorganic nature. When both are combined against him, he succumbs after a shorter or longer struggle, and the fields he has won from the primeval wood relapse into their original state of wild and luxuriant, but unprofitable, forest growth, or fall into that of a dry and barren wilderness.

Rome imposed on the products of agricultural labor, in the rural districts, taxes which the sale of the entire harvest would scarcely discharge; she drained them of their population by military conscription; she impoverished the peasantry by forced and unpaid labor on public works; she hampered industry and both foreign and internal commerce by absurd restrictions and unwise regulations.* Hence, large tracts of land were left uncultivated,

ants, of those who had work and bread, and they were then the few."-Pétition à la Chambre des Députés pour les Villageois que l’on empêche de danser.

Arthur Young, who travelled in France from 1787 to 1789, gives, in the twenty-first chapter of his Tracels, a frightful account of the burdens of the rural population even at that late period. Besides the regular governmental taxes and a multitude of heavy fines imposed for trifling offences, he enumerates about thirty seignorial rights, the very origin and nature of some of which are now unknown, while those of some others are as repulsive to humanity and morality as the worst abuses ever practised by heathen despotism. But Young underrates the number of these oppressive impositions. Moreau de Jonnès, a higher authority, asserts that in a brief examination he had discovered upwards of three hundred distinct rights of the feudatory over the person or the property of his vassal. See Etat Économique et Social de la France, Paris, $18 \% 0$, p. 389. Most of these, indeed, had been commuted for money payments, and were levied on the peasantry as pecuniary imposts for the benefit of prelates and lay lords, who, by virtue of their nobility, were exempt from taxation. The collection of the taxes was enforced with unrelenting severity. On one occasion, in the reign of Louis XIV., the troops sent out against the recreant peasants made more than 3,000 prisoners, of whom 400 were condemned to the galleys for life, and a number so large that the government did not dare to disclose it, were hung on trees or broken on the wheel.-Moreau de Jonnes, État Économique et Social de la France, n. 420. Who can wonder at the hostility of the French plebeian classes towards the aristocracy in the days of the Revolution?

* Commerce, in common with all gainful occupations except agriculture, was despised by the Romans, and the exercise of it was forbidden to the higher ranks. Cicero, however, admits that though retail trade, which could only prosper by lying and knavery, was contemptible, yet wholesale commerce was not altogether to be condemned, and might even be laudable, provided the merchant retired early from trade and invested his gains in farm lands. $-D_{\text {o }}$ Officiis, lib. i., 42 . 
or altogether deserted, and exposed to all the destructive forces which act with such energy on the surface of the earth when it is deprived of those protections by which nature originally gruarded it, and for which, in well-ordered husbandry, human ingenuity has contrived more or less efficient substitutes.* Sinilar abuses have tended to perpetuate and extend these evils in later agres, and it is but recently that, even in the most populous parts of Europe, public attention has been half awakened to the necessity of restoring the disturbed harmonies of nature, whose well-balanced influences are so propitious to all her organic offspring, and of repaying to our great mother the debt which the prodigality and the thriftlessness of former generations have imposed upon their successors-thus fulfilling the command of religion and of practical wisdom, to use this world as not abusing it.

\section{New School of Geographers.}

The labors of Humboldt, of Ritter, of Guyot and their followers, have given to the science of Geography a more philosophical, and, at the same time, a more imaginative character than it had receired from the hands of their predecessors. Perhaps the most interesting field of speculation, thrown open by the new school to the cultivators of this attractive study, is the inquiry: how far external physical conditions, especially the configuration of the earth's surface, and the distribution, outline and relative position of land and water, have influenced the social life and social progress of man.

The revolutions of the seasons, with their alterations of temperature and of length of day and night, the climates of different zones, and the general conditions and movements of the atmos-

* The temporary depopulation of an exhausted soil may be, in some cases, a physical, though, like fallows in agriculture, a dear-bought advantige. Under favorable circumstances, the withdrawal of man and his flocks allows the earth to clothe itself again with forests, and in a few generations to recover its ancient productiveness. In the Middle Ages, worn-out fields were depopulated, in many parts of the Continent, by civil and ecclesiastical tyramuies which insisted on the surrender of the half of a loaf already too small to suslain its producer. Thus abandoned, these lands often relapsed into the forest state, and, some centuries later, were again brought under cultivation with renovated fertility. 
phere and the seas, depend upon causes for the most part cosmi. cal, and, of course, wholly beyond our control. The elevation, configuration and composition of the great masses of terrestrial surface, and the relative extent and distribution of land and water, are determined by geological influences equally remote from our jurisdiction. It would hence seem that the physical adaptation of different portions of the earth to the use and enjoyment of man is a matter so strictly belonging to mightier than human powers, that we can only accept geographical nature as we find her, and be content with such soils and such skies as she spontaneously offers.

\section{Reaction of Man on Nature.}

But it is certain that man has reacted upon organized and inorganic nature, and thereby modified, if not determined, the material structure of his earthly home. The measure of that reaction manifestly constitutes a very important element in the appreciation of the relations between mind and matter, as well as in the discussion of many purely physical problems. But though the subject has been incidentally touched upon by many geographers, and treated with much fulness of detail in regard to certain limited fields of human effort and to certain specific effects of human action, it has not, as a whole, so far as I know, been made matter of special observation, or of historical research, by any scientific inquirer. Indeed, until the influence of geographical conditions upon human life was recognized as a distinct branch of philosophical investigation, there was no motive for the pursuit of such speculations; and it was desirable to inquire how far we have, or can, become the architects of our own abiding place, only when it was known how the mode of our physical, moral and intellectual being is affected by the character of the home which Providence has appointed, and we have fashioned, for our material habitation.*

It is still too early to attempt scientific method in discussing this problem, nor is our present store of the necessary facts by any

* Gods Almagt wenkte van den troon,

En schiep elk volk een land ter woon :

Hier vestte $Z$ ij een grondgebied,

Dat Zij ons zelven scheppen liet. 
means complete enough to warrant me in promising any approach to fulness of statement respecting them. Systematic observation in relation to this subject has hardly yet begun, and the seattered data which have chanced to be recorded have never been collected. It has now no place in the general scheme of physical science, aud is matter of suggestion and speculation only, not of established and positive conclusion. At present, then, all that I can hope is to excite an interest in a topic of much economical importauce, by pointing out the directions and illustrating the modes in which human action has been, or may be, most injurious or most beneficial in its influence upon the physical conditions of the earth we inhabit.

We can not always distinguish between the results of man's action and the effects of purely geological or cosmical causes. The destruction of the forests, the drainage of lakes and marshes, and the operations of rural husbandry and industrial art, have unquestionably tended to produce great changes in the hygrometric, thermometric, electric, and chemical condition of the atmosphere, though we are not yet able to measure the force of the different elements of disturbance, or to say how far they have been neutralised by each other or by still obscurer influences; and it is equally certain that the myriad forms of animal and vegetable life, which covered the earth when man first entered upon the theatre of a nature whose harmonies he was destined to derange, have been, through his interference, greatly changed in numerical proportion, sometimes much modified in form and product, and sometimes entirely extirpated.*

* MIan has not only subverted the natural numerical relations of wild as well as domestic quadrupeds, fish, birds, reptiles, insects, and common plants, and even of still humbler tribes of animal and vegetable life, but he has effected, in the forms, habits, nutriment and products of the organisms which minister to his wants and his pleasures, changer which, more than any other manifestation of human energy, resemble the ex. "cise of a creative power. Even wild animals have been compelled by him, thu Jugh the destruction of plants and insects which furnished their proper aliment, to resort to food belonging to a different kingdom of nature. Thus a New Zealand bird, originally granivorous and insectivorous, has become carnivorous, from the want of its natural supplies, and now tears the tleeces from the backs of the sheep in order to feed on their living flesh.

All these changes have exercised more or less direct or indirect action on 
The physical revolutions thus wrought by man have not indeed all been destructive to human interests, and the heaviest blows he has inflicted upon nature have not been wholly without their compensations. Soils to which no nutritious vegetable was indigenous, countries which once brought forth but the fewest products suited for the sustenance and comfort of man-while the severity of their climates created and stimulated the greatest number and the most imperious urgency of physical wants-surfaces the most rugged and intractable, and least blessed with natural facilities of communication, have been brought in modern times to yield and distribute all that supplies the material necessities, all that contributes to the sensuous enjoyments and conveniences of civilized life. The Scythia, the Thule, the Britain, the Germany and the Gaul which the Roman writers describe in such forbidding terms, have been brought almost to rival the native luxuriance and easily won plenty of Southern Italy; and, while the fountains of oil and wine that refreshed old Greece and Syria and Northern Africa have almost ceased to flow, and the soils of those fair lands are turned to thirsty and inhospitable deserts, the hyperborean regions of Europe have learned to conquer, or rather compensate, the rigors of climate, and have attained to a material wealth and variety of product that, with all their natural advantages, the granaries of the ancient world can hardly be said to have enjoyed.

the inorganic surface of the globe ; and the history of the geographical revolutions thus produced would furnish ample material for a volume.

The modification of organic species by domestication is a branch of philosophic inquiry which we may almost say has been created by Darwin; but the geographical results of these modifications do not appear to have yet been made a subject of scientific investigation.

I do not know that the following passage from Pliny has ever been cited in connection with the Darwinian theories, but it is worth a reference:

"But behold a very strange and new fashion of them [cucumbers] in Campane, for there you shall have abundance of them come up in forme of a Quince. And as I heare say, one of them chaunced so to grow first at a very venture; but afterwards from the seed of it came a whole race and progenie of the like, which therefore they call Melopopones, as a man would say, the Quince-pompions or cucumbers."-Plin, Nat. Hist., Holland's translation, book xix., c. 5 .

The word cucumis used in the original of this passage embraces many of the cucurbitacex, but the context shows that it here means the cucumber. 


\section{Observation of Nature.}

In these pages it is my aim to stimulate, not to satisfy, curiosity, and it is no part of my object to save my readers the labor of ob. servation or of thought. For labor is life, and

\section{Death lives where power lives unused.*}

Self is the schoolmaster whose lessons are best worth his wages; and since the subject I am considering has not yet become a branch of formal instruction, those whom it may interest can, fortunately, have no pedagogue but themselves. To the natural philosopher, the descriptive poet, the painter, the sculptor, and indeed every earnest observer, the power most important to cultivate, and, at the same time, hardest to acquire, is that of seeing what is before him. Sight is a faculty; seeing, an art. The eye is a physical but not a self-acting apparatus, and in general it sees only what it seeks. Like a mirror, it reflects objects presented to it; but it may be as insensible as a mirror, and not consciously perceive what it reflects. $\dagger$

It has been maintained by high authority, that the natural acuteness of our sensuous faculties can not be heightened by use, and hence, that the minutest details of the image formed on the retina are as perfect in the most untrained as in the most thoroughly disciplined organ. This may be questioned, and it is agreed on all hands that the power of multifarious perception and rapid discrimination may be immensely increased by welldirected practice. $\neq$ This exercise of the eye I desire to promote,

* Verses addressed by G. C. to Sir Walter Raleigh.-HAkLUrT, i., p. 668.

t- I troer, at Synets Sands er lagt i Öiet,

Mens dette kun er Redskab. Synet strömmer

Fra Sjælens Dyb, og Öiets fine Nerver

Gaae ud fra Hjernens hemmelige Værksted.

Henrik Hertz, Kong Renés Datter, sc. ii.

In the material eye, you think, sight lodgeth !

The eye is but an organ. Seeing streameth

From the soul's inmost depths. The fine perceptive

Nerve springeth from the brain's mysterious workshop.

$\ddagger$ I have witnessed instances of extraordinary powers of vision in Arabs of the Desert, and in seamen, but I have not had an opportunity of testing how far this acuteness of sight was due to practice. In regard to the faculty of 
and, next to moral and religious doctrine, I know no more important practical lessons in this earthly life of ours-which, tc the wise man, is a school from the cradle to the grave-than those relating to the employment of the sense of vision in the study of nature.

The pursuit of physical geography, embracing actual observation of terrestrial surface, affords to the eye the best general training that is accessible to all. The majority of even cultivated men have not the time and means of acquiring more than a very superficial acquaintance with any branch of physical knowledge. Natural science has become so vastly extended, its re-

hearing I can speak with more confidence. Every person who has had any considerable experience in linguistic studies knows that many of the peculiar articulate sounds of almost any human speech are not only not readily imitab!e by those unacquainted with the language, but at first absolutely inaudible, though with frequent repetition they can not only be heard but reproduced.

The senses of children are exceedingly acute, but become less so in mature life. I remember seeing, in a city on the shore of one of our American lakes, a boy about twelve years old who recognized, by the sound of the puff of the high-pressure engines then in use, every steamer which approached the harbor. In a case where a thief had fled from the scene of his plunder, leaving his hat behind him, the police officer carried the hat to a neighboring school, where it was at once recognized by the boys as belonging to a particular individual, and upon that indication the thief was arrested.

Skill in marksmanship, whether with firearms or with other projectile weap. ons, depends more upon the training of the eye than is generally supposed, and I have often found particularly good shots to possess an almost telescopio vision. In the ordinary use of the rifle, the barrel is guided by the eye, but there are sportsmen who fire with the butt of the gun at the hip. In this case, as in the use of the sling, the lasso, and the bolas, in hurling the knife (see BABINET, Lectures, vii., p. 84), in throwing the boomerang, the javelin, or a stone, and in the employment of the blowpipe and the bow, the movements of the hand and arm are guided by that mysterious sympathy which exists between the eye and the unseeing organs of the body.

"Some men wonder whye, in casting a man's eye at the marke, the hand should go streighte. Surely if he considered the nature of a man's eye he would not wonder at it: for this I am certaine of, that no servaunt to his maister, no childe to his father, is so obedient, as every joynte and peece of the bodye is to do whatsover the eye biddes."-Roger Ascham, Toxophilus, Book ii.

In shooting the tortoises of the Amazon and its tributaries, the Indians use an arrow with a long twine and a float attached to it. Avé-Lallemant (Dio Benutzung der Palmen am Amazonenstrom, p. 32) thus describes their mode of aiming: "As the arrow, if aimed directly at the floating tortoise, would strike it at a small angle and glance from its flat and wet shell, the urchers have a 
corded facts and its unanswered questions so immensely multiplied, that every strictly scientific man must be a specialist, and must confine the researches of a whole life within a comparatively narrow circle. The study I am recommending, in the view I propose to take of it, is yet in that imperfectly developed state which allows its votaries to occupy themselves with broad and general views attainable by every person of culture, and it does not now require a knowledge of special details which only years of application can master.* It may be profitably pursued by all:

peculiar method of shooting. They are able to calculate exactly their own muscular effort, the velocity of the stream, the distance and size of the tortoise, and they shoot the arrow directly up into the air, so that it falls almost vertically upon the shell of the tortoise, and sticks in it." Analogous calculations-if such physico-mental operations can properly be so called-are made in the use of other missiles; for no projectile flies in a right line to its mark. The exact training of the eye lies at the bottom of them all, and marksmanship depends almost wholly upon the power of that organ, whose directions the blind muscles implicitly follow. Savages accustomed only to the use of the bow become good shots with firearms after very little practice. It is perhaps not out of place to observe here that our English word aim comes from the Latin astimo, I calculate or estimate. See TVEDGwood's Dictionary of English Etymology, and the note to the American edition, under Aim.

Another proof of the control of the limbs by the eye has been obsewed in deaf-and-dumb schools, and in others where pupils are first taught to write on large slates or blackboards. The writing is in large characters, the small letters being an inch or more high. They are formed with chalk or a slate pencil firmly grasped in the fingers, and by appropriate motions of the wrist, elbow, and shoulder, not of the finger joints. Nevertheless, when a pen is put into the hand of a pupil thus taught, his handwriting, though produced by a totally different set of muscles and muscular movements, is identical in character with that which he has practiced on the blackboard.

For a very remarkable account of the restoration of vision impaired from age, by judicious training, see Lessons in Life by Tпrotri Tiтcomb, lesson xi.

It has been much doubted whether the artists of the classic ages possessed a more perfect sight than those of modern times, or whether, in executing their minute mosaies and gem engravings, they used magnifiers. Crlasses ground convex have been found at Pompeii, but they are too rudely fashioned and too imperfectly polished to have been of any practical use for optical purposes. But though the ancient artists may have had a microscopic vision, their astronomers can not have had a telescopic power of sight ; for they did not discover the satellites of Jupiter, which are often seen with the naked eye at Oormecalh, in Persia, and sometimes, as I can testify by personal observation, at Cairo.

* The introduction of mathematical method into the study of plyssical 
and every traveller, every lover of rural scenery, every agriculturist, who will wisely use the gift of sight, may add valuable contributions to the common stock of knowledge on a sulject which, as I hope to convince my readers, though long neglected and now inartificially presented, is not only a very important but a very interesting field of inquiry.

\section{Measurement of Man's Influence.}

The exact measurement of the geographical and climatic changes hitherto effected by man is impracticable, and we possess, in relation to them, the means of only qualitative, not quantitative, analysis. The fact of such revolutions is established partly by historical evidence, partly by analogical deduction from effects produced, in our own time, by operations similar in character to those which must have taken place in more or less remote ages of human action. Both sources of information are alike defective in precision; the latter, for general reasons too obvious to require specification; the former, because the facts to which it bears testimony occurred before the habit or the means of rigorously scientific observation upon any branch of physical research, and especially upon climatic changes, existed.

\section{Uncertainty of our Historical Conclusions on Ancient Cli- mates.}

The invention of measures of heat and of atmospheric moisture, pressure and precipitation, is extremely recent. Hence, ancient physicists have left us no thermometric or barometric records, no tables of the fall, evaporation and flow of waters, and even no accurate maps of coast lines and the course of rivers. Their notices of these phenomena are almost wholly confined to excessive and exceptional instances of high or of low temperatures, to extraordinary falls of rain and snow, and to unusual floods or droughts. Our knowledge of the meteorological condition of the earth, at any period more than two centuries before

science, though attended with some highly beneficial results, has impeded the progress of Physical Geography by discouraging its pursuit as unworthy of cultivation because incapable of precise results. 
our own time, is derived from these imperfect details, from the vague statements of ancient historians and geographers in regard to the volume of rivers and the relative extent of forest and cultivated land, from the indications furnished by the history of the agriculture and rural economy of past generations, and from other almost purely casual sources of information.*

Among these latter we must rank certain newly laid-open fields of investigation, from which facts bearing on the point now under consideration have been gathered. I allude to the discovery of artificial objects in geological formations older than any hitherto recognized as exhibiting traces of the existence of man; to the ancient lacustrine habitations of Switzerland and of the terremare of Italy, containing the implements of the occupants, remains of their food, and other relies of human life; to the curious revelations of the Kjökkenmöddinger, or heaps of kitchen refuse, in Denmark and elsewhere, and of the peat mosses in the same and other northern countries; to the dwellings and other evidences of the industry of man in remote ages, sometimes laid bare by the movement of sand dunes on the coasts of France and of the North Sea ; and to the facts disclosed on the tide-washed flats of the latter shores by excavations in Halligs, or inhabited mounds, which were probably raised before the era of the Roman Empire. $\neq$ These remains are memorials of races which have left no written records-races which perished at a period beyond the reach of even historical tradition. The plants and animals that furnished the relies found in the deposits were certainly contemporaneous with man; for they are associated with his works, and have evidently served his uses. In some cases, the animals belonged to species well ascer-

* The subject of climatic change, with and without reference to human action as a cause, has been much discussed by Moreau de Jonnès, Dureau de la Malle, Arago, Humboldt, Fuster, Gasparin, Becquerel, Schleiden and many other writers in Europe, and by Noah Webster, Forry, Drake and others in America. Fraas has endeavored to show, by the history of vegetation in Greece, not merely that clearing and cultivation have affected climate, but that change of climate has essentially modified the character of vegetable life. See his Klima und Pflanzenwelt in der Zeit.

+ See two learned articles by Pigorini, in the Nuova Antologia for January and October, 1870.

$\ddagger$ For a very picturesque description of the Halligs, see PlinY, $N$. $I$., Bools Irvi., c. 1 . 
tained to be now altogether extinct; in some others, both the ani mals and the regetables, though extant elsewhere, have ceased to inhabit the regions where their remains are discovered. From the character of the artificial objects, as compared with others belonging to known dates, or at least to known periods of civilization, ingenious inferences have been drawn as to their age; and from the vegretable remains which accompany them, as to the climates of Central and Northern Europe at the time of their production.

There are, however, sonrces of error which have not always been sufficiently guarded agaiust in making these estimates. When a boat, composed of several pieces of wood fastened together by pins of the same material, is dug out of a bog, it is inferred that the ressel, and the skeletons and implements found with it, belong to an age when the use of iron was not known to the builders. But this conclusion is not warranted by the simple fact that metals were not employed in its construction; for the Nubians at this day build boats, large enough to carry half a dozen persons across the Nile, out of small pieces of acacia wood pinned together entirely with wooden bolts, and large vessels of similar construction are used by the islanders of the Malay archipelago. Nor is the occurrence of flint arrowheads and knives, in conjunction with other evidences of human life, conclusive proof as to the antiquity of the latter. Lyell informs that some Oriental tribes still continue to use the same stone implements as their ancestors, "after that mighty empires, where the use of metals in the arts was well known, had Hourished for three thousand years in their neighborhood"; * and the North American Indians now manufacture weapons of stone, and even of glass, chipping them in the latter case out of the bottoms of thick bottles with great facility. $\dagger$

* Antiquity of Man, p. 37\%.

$\uparrow$ "One of the Indians seated himself near me, and made from a fragment of quartz, with a simple piece of round bone, one end of which was hemispherical, with a small crease in it (as if worn by a thread) the sixteenth of an inch deep, an arrow head which was very sharp and piercing, and such as they use on all their arrows. The slill and rapidity with which it was made, without a blow, but by simply breaking the sharp edges with the creased bone by the strengtlı of his hauds-for the crease merely served to prevent the instrument from slipping, affording no leverage-was remarkable." - Reports of Ex- 
We may also be misled by our ignormee of the commercial relations existing between savage tribes. Extremely rude nations, in spite of their jealous's and their perpetual wars, sometimes contrive to exchange the products of provinces very widely separated from each other. The mounds of Ohio contain pearls, thought to be marine, which must have come from the Gulf of Mexico, or perhaps even from California, and the knives and pipes found in the same graves are often formed of far-fetelied material, that was naturally paid for by some home product exported to the locality whence the material was derived. The art of preserving fish, flesh and fowl by drying and smoking is widely diffused and of great antiquity. The Indians of Long Islaud Sound are said to have carried on a trade in dried shell-fish with tribes residing very far inland. From the earliest ages, the inhabitants of the Faroe and Orkney Islands, and of the opposite mainland coasts, have smoked wild forvl and other flesh. Hence it is possible that the animal and the vegetable food, the remains of which are found in the ancient deposits I am speaking of, may sometimes have been brought from climates remote from that where it was consumed.

The most important, as well as the most trustworthy, conclusions with respect to the climate of ancient Europe and Asia, are those drawn from the accounts given by the classical writers of the growth of cultivated plants; but these are by no means free from uncertainty, because we can seldom be sure of an identity of species, almost never of an identity of race or variety, between vegetables known to the agriculturists of Greece and Rome and those of modern times which are thought most nearly to resemble them. Besides this, there is always room for doubt whether the habits of plants long grown in different countries may not have been so changed by domestication or by natural selection, that the conditions of temperature and humidity which they required twenty centuries ago were different from those at present demanded for their advantageous cultivation.*

plorations and Surveys for Pucific Railroad, vol. ii., 1855, Licut. BEскwIтr's Report, p. 43. See also American Naturalist for MIaj, 1Si0, and especially STEvens, Flint Chips, London, 1870, pp. 77 et seq.

Mariette Bey lately saw an Egyptian barber share the head of an Arab with a flint razor.

* Probably no cultivated vegretible affords so good an opportunity of study. 
Even if we suppose an identity of species, of race, and of habit, to be established between a given ancient and modern plant, the negative fact that the latter will not grow now where it flourished two thousand years ago, does not, in all cases, prove a change of climate. The same result might follow from the exhaustion of the soil,* or from a change in the quantity of moisture it habitu-

ing the laws of acclimation of plants as maize or Indian corn. Mraize is grown from the tropics to at least lat. $47^{\circ}$ in Northeastern America, and farther north in Europe. Every two or three degrees of latitude bring you to a new variety, with new climatic adaptations, and the capacity of the plant to accommodate itself to new conditions of temperature and season seems almost unlimited.

Jany persons now living remember that, when the common tomato was first introduced into Northern New England, it often failed to ripen; but, in the course of a very few years, it completely adapted itself to the climate, and now not only matures both its fruit and its seeds with as much certainty as auy cultivated vegetable, but regularly propagates itself by self-sown seed. Meteorological observations, however, do not show any amelioration of the summer climate in those States within that period.

It may be said that these cases-and indeed all cases of a supposed acclimation consisting in physiological changes-are instances of the origination of new varieties by natural selection, the hardier maize, tomato, and other vegetables of the North, being the progeny of seeds of individuals endowed, exceptionally, with greater power of resisting cold than belongs in general to the species which produced them. But, so far as the evidence of change of climate, drawn from a difference in regetable growth, is concerned, it is immaterial whether we adopt this view or maintain the older and more familiar doctrine of a local modification of character in the plants in question.

Maize and the tomato, if not new to human use, have not been long known to civilization, and were, very probably, reclaimed and domesticated at a much more recent period than the plants which form the great staples of agricultural husbandry in Europe and Asia. Is the great power of accommodation to climate possessed by them due to this circumstance? There is some reason to suppose that the character of maize has been sensibly changed by cultivation in South America; for, according to Tschudi, the ears of this grain found in old Peruvian tombs belong to varieties not now known in Peru.Tracels in Peru, chap. vii. See important observations in ScrüBELEn, Die Pflanzenoelt Norrcegens (Allgemeiner Theil), Christiana, 1873, 77 and following $\mathrm{pp}$.

* The cultivation of madder is said to have been introduced into Europe by an Oriental in the year 1765, and it was first planted in the neighborhood of A rignon. Of course, it has been grown in that district for less than a century; but upon soils where it has been a frequent crop, it is already losing much of its coloring properties.-Lavergne, Économie Rurale de la France, pp. 259-291.

I believe there is no doubt that the cultivation of madder in the vicinity of 
ally contains. After a district of country has been completely or even partially cleared of its forest growth and brought under cul. tivation, the drying of the soil, under favorable circumstances, goes on for generations, perhaps for ages.* In other cases, from

Avignon is of recent introduction; but it is certain that it was grown by tho ancient Romans, and throughout nearly all Europe in the middle ages. The madder brought from Persia to France, may belong to a different species, or at least variety.

* In many parts of New England there are tracts, many square miles in extent and presenting all varieties of surface and exposure, which were partially cleared sixty or seventy years ago, and where little or no change in the proportion of cultivated ground, pasturage and woodland has taken place since. In some cases, these tracts compose basins apparently scarcely at all exposed to any local influence in the way of percolation or infiltration of water towards or from neighboring valleys. But in such situations, apart from accidental disturbances, the ground is growing drier and drier from year to year, springs are still disappearing, and rivulets still diminishing in their summer supply of water. A probable explanation of this is to be found in the rapid drainage of the surface of cleared ground, which prevents the sulterranean natural reservoirs, whether cavities or merely strata of bibulous earth, from filling up. How long this process is to last before an equilibrium is reached, none can say. It may be, for years ; it may be, for centuries.

Livingstone states facts which strongly favor the supposition that a secular desiccation is still going on in Central Africa, and there is reason to suspect that a like change is taking place in California. When the regions where the earth is growing drier were cleared of wood, or, indeed, whether forests ever grew there, we are unable to say, but the change appears to have been long in progress. A similar revolution appears to have occurred in Arabia Petræa. In many of the vadis, and particularly in the gorges between Wadi Feirun and Wadi Esh Sheikh, there are water-worn banks showing that, at no very remote period, the winter floods must have risen fifty feet in channels whero the growth of acacias and tamarisks and the testimony of the Arabs concur to prove that they have not risen six feet within the menory or tradition of the present inhabitants. Recent travellers have discorered traces of extensive ancient cultivation, and of the former existence of large tomus in the Tih desert, in localities where all agriculture is now impossible for want of water. Is this drought due to the destruction of ancient forests or to some other cause? L'Année Géographique for 1873 , pp. 72 and 176, has some very interesting observations on the secular desiccation of the Sahara and of Persia.

For important remarks on supposed changes in our Western prairie region, from cultivation of the soil and the introduction of domestic cattle, see BRYANT's valuable Forest Trees, 1871, chapter $\nabla$., and IIArDex, Prcliminary Report on Survey of Wyoming, p. 455.

Some physicists believe that the waters of our earth are, from chemical os other less known causes, diminishing by entering into new inorganic combi. nations, and that this element will finally disapnear from the globe. 
injudicious husbandry, or the diversion or choking up of natural watercourses, it may become more highly charged with humidity. An increase or diminution of the moisture of a soil almost necessarily supposes an elevation or a depression of its winter or its summer heat, and of its extreme if not of its mean annual temperature, though such elevation or depression may be so slight as not sensibly to raise or lower the mercury in a thermometer exposed to the open air. Any of these causes, more or less humidity, or more or less warmth of soil, would affect the growth both of wild and of cultivated vegetation, and consequently, without any appreciable change in atmospheric temperature, precipitation or evaporation, plants of a particular species might cease to be advantageously cultivated where they had once been easily reared.*

* The soil of newly subdued countries is generally highly favorable to the growth of the fruits of the garden and the orchard, but usually becomes much less so in a very few years. Plums, of many varieties, were formerly grown, in great perfection and abundance, in many parts of New England where at present they can scarcely be reared at all; and the peach, which, a generation or two ago, succeeded admirably in the southern portion of the same States, has almost ceased to be cultivated there. The disappearance of these fruits is partly due to the ravages of insects, which have in later years attacked them; but this is evidently by no means the sole, or even the principal cause of their decay. In these cases, it is not to the exhaustion of the particular acres on which the fruit trees have grown that we are to ascribe their degeneracy, but to a general change in the condition of the soil or the air ; for it is equally impossible to rear them successfully on absolutely new land in the neighborhood of grounds where, not long since, they bore the finest fruit.

I remember being told, many years ago, by intelligent early settlers of the State of Ohio, that the apple-trees raised there from seed sown soon after the land was cleared, bore fruit in less than half the time required to bring to bearing those reared from seed sown when the ground had been twenty years under cultivation. I can testify from personal recollection that orchards planted by the early settlers in many parts of my native State, Vermont, produced, when they came to bearing, fruit of a quality greatly superior to that borne by the same trees after they were deprived of the shelter of the neighboring forest in consequence of the clearing of the ground for cultivation. I call to mind instances of particular trees whose fruit, originally of great excellence, became almost unpalatable from this cause, or from other influences of rural improvement. For notice of a similar change within the last half century in Scotland, see Nature, Nov. 27, 1873, p. 72.

Analogous changes occur slowly and almost imperceptibly even in spontaneous vegetation. In the peat mosses of Denmark, Scotch firs and othes 


\section{Uncertainty of MLodern Meteorology.}

We are very imperfectly acquainted with the present mean and extreme temperature, or the precipitation and the eviporation of any extensive region, even in countries most densely peopled and best supplied with instruments and observers. The progress of science is constantly detecting errors of method in older observations, and many laboriously constructed tables of ineteorological phenomena are now thrown aside as fallacious, and therefore worse than useless, because some condition necessary to secure accuracy of result was neglected, in obtaining and recording the data on which they were founded.

To take a familiar instance : it is but recently that attention has been drawn to the great influence of slight differences in station upon the results of observations of temperature and precipitation. Two thermometers hung but a few hundred yards from each other differ not unfrequently five, sometimes even ten degrees in their readings; $*$ and when we are told that the annual fall of rain on the roof of the observatory at Paris is two inches less than on the ground by the side of it, we may see that the height of the rain-

trees not now growing in the same localities, are found in abundance. Every generation of trees leaves the soil in a different state from that in which it found it; every tree that springs up in a group of trees of another species than its own, grows under different influences of light and shade and atmosphere from its predecessors. Hence the succession of crops, which occurs in all natural forests, seems to be due rather to changes of condition than of climate. See pp. 363-4, post.

* Tyndall, in a lecture on Radiation, expresses the opinion that from ten to fifteen per cent. of the heat radiated from the earth is absorbed by aqueous vapor within ten feet of the earth's surface.-Fragments of Science, 3d edition, London, 1871, p. 203.

Thermometers at most meteorological stations, when not suspended at points regulated by the mere personal convenience of the observer, are hung from 20 to 40 feet above the ground. In such positions they are less exposed to disturbance from the action of surrounding bodies than at a lower level, and their indications are consequently more uniform; but according to Tyndall's views they do not mark the temperature of the atmospheric stratum in which nearly all the vegetables useful to man, except forest trees, bud and blossom and ripen, and in which a vast majority of the ordinary operations of material life are performed. They give the rise and fall of the mercury at heights arbitrarily taken, without reference to the relations of temperature to human interests, or to any other scientific consideration than a somerwhat less liability. to accidental disturbance. 
gauge above the earth is a point of much consequence in making estimates from its measurements.* The data from which results

* Careful observations by the late lamented Dallas Bache appeared to show that there is no such difference in the quantity of precipitation falling at slightly different levels as has been generally supposed. The apparent difference was ascribed by Prof. Bache to the irregular distribution of the drops of rain and flakes of snow, exposed, as they are, to local disturbances by the currents of air around the corners of buildings or other accidents of the surface.

Mr. Bache's conclusions seem not to be accepted by some experimenters in England (see Qurterly Journal of Science for January, 1871, p. 123), but according to Greaves, President of the Meteorological Society (see Academy, 7 th Dec., 1878, p. 547 ), the difference above alluded to is now generally acknowledged to be almost entirely due to the action of wind. The periodical Nuture of Sept. 22, 1881, p. 495, also contains an article on Prof. Phillips's observations of the rain-fall at Yorkminster, which appears to confirm this theory. The general conclusion of the article is in favor of Prof. Jevons's views, announced in 1861, namely: that the phenomena observed were all consistent with the supposition that the fall of rain was practically identical at all elevations, the observed differences being due to imperfect collection by the gauges. Prof. Jevons's theory is now almost universally adopted, and it shows the importance of great care in the selection of positions for raingauges; but in this theory he refers merely to the height of the gauge above the ground, and takes no notice of the remarkable difference of rain-fall observed at stations at very small distances from each other.

Thus, by the Report of Dr. B. A. Gould, Director of the Observatory at Cordova, in the Argentine Confederation, it appears that at the house of the secretary, which is one mile distant from the Observatory, and 36.6 metres lower, during a period not given, but apparently of some months, a pluviom. eter, three and a half metres above the ground, showed a precipitation of 496.5 millimetres. The measured fall at the Observatory during the same period was 459.1 millimetres, showing a difference of eight per cent. in favor of the lower station.

In a period of some weeks, a rain-gauge on the roof of a house near the Observatory, 4.02 metres above the standard instrument at the Observatory, registered 137.04 millimetres, the standard pluviometer 150 millimetres, a difference of eight per cent. in favor of the lower station.

The island of Mauritius, lying in the Indian Ocean in about $20^{\circ} \mathrm{N}$. L., is less than forty miles long by about thirty in breadth. Its surface is very irregular, and though it consists, to a considerable extent, of a plateau from 1,200 to 1,500 feet high, there are three mountain peaks ranging from 2,300 to 2,700 feet in height. Hence, though the general climatic influences are everywhere substantially the same, there is room for a great variety of exposures and of other purely local conditions. It is said that the difference of temperature between the highest and lowest stations does not exceed eight degrees F., while, according to observations at thirty-five stations, the rain-fall in 1872 varied from thirty-three inches at Gros Cailloux to one hundred and 
have been deduced with respect to the hygrometrical and thermometrical conditions, to the climate, in short, of different countries, have very often been derived from observations at single points in cities or districts separated by considerable distances. The tendency of errors and accidents to balance each other authorizes us, indeed, to entertain greater confidence than we could otherwise feel in the conclusions drawn from such tables; but it is in the highest degree probable that they would be much modified by more numerous series of observations at different stations within narrow limits.*

forty-six inches at Cluny.-Nature, September 24, 1874. This enormous difference in measurement is too great to be explained by possible errors of observation or other accidental circumstances, and we must suppose that there are, in different parts of this small island, great differences in the actual precipitation, but still much of this variation must be due to causes whose range of influence is extremely limited

In 1859 at Charleston, S. C., there fell at the U. S. Arsenal, in a single rainstorm of an hour and a half, two inches of water; at the Register's Office in the same city, at the distance of two miles from the Arsenal, the fall was but one-third.of an inch.

In the same year observations at three stations in the city of San Francisco, gave a total rain-fall of $16^{\prime \prime} 34 ; 25^{\prime \prime} 41$; and $21^{\prime \prime} 39$, respectively, and during the whole period from 1853 to 1860 , the meteorological records at different stations in the same city show similar discrepancies. See Smithsonian Contributions, Vol. XVIII., p. 143.

Like differences are constantly found in the temperature registered at different stations in the same vicinity, and it is obvious that in such cases no trustworthy conclusions as to the general meteorology of territories of even very small extent, can be obtained by mere averages of interpolations.

As every astronomical observer has his personal, so every meteorological station has its local, equation, and the determination of these equations ought to be a cardinal object in every system of pluviometrical or thermometrical observations. Records of observations at the same hours and by the same methods, with the same or other carefully compared instruments, for a series of years, may authorize conclusions as to the essential or accidental climatic conditions of that precise locality ; but in the present state of our knowledge, such records alone warrant no inference as to the meteorology of any other point, even within the distance of a mile, unless it may be in the case of observations with instruments absolutely insulated on great plains, or otherwise placed in exactly corresponding positions. Hence, until the equations we speak of are ascertained, results deduced from the comparison of observa. tions made at different periods and at different stations can have no scientific value whatever.

* The nomenclature of meteorology is vague and sometimes equivocal. Not long since, it was suspected that the observers reporting to a scientific institu. 
There is one branch of research which is of the utmost import. ance in reference to these questions, but which, from the great difficulty of direct observation upon it, has been less successfully studied than almost any other problem of physical science. I refer to the proportions between precipitation, superficial drainage, absorption and evaporation. Precise actual measurement of these quantities upon even a single acre of ground is impossible; and in all cabinet experiments on the subject, the conditions of the surface observed are so different from those which occur in nature, that we can not safely reason from one case to the other. In nature, the inclination and exposure of the ground, the degree

tion did not agree in their understanding of the mode of expressing the direction of the wind prescribed by their instructions. It was found, upon inquiry, that very many of them used the names of the compass-points to indicate the quarter from which the wind blew, while others employed them to signify the quarter toroards which the atmospheric currents were moving. In some in. stances, the observers were no longer within the reach of inquiry, and of course their tables of the wind were of no value.

"Winds," says MIrs. Somerville, "are named from the points whence they blow, currents exactly the reverse. An easterly wind comes from the east; whereas an easterly current comes from the west, and flows towards the east." -Physical Geography, p. 229.

There is no philological ground for this distinction, and it probably originated in a confusion of the terminations -2cardly and -crly, both of which are mudern. The root of the former ending implies the direction to or to-vards which motion is supposed. It corresponds to, and is probably allied with, the Latin versus. The termination -erly is a corruption or softening of -crnly, easterly for easternly, and many authors of the seventeenth century so write it. In Hakluyt (i., p. 2), easterly is applied to place, "easterly bounds," and means eastern. In a passage in Drayton, "easterly winds" must mean winds from the east; but the same author, in speaking of nations, uses northerly for northern. Hakewell says: "The sonne cannot goe more southernely from vs, nor come more northernely towards vs." Holland, in his translation of Pliny, referring to the moon, has: "When shee is northerly," and "shee is gone southerly." Richardson, to whom I am indebted for the above citations, quotes a passage from Dampicr where vesterly is applied to the wind, but the context does not determine the direction. The only example of the termination in -vardly given by this lexicographer is from Donne, where it means toroards the west.

Shakspeare, in Famlet (v., ii.), uses northerly wind for wind from the north. Milton does not employ either of these terminations, nor were they known to the Anglo-Saxous, who, however, had adjectives of direction in -an or en, -ern and -weard, the last always meaning the point towards which motion is supposed, the others that from which it proceeds.

The vocabulary of science has no specific name for one of the most import. 
of freedom or obstruction of the flow of water over the surface, the composition and density of the soil, its temperature, ${ }^{*}$ the dryness or saturation of the subsoil, the presence or absence of perforations by worms and small burrowing quadrupeds-in sloort, all the conditions upon which the permeability of the ground by water and its power of absorbing and retaining or transmitting moisture depend-vary at comparatively short distances; and though the precipitation upon very small geographical basins and the superficial flow from them may be estimated with an approach to precision, yet even here we have no present means of knowing how much of the water absorbed by the earth is restored to the atmosphere by evaporation, and how much carried off by infiltration or other modes of underground discharge. When, therefore, we attempt to use the phenomena observed on a few square or cubic yards of earth, as a basis of reasoning upon the meteorol-

ant phenomena in meteorology-I mean for watery vapor condensed and rendered visible by cold. The Latins popularly expressed this condition of water by the word vapor. For invisible vapor natural philosophers used vapor and spivitus, but with a looseness corresponding to the vagueness of their ideas on the subject, and Van Helmont was obliged to invent a word, gas, as a scientific generic name for watery and other fluids in the invisible state. The moderns have perverted the familiar meaning of the word vapor, and in science its use is contined to express water in the gaseous and invisible state. When vapor is rendered visible by condensation, we call it fog or mist if it is lying on or near the surface of the earth or of water; when it floats in the air we call it cloud; but between these three words there is no clearly established distinction, for the condition of water in the "swirling cloud" is the sume as in the "misty wreath." They only express the form and position of the aqueous aggregation, not the condition of the water-globules which compose it.

The breath from our mouths, the steam from an engine, thrown out into cold air, become visible, and consist of water in the same state as in fog or cloud; but we do not apply those terms to these phenomena. It would be an improvement in meteorological nomenclature to restore vapor to its original popular meaning, and to employ a new word, such for example as hydrogas, to express the new scientific idea of water in the invisible state.

* Temperature, as conditioning the capillarity of rock and the hygroscopicity of earth, has not been much considered by physical inquirers, but it is certainly an element of very great importance. See Stoppaxt, Geologia, I, $\S 600,607$. The instance of the foundry, where, when its floor of earth had receired a great quantity of water by infiltration from a neighboring river at flood, almost the whole of the moisture was absorbed by the portions of the floor which had been heated by fires kindled upon it to dry the moulds, is rery instructive. 
ogy of a province, it is evident that our data must be insufficient to warrant positive general conclusions. In discussing the climatology of whole countries, or even of comparatively small local divisions, we may safely say that none can tell what percentage of the water they receive from the atmosphere is evaporated; what absorbed by the ground and conveyed off by subterranean conduits; what carried down to the sea by superficial channels; what drawn from the earth or the air by a given extent of forest, of short pasture vegetation, or of tall meadow-grass; what given out again by surfaces so covered, or by bare ground of various textures and composition, under different conditions of atmospheric temperature, pressure and humidity; or what is the amount of evaporation from water, ice or snow, under the varying exposures to which, in actual nature, they are constantly subjected. If, then, we are so ignorant of all these climatic phenomena in the best-known regions inhabited by man, it is evident that we can rely little upon theoretical deductions applied to the former more natural state of the same regions-less still to such as are adopted with respect to distant, strange and primitive countries.

\section{Stability of Nature.}

Nature, left undisturbed, so fashions her territory as to give it almost unchanging permanence of form, outline and proportion, except when shattered by geologic convulsions; and in these comparatively rare cases of derangement, she sets herself at once to repair the superficial damage, and to restore, as nearly as practicable, the former aspect of her dominion. In new countries, the natural inclination of the ground, the self-formed slopes and levels, are generally such as best secure the stability of the soil. They have been graded and lowered or elevated by frost and chemical forces and gravitation and the flow of water and vegetable deposit and the action of the winds, until, by a general compensation of conflicting forces, a condition of equilibrium has been reached which, without the action of man, would remain with little fluctuation for countless ages.

We need not go far back to reach a period when, in all that portion of the North American continent which has been occupied by British colonization, the geographical elements very 
nearly balanced and compensated each other. At the com. mencement of the seventeenth century, the soil, with insignificant exceptions, was covered with forests; * and whenever the Indian, in consequence of war or the exhaustion of the beasts of the chase, abandoned the narrow fields he had planted and the woods he had burned over, they speedily returned, by a succession of herbaceous, arborescent and arboreal growths, to their original state. Even a single generation sufficed to restore them almnst to their primitive luxuriance of forest vegetation. $†$ The unbroken forests had attained to their maximum density and strength of growth, and, as the older trees decayed and fell, they were succeeded by new shoots or seedlings, so that from century to century no perceptible change seems to have occurred in the wood, except the slow, spontaneous succession of crops. This succession involved no interruption of growth, and but little break in the "boundless contiguity of shade"; for in the husbandry of nature there are no fallows. Trees fall singly, not by square roods, and the tall pine is hardly prostrate, before the light and heat, admitted to the ground by the removal of the dense crown of foliage which had shut them out, stimulate the germination of the seeds of broad-leaved trees that had lain, waiting this kindly influence, perhaps for centuries.

\section{Formation of Bogs: $\neq$}

Two natural causes, destructive in character, were, indeed, in operation in the primitive American forests, though, in the

* I do not here speak of the vast prairie region of the Mississippi valley, which can not properly be said ever to have been a field of British colonization; but of the original colonies and their dependencies in the territory of the present United States and in Canada. It is, howerer, equally true of the Western prairies as of the Eastern forest land, that they had arrived at a state of equilibrium, though under very different conditions.

+ The great fire of Miramichi in 1825, probably the most extensive and terrific conflagration recorded in authentic history, sprend its ravages over nearly six thousand square miles, chiefly of woodland, and was of such intensity that it seemed to consume the very soil itself. But so great are the recuperative powers of nature, that, in twenty-five years, the ground was thickly covered again with trees of fair dimensions, except where cultivation and pasturage kept down the forest growth.

$\ddagger$ The English nomenclature of this geographical feature does not seem well 
Northern colonies at least, there were sufficient compensations; for we do not discover that any considerable permanent change was produced by them. I refer to the action of beavers and of

settled. We have bog, swamp, marsh, morass, moor, fen, turf-moss, peat-moss, quagmire, all of which, though sometimes more or less accurately discriminated, are often used interchangeably, or are perhaps employed, each exclusively, in a particular district. In Sweden, where, especially in the Lappish provinces, this terraqueous formation is very extensive and important, the names of its different kinds are more specific in their application. The general designation of all soils permanently pervaded with water is $K \ddot{r} r$. The elder Læstadius divides the Kürr into two genera: Blyror (sing. myra), and Mossar (sing. mosse). " The former," he observes, " are grass-grown, and overflowed with water through almost the whole summer; the latter are covered with mosses and always moist, but very seldom overflowed." He enumerates the following species of Myra, the character of which will perhaps be sufficiently understood by the Latin terms into which he translates the vernacular names, for the benefit of strangers not altogether familiar with the language and the subject: 1. Hömyror, paludes graminosæ. 2. $D y$, paludes profundæ. 3. Flarkmyror, or proper kärr, paludes limosæ. 4. Fijällmyror, paludes uliginosæ. 5. Tufmyror, paludes cæspitosæ. 6. Rismyror, paludes virgatæ. 7. Starrängar, prata irrigata, with their subdivisions, dry starrängar or risängar, wet starrängar and fräkiengropar. 8. Pölar, lacunæ. 9. Gölar, fossæ inundatæ. The Mossar, paludes turfosæ, which are of great extent, have but two species: 1. Torfmossar, called also Mossmyror and Snottermyror, and, 2. Bjornmossar.

The accumulations of stagnant or stagnating water originating in bogs are distinguished into Trüsk, stagna, and Tjernar or Tjürnar (sing. Tjern or Tjärn), stagnatiles. Träsk are pools fed by bogs, or water emanating from them, and their bottoms are slimy; Tjernar are small Träsk situated within the limits of Mossar.-L. L. LEESTADIUS, om Möjligheten af Uppodlingar : Lappmarken, pp. 23, 24.

Although the quantity of bog land in New England is less than in many other regions of equal area, yet there is a considerable extent of this formation in some of the Northeastern States. Dana (Manual of Geology, p. 614) states that the quantity of peat in Massachusetts is estimated at 120,000,000 cords, or nearly $569,000,000$ cubic yards, but he does not give either the area or the depth of the deposits. In any event, however, bogs cover but a small percentage of the territory in any of the Northern States, while it is said that one-tenth of the whole surface of Ireland is composed of bogs, 3,000,000 acres of which are peat-bogs, these being sometimes 40 feet thick, and there are still extensive tracts of undrained marsh in England. The amount of this formation in Great Britain has been estimated at $6,000,000$ acres, with an average depth of twelve feet, which would yield 21,600,000 tons of air-dried peat.-AsBJöRNsev, Torv og Torrdrift, Christiana, 1868, p. 6. But more recent investigations greatly raise this estimate.

Peat beds have sometimes a thickness of ten or twelve yards, or even more. A depth of ten yards would give 48,400 cubic yards to the acre. The greatest 
fallen trees in producing bogs, and of smaller animals, insects, aud birds, in destroying the woods.*

Bogs generally originate in the checking of watercourses by the falling of timber or of earth and rocks, or by artificial obstructions across their channels. If the impediment is sufficient to retain a permanent accumulation of water behind it, the trees whose roots are overflowed soon perish, and then by their fall increase the obstruction, and, of course, occasion a still wider spread of the stagnating stream. This process goes on until the water finds a new outlet, at a higher level, not liable to similar interruption. The fallen trees not completely covered by water are soon overgrown with mosses; aquatic and semi-aquatic plants propagate themselves, and spread until they more or less completely fill up the space occupied by the water, and the surface

quantity of firewood yielded by the forests of New England to the acre is 100 cords solid measure, or 474 cubic yards; but this comprises only the trunks and larger branches. If we add the small branches and twigs, it is possible that 600 cubic yards might, in some cases, be cut on an acre. This is only one-eightieth part of the quantity of peat sometimes found on the same area. It is true that a yard of peat and a yard of wood are not the equivalents of each other, but the fuel on an acre of deep peat is worth much more than that on an acre of the best woodland. Besides this, wood is perishable, and the quantity on an acre can not be increased beyond the amount just stated; peat is indestructible, and the beds are always growing. See post, Chap. IV. Cold favors the conversion of aquatic vegetables into peat. Asbjörnsen says some of the best peat he has met with is from a bog which is frozen for forty weeks in the year.

The Greeks and Romans were not acquainted with the employment of peat as fuel, but it appears from a curious passage which I have already cited from Pliny, $N . H$., book xvi., chap. 1, that the inhabitants of the North Sea coast used what is called kneaded turf in his time. This is the finer and more thoroughly decomposed matter lying at the bottom of the peat, kneaded by the hands, formed into small blocks and dried. It is still prepared in precisely the same way by the poorer inhabitants of those shores.

But though the Low German tribes, including probably the Anglo-Saxons, have used peat as fuel from time immemorial, it appears not to have been known to the High Germans until a recent period. At least, I can find neither in Old nor in Middle High German lexicons and glossaries any word signifying pent. Zurb indeed is found in Graff as an Old High German word, but only in the sense of grass-turf, or greensward. Peat bogs of vast extent occur in many High German localities, but the former abundance of wood in the same regions rendered the use of peat unnecessary.

* See Chapter II., post. 
is gradually converted from a pond to a quaking morass. The morass is slowly solidified by vegetable production and deposit, then very often restored to the forest condition by the growth of black ashes, cedars, or, in southern latitudes, cypresses and other trees suited to such a soil, and thus the interrupted harmony of nature is at last re-established.*

In countries somewhat further advanced in civilization than those occupied by the North American Indians, as in mediæval Ireland, the formation of bogs may be commenced by the neglect of man to remove, from the natural channels of superficial drainage, the tops and branches of trees felled for the various purposes to which wood is applicable in his rude industry; and, when the flow of the water is thus checked, nature goes on with the processes I have already described. In such half-civilized regions, too, wind-falls are more frequent than in those where the forest is unbroken, because, when openings have been made in it for agricultural or other purposes, the entrance thus afforded to the wind occasions the sudden overthrow of hundreds of trees which might otherwise have stood for generations, and which would then hare fallen to the ground only one by one, as natural decay brought them down. $\dagger$ Besides this, the flocks bred by man in the pas-

* "Aquatic plants have a utility in raising the level of marshy grounds, which renders them rery valuable, and may well be called a geological function.....

"The engineer drains ponds at a great expense by lowering the surface of the water; nature attains the same end, gratuitously, by raising the level of the soil without depressing that of the water; but she proceeds more slowly. There are, in the Landes, marshes where this natural filling has a thickness of four metres, and some of them, at first lower than the sea, have been thus raised and drained so as to grow summer crops, such, for example, as maize." -Bortel, Mise en valeur des Terres pauvres, p. 227.

The bogs of Denmark-the examination of which by Steenstrup and Vaupell has presented such curious results with respect to the natural succession of forest trees-appear to have gone through this gradual process of drying, and the birch, which grows freely in rery wet soils, has contributed very effectually by its annual deposits to raise the surface above the water level, and thus to prepare the ground for the oak.-VAUPELL, Bögens Indrandring, pp. 39, 40.

The growth of the peat not unfrequently raises the surface of bogs considerably above the level of the surrounding country, and these sometimes burst and overflow lower grounds with a torrent of mud and water as destructive as a current of lava.

tCareful examination of the peat mosses in North Sjælland-which are sc 
toral state keep down the incipient growth of trees on the halfdried bogs, and prevent them from recovering their primitive condition.

Young trees in the native forest are sometimes girdled and killed by the smaller rodent quadrupeds, and their growth is checked by birds which feed on the terminal bud; but these animals, as we shall see, are generally found on the skirts of the wood only, not in its deeper recesses, and hence the mischief they do is not extensive.

In fine, in countries untrodden by man, the proportions and relative positions of land and water, the atmospheric precipitation and evaporation, the thermometric mean, and the distribution of regetable and animal life, are maintained by natural compensations, in a state of approximate equilibrium, and are subject to appreciable change only from geological influences so slow in their operation that the geographical conditions may be regarded as substantially constant and immutable.

\section{Natural Conditions favorable to Geographical Cliange.}

There are, nevertheless, certain climatic conditions and certain forms and formations of terrestrial surface, which tend respects ively to impede and to facilitate the physical degradation both of new countries and of old. If the precipitation, whether great or small in amount, be equally distributed through the seasons, so that there are neither torrential rains nor parching droughts, and if, further, the general inclination of ground be moderate, so that the superficial waters are carried off without destructive rapidity of flow, and without sudden accumulation in the channels of natural drainage, there is little danger of the deg'radation of the soil in consequence of the removal of forest or other regetable covering, and the natural face of the earth may be considered as virtually permanent. These conditions are well exemplified in Ireland, in a great part of England, in extensive districts in Germany and France, and, fortunately, in an immense proportion of

abundant in fossil wood that within thirty jears they have yielded abore a million of trees-shows that the trees have generally fallen from age and not from wind. They are found in depressions on the declivities of which they grew, and they lie with the top lowest, always falling towards the bottom of the valley.--VAUPELL, Bögens Indrandring $i$ de Danske Skove, pp. 10, 14. 
the valley of the Mississippi and the basin of the great American lakes, as well as in many parts of the continents of South America and of Africa; and it is partly, though by no means entirely, owing to topographical and climatic causes that the blight, whicb has smitten the fairest and most fertile provinces of Imperial Rome, has spared Britannia, Germania, Pannonia and Mcesia, the comparatively inhospitable homes of barbarous races, who, in the days of the Crsars, were too little advanced in civilized life to possess either the power or the will to wage that war against the order of nature which seems, hitherto, an almost inseparable condition precedent of high social culture and of great progress in fine and mechanical art.

Destructive changes are most frequent in countries of irregular and mountainous surface, and in climates where the precipitation is confined chiefly to a single season, and where, of course, the year is divided into a wet and a dry period, as is the case throughout a great part of the Ottoman empire, and indeed in a large proportion of the whole Mediterranear basin.

In mountainous countries various causes combine to expose the soil to constant dangers. The rain and snow usually fall in greater quantity, and with much inequality of distribution; the snow on the summits accumulates for many months in succession, and then is not unfrequently almost wholly dissolved in a single thaw, so that the entire precipitation of months is in a few hours hurried down the flanks of the mountains, and through the ravines that furrow them; the natural inclination of the surface promotes the swiftness of the gathering currents of diluvial rain and of melting snow, which soon acquire an almost irresistible force and power of removal and transportation; the soil itself is less compact and tenacious than that of the plains, and if the sheltering forest has been destroyed, it is confined by few of the threads and ligaments by which nature had bound it together and attached it to the rocky groundwork. IIence every considerable shower lays bare its roods of rock, and the torrents sent down by the thaws of spring, and by occasional heavy discharges of the summer and autumnal rains, are seas of mud and rolling stones that sometimes lay waste and bury beneath them acres, and even miles, of pasture and field and vineyard.*

* The character of geological formation is an element of very great import- 


\section{Destmuctiveness of Man.}

$\mathrm{Mar}_{\iota}$ has too long forgotten that the earth was given to him for usufruct alone, not for consumption, still less for profligate waste. Nature has provided against the absolute destruction of any of her elementary matter, the raw material of her works; the thunderbolt and the tornado, the most convulsive throes of even the volcano and the earthquake, being only phenomena of decomposition and recomposition. But she has left it within the power of man irreparably to derange the combinations of inorganic matter and of organic life, which through the night of æons she had been proportioning and balancing, to prepare the earth for his habitation, when in the fulness of time his Creator should call him forth to enter into its possession.

Apart from the hostile influence of man, the organic and the inorganic world are, as I have remarked, bound together by such mutual relations and adaptations as secure, if not the absolute permanence and equilibrium of both, a long continuance of the established conditions of each at any given time and place, or at least, a very slow and gradual succession of changes in those conditions. But man is everywhere a disturbing agent. Wherever he plants his foot, the harmonies of nature are turned to discords. The proportions and accommodations which insured the stability of existing arrangements are overthrown. Indigenous vegetable and animal species are extirpated, and supplanted by others of foreign origin, spontaneous production is forbidden or restricted, and the face of the earth is either laid bare or covered with a new and reluctant growth of vegetable forms and with alien tribes of animal life. These intentional changes and substitutions constitute, indeed, great revolutions; but vast as is their magnitude and im-

ance in determining the amount of erosion produced by running water, and, of course, in measuring the consequences of clearing off the forests. The soil of the French Alps yields very readily to the force of currents, and the declivities of the northern Apennines, as well as of many minor mountain ridges in Tuscany and other parts of Italy, are covered with earth which becomes itself almost a fluid when saturated with water. Hence the erosion of such surfaces is vastly greater than on many other mountains of equal steepness of inclination. The traveller who passes over the route between Bologna and Florence, and the Perugia and the Siena roads from the latter city to Rome, will have many opportunities of observing such localities. 
portance, they are, as we shall see, insignificant in comparison with the contingent and unsought results which have flowed from them.

The fact that, of all organic beings, man alone is to be regarded as essentially a destructive power, and that he wields energies to resist which Nature - that nature whom all material life and all inorganic substance obey-is wholly impotent, tends to prove that, though living in physical nature, he is not of her, that he is of more exalted parentage, and belongs to a higher order of existences, than those which are born of her womb and live in blind submission to her dictates.

There are, indeed, brute destroyers, beasts and birds and insects of prey-all animal life feeds upon, and, of course, destroys other life,-but this destruction is balanced by compensations. It is, in fact, the very means by which the existence of one tribe of animals or of vegetables is secured against being smothered by the encroachments of another; and the reproductive powers of species which serve as the food of others are always proportioned to the demand they are destined to supply. Man pursues his victims with reckless destructiveness; and while the sacrifice of life by the lower animals is limited by the cravings of appetite, he unsparingly persecutes, even to extirpation, thousands of organic forms which he can not consume.*

* The terrible destructiveness of man is remarkably exemplified in the chase of large mammalia and birds, for single products, attended with the entire waste of enormous quantities of flesh and of other parts of the animal which are capable of valuable uses. The wild cattle of South America are slaughtered by millions, for their hides and horns; the buffalo of North America, for his skin or his tongue; the elephant, the walrus, and the narwhal, for their tusks; the cetacea, and some other marine animals, for their whalebone and oil ; the ostrich and other large birds, for their plumage. Within a few years, sheep have been killed in New England, by whole flocks, for their pelts and suet alone, the flesh being thrown arvay; and it is even said that the bodies of the same quadrupeds have been used in Australia as fuel for limekilns. What a vast amount of human nutriment, of bone, and of other animal products valuable in the arts, is thus recklessly squandered I In nearly all these cases, the part which constitutes the motive for this wholesale destruction, and is alone saved, is essentially of insignificant value as compared with what is thrown away. The horns and hide of an ox are not economically worth a tenth part as much as the entire carcass. During the present year, large quantitics of Indian corn have been used as domestic fuel, and even for burning 
The earth was not, in its natural condition, completely adlapted to the use of man, but only to the sustenance of wild animals and wild vegetation. These live, multiply their kind in just proportion, and attain their perfect measure of strength and beauty,

lime, in Iowa and other Western States. Corn at from fifteen to eiglateen cents prer bushel is found cheaper than wood at from five to seven dollars per cord, or coal at six or seven dollars per ton.-Rep. Agric.Dept., Nov, and Dec., 1872, p. $48 \%$.

One of the greatest benefits to be expected from the improvements of civilization is, that increased facilities of communication will render it possible to transport to places of consumption much valuable material that is now wasted because the price at the nearest market will not pay freight. The cattle slaughtered in South America for their hides would feed millions of the starring population of the Old World, if their flesh conld be economically preserved and transported across the ocean. This indeed is already done, but on a scale which, though absolutely considerable, is relatively insignificant. South America sends to Europe a certain quantity of nutriment in the form of meat extracts, Liebig's and others; and preserved flesh from Australia is beginning to figure in the English market.

[Since the above paragraph was written the trausportation of fresh meat from distant countries to England has been attended with remarkable success. A single ship is said on good authority to have brought from New Zealand to England, in the spring of 1882 , the flesh of 5,000 sheep in perfectly grood condition. The course of this vessel necessarily lay across the tropies, and her delicate freight sustained no injury whatever from the great heat to which she was exposed. By means of a refrigerating apparatus the meat was kept at a temperature near or at the freezing point.]

A very important recent economy is the utilization of those portions of certain agricultural products that were formerly treated as mere refuse. The cotton-growing States in America produce annually about three million tons of cotton seed. This until very recently has been thrown away as a useless incumbrinee, but it is now valued at from ten to twelve dollars per ton for the cotton fibre which adheres to it, for the oil extracted from it, and for the feed which it afterwards furnishes to cattle. The oil-which may be described as neutral-is used very largely for mixing with other oils, many of which bear a large proportion of it without injury to their special properties. The sense, or pulp of the olive remaining after the oil has been expressed, until very recently considered worthless except as manure, is now found to be capable of yielding, by a different treatment, a considerable quantity of oil and some other valuable products. Even the waste from silk mamufactories, and the shreds and fragments from the shops of modistes, formerly thrown away as useless, are now carefully saved. A long series of costly experiments has led to the invention of processes for reducing all this material to a fibrous condition, and for re-spinning and weaving it into every possible tissue. The opera. tion is carried on in England on a seale of really great industrial importance.

The substitution of expensive machinery for mamual labor, even in agricul. 
without producing or requiring any important change in the nataral arrangements of surface or in each other's spontaneous tendencies, except such mutual repression of excessive increase as may prevent the extirpation of one species by the encroachments

ture-not to speak of older and more familiar applications-besides being highly remuncrative, has better secured the harvests, and it is computed that. the 230,000 threshing machines used in the United States in 1870 obtained five per cent. more grain from the sheaves which passed through them than could have been secured by the use of the flail.

We are also beginning to learn a better economy in dealing with the inorganic world. The utilization-or, as the Germans more happily call it, the Verwerthung, the becoorthing-of waste from metallurgical, chemical and manufacturing establishments, is among the most important results of the application of science to industrial purposes. The incidental products from the laboratories of manufacturing chemists often become more valuable than those for the preparation of which they were erected. The slags from silver refineries, and even from smelting houses of the coarser metals, have not unfrequently yielded to a second operator a better return than the first had derived from dealing with the natural ore; and the saving of lead carried off in the smoke of furuaces has, of itself, given a large profit on the capital invester in the works. According to Ure's Dictionary of Arts, see vol. ii., p. 832, an English miner has constructed flues five miles in length for the condensation of the smoke from his lead-works, and makes thereby an annual saving of metal to the value of ten thousand pounds sterling. A few years ago, an ofîcer of an American mint was charged with embezzling gold committed to him for coinage. He insisted, in his defence, that much of the metal was volatilized and lost in refining and melting, and upon scraping the chimneys of the melting furnaces and the roofs of the adjacent houses, gold enough was found in the soot to account for no small part of the deficiency.

It is familiarly known that the sweepings of gold and silver smiths' shops have a regular market value. It is worth noticing that the "sweep" of the British mint in 1873 yielded L. 2,995, 8, 3 .

There are still, however, cases of enormous waste in many mineral and mechanical industries. Thus, while in many European countries common salt is a government monopoly, and consequently so dear that the poor do not use as much of it as health requires, in others, as in Transylvania, where it is quarried like stone, the large blocks only are saved, the fragments, to the amount of millions of hundredweights, being thrown away.-Boner, Transylcania, p. 455,6 .

One of the most interesting and important branches of economy at the present day is the recovery of agents such as ammonia and others which had been utilized in chemical manufactures, and re-employed them indefinitely after wards in repeating the same process.

Among the supplemental exhibitions which will be formed in connection with the Vienna Universal Exhibition is to be one showing what steps have been 
of another. In short, without man, lower animal and spontaneous vegetable life would have been practically constant in type, distribution and proportion, and the physical geography of the earth would have remained undisturbed for indefinite periods, and been subject to revolution only from slow development, srom possible unknown cosmical causes, or from geological action.

But man, the domestic animals that serve him, the field and garden plants the products of which supply him with food and clothing, can not subsist and rise to the full development of their ligher properties, unless brute and unconscious nature be effectually combated, and, in a great degree, vanquished by human art. Hence, a certain measure of transformation of terrestrial surface, of suppression of natural, and stimulation of artificially modified productivity becomes necessary. This measure man has unfortunately exceeded. He has felled the forests whose network of fibrous roots bound the mould to the rocky skeleton of the earth; but had he allowed here and there a belt of woodland to reproduce itself by spontaneous propagation, most of the mischiefs which his reckless destruction of the natural protection of the soil has occasioned would have been averted. He has broken up the mountain reservoirs, the percolation of whose waters through unseen channels supplied the fountains that refreshed his cattle and fertilized his fields; but he has neglected to maintain the cisterus and the canals of irrigation which a wise antiq. uity had constructed to neutralize the consequences of its own imprudence. While he has torn the thin glebe which confined the light earth of extensive plains, and has destroyed the fringe of semi-aquatic plants which skirted the coast and checked the drifting of the sea sand, he has failed to prevent the spreading of the dunes by clothing them with artificially propagated vegetation. He has ruthlessly warred on all the tribes of animated nature whose spoil he could convert to his own uses, and he has not

taken since 1851 (the date of the first London Exhibition) in the utilization of substances previously regarded as waste. On the one hand will be shown the waste products in all the industrial processes included in the forthcoming Exhibition; on the other hand, the useful products which have been obtained from such wastes since 1851. This is intended to serve as an incentive to fur ther researches in the same important direction. 


\title{
protected the birds which prey on the insects most destructive to his own harvests.
}

\author{
Purely untutored humanity, it is true, interferes comparatively
} little with the arrangements of nature,* and the destructive

$\because$ It is an interesting and not hitherto sufficiently noticed fact, that the domestication of the organic world, so far as it has yet been achieved, belongs, not indeed to the savage state, but to the earliest dawn of civilization; the conquest of inorganic nature, almost as exclusively to the most advanced stages of artificial culture. Civilization has added little to the number of vegetable or animal species grown in our fields or bred in our folds-the cranberry and the wild gripe being almost the only plants which the Anglo-American has reclaimed out of our vast native florit and added to his harvests-while, on the contrary, the subjugation of the inorganic forces, and the consequent extension of man's sway over, not the annual products of the earth only, but her substance and her springs of action, is almost entirely the work of highly refined and cultivated ages. The employment of the clasticity of wood and of horn, as a projectile power in the bow, is netrly universal among the rudest savages. The application of compressed air to the same purpose in the blowpipe is more restricted, and the use of the mechanical powers, the inclined plane, the wheel and axle, and even the wedge and lever, seems almost unkwown except to civilized man. I have myself seen European peasants to whom one of the simplest applications of this latter power was a revelation.

It is familiarly known to all who have occupied themselves with the psychology and habits of the ruder races, and of persons with imperfectly developed intellects in civilized life, that although these humble tribes and individuals sacrifice, without scruple, the lives of the lower animals to the gratification of their appetites and the supply of their other physical wants, yet they nevertheless seem to cherish with brutes, and even with regetable life, sympathies which are much more feebly felt by civilized men. May we not ascribe to this sympathy the fact that Homer does not refer to the ass as a type of stupidity, nor to the swine as an example of uncleanness? The father of Ulysses is called the goullike soineterd. The popular traditions of the simpler peoples recognize a certain community of nature between man, brute animals, and even plants; and this serves to explain why the apologue or fable, which ascribes the power of speech and the faculty of reason to birds, quadrupeds, insects, flowers and trees, is one of the earliest forms of literary composition.

In almost every wild tribe, some particular quadruped or bird, though persecuted as a destroyer of other animals more useful to man, or hunted for food, is regarded with peculiar respect, one might almost say, affection. The Ainos, after killing a bear, sit round the body in great solemnity, as if worshipping, and offer it food and drink. Some of the North American aboriginal nations celebrate a propitiatory feast to the manes of the intended victim before they commence a bear-hunt; and the Norwegian peasantry have not only retained an old proverb which ascribes to the same animal " $t i$ IFonds Styrke og tolv Moends Fid," ten men's strength and twelve men's cunning, but 
agency of man becomes more and more energetic and unsparing as he advances in civilization, until the impoverishment, with which his exhaustion of the natural resources of the soil is threatening him, at last awakens him to the necessity of preserving what is left, if not of restoring what has been wantonly wasted. The

they still pay to him something of the reverence with which ancient superstition invested him. The student of Icelandic literature will find in the saga of Finnbogi hinn rami a curious illustration of this feeling, in an account of a dialogue between a Norwegian bear and an Icelandic champion-dumb show on the part of Bruin, and chivalric words on that of Finnbogi-followed by a duel, in which the latter, who had thrown away his arms and armor in order that the combatants might meet on equal terms, was victorious. See also Fris, Lappisk Mythologi, Christiania, 1871, §37, and the earlier authors there cited. Drummond Hay's very interesting work on Morocco contains many amusing notices of a similar feeling entertained by the Moors towards the redoubtable enemy of their flocks-the lion.

This sympathy helps us to understand how it is that most if not all the domestic animals - if indeed they ever existed in a wild state-were appropriated, reclaimed and trained before men had been gathered into organized and fixed communities, that almost every known esculent plant had acquired substantially its present artificial character, and that the properties of nearly all vegetable drugs and poisons were known at the remotest period to which historical records reach. Did nature bestow upon primitive man some instinct alin to that by which she has been supposed to teach the brute to select the nutritious and to reject the noxious vegetables indiscriminately mixed in forest and pasture?

This instinct, it must be admitted, is far from infallible, and, as has been hundreds of times remarked by naturalists, it is in many cases not an original faculty but an acquired and transmitted habit. It is a fact familiar to persons engaged in sheep husbandry in New England-and I have seen it confirmed by personal observation-that sheep bred where the common laurel, as it is called, Kalmia angustifolia, abounds, almost always avoid browsing upon the leaves of that plant, while those brought from districts where laurel is unknown, and turned into pastures where it grows, very often feed upon it and are poisoned by it. A curious acquired and hereditary instinct, of a different character, may not improperly be noticed here. I refer to that by which horses bred in provinces where quicksands are common avoid their dangers or extricate themselves from them. See Brésontier, Mémoire sur les Duncs, Annales des Ponts et Chaussées, 1833 : premier sémestre, pp. 155-157.

It is commonly said in New England, and I beliere with reason, that the crows of this generation are wiser than their ancestors. Scarecrows which were effectual fifty years ago are no longer respected by the plunderers of the cornfield, and new terrors must from time to time be invented for its protection.

Schroeder van der Kolk, in Het Verschil tusschen den Psychischen Aanleg van 
wandering savage grows no cultivated vegetable, fells no forest, and extirpates no useful plant, no noxious weed. If his skill in the chase enables him to entrap numbers of the animals on which he feeds, he compensates this loss by destroying also the lion, the tiger, the wolf, the otter, the seal, and the eagle, thus indirectly protecting the feebler quadrupeds and fish and fowls, which would otherwise become the booty of beasts and birds of prey. But with stationary life, or at latest with the pastoral state, man at once commences an almost indiscriminate warfare upon all the forms of animal and regetable existence around him, and as he advances in civilization, he gradually eradicates or transforms every spontaneous product of the soil he occupies.*

\section{Human and Brute Action Compared.}

It is maintained by authorities as high as any known to modern science, that the action of man upon nature, though greater in degree, does not differ in kind from that of wild animals. It is

het Dier en van den Mensch, cites many interesting facts respecting instincts lost, or newly developed and become hereditary, in the lower auimals, and he quotes Aristotle and Pliny as evidence that the common quadrupeds and fowls of our fields and our poultry yards were much less perfectly domesticated in their times than long, long ages of servitude have now made them.

Among other instances of obliterated instincts, this author states that in Holland, where, for centuries, the young of the cow has been usually taken from the dam at birth and fed by hand, calves, even if left with the mother, make no attempt to suck; while in England, where calves are not weaned until several weeks old, they resort to the udder as naturally as the young of wild quadrupeds.-Ziel en Ligchaam, p. 128, $n$.

Perhaps the half-wild character ascribed by P. Læstadius and other Swedish writers to the reindeer of Lapland, may be in some degree due to the comparative shortness of the period during which he has been partially tamed. The domestic swine bred in the woods of Hungary, and the buffalo of Southern Italy, are so wild and savage as to be very dangerous to all but their keepers. The former have relapsed into their original condition, the latter, perhaps, have never been fully reclaimed from it.

* The difference between the relatious of savage life and of incipient civilization to nature, is well seen in that part of the valley of the Mississippi which was once occupied by the mound builders and afterwards by the far less developed Indian tribes. When the tillers of the fields which must have been cultivated to sustain the large population that once inhabited those regions, perished or were driven out, the soil fell back to the normal forest state, and the savages who succeeded the more advanced race interfered very little, if at all, with the ordinary course of spontaneous nature 
perhaps imposible to establish a radical distinction in genere between the two classes of eflects, but there is an essential diflerence between the motive of action which calls ont the cinereves of civilized man and the mere appetite which controls the life of the beast. The action of man, indeed, is frequently followed ly unforeseen and undesired results, yet it is nevertheless guided by a self-conscious will aiming ats often at secondary and remote at at inmediate objects. The wild anmal, on the other hand, acts instinctively, and, so far as we are able to perceive, always with a view to single and direct purposes. The backwoodsinan and the beaver alike fell trees; the man, that he may comvert the forest into an olive grove that will mature its fruit only for a succeeding generation; the bearer, that he may feed upon the bark of the trees or nse them in the construction of his habitation. The action of brutes upon the material world is slow and gradual, and usually limited, in any given case, to a narrow extent of territory. Nature is allowed time and opportunity to set her restorative powers at work, and the destructive animal has hardly retired from the field of his ravages before nature has repaired the damages occasioned by his operations. In fact, he is expelled from the seene by the very efforts which she makes for the restoration of her dominion. Man, on the contrary, extends his action over vast spaces, his revolutions are swift and radical, and his devastations are, for an almost incalculable time after he has withdrann the arm that gave the blow, irreparable.

The form of geographical surface, and very probably the climate, of a given comntry, depend much on the character of the regetable life belonging to it. Man has, by domestication, greatly, changed the habits and properties of the plants he rears; he hasby roluntary selection, immensely modified the forms and qualities of the animated creatures that serve him; and he lias, at the same time, completely rooted out many forms of animal if not of regetable being." What is there in the influence of brute life

* Whatever may be thought of the modification of organic species by natural selection, there is certainly no evidence that animals have exerted upon any form of life an influence analogous to that of domestication upon plants, quadrupeds and birds reared artificially by man; and this is as true of unforeseen as of purposely effected improvements accomplished by voluntary selection of breeding animals.

It is true that nature employs birds and quadrupeds for the dissemination of 
that corresponds to this? We have no reason to believe that, in that portion of the American continent which, though peopled by many tribes of quadruped and fowl, remained uninhabited by man or only thinly occupied by purely savage tribes, any sensible geographical change had occurred within twenty centuries before the epoch of discovery and colonization, while, during the same period, man had changed millions of square miles, in the fairest and most fertile regions of the Old World, into the barrenest deserts.

The ravages committed by man subvert the relations and destroy the balance which nature had established between her organized and her inorganic creations, and she avenges herself upon the intruder, by letting loose upon her defaced provinces destructive energies hitherto kept in check by organic forces destined to be his best auxiliaries, but which he has unwisely dispersed and driven from the field of action. When the forest is gone, the great reservoir of moisture stored up in its vegetable mould is evaporated, and returns only in deluges of rain to wash away the parched dust into which that mould has been converted. The well-wooded and humid hills are turned to ridges of dry rock, which encumber the low grounds and choke the watercourses with their débris, and-except in countries favored with an equable distribution of rain through the seasons, and a moderate and regular inclination of surface-the whole earth, unless rescued by human art from the physical degradation to which it tends, becomes an assemblage of bald mountains, of barren, turfless hills, and of swampy and malarious plains. There are parts of Asia Minor, of Northern Africa, of Greece, and even of Alpine Europe, where the operation of causes set in action by man has brought the face of the earth to a desolation almost as complete as that of the moon; and though, within that brief space of time which we we call "the historical period," they are known to have been covered with luxuriant woods, verdant pastures, and fertile meadows, they are now too far deteriorated to be reclaim-

vegetable and even of animal species. But when the bird drops the seed of a fruit it has swallowed, and when the sheep transports in its fleece the seedvessel of a burdock from the plain to the mountain, its action is purely mechanical and unconscious, and does not differ from that of the wind in producing the same effect. 
able by man, nor can they become again fitted for human use, except through great geological changes, or other mysterious influences or agencies of which we have no present knowledge and over which we have no prospective control. The earth is fast becoming an unfit home for its noblest inhabitant, and another era of equal human crime and human improvidence, and of like duration with that through which traces of that crime and that improvidence extend, would reduce it to such a condition of impoverished productiveness, of shattered surface, of climatic excess, as to threaten the depravation, barbarism and perhaps even extinction of the species.*

\section{Physical Improvement.}

True, there is a partial reverse to this picture. On narrow theatres, new forests have been planted; inundations of flowing streams restrained by heavy walls of masonry and other constructions; torrents compelled to aid, by depositing the slime with which they are charged, in filling up lowlands, and raising the level of morasses which their own overflows had created; ground submerged by the encroachments of the ocean, or exposed to be covered by its tides, has been rescued from its dominion by diking; swamps and even lakes have been drained, and their beds brought within the domain of agricultural industry; drifting coast dunes have been checked and made productive by plantation; seas and inland waters have been repeopled with

* __ And it may be remarked that, as the world has passed through these several stages of strife to produce a Christendom, so by relaxing in the enterprises it has learnt, does it tend downwards, through inverted steps, to wildness and the waste again. Let a people give up their contest with moral evil ; disregard the injustice, the ignorance, the greediness, that may prevail among them, and part more and more with the Christian element of their civilization; and in declining this battle with sin, they will inevitably get embroiled with men. Threats of war and revolution punish their unfaithfulness; and if then, instead of retracing their steps, they yield again, and are driven before the storm, the very arts they had created, the structures they had raised, the usages they had established, are swept away ; ' in that very day their thoughts perish.' The portion they had reclaimed from the young earth's ruggedness is lost; and failing to stand fast against man, they finally get embroiled with nature, and are thrust down beneath her ever-living hand."-MAntweau's Sermon, "The Good Soldier of Jesus Christ." 
fish, and even the sands of the Sahara have been fertilized by artesian fountains. These achievements are more glorious than the proulest trimmphs of war, but, thus far, they give iut faint hope that we shall yet make full atonement for our spendthrift waste of the bounties of nature.*

\section{Limits of Human Power.}

It is, on the one hand, rash and muphilosophical to attempt to set limits to the ultimate power of man over inorganic nature, and it is mprofitable, on the other, to speculate on what may be accomplished by the discovery of now unknown and unimagined natural forces, or eveu by the invention of new arts and new processes. But since we have seen aerostation, the motive power of elastic vapor's, the wonders of modern telegraphy, the destructive explosiveness of gumpowder, of nitro-glycerine, and even of a substance so harmless, unresisting and inert as cotton, there is little in the way of mechanical achievement which seems hopelessly impossible, and it is hard to restrain the imagination from wandering forward a couple of generations to an epoch when our descendants shall hare adranced as far beyond us in physical conquest, as we have marehed beyond the trophies erected by our grandfather's. There are, nevertheless, in actual practice, limits to the efficiency of the forces which we are now able to bring into the field, and we must admit that, for the present, the agencies known to man and controlled by him are inadequate to the reducing of great Alpine precipices to such slopes as would enable them to support a vegetable clothing, or to the covering of large extents of denuded rock with earth, and planting upon them a forest growth. Yet among the mysteries which science is hereafter to reveal, there may be still undiscovered methods of accomplishing even grander wonders than these. Mechanical philosophers have suggested the possibility of accumulating and treasuring up for human use some of the greater natural forces,

\footnotetext{
* The wonderful success which has attended the measures for subduing torrents and preventing inundations employed in Southern France since 1865, and described in Chapter III., post, ought to be here noticed as a splendid and inost encouraging example of well-directed effort in the way of physical resto. ration.
} 
which the action of the elements puts forth with such astonishing energe.* Could we gather, and bind, and make sulsecrient to our eontrol, the puwer which a Thest Inllan linrricane exerts through a small area in one continuous blast, or the momentum expeniled by the wares, in a tempestnous winter, upon the hreakwater at Cherbourg, or the lifting power of the tirle, for a month,

* Some well-knomn experiments show that it is quite posible to accumulate the solar heat by a simple anparatus, and thus to obtain a temperature which might be economically important even in the climate of switzerland. Salussure, by receiving the sun's rays in a nest of boxes blackened within and cor. ered with glass, raised a thermoneter enclosed in the imer box to the boiling print ; and under the more powerful sun of the Cape of Good Hope, Sir John Iferschel cooked the materials for a family dimer by a similar process, usiug, however, but a single hox, surrounded with dry sand and covered with two glitsses. Thiy should not so catsy a method of cconomizing fuel be resorted to in Italy, in Spain, and even in more northerly climates?

The unfortunate. John Davidion records in his journal that he saved fuel in MIorocco by expowing his tea-kettle to the sum on the roof of his house, mhere the water rose to the temperature of one hundred and forty degrees, and, of course, needed little fire to bring it to boil. But this was the direct and simple, not the concentrated or accumulated, heat of the sun.

On the utilizing of the solar heat, simply as heat, see the work of Mогснот, La Chaleur solaire et ses applications industrielles. Paris, 1869.

The reciprocal convertibility of the natural forces has suggested the posibility of advantageously converting the heat of the sun into mechanical potrer. Ericson catculates that in all latitudes hetween the equator and tij, a huudred square fect of surface exposer to the solar rays develop contiuuously, for niue hours a day on an average, eight and one-fifth horse power.

I do not know that any attempts have been made to accumulate and store up for use at pleasure, force derived from this powerful source.

$\uparrow$ In heavy storms, the force of the waves as they strike against a sea-wall is from one and a half to two tons to the square foot, and Sterenson, in one instance at Skerryvore and in another at the Bell Rock lighthouse, found this force equal to nearly three tons per foot.

The seaward front of the breakwater at Cherbourg exposes a surface of about :, 500 , (1000 sruare feet. In rough weather the wares beat against this whole face, thourh, at the depth of twenty-two rards, which is the incieht of the brakwater, they exert a very much less riolent motive force than at and near the surface of the sea, because this force diminishes in geometrical, as the distance below the surface increases in aritlmetical, proportion. The shock of the watres is received several thousind tines in the cmaras of twentyfour hours, and hence the sum of impulse which the lorealswater re-ists in one stormy dity amounts to many thousands of millions of toms. The breakwater is entire]y an artifial construction. If then man could accummlate and control the furces which he is able effectually to resint, he might be said to be physically speaking, omnipotent. 
at the head of the Bay of Fundy, or the pressure of a square mile of sea water at the depth of five thousand fathoms, or a moment of the might of an earthquake or a voleano, our age-which moves no mountains and casts them into the sea by faith alonemight hope to scarp the rugged walls of the Alps and Pyrenees and Mount Taurus, robe them once more in a vegetation as rich as that of their pristine woods, and turn their wasting torrents into refreshing streams.

The recent discoveries of, if not new laws, at least of new relations between electrical energy and other natural forces and objects, and the various inventions for rendering this energy available for human uses, open a prospect of vast addition to the powers hitherto wielded by man. It is too soon even to conjecture by what limits these powers are conditioned, but it would seem that there is every reason to expect that man's most splendid achievements hitherto, in the conquest of Nature, will soon be eclipsed by new and more brilliant victories of mind over matter.

Could this old world, which man has overthrown, be rebuilded, could human cunning rescue its wasted hillsides and its deserted plains from solitude or mere nomade occupation, from barrenness, from nakedness, and from insalubrity, and restore the ancient feriility and healthfulness of the Etruscan sea coast, the Campagna and the Pontine marshes, of Calabria, of Sicily, of the Peloponnesus and insular and continental Greece, of Asia Minor, of the slopes of Lebanon and Hermon, of Palestine, of the Syrian desert, of Mesopotamia and the delta of the Euphrates, of the Cyrenaica, of Africa proper, Numidia and Mauritania, the thronging millions of Europe might still find room on the Eastern continent, and the main current of emigration be turned towards the rising instead of the setting sun.

But changes like these must await not only great political and moral revolutions in the governments and peoples by whom those regions are now possessed, but, especially, a command of pecuniary and of mechanical means not at present enjoyed by those nations, and a more advanced and generally diffused knowledge of the processes by which the amelioration of soil and climate is possible than now anywhere exists. Until such circumstances shall conspire to favor the work of geographical regeneration, the countries I have mentioned, with here and there a local excep- 
tion, will continue to sink into yet deeper desolation, and in the meantime the American continent, Southern Africa, Australia, New Zealand, and the smaller oceanic islands, will be almost the only theatres where man is engaged, on a great scale, in transforming the face of nature.

\section{Importance of Physical Conservation and Restoration.}

Comparatively short as is the period through which the colonization of foreign lands by European emigrants extends, great and, it is to be feared, sometimes irreparable injury has already been done in the various processes by which man seeks to subjugate the virgin earth; and many provinces, first trodden by the homo sapiens Europa within the last two centuries, begin to show signs of that melancholy dilapidation which is now driving so many of the peasantry of Europe from their native hearths. It is evidently a matter of great moment, not only to the population of the states where these symptoms are manifesting themselves, but to the general interests of humanity, that this decay should be arrested, and that the future operations of rural husbandry and of forest industry, in districts yet remaining substantially in their native condition, should be so conducted as to prevent the widespread mischiefs which have been elsewhere produced by thoughtless or wanton destruction of the natural safeguards of the soil. This can be done only by the diffusion of knowledge on this subject among the classes that, in earlier days, subdued and tilled ground in which they had no vested rights, but who, in our time, own their woods, their pastures, and their ploughlands as a perpetual possession for them and theirs, and have, therefore, a strong interest in the protection of their domain against deterioration.

\section{Physical Restoration.}

Many circumstances conspire to invest with great present interest the questions: how far man can permanently modify and ameliorate those physical conditions of terrestrial surface and climate on which his material welfare depends; how far he can compensate, arrest, or retard the deterioration which many of his agricultural and industrial processes tend to produce; and how far he can restore fertility and salubrity to soils which his follies 
or his crimes have made barren or pestilential. Among these circumstances, the most prominent, perhaps, is the necessity of providing new homes for a European population which is increasing more rapidly than its means of subsistence, new physical comforts for classes of the people that have now become too much eulightened, and have imbilsed too much culture, to submit to a longer deprivation of a share in the material enjoyments which the privileged rauks have hitherto monopolized.

To supply new lives for the emigrant swarms, there are, first, the vast unoccupied prairies and forests of America, of Australin, and of many other great occanic islands, the sparsely inhabited and still unexhansted soils of Southern and even Central Africa, and, fimally, the inporerished and half-depopulated shores of the Mediterrane:m, and the interior of Asia límor and the farther East. To fumish those who remain, after emigration shall have conveniently reducerl the too dense population of many Euro pean states, with nose means of sensuous and of intellectual well-heing which are styled "artificial wauts" when demanded by the humble and the pour, but are admitted to be "necessaries" when claimed by the noble and the rich, the soil must be stimulated to its highest power's of production, and man's utmost ingenuity and energy must he taslied to renovate a nature dintined, by his improvidence, of fomtains which a wise economy would have made plenteons and peremnial sonrces of beanty, health and wealth.

In those yet virgin lamds which the progress of modern discovery in both hemispheres has brought and is still bringing to the knowledge and control of cirilized man, not much inprovement of great physical conditions is to be looked for. The proportion of forest is indeed to be considerably reduced, superfluous waters to be drawn off, and routes of internal communication to be constructed; but the primitive geouraphical and climatic features of these countries onght to be, as far as possible, retained.

In reclaiming and reoceupying lands laid waste by human improvidence or malice, and abandoned by man or oceupied only by a nomale or thinly scattered population, the task of the pioneer settler is of a very different character. He is to become a co-Torker with nature in the reconstruction of the damaged 
fabric which the negligence or the wantonness of former lodgers has rendered untenantable. He must aid her in reclothing the mountain slopes with forests and vegetable mould, thereloy restoring the fountains which she provided to water them; in checking the devastating fury of torrents, and bringing lack the surface drainage to its primitive narrow channels; and in drying deally morasses by opening the natural sluices which have been choked up, and cutting new canals for drawing off their stagnant waters. He must thus, on the one hand, create new reservoirs, and, on the other, remove mischievous accumulations of moisture, thereby equalizing and regulating the sources of atmospheric humidity and of flowing water, both which are so essential to all vegetable growth, and, of course, to human and lower animal life.

I have remarked that the effects of human action on the forms of the earth's surface could not always be distinguished from those resulting from geological causes, and there is also much uncertainty in respect to the precise influence of the clearing and cultivating of the ground, and of other rural operations, upon climate.* It is disputed whether either the mean or the extremes of temperature, the periods of the seasons, or the amount of distribution of precipitation and of evaporation, in any comntry whose ammals.are known, have nndergone any change during the historical period. It is, incleed, as has been already olserved, impossible to doulst that many of the operations of the pioneer settler tend to produce great modifications in atmospheric humidity, temperature and electricity; but we are at present umathe to

* The indestructibility of some forms of human construction is well exemplified by the ancient maize-fields of the American Indians, where the little hillocks in which the seeds were deposited remain plainly divinguishable after the lapse of centuries. The most remarkable case of this sort known to me, however, is the persistence of the ancient ditches and ridges of loose earth, which served as boundaries for the allotments of land to disclarged reterans of the Roman soldiery under the emperors. These are particularly noticed by Reclus, and they are as enduring as are the veres in which Virgil complains of being thus ejected from his possessions near . Inutua, by forein legionaries to whom his l:meds had been assigned as a military hounty. The same rentark may be applied to the small ancient channels of irrigation in Armenia and other Eistern provinees, in ficlds probably abandoned even before the foundation of Rome. 
determine how far one set of effects is neutralized by another, or compensated by unknown agencies. This question scientific research is inadequate to solve, for want of the necessary data; but well-conducted observation in regions now first brought under the occupation of man, combined with such historical evidence as still exists, may be expected at no distant period to throw much light on this subject.

Australia and New Zealand are, perhaps, the countries from which we have a right to expect the fullest elucidation of these difficult and disputable problems. Their colonization did not commence until the physical sciences had become matter of almost universal attention, and is, indeed, so recent that the memory of living men embraces the principal epochs of their history; the peculiarities of their fauna, their flora, and their geology are such as to have excited for them the liveliest interest of the votaries of natural science; their mines have given their people the necessary wealth for procuring the means of instrumental observation, and the leisure required for the pursuit of scientific research; and large tracts of virgin forest and natural meadow are rapidly passing under the control of civilized man. Here, then, exist greater facilities and stronger motives for the careful study of the topics in question than have ever been found combined in any other theatre of European colonization.

In North America, the change from the natural to the artificial condition of terrestrial surface began about the period when the most important instruments of meteorological observation were invented. The first settlers in the territory now constituting the United States and the British American provinces had other things to do than to tabulate barometrical and thermometrical readings, but there remain some interesting physical records from the early days of the colonies,* and there is still an immense ex-

* The Travels of Dr. Dwight, president of Yale College, which embody the results of his personal observations, and of his inquiries among the early settlers, in his vacation excursions in the Northern States of the American Union, though presenting fow instrumental measurements or tabulated results, are of value for the powers of observation they exhibit, and for the sound common sense with which many natural phenomena, such for instance as the formation of the river meadows, called "intervales," in New England, are explained. They present a true and interesting picture of physical conditions, many of 
tent of North American soil where the industry and the folly of man have as yet produced little appreciable change. Ilere, too, with the present increased facilities for scientific observation, the future effects, direct and contingent, of man's labors, can be measured, and such precautions taken in those rural processes which we call improvements, as to mitigate evils, perhaps, in some degree, inseparable from every attempt to control the action of natural laws.

In order to arrive at safe conclusions, we must first obtain a more exact knowledge of the topography, and of the present superficial and climatic condition, of countries where the natural surface is as yet more or less unbroken. This can only be accomplished by accurate surveys, and by a great multiplication of the points of meteorological registry, ${ }^{*}$ already so numerous; and as, moreover, considerable changes in the proportion of forest and of cultivated land, or of dry and wholly or partially submerged surface, will often take place within brief periods, it is highly desirable that the attention of observers-in whose neighborhood the clearing of the soil, or the drainage of lakes and swamps, or other great works of rural improvement, are going on or meditatedshould be especially drawn not only to revolutions in atmospheric temperature and precipitation, but to the more easily ascertained and perhaps more important local changes produced by these

which have long ceased to exist in the theatre of his researches, and of which few other records are extant.

* The general law of temperature is that it decreases as we ascend. But in hilly recions the law is reversed in cold, still weather, the cold air descending, by reason of its greater gravity, into the valleys. If there be wind enough, however, to produce a disturbance and intermixture of higher and lower atmospheric strata, this exception to the general law does not take place. These facts have long been familiar to the common people of Switzerland and of New England, but their importance has not been sufficiently taken into account in the discussion of meteorological observations. The descent of the cold air and the rise of the warm affect the relative temperatures of hills and valleys to a much greater extent than has been usually supposed. A gentleman well known to me kept a thermometrical record for nearly half a century, in a New England country town, at an elevation of at least 1,500 feet abore the sea. During these years his thermometer never fell lower than $26^{\circ}-$ Fah. renheit, while at the shire town of the county, situated in a basin one thousand feet lower, and only ten miles distant, as well as at other points in similar po sitions, the mercury froze several times in the same period. 
operations in the temperature and the hygrometric state of the superficial strata of the earth, and in its spontaneous vegetable and animal products.

The rapid extension of railroads which now everywhere keep pace with, and sometimes even precede, the occupation of new soil for agricultural purposes, furnishes great facilities for eularging our linowledge of the topography of the territory they traverse, because their cuttings reveal the composition and general structure of surface, and the inclination and elevation of their lines constitute known hypsometrical sections, which give numerons points of departure for the measurement of higher and lower stations, and of comrse for determining the relief and depression of surface, the slope of the beds of watercourses, and many other not less important questions.*

* Railroad surveys must be received with great caution where any motive exists for cooking them. Capitalists are shy of investments in roads with steep grades, and of course it is important to make a fair show of facilities in obtaining funds for new routes. Joint-stock companies have no souls; their managers, in general, no consciences. Cases can be cited where engineers and directors of railroads, with long grades above one hundred feet to the mile, have regularly sworn in their ammal reports, for years in succession, that there were no grades upon their routes exceeding half that elevation. In fact, every person conversant with the history of these enterprises knows that in their public statements falsehood is the rule, truth the exception.

What I am about to remark is not exactly relevant to my subject; but it is lard to "get the floor" in the world's great debating society, and when a speaker who has anything to say once funds access to the public ear, he must make the most of his opportumity, without inquiring too nicely whether his ofservations are "in order." I shall harm no honest man by endeavoring, as I have often done elsewhere, to excite the attention of thinking and conscientious men to the dangers which threaten the great moral and even political interests of Christendom, from the unscrupulousness of the private associations that now control the monetary affiirs, and regulate the transit of persons and property, in almost every civilized country. Nore than one American State is literally governed by unprincipled corporations, which not only defy the legislative power, but have, too often, corrupted even the administration of justice. The tremendous power of these associations is due not merely to pecuniary corruption, but partly to an old legal superstition-fostered by the decision of the Supreme Court of the Unitcd States in the famous Dartmouth College casein regard to the sacredness of corporate prerogatives. There is no good reason why private rights derived from God and the very constitution of society should be less respected than privileyes granted by legislatures. It should never be forgotten that no privilege can be a riglet, and lemislative bodies ought never to 
The geological, hydrographical and topongraphical surveys, which almost every general and eren local govermment of tho civilized workl is carrying on, are making yet more inportunt contributions to our stock of gengraphical and general physical knowlerlge, and, within a comparatively short space, there will he

make a grant to $\varepsilon$ corporation, without express reservation of what many sound jurists now hold to be involved in the very miture of such gramte, the power of revocation. Similar evils have become almost equally rife in Lingland, and on the Continent; and I believe the decaly of commercial morility, and of the sense of all higher obligations than those of a pecuniary nature, on both sicles of the Atlantic, is to be ascribed more to the influence of joint-stock banks and mimufacturing and railway companies, to the workings, in short, of what is called the principle of "associate action,". than to any other one cause of demoralization.

The apophthegm, "the world is groverued too much," though unhappily too truly spoken of many countries-and perhaps, in some aspects, true of allhas done much mischief whenever it has been too unconditionally accepted as a political axiom. The popular apprehension of being over-governed, and, I am afraid, more emphatically the fear of being over-taxed, has hat much to do with the general ab)andomment of certain govermmental duties by the ruling powers of most modern states. It is theoretically the duty of government to provide all those public facilities of intercommunication and commerce, which are essential to the prosperity of civilized commonwealths, but which individual means are inadequate to furnish, and for the due administration of which individual guaranties are insulticient. Hence public roads, canals, railroads, postal communications, the circulating medium of exchange whether metallic or representative, armies, navies, being all matters in which the nation at large has a vastly deeper interest than any private association can have, ought legitimately to be constructed and provided only by that which is the visible personitication and enbodiment of the nation, name]y, its levislitive head. No doubt the organization and management of these institutions by government are liable, as are all things human, to great abuses. The multiplication of public plitcholders, which they imply, is a serious evil. But the corruption thus engendered, foul as it is, does not strike so deep as the rottenness of private corporations; and official rank, position and duty have, in prictice, proved better securities for fidelity and pecuniary integrity in the conduct of the interests in question, than the suretyships of private corporate agents, whose bondsmen so often fail or abscond before their principal is detected.

Iany theoretical statesmen have thought that voluntary associations for strictly pecuniary and industrial purposes, and for the construction and control of public works, might furnish, in democratic countries, a compensation for the small and doubtful advantages, and at the same time secure an excmption from the great and certain evils, of aristocratic institutions. The example of the American States shows that private corporations-whose rule of 
an accumulation of well-established constant and historical facts, from which we can safely reason upon all the relations of action and reaction between man and external nature.

But we are, even now, breaking up the floor and wainscoting and doors and window frames of our dwelling, for fuel to warm our bodies and to seethe our pottage, and the world can not afford to wait till the slow and sure progress of exact science has taught it a better economy. Many practical lessons have been learned by the common observation of unschooled men; and the teachings of simple experience, on topics where natural philosophy has scarcely yet spoken, are not to be despised.

In these humble pages, which do not in the least aspire to rank among scientific expositions of the laws of nature, I shall attempt to give the most important practical conclusions suggested by the history of man's efforts to replenish the earth and subdue it; and I shall aim to support those conclusions by such facts and illustrations only as address themselves to the understanding of every intelligent reader, and as are to be found recorded in works capable of profitable perusal, or at least consultation, by persons who have not enjoyed a special scientific training.

action is the interest of the association, not the conscience of the individualthough composed of ultra-democratic elements, may become most dangerous enemies to rational liberty, to the moral interests of the commonwealth, to the purity of legislation and of judicial action, and to the sacredness of private rights. 


\section{CHAPTER II.}

TRANSFER, MODIFIOATION AND EXTIRPATION OF VEGETABLE AND OF ANIMLA SPECIES.

Modern geography takes account of organic life-Geographical importance of plants-Origin of domestic vegetables-Transfer of vegetable lifeObjects of modern commerce-Foreign plants, how introduced-Vegetable power of accommodation-Agricultural products of the United States -Useful American plants grown in Europe-Extirpation of vegetablesAnimal life as a geological and geographical agency-Origin and transfer of domestic quadrupeds-Extirpation of wild quadrupeds-Large marine animals relatively unimportant in geography-Introduction and breeding of fish-Destruction of fish-Geographical importance of birds-Introduction of birds-Destruction of birds-Utility and destruction of reptiles-Utility of insects and worms-Injury to the forest by insects-Introduction of insects-Destruction of insects-Minute organisms.

\section{Modern Geography embraces Organic Life.}

IT was a narrow view of geography which confined that science to delineation of terrestrial surface and outline, and to description of the relative position and magnitude of land and water. In its improved form it embraces not only the globe itself and the atmosphere which bathes it, but the living things which vegetate or move upon it, the varied influences they exert upon each other, the reciprocal action and reaction between them and the earth they inhabit. Even if the end of geographical studies were only to obtain a knowledge of the external forms of the mineral and fluid masses which constitute the globe, it would still be necessary to take into account the element of life; for every plant, every animal, is a geographical agency, man genererally a destructive; vegetables, and in some cases even wild beasts, restorative powers.

The rushing waters of rains and of melting snows sweep down earth from the uplands; in the first moment of repose, vegetation seeks to re-establish itself on the bared surface, and, by the slow deposit of its decaying products, to raise again the soil which the 
torrent had lorrered. So important an element of reconstruetion is this, that it has been seriously questioned whether, mpon the whole, regetation does not contribute as much to elevate, as the - waters to depress, the level of the surface.

Whenerer man has transported a plant from its native habitat to a new soil, he has introduced a new geographical force to act upon it, and this generally at the expense of some indigenous growth which the foreign regetable supplants. The new and the old plants are rarely the equivalents of each other, and the sulsstitution of an exotic for a native tree, shrub, or grass, increases or diminishes the relative importance of the regretable element in the geography of the country to which it is removed. Further, man sows that he may reap. The products of agricultumal industry are not suffered to rot upon the ground, and thus raise it by an ammul stratum of new mould. They are gathered, transported to greater or less distances, and after they have served their uses in human ceonomy, they enter, on the final decomposition of their elements, into new combinations, and are only in small proportion returned to the soil on which they grew. The roots of the grasses and of many other cultivated plants, however, usually remain and decay in the earth, and contribute to raise its surface, though certainly not in the same degree as does the forest.

The smaller vegetalbles which have taken the place of trees unquestionably perform many of the same functions. They radiate heat, they absorb gates, they exhale uncombined gases and watery vapor, and conseguently act upon the chemical constitution and lyygrometrical condition of the air ; their roots penetrate the earth to greater depths than is commonly supposed, and form an inextricable labyrinth of filanents which bind the soil together and prevent its erosion by water. The broad-leaved amuals and perennials, too, shade the ground, and prevent the evaporation of moisture from its surface by wind aud sum.* At a certain stage

* It is impossible to say how far the abstraction of water from the carth by broad-leaved field and garden plants-such as maize, the gourd fanily, the cabbage, etc.-is compensated by the condensation of dew, which sometimes pours from them in a stream, by the exhalation of aqueous vapor from their leaves, which is directly absorbed by the ground, and by the shelter they afford the soil from sun and wind, thus prevanting evaporation. American 
of growth, grass land is probably a more energetic evaporator and refrigerator than even the forest, but this powerful action is exerted, in its full intensity, for a comparatively short time only, while trees continue such functions, with unabated vigor, for many months in succession. Upon the whole, it seems quite certain that no cultivated ground is as efficient in tempering climatic extremes, or in conservation of geographical surface and outline, as is the soil which nature herself has planted.

\section{Origin of Domestic Plants.}

One of the most important questions connected with our subject is: how far we are to regard our cereal grains, our esculent bulbs and roots, and the multiplied tree-fruits of our gardens, as artificially modified and improved forms of wild, self-propagating vegetation. The narratives of botanical travellers have often announced the discovery of the original form and habitat of domesticated plants, and scientific journals have described the experiments by which the identity of particular wild and cultivated vegetables has been thought to be established. It is confidently affirmed that maize and the potato-which we must suppose to have been first cultivated at a much later period than the breadstuffs and most other esculent vegetables of Europe and the East - are found wild and self-propagating in Spanish America, though in forms not recognizable by the common observer as identical with the familiar corn and tuber of modern agriculture. It was lately asserted, upon what seemed rery strong evidence, that the

farmers often say that after the leaves of Indian corn are large enough to "shade the ground," there is little danger that the plants will suffer from drought; but it is probable that the comparative security of the fields from this evil is in part due to the fact that, at this period of growth, the roots penetrate down to a permanently humid stratum of soil, and draw from it the moisture they require. Stirring the ground between the rows of maize with a light harrow or cultivator, in very dry seasons, is often recommended as a preventive of injury by drought. It would seem, indeed, that loosening and turning over the surface earth might aggravate the evil by promoting the evaporation of the little remaining moisture; but the practice is founded partly on the belief that the hygroscopicity of the soil is increased by it to such a degree that it gains more by absorption than it loses by evaporation, and partly on the doctrine that to admit air to the rootlets, or at least to the earth in con. tact with them, is to supply directly elements of vegetable growth. 
Egitops ovata, a plant growing wild in Southern France, had been actually conterted into common wheat; but, upon a repetition of the experiments, later observers have declared that the apparent change was only a case of temporary hybridation or fecundation by the pollen of true wheat, and that the grass alleged to be transformed into wheat could not be perpetuated as such from its orwn seed.

The very great modifications which cultivated plants are constantly undergoing under our eyes, and the numerous rarieties and races which spring up among them, certainly countenance the doctrine, that every domesticated regetable, howerer dependent upon human care for growth and propagation in its present form, may hare been really derived, by a long succession of changes, from some wild plant not now perhaps much resembling it.* But it is, in erery case, a question of eridence. The only satisfactory proof that a giren wild plant is identical with a given garden or field regetable, is the test of experiment, the actual growing of the one from the seed of the other, or the conversion of the one into the other by transplantation and change of conditions. ${ }^{\prime}$ It is hardly contended that any of the cereals, or other

* What is the possible limit of such changes, we do not know, but they may doubtless be carried rastly beyond what experience has yet shown to be practicable. Cirilized man has experimented little on wild plants, and especially on forcst trees. He has indeed improved the fruit, and dereloped new varieties, of the chestnut, by cultivation, and it is observed that our American foresttree nuts and berries, such as the butternut and the wild mulberry, become larger and better flavored in a single generation by planting and training. (BrTANT, Forest Trees, 18テ1, 1p. 99, 115.) Thy should not the industry and ingenuity which have wrought such wonders in our horticulture and floriculture produce analogous results when applied to the cultivation and amelioration of larger regetables? Might not, for instance, the ivory nut, the fruit of the Phytclophas macrocarpa, possibly be so increased in size as to serre nearly all the purposes of animal ivory now becoming so scarce? Might not the various milk-producing trees become, by cultivation, a really important source of nutriment to the inhabitants of warm climates? In short, there is room to hope incalculible advantage from the exercise of human skill in the improvement of yet untamed forms of vegetable life.

t The poisonous wild parsnip of New England has been often asserted to be convertible into the common garden parsnip by cultivation, or rather to be the same regetable growing under different conditions, and it is said to be deprived of its deleterious qualities simply by an increased luxuriance of growth in rich, tilled earth. Wild medicinal plants, so important in the rustic mate- 
plants important as human aliment or as objects of agricultural industry, exist and propagate themselves uncultivated in the same form and with the same properties as when sown and reared by human art.* In fact, the cases are rare where the identity of a wild with a domesticated plant is considered by the best authorities as conclusively established, and we are warranted in affirming of but few of the latter, as a historically known or experimentally proved fact, that they ever did exist, or could exist, independently of man. $\dagger$

ria medica of New England-such as pennyrojal, for example-are generally much less aromatic and powerful when cultivated in gardens than when selfsown on meagre soils. On the other haud, the cinchona, lately introduced from South America into British India and carefully cultivated there, is found to be richer in quinine than the American tree.

* Some recent observations of Wetzstein are worthy of special notice. "The soil of the Haurûn," he rémarks, "produces, in its primitive condition, much wild rye, which is not known as a cultivated plant in Syria, and much wild barley and oats. These cereals precisely resemble the corresponding cultivated plants in leaf, ear, size, and height of straw, but their grains are sen sibly flatter and poorer in flour."-Reisebericht über Hourîn und die Tructionen, p. 40 .

Some of the cereals are, to a certain extent, self-propagating in the soil and climate of California. "Volunter crops are grown from the seed which falls out in harvesting. Barley lats-been known to volunteer five crops in succession."-Prayer-Frowd, Six Months in California, p. 139.

t This remark is much less applicable to fruit trees than to garden veretables and the cerealia. The wild orange of Florida, though once considered indigenous, is now generally thought by botanists to be descended from the European orange introduced by the early colonists. On the wild apple trees of Massachusetts see an interesting chapter in THoread, Excursions. The fig and the olive are found growing wild in every country where those trees are cultivated. The wild fig differs from the domesticated in its habits, its season of fructification, and its insect population, but is, I believe, not specitically distinguishable from the garden fig, though I do not know that it is reclaimable by cultivation. The wild olive, which is so abundant in the Tuscan Maremma and Sardinia, produces good fruit without further care, when thinned out and freed from the shade of other trees, and is particularly suited

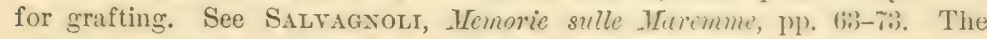
olive is indigenous in Syria and in the Punjaub, and forms valst forests in the Himalayas at from 1,400 to 2,100 feet above the level of the sea.-C'regronx, Memoir on the Timber procured from the Indus, cte., pl). 8-15. Prgevalsky found the apple and some other orchard fruits growing luxuriantly in the woods on the borders of Thibet.

Frass, Klima und Pflanzeneclt in der Ziit, pp. 3j-38, gives, upon the nuthority of Link and other botanical writers, a list of the native habitats of 


\section{Transfer of Vegetable Life.}

It belongs to vegetable and animal geography, which are almost sciences of themselves, to point out in detail what man has done to change the distribution of plants and of animated life, and to revolutionize the aspect of organic nature; but some of the more important facts bearing on the first branch of this subject may pertinently be introduced here. Most of the cereal grains, the pulse, the edible roots, the tree fruits, and other important forms of esculent vegetation grown in Europe and the United States are believed, and-if the testimony of Pliny and other ancient naturalists is to be depended upon-many of them are historically known, to have originated in the temperate climates of Asia. The agriculture of even so old a country as Egypt has been almost completely revolutionized by the introduction of foreign plants, within the historical period. "With the exception of wheat," says Hehn, "the Nile valley now yields only new products, cotton, rice, sugar, indigo, sorghum, dates," being all unknown to its most ancient rural husbandry.* The wine grape has been thought to be truly indigenous only in the regions bordering on the eastern end of the Black Sea, where it now, particularly on the banks of the Rion, the ancient Phasis, propagates

most cereals and of many fruits, or at least of localities where these plants are said to be now found wild; but the data do not appear to rest, in general, upon very trustworthy evidence. Theoretically, there can be little doubt that all our cultivated plants are modified forms of spontaneous vegetation, though the connection is not historically shown, nor are we able to say that the originals of some domesticated vegetables may not be now extinct and unrepresented in the existing wild flora. See, on this subject, HuMBoldt, Ansichten der Natur, I., pp. 208, 209.

The Adams of modern botany and zoölogy have been put to hard shifts in finding names for the multiplied organisms which the Creator has brought before them, "to see what they would call them"; and naturalists and philosophers have shown much moral courage in setting at naught the laws of philology in the coinage of uncouth words to express scientific ideas. I have elsewhere noticed Asagroa and Gaylussacia as, to say the least, very odd designations of species. It is much to be wished that some bold neologist would devise English technical equivalents for the German verwildert, run-wild, and veredelt, improved by cultivation.

* On these points see the learned work of Hems, Kultur Pflanzen una Thiere in ihrem Uebergang aus Asien. 1877. On the migration of plants generally, see LYeLL, Principles of Geology, 10th ed., vol. ii., c. 
itself spontaneously, and grows with unexampled luxuriance.* But some species of the vine seem native to Europe, and many varieties of grape have been too long known as common to every part of the United States to admit of the supposition that they were introduced by European colonists. $\dagger$

\section{Objects of Modern Commerce.}

It is an interesting fact that the commerce-or at least the maritime carrying trade-and the agricultural and mechanical industry of the world are, in very large proportion, dependent on vegetable and animal products little or not at all known to ancient Greek, Roman and Jewish civilization. In many instances, the chief supply of these articles comes from countries to which they are probably indigenous, and where they are still almost exclusively grown; but in most cases, the plants or animals from which they are derived have been introduced by man into regions now

* The vine-wood planks of the ancient great door of the cathedral at Ravenna, which measured thirteen feet in length by a foot and a quarter in width, are traditionally said to have been brought from the Black Sea, by way of Constantinople, about the eleventh or twelfth century. Vines of such dimensions are now very rarely found in any other part of the East, and, though I have taken some pains on the subject, I never found in Syria or in Turkey a vine-stock exceeding six inches in diameter, bark excluded. Schulz, however, saw at Beitschin, near Ptolemais, a vine measuring eighteen inches in diameter. Strabo speaks of vine-stocks in Margiana (Khorasan) of such dimensions that two men, with outstretched arms, could scarcely embrace them. See Strabo, ed. Casaubon, pp. 73, 516, 826. Statues, and even temple columns, of vine-wood are mentioned by ancient writers. Very large vine-stems are not common in Italy, but the vine-wood panels of the door of the chapterhall of the church of St. John at Saluzzo are not less than ten inches in width, and $I$ observed not long since, in a garden at Piè di Mfulera, a vine-stock with a circumference of thirty inches.

+ The Northmen, who-as I think it has been indisputably established by Professor Rafn, of Copenhagen-visited the coast of MIassacbusetts about the year 1000 , found grapes growing there in profusion, and the wild vine still flourishes in great variety and abundance in the south-eastern counties of that State. The townships in the vicinity of the Dighton rock, supposed by many-with whom, however, I am sorry I can not agrec-to bear a Scandinavian inscription, abound in wild vines. According to LAUDONNIÈre, Histoive Nitalle de la Floride, reprint, Paris, 1858 , p. 5, the French navigators in 1562 found in that peninsula "wild vines which climb the trees and produce gnod grapes." 
remarkable for their successful cultivation, and that, too, in comparatively recent times, or, in other words, within two or three centuries.

Something of detail on this subject can not, I think, fail to prove interesting. Pliny mentions about thirty or forty oils as known to the ancients, of which only olive, sesame, rape seed and walnut oil-for except in one or two doubtful passages $I$ find in this author no notice of linseed oil--appear to hare been used in such quantities as to have had any serious importauce in the carrying trade. At the present time the new oils, linseed oil, the oil of the whale and other large marine animals," petroleum (of which the total consumption of the world in 1871 was estimated at $6,000,000$ barrels, and in 1580 is supposed to have reached at least $8,000,000$ barrels, the port of Philadelphia alone exporting more than $\$ 8,000,000$ gallons in that year), pilm oil, recently introduced into commerce, and of which more than 50,000 tons were imported into England from the coast of $\perp$ frica in the year 1SS0 - these alone undoulbtedly gire employment to more shipping than did the whole commerce of Italy at the most flourishing period of the Roman Empire, with the exception of wheat, marble and other stones ${ }^{+}$According to the statistics of 1850 ,

* A very fer years sinoe, the Tnited States had more than six hundred large ships engaged in the whale fishery, and the number of American whalers, in spite of the introduction of many new sources of oils, still amounts to two hundred and fifty.

t The city of Rome imported from Sicily, from Africa, and from the Levant, enormous quantities of grain for gratuitous distribution among the luwer classes of the capital. The pecuniary ralue of the gems, the spices, the unguents, the perfumes, the cosmetics and the tissues, which came principally from the East, was great, but these articles were neither heary nor bulliy and their transportation required but a small amount of shipping. The marbles, the obelisks, the statuary and other objects of art plundered in conquered provinces by Roman generals and governors, the wild animals, such as clephants, rhinoceroses, hippopotami, camclopards and the larger beasts of prey imported for slaughter at the public games, and the prisoners captured in foreign wars and brought to Italy for sale as slaves, or for butchery as gladiators, furnished employment for much more tonnage than all the legitimate commerce of the empire, with the possible exception of wheat and wrought and unwrought stone.

Independently of the direct testimony of Latin authors, the Greek statuary, the Egyptian obelisks, and the rast quantities of forcign marbles, granite, por phyry, bisalt, and other stones used in sculpture and in architecture, which 
England now annually imports more than 1,000,000 tons of sugar, about 250,000 tons of jute and esparto, 730,000 tons of cotton, of which the value of $\$ 350,000,000$ is exported again in the form of manufactured goods-including, by a strange industrial revolution, a large amount of cotton farn and cotton tissues sent to India, and directly or indirectly paid for by raw cotton to be manufactured in England-30,050 tous of tobaceo, from 200,000 to 400,000 tons of guano, hundreds of thousands of tons of tea, coffee, cacao, caoutchouc, gutta-percha, and numerous other important articles of trade wholly unlnown, as objects of commerce, to the ancient European world; and this immense importation is balanced by a corresponding amount of exportation, not consisting, however, by any means, exclusively of articles new to commerce.*

have been found in the remains of ancient Rome, show that the Imperial capital must have emplojed an immense amount of tonnage in the importation of heavy articles for which there could have been no return freight, unless in the way of military transportation. Some of the Egyptian obelisks at Rome weigh upwards of four hundred tons, and many of the red granite columus from the same country must have exceeded one hundred tons. Greek and African marbles were largely used not only for columus, entablatures, and solid walls, but for casing the exterior and veneering the interior of public and private buildings. Scaurus imported, for the scene alone of a temporary theatre designed to stand scarcely for a month, three hundred and sixty columns, which were disposed in three tiers, the lower range being forty-two feet in height. - see Pliny, Nat. Hist., Lib. xxxvi.

Italy produced very little for export, and her importations, when not consisting of booty, were chicly paid for in coin which was priucipally either the spoil of war or the fruit of official extortion.

* Mrany of these articles would undoubtedly have been made known to the Greels and Romans and have figured in their commerce, but for the slowness and costlimess of ancient navigation, which, in the seas familar to them, was suspended for a full third of tho year from the inability of their vessels to cope with winter weather. The present speed and economy of transportation have wrought and are still working strange commercial and inclustrial revolutions. Algeria now supplies Northern Germany with fresh caulitlowers, and in the carly spring the market-gardeners of Naples find it more profitable to scud their first fruits to St. Petersburg than to furnish them to Florence and Rome. Cirio, a very enterprising Italian of the agricultural class, has been, if not the actual pioneer in this commercial industry, certainly the most efficient agent in carrying it on. Freight cars, marked with his name and loaded with every variety of early produce from the seas and shores of Southern Italy, might be seen daily, during the spring of 1882 , steaming northward through the penin. sula on their way to hyperborean Russia. 


\section{Foreign Plants, how Introduced.}

Besides the regetables I have mentioned, we know that many plants of smaller economical value have been the subjects of international exchange in very recent times. Busbequius, Austrian ambassador at Constantinople about the middle of the sixteenth century-whose letters contain one of the best accounts of Turkish life which have appeared down to the present daybrought home from the Ottoman capital the lilac and the tulip. The Belgian Clusius about the same time introduced from the East the horse chestnut, which has since wandered to America. The weeping willows of Europe and the United States are said to have sprung from a slip received from Smyrna by the poet Pope, and planted by him in an English garden; Drouyn de l'Huys, in a discourse delivered before the French Société d'Acclimitation, in 1860, claims for Rabelais the introduction of the melon, the artichoke and the Alexandria pink into France; and the Portnguese declare that the progenitor of all the European and American oranges was an Oriental tree transplanted to Lisbon, and still living in the last generation.* The present favorite flowers of the parterres of Europe have been imported from America, Japan and other remote Oriental countries, within a century and a half,

* The name portogallo, so generally applied to the orange in Italy, seems to favor this claim. The orange, however, was known in Europe before the discovery of the Cape of Good Hope, and, therefore, before the establishment of direct relations between Portugal and the East.-See AMari, Storia dei Mrusulmani in Sicitia, vol. ii., p. 445.

For an interesting account of the introduction of the mango into the West Indies, and for other facts bearing on this subject, see a Lecture on the Distribu. tion of the American Flora, delivered April, 1878, by the President of the Royal Society, Sir J. D. Hooker.

The date-palms of eastern and southern Spain were certainly introduced by the Moors. Leo von Rozmital, who visited Barcelona in 1476, says that the date-tree grew in great abundance in the environs of that city and ripened its fruit well. It is now scarcely cultivated further north than Valencia. It is singular that Ritter in his very full monograph on the palm does not mention those of Spain.

On the introduction of coniferce into England see an interesting article in the Edinburgh Review of October, 1864.

MÜLler, Das Buch der Pflanzenwelt, p. 86, asserts that in 1802 the ancestor of all the mulberries in France, planted in 1500, was still standing in a garden in the village of Allan-Montelimart. 
and, in fine, there are few vegetables of any agricultural importance, few ornamental trees or decorative plants, which are not now common to the three civilized continents.

The statistics of vegetable emigration exhibit numerical results quite surprising to those not familiar with the subject. The lonely island of St. Helena is described as producing, at the time of its discovery in the year 1501, about sixty vegetable species, including some three or four known to grow elsewhere also.* At the present time its flora numbers seven hundred and fifty species -a natural result of the position of the island as the half-way house on the great ocean highway between Europe and the East. Humboldt and Bonpland found, among the unquestionably indigenous plants of tropical America, monocotyledons only, all the dicotyledons of those extensive regions having been probably introduced after the colonization of the New World by Spain. $\dagger$

The seven hundred new species which have found their way to St. Helena within three centuries and a half, were certainly not all, or even in the largest proportion, designedly planted there by human art, and if we were well acquainted with vegetable emigration, we should probably be able to show that man has intentionally transferred fewer plants than he has accidentally introduced into countries foreign to them. After the wheat, follow the tares that infest it. The weeds that grow among the cereal grains, the pests of the kitchen garden, are the same in America as in Europe. The overturning of a wagon, or any of the

* It may be considered very highly probable, if not certain, that the undiscriminating herbalists of the sixteenth century must have overlooked many plants native to this island. An English botanist, in an hour's visit to Aden, discovered several species of plants on rocks always reported, even by scientific travellers, as absolutely barren. But after all, it appears to be well established that the original flora of St. Helena was extremely limited, though now counting hundreds of species.

† See Wittwer, Physikalische Geographie, Leipzig, 1855, pp. 486, 495.

$\ddagger$ Some years ago I made a collection of weeds in the whent-fields of Upper Esypt, and another in the gardens on the Bosphorus. Nearly all the plants were identical with those which grow under the same conditions in New England. I do not remember to have seen in America the scarlet wild poppy so common in European grain-fields. I have heard, however, that it has lately crossed the Atlantic, and I am not sorry for it. With our abundant harvests of wheat, we can well afford to pay now and then a loaf of bread for the cheerful radiance of this brilliant flower. 
thousand accidents which befall the emigrant in his journey across the Western plains, may scatter upon the ground the seeds he designed for his garden, and the herbs which fill so important a place in the rustic materia merlica of the Eastern States, spring up along the prairie paths but just opened by the caravan of the settler. *

"A negro slave of the great Cortez," says Mumboldt, "was the first who sowed wheat in New Spain. He found three grains of it among the rice which had been brought from Spain as food for the soldiers."

About twenty years ago, a Japanese forage plant, the Lespedera striata, whose seeds had been brought to the United States by some unknown accident, made its appearance in one of the Souther'n States. It spread spontaneously in various directions, and in a few year's was widely diffused. It grows upon poor and exhansted soils, where the formation of a turf or sward by the ordinary grasses would be impossible, and where consequently no regular pastures or meadows can exist. It makes excellent fodder for stock, and though its ralue is contested, it is nevertheless generally thought a very important addition to the agricultural resources of the South. +

* Josselyn, who wrote about fifty ycars after the foundation of the first British colony in New England, says that the settlers at Plymouth had observed more than twenty English plants springing up spontaneously near their improvements.

Every country has many plants not now, if ever, made use of by man, and therefore not designedly propagated by him, but which cluster around his dwelling, and continue to grow luxuriantly on the ruins of his rural habitation after he has abandoned it. The site of a cottage, the very foundation stones of which have been carried off, may often be recognized, years afterwards, by the rank weeds which cover it, though no others of the same species are found for miles.

"Mediceal Catholicism," says Vaupell, "brought us the red horsehoofwhose reddish-brown flower-buds shoot up from the ground when the snow melts, and are followed by the large leaves-comfrey and snake-root-which grow only where there were convents and other dwellings in the Hiddle Ages."-Bögens Indvandring $i$ de Danske Skove, pp. 1, 2.

+ Accidents sometimes limit, as well as promote, the propagation of forcign vegetibles in countries new to them. The Lombardy poplar is a diocious tree, and is very easily grown from cuttings. In most of the countries intc which it has been introduced, the cuttings have been tilken from the male, and as, consequently, males only have grown from them, the poplar does not 
In most of the Southern countries of Europe, the sheep and horned cattle winter on the plains, but in the summer are driven, sometimes many days' journey, to mountain pastures. Their conts and flecees transport seeds in both directions. Ifence we see Alpine plants in champaign districts, the plants of the plains on the borders of the glaciers, though in neither ease do these vegetables ripen their seeds and propagate themselves. This cxplitins the occurrence of tufts of common red clover with pallid and sickly flowers, on the flanks of the Alps at heights exceeding seven thousand feet.

The hortus siccus of a botanist may accidentally sow seeds from the foot of the Himalayas on the plains that sliirt the Alps; and it is a fact of very familiar olservation, that exotics, transplanted to foreign climates suited to their growth, often escape from the flower garden and naturalize themselves among the spontaneous vegretation of the pastures. When the cases containing the artistic treasures of Thorraldsen were opened in the court of the museum where they are deposited, the straw and grass employed in packing then mere seattered upon the ground, and the next season there sprang up from the seeds no less than twenty-fire species of plants belonging to the Roman campagna, some of which were preserved and cultivated as a new tribute to the memory of the great Scandinavian sculptor, and at least four are said to hare spontaneonsly naturalized themselves about Copenhagen.* The Turkish armies, in their incursions into Europe, brought Eastern vegretables in their train, and left the seeds of Oriental wall-plants to grow upon the ramparts of Buda and Viennat In the campaign of 181 , the Russian troops brought, in the stufting of their saddles and by other accidental means, seeds from the banks of the Dnieper to the valley of the Phine, and even introduced the plants of the steppes into the environs of Paris.

produce seed in those regions. This is a fortunate circumstance, for otherwise this most worthless and least ornamental of trees would spread with a rapidity that would make it an annoyance to the agriculturist.

* VAUTELL, Bögens Indvandring i de Danste Skove, p. 2.

+ I believe it is certain that the Turks introduced tobacco into Ifungary, and probable that they in some measure compensated the injury by introducing maize also, which, as well as tobacco, has been claimed as Hungarian by patriotic Magyars. 
The forage imported for the French army in the war of 1870 1871 has introduced numerous plants from Northern Africa and other countries into France, and this vegetable emigration is so extensive and so varied in character, that it will probably have an important botanical, and even economical, effect on the flora of that country.*

The Canada thistle, Cnicus avensis, which is said to have accompanied the early French voyagers to Canada from Normandy, is reported to have been introduced into other parts of Europe two hundred years ago by a seed which dropped out of the stuffed skin of an American bird.

\section{Tegetable Power of Accommodation.}

The cereals and other vegetables which, so far as we know their history, seem to have been longest the objects of human care, can, by painstaking industry, be made to grow under a great variety of circumstances, and some of them prosper nearly equally well when planted and tended on soils of almost any geological character; but the seeds of most of them vegetate only in artificially prepared ground, they have little self-sustaining power, and they soon perish when the nursing hand of man is withdrawn from them.

The vine genus is very catholic and cosmopolite in its habits, but particular varieties are extremely fastidious and exclusive in their requirements as to soil and climate. The stocks of many celebrated vineyards lose their peculiar qualities by transplantation, and the most famous wines are capable of production only in certain well-defined and for the most part narrow districts. The Ionian vine, which bears the little stoneless grape known in

\footnotetext{
* In a communication lately made to the French Academy, Mr. Vibraye givas numerous interesting details on this subject, and says the appearance of the many new plants observed in France in 1871, " results from forage supplied from abroad, the seeds of which had fallen upon the ground. At the present time, several Mediterranean plants, chiefly Algerian, having braved the cold of an exceptionally severe winter, are being largely propagated, forming extensive meadows, and changing soil that was formerly arid and produced no vegetable of importance into veritable oases." See Nature, Aug. 1, 1872, p. 263. We shall see on a following page that canals are efficient agencies in the unintentional interchange of organic life, vegetable as well as animal, between regions connected by such channels.
} 
commerce as the Zante currant, has resisted almost all efforts to naturalize it elsewhere, and is scarcely grown except in two or three of the Ionian islands and in a narrow territory on the northern shores of the Morea.

The attempts to introduce European varieties of the vine into the United States have not been successful except in California,* and perhaps in Texas; but cultivation has improved many native stocks to a degree that renders them fairly equal to the vines of Europe. $\dagger$ On the other hand, American garden vegetables are less luxuriant, productive and tasteful in Europe than in the United States, and many of them lose their special qualities and run out, as the phrase is, in a very few crops. $\neq$

The saline atmosphere of the sea is especially injurious both to seeds and to very many young plants, and it is only recently that the transportation of some very important vegetables across the ocean has been made practicable, through the invention of Ward's air-tight glass cases. By this means large numbers of the trees which produce the Jesuit's bark were successfully transplanted from America to the British possessions in the East, where this valuable plant may now be said to have become fully naturalized. $\S$

Vegetables, naturalized abroad either by accident or design, sometimes exhibit a greatly increased luxuriance of growth. The

* In 1869, a vine of a European variety, planted in Sta. Barbara county in 1833 , measured a foot in diameter four feet above the ground. Its ramifications covered ten thousand square feet of surface, and it annually produrees twelve thousand pounds of grapes. The bunches are sixteen or eighteen Inches long, and weigh six or seven pounds.-Letter from Commissioner of Land-Office, dated May 13, 1869.

$\uparrow$ The American vines introduced into Europe have, for the most part, withstood the destructive effects of the phylloxera, and they have been substituted in many French vineyards for the original plants.

$\ddagger$ Thus American sweet corn, Lima beans and marronfat pease require the importation of new seed every two or three years.

\$ See Cleghorn, Forests and Gardens of South India, Edinburgh, 1861, and The British Parliamentary Return on the Chinchona plant, 1866. It has been found that the seeds of several species of chinchona preserve their vitality long enough to be transported to distant regions. The swiftness of steamnavigation renders it possible to transport to foreign countries, not only seeds, but delicate living plants which could not have borne a long royage by sailing vessels. 
European cardoon, an esculent thistle, has broken out from the gardens of the Spanish colonies on the La Plata, acquired a gigantic stature, and propagated itself, in impenetrable thickets, over hundreds of leagues of the Pampas; and the Anacharis al sinastim, a water plant not much inclined to spread in its native American habitat, has found its way into English rivers, and extended itself to such a degree as to form a serious obstruction to the flow of the current, and even to navigation.* This plant was first observed in England in 182 $T$, and soon made its way to the valley of the Rhine. It is now announced as having made its appearance in the Moselle.

Not only do many wild plants exhibit a remarkable facility of accommodation, but their seeds usually possess great tenacity of life, and their germinating power resists very severe trials. Hence, while the seeds of many cultivated regetables lose their vitality in two or three years, and can be transported safely to distant countries only with great precautions, the weeds that infest those vegetables, though not cared for by man, continue to accompany him in his migrations, and find a new home on every soil he colonizes.

Indeed, the faculty of spontaneous reproduction and perpetuation necessarily supposes a greater power of accommodation, within a certain range, than we find in most domesticated plants; for it would rarely happen that the seed of a wild plant would fall into ground as nearly similar in composition and condition to that whereon its parent grew, as are to each other the soils of different fields artificially prepared for growing a particular vegretable. Accordingly, though every wild species affects a habitat of a particular character, it is found that, if accidentally or designedly sown elsewhere, it will grow under conditions ex-

* "It is stated by a celebrated English author that the providential spread of the American weed Anacharis alsinastrum has saved thousands of lives by the purifying influence which it has exerted on the watercourses in certain districts in England. These plants liberate oxygen, which attacks poisonous dead organic matter and destroys it, thus ridding the water of its most dangerous impurities. It occasionally happens, however, owing perhaps to some peculiarity of the season, that microscopic animals or plants multiply to such an unusual extent in the waters of lakes or rivers as to produce serious annoyance. This occurred some years ago in Croton Lake, in the State of New Zork." 
tremely unlike those of its birthplace. Cooper says, "We can not say positively that any plant is uncultivable anywhere until it has been tried"; and this seems to be even more true of wild than of domesticated vegetation.

As the wild plant is much hardier than the domesticated vegetille, so the same law prevails in animated brute and even in human life. Nature fights in defence of her free children, but wars upon them when they have deserted her banners and tamely sul)mitted to the dominion of man.* The beasts of the chase we more capable of endurance and privation, and more tenacious of life, than the domesticated animals which most nearly resemble them. The savage fights on after he has received half a dozen mortal wounds, the least of which would have instantly paralyzed the strength of his civilized enemy, and, like the wild boar, he has been known to press forward along the shaft of the spear which was transpiercing his vitals, and to deal a death-blow on the soldier who wielded it.

True, domesticated plants can be gradually acclimatized to bear a degree of heat or of cold, which, in their wild state, they would not have supported; the trained English racer outstrips the swiftest horse of the pampas or prairies, perhaps even the less systematically educated courser of the Arab; the strength of the European, as tested by the dynamometer, is greater than that of the New-Zealander. But all these are instances of excessive development of particular capacities and faculties at the expense of general vital power. Expose untamed and domesticated forms of life, t?gether, to an entire set of physical conditions equally alien to the former habits of both, so that every power of resistance and accommodation shall be called into action, and the wild plant or animal will live, while the domesticated will perish. $\dagger$

* Tempests, violent enough to destroy all cultivated plants, frequently spare those of spontaneous growth. I have often seen in Northern Italy, vineyards, maize-fields, mulberry and fruit trees completely stripped of their foliage by hail, while the native forest trees scattered through the meadows, and the shrubs and brambles which sprang up by the wayside, passed through the ordeal with scarcely the loss of a leaflet.

f "Considering weeds to be plants of the nature of herbs which tend to take prevalent possession of soil used for man's purposes, irrespective of his will, Professor Asa Gray inquires, in a recent paper in Silliman's Journal 


\section{Agricultural Products of the United States.}

According to the census of 1870 , the United States had, on the first of June in that year, in round numbers, 189,000,000 acres of improved land, * the quantity having been increased by $16,000,000$ acres within the ten years next preceding. In 1880 the number of acres of improved land was $28 \pm, 721,042$, showing an increase during the last decade of nearly 96,000,000. Not to mention less important crops, this land produced in 1879 , in round numbers, $460,000,000$ bushels of wheat, $20,000,000$ bushels of rye, 408,000,000 bushels of oats, nearly $10,000,000$ bushels of pease and beans, $44,000,000$ bushels of barley, orchard fruits to the value

whether weeds have any common characteristic which may give them advantage, and why most of the weeds of the United States, and probably of similar temperate countries, should be foreigners. This latter is strikingly the case on the Atlantic side of temperate North America, where the weeds have mainly come from Europe, and the common answer to the question must be largely true-viz., that as the region was not really forest clad, there were few of its native herbs which, if they could bear the exposure at all, could compete on cleared land with emigrants from the Old World. A certain number of weeds in that region have come from the west and south, some with rather rapid strides in recent years owing to increased means of communication, and there are also native American weeds, indigenous to the region, which have become strongly aggressive through changed conditions. Professor Claypole, of Ohio, has tried to account for the predominance of Old World weeds in the Atlantic United States by supposing a greater 'plasticity' in European than in American flora (the plant more easily adapting itself, if the change be not too great or sudden, to its new situation, and taking out a new lease of life as a weed). But Professor Gray regards this view as purely hypothetical. Again, Mr. Henslow thinks that weeds or intrusive dominant plants generally have a common characteristic to which this dominance may be attributed-viz., that they are in general self-fertilized plants. The question whether the weeds which Europe has given to North America are more self-fertilizing or less subject to cross fertilization than others is examined by Professor Gray, and he is led to answer that self-fertilization is neither the cause nor a perceptible cause of the prepotency referred to. A similar conclusion is justified by a cursory examination of the indigenous weeds of the Atlantic States, and of the prevalent species in California, which (as might be expected) are mostly indigenous species or immigrants from South America, though the common weeds of the Old World, especially of Southern Europe, are coming in."

* Ninth Census of the United States, 1872, p. 341. By "improved" land, in the reports on the census of the United States, is meant " cleared land used for grazing, grass, or tillage, or which is now fallow, connected with or belonging to a farm."-Instructions to Marshals and Assistants, Census of 1870. 
of nearly $\$ ., 1,000,000$, nearly 2,000,000 bushels of clover-secel, $1,301,000$ bulitiels of other grilss seed, 5,025 tons of hemp, 1,565, 000 poumels of flax, and 7,000,000 bushels of flax-seert. These regetalle growths were familiar to ancient European agrieulture, but they were all introduced into North America after the cluse of the sixteenth century.

Of the fruits of agricultural industry unknown to the Greeks and Romaus, or too little employed by them to be of commercial importance, the United States produced, in 1S79, 110,000,000 pounds of rice, nearly $12,000,000$ bushels of buckwheat, 5,700 ,000 bales of cotton, * 178,000 logsheads of cane sugar, 16,500,000 gallons of cane molasses, 2S,000,000 gallons of sorghum molasses, all yielded by regetables introduced into that country within two hundred years, and-with the exception of buckwheat, the origin of which is uncertain, and of cotton-all, directly or indirectly, from the East Indies; besides, from indigenous plants unknown to ancient agriculture, $1,754,590,000$ bushels of Indian corn, $472,600,000$ pounds of tobacco, about $170,000,000$ bushels of the common potato, $33,000,000$ bushels of sweet potatoes, $36,500,000$ pounds of maple sugar, and 1,S00,000 gallons of maple molisses.t To all this we are to add $35,000,000$ tons of bay,-produced partly by new, partly by long known, partly by

* Cotton, though cultirated in Asia from the remotest antiquity, and known ns a rare and costly product to the Latins and the Greeks, was not used by them except as an article of luxury, nor did it enter into their commeree to any considerable extent as a regular object of importation. The early royagers found it in common use in the Test Indies and in the provinces first colonized by the Spaniards; but it was introduced into the territory of the Lnited States by European settlers, and did not become of any importance until after the Revolution. Cotton-seed was sown in Virginia as early as 1621, but was not cultivated with a view to profit for more than a century afterwards. Seaisland cotton was first grown on the coast of Georgia in 1786, the seed having been brought from the Bahamas, where it had been introduced from Anguilla. -Bigelow, Les États-Unis en 1863, p. 370.

t There was a falling off between 1860 and $18 \% 0$ of $11,000,000$ pounds in the quantity of maple sugar, and of more than 1,000,000 gallons of maple molasses, the amount in $18 \% 0$ being, of sugar, $28,000,000$ pounds ; of molasses, 925,000 gallons. The high price of cane sugar during and after the civil war must have tended to stimulate the production of maple sugar and molasses, but the domestic warfare on the woods more than compensated this cause of increase. The above statisties for $18 \mathrm{~S}$ ), however, show that these products have now nearly reached their former high figure. 
exotic and partly by native herbs and grasses, the value of $\$ 22$,000,000 in garden vegetables chiefly of European or Asiatic origin, and many minor agricultural products.* 'The number of gallons of wine for this year is not yet reported, but there has been a great increase in its production since 1870 , when it was estimated at $3,000,000$ gallons.

The weight of this harvest of a year would be many times the tonnage of all the shipping of the United States at the close of the year 1880 - and, with the exception of maple sugar, maple molasses, and the products of the Western prairie lands and of some small Indian clearings, it was all grown upon lands wrested from the forest by the European race within little more than two hundred years. The wants of Europe have introduced into the colonies of tropical America the sugar-cane, the coffee-plant, the orange and the lemon, all of Oriental origin, have immensely stimulated the cultivation of the former two in the countries of which they are natives, and, of course, promoted agricultural operations which must have affected the geography of those regions to an extent proportionate to the scale on which they have been pursued.

\section{Useful American Plants Grown in Europe.}

America has partially repaid her debt to the Eastern continent. Maize and the potato are very valuable additions to the field agriculture of Europe and the East, and the tomato is no mean gift to the kitchen gardens of the Old World, though certainly not an adequate return for the multitude of esculent roots and leguminous plants which the European colonists carried with them.

\footnotetext{
* Ramie, Bochmeria tenacissima, a species of Chinese nettle producing a fibre which may be spun and woven, and which unites many of the properties of silk and of linen, has been completely naturalized in the United States, and results important to the industry of the country are expected from it.

$\uparrow$ The sugar-cane was introduced by the Arabs into Sicily and Spain as early as the ninth century, and though it is now scarcely grown in those localities, I am not aware of any reason to doubt that its cultivation might be revived with advantage. From Spain it was carried to the West Indies, though different varieties have since been introduced into those islands from other sources.

$\ddagger$ John Smith mentions, in his Historie of Virginia, 1624, pease and beans as having been cultivated by the natives before the arrival of the whites, and there is no doubt, I believe, that several common cucurbitaceous plants are of
} 
I wish I could believe, with some, that America is not alone responsible for the introduction of the filthy weed, tobacco, the use of which is the most vulgar and pernicious habit engrafted by the semi-barbarism of modern civilization upon the less multifarious sensualism of ancient life; but the alleged occurrence of pipe-like objects in old Sclavonic, and, it has been said, in Hungarian sepulchres, is hardly sufficient evidence to convict those races of complicity in this grave offence against the temperance and the refinement of modern society.

\section{Extirpation of Vegetables.}

Lamentable as are the evils produced by the too general felling of the woods in the Old World, I believe it does not appear that any species of native forest-tree has yet been extirpated by man on the Eastern continent. The roots, stumps, trunks, and foliage found in bogs are recognized as belonging to still extant species. Except in some few cases where there is historical evidence that foreign material was employed, the timber of the oldest European buildings, and even of the lacustrine habitations of Switzerland, is evidently the product of trees still common in or near the countries where such architectural remains are found; nor have the Egyptian catacombs themselves revealed to us the former ex. istence of any woods not now familiar to us as the growth of still living trees.* It is, however, said that the yew tree, Taxus

American origin ; but most, if not all the varicties of pease, beans, and other pod fruits now grown in American gardens, are from European and other foreign seed.

Cartier, A.D. 1535-'6, mentions “vines, great melons, cucumbers, gourds, [courges], pease, beans of various colors, but not like ours," as common among the Indians of the banks of the St. Lawrence.-Bref Recit, etc., reprint. Paris, 1863, pp. $13, \mathrm{a} ; 14, \mathrm{~b} ; 20, \mathrm{~b} ; 31$, a.

* Some botanists think that a species of water lily represented in many Egyp. tian tombs has become extinct, and the papyrus, which must have once been abundant in Egypt, is now found only in a very few localities near the mouth of the Nile. It grows very well and ripens its seeds in the waters of the Anapus near Syracuse, and I have seen it in garden ponds at Messina and in Malta. There is no apparent reason for believing that it could not be easily cultivated in Egypt, to any extent, if there were any special motive for encouraging its growth.

Silphium, a famous medicinal plant of Lybia and of Persia, seems to have 
baccata, formerly very common in England, Germany, and-as we are authorized to infer from Theophrastus-in Greece, has almost wholly disappeared from the latter country, and seems to be dying out in Germany. The wood of the yew surpasses that of almost any other European tree in closeness and finemess of grain, and it is well known for the elasticity which of old made it so great a favorite with the English archer. It is much in request among wood-carver's and turners, and the demand for it explains, in part, its increasing scarcity. It is also asserted that scircely any insect depends upon it for food or shelter, or aids in its fructification, and birds very rarely feed upon its berries. These are circumstances of 110 small importance, because the tree hence wants means of propagation or diffusion common to so many other plauts." But it is alleged-though apparently on insufficient evidence, for it is certainly reproduced in England like other wild trees-that the reproductive power of the yew in Germany is exhausted, and that it can no longer be readily propagated by the natural sowing of its seeds, or by artificial methods. If further investigation and careful experiment should establish this fact, it will go far to show that a climatic change, of a character unfavorable to the growth of the yew, has really taken place in Germany, though not yet proved by instrumental observation, and the most probable cause of such change would be found in the diminution of the area covered by the forests.

The industry of man is said to have been so successful in the

disappeared entirely ; at any rate its present existence in either of these regions is disputed. The Silplium of Greek and Roman commerce appears to have come almost wholly from Cyrene, that from the Asiatic deserts being generally of less value, or, as Strabo says, perhaps of an inferior variety. The province ne:r Cyrene which produced it was very limited, and according to Strabo (ed. Casaubon, p. 887), it was at one time almost entirely extirpated by the nomade Africans who invaded the province and rooted out the plant.

The vegetable which produced the Balm of Gilead has not bcen identified in modern times, although the localities in which it anciently grew have been carefully explored.

* I am informed by my friend, Sir Alexander Malet, that the above remarks can not fairly be applied to the yew in England-that the common blackbird and various kinds of thrush feed readily on its berries, and that, consequently, young plants are continually springing up in the neighborhood of the old trees. He adds his belief that these plants, if left entirely to themselves, would almost completely extirpate every other arborescent growth. 
local extirpation of noxious or useless regetables in China, that, with the exception of a few water plants in the rice grounds, it is sometimes impossible to find a single weed in an extensive district; and the late eminent agriculturist, $\mathrm{Mr}$. Coke, is reported to have offered in rain a considerable reward for the detection of a weed in a large wheat-field on his estate in England. In these eases, howerer, there is no reason to suppose that diligent husbandry has done more than to eradicate the pests of agriculture within a comparatively limited area, and the cockle and the darnel will probably remain to plague the slovenly cultivator as long as the cereal grains continue to bless him.*

* Although it is not known that man has absolutely extirpated any vegetable, the mysterious diseases which have, for the last twenty years, so injuriously affected the potato, the vine, the orange, the olive, and sillk husbandry, are ascribed by some to a climatic deterioration produced by excessive destruction of the woods. As will be seen in the next chapter, a retardation in the period of spring has been observed in numerous localities in Southern Europe, as well as in the United States, and this change has been thought to favor the multiplication of the obscure parasites which cause the injury to the vegetable just mentioned.

Babinet supposes the parasites which attack the grape and the potato to be animal, not vegetable, and he ascribes their multiplication to excessive manuring and stimulation of the growth of the plants on which they live. They are now generally, if not universally, regarded as vegretable, and if they are so, Babinet's theory would be even more plausible than on his own supposition.Études et Lectures, ii., p. 269.

It is a fact of some interest in agricultural economy, that the oïdium, which is so destructive to the grape, has produced no pecuniary loss to the proprietors of the vineyards in France. "The price of wine," says Lavergne, "has cuintupled, and as the product of the rintage has not diminished in the same proportion, the crisis has been, on the whole, rather advantageous thatn detrimental to the country."-Economie Rurale de la France, pp. 263, 261.

France produces a large surplus of wines for exportation, and the sales to foreisn consumers are the principal source of profit to French vine-rrowers. In Firthern Italy, on the contrary, which exports little wine, there has been no such increase in the price of wine as to compensate the great diminution in the yield of the vines, and the loss of this harvest is severely felt. In sicily, however, which exports much wine, prices have risen as rapidly as in France. Wiltershausen informs us that in the years 18:35-4.2, the red wine of Mount Etna sold at the rate of one kreuzer and a half, or one eent the bottle, and sometimes even at but two-thirds that price, but that at present it commands five or six times as much.

The grape disease has operated severely on small cultivators whose vineyards only furmished a supply for domestic use, but sicily has received a compensittion in the immense increase which it has occasioned in both the product and 
All the operations of rural husbandry are destructive to spon taneous vegetation by the voluntary substitution of domestic for wild plants, and, as we have seen, the armies of the colonist are attended by troops of irregular and unrecognized camp-followers, which soon establish and propagate themselves over the new conquests. These unbidden and hungry guests-the gipsies of the vegetable world-often lave great aptitude for accommodation and acclimation, and sometimes even crowd out the native growth to make room for themselves. The botanist Latham informs us that indigenous flowering plants, once abundant on the Northwestern prairies, have been so nearly extirpated by the inroads of half-wild vegetables which have come in the train of the Eastern immigrant, that there is reason to fear that, in a few years, his herbarium will constitute the only evidence of their former existence.*

There are plants - themselves perhaps sometimes stragglers from their proper habitat-which are found only in small numbers and in few localities. These are eagerly sought by the botanist, and some such species are believed to be on the very verge of extinction, from the zeal of collectors.

\section{Animal Life as a Geological and Geographical Agenoy.}

The quantitative value of animated life, as a geological agency, seems to be inversely as the volume of the individual organism; for nature supplies by numbers what is wanting in the bulk of the animal out of whose remains or structures she forms strata covering whole provinces, and builds up from the depths of the sea large islands if not continents. There are, it is true, near the mouths of the great Siberian rivers which empty themselves into the Polar Sea, drift islands composed, in an incredibly large pro-

the profits of the sulphur mines. Flour of sulphur is applied to the vine as a remedy against the disease, and the operation is repeated from two to three or four-and sometimes even eight or ten-times in a season. Hence there is a great demand for sulphur in all the vine-growing countries of Europe, and Waltershausen estimates the annual consumption of that mineral for this single purpose at 850,000 centner, or more than forty thousand tons. The price of snlphur has risen in about the same proportion as that of wine.-WALTERSHAUSEN, Ueber den Sicitianischen Ackerbau, pp. 19, 20.

* Report of Commissioner of Agriculture of the United States for 1870. 
portion, of the bones and tusks of elephants, mastodons, and other huge pachyderms; and many extensive caves in various parts of the world are half filled with the skeletons of quadrupeds, sometimes lying loose in the earth, sometimes cemented together into an osseous breccia by a calcareous deposit or other binding material. These remains of large animals, though found in comparatively late formations, generally belong to extinct species, and their modern congeners or representatives do not exist in sufficient numbers to be of sensible importance in geology or in geography by the mere mass of their skeletons.* But the vegetable products

* Could the bones and other relics of the domestic quadrupeds destroyed by disease or slaughtered for human use in civilized countries be collected into large deposits, as obscure causes have gathered together those of extinct animals, they would soon form aggregations which might almost be called mountains. There were in the United States, in 1870, as we shall see hereafter, nearly one hundred millions of horses, black cattle, sheep, and swine. There are great numbers of all the same animals in the British American Provinces and in Mexico, and there are large herds of wild horses on the plains, and of tamed horses among the independent Indian tribes of North America. It would perhaps not be extravagant to suppose that all these cattle may amount to two-thirds as many as those of the United States, and thus we have in North America a total of $160,000,000$ domestic quadrupeds belonging to species introduced by European colonization, besides dogs, cats, and other four-footed household pets and pests, also of foreign origin.

If we allow half a solid foot to the skelcton and other slowly destructible parts of each animal, the remains of these herds would form a cubical mass measuring not much short of four hundred and fifty feet to the side, or a pyramid equal in dimensions to that of Cheops, and as the average life of these animals does not exceed six or seven years, the accumulations of their bones, horns, hoofs, and other durable remains, would amount to at least fifteen times as great a volume in a single century. If the statistics of 1880 were taken as the basis of the above calculation, the figures would be raised in a surprising ratio, and the accumulation of a century would be shown to be far greater than is here claimed. It is true that the actual mass of solid matter, left by the decay of dead domestic quadrupeds and permanently added to the crust of the earth, is not so great as this calculation makes it. The greatest proportion of the soft parts of domestic animals, and even of the bones, is soon decomposed through direct consumption by man and other carnivora, industrial use, and employment as manure, and thus enters into new combinations in which its animal origin is scarcely traceable. There is, nevertheless, a large annual residuum, which, like decayed vegetable matter, becomes a part of the superficiai mocald; and in any event, brute life immensely changes the form and character of the superficial strata, if it does not sensibly augment the quantity of the matter composing them.

The remains of man, too, add to the earthly coating that covers the face of 
found with them, and, in rare cases, in the stomachs of some of them, are those of yet extant plants; and besides this evidence, the discovery of worlis of human art, deposited in juxtaposition with fossil bones, and evidently at the same time and by the same agency which buried these latter-not to speak of human bones found in the same strata-proves that the animals whose former existence they testify were contemporaneous with man, and possibly even extirpated by him.* I do not propose to enter upon the thorny question, whether the existing races of man are genealogically connected with these ancient types of humanity, and I advert to these facts only for the sake of the suggestion, that man,

the globe. The humin bodies deposited in the catacombs during the long, loug ages of Egyptian history, would perhaps build as large a pile as one generation of the quadrupeds of the Uuited States. In the barbarous days of old Moslem warfare, the conquerors crected large pyramids of human skulls. The soil of cemeteries in the great cities of Europe has sometimes been raised several feet by the deposit of the dead during a few generations. In the East, Turks and Christiuns alike bury bodies but a couple of feet beneath the surface. The grave is respected as long as the tombstone remains, but the sepulchres of the ignoble poor, and of those whose monuments time or accident has removed, are opened again and again to receive fresh occupants. Hence the ground in Oriental cemeteries is pervaded with relics of humanity, if not wholly composed of them; and an examination of the soil of the lower part of the Petit Champ des IForts, at Pera, by the naked eye alone, shows the observer that it consists almost exclusively of the comminuted bones of his fellow-man.

* The bones of mammoths and mastodons, in many instances, appear to have been grazed or cut by flint arrow-heads or other stone weapons, and the bones of animals now extiuct are often found wrought by contemporary man into arms and utensils, or split to extract the marrow. These accounts have of ten been discredited, because it has been assumed that the extinetion of these animals was more ancient than the existence of man. Recent discoveries render it certain that this latter conclusion has been too hastily adopted.

On page 143 of the Antiquity of Irun, Lyell remarks that man "no doubt played his part in hastening the era of the extinction" of the large pachyderms and beasts of prey; but, as contemporaneous species of other animals, which man can not be supposed to have extirpated, have also become extinct, he argues that the disappearance of the quadrupeds in question can not be ascribed to human action alone.

On this point it may be observed that, as we can not know what precise physical conditions were necessary to the existence of a given extinct organism, we can not say how far such conditions may have been modified by the action of man, and he may therefore have influenced the life of such organ isms in ways, and to an extent, of which we can form no just idea. 
.n his earliest known stages of exi-tnce, was probably a destructive power upon the earth, though perhaps not so emphatically as are his present representatives.

The larger wild animals are not now numerous enough in any one region to form extensive deposits by their remains; but they have, nevertheless, a certain geographical importance. If the myriads of large browsing and grazing quadrupeds which wander over the plains of South Africa-and the slaughter of which by thousands is the source of a ferocious pleasure and a brutal triumph to professedly civilized hunters-if the herds of the American bison, which are numbered by huudrerls of thousands, do not produce visible changes in the forms of terrestrial surface, they have at least an immense influence on the growth and distribution of vegetable life, and, of course, indirectly upon all the physical conditions of soil and climate between which and vegetation a mutual interdependence exists.

In the preceding chapter I referred to the agency of the beaver in the formation of bogs as producing sensible geographical effects.

I am disposed to think that more bogs in the Northern States owe their origin to beavers than to accidental obstructions of rivulets by wind-fallen or naturally decayed trees; for there are few swamps in those States, at the outlets of which we may not, by careful search, find the remains of a beaver dam. The beaver sometimes inhabits natural lakelets and even large rivers like the Upper Mississippi, when the current is not too rapid, but he prefers to owe his pond to his own ingenuity and toil. The reservoir once constructed, its inhabitants rapidly multiply so long as the trees, and the harvests of poud lilies and other aquatic plants on which this quadruped feeds in winter, suffice for the supply of the growing population. But the extension of the water causes the death of the neighboring trees, and the ammal growth of those which could be reached by canals and floated to the pond soon becomes insufficient for the wants of the community, and the beaver metropolis now sends out expeditions of discovery and colonization. The pond gradually fills up, by the operation of the same causes as when it owes its existence to an accidental obstr:ıction, and when, at last, the original settlement is converted into a bog by the usual processes of regetable life, the remaining 
inhabitunts abandon it and build on some virgin brooklet a new city of the waters.*

* I find confirmation of my own observations on this point (published in 1863) in the North- West Passage by Land of Milton and Cheadle, London, 1865. These travellers observed "a long chain of marshes formed by the damming up of a stream which had now ceased to exist," Chap. X. In Chap. XII. they state that "nearly every stream between the Pembina and the Athabasca-except the large river MIcLeod-appeared to have been destroyed by the agency of the beaver," and they question whether the vast extent of swampy ground in that region "has not been brought to this condition by the work of beavers who have thus destroyed, by their own labor, the streams important to their own existence."

But even here nature provides a remedy, for when the process of "consolidation " referred to in treating of bogs in the first chapter shall have been completed, and the forest re-established upon the marshes, the water now diffused through them will be collected in the lower or more yielding portions, cut new channels for their flow, become running brooks, and thus restore the ancient aspect of the surface.

The authors add the curious observation that the beavers of the present day seem to be a degeuerate race, as they neither fell large trees nor construct great dams, while their progenitors cut down trees two feet in diameter and dammed up rivers a hundred feet in width. The change in the habits of the beaver is probably due to the diminution of their numbers since the introduction of fire. arms, and to the fact that their hydraulic operations are more frequently interrupted by the encroachments of man.

In the valley of the Yellowstone, which has but lately been much visited by the white man, Hayden saw stumps of trees thirty inches in diameter which had been cut down by beavers._-Geological Survey of Wyoming, p. 135.

The American beaver closely resembles his European congener, and I believe most naturalists now regard them as identical. A difference of species had been inferred from a difference in their modes of life, the European animal being solitary and not a builder, the American gregarious and constructive. But late careful researches in Germany have shown the former existence of numerous beaver dams in that country, though the animal, having become too rare to form colonies, has of course ceased to attempt works which require the co-operation of numerous individuals.-ScHLEIDEN, Für Baum und Wald, Leipzig, 1870, p. 68.

From a passage in the Dittamondo of Fazio degli Uberti, L. III., ch. ii., ir appears that in the time of that author, about 1360 , the beaver of Northerr. Italy was a constructive animal. Speaking of the beaver of the territory of Ferrara, he says :

\footnotetext{
"Nei suol laguni un animal ripara Che é bestia e pesce, il qual bevero ha nome.

La casa fa incastellata, etc., etc."
}

I have been lately informed, on good authority, that the beaver is still sometimes found in the Delta of the Po.

On the question of identity and on all others relating to this interesting 


\section{Infruence of Animal Life on Vegetation.}

The influence of wild quadrupeds upon vegetable life has been little studied, and not many facts bearing upon it have been recorded; but so far as is known, it appears to be conservative rather than pernicious. Few wild animals depend for their subsistence on regetable products obtainable only by the destruction of the plant, and they seem to confine their consumption almost exclusively to the annual harvest of leaf or trigg, or at least of parts of the regetable easily reprodaced. If there are exceptions to this rule, they are in cases where the numbers of the animal are so proportioned to the abundance of the vegetable that there is no danger of the extermination of the plant from the voracity of the quadruped, or of the extinction of the quadruped from the searcity of the plant.* In diet and natural wants the bison re-

animal, see L. H. JIongav's important monograph, The American Beacer and his Works, Philadelphia, 1868. Among the many new facts obserred by this investigator, is the construction of canals by the beaver to float trunks and branches of trees to his ponds. These canals are sometimes 600 or 700 feet long, with a width of two or three feet and a depth of one to one and a half.

* European foresters speak of the action of the squirrel as injurious to trees. Doubtless this is sometimes true in the case of artificial forests, but in woods of spontaneous growth, ordered and governed by nature, the squirrel does not attack trees, or at least the injury he may do is too trifling to be perceptible; but he is a formidable enemy to the plantation. "The squirrels bite the cones of the pine and consume the seed which might serve to restock the wood; they do still more mischicf by gnawing off, near the leading shoot, a strip of bark, and thus often completely girdling the tree. Trees so injured must be felled, as they would never acquire a vigorous growth. The squirrel is especially destructive to the pine in Sologne, where he gnaws the bark of trees twenty or twenty-five years old." But even here, nature sometimes provides a compensation, by making the appetite of this quadruped serve to prevent an excessive production of seed cones, which tends to obstruct the due growth of the leading shoot. "In some of the pineries of Brittany which produce cones so abundantly as to strangle the development of the leading shoot of the maritime pine, it has been observed that the pines are most vigorous where the squirrels are most numerous, a result attributed to the repression of the cones by this rodent."-BotTel, Mise en valeur des Terres paurres, p. 50. Journal of Forestry, No. 20, pp. 569-570, contains an article stating that squirrels are very fond of sap, and a large English landholder informs me that these rodents destroyed a great number of fine beeches in his woods by gnawing through the bark to reach the sap-vessels, thus completely girdling the trees.

Very interesting observations, on the agency of the squirrel and other small 
sembles the ox, the ibex and the chammis assimilate themselves to the goat and the sheep) but while the wild animal does not ap. pear to be a destructive agency in the garden of nature, his domestic congeners are eminently so.* This is partly from the change of habits resulting from domestication and association with man, partly from the fact that the number of reclaimed animals is not determined by the natural relation of demand and spontaneous supply which regulates the multiplication of wild creatures, but by the convenience of man, who is, in comparatively few things, amenable to the control of the merely physical arrangements of nature. When the domesticated animal escapes from human jurisdiction, as in the case of the ox, the horse, the goat, and perhaps the ass-which, so far as I know, are the only well-authenticated instances of the complete emancipation of household quadrupeds-he becomes again an unresisting subject of nature, and all his economy is governed by the same laws as that of his fellows which have never been enslaved by man; but, so long as he obeys a human lord, he is an auxiliary in the warfare his master is ever waging against all existences except those which he can tame to a willing servitude.

animals in planting and in destroying nuts and other seeds of trees, may be found in a paper on the Succession of Forests in Thoreau's Excursions, pp. 135 et seq.

I once saw several quarts of beach-nuts taken from the winter quarters of a family of flying-squirrels in a lollow tree. The kernels were neatly stripped of their shells and carefully stored in a dry cavity.

* Evelyn thought the depasturing of grass by cattle serviceable to its growth. "The biting of cattle," he remarks, "gives a gentle loosening to the roots of the herbage, and makes it to grow fine and sweet, and their very breath and treading as well as soil, and the comfort of their warm bodies, is wholesome and marvellously cherishing."-Terra, or Philosophical Discourse of Earth, p. 36.

In a note upon this passage, Hunter observes: "Nice farmers consider the lying of a beast upon the ground, for one night only, as a suflicient tilth for the year. The breath of graminivorous quadrupeds does certainly enrich the roots of grass; a circumstance worthy of the attention of the philosophical farmer."-Terra, same page.

The "philosophical farmer" of the present day will not adopt these opinions without some qualification, and they certainly are not sustained by American observation.

The Report of the Department of Agriculture for MIarch and April, 1872, states that the native grasses are disappearing from the prairies of Texas, especially on the bottom-lands, depasturing by cattle being destructive to them. 


\section{Origin and Trensfer of Domestic Quadmupeds.}

Civilization is so intimately associated with certain inferior forms of animal life, if not dependent on them, that cultivated man has never failed to accompany liimself, in all his migrations, with some of these humbler attendants. The ox, the horse, the sheep, and eren the comparatively useless dog and cat, as well as several species of poultry, are voluntarily transferred by erery emigrant colony, and they soon multiply to numbers far exceeding those of the wild genera most nearly corresponding to them.*

Of the origin of our domestic animals, we know historically nothing, because their domestication belongs to the ages which preceded written annals; but though they can not all be specifically identified with now extant wild animals, it is presumal)le that they have been reclaimed from an origimally wild state. Ancient writers have preserved to us fewer data respecting the introduction of domestic animals into new countries than respecting the transplantation of domestic regetables. Ritter, in his learned essay on the camel, has shown that this animal was not employed by the Egyptians until a comparatively late period in their history; + that he was unknown to the Carthaginians until

* The rat and the mouse, though not voluntarily transported, are passengers by every ship that sails for a foreign port, and several species of these quadrupeds have, consequently, much extended their range and incrensed their numbers in modern times. From a story of IIeliogabalus related by L.ı. PRIDIUs, Ifist. Aug. Scriptores, ed. Casaubon, 1690, p. 110, it would seem that mice at least were not very common in ancient Rome. Among the capricious freaks of that emperor, it is said that he undertook to investigate the statistics of the arachnoid population of the capital, and that 10,000 pounds of spiders (or spiders' webs-for aranea is equivocal) were readily collected; but when he got up a mouse-show, he thought ten thousand mice a very fair number. Rats are not less numerous in all great cities; and in Paris, where their skins are used for gloves, and their flesh, it is whispered, in some very complex and equivocal dishes, they are caught by legions. I have read of a minufacturer who contracted to buy of the rat-catchers, at a ligh price, all the rat-skins they could furnish before a certain date, and failed, within a week for want of capital, when the stock of peltry had run up to 600,000 .

Civilization has not contented itself with the introduction of domestic animals alone. The English sportsman imports foxes from the continent, and, Grimalkin-like, turns them loose in order that he may have the pleasure of chasing them afterwards.

+ The horse and the ass were equally unknown to ancient Egypt, and do not 
after the downfall of their commonwealth; and that his first ap. pearance in Western Africa is more recent still. The Bactrian camel was certainly brought from Asia Minor to the Northern shores of the Black Sea, by the Goths, in the third or fourth century, and the buffalo first appeared in Italy about A.D. 600 , though it is unknown whence or by whom he was introduced.* The Arabian single-humped camel, or dromedary, has been carried to the Canary Islands, partially introduced into Australia, Greece, Spain, and even Tuscany, experimented upon to little purpose in Venezuela, and finally imported by the American Government into Texas and New MIexico, where it finds the climate and the vegetable products best suited to its wants, and promises to become a very useful agent in the promotion of the special civilization for which those regions are adapted. The buffalo was introduced into Italy by the Lombards, A.D. 595-6. According to the Italia Agricola, there were, in 1862, sixty-five thousand buffaloes in the Southern Provinces of that country.

Quadrupeds, both domestic and wild, bear the privations and discomforts of long voyages better than would be supposed. The elephant, the giraffe, the rhinoceros, and even the hippopotamus, do not seem to suffer much at sea. Some of the camels imported by the U. S. Government into Texas from the Crimea and Northern Africa were a whole year on shipboard. On the other hand, George Sand, in Un Hiver au MFidi, gives an amusing description of the sea-sickness of swine in the short passage from the Baleares to Barcelona.

America had no domestic quadruped except a species of dog, the lama tribe, and, to a certain extent, the bisnn or buffalo. $\dagger$

appear in the sculptures before the XV. and XVI. dynasties. But even then, the horse was only known as a draught animal, and the only representation of a horseman yet found in the Egyptian tombs is on the blade of a battle-axe of uncertain origin and period.

* Erdkunde, viii., Asien, 1ste Abtheilung, pp. 660, 758. HenN, Kulturpflanzen, p. 345 .

+ See Chapter III., post; also Huмвold , Ansichten der Natur, i., p. 71. From the anatomical character of the bones of the urus, or auerochs, found among the relics of the lacustrine population of ancient Switzerland, and from other circumstances, it is inferred that this animal had been domesticated by that people; and it is stated, I know not upon what authority, in Le Alpi che cingono l'Italia, that it had been tamed by the Veneti also. See LreLL, $A n$. 
Of course, it owes the horse, the ass, the ox, the sheep, the goat, and the swine, as does also Australia, to European colonization. Modern Europe has, thus far, not accomplished much in the way of importation of new animals, though some interesting essays have been made. The reindeer was successfully introduced into Iceland about a century ago, while similar attempts failed, about the same time, in Scotland. The Cashmere or Thibet goat was brought to France a generation since, and succeeds well. The same or an allied species and the Asiatic buffalo were carried to South Carolina about the year 1850, and the former, at least, is thought likely to prove of permanent value in the United States.* The yak, or Tartary ox, seems to thrive in France, and it is hoped that success will attend the present efforts to introduce the South American alpaca into Europe. $†$

tiquity of Man, pp. 24, 25, and the last-named work, p. 489. This is a fact of much interest, because it is one of the very few historically known instances of the extinction of a domestic quadruped, and the extreme improbability of such an event gives some countenance to the theory of the identity of the domestic ox with, and its descent from, the urus.

* The goat introduced into South Carolina was brought from the district of Angora, in Asia Minor, which has long been celebrated for flocks of this valuable animal. It is calculated that more than a million of these goats are raised in that district, and it is commonly believed that the Angora goat and its wool degenerate when transported. Probably this is only an invention of the shepherds to prevent rivals from attempting to interfere with so profitable a monopoly. But if the popular prejudice has any foundation, the degeneracy is doubtless to be attributed to ignorance of the special treatment which long experience has taught the Angora shepherds, and the consequent neglect of such precautions as are necessary to the proper care of the animal. Throughout nearly the whole territory of the United States the success of the Angora goat is perfect, and it would undoubtedly thrive equally well in Italy, though it is very doubtful whether in either country the value of its fleece would compensate the damage it would do to the woods.

t The reproductive powers of animals, as well as of plants, seem to be sometimes stimulated in an extraordinary way by transfer to a foreign clime. The common warren rabbit, introduced by the early colonists into the island of MIadeira, multiplied to such a degree as to threaten the extirpation of vegetation, and in Australia the same quadruped has become so numerous as to be a very serious evil. The colonists are obliged to employ professional rabbit-hunters, and one planter has enclosed his grounds by four miles of solid wall, at an expense of $\$ 6,000$, to protect his crops against these ravagers.-Revue des Eaus et Ficrtes, 1870 , p. 88. 


\section{ORIGIN AND TRANSFER OF DOMESTIC QUADRUPEDS.}

According to the census of the United States for $18 \% 0, *$ the to. tal number of hores in all the States of the American Union, was, in round numbers, $7,100,000$; of asses and mules, 1,100,000 ; of the ox tribe, $25,000,000$; of sheep, $28,000,000$; and of swine, 25,000,000. The only indigenous Nortl American quadruped sulticiently gregarious in habits, and sufficiently multiplied in numbers, to form really large herds, is the bison, or, as he is commonly called in America, the buffalo; and this animal is confined to the prairie region of the Mississippi basin, a small part of British America, and Northern Mexico. The engineers sent out to surrey railroad routes to the Pacific estimated the number of a single herd of bisons seen within the last fifteen years on the great plains near the Upper ALissouri, at not less than 200,000, and yet the range oceupied by this animal is now very much smaller in area than it was when the whites first established themselves on

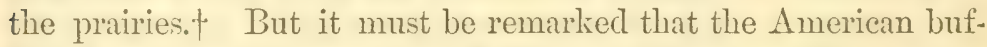
falo is a migratory animal, and that, at the season of his annual journeys, the whole stock of a rast extent of pasture-ground is collected into a single army, which is seen at or very near any

*In the enumeration of farm stock, "sucking pigs, spring lambs, and calves," are omitted. I believe they are included in the numbers reported by the census of 1860 . Horses and horned cattle in towns and cities were excluded from both enumcrations, the law providing for returus on these points from rural districts only. On the whole, there is a diminution in the number of all farm stock, except sheep, since 1860 . This is ascribed by the Report to the destruction of domestic quadrupeds during the civil war, but this hardly explaius the reduction in the number of swine from $39,000,000$ in 1860 to $25,000,000$ in 1870 .

The census of $1 S 80$ shows the total number of horses in the United States (exclusive of those owned by persons not cultivating farms, whether in cities or villages, or elsewhere) to be considerably over $10,000,000$; that of asses and mules $1,800,000$; of the ox tribe, $35,000,000$; of sheep, $35,000,000$; of swine, nearly $48,000,000$.

+ "About five miles from camp we ascended to the top of a high hill, and for a great distance ahead every square mile seemed to have a herd of buffalo upon it. Their number was variously estimated by the members of the party ; by some as high as half a million. I do not think it any exaggeration to set it down at 200,000."-Stevens's Narrative and Final Report. Reports of Explorations and Surveys for Railroad to Pacific, vol. xii., book i., 1860.

The next day the party fell in with a "buffalo trail," where at least 100,000 were thought to have crossed a slough.

As late as 1868 , Sheridan's party estimated the number of bisons seen by them in a single day at 200,000.-Sheridan's Troopers on the Border, 1868, p. 41 
one point only for a few days during the entire season. Hence there is risk of great error in estimating the numbers of the bison in a given district from the magnitude of the herds seen at or about the same time at a single place of observation; and, upon the whole, it is neither proved nor probable that the bison was ever, at any one time, as numerous in North America as the domestic bovine species is at present. The elk, the moose, the musk ox, the caribou, and the smaller quadrupeds popularly embraced under the general name of deer, though sufficient for the wants of a sparse savage population, were never numerically very abundant, and the carnivora which fed upon them were still less so. It is almost needless to add that the Rocky Mountain sheep aud goat must always have been very rare.

Summing up the whole, then, it is evident that the wild quadrupeds of North America, even when most numerous, were few compared with their domestic successors, that they required a much less supply of vegetable food, and consequently were far less important as geographical elements than the many millions of hoofed and horned cattle now fed by civilized man on the same continent.

\section{Extirpation of Wild Quadrupeds.}

Although man never fails greatly to diminish, and is perhaps destined ultimately to exterminate, such of the larger wild quadrupeds as he can not profitably domesticate, yet their numbers often fluctuate, and even after they seem almost extinct, they sometimes suddenly increase without any intentional steps to promote such a result on his part. During the wars which followed the French Revolution, the wolf multiplied in many parts of Europe, partly because the hunters were withdrawn from the woods to chase a nobler game, and partly because the bodies of slain men and horses supplied this voracious quadruped with more abundant food.* The same animal became again more numerous in Poland after the general disarming of the rural popu-

\footnotetext{
* During the late civil war in America, deer and other animals of the chase multiplied rapilly in the regions of the Southern States, which were partly depopulated and deprived of their sportsmen by the military operations of the contest, and the bear is said to have reappeared in districts where he had not been seen in the memory of living men.
} 
lation by the Russian Government. On the other hand, when the hunters pursue the wolf, the graminivorous wild quadrupeds increase, and thus in turn promote the multiplication of their great four-footed destroyer by augmenting the supply of his nourishment. So long as the fur of the beaver was extensively employed as a material for hats, it bore a very high price, and the chase of this quadruped was so keen that naturalists feared its speedy extinction. When a Parisian manufacturer inrented the silk hat, which soon came into almost universal use, the demand for beavers' fur fell off, and this animal-whose habits are an important agency in the formation of bogs and other modifications of forest nature-immediately began to increase, reappeared in haunts which he had long abaudoned, and can no longer be regarded as rare enough to be in immediate danger of extirpation. Thus the convenience or the caprice of Parisian fashion has unconsciously exercised an influence which may sensibly affect the physical geography of a distant continent.

Since the invention of gunpowder, some quadrupeds have completely disappeared from many European and Asiatic comntries where they were formerly numerous. The last wolf was killed in Great Britain two hundred years ago, and the bear was extirpated from that island still earlier. The lion is believed to have inhabited Asia Minor and Syria, and probably Greece and Sicily also, long after the commencement of the historical period, and he is even said to have been not yet extinct in the first-named two of these countries at the time of the first crusade.*

The British wild ox is extinct except in a few English and Scottish parks, while in Irish bogs, of no great apparent antiquity, are found antlers which testify to the former existence of a stag much

\footnotetext{
* In maintaining the recent existence of the lion in the countries named in the text, naturalists have, perhaps, laid too much weight on the frequent occurrence of representations of this animal in sculptures apparently of a historical character. It will not do to argue, twenty centuries hence, that the lion and the unicorn were common in Great Britain in Queen Victoria's time, because they are often seen "fighting for the crown" in the carvings and paintings of that period. Many palæontologists, however, identify the great cat-like animal, whose skeletons are frequently found in British bone-caves, with the lion of our times.

The leopard (panthera), though already growing scarce, was found in Cilicia in Cicero's time. See his letter to Cœlius. Epist. ad Diversos, Lib. II., Ep. 11.
} 
larger than any extant European species. Two large graminivorous or browsing quadrupeds, the ur and the schelk, once common in Germany, have been utterly extirpated, the eland and the auerochs nearly so. The Nibelungen-Lied, which, in the oldest form preserved to us, dates from about the year 1200, though its original composition no doubt belongs to an earlier period, thus sings :

Chen slowe the dowghtic Sigfrid a wigent and an clli, fje smote font stoute uroxen and a grim and sturdie schelk. *

Modern naturalists identify the elk with the eland, the wisent with the auerochs. The period when the ur and the schelk became extinct is not known. The auerochs survived in Prussia until the middle of the last century, but unless it is identical with a sinilar quadruped said to be found on the Caucasus, it now exists only in the Russian imperial forest of Bialowitz, where about a thousand are still preserved, and in some great menageries, as for example that at Schönbrunn, near Vienna, which, in 1852, had four specimens. The eland is still kept in the royal preserves of Prussia to the number of four or five hundred individuals. $\dagger$ The chanois is becoming rare, and the ibex or steinbock, once common in all the high Alps, is now believed to be confined to the Cogne mountains in Piedmont, between the valleys of the Dora Baltea and the Oreo, though it is said that a few still linger about the Grandes Jorasses near Cormayeur.

The chase, which in early stages of human life was a necessity, has become with advancing civilization not merely a passion but a dilettanteism, and the cruel records of this pastime are among

* Far unch sluager schicre, rinen wisent unde elch. Starker mre vicre, wnt rimen grimmen schelel.

XVI. Aventiure.

The testimony of the Nibelungen-Lied is not conclusive evidence that these quadrupeds existed in Germany at the time of the composition of that poem. It proves too much; for, a few lines above those just quoted, Sigfrid is said to Lave killed a lion, an animal which the most patriotic Teuton will hardly claim as a denizen of mediæval Germany.

t The animal now generally called eland is an African species of the antelope family, oreas canna. The name was doubtless transferred to the African ani. mal by the Dutch colonists. 
the most discreditable pages in modern literature. It is true that in India and other tropical countries the number and ferocity of the wild beasts not only justify but command a war of exter. mination against them, but the indiscriminate slaughter of many quadrupeds which are favorite objects of the chase can urge no such apology. Late official reports from India state the number of human victims of the tiger, the leopard, the wolf, and other beasts of prey, in ten "districts," at more than twelve thousand within three years, and we are informed on like authority that within the last six years more than ten thousand men, women and children have perished in the same way in the Presidency of Bengal alone. One tiger, we are told, had killed more than a hundred people, and finally stopped the travel on an important road, and another had caused the desertion of thirteen villages and thrown 250 square miles out of cultivation. In such facts we find abundant justification of the slaying of seven thousand tigers, nearly six thousand leopards, and twenty-five hundred other ravenous beasts in the Bengal Presidency, in the space of half a dozen years. But the humane reader will not think the value of the flesh, the skin, and other less important products of inoffensive quadrupeds, a satisfactory excuse for the ravages committed upon them by amateur sportsmen as well as by professional hunters. In 1861, it was computed that the annual supply of the English market with ivory cost the lives of 8,000 elephants. Others make the number much larger, and it is said that half as much ivory is consumed in the United States as in Great Britain. In Ceylon, where the elephants are numerous and destructive to the erops as well as dangerous to travellers, while their tusks are small and of comparatively little value, the government pays a small reward for killing them. According to Sir Emerson Tennant, * in three years prior to 1848 , the premium was paid for 3,500 elephants in a part of the northern district, and between 1851 and 1856 for 2,000 in the southern district. Major Rogers, famous as an elephant shooter in Ceylon, ceased to count his victims after he had slain 1,300, and Cumming in South Africa sacrificed his hecatombs every month.

In spite of the rarity of the chamois, his cautious shyness, and

* Natural History of Ceylon, chap. iv. 
the comparative inaccessibility of his favorite haunts, Colani of Pontresina, who died in 1837, had killed not less than 2,000 of these animals; Küng, who is still living in the Upper Engadine, 1,500; Hitz, 1,300, and Zwichi an equal number; Soldani shot 1,100 or 1,200 in the mountains which enclose the Val Bregaglia, and there are many living hunters who ean boast of having killed from 500 to 800 of these interesting quadrupeds. * According to the Nere Alpenpost, 779 ehamois were shot in the Grisons in 1876 , and it is added that, from a comparison of these figures with those of preceding years, the conclusion is that the number of chanois is rather increasing than diminishing in the districts open to sportsmen. In the same Canton, were killed, during the same year, 4 bears, 5 vultures, 4 eagles, 15 owls, 69 sparrowhawks, 324 magpies, and 1 otter.

In America, the chase of the larger quadrupeds is not less destructive. In a late number of the American Naturalist, the present annual slaughter of the bison is calculated at the enormous number of 50.0,000, and the elk, the moose, the caribou, and the more familiar species of deer furnish, perhaps, as many victims. The most fortunate deer-hunter I have personally known in New England had killed only 960 ; but in the northern part of the State of New York a single sportsman is said to have shot 1,500, and this number has been doubtless exceeded by zealous Nimrods of the West.

But so far as numbers are concerned, the statistics of the furtrade furnish the most surprising results. Russia sends annually to foreign markets not less than 20,000,000 squirrel skins. Great Britain has sometimes imported from South America 600,000 nutria skins in a year. The Leipzig market receives annually nearly 200,000 ermine, and the Hudson Bay Company is said to have occasionally burnt 20,000 ermine skins in order that the market might not be overstocked. A late Parliamentary Report estimates the annual consumption in England of the skins of the

* Although it is only in the severest cold of winter that the chamois descends to the vicinity of grounds occupied by man, its organization does not confine it to the mountains. In the royal park of Racconigri, on the plain a few miles from Turin, at a height of less than 1,000 feet, is kept a herd of thirty or forty chamois, which thrives and breeds apparently as well as in the Alps. 
rabbit-which, even when reared in warrens, is still a half-wild animal-at 30,000,000.

Of course natural reproduction can not keep pace with this enormous destruction, and many animals of much interest to natural science are in imminent danger of final extirpation.*

\section{Large ILarine Animals relatively unimportant in Geography.}

Vast as is the bulk of some of the higher orders of aquatic animals, their remains are generally so perishable that, even where most abundant, they do not appear to be now forming permanent deposits of any considerable magnitude; but it is quite otherwise with shell-fish, and, as we shall see hereafter, with many of the minute limeworkers of the sea. There are, on the southern coast of the United States, beds of shells so extensive that they were formerly supposed to have been naturally accumulated, and were appealed to as proofs of an elevation of the coast by geological causes; but they are now ascertained to have been derived chiefly from oysters and other shell-fish consumed in the course of long ages by the inhabitants of Indian towns. The planting of a bed of oysters in a new locality might very probably lead, in time, to the formation of a bank, which, in connection with other deposits, might perceptibly affect the line of a coast, or, by changing the course of marine currents or the outlet of a river, produce geographical changes of no small importance.

\section{Introduction and Breeding of Fish.}

The introduction and successful breeding of fish of foreign species appears to have been long practised in China, and was not unknown to the Greeks and Romans. + This art has been revived

* Objectionable as game laws are, they have done something to prevent the extinction of many quadrupeds which naturalists would be loth to lose, and, as in the case of the British ox, private parks and preserves have saved other species from destruction. Some few wild animals, such as the American mink, for example, hare been protected and bred with profit, and in Pennsylvania an association of gentlemen has set apart, and is about enclosing, a park of 16,000 acres for the breeding of indigenous quadrupeds and fowls.

t The observations of Colcirelua, de Re Rustica, lib. viii., sixteenth and following chapters, on fish-breeding, are interesting. The Romans not only stocked natural but constructed artificial ponds, of both fresh and salt water 
in modern times, but thus far without any important results, economical or physical, though there seems to be good reason to believe it may be employed with advantage on an extended scale. $\mathrm{As}$ in the case of plants, man has sometimes undesignedly introduced new species of aquatic animals into countries distant from their birthplace. The accidental escape of Chinese goldfish from ponds where they were bred as a garden ornament, has peopled some European, and, it is said, American streams with this species. Canals of navigation and irrigation interehange the fish of lakes and rivers widely separated by natural barriers, as well as the plants which drop their seeds into the waters. The Erie Canal, as measured by its own channel, has a length of about three hundred and sixty miles, and it has ascending and descending locks in both directions. By this route, the fresh-water fish of the Hudson and the Upper Lakes, and some of the indigenous vegetables of these respective basins, have intermixed, and the fauma and flora of the two regions have now more species common to both than before the canal was opened.* The opening of the Suez Canal will, no doubt, produce very interesting revolutions in the animal and vegetable population of both basins. The Mediterranean, with some local exceptions-such as the bays of Calabria, and the coast of Sicily so picturesquely described by Quatrefages + -is comparatively poor in marine vegetation, and in shell as well as in fin fish. The scarcity of fish in some of its gulfs is proverbial, and you may scrutinize long stretches of beach on its northern shores, after every south wind for a whole winter, without finding a dozen shells to reward your search. But no one who has not looked down into tropical or subtropical seas can conceive the amazing wealth of the Red Sea in organic life. Its bottom is carpeted or paved with marine plants, with zoöphytes and with shells, while its waters are teeming with infinitely varied forms of moving life. $\mathrm{V}$ Most of its regetables and its animals, no

aud cut off bays of the sea for this purpose. They also naturalized various species of sea-fish in fresh water.

* The opening or rather the reconstruction of the Claudian emissary by Prince Torlonia, designed to drain the Lake Fucinus, or Celano, has introduced the fish of that lake into the Liri or Garigliamo which receives the discharge from the lake.-DonoteA, Sommario storico dell' Alieutica, p. 60.

† Souvenirs d'un Naturaliste, i., pp. 204 et seq. 
doubt, are confined by the laws of their organization to a warmer temperature than that of the Mediterranean, but among them there must be many whose habitat is of a wider range, many whose powers of accommodation would enable them to acclimate themselves in a colder sea.

We may suppose the less numerous aquatic fauna and flora of the Mediterranean to be equally capable of climatic adaptation, and hence there will be a partial interchange of the organic population not already common to both seas. Destructive species, thus newly introduced, may diminish the numbers of their proper prey in either basin, and, on the other hand, the increased supply of appropriate food may greatly multiply the abundance of others, and at the same time add important contributions to the aliment of man in the countries bordering on the Mediterranean.*

Some accidental attraction not unfrequently induces fish to follow a vessel for days in succession, and they may thus be enticed into zones very distant from their native habitat. Several years ago, I was told at Constantinople, upon good authority, that a couple of fish, of a species wholly unknown to the natives, had just been taken in the Bosphorus. They were alleged to have followed an English ship from the Thames, and to have been frequently observed by the crew during the passage; but I was unable to learn their specific character. $\dagger$

Many fish which pass the greater part of the year in salt water, spawn in fresh; and some fresh-water species, the common brooktrout of New England for instance, which under ordinary circumstances never visits the sea, will, if transferred to brooks empty-

* The dissolution of the salts in the bed of the Bitter Lakes impregnated the water admitted from the Red Sea so highly that for some time fish were not seen in that basin. The flow of the current through the canal has now reduced the proportion of saline matter to five per cent., and late travellers speak of fish as abundant in its waters. Interesting observations on the process of interchange between the two seas, which seems to be a slow one, will be found in Petermann's Mitthelungen, No. III., for 18-, p. 120.

+ Fifteen or twenty years ago, the Italian Government imported from France a dredging machine for use in the harbor of La Spezia. The dredge brought, attached to its hull, a shell-fish not known in Italian waters. The mollusk, finding the local circumstances favorable, established itself in this new habitat, multiplied rapidly, and is now found almost everywhere on the west coast of the Peninsula. 
ing directly into the ocean, go down into the salt water after spawning-time, and return again the next season. Some sea fish have been naturalized in fresh water, and scientists have argued from the character of the fish of Lake Baikal, and especially from the existence of the seal in that locality, that all its inhabitants were originally marine species, and that they have entirely changed their habits during the gradual conversion of this lake-once, as is assumed, a maritime bay-into a fresh-water basin.* The presence of the seal is hardly conclusive on this point, for it is sometimes seen in Lake Champlain at the distance of some hundreds of miles from even brackish water. One of these animals was killed on the ice in that lake in February, 1810, another in February, $18 \pm 6, \uparrow$ and remains of the seal have been found at other times in the same waters.

The intentional naturalization of foreign fish, as I have said, has not thus far yielded important fruits; but though this particular branch of what is called, not very happily, pisciculture, has not yet established its claims to the attention of the physical geographer or the political economist, the artificial breeding of domestic fish, of the lobster and other crustacea, has already produced very valuable results, and is apparently destined to occupy an extremely conspicuous place in the history of man's efforts to compensate his prodigal waste of the gifts of nature. The arrangements for breeding fish in the Venetian lagoon of Comacchio date far back in the Middle Ages, but the example does not seem to have been followed elsewhere in Europe at that period, except in small ponds where the propagation of the fish was left to nature without much artificial aid. The transplantation of oysters to artificial ponds has long been common, and it appears to have recently succeeded well on a large scale in the open sea on the French coast. $\neq$ A great extension of this fishery is hoped

* BABINeT, Études et Lectures, ii., pp. 108, 110.

+ Thospson, Natural History of Vermont, p. 38, and Appendix, p. 13. There is no reason to believe that the seal breeds in Lake Champlain, but the individual last taken there must have been some weeks, at least, in its waters. It was killed on the ice in the widest part of the lake, on the $23 \mathrm{~d}$ of February, thirteen days after the surface was entirely frozen, except the usual small cracks, and a month or two after the ice was closed at all points north of the place where the seal was found.

$\ddagger$ For most valuable facts on this subject see a publication of the Fishery 
for, and it is now proposed to introduce upon the same coast the American soft clam, which is so abundant in the tide-washed beach sands of Long Island Sound as to form an important article in the diet of the neighboring population. Experimental pisciculture has been highly successful in the United States, and will probably soon become a regular branch of rural industry, especially as Congress has made liberal provision for its promotion.*

The restoration of the primitive abundance of salt and fresh water fish, is perhaps the greatest material benefit that, with our present physical resources, governments can hope to confer upon their subjects. The rivers, lakes, and sea-coasts, once re-stocked and protected by law from exhaustion by taking fish at improper seasons, by destructive methods, and in extravagant quantities, would continue indefinitely to furnish a very large supply of most healthful food, which, unlike all domestic and agricultural products, would spontaneously renew itself and cost nothing but the taking. There are many sterile or worn-out soils in Europe so situated that they might, at no very formidable cost, be converted into permanent lakes, which would serve not only as reserroirs to retain the water of winter rains and suow, and give it out in the dry season for irrigation, but as breeding ponds for fish, and would thus, without further cost, yield a larger supply of human food than can at present be obtained from them even at a great expenditure of capital and labor in agricultural operations. $\dagger$ The additions which might be made to the nutriment of

Census, entitled, Oyster Industry, by Ernest Ingersoll, 1881. This exhaustive work, prepared under the direction of Profs. S. F. Baird and G. Brown Goode of the Smithsonian Institution, is a mine of information on the culture and the commerce of the oyster. The extent of this fishery will be a surprise even to those who have watched with anxiety its rapidly increasing proportious, and the statements made with regard to the numerous enemies that attack the young oyster plantations render ouly too probable the conclusion of Prof. G. B Goode: "A speedy extermination of this most valuable mollusk will doubtless result unless some effective means of protection and of artificial culture are soon employed."

* The operations of the United States Government, under Prof. S. F. Baird and his associates, have been attended with surprising results. Not only new habitats, but new species of edible ocean-fish were discovered, in 1881, in great numbers, near our coasts, and the artificial propagation of fish has for some time been successfully prosecuted under the same general direction.

† siee Ackernof, Die Nutzung der Teiche und Geiö̈ser. Quedlinburg, 1869. 
the civilized world by a judicious administration of the resources of the waters, would allow some restriction of the amount of soil at present employed for agricultural purposes, and a corresponding extension of the area of the forest, and would thus ficilitate a return to primitive geographical arrangements which it is important partially to restore.

\section{Destruction of Fish.}

The inhabitants of the waters seem comparatively secure from human pursuit or interference by the inaccessibility of their re. treats, and by our ignorance of their habits-a natural result of the difficulty of observing the ways of creatures living in a medium in which we can not exist. Human ageney has, nevertheless, both directly and incidentally, produced great changes in the population of the sea, the lakes, and the rivers, and if the effects of such revolutions in aquatic life are apparently of small importance in general geography, they are still not wholly inappreciable. The great diminution in the alsundance of the larger fish employed for food, or pursued for products useful in the arts, is familiar, and when we consider how the regetable and animal life on which they feed must be affected by the reduction of their numbers, it is easy to see that their destruction may involve considerable modifications in many of the material arrangements of nature. The whale* does not appear to hare been an olject of pursuit by the ancients, for any purpose, nor do we know when the whale fishery first commeneed. It was, howerer, very actively prosecuted in the Middle Ages, and the Biscayans seem to hare been particularly successful in this as indeed in

* I use viate not in a technical sense, but as a generic term for all the largo inhabitants of the sea popularly grouped under that name.

The Greek kr,-os and the Latin Baliena, though sometimes, especially in later classical writers, specifically applied to true cetaceans, were generally much more comprehensive in their signitication than the modern word ufhale. This appears abundantly from the enumeration of the marine animals embraced by Oppian under the name kitos, in the first book of the Halieutica.

There is some confusion in Oppian's account of the fishery of the $\kappa \tilde{\eta}$ ros in the fifth book of the Halieutica. Part of it is probably to be understood of cetaceans which have grounded, as some species often do; but in general it evidently applies to the taking of large fish-sharlis, for exumple, as appeara by the description of the teeth-with hook and bait. 
otlier branches of nautical industry.* Five hundred years ago, whales abounded in every sea. They long since became so rare in the Mediterranean as not to afford encouragement for the fishery as a regular occupation; and the great demand for oil and whalebone for mechanical and manufacturing purposes, in the present century, has stimulated the pursuit of the "hugest of living creatures" to such activity, that he has now almost wholly disappeared from many favorite fishing grounds, and in others is greatly diminished in numbers.

What special functions, besides his uses to man, are assigned to the whale in the economy of nature, we do not know; but some considerations, suggested by the character of the food upon which certain species subsist, deserve to be specially noticed. None of the great mammals grouped under the general name of whale are rapacious. They all live upon small organisms, and the most numerous species feed almost wholly upon the soft, gelatinous mollusks in which the sea abounds in all latitudes. We can not calculate even approximately the number of the whales, or the quantity of organic nutriment consumed by an individual, and of course we can form no estimate of the total amount of animal matter withdrawn by them, in a given period, from the waters of the sea. It is certain, however, that it must have been enormous

* From the narrative of Ohther, introduced by King Alfred into his translation of Orosius, it is clear that the Northmen pursued the whale fishery in the ninth century, and it appears, both from the poem called The Whale, in the Codex Exoniensis, and from the dialogue with the fisherman in the Colloquies of Aelfric, that the Anglo-Saxons followed this dangerous chase at a period not much later. I am not aware of any evidence to show that any of the Latin nations engaged in this fishery until a century or two afterward, though it may not be easy to disprove their earlier participation in it. In mediæval literature, Latin and Romance, very frequent mention is made of a species of vessel called in Latin baleneria, balenerium, balenerius, balaneria, etc.; in Catalan, balener; in French, balenier; all of which words occur in many other forms. The most obvious etymology of these words would suggest the meaning, whaler, baleinier; but some have supposed that the name was descriptive of the great size of the ships, and others have referred it to a different root. From the fourteenth century, the word occurs oftener, perhaps, in old Catalan than in any other language; but Capmany does not notice the whale fishery as one of the maritime pursuits of the very enterprising Catalan people, nor do I find any of the products of the whale mentioned in the old Catalan tariffs. The whalebone of the mediæval writers, which is described as very white, is doubtless the ivory of the walrus or of the narwhal. 
when they were more abundant, and that it is still very consider. able. In 1846 the United States had six hundred and serenty. eight whaling ships chiefly employed in the Pacific, and the product of the American whale-fishery for the year ending June 1, 1560, was seven millions and a half of dollars.* The mere bulk of the whales destroyed in a single year by the American and the European vessels engaged in this fishery would form an island of no inconsiderable dimensions, and each one of those taken must have consumed, in the course of his growth, many times his own

* In consequence of the great scarcity of the whale, the use of coal-gas for illumination, the substitution of other fatty and oleaginous substances, such as lard, palm-oil, and petroleum for right-whale oil and spermaceti, the whalefishery has rapidly fallen off within a few years. The great supply of petroleum, which is much used for lubricating machinery as well as for numerous other purposes, has produced a more perceptible effect on the whale-fishery than any other single circumstance. According to Bigelow, Les ÉtatsUnis en 1863 , p. 346, the American whaling fleet was diminished by 29 in 1858,57 in 1860, 94 in 1861, and 65 in 1862. The number of American ships employed in that fishery in 1862 was 353 . In 1868 the American whaling fleet was reduced to 223 . The product of the whale-fishery in that year was 1,485,000 gallons of sperm oil, 2,065,612 gallons of train oil, and 901,000 pounds of whalebone. The yield of the two species of whale is about the same, being estimated at from 4,000 to 5,000 gallons for each fish. Taking the average at 4,500 gallons, the American whalers must have captured 789 whales, besides, doubtless, many which were killed or mortally wounded and not secured. The returns for the year are valued at about five million and a half dollars. Mr. Cutts, from a Report by whom most of the above facts are taken, estimates the annual value of the "products of the sea" at $\$ 90,000,000$. - The Commerce in the Products of the Sea, a Report by Col. R. D. Cutts, communicated to the U. S. Senate, Washington, 1872.

The latest statistics (1880) would lead to a much higher estimate, varying from $\$ 120,000,000$ to $\$ 225,000,000$. See the very important article on FisIErIes, by Prof. G. Brown Goode, in the Cyclopedia of Political Economy, p. 231.

According to the New Bedford Standard the American whalers numbered 722 , measuring 230,218 tons, in 1846 . On the 31st December, $18 \% 2$, the number was reduced to 204 , with a tonnage of 47,787 tons, and the importation of whale and sperm oil amounted in that year to 79,000 barrels. In 1880 the number of vessels employed in this fishery in the United States was 1r1, and its product was valued at something over $\$ 2,300,000$.

Svend Föyn, an energetic Norwegian, now carries on the whale-fishery in the Arctic Ocean in a steamer of twenty horse-power, accompanied by freightships for the oil. The whales are killed by explosive shells fired from a small cannon. The number usually killed by Föyn is from thirty-five to forty-five per year. 
weight of mollusks. The destruction of the whales must have been followed by a proportional increase of the organisms they feed upon, and if we had the means of comparing the statistics of these humble forms of life, for even so short a period as that between the years 1760 and 1560 , we should find a difference possibly sufticient to suggest an explanation of some phenomena at present unaccounted for.

For instance, as I liave observed in another work, * the phosphorescence of the sea was unknown to ancient writers, or at least scarcely noticed by them, and even Homer-who, blind as tradition makes him when he composed his epies, had seen, and marked, in earlier life, all that the glorious nature of the Mediterranean and its coasts discloses to unscientific observation-nowhere alludes to this most beautiful and striking of maritime wonders. In the passage just referred to, I have endeavored to explain the silence of ancient writers with respect to this as well as other remarkable phenomena on psychological grounds; but is it not possible that, in modern times, the animalculæ which produce it may have immensely multiplied, from the destruction of their natural enemies by man, and hence that the gleam shot forth by their decomposition, or by their living processes, is both more frequent and more brilliant than in the days of classic antiquity?

Aithough the whale does not prey upon smaller creatures resembling himself in form and habits, yet true fishes are extremely voracious, and almost every tribe devours unsparingly the feebler species, and even the spawn and young of its own.t The enormous destruction of the shark, $f$ the pike, the trout family and other ravenous fish, as well as of the fishing-birds, of the seal and the otter, by man, would naturally have occasioned a great in-

* The Origin and History of the English Language, etc., pp. 424, 425.

† Two young pickerel, Gystes fasciatus, five inches long, ate 128 minnows, an inch long, the first day they were fed, 132 the second, and 150 the third.Fifth Report of Commissioners of Massachusetts for Introduction of Fish, 1871, p. 17 .

‡ The shark is pursued in all the tropical and subtropical seas for its finsfor which there is a great demand in China as an article of diet-its oil and other products. About 40,000 are taken annually in the Indian Ocean and the contiguous seas. In the North Sea and the Arctic Ocean large numbers are annually caught. See MErk, Waarenlexition-a work of great accuracy and value (Leipzig, 1870), article Haifisch. 
crease in the weaker and more defenceless fish on which they feed, had he not been as hostile to them also as to their persecutors.

\section{Destruction of Aquatic Animals.}

It does not seem probable that man, with all his rapacity and all his enginery, will succeed in totally extirpating any salt-water fish, but he has already exterminated at least one marine warmblooded animal-Steller's sea-cow-and the walrus, the sea-lion, and other large amphibia, as well as the principal fishing quadrupeds, are in imminent danger of extinction. Steller's sea-conRhytina Stelleri-was first seen by Europeans in the year 1741 on Behring's Island. It was a huge, amphibious mammal weighing not less than eight thousand pounds, and appears to have been confined exclusively to the islands and coasts in the neighborhood of Behring's Strait. Its flesh was very palatable, and the localities it frequented were easily accessible from the Russian establishments in Kamschatka. As soon as its existence and character, and the abundance of fur animals in the same waters, were made known to the occupants of those posts by the return of the survivors of Behring's expedition, so active a chase was commenced against the amphibia of that region, that, in the course of twenty-seven years, the sea-cow, described by Steller as extremely numerous in 1741 , is believed to have been completely extirpated, not a single individual having been seen since the year 1768.* - The various tribes of seals $\dagger$ in the Northern and Southern Pacific, the walrus $\neq$ and the sea-otter, are already so

* According to the Voyage of the Vega, a sea-cow was killed in the Arctic Sea in 1854, and another in 1868.

t The most valuable variety of fur seal, formerly abundant in all cold latitudes, is stated to have been completely exterminated in the Southern hemisphere, and to be now found only on one or two small islands of the Aleutian group. In 1867 more than 700,000 seal-skins were imported into Great Britain, and at least 600,000 seals are estimated to have been taken in $18 \% 0$. These numbers do not include the seals killed by the Esquimaux and other rude tribes. According to the estimates made in 1850 , the total annual capture of the common fur seal is now about $1,000,000$ individuals, the value of the oil alone amounting to $\$ 1,250,000$, independently of the skins.

$\ddagger$ In 1868 a few American ships engaged in the North Pacific whale-fishery turned their attention to the walrus, and took from 200 to 600 each. In 1869 other whalers engaged in the same pursuit, and in $18 \% 0$ the American fleet is 
reduced in numbers that they seem destined soon to follow the sea-cow, unless protected by legislation stringent enough, and a police energetic enough, to repress the ardent cupidity of their pursuers. It is a satisfaction to know that since the acquisition of Alaska by the United States, the fur seal which frequents some of the islands in Behring's Straits, has been protected by limiting the captures by the lessees of these islands to 100,000 males per year. It is said that this restrictive Government contract operates effectually to prevent any diminution in the numbers of this species in those regions. Indeed the monograph of H. W. Elliott on The Seal-Islands of Alaskia, published by the Department of the Interior in 1881, seems to put this point beyond a doubt.

The seals, the otter tribe, and many other amphibia which feed almost exclusively upon fish, are extremely voracious, and of course their destruction or numerical reduction must have favored the multiplication of the species of fish principally preyed upon by them. I have been assured by the keeper of several young seals that, if supplied at frequent intervals, each seal would devour not less than fourteen pounds of fish, or about a quarter of his own weight, in a day. A very intelligent and observing hunter, who has passed a great part of his life in the forest, after carefully watching the habits of the fresh-water otter of the North American States, estimates their consumption of fish at about four pounds per day.

Man has promoted the multiplication of fish by making war on their brute enemies, but he has by no means thereby compensated his own greater destructiveness.* The bird and beast of

believed to have destroyed not less than fifty thousand of these animals. They yield about twenty gallons of oil and four or five pounds of ivory each.

* According to Hartwig, the United Provinces of Holland had, in 1618, three thousand herring busses, and nine thousand vessels engaged in the transport of these fish to market. The whole number of persons employed in the Dutch herring fishery was computed at 200,000 .

In the latter part of the eighteenth century, this fishery was most successfully prosecuted by the Swedes, and in 1781, the town of Gottenburg alone exported 136,649 barrels, each containing 1,200 herrings, making a total of about $164,000,000$; but so rapid was the exhaustion of the fish, from this keen pursuit, that in 1799 it was found necessary to prohibit the exportation of them altogether.-Das Leben des Meeres, p. 182.

In 1855 , the British fisheries produced 900,000 barrels, or almost enough to supply a fish to every human inhabitant of the globe.

On the shores of Long Island Sound, the white fish, a species of herring toc 
prey, whether on land or in the water, hunt only as long as they feel the stimulus of humger, their ravages are limited by the deminds of present appetite, and they do not mastefully destroy what they ean not consmue. Man, on the contrary, angles to-day that he may dine to-morrow; he takes and dries millions of fish on the banks of Newfoundland and the coast of Norway, that the fervent Catholic of the shores of the Mediterranean may have wherewithal to satisfy the cravings of the stomach during next year's Lent, without violating the discipline of the Romish church; * and all the arrangements of his fisheries are so organized as to involve the destruction of many more fish than are secured for human use, and the loss of a large proportion of the ammal harrest of the sea in the process of curing, or in transportation to the places of its consumption. The Atlantic salmon,

bony to be easily eaten, is used as manure in very great quantities. Ten thousand are employed as a dressing for an acre, and a single net has sometimes taken 200,000 in a day.-DwignT's Travels, ii., pp. 512, 515. These numbers, however, sink almost into insignificance before the statements made by Prof. Goode of the Smithsonian in regard to the menhaden fisheries of the United States. According to him this fish excels all others as a bait fish, and in 1877 the total consumption of menhaden for this purpose did not fall below $26,000,000$ fish. Ten years before, when the entire mackerel flect was fishing with hooks, the consumption was much greater. In $18 \% 8$, the menhaden oil and guano industry employed capital to the amount of $\$ 2,350,000,8,38 \% \mathrm{men}$, 61 steamers, 279 sailing vessels, and consumed 777,000,000 fish. These estimates do not include the quantities applied directly to the soil, nor those used for food, many thousands of barrels being salted down for domestic use or for exportatiou. It may be fairly inferred, from the statistics given by Prof. Goode, that not less than $a$ thousand million of these fish are now taken yearly on our coast.

The London Times of May 11, 1872, informs us that 1,100 tons of mackerel estimated to weigh one pound each had recently been taken in a single night at a fishing station on the British coast.

About ten million eels are sold annually in Billingsgate market, but vastly greater numbers of the young fry, when but three or four inches long, are taken. So abundant are they at the mouths of many French and English rivers, that they are carried into the country by cart-loads, and not only eaten, but given to swine or used as manure.

* The fisheries of Sicily alone are said to yield 20,000 tons of tunny a year. The tunny is principally consumed in Italy during Lent, and a large propor. tion of the twenty millions of codfish taken annually at the Lofoden fishery on the coast of Norway is exported to the Mediterranean.

+ According to Berthelot, in the Gulf of Lyons, between Marseilles and the easternmost spur of the Pyrenees, about 5,000,000 small fish are taken an- 
which was once so abundant in the rivers of Europe and the United States, is now nearly exterminated except in a few streams where it is protected by stringent laws. But the capture and camning of the California or quinnat salmon on the Pacific coast is now an industry of great importance, large quantities being exported from California, Oregon, and Washington Territory to every part of the world. The number of these fish now taken annually on the Pacific coast, according to the statistics of 1880 , amounts to little less than 3,000,000, and their multiplication must be enormous to support such a drain without danger of sharing the fate of the Atlantic salmon. Wulfsberg, however, affirms that the deep-sea fisheries on the coast of Norway are still as plentiful as ever, and argues that they are practically inexhaustible, because the number of fish destroyed by man forms but an infinitesimal proportion of the increase, and is entirely insignificant in comparison with the consumption by birds and marine animals of prey. Of salt-water fish, only those which resort to the mouths of rivers for spawning have diminished.

Fish are more affected than quadrupeds by slight and even imperceptible differences in their breeding places and feeding grounds. Every river, every brook, every lake stamps a special character upon its salmon, its shad, and its trout, which is at once recognized by those who deal in or consume them. No skill can give the fish fattened by food selected and prepared by man the flavor of those which are nourished at the table of nature, and the trout of the artificial ponds in Germany and Switzerland are so inferior to the brook-fish of the same species and climate, that it is hard to believe them identical. It is an observation familiar to every one acquainted with both continents, that the American trout and other fresh-water fishes are superior in sapidity to the

mually with the drag-net, and not less than twice as many more, not to speak of spawn, are destroyed by the use of this net.

Between 1861 and 1865 France imported from Norway, for use as bait in the sardine fishery, cod-roes to the value of three million francs.-CuTts, Report on Commerce in the Products of the Sea, 1872, p. 82.

The most reckless waste of aquatic life I remember to have seen noticed, if we except the destruction of herring and other fish with spawn, is that of the eggs of the turtle in the Amazon for the sake of the oil extracted from them. Bates estimates the eggs thus annually sacrificed at 48,000,000.-Naturalist on the Amazon, 2d edition, 1864, p. 365. 
most nenrly corresponding European species, and this is probably due less to specific difference than to the fact that even in the parts of the New World which have been longest eultivated, wild nature is not yet tamed down to the character it has assumed in the Old, and which it will acquire in America also when her civilization shall be as ancient as is now that of Europe.*

Man has, hitherto, hardly anywhere produced such climatic or other changes as would suffice of themselves totally to banish the wild inhabitants of the dry land, and the disappearance of the native birds and quadrupeds from particular localities is to be ascribed quite as much to his direct persecutions as to the want of forest shelter, of appropriate food, or of other conditions indispensable to their existence. But almost all the processes of agriculture, and of mechanical and chemical industry, are fatally destructive to aquatic animals within reach of their influence. When, in consequence of clearing the woods, the changes already described as thereby produced in the beds and currents of rivers are in progress, the spawning grounds of fish are exposed from year to year to a succession of mechanical disturbances; the temperature of the water is higher in summer, lower in winter, than when it was shaded and protected by wood; the smaller organisms, which formed the sustenance of the young fry, disappear or are reduced in numbers, and new enemies are added to the old foes that preyed upon them; the increased turbidness of the water in the annual inundations chokes the fish; and, finally, the quickened velocity of its current sweeps them down into the larger rivers or into the sea, before they are yet strong enough to

* It is possible that time may modify the habits of the fresh-water fish of the North American States, and accommodate them to the new physical conditions of their native waters. Hence it may be hoped that nature, even unaided by art, will do something towards restoring the ancient plenty of our likkes and rivers. The decrease of our fresh-water fish can not be ascribed alone to exhaustion by fishing, for in the waters of the valleys and flanks of the Alps, which have been inhabited and fished ten times as long by a denser population, fish are still very abundant, and they thrive and multiply under circumstances where no American species could live at all. On the southern slope of those mountains, trout are caught in great numbers, in the swift streams which rush from the glaciers, where the water is of icy coldness and so turbid, from particles of fine-ground rock, that you can not see an inch below the surface. The glacier streams of Switzerland, however, are less abundant in fish. 
suppert so great a change of circumstances.* Industrial operations are not less destructive to fish which live or spawn in fresh water. Mill-dams impede their migrations, if they do not absolutely prevent them; the saw-dust from lumber-mills clogs their gills; and the thousand deleterious mineral substances, discharged into river's from metallurgical, chenical and manufacturing establishments, poison them by shoals. $†$ The Scottish jomruals, a few years since, stated that, in an inundation of the river Dee, many factories had been destroyed, and a large quantity of chemical substances, employed for dyeing and other purposes, were swept into the stream. The effect of this was such as absolutely to exterminate all the fish in the river for the distance of eight or ten miles. The London Times also made important statements respecting the injury to the salmon-fishery in the Tweed, in 1874, by the discharge of factory refuse into the river.

We have little evidence that any fish employed as human food has naturally multiplied in modern times, while all the more valuable tribes have been immensely reduced in numbers. This reduction must have affected the more voracious species not used as food by man, and accordingly the shark, and other fish of similar habits, eren when not objects of systematic pursuit, are now comparatively rare in many waters where they formerly abounded.

* A fact mentioned by Schubert-and which, in its causes and many of its results, corresponds almost precisely to those connected with the escape of Barton Pond in Vermont, so well known to geological students-is important as showing that the diminution of the fish in rivers exposed to inundations is chiefly to be ascribed to the mechanical action of the current, and not mainly, as some hare supposed, to changes of temperature occasioned by clearing. Our author states that, in 1796, a terrible inundation was produced in the Indalself, which rises in the Storsjö in Jemtland, by drawing off into it the waters of another lake near Ragunda. The flood destroyed houses and fields; much earth was swept into the channel, and the water made turbid and muddy ; the salmon and the smaller fish forsook the river altogether, and never returned. The banks of the river have never regained their former solidity, and portions of their soil are still continually falling into the water and destroying its purity.-Resa genom Sverge, ii., p. 51 .

t The mineral water discharyed from a colliery on the river Doon, in Scotland, discolored the stones in the bed of the river, and killed the fish for twenty miles below.

The fish of the streams in which hemp is macerated in Italy are often poi soned by the juices thus extracted from the plant.-DonoteA, Sommario della storia dell' Alieutica, pp. 64, 65. 
The result is, that man has greatly reduced the numbers of all larger marine animals, and consequently indirectly favored the multiplication of the smaller aquatic organisms which entered into their nutriment. This change in the relations of the organic and inorganic matter of the sea must have exercised an influence on the latter. What that influence has been we can not say, still less can we predict what it will be hereafter; but its action is not for that reason the less certain.*

\section{Geographical Importance of Birds.}

Wild birds form of themselves a very conspicuous and interesting feature in the staffage, as painters call it, of the natural landscape, and they are important elements in the view we are taking of geography, whether we consider their immediate or their incidental influence. Birds affect vegetation directly by sowing seeds and by consuming them; they affect it indirectly by destroying insects injurious, or, in some cases, beneficial to regetable life. Hence, when we kill a seed-sowing bird, we check the dissemination of a plant; when we kill a bird which digests the seed it swallows, we promote the increase of a vegetable. Nature protects the seeds of wild much more effectnally than those of domesticated plants. The cereal grains are completely digested when consumed by birds, but the germ of the smaller stone-fruits

* Among the unexpected results of human action, the destruction or multiplication of fish, as well as of other animals, is a not unfrequent occurrence. Williams, in his History of Termont, i., p. 149, records such a case of the in. crease of trout. In a pond formed by damming a small strenm to obtain water-power for a saw-mill, and covering one thousand acres of primitive forest, the increased supply of food brought within reach of the fish multiplied them to that legree, that, at the head of the pond, where, in the spring, they crowded together in the brook which supplied it, they were taken by the hands at pleasure, and swive caught them without difficulty. A single sweep of a small scoop-uet would bring up half a bushel, carts were filled witl them as fast as if picked up on dry land, and in the fishing season they were commonly scld at a shilling (eightpence halfpenny, or about seventeen cents) a bushel. The increase in the size of the trout was as remarkable as the multiplication of their numbers.

The construction of dams and mills is destructive to many fish, but operates as a protection to their prey. The mills on Connecticut River greatly diminished the number of the salmon, but the striped bass, on which the salmon leeds, multiplied in proportion.-Dr. Dwant, Traiets, rol. ii., p. 325. 
and of very many other wild vegetables is uninjured, perinaps even stimulated to more vigorous growth, by the uatural chemistry of the bird's stomach. The power of flight and the restless habits of the bird enable it to transport heary seeds to far greater distances than they could be carried by the wind. A smift-minged bird may drop cherry-stones a thousand miles from the tree they grow on; a hawk, in tearing a pigeon, may scatter from its crop the still fresh rice it had swallowed at a distance of ten degrees of latitude, and thus the occurrence of isolated plants, in situations where their presence can not otherwise be well explained, is easily accounted for.* There is a large class of seeds apparently specially fitted by nature for dissemination by animals. I refer to those which attach themselves, by means of hooks, or by viscous juices, to the coats of quadrupeds and the feathers of birds, and are thus transported wherever their living vehicles may chance to wander. Some birds, too, deliberately bury seeds in the earth, or in holes excavated by them in the bark of trees, not indeed with a foresight aiming directly at the propagation of the plant, but from apparently purposeless secretiveness, or as a mode of preserving food for future use.

The tame fowls play a much less conspicuous part in rural life than the quadrupeds, and, in their relations to the economy of nature, they are of very much less moment than four-footed animals, or than the undomesticated birds. The domestic turkey + is probably more numerous in the territory of the United States than the wild bird of the same species ever was, and the grouse can not, at the period of their greatest abundance, have comnted as

* Pigeons were shot near Albany, in New York, a few years ago, wiil green rice in their crops, which it was thought must have been growing, a very few hours before, at the distance of seven or eight hundred miles. The efforts of the Dutch to confine the cultivation of the nutmeg to the island of Banda are said to have been defeated by the birds, which transported this heavy fruit to other islands.

+ The wild turkey takes readily to the water, and is able to cross rivers of very considerable width by swimming. By way of giving me an idea of the former abundance of this bird, an old and highly respectable gentleman who was among the early white settlers of the West, told me that he once counted, in walking down the northern bank of the Ohio River, within a distance of four miles, eighty-four turkeys as they landed singly, or at most in pairs, after swimming over from the Kentucky side. 
many as we now number of the common hen. The dove, however, must fall greatly short of the wild pigeon in multitude, and it is hardly probable that the flocks of domestic geese and duckis are as numerous as once were those of their wild congeners. The pigeon, indeel, seems to have multiplied immensely, for some year's after the first clearings in the woods, because the settlers marred unsparingly upon the hawk, while the crops of grain and other regetable-growths increased the supply of food within the reach of the young birds, at the age when their power of flight is not yet great enough to enable them to seek it orer a wide area.* The pigeon is not described by the earliest white inhabitants of the American States as filling the air with such clouds of winged life as astonished naturalists in the descriptions of Audubon, and, at the present day, the net and the gun hare so reduced its abundance, that its appearance in large numbers is recorded only at long intervals, and it is never seen in the great flocks remembered by many still living observers as formerly very common. During the year 187\%, howerer, a "pigeon-roost" as it is called, or breeding-place, covering a space of fifty square miles, was formed in a forest in Benzie County, Michigan. The breeding season lasted about six weeks, and the hundreds of sportsmen who filled the forest seemed to produce no diminution in the numbers of the birds.

\section{Introduction of Birds.}

Man has undesignedly introduced into new districts perhaps fewer species of birds than of quadrupeds; $\uparrow$ but the distribution of birds is very much influenced by the character of his industry,

* The wood-pigeon, as well as the domestic dove, has been obserred to increase in numbers in Europe also, when pains have been taken to exterminate the hawk. The American pigeons, which migrated in flocks so numerous that they were whole days in passing a given point, were no doubt injurious to the grain, but probably less so than is generally supposed; for they did not onnfine themselves exclusirely to the harrests for their nourishment.

+ The first mention $I$ have found of the naturalization of a wild bird in modern Europe is in the IFenagitna, vol. iii., p. 1\%t, edition of $1 \% 1 \mathrm{~J}$, where it is stated that René, King of Sicily and Duke of Anjou, who died in 1480, introduced the red-legged partridge into the latter country. Attempts lave been made, and I believe with success, to naturalize the European lark on Long Island, and the English sparrow has been introduced into various parts of the 
and the transplantation of every object of agricultural produa tion is, at a longer or shorter interval, followed by that of the birds which feed upon its seeds, or more frequently upon the in sects it harbors. The vulture, the crow, and other winged scavengers, follow the march of armies as regularly as the wolf. Birds accompany ships on long royages, for the sake of the offal which is thrown overboard, and, in such cases, it might often happen that they rould breed and become naturalized in countries where they had been unknom before.* There is a familiar story of an English bird which built its nest in an unused block in the rigging of a ship, and made one or two short voyages with the vessel while hatching its eggs. Had the young become fledged while lying in a foreign harbor, they would of course have claimed the rights of citizenship in the country where they first took to the wing. $\dagger$

Northern States, where he is useful by destroying noxious insects and worms not preyed upon by native birds.

The humming-bird has resisted all efforts to acclimate him in Europe, though they have not unfrequently survived the passage across the ocean.

In Switzerland and some other parts of Europe the multiplication of insectivorous birds is encouraged by building nests for them, and it is alleged that hoth fruit and forest trees have been essentially benefited by the protection thus afforded them. A few years since a society was formed at Inalle for feeding wild birds in winter. This society established 22 stations in the neighborhood of the town, where during the severe weather many hundreds of birds were fed, and it was believed that the expense would be repaid a humdred-fold by the destruction of noxious insects.

* Gulls hover about ships in port, and often far out at sea, diligently watching for the waste of the caboose. While the four great flects, English, French, Turkish. and Egyptian, were lying in the Bosphorus, in the summer and autumn of $18.5 \%$, a young lady of my family called my attention to the fact that the gulls were far more numerous about the ships of one of the fleets than about the others. This was verified by repeated observation, and the difference was owing no doubt to the greater abundance of the refuse from the cook-rooms of the naval squadron most frequented by the birds. Persons acquainted with the economy of the navies of the States in question, will be able to conjecture which fleet was most favored with these delicate attentions. The American guli follows the steamers up the Mississippi, and has been shot 1,500 miles from the sea.

+ Birds do not often voluntarily take passage on board ships bound for forcign countries, but I can testify to one such case. A stork, which had nested aear one of the palaces on the Bosphorus, had, by some accident, injured a wing, and was unable to join his fellows when they commenced their winter 
An unfortunate popular error greatly magnifies the injuxy done to the crops of grain and leguminous vegetables by wild birds. Very many of those generally supposed to consume large quantities of the seeds of cultivated plants really feed almost exclusively upon insects, and frequent the wheat-fields, not for the sake of the grain, but for the eggs, larve, and fly of the multiplied tribes of insect life which are so destructive to the harrests. This fact has been so well established by the examination of the stomachs of great numbers of birds in Europe and the United States, at different seasons of the year, that it is no longer open to doubt; and it appears highly probable that even the species which consume more or less grain, generally make amends by destroying insects whose ravages would have been still more injurious.* On this subject, we have much other evidence besides

migration to the banks of the Nile. Before he was able to fly again, he was caught, and the flag of the nation to which the palace belonged was tied to his leg, so that he was easily identified at a considerable distance. As his wing grew stronger, he made several unsatisfactory experiments at flight, and at last, by a vigorous effort, succeeded in reaching a passing ship bound southward, and perched himself ou a topsail-yard. I happened to witness this movement, and observed him quietly maintaining his position as long as $\mathrm{I}$ could discern him with a spy-glass. I supposed he finished the voyage, for he certainly did not return to the palace.

* Even the common crow has found apologists, and it has been asserted that he pays for the Indian corn he consumes by destroying the worms and larve which infest that plant.

Professor Treadwell, of JIassachusetts, found that a half-grown American robin in confinement ate in one day sixty-eight worms, weighing together nearly once and a half as much as the bird himself, and another had previously starved upen a daily allowance of eight or ten worms, or about twenty per cent. of his own weight. The largest of these numbers appeared, so far as could be judged by watching parent birds of the same species as they brought food to their young, to be much greater than that supplied to them when fed in the nest; for the old birds did not return with worms or insects oftener than once in ten minutes on an average. If we suppose the parents to hunt for food twelve hours in a day, and a mest to contain four young, we should have serenty-two worms, or eighteen each, as the daily supply of the brood. It is probable enough that some of the food collected by the parents may be more mutritious than the earthworms, and consequently that a smaller quantity sufficed for the young in the nest than when reared uuder artificial conditions.

The supply required by growing birds is not the mensure of their wants after they have arrived at maturity, and it is not by any means certain that 
that derived from dissection. Direct observation has shown, in many instances, that the destruction of wild birds has been fol. lowed by a great multiplication of noxious insects, and, on the other hand, that these latter have been much reduced in numbers by the protection and increase of the birds that devour them. Many interesting facts of this nature have been collected by professed naturalists, but I shall content myself with a few taken from familiar and generally accessible sources. The following extract is from Michelet, L'Oiseau, pp. 169, 170:

"The stingy farmer-an epithet justly and feelingly bestowed by Virgil. Avaricious, blind, indeed, who proseribes the birdsthose destroyers of insects, those defenders of his harvests. Not a grain for the creature which, during the rains of winter, hunts the future insect, finds out the nests of the larvæ, examines, turns over every leaf, and destroys, every day, thousands of incipient caterpillars. But sacks of corn for the mature insect, whole fields for the grasshoppers, which the bird would have made war upon. With eyes fixed upon his furrow, upon the present moment only, without seeing and without foreseeing, blind to the great harmony which is never broken with impunity, he has everywhere demanded or approved laws for the extermination of that necessary ally of his toil-the insectivorous bird. And the insect has well avenged the bird.* It has become necessary to revoke in haste the proscription. In the Isle of Bourbon, for instance, a price was set on the head of the martin; it disappeared, and the

great muscular exertion always increases the demand for nourishment, either in the lower animals or in man. The members of the English Alpine Club are not distinguished for appetites which would make them unwelcome guests to Swiss landlords, and I think every man who has had the personal charge of field or railway hands, must have observed that laborers who spare their strength the least are not the most valiant trencher champions. During the period when imprisonment for debt was permitted in New England, persons confined in county jails had no specific allowance, and they were commonly fed without stint. I have often inquired concerning their diet, and been as sured by the jailers that their prisoners, who were not provided with work or other means of exercise, consumed a considerably larger supply of food than common outdoor laborers.

* The estimated annual destruction of property in the United States by insects amounts to not less than $400,000,000$ dollars, and no inconsiderable proportion of this loss might doubtless be prevented by a judicious protection of insectivorous birds. 
grasshopper took possession of the island derouring, withering, scorching with a biting drought all that they did not consume. In North America it has been the same with the starling, the protector of Indian corn.* Even the sparrow, which really does attack grain, but which protects it still more, the pilferer, the outlaw, loaded with abuse and smitten with curses-it has been found in Hungary that they were likely to perish without him, that he alone could sustain the mighty war against the beetles and the thousand winged enemies that swarm in the lowlands; they have revoked the decree of banishment, recalled in haste the raliant militia, which, though deficient in discipline, is nevertheless the salvation of the country. $\dagger$

"Not long since, in the neighborhood of Rouen and in the valley of Monville, the blackbird was for some time proscribed. The beetles profited well by this proscription; their larvæ, infinitely multiplied, carried on their subterranean labors with such success, that a meadow was shown me, the surface of which was completely dried up, every herbaceous root was consumed, and the whole grassy mantle, easily loosened, might have been rolled up and carried away like a carpet."

The general hostility of the European populace to the smaller birds is, in part, the remote effect of the reaction created by the game laws. When the restrictions imposed upon the chase by those laws were suddenly removed in France, the whole people at once commenced a destructive campaign against erery species of wild animal. Arthur Young, writing in Prorence, on the 30th of August, 1789, soon after the National Assembly had declared the chase free, thus complains of the annoyance he experienced from the use made by the peasantry of their newly-won liberty:

* I hope Michelet has good authority for this statement, but I am unable to confirm it.

+ Apropos of the sparrow-a single pair of which, according to Michelet, p. 315 , carries to the nest four thousand and three hundred caterpillars or coleoptera in a week-I find in an English newspaper a report of a meeting of a "Sparrow Club," stating that the member who took the first prize had destroyed 1,467 of these birds within the year, and that the prowess of the other members had brought the total number up to 11,944 birls, besides 2,556 eggs. Every one of the fourteen thousand hatched and unhatched birds, thus sacrificed to puerile vanity and ignorant prejudice, would have saved his bushe. of wheat by preying upon insects that destroy the grain. 
"One would think that every rusty firelock in all Provence was at work in the indiscriminate destruction of all the birds. The wadding buzzed by my ears, or fell into my carriage, five or six times in the course of the day." . . . "The declaration of the Assembly that every man is free to hunt on his own land .... has filled all France with an intolerable clond of sportsmen. . . . . The declaration speaks of compensations and indemmities [to the seigneurs], but the ungovernable populace takes advantage of the abolition of the game laws and laughs at the obligation imposed by the decree."

The contagious influence of the French Revolution occasioned the removal of similar restrictions, with similar results, in other countries. The habits then formed have become hereditary on the Continent, and though game laws still exist in England, there is little doubt that the blind prejudices of the ignorint and halfeducated classes in that country against birds are, in some degree, at least, due to a legislation, which, by restricting the chase of game worth killing, drives the unprivileged sportsman to indemnify himself by slaughtering all wild life which is not reserved for the amusement of his betters. Hence the lord of the manor buys his partridges and his hares by sacrificing the bread of his tenants, and so long as the members of "Sparrow Clubs" are forbidden to follow higher game, they will suicidally revenge themselves by destroying the birds which protect their wheatfields.

On the Continent, and especially in Italy, the comparative scarcity and dearness of animal food combine with the feeling I have just mentioned to stimulate still further the destructive passions of the fowler. In the Tuscan province of Grosseto, containing less than 2,000 square miles, nearly 300,000 thrushes and other small birds are annually brought to market.*

* Salvagnoli, Memorie sulle Maremme Toscane, p. 143. The country about Naples is filled with slender towers fifteen or twenty feet high, which are a standing puzzle to strangers. They are the stations of the fowlers who watch from them the flocks of small birds and drive them down into the nets by throwing stones over them.

In Northern and Central Italy, one often sees hillocks crowned with grovelike plantations of small trees, much resembling large arbors. These serve to collect birds, which are entrapped in nets in great numbers. These plantations are called ragnaje, and the reader will find, in Bindi's edition of Davanzati, a 
Birds are less hardy in constitution, they possess less facility of accommodation,"* and they are more severeiy affected by climatic excess than quadrupeds. Besides, they generally want the special means of shelter against the inclomency of the weather and

very pleasant description of a ragnaja, though its authorship is not now ascribed to that eminent writer.

Tschudi has collected in his little work, Ueber dic Landuirthschaftliche Bedeutung der Foygl, many interesting facts respecting the utility of birds, and the wanton destruction of them in Italy and elsewhere. Not only the owl, but many other birds more familiarly known as predacious in their habits, are useful by destroying great numbers of mice and moles. The importance of this last service becomes strikingly apparent when it is known that the burrows of the moles are among the most frequent causes of rupture in the dikes of the Po, and, consequently, of inundations which lay many square miles of land under water. See Annates des Ponts et Chaussées, 1847, 1ere sémestre, p. 150 ; Vogt, Nützliche and schälliche Thiere; and particularly articles in the Giornale del Club Alpino, vol. iv., No. 15, and vol. v., No. 16.

See also in Aus der Natur, vol. 54, p. 797, an article entitled Nutzen der Vögel für die Landwoirthschaft, where it is aftirmed that "without birds no agriculture or even vegetation would be possible."

In an interesting memoir by Rondani, published in the Bollitinn del Comizio agrario di Parma for December, 1868, it is maintained that birds are often injurious to the agriculturist, by preying not only on noxious insects, but sometimes exclusively, or at least by preference, on entomophagous tribes which would otherwise destroy those injurious to eultivated plauts. See also articles by Prof. Sabbioni in the Giornale di Ayricolture di Buldrgne, November and December, 18\%0, and other articles in the same journal of 15 th and 30th April, 1870.

* Wild birds are very tenacious in their habits. The extension of particular branches of agriculture introduces new birls; but unless in the case of such changes in physical conditions, particular species seem indissolubly attached to particular localities. The migrating tribes follow almost undeviatingly the same precise line of flight in their amull journeys, and establish themselves in the same breeding-places from year to year. The stork is a strong-winged bird and roves far for food, but very rarely establishes new colonies. He is commou in Holland, but unknown in England. Not above five or sis pairs of storks commonly breed in the suburbs of Constantinople along the European shore of the narrow Bosphorus, while-much to the satisfaction of the Moslems, who are justly proud of the marked partiality of so orthodox a bird -dozens of chimneys of the true believers on the A siatic side are crowned with his nests.

The appearance of the dove-like grouse, Tctreo paradoxus, or Syrrhaptes Pallasii, in various parts of Europe, in 1859 and the following years, is a noticeable exception to the law of regularity which seems to govern the movements and determine the habitat of birds. The proper home of this bird is the steppes of Tartary, and it is not recorded to have been observed in Europe, or 
against pursuit by their enemies, which holes and dens afford to burrowing animals and to some larger beasts of prey. The egg is exposed to many dangers before hatching, and the young bird is especially tender, defenceless and helpless. Every cold rain, every violent wind, every hailstorm during the breeding season, destroys hundreds of nestlings, and the parent often perishes with her progeny while brooding over it in the vain effort to protect it.* The great proportional numbers of birds, their migratory habits, and the ease with which by their power of flight they may escape most dangers that beset them, would seem to secure them from extirpation, and even from very great numerical reduction. But experience shows that when not protected by law, by popular favor or superstition, or by other special circumstances, they yield very readily to the hostile influences of civiliz. ation, and, though the first operations of the settler are favorable to the increase of many species, the great extension of rural and of mechanical industry is, in a variety of ways, destructive even to tribes not directly warred upon by man. $\dagger$

at least west of Russia, until the year above mentioned, when many flocks of twenty or thirty, and even a hundred individuals, were seen in Bohemia, Germany, Holland, Denmark, England, Ireland and France. A considerable flock frequented the Frisian island of Borkum for more than five months. It was hoped they would breed and remain permanently in the island, but this expectation has been disappointed, and the steppe-grouse seems to have disappeared again altogether.

* It is not the unfledged and the nursing bird alone that are exposed to destruction by severe weather. Whole flocks of adult and strong-winged tribes are killed by hail. Severe winters are usually followed by a sensible diminution in the numbers of the non-migrating birds, and a cold storm in summer often proves fatal to the more delicate species. On the 10 th of June, 184-, five or six inches of snow fell in Northern Vermont. The next morning I found a humming-bird killed by the cold, and hanging by its claws just below a loose clapboard on the wall of a small wooden building where it had sought shelter.

† Lrell, Antiquity of Man, p. 409, observes: "Of birds it is estimated that the number of those which die every year equals the aggregate number by which the species to which they respectively belong is, on the average, permanently represented."

A remarkable instance of the influence of new circumstances upon birds was observed upon the establishment of a lighthouse on Cape Cod some years since. The morning after the lamps were lighted for the first time, more than a hundred dead birds of several different species, chiefly water-fowl, were 
Nature sets bounds to the disproportionate increase of birds, whilst at the same time, by the multitude of their resources, she secures them from extinction through her own spontaneous agencies. Man both preys upon them and wantonly destroys them. The delicions flavor of game-birds, and the skill implied in the various arts of the sportsman who devotes himself to fowling, make them favorite objects of the chase, while the beauty of their plumage, as a military and feminine decoration, threatens to involve the sacrifice of the last survivor of many once numerous

found at the foot of the tower. They had been killed in the course of the night by flying against the thick glass or grating of the lantern.

From an article by $\mathrm{A}$. Esquiros, in the Revue des Deux Yrondes for September 1, 1861, entitled La vie Anglaise, p. 119, it appears that such occurrences as that stated in the note have been not unfrequent on the British coast. "In 1877," says a French journal, "a curious phenomenon was witnessed at the lighthouse of the Basquets in the English Channel. One night, between the hours of 11 P.M. and 4 A.Mr., quantities of birds-woodcocks, blackbirds, thrushes, and swallows-came flying about the light. MIany dashed themselves against the glass and were killed. MIore than a hundred swallows were found dead in the morning; but the larger birds for the most part avoided actually striking the glass, and only fluttered about in the surrounding light." Are the birds thus attracted by new lights, flocks in migration ?

Migrating birds, whether for greater security from eagles, hawks and other enemies, or for some unknown reason, perform a great part of their annual journeys by night; and it is observed in the Alps that they follow the highroads in their passage across the mountains. This is partly because the food in search of which they must sometimes descend is principally found near the roads. It is, however, not altogether for the sake of consorting with man, or of profiting by his labors, that their line of fight conforms to the paths he has traced, but rather because the great roads are carried through the natural depressions in the chain, and hence the birds can cross the summit by these routes without rising to a height where, at the seasons of migration, the cold would be excessive.

The instinct which guides migratory birds in their course is not in all cases infallible, and it seems to be confounded by changes in the condition of the surface. I am familiar with a village in New England, at the junction of two valleys, each drained by a mill-stream, where the flocks of wild geese, which formerly passed every spring and autumn, were very frequently lost, as it was popularly phrased, and $I$ have often heard their screams in the night as they Hlew wildly about in perplexity as to the proper course. Perhaps the village lights embarrassed them, or perhaps the constant changes in the face of the country, from the clearings then going on, introduced into the landscape features not according with the ideal map handed down in the anserine fam. ily, and thus deranged its traditional geography. 
species.* Thus far, but few birds described by ancient or modern naturalists are known to have become absolutely extinct, though there are some cases in which they are ascertained to have utterly disappeared from the face of the earth in very recent times. The most familiar instances are those of the dodo, a large bird peculiar to the Nauritius or Isle of France, exterminated about the year 1690 and now known only by more or less fragmentary skeletons, and the solitary, which inhabited the islands of Bourbon and Rodriguez, but has not been seen for more than a century. A parrot and some other birds of the Norfolk Island group are said to have lately become extinct. The wingless auk, Alca impennis, a bird remarkable for its excessive fatness, was very abundant two or three hundred years ago in the Faroe Islands and on the whole Scandinavian seaboard. The early voyagers found either the same or a closely allied species, in immense numbers, on all the coasts and islands of Newfoundland. The value

* The following is an extract from a letter written to the English Times by Mr. A. Newton, of Magdalene College, Cambridge :

"When, some years since, I drew the attention of the British Association to the cruelty and evil consequences of the then prevailing fashion of ladies wearing 'plumes' of sea birds' feathers, you were good enough to notice my efforts favourably, and in the ensuing Session of Parliament an Act was passed whereby the mischief was effectually stopped. I therefore now solicit your aid in bringing before the public a fashion quite as disastrous to the feathered race, though, I regret to say, one that can not be put an end to by the same simple means. Like others of my brother naturalists, I have been long aware by report of the enormous sales of birds' fenthers which are being constantly held in London; but the particulars of them do not, except by accident, come before us. Chance has thrown in my way a catalogue, or portion of a cata logue, of one of these auctions, and its contents are such as to horrify me, for I had no conception of the amount of destruction to which exotic birds are condemned by fashion-an amount which can not fail speedily to extirpate some of the fairest members of creation, for I must premise, for the benefit of your non-ornithological readers, that it is chiefly, if not solely, at the breeding season that the most beautiful, and therefore the most valuable feathers, are developed in birds. What I have before me is a 'First Supplement to - - 's Feather Sale of -th January, 1876' (I omit the name and date for obvious reasons), and gives the details of lots $71-228$, to be offered for sale on that day. The second page of this document (the first being occupied by the title) relates to 2,077 bundles of herons' or egrets' feathers (they go by other names 'in the trade'), the weight of which I find to be given as $702 \mathrm{oz}$. How many feathers may go to a bundle I can not say, but, weighing some 20 exceptionally stout feathers (not herons') which happened to be at hand, I find them to 
of its flesh and its oil made it one of the most important resources of the inhabitants of those sterile regions, and it was naturally an object of lieen pursuit. It is supposed to be now completely extinct, and few museums can show even its skeleton.

There seems to be strong reason to believe that modern civilization is guiltless of one or two sins of extermination which have been committed in recent ages. New Zealand formerly possessed sereral species of dinornis, one of which, called moa by the islanders, was larger than the ostrich. The condition in which the bones of these birds have been found and the traditions of the natives concur to prove that, though the aborigines had probably extirpated them before the discovery of New Zealand by the whites, they still existed at a comparatively late period. The same remarks apply to a winged giant the eggs of which have been brought from Madagascar. This bird must have much exceeded the dimensions of the moa, at least so far as we can judge from the egg, which is eight times as large as the average size of

balance $\frac{1}{4} \mathrm{oz}$, exactly. I think, therefore, that these 2,077 bundles can not well contain fewer than 56,160 feathers, and, allowing 20 of them to each bird (which I believe to be a fair allowance), we have evidence of the death of 2,808 herons or egrets. The next page relates to 2,948 similar bundles, weighing $1,168 \mathrm{oz}$., showing, on the same estimate, 4,672 birds. To this follow other lots, which in like manner I compute to represent 2,220 birds-or, in all, 9,700 herons or egrets. All these lots are said to have arrived from India, and nearly all to have been warehoused last autumn. The spoils of how many more birds were included in the catalogue itself, to which this is a first supplement, or of how many in the second supplement, I of course can not say ; but even if there were none, I venture to affirm that no country could long supply nearly 10,000 herons or egrets, killed in a single breeding senson, without the stock becoming utterly rooted out. Yet I am told that there is one or more of these sales almost weekly. But this sale included also the skins of other birds-mostly, to all appearance, from South America or its islands. Of these there are enumerated 15,574 humming-birds, 740 of which are specified as being of one kind, the ruby humming-bird. I will not occupy your space by giving details of the rest-sufficient to say that parrots, kingfishers, trogons, tanagers, and various other brightly-coloured birds are there by the thousand. It may be that the Government of India might take steps, by establishing a close time, to save the herons and egrets from utter extirnation, and the same might be done in our colonies of Trinidad and Demarara, whence I have reason to think that many of the other victims are procured. But the most effectual remedy would be for every right-minded man or woman to discountenance the wearing of feathers on the person or their use in the decoration of fur. niture." 
the ostrich egg, or about one hundred and fifty times that of the hen.

But though we have no evidence that man has exterminated many species of birds, we know that his persecutions have caused their disappearance from many localities where they once were common, and greatly diminished their numbers in others. The cappercailzie, Tetrao urogallus, the finest of the grouse family, formerly abundant in Scotland, had become extinct in Great Britain, but has been reintroduced from Sweden.* The ostrich is mentioned, by many old travellers, as common on the Isthmus of Suez down to the middle of the seventeenth century. It appears to have frequented Palestine, Syria, and even Asia Minor at earlier periods, but is now rarely found except in the seclusion of remoter deserts. $\dagger$

The modern increased facilities of transportation have brought distant markets within reach of the professional hunter, and thereby given a new impulse to his destructive propensities. Not only do all Great Britain and Ireland contribute to the supply of game for the British capital, but the canvas-back duck of the Potomac, and even the prairie hen from the basin of the Mississippi, may be found at the stalls of the London poulterer. Kohl $\ddagger$ informs

* The cappercailzie, or tjïder, as he is called in Sweden, is a bird of singular habits, and seems to want some of the protective instincts which secure most other wild birds from destruction. The younger Læstadius frequently notices the tjïder, in his very remarkable account of the Swedish Laplanders. The tjäder, though not a bird of passage, is migratory, or rather wandering in domicile, and appears to undertake very purposeless and absurd journeys. "When he flits," says Læstadius, "he follows a straight course, and sometimes pursues it quite out of the country. It is said that, in foggy weather, he sometimes flies out to sea, and, when tired, falls into the water and is drowned. It is accordingly observed that, when he flies westwardly, towards the mountains, he soon comes back again; but when he takes an eastwardly course, he returns no more, and for a long time is very scarce in Lapland. From this it would seem that he turns back from the bald mountains, when he discovers that he has strayed from his proper home, the wood; but when he finds himself over the Baltic, where he can not alight to arise and collect himself, he flies on until he is exhausted and falls into the sea."-PETrus LAstadiUs, Journal af första året, etc., p. 325.

+ Frescobaldi saw ostriches in the fourteenth century between Suez and Mit. Sinai. Viaggio in Terra Santa, p. 65. See also VAnsles, Voyage d'Égypte, p. 103, and an article in Petermann, Mittheilungen, 1870, p. 380, entitled Dis Verbreitung des Strausses in Asien.

$\ddagger$ Die Herzogthümer Schleswig und Holstein, i., p. 203. 
us that on the coasts of the North Sea, twenty thousand wild ducks are usually taken in the course of the season in a single decoy, and sent to the large maritime towns for sale. The statistics of the great European cities show a prodigions consumption of game.birds, but the official returns fall far below the truth, be cause they do not include the rural districts, and because neither the poacher nor his customers report the number of his victims. Reproduction, in cultivated countries, can not keep pace with this excessive destruction, and there is no doubt that all the wild birds which are chased for their flesh or their plumage are diminishing with a rapidity which justifies the fear that the last of them will soon follow the dodo and the wingless auk.

Fortunately the larger birds which are pursued for their flesh or for their feathers, and those the eggs of which are used as food, are, so far as we know the functions appointed to them by nature, not otherwise specially useful to man, and, therefore, their wholesale destruction is an economical evil only in the same sense in which all waste of productive capital is an evil.* If it were possible to confine the consumption of game-fowl to a number equal to the annual increase, the world would be a gainer, but not to the same extent as it would be by checking the wanton sacrifice of millions of the smaller birds, which are of no real value as food, but which, as we have seen, render a most important service by battling, in our behalf as well as in their own, against the countless legions of humming and of creeping things, with which the prolific powers of insect life would otherwise cover the earth.

\section{Jitity and Destruction of Reptiles.}

The disgust and fear with which the serpent is so universally regarded expose him to constant persecution by man, and perhaps no other animal is so relentlessly sacrificed by him. Nerertheless, snakes as well as lizards and other reptiles are not wholly

\footnotetext{
* The increased demand for animal oils for the use of the leather-dresser is now threatening the penguin with the fate of the wingless auk. According to the Report of the Agricultural Department of the U.S. for August and Sep. tember, 1871 , p. 340 , small vessels are fitted out for the chase of this bird, and return from a six wecks' cruise with 25,000 or 30,000 gallons of oil. About eleven birds are required for a gallon, and consequently the vessels take upon an average 300,000 penguins each.
} 
useless to their great enemy. The most formidable foes of the insect, and even of the small rodents, are the reptiles. The chameleon approaches the insect perched upon the twig of a tree, with an almost imperceptible slowness of motion, until at the dis. tance of a foot, he shoots out his long, slimy tongue, and rarely fails to secure the victim. Even the slow toad catches the swift and wary housefly in the same manner; and in the warm countries of Europe, the numerous lizards contribute very essentially to the reduction of the insect population, which they both surprise in the winged state upon walls and trees, and consume as egg, worm and chrysalis, in their earlier metamorphoses. The serpents feed much upon insects, as well as upon mice, moles and small reptiles, including also other snakes.

In temperate climates, snakes are consumed by scarcely any beast or bird of prey except the stork, and they have few dangerous enemies but man, though in the tropies other animals prey upon them.* It is doubtful whether any species of serpent has been exterminated within the human period, and even the dense population of China has not been able completely to rid itself of the viper. They have, however, almost entirely disappeared from particular localities. The rattlesnake is now wholly unknown in many large districts where it was extremely common half a century ago, and Palestine has long been, if not absolutely free from venomous serpents, at least very nearly so.†

* It is questionable whether there is any foundation for the popular belief in the hostility of swine and of deer to the rattlesnake, and careful experiments as to the former quadruped would seem to show that the supposed enmity is wholly imaginary. Redlitz, United States Survey of Territories, vol. iv., chap. i., p. 264, says, however, that wild pigs, peccaries and deer are destructive enemies of the rattlesnake, and it is aftirmed in an article in Nature, June 11, 1872, p. 215 , that the pigs have exterminated the rattlesnake in some parts of Oregon, and that swine are destructive to the cobra de capello in India. $\mathrm{Ob}$ serving that the starlings, stornelli, which bred in an old tower in Piedmont, carried something from their nests and dropped it upon the ground about as often as they brought food to their young, I watched their proceedings, and found every day lying near the tower numbers of dead or dying slowworms, and, in a few cases, small lizards, which had, in every instance, lost about two inches of the tail. This part I believe the starlings gave to their nestlings, and threw away the remainder.

† Russell denies the existence of poisonous snakes in Northern Syria, and states that the last instance of death known to have occurred from the bite of 
The serpent does not appear to have any natural limit of growth, and we are therefore not authorized wholly to discredit the evidence of ancient naturalists in regard to the extraordinary dimensions which these reptiles are said by them to have some-

a serpent near Aleppo took place a hundred years before his time. In Palestine, the climate, the thinness of population, the multitude of insects and of lizards, in fact all circumstances seem very favorable to the multiplication of serpents, but the venomous species, at least, are extremely rare, if at all known, in that country. I have, however, been assured by persons very familiar with Mount Lebanon, that cases of poisoning from the bite of snakes had occurred, within a few years, near Hasbeiyeh and at other places on the southern declivities of Lebanon and Hermon, and I am informed that vipers are not uncommon about the Pools of Solomon near Jerusalem. In Egypt, the cobra, the asp, and the cerastes are as numerous as ever, and are much dreaded by all the natives except the professional snake-charmers.

The recent great multiplication of vipers in some parts of France is a singular and startling fact. Toussenel, quoting from official documents, states that upon the offer of a reward of fifty centimes, or ten cents, a head, twoelce thousand vipers were brought to the prefect of a single department, and that in 1859 fifteen hundred snakes and twenty quarts of snakes' eggs were found under a farm-house hearthstone. The granary, the stables, the roof, the very beds swarmed with serpents, and the family were obliged to abandon its habitation. Dr. Viaugrandmarais, of Nantes, reported to the prefect of his department more than two hundred recent cases of viper bites, twenty-four of which proved fatal.-Tristia, p. $176 \mathrm{et} \mathrm{seq.} \mathrm{According} \mathrm{to} \mathrm{the} \mathrm{Journal} \mathrm{des} \mathrm{Débats} \mathrm{for}$ Oct. 1st, 1867, the Department of the Côte d'Or paid in the year 1866 eighteen thousand francs for the destruction of vipers. The reward was thirty centimes a head, and consequently the number killed was about sixty thousand. A friend residing in the department informs me that it was strongly suspected that many of these snakes were imported from other departments for the sake of the premium.

In Nature for $18 \% 0$ and 1871 we are told that the number of denths from the bites of venomous serpents in the Bengal Presidency, in the year 1869, was 11,416, and that in the whole of British India not less than 40,000 human lives are annually lost from this cause. In one small department, a reward of from three to six pence a head for poisonous serpents brought in 1,200 a day, and in two months the government paid $£ 10,000$ sterling for their destruction.

The statistics for the year 1877 show that there were as many as 19,695 persons killed by wild beasts and snakes in British India in that year. Tigers head the list. There were 819 persons killed by tigers, 561 by wolves, 200 by leopards, 85 by bears, 46 by elephants, 24 by hyenas, 1,180 by other wild beasts. The other $16,7 \% 7$ victims were killed by suakes. These various enemies of mankind killed also 53,197 cattle in the year. The measures adopted in Indis for exterminating wild beasts and venomous snakes, resulted in the destruction of $22,8,51$ of the former and $127,29 \%$ of the latter in the course of the year, and for this deliverance from them rewards were paid to the amount of $£ 10,301$. 
times attained. The use of firearms has enabled man to reduce the numbers of the larger serpents, and they do not often escape him long enough to arrive at the size ascribed to them by travellers a century or two ago. Captain Speke, however, shot a serpent in Africa which measured fifty-one and a half feet in length.

Some enthusiastic entomologist will, perhaps, by and by discover that insects and worms are as essential as the larger organisms to the proper working of the great terraqueous machine, and we shall have as eloquent pleas in defence of the mosquito, and perhaps even of the tzetze-fly, as Toussenel and Michelet have framed in behalf of the bird. The silkworm, the lac insect, and the bee need no apologist; a gallnut produced by the puncture of a cynips on a Syrian oak is a necessary ingredient in the ink I am writing with, and from my windows I recognize the grain of the kermes and the cochineal in the gay habiliments of the holiday groups beneath them.

These humble forms of being are seldom conspicuous by mere mass, and though the winds and the waters sometimes sweep together large heaps of locusts and even of May-flies, their remains are for the most part speedily decomposed, their exuvis and their structures rarely form strata, and still less does nature use them, as she does the calcareous and silicious cases and dwellings of animalcular species, to build reefs and spread out submarine deposits which subsequent geological action may convert into islands and even mountains.*

* Calcaire a friganes, as it is locally called, or limestone filled with the in dusice of the larvæ of May-flies, covers some square miles near Clermont in Auvergne.

Although the remains of extant animals are rarely, if ever, gathered in suflicient quantities to possess any geographical importance by their mere mass, the decayed exuvix of even the smaller and humbler forms of life are sometimes abundant enough to exercise a perceptible influence on soil and atmosphere. "The plain of Cumana," says Humboldt, "presents a remarkable phenomenon, after heavy rains. The moistened earth, when heated by the rays of the sun, diffuses the musky odor common in the torrid zone to animals of very different classes, to the jaguar, the small species of tiger-cat, the cabiai, the gallinazo vulture, the crocodile, the viper, and the rattlesnake. The gaseous emanations, the vehicles of this aroma, appear to be disengaged in proportion as the soil, which contains the remains of an innumerable mul. 
But the action of the creeping and swarming things of the earth, though often passed unnoticed, is not without important effects in the general economy of nature. The geographical importance of insects proper, as well as of worms, depends principally on their connection with vegetable life as agents of its fecundation, and of its destruction. We learn from Darwin, "On Various Contrivances by which British and Foreign Orchids are Fertilized by Insects," that some six thousand species of orchids are absolutely dependent upon the agency of insects for their fertilization, and that consequently, were those plants unvisited by insects, they would all rapidly disappear. What is true of the orchids is more or less true of many other vegetable families.* We do not know the limits of this agency, and many of the insects habitually regarded as unqualified pests, may directly or indirectly perform functions as important to the most valuable plants as the services rendered by certain tribes to the orchids. I say directly or indirectly, because, besides the other

titude of reptiles, worms and insects, begins to be impregnated with water. Wherever we stir the earth, we are struck with the mass of organic substances which in turn are developed and become transformed or decomposed. Nature in these climes seems more active, more prolific, and, so to speak, more prodigal of life."

* Later observations of Darwin and other naturalists have greatly raised former estimates of the importance of insect life in the fecundation of plants, and among other remarkable discoreries it has been found that, in many cases at least, insects are necessary even to monœcious vegetables, because the male flower does not impregnate the female growing on the same stem, and the latter can be fecundated only by pollen supplied to it by insects from another plant of the same species.

"Who would ever have thought," says Prejer, "that the abundance and beauty of the pansy and of the clover were dependent upon the number of cats and owls? But so it is. The clover and the pansy can not exist without the humble-bee, which, in search of his vegetable nectar, transports unconsciously the pollen from the masculine to the feminine flower, a service which other insects perform only partially for these plants. Their existence therefore depends upon that of the humble-bee. The mice make war upon this bee. In their fondness for honey they destroy the nest and at the same time the bee. The principal enemies of mice are cats and owls, and therefore the finest clovers and the most beautiful pansies are found near villages where cats and owls abound."-Prerer, Dor Kampf um das Dasein, p. 22. See also Delprino, Pensieri sulla biologia vegetale, and other works of the same able observer on vegetable physiology. 
arrangements of nature for checking the undue multiplication of particular species, she has established a police among insects themselves, by which some of them keep down or promote the increase of others; for there are insects, as well as birds and beasts, of prey. The existence of an insect which fertilizes a useful regetable may depend on that of another insect which constitutes his food in some stage of his life, and this other again may be as injurious to some plant as his destroyer is to a different species.

The ancients, according to Pliny, were accustomed to hang branches of the wild fig upon the domestic tree, in order that the insects which frequented the former might hasten the ripening of the cultivated fig by their punctures-or, as others suppose, might fructify it by transporting to it the pollen of the wild fruit-and this process, called caprification, is not yet entirely obsolete.*

The perforations of earthworms and of many insect larvæ mechanically affect the texture of the soil and its permeability by water, and they therefore have a certain influence on the form and character of terrestrial surface. The earthworms long ago made good their title to the respect and gratitude of the farmer as well as of the angler. Their utility has been pointed out in many scientific as well as in many agricultural treatises. The following extract from an essay on this subject will answer my present purpose:

"Worms are great assistants to the drainer, and valuable aids to the farmer in keeping up the fertility of the soil. They love moist, but not wet soils; they will bore down to, but not into, water; they multiply rapidly on land after drainage, and prefer a deeply-dried soil. On examining part of a field which had been deeply drained, after long-previous shallow drainage, it was found

* The utility of caprification has been a good deal disputed, and it has, I believe, been generally abandoned in Italy, though still practiced in Greece. See Browne, The Trees of America, p. 475, and on caprification in Kabylia, N. Brвesco, Les Kabyles du Djurdjura, in Revue des Doux Mondes for April 1st, 1865, p. 589; also, Aus der Natur, vol. xxx., p. 684, and Purrson, Utilization of Minute Life, p. 59. In some parts of Sicily, sprigs of mint, mentha mulegium, are used instead of branches of the wild fig for caprification. Pitre, Usi popolari Siciliani, 1871, p. 18. 
that the worms had greatly increased in number, and that their bores descended quite to the level of the pipes. Many wormbores were large enough to receive the little finger. A piece of land near the sea in Lincolnshire, over which the sea had broken and killed all the worms, remained sterile until the worms again inlabited it. $\Lambda$ piece of pasture-land, in which worms were in such numbers that it was thought their casts interfered too much with its produce, was rolled at night in order to destroy the worms. The result was, that the fertility of the field greatly declined, nor was it restored until they had recruited their numbers, which was aided by collecting and transporting multitudes of worms from the fields.

"The great depth into which worms will bore, and from which they push up fine fertile soil and cast it on the surface, have been well shown by the fact that in a few years they have actually elevated the surface of fields by a large layer of rich mould several inches thick, thus affording nourishment to the roots of grasses, and increasing the productiveness of the soil."

It should be added that the writer quoted, and all others who have discussed the subject, have, so far as I know, overlooked one very important element in the fertilization produced by earthworms. I refer to the enrichment of the soil by their excreta during life, and by the decomposition of their remains when they die. The manure thus furnished is as valuable as the like amount of similar animal products derived from higher organisms, and when we consider the prodigious numbers of these worms found on a single square yard of some soils, we may easily see that they furnish no insignificant contribution to the nutritive material required for the growth of plants.*

I believe there is no foundation for the supposition that earthworms attack the tuber of the potato. Some of them, especially

* Since the publication of the previous editions of this work, MIr. Darwin's very recent observations on the earthworm have given to this humble form of life a new importance. He has shown that the magnitude of the effects produced by these organisms, so individually insignificant, is rastly greater than had hitherto been supposed-that they not only improve the soil, first by manipulating, then by their excreta and decay, as stated in the text, but that they transplace it to such an extent as to be justly reckoned an important element in superficial geography. 
one or two species employed by anglers as bait, if natives of the woods, are at least rare in shaded grounds, but multiply very rapidly after the soil is brought under cultivation. Forty or fifty years ago they were so scarce in the newer parts of New England, that the rustic fishermen of every village kept secret the few places where they were to be found in their neighborhood, as a professional mystery, but at present one can hardly turn over a shovelful of rich, moist soil anywhere without unearthing several of them. A very intelligent lady, born in the woods of northern New England, told me that, in her childhood, these worms were almost unknown in that region, though anxiously sought for by the anglers, but that they increased as the country was cleared, and at last became so numerous in some places, that the water of springs, and even of shallow wells, which had formerly been excellent, was rendered undrinkable by the quantity of dead worms that fell into them. The increase of the robin and other small birds which follow the settler when he has prepared a suitable home for them, at last checked the excessive multiplication of the worms and abated the nuisance.

The carnivorous, and often herbivorous, insects render another important service to man by consuming dead and decaying animal and vegetable matter, the decomposition of which would otherwise fill the air with effluvia noxious to health. Some of them, the grave-digger beetle, for instance, bury the small animals in which they lay their eggs, and thereby prevent the escape of the gases disengaged by putrefaction. The prodigious rapidity of development in insect life, the great numbers of the individuals in many species, and the voracity of most of them while in the larva state, justify the appellation of nature's scavengers which has been bestowed upon them, and there is very little doubt that, in warm countries, they consume a larger quantity of putrescent organic matter than the quadrupeds and birds which feed upon such aliment.

\section{Injury to the Forest by Insects.}

The action of the insect on vegetation, as we have thus far described it, is principally exerted on smaller and less conspicuous plants, and it is therefore matter rather of agricultural than of geographical interest. But in the economy of the forest, European 
writers ascribe to insect life an importanee which it has not reached in America, where the spontaneous woods are protected by safeguards of nature's own devising.

The insects which damage primitive forests by feeding upon products of trees essential to their growth, are not numerous, nor is their appearance in destructive numbers frequent, while those which perforate the stems and branches, to deposit and hatch their eggs, more commonly select dead trees for that purpose, though, unhappily, there are important exceptions to this latter remark.* I do not know that we have any evidence of the destruction or serious injury of American forests by insects, before or eren soon after the period of colonization; but since the white man has laid bare a vast proportion of the earth's surface, and thereby produced changes farorable, perhaps, to the multiplication of these pests, they have greatly increased in numbers, and, apparently, in

* The locust insect, Clitus pictus, which deposits its eggs in the American locust, Robinia pseudacacia, is one of these, and its ravages have been and still are most destructive to that very valuable tree, so remarkable for combining rapidity of growth with strength and durability of wood. This insect, I believe, has not yet appeared in Europe, where, since the so general employment of the Rotinia to clothe and protect embankments and the scarps of deep cuts on railroads, it would do incalculable mischief. As a traveller, however, I should find some compensation for this evil in the destruction of these acacia hedges, which as completely obstruct the view on hundreds of miles of French aud Italian railways, as do the garden-walls of the same countries on the ordinary roads.

The lignivorous insects, that attack living trees, almost uniformly confine their ravages to trees already unsound or diseased in growth from the depredations of leaf-eaters, such as caterpillars and the like, or from other causes. The decay of the tree, therefore, is the cause, not the consequence, of the invasions of the borer. This subject has been discussed by Perris in the dnnales de lis Société Entomologique de la France for 1852, and his conclusions are confirmed by the observations of Samanos, who quotes at some length the views of Perris. "Having, for fifteen years," says the latter author, "incessantly studied the habits of lignivorous insects in one of the best wooded regions of France, I have observed facts enough to feel myself warranted in expressing my conclusions, which are: that insects in general-I am not speaking of those which confine their voracity to the leaf-do not attack trees in sound health, and they assail those only whose normal conditions and functions have been by some cause impaired."

See, more fully, Samanos, Traité de la Cutture du Pin Maritime, Paris, 1864, pp. 140-145, and Siexoni, Manuale dell' Arte Forcstale. 2d edition. Florence, 1872. 
voracity also. Not many years ago the pines on thousands of acres of land in North Carolina were destroyed by insects not known to have ever done serious injury to that tree before. In such cases as this and others of the like sort, there is good reason to believe that man is the indirect cause of an evil for which he pays so heavy a penalty. Insects increase whenever the birds which feed upon them disappear. Hence, in the wanton destruction of the robin and other insectivorous birds, the bipes implumis, the featherless biped, man, is not only exchanging the vocal orchestra, which greets the rising sun for the drowsy beetle's evening drone, and depriving his groves and his fields of their fairest ornament, but he is waging a treacherous warfare on his natural allies.*

* In the artificial woods of Europe insects are far more numerous and destructive to trees than in the primitive forests of America, and the same remark may be made of the smaller rodents, such as moles, mice, and squirrels. In the dense, native wood, the ground and the air are too humid, the depth of shade too great, for many tribes of these creatures, while near the natural meadows and other open grounds, where circumstances are otherwise more favorable for their existence and multiplication, their numbers are kept down by birds, serpents, foxes, and smaller predacious quadrupeds. See a curious article on the wild mammalia useful to man, by Asbjörnsen, in the Norske Landmandsbog, 1866, p. 85. In civilized countries these natural enemies of the worm, the beetle, and the mole, are persecuted, sometimes almost exterminated, by man, who also removes from his plantations the decayed or wind-fallen trees, the shrubs and underwood, which, in a state of nature, furnished food and shelter to the borer and the rodent, and often also to the animals that preyed upon them. Hence the insect and the gnawing quadruped are allowed to increase, from the expulsion of the police which, in the natural wood, prevent their excessive multiplication, and they become destructive to the forest because they are driven to the living tree for nutriment and cover. The forest of Fontainebleau is almost wholly without birds, and their absence is ascribed by some writers to the want of water, which, in the thirsty sands of that wood, does not gather into running brooks; but the want of undergrowth is perhaps an equally good reason for their scarcity:

On the other hand, the thinning out of the forest and the removal of underwood and decayed timber, by which it is brought more nearly to the condition of an artificial wood, is often destructive to insect tribes which, though not injurious to trees, are noxious to man. Thus the troublesome woodtick, formerly very abundant in the Northeastern, as it unhappily still is in native forests in the Southern and Western States, has become nearly or quite extinct in the former region since the woods have been reduced in extent and laid more open to the sum and air.-Asa Fiтce, in Report of Nero Tork Agricultural So. ciety for $1870, \mathrm{pp} .363,364$. 


\section{Introduction of Insects.}

The general tendency of man's encroachments upon spontancons nature has been to increase insect life at the expense of vegetation and of the smaller quadrupeds and birds. Doubtless there are insects in all woods, but in temperate climates they are comparatively few and harmless, and the most numerous tribes which breed in the forest, or rather in its waters, and indeed in all solitudes, are those which little injure vegetation, such as mosquitoes, gnats, and the like. With the plants cultivated by man come the myriad tribes which feed or breed upon them, and agriculture not only introduces new species, but so multiplies the number of individuals as to defy calculation. Newly introduced vegetables frequently escape for years the insect plagues which had infested them in their native habitat; but the importation of other varieties of the plant, the exchange of seed, or some mere accident, is sure in the long run to carry the egg, the larva, or the chrysalis to the most distant shores where the plant assigned to it by nature as its possession had preceded it. For many years after the colonization of the United States, few or none of the insects which attack wheat in its different stages of growth, were known in America. During the Revolutionary war, the Hessian fly, Cecidomyia destructrix, made its appearance, and it was so called because it was first observed in the year when the Hessian troops were brought over, and was popularly supposed to have been accidentally imported by those unwelcome strangers. Other destroyers of cereal grains have since found their way across the Atlantic, and a noxious European aphis has first attacked the American wheat-fields within the last twenty-five or thirty years. Unhappily, in these cases of migration, the natural corrective of excessive multiplication, the parasitic or voracious enemy of the noxious insect, does not always accompany the wanderings of its prey, and the bane long precedes the antidote. Hence, in the United States, the ravages of imported insects injurious to cultivated crops, not being checked by the counteracting infuences which nature had provided to limit their devastations in the Old World, are more destructive than in Europe. It is not known that the wheat midge is preyed upon in America by any other insect, and in seasons favorable to it, it multiplies to a degree 
which would prove almost fatal to the entire harvest, were it not that, in the great territorial extent of the United States, there is room for such differences of soil and climate as, in a given year, to present in one State all the conditions favorable to the increase of a particular insect, while in another, the natural influences are hostile to it. The only apparent remedy for this evil is, to balance the disproportionate development of noxious foreign species by bringing from their native country the tribes which prey upon them. This, it seems, has been attempted. The United States Census Report for 1860, p. 82, states that the New York Agricultural Society "has introduced into this country from abroad certain parasites which Providence has created to counteract the destructive powers of some of these depredators." *

This is, however, not the only purpose for which man has designedly introduced foreign forms of insect life. The eggs of the silkworm are known to have been brought from the farther East to Europe in the sixth century, and new silk-spinners which feed on the castor-oil bean and the ailanthus, have recently been reared in France and in South America with promising success. $†$ The cochineal, long regularly bred in aboriginal America, has been transplanted to Spain, and both the kermes insect and the cantharides have been transferred to other climates than their own. The honey-bee must be ranked next to the silkworm in economical importance. This useful creature was carried to the United States by European colonists, in the latter part of the seventeenth century; it did not cross the Mississippi till the close of the eighteenth, and it is only in 1853 that it was transported to California, where it was previously unknown. The Italian bee, which seldom stings, has lately been introduced into the United States. $f$

* On parasitic and entomophagous insects, see a paper by Rondani referred to p. 117 ante.

t The silkworm which feeds on the ailanthus has naturalized itself in the United States, but the promises of its utility have not been realized.

$\ddagger$ Bee-husbandry, now very general in Switzerland and other Alpine regions, was formerly an important branch of industry in Italy. It has lately been revived and is now extensively prosecuted in that country. In fact, the market demand for Swiss honey has become so great that the producing powers of the bee are not found equal to meet it, and $I$ am informed by an in 
The insects and worms intentionally transplanted by man beat but a small proportion to those accidentally introduced by him. Plants and animals often carry their parasites with them, and the traftic of commercial countries, which exchange their products with every zone and every stage of social existence, can not fail to transfer in both directions the minute organisms that are, in one way or another, associated with almost every object important to the material interests of man.*

The tenacity of life possessed by many insects, their prodigious fecundity, the length of time they often remain in the different phases of their existence, the security of the retreats into which

telligent friend that, in the early part of this year (1882) a single manufactory in Switzerland had multiplied a comparatively few pounds of the genuine article into a quantity of honey equal to a season's supply for all the summer visitors to that attractive country, and that in appearance and flavor this product was scarcely inferior to bee-honey, that it was eaten in good faith at all the hotel tables, and found to be equally wholesome. It is interesting to observe that many of the methods recently introduced into bee-husbandry in England and the United States, such, for example, as the removable honeyboxes, are reinventions of Italian systems at least three hundred years old. See Gallo, Le venti Giornate dell' Agricultura, cap. xv.

The temporary decline of this industry in Italy was doubtless in a great measure due to the use of sugar which had taken the place of honey, but perhaps also in part to the decrease of the wild vegetation from which the bee draws more or less of his nutriment.

A new wax-producing insect, a species of coccus, very abundant in China, where its annual produce is said to amount to the value of ten millions of francs, has recently attracted notice in France. The wax is white, resembling spermaceti, and is said to be superior to that of the bee.

* A few years ago, a laborer, employed at a North American port in discharging a cargo of hides from the opposite extremity of the continent, was fatally poisoned by the bite or the sting of an unknown insect, which ran out from a hide he was handling.

The Phylloxera vastatrix, the most destructive pest which has ever attacked European vineyards-for its ravages are fatal not merely to the fruit, but to the vine itself-is said by entomologists to be of American origin, but I have seen no account of the mode of its first introduction into Europe.

† In many insects, some of the stages of life regularly continue for several years, and they may, under peculiar circumstances, be almost indefinitely prolonged. Dr. Dwight mentions the following remarkable case of this sort : "I saw here an insect, about an inch in length, of a brown color tinged with orange, with two antennæ, not unlike a rosebug. This insect came out of a tea-table made of the boards of an apple-tree." Dr. Dwight found the "cavity whence the insect had emerged into the light," to be "about two inches in 
their small dimensions enable them to retire, are all circumstances very favorable not only to the perpetuity of their species, but to their transportation to distant climates and their multiplication in their new homes. The teredo, so destructive to shipping, has been carried by the ressels whose wooden walls it mines to almost every part of the globe. The termite, or white ant, is said to have been brought to Rochefort by the commerce of that port a hundred years ago.* This creature is more injurious to wooden structures and implements than any other known insect. It eats out almost the entire substance of the wood, leaving only thin partitions between the galleries it excavates in it; but as it never gnaws through the surface to the air, a stick of timber may be almost wholly consumed without showing any external sign of the damage it has sustained. The termite is found also in other parts of France, and particularly at Rochelle, where, thus far, its ravages are confined to a single quarter of the city. A borer of similar habits is not uncommon in Italy, and you may see in that country handsome chairs and other furniture which have been reduced by this insect to a framework of powder of post, covered and apparently held together by nothing but the varnish.

\section{Destruction of Insects.}

It is well known to naturalists, but less familiarly to common observers, that the aquatic larvæ of some insects which in other stages of their existence inhabit the land, constitute, at certain seasons, a large part of the food of fresh-water fish, while other larvæ, in their turn, prey upon the spawn and even the young of their persecutors. $\dagger$ The larvæ of the mosquito and the gnat are

length. Between the hole, and the outside of the leaf of the table, there were forty grains of the wood." It was supposed that the sawyer and the cabinetmaker must have removed at least thirteen grains more, and the table had been in the possession of its proprietor for twenty years.

* It does not appear to be quite settled whether the termites of France are indigenous or imported. See QUATREFAGEs, Souvenirs d'un Naturaliste, ii., pp. $400,542,543$.

The white ant has lately appeared at St. Helena and is in a high degree destructive, no wood but teak, and even that not always resisting it.-Nature for March 2d, 1871, p. 362.

† I have seen the larva of the dragon-fly in an aquarium bite off the head of a young fish as long as itself. 
the favorite food of the trout in the wooded regions where those insects abound.* Earlier in the year the trout feeds on the larvæ of the May-fly, which is itself very destructive to the spawn of the salmon, and hence, by a sort of house-that-Jack-built, the destruction of the mosquito, that feeds the trout that preys on the May-fly that destroys the eggs that hatch the salmon that pampers the epicure, may occasion a scarcity of this latter fish in waters where he would otherwise be abundant. Thus all nature is linked together by invisible bonds, and every organic creature, however low, however feeble, however dependent, is necessary to the well-being of some other among the myriad forms of life with which the Creator has peopled the earth.

I have said that man has promoted the increase of the insect and the worm, by destroying the bird and the fish which feed upon them. $\dagger$ Many insects, in the four different stages of their

* Insects and fish-which prey upon and feed each other-are the only forms of animal life that are numerous in the native woods, and their range is, of course, limited by the extent of the waters. The great abundance of the trout, and of other more or less allied genera in the lakes of Lapland, seems to be due to the supply of food provided for them by the swarms of insects which in the larva state inhabit the waters, or, in other stages of their life, are accidentally swept into them. All travellers in the north of Europe speak of the guat and the mosquito as very serious drawbacks upon the enjoyments of the summer tourist, who visits the head of the Gulf of Bothnia to see the midnight sun, and the brothers Læstadius regard them as one of the great plagues of sub-arctic life. "The persecutions of these insects," says Lars Levi Lwestadius [Culex pipiens, Culex reptans, and Culex pulicaris], "leave not a moment's peace, by day or night, to any living creature. Not only man, but cattle, and even birds and wild beasts, suffer intolerably from their bite." $\mathrm{He}$ adds in a note, "I will not affirm that they have ever devoured a living man, but many young cattle, such as lambs and calves, have been worried out of their lives by them. All the people of Lapland declare that joung birds are killed by them, and this is not improbable, for birds are scarce after seasons when the midge, the gnat, and the mosquito are numerous."-Om Tppodlingar i Lappmarken, p. 50 .

Petrus Læstadius makes similar statements in his Journal för första året, $\mathrm{p}$. 285.

t The following is an extract from a highly respectable Journal, the article from which it is taken having been inspired by the plague of locusts and grasshoppers which were at that time consuming the harvests of whole States : "It was recently stated in a Chicago paper that 10,000 quails and prairie chickens were fed to swine in a single day, in that city. It went on to say that, in the country west of Chicago, quails, ruffed grouse, and prairie chickens are destroyed by the million, irrespective of law or season. Tons of 
growth, inhabit in succession the earth, the water, and the air. In each of these elements they have their special enemies, and, deep and dark as are the minute recesses in which they hide themselves, they are pursued to the remotest, obscurest corners by the executioners that nature has appointed to punish their delinquencies, and furnished with cunning contrivances for ferreting out the offenders and dragging them into the light of day. One tribe of birds, the woodpeckers, seems to depend for subsistence almost wholly on those insects which breed in dead or dying trees, and it is, perhaps, needless to say that the injury these birds do the forest is imaginary. They do not cut holes in the trunk of the tree to prepare a lodgment for a future colony of boring larvæ, but to extract the worm which has already begun his mining labors. Hence these birds are not found where the forester removes trees as fast as they become fit habitations for such insects. In clearing new lands in the United States, dead trees, especially of the spike-leaved kinds, too much decayed to serve for timber, and which, in that state, are worth little for fuel, are often allowed to stand until they fall of themselves. Such stubs, as they are popularly called, are filled with borers, and often deeply cut by the woodpeckers, whose strong bills enable them to penetrate to the very heart of the tree and drag out the lurking larvæ. After a few years, the stubs fall, or, as wood becomes valuable, are cut and carried off for firewood, and, at the same time, the farmer selects for felling, in the forest he has reserved as a permanent source of supply of fuel and timber, the decaying trees which, like the dead stems in the fields, serve as a home for both the worm and his pursuer. We thus gradually extirpate

birds, snared and shot out of season, are boiled and fed to swine. On one day there stood, in the corner of two streets, a wagon containing one hundred and eighty dozen of prairie chickens, while on the near sidewalk were piled thirtyseven boxes, containing five hundred and sixty dozen of quails, corrupt, decomposing, and condemned by the health officers. They are trapped, shot and snared, and sent to the market where they find a ready sale up to the mid. dle of March; but even after that, the indiscriminate slaughter continues. The young birds and setting hens are alike captured and sent to Chicago and other cities, on commission, and destined to be fed to swine. The birds must soon disappear before such recklessness and vice. In fact they have disappeared, almost entirely, from many Western localities, and grasshoppers and other noxious insects have, in consequence, multiplied and swarmed forth to spread famine and desolation over the land." 
this tribe of insects, and, with them, the species of birds which subsist principally upon them. Thus the fine, large, red-headed woodpecker, Picus erythrocephatus, formerly very common in New England, has almost entirely disappeared from those States since the dend trees are gone, and the apples, his favorite vegetable food, are less abundant.

There are even large quadrupeds which feed almost exclusively upon insects. The ant-bear is strong enough to pull down the clay houses built by the species of termites that constitute his ordinary diet, and the curious ai-ai, a climbing quadruped of Madagascar, is provided with a very slender, hook-nailed finger, long enough to reach far into a hole in the trunk of a tree, and to extract the worm which bored it.*

\section{Minute Organisms.}

Besides the larger inhabitants of the land and of the sea, the quadrupeds, the reptiles, the birds, the amphibia, the crustacea, the fish, the insects, and the worms, there are other countless forms of vital being. Earth, water, the ducts and fluids of vegetable and of animal life, the very air we breathe, are peopled by minute organisms which perform most important functions in both the living and the inanimate kingdoms of nature. Of the offices assigned to these creatures, the most familiar to common observation is the extraction of lime, and, more rarely, of silex, from the waters inhabited by them, and the deposit of these minerals in a solid form, either as the material of their habitations or as the exuviæ of their bodies. The microscope and other means of scientific observation assure us that the chalk-beds of England and of France, the coral reefs of marine waters in warm climates, vast calcareous and silicious deposits in the sea and in many freshwater ponds, the common polishing earths and slates, and many species of apparently dense and solid rock, are the work of the humble organisms of which I speak, often indeed of animalculæ so small as to become visible only by the aid of lenses magnifying thousands of times the linear measures. It is popularly supposed that animalculæ, or what are commonly embraced under the vague name of infusoria, inhabit the water alone, but naturalists have

\footnotetext{
* On the destruction of insects by reptiles, see page 123 ante.
} 
long known that the atmospheric dust transported by every wind and deposited by every calm is full of microscopic life or of its relics. The soil on which the city of Berlin stands, contains, at the depth of ten or fifteen feet below the surface, living elaborators of silex; * and a microscopic examination of a handful of earth connected with the material eridences of guilt has enabled the naturalist to point out the very spot where a crime was committed. It has been computed that onc-sixth part of the solid matter let fall by great rivers at their outlets consists of still recognizable infusory shells and shields; and, as the friction of rolling water must reduce many of these fragile structures to a state of comminution which even the microscope can not resolve into distinct particles, and thus identify as relies of animal or of vegetable life, we must conclude that a considerably larger proportion of river deposits is really the product of animalcules. $\dagger$

It is evident that the chemical, and in many cases the mechanical, character of a great number of the objects important in the material economy of human life, must be affected by the presence of so large an organic element in their substance, and it is equally obvious that all agricultural and all industrial operations tend to disturb the natural arrangements of this element, to increase or to diminish the special adaptation of every medium in which it lives to the particular orders of being inhabited by it. The conversion of woodland into pasturage, of pasture into plough-land, of swamp or of shallow sea into dry ground, the rotations of cultivated crops, must prove fatal to millions of living things upon every rood of surface thus deranged by man, and must, at the same time, more or less fully compensate this destruction of

* WrTtwer, Physikalische Geographie, p. 142.

$\nmid$ To vary the phrase, I make occasional use of animalcule, which, as a popular designation, embraces all microscopic organisms. The name is founded on the now exploded supposition that all of them are animated, which was the general belief of naturalists when attention was first drawn to them. It was soon discovered that many of them were unquestionably vegetable, and there are numerous genera the true classification of which is matter of dispute among the ablest observers. There are cases in which objects formerly taken for living auimalcules turn out to be products of the decomposition of matter once animated, and it is admitted that neither spontaneous motion nor even apparent irritability are sure signs of animal life. 
life by promoting the growth and multiplication of other tribes equally minute in dimensions.

I do not know that man has yet endeavored to avail himself, by artificial contrivances, of the agency of these wonderful architects and manufacturers. We are hardly well enough acquainted with their natural economy to devise means to turn their industry to protitable account, and they are in very many cases too slow in producing visible results for an age so impatient as ours. The over-civilization of the nineteenth century can not wait for wealth to be amassed by infinitesimal gains, and we are in haste to specuZute upon the powers of nature, as we do upon objects of bargain and sale in our trafficking one with another. But there are still some cases where the little we know of a life, whose workings are invisible to the naked eye, suggests the possibility of advantageonsly directing the efforts of troops of artisans that we can not see. Upon coasts occupied by the corallines, the reef-building animalcule does not work near the mouth of rivers. Hence the change of the outlet of a stream, often a very easy matter, may promote the construction of a barrier to coast navigation at one point, and check the formation of a reef at another, by diverting a current of fresh water from the former and pouring it into the sea at the latter. Cases may probably be found, in tropical seas, where rivers have prevented the working of the coral animalcules in straits separating islands from each other or from the mainland. The diversion of such streams might remove this obstacle, and reefs consequently be formed which should convert an archipelago into a single large island, and finally join that to the neighboring continent.

Quatrefages proposed to destroy the teredo in harbors by impregnating the water with a mineral solution fatal to them. Perhaps the labors of the coralline animals might be arrested over a considerable extent of sea-coast by similar means. The reef-builders are leisurely architects, but the precions coral is formed so rapidly that the beds may be refished advantageously as often as once in ten years.* It does not seem impossil)le that

\footnotetext{
* The smallest twig of the precious coral thrown back into the sea attachea itself to the bottom or to a rock, and grows as well as on its native stem.

See an interesting report on the coral fishery, by Sant' A galbio, Italian Con sul-General at Algiers, in the Bollettino Consulare, published by the Depart
} 
branches of this coral might be attached to the keel of a ship and transplanted to the American coast, where the Gulf stream would furnish a suitable temperature beyond the climatic limits that otherwise confine its growth; and thus a new source of profit might perhaps be added to the scanty returns of the hardy fishermen. This experiment is certainly well worth trying.

In certain geological formations, the diatomaceæ deposit, at the bottom of fresh-water ponds, beds of silicious shields, valuable as a material for a species of very light firebrick, in the manufacture of water-glass and of hydraulic cement, and ultimately, doubtless, in many yet undiscovered industrial processes. An attentive study of the conditions favorable to the propagation of the diatomacer might perhaps help us to profit directly by the productivity of this organism, and, at the same time, disclose secrets of nature capable of being turned to valuable account in dealing with silicious rocks and the metal which is the base of them.

Our acquaintance with the obscure and infinitesimal life of which I have now been treating is very recent, and still very imperfect. We know that it is of vast importance in geology, but we are so ambitious to grasp the great, so little accustomed to occupy ourselves with the minute, that we are not yet prepared to enter seriously upon the question how far we can control and utilize the operations, not of unembodied physical forces merely, but of beings, in popular apprehension, almost as immaterial as they.

\section{Disturbance of Natural Balances.}

It is highly probable that the reef-builders and other yet unstudied minute forms of vital existence have other functions in the economy of nature besides aiding in the architecture of the globe, and stand in important relations not only to man, but to the plants and the larger sentient creatures over which he has dominion. The diminution or multiplication of these unseen friends or foes may be attended with the gravest consequences to all his material interests, and he is dealing with dangerous weap-

ment of Foreign Affairs, 1862, pp. 139, 151, and in the Annali di Agricolture Industria e Commercio, No. ii., pp. 360, 373. 
ons whenerer he interferes with arrangements pre-established by a power higher than his own. The equation of animal and vegetable life is too complicated a problem for human intelligence to solve, and we can never lnow how wide a circle of disturbance we produce in the harmonies of nature when we throw the smallest pebble into the ocean of organic being.

This much, however, the facts I have hitherto presented authorize us to conclude: as often as we destroy the balance by deranging the original proportions between different orders of spontaneous life, the law of self-preservation requires us to restore the equilibrium, by either directly returning the weight abstracted from one scale, or by removing a corresponding quantity from the other. In other words, destruction must be either repaired by reproduction or compensated by new destruction in an opposite quarter.

The parlor aquarium has taught even those to whom it is but an amusing toy, that the balance of animal and vegetable life must be preserved, and that the excess of either is fatal to the other, in the artificial tank as well as in natural waters. A few years ago, the water of the Cochituate aqueduct at Boston became so offensive in smell and taste as to be quite unfit for use. Scientific investigation found the cause in the too scrupulous care with which aquatic vegetation had been excluded from the reservoir, and the consequent death and decay of the animalculæ, which could not be shut out, nor live in the water without the vegetable element.*

* It is remarkable that Palissy, to whose great merits as an acute observer I am happy to have frequent occasion to bear testimony, had noticed that vegetation was necessary to maintain the purity of water in artificial reservoirs, though he mistook the rationale of its influence, which he ascribed to the elemental "salt " supposed by him to play an important part in all the operations of nature. In his treatise upon Waters and Fountains, p. 17t of the reprint of 1814, he says: "And in special, thou shalt note one point, the which is understood of few : that is to say, that the leaves of the trees which fall upon the parterre, and the herbs growing beneath, and singularly the fruits, if any there be upon the trees, being decajed, the waters of the parterre shall draw unto them the salt of the said fruits, leaves, and herbs, the which shall greatly better the water of thy fountains, and hinder the putrefaction thereof." 


\section{Animalcular Iife.}

Nature has no unit of magnitude by which she measures her works. Man takes his standards of dimension from himself. The hair's breadth was his minimum until the microscope told him that there are animated creatures to which one of the hairs of his head is a larger cylinder than is the trunk of the giant California sequoia to him. He borrows his inch from the breadth of his thumb, his palm and span from the width of his hand and the spread of his fingers, his foot from the length of the organ so named; his cubit is the distance from the tip of his middle finger to his elbow, and his fathom is the space he can measure with his outstretched arms.* To a being who instinctively finds the standard of all magnitudes in his own material frame, all objects exceeding his own dimensions are absolutely great; all falling short of them, absolutely small. Hence we habitually regard the whale and the elephant as essentially large and therefore important creatures, the animalcule as an essentially small and therefore unimportant organism. But no geological formation owes its origin to the labors or the remains of the huge mammal, while the animalenle composes, or has furnished, the substance of strata thousands of feet in thickness, and extending, in un-

\footnotetext{
* The French metrical system secms destined to be adopted throughout the civilized world. It is indeed recommended by great advantages, but it is very doubtful whether they are not more than counterbalanced by the selection of too large a unit of measure, and by the inherent intractability of all decimal systems with reference to fractional divisions. The experience of the whole world has established the superior convenience of a smaller unit, such as the braccio, the cubit, the foot, and the palm or span, and in practical life every man finds that he has much more frequent occasion to use a fraction than a multiple of the metre. Of course, he must constantly employ numbers expressive of several centimetres or nillimetres instead of the name of a single smaller unit than the metre. Besides, the metre is not divisible into twelfths, eighths, sixths, or thirds, or the multiples of any of these proportions, two of which at least-the eighth and the third-are of as frequent use as any other fractions. The adoption of a fourth of the earth's circumference as a base for the new measures was itself a leparture from the decimal system. Had the Commissioners taken the enure circumference as a base, and divided it into $100,000,000$ instead of $10,000,000$ parts, we should have had a unit of about sixteen inches, which, as a compromise between the foot and the cubit, would have been much better adipted to universal use than so large a unit as the metre.
} 
broken beds, over many degrees of terrestrial surface. If man is destined to inhabit the earth much longer, and to advance in natural knowledge with the rapidity which has marked his progress in physical science for the last two or three centuries, he will learn to put a wiser estimate on the works of creation, and will derive not only great instruction from studyiug the ways of nature in her obsemest, humblest walks, but great material advantige from stimulating her productive energies in provinces of her empire hitherto regarded as forever inacessible, utterly barren.*

* The fermentation of liquids, and in many cases the decomposition of semisolids, formerly supposed to be owing purely to chemical action, are now ascribed by many chemists to vital processes of living minute organisms, both vegetable and animal, and consequeutly to physiological as well as to chemical forces. Even alcohol is stated to be an animal product. The whole subject of animalcular, or rather minute organic, life, has assumed a new and startling importance from the recent researches of Pasteur and other naturalists and physiologists into the agency of such life, vegetable or animal, in exciting and communicating malignant and contagious diseases, and it is extremely probable that what are vaguely called germs, to whichever of the organic kingdoms they may be assigned, creatures inhabiting rarious media, and capable of propagating their kind and rapidly multiplying, are the true scerls of infection and death in the maladies now called zymotic, as well perhaps as in many others. The very late investigations of Iock into tubercular diseases, which, according to the announcement in the Berliner Flinische Wirhenschrift, April 10th, 1852, have resulted in the most important discovery of the Bucillus tuberculesus, and the suggestions of physiologists with regard to the possibility of mitigating, by means of inoculation, the rirulence of other diseases besides the small-pox, are of vital interest to humanity.

The literature of this subject is now very voluminous. For observations with high microscopic power on this subject, see BEALE, Diserse Crerms, their supposer Nature, and Disease Germs, their real Nature, both published in London in 1870.

The increased frequency of typhoidal, zymotic and malarions diseases in some parts of the United States, and the now common occurrence of some of them in districts where they were unknown forty years a and it is a very interesting question how far man's acts or nerlects may have

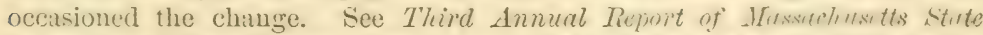
Jimal of Hertth for 18\%2. The causes and renedies of the insalubrity of Rome and its environs have been for some time the object of careful investigation, and many valuable reports have been published on the subject. Among the most recent of these are: Relazione sulle condizioni agrarie ed igieniche della Campagna di Roma, ner Raffatele PAreto; Cenni Storici sulla questione dell' Agro Romano di G. Guenzosi; Cenni sulle condiziuni Fisicoeconomiche di Roma per F. GIondaxo; and a rery important paper in 


\title{
CHAPTER III.
}

\author{
THE WOODS.
}

The habitable earth originally wooded-General meteorological influence of the forest-Electrical action of trees-Chemical influence of woodsTrees as protection against malaria-Trees as shelter to ground to the leeward-Influence of the forest as inorganic on temperature-Thermometrical action of trees as organic-Total influence of the forest on temperature-Influence of forests as inorganic on humidity of air and earth-Influence as organic-Balance of conflicting influences-Influence of woods on precipitation-Total climatic action of the forest-Influence of the forest on humidity of soil-The forest in winter-Summer rain, importance of-Influence of the forest on the flow of springs-Influence of the forest on inundations and torrents-Destructive action of torrents -Floods of the Ardiche-Excavation by torrents-Extinction of torrents -Crushing force of torrents-Transporting power of water-The Po and its deposits-MIountain slides-Forest as protection against avalanchesMinor uses of the forest-Small forest plants and vitality of seedsLocusts do not breed in forests-General functions of forest-General consequences of destruction of-Due proportion of woodland-Proportion of woodland in European countries-Forests of Great BritainForests of France-Forests of Italy-Forests of Germany-Forests of United States-American forest trees-European and American forest trees compared-The forest does not furnish food for man-First removal of the forest-Principal causes of destruction of forest-Destruction and protection of forests by governments-Royal forests and game-lawsEffects of the French revolution-Increased demand for lumber-Effects of burning forest-Floating of timber-Restoration of the forest-Economy of the forest-Forest legislation-Plantation of forests in AmericaFinancial results of forest plantations-Instability of American life.

\section{The Habitable Earth originally Wooded.}

THERE is good reason to believe that the surface of the habitable earth, in all the climates and regions which have been the

the journal Lo Sperimentale for 1870 , by Dr. D. Pantaleoni. Very recently observations of great interest have been made on the same subject by Dr. Tommaso Crudeli and his associates in Rome. The results will be found in the Transactions of the $R$. Accademia dei Lincei, for 1881-2.

There are climates, parts of California for instance, where the flesh of dead animals, freely exposed, shows no tendency to putrefaction, but dries up and may be almost indefinitely preserved in this condition. Is this owing to the absence of destructive animalcular life in such localities, and has man any agency in the introduction and naturalization of these organisms in regions previously not infested by them ? 
abodes of dense and civilized populations, was, with few exceptions, alreacly corered with a forest growth when it first became the home of man. This we infer from the extensive regetable remains-trunks, branches, roots, fruits, seeds and leaves of trees -so often found, in conjunction with works of primitive art, in the boggry soil of districts where no forests appear to have existed within the eras through which written annals reach; from ancient Ihistorical records, which prove that large provinees, where the earth has long been wholly bare of trees, were clothed with vast and almost unbroken woods when first made known to Greek and Roman civilization; * and from the state of much of North and of South America, as well as of many islands, when they wero discovered and colonized by the European race. $†$

These evidences are strengthened by observation of the natural economy of our own time; for, whenever a tract of country, once inhabited and cultivated by man, is abandoned by him and by domestic animals, and surrendered to the undisturbed influences of spontaneous nature, its soil sooner or later clothes itself with herbaceous and arborescent plants, and, at no long interval, with a dense forest growth. Indeed, upon surfaces of a certain stability and not absolutely precipitous inclination, the special conditions required for the spontaneous propagation of trees may all be negatively expressed and reduced to these three: exemption from defect or excess of moisture, from perpetual frost, and from the depredations of man and browsing quadrupeds. Where these requisites are secured, the hardest rock is as certain to be over-

* The recorded evidence in support of the proposition in the text has been collected by L. F. Alfred Maury, in his Histoire des grandes Forits de la Gaule et de l'ancienne Fr'rance, and by Becquerel, in his important work, Des climats et de l'Influence qu'exercent les Sols boisćs et non boisís, livre ii., chap. i.iv. to

We may rank among historical evidences on this point, if not technically among historical records, old geographical names and terminations eytmologically indicating forest or grove, which are so common in many parts of the Eastern Continent now entirely stripped of woods-such as, in Southern Europe, Breuil, Broglio, Brolio, Brolo; in Northern, Brühl, and the endings -dean, -den, -don, -ham, -holt, -horst, -hurst, -lund, -shaw, -shot, -skog, -skov, -wald, -weald, -twold, -wood.

t The island of Madeira, whose noble forests were devastated by fire not long after its colonization by European settlers, takes its name from the Portuguese word for wood. 
grown with wood as the most fertile plain, though, for obvious reasons, the process is slower in the former than in the latter case. Lichens and mosses first prepare the way for a more highly organized vegetation. They retain the moisture of rains and dews, and bring it to act, in combination with the gases evolved by their organic processes, in decomposing the surface of the rocks they cover; they arrest and confine the dust which the wind scatters over them, and their final decay adds new material to the soil already half formed beneath and upon them. A very thin stratum of mould is sufficient for the germination of the seeds of hardy evergreens and birches, the roots of which are often found in immediate contact with the rock, supplying the trees with nourishment from a soil deepened and enriched by the decomposition of their own foliage, or sending out long rootlets into the surrounding earth in search of juices to feed them.*

The eruptive matter of volcanoes, forbidding as is its aspect, does not refuse nutriment to the woods. The refractory lava of Etna, it is true, remains long barren, and that of the great eruption of 1669 is still almost wholly devoid of vegetation. $\dagger$ But the cactus is making inroads even here, while the rolcanic sand

* One of the best examples I can call to mind of the spontaneous action of nature, in re-clothing with vegetation rock and earth once denuded of it, is in the Canale della Picre, below Feltre. This gorge is inclosed by high and often precipitous cliffs, whose surface is in a state of disintegration favorable to the growth of plants and shrubs, and the faces of very steep roclis, long bared of all vegetation, are now covered with verdure to a surprising extent. If the goat and other browsing animals can be excluded for a few years, these mountains, steep as they are, will be clothed with a luxuriant growth of shrubs and trees.

+ Even the volcanic dust of Etna remains very long unproductive. Near Nicolosi is a great extent of coarse black sand, thrown out in 1669, which, for almost two centuries, lay entirely bare, and can be made to grow plants only by artificial mixtures and much labor.

The increase in the price of wines, in consequence of the diminution of the product from the grape disease, however, has brought even these ashes under cultivation. "I found," says Waltershausen, referring to the years 1861-62, "plains of volcanic sand and half-subdued lava streams, which, twenty years ago, lay utterly waste, now covered with fine vineyards. The ash-field of ten square miles above Nicolosi, created by the eruption of 1669 , which was entirely barren in 1835 , is now planted with viues almost to the summits of Monte IRosso, at a height of three thousand feet."-Ueber den Sicilianischen Ackerbau, p. 19. 
and molten rock thrown out by Vesuvius soon become prorluc. tive. Before the great eruption of 1631 even the interior of the crater was covered with vegetation. George Sandys, who visiterl Vesuvius in 1611, after it had reposed for several centuries found the throat of the voleano at the buttom of the crater "almost choked with broken rocks and trees that are falne therein." "Next to this," he continues, "the matter thrown up is ruddy, light, and soft: more removed, blacke and ponderous: the uttermost brow, that declineth like the seates in a theater, flomishing with trees and excellent pasturage. The midst of the hill is shaded with chestnut trees, and others bearing sundry fruits." *

I am convinced that forests would soon cover many parts of the Arabian and African deserts, if man and domestic animals, especially the goat and the camel, were banished from them. The hard palate and tongue, and strong teeth and jaws, of this latter quadruped enable him to break off and masticate tough and thorny branches as large as the finger. He is particularly fond of the smaller twigs, leaves and seed-pods of the sont and other acacias, which, like the American Robinia, thrive well on dry and sandy soils, and he spares no tree the branches of which are within his reach, except, if I remember rightly, the tamarisk that produces manna. Young trees sprout plentifully around the springs and along the winter watercourses of the desert, and these are just the halting-stations of the caravans and their routes of travel. In the shade of these trees, annual grasses and perennial shrubs shoot up, but are mown down by the hungry cattle of the Bedouin as fast as they grow. A few years of undisturbed vegetation would suffice to cover such points with groves, and these would gradually extend themselves over soils where now

* A Relation of a Journey Begun An. Dom. 1610, lib. 4, p. 260, edition of 1615. The testimony of Sandys on this point is confirmed by that of Pighio, Braccini, Magliocco, Salimbeni, and Nicola di Rubco, all cited by Rotm, Der Vesuv., p. 9. There is some uncertainty about the date of the last eruption previous to the great one of 1631. Ashes, though not lava, appear to have been thrown out about the year 1500 , and some chroniclers have recorded an eruption in the year 1306 ; but this seems to be an error for 1036 , when a great quantity of lava was ejected. In 1139, ashes were thrown out for many days. I take these dates from the work of Roth just cited. 
scarcely any green thing except the bitter colocynth and the poisonous foxglove is ever seen.*

\section{General IIeteorological Influence of the Forest.}

The physico-geographical influence of forests may be divided into two great classes, each having an important influence on vegetable and on animal life in all their manifestations, as well as on every branch of rural economy and productive industry, and, therefore, on all the material interests of man. The first respects the meteorology of the countries exposed to the action of these influences; the second, their superficial geography, or, in other words, the configuration, consistence and clothing of their surface.

For reasons assigned in the first chapter, and for others that will appear hereafter, the meteorological or climatic branch of the subject is the most obscure, and the conclusions of physicists respecting it are, in a great degree, inferential only, not founded on experiment or direct observation. They are, as might be expected, somewhat discordant, though one general result is almost universally accepted, and seems indeed too well supported to admit of serious question, and it may be considered as established that forests tend to mitigate, at least within their own precincts, extremes of temperature, humidity and drought. By what precise agencies the meteorological effects of the forest are produced we can not say, because elements of totally unknown value enter into its action, and because the relative intensity of better understood causes can not be measured or compared. I shall not occupy much space in discussing questions which at present admit of no solution, but I propose to notice most of the known forces whose concurrent or conflicting energies contribute to the general result, and to point out, in some detail, the value of those influences whose mode of action has been ascertained.

* The French traveller, Largeau, believes the Sahara to have been anciently well watered and well wooded, and to have been reduced to its present con. dition by the folly and improvidence of man. He thinks, too, that much of it might easily be restored to fertility.-Le Pays de Rirha, Paris, 1879, chap. viii., ix., xvii., et alibi. 


\section{Electrical Influence of Trees.}

The properties of trees, singly and in groups, as exciters or conductors of electricity, and their consequent influence upon the electrical state of the atmosphere, do not appear to have been much investigated; and the conditions of the forest as a whole are so variable and so complicated, that the solution of any gencral problem respecting its electrical influence would be a matter of extreme difficulty. It is, indeed, impossible to suppose that a dense cloud, a sea of vapor, can pass over miles of surface bristling with good conductors, without undergoing and producing some change of electrical condition. Hypothetical cases may be put in which the character of the change could be deduced from the known laws of electrical action. But in actual nature the elements are too numerous for us to seize. The true electrical condition of neither cloud nor forest could be known, and it could seldom be predicted whether the vapors would be dissolved as they floated over the wood, or discharged upon it in a deluge of rain. With regard to possible electrical influences of the forest, wider still in their range of action, the uncertainty is even greater. The data which alone could lead to positive, or even probable, conclusions are wanting, and we should, therefore, only embarrass our argument by any attempt to discuss this meteorological element, important as it may be, in its relations of cause and effect to more familiar and better understood meteoric phenomena. It may, however, be observed that hail-storms-which were once generally supposed, and are still held by many, to be produced by a specific electrical action, and which, at least, appear to be always accompanied by electrical disturbances-are believed, in all countries particularly exposed to that scourge, to have become more frequent and destructive in proportion as the forests have been cleared. Caimi observes: "When the chains of the Alps and the Apennines had not yet been stripped of their magnificent crown of woods, the May hail, which now desolates the fertile plains of Lombardy, was much less frequent; but since the general prostration of the forest, these tempests are laying waste even the mountain-soils whose older inhabitants scarcely knew this 
plagne.* The paragrandini, $\uparrow$ which the learned curate of Ri. volta advised to erect, with sheaves of straw set up vertically, over a great extent of cultivated country, are but a Liliputian image of the vast paragrandini, pines, larehes and firs, which nature had planted by millions on the crests and ridges of the Alps and the Apemines." $*$ "Electrical action being diminished," says Megurscher, "and the rapid congelation of vapors by the abstraction of heat being impeded by the inlluence of the woods, it is rare that hail or watersponts are produced within the precincts of a large forest when it is assailed by the tempest." \& Arthur Young was told that since the forests which corered the mountains between the Riviera and the county of MLontferrat had disappenred, hail had become more destructive in the district of Acqui, $\|$ and a similar increase in the frequency and violence of hail-

* There are, in Northern Italy and in Switzerland, joint-stock companies which insure against damage by hail, as well as by fire and lightuing. Between the years $185 \cdot t$ aud 1861, a single one of these companies, La Riunione Adriatica, paid, for damage by hail in Piedmont, Venetian Lombardy and the Duchy of Parma, above 6,500,000 frames, or nearly $\$ 200,000$ per year. The total damage by hail in the Northern Provinces of Italy, between 1834 and 1880, is estimated at $25 \%, 000,000$ francs, and the Assicuranione Generale of Venice states, in its public notices issued at the beginuing of 1882, that it had paid out for damages by hail, during the preceding three years, the sum of $8,193,906$ francs, equal to $\$ 1,638,780$.

+ The paragrandine, or, as it is called in French, the paragrite, is a species of conductor by which it has been hoped to protect the harvests in countries particularly exposed to damage by hail. It was at first proposed to employ for this purpose poles supporting sheaves of strar connected with the ground by ropes of the same material; but the experiment was afterwards tried in Lombardy on a large scale, with more perfect electrical conductors, consisting of poles secured to the top of tall trees and provided with a pointed wire entering the ground and reaching above the top of the pole. It was at first thought that this apparatus, erected at numerous points over an extent of several miles, was of some service as a protection against hail, but this opinion was soon disputed, and does not appear to be supported by well-ascertained facts. The question of a repetition of the experiment over a wide area has been again agitated within a very few years in Lombardy; but the doubts expressed by very able physicists as to its efficacy and as to the point whether hail is an electrical phenomenon, have discouraged its advocates from attempt. ing it.

$\ddagger$ Cenni sulla Importanza e Coltura dei Boschi, p. 6.

§ Memoria sui Boschi, etc., p. 44.

$\|$ Travels in Italy, chap. iii. 
storms in the neighborhood of Saluzzo and MIondovi, the lower part of the Valtelline, and the territory of Verona and Vicenza, is probably to be ascribed to a similar cause.*

\section{Chemical Influence of the Forest.}

We know that the air in a close apartment is appreciably affected throngh the inspiration and expiration of gases by plants growing in it. The same operations are performed on a gigantic scale by the forest, and it has even been supposed that the absorption of carbon, by the rank vegetation of earlier geological periods, occasioned a permanent change in the constitution of the terrestrial atmosphere $\dagger$ To the effects thus produced, are to be added those of the ultimate gaseous decomposition of the vast regetable mass annually shed by trees, and of their trunks and branches when they fall a prey to time. But the quantity of gases thus abstracted from and restored to the atmosphere is inconsiderable-infinitesimal, one might almost say-in comparison with the ocean of air from which they are drawn and to which they return; and though the exhalations from bogs, and other

* Le Alpi che cingono l"Italia, i., p. 37\%. See "On the Influence of the Forest in Preventing Hail-storms," a paper by Becquerel, in the Mémoires de l'Académie des Sciences, vol. $\mathrm{xxxv}$. The conclusion of this eminent physicist is, that woods do exercise, both within their own limits and in their vicinity, the influence popularly ascribed to them in this respect, and that the effect is probably produced partly by mechanical and partly by electrical action.

$\dagger$ "Long before the appearance of man, .... they [the forests] had robbed the atmosphere of the enormous quantity of carbonic acid it contained, and thereby transformed it into respirable air. Trees heaped upon trees had already filled up the ponds and marshes, and buried with them in the bowels of the earth-to restore it to us, after thousands of ages, in the form of bituminous coal and of anthracite-the carbon which was destined to become, by this wonderful condensation, a precious store of future wealth."-Cuavé, Etudes sur l'Économie Forestière, p. 13.

This opinion of the modification of the atmosphere by vegetation is contested.

MIossman ascribes the great luxuriance and special character of the Australian and New Zealand forests, as well as other peculiarities of the vegetation of the Southern hemisphere, to a supposed larger proportion of carbon in the atmosphere of that hemisphere, though the fact of such excess does not appear to have been established by chemical analysis.-Mossurar, Origin of the Seasons, Edinburgh, 1869. Chaps. xvi. and xvii. 
low grounds covered with decaying vegetable matter, are highly deleterious to human health, yet, in general, the air of the forest is hardly chemically distinguishable from that of the sand-plains, and we can as little trace the influence of the woods in the analysis of the atmosphere, as we can prove that the mineral ingredients of land-springs sensibly affect the chemistry of the sea. I may, then, properly dismiss the chemical, as I have done the electrical, influences of the forest, and treat them both alike, if not as unimportant agencies, at least as quantities of unknown value in our meteorological equation.* Our inquiries upon this branch of the subject will accordingly be limited to the thermometrical and hygrometrical influences of the woods. There is, however, a special protective function of the forest, perhaps in part of a chemical nature, which may be noticed here.

\section{Trees as a Protection against Malaria.}

The influence of forests in preventing the diffusion of miasmatic vapors is not a matter of familiar observation, and perhaps it does not come strictly within the sphere of the present inquiry, but its importance will justify me in devoting some space to the subject. "It has been observed" (I quote from Becquerel) "that humid air, charged with miasmata, is deprived of them in passing through the forest. Rigaud de Lille observed localities

* Schacht ascribes to the forest a specific, if not a measurable, influence, upon the constitution of the atmosphere. "Plants imbibe from the air carbonic acid and other gaseous or volatile products exhaled by animals or developed by the natural phenomena of decomposition. On the other hand, the vegetable pours into the atmosphere oxygen, which is taken up by animals and appropriated by them. The tree, by means of its leaves and its young herbaceous twigs, presents a considerable surface for absorption and evaporation; it abstracts the carbon of carbonic acid, and solidifies it in wood, fecula, and a multitude of other compounds. The result is that a forest withdraws from the air, by its great absorbent surface, much more gas than meadows or cultivated felds, and exhales proportionately a considerably greater quantity of oxygen. The influence of the forests on the chemical composition of the atmosphere is, in a word, of the highest importance."-Les Arbres, p. 111.

See on this subject a paper by J. Jamin, in the Revue des Deux Mondes for Sept. 15, 1864; and, on the effects of human industry on the atmosphere, an article in Aus der Natur, vol. 29, 1864, pp. 443, 449, 465, et seq. See also AIr FRED MAURY, Les Forêts de la Gaule, p. 107. 
in Italy where the interposition of a screen of trees preserved everything beyond it, while the unprotected grounds were subject to fevers." Few European countries present better opportunities for observation on this point than Italy, because in that kingdom the localities exposed to miasmatic exhalations are numerous, and belts of trees, if not forests, are of so frequent occurrence that their efficacy in this respect can be easily tested. The belief that rows of trees afford an important protection against malarious influences is very general among Italians best qualified by intelligence and professional experience to judge upon the subject. The commissioners, appointed to report on the measures to be adopted for the improvement of the Tuscan Maremme, advised the planting of three or four rows of poplars, Populus alba, in such directions as to obstruct the currents of air from malarious localities, and thus intercept a great proportion of the pernicious exhalations." * Maury believed that a few rows of sunflowers, planted between the Washington Observatory and the marshy banks of the Potomac, had saved the inmates of that establishment from the intermittent fevers to which they had been formerly liable. Manry's experiments have been repeated in Italy. Large plantations of sunflowers have been made upon the alluvial deposits of the Oglio, above its entrance into the Lake of Iseo, near Pisogne, and it is said with favorable results to the health of the neighborhood. $\dagger$ In fact, the generally beneficial effects of a forest wall or other vegetable screen, as a protection against noxious exhalations from marshes or other sources of disease, situated to the windward of them, are very commonly admitted.

It is argued that, in these cases, the foliage of trees and of other vegetables exercises a chemical as well as a mechanical effect upon the atmosphere, and some, who allow that forests may intercept the circulation of the miasmatic effluvia of swampy soils, or even render them harmless by decomposing them, contend, nevertheless, that they are themselves active causes of the production of malaria. The subject has been a good deal discussed 124.

* Salvagnoli, Rapporto sul Bonificamento delle Mareme Toscane, pp. xli.

†1l Politecnico, MFilano, Aprile e Maggio, 1863, p. 35. 
in Italy, and there is some reason to think that under special circumstances the influence of the forest in this respect may be prejudicial rather than salutary, though this does not appear to be generally the case." It is, at all events, well known that the

* Salvagroli, Memorie sulle Maremme Toscune, pp. 213, 214. The sanitary action of the forest has been lately matter of much attention in Italy. See Rendiconti del Congresso Medico del 1869 a Firenve, and especially the important observations of Selarr, Il Miasma Palustre, Padua, 15\%0, pp. 109 et seq. This action is held by this able writer to be almost wholly chemical, and he earnestly recommends the plantation of groves, at least of belts of trees, as an effectual protection against the miasmatic influence of marshes. Very interesting observations on this point will be found in EBeruaren, Die Physilialischen Eincirliungen des Waldes, Aschaftenburg, 1873, B. I., pp. 237 et seq., where great importance is ascribed to the development of ozone by the chemical action of the forest. The beneficial influence of the ozone of the forest atmosphere on the human system is, however, questioned by some observers. See also the able memoir: Del Miasma vegctale e delle Malattie Miasmatiche of Dr. D. Pantaleoni in Lo Sperimentale, vol. xxii., 1870.

The necessity of such hygienic improrements as shall render the new capital of Italy a salubrious residence gives great present importance to this question, and it is much to be hoped that the $\mathrm{Agro}$ Romano, as well as more distant parts of the Campagna, will soon be dotted with groves and traversed by fles of rapidly growing trees. Many forest trees grow with great luxuriance in Italy, and a moderate expense in plantation would in a very ferv years determine whether any amelioration of the sanitary condition of Rome can be expected from this measure.

It is said by recent writers that in India the villages of the natives and the encampments of European troops, situated in the midst or in the neighborhood of groves and of forests, are exempt from cholera. Similar observations were also made in 1854 in Germany when this terrible disease was raging there. It is hence inferred that forests prerent the spreading of this malady, or rather the derelopment of those unknown influences of which cholera is the result. These influences, if we may beliere certain able writers on medical subjects, are telluric rather than meteoric; and they regard it as probable that the uniform moisture of soil in forests may be the immediate cause of the immunity enjoyed by such localities. See an article by Pententofer in the Süd-Deutsche Presse, August, 1869 ; and the obserrations of EBEracaren in the work above quoted, pp. 246 et seq.

In Australia and New Zealand, as well as generally in the Southern Hemisphere, the indigenous trees are all evergreens, and even deciduous trees introduced from the other side of the equator become evergreen. In those regions, even in the most swampy localities, malarious diseases are nearly, if not altogether, unknown. Is this most important fact due to the persistence of the foliage ?

Mossman, Origin of Climates, pp. 374, 393, 410, 425 et seq. 
great swamps of Virginia and the Carolinas, in climates nearly similar to that of Italy, are healthy eren to the white man so long as the forests in and around them remain, but become very insalubrious when the woods are felled." The "Dismal Swamp," partly in North Carolina and partly in Virginia, is said to be an entire misnomer. There is nothing dismal about it except its gencral solitude. It is described by recent visitors as a capital resort for sportsmen, game being abundant, and fish ready to rise to the fly. The most curious features of the swamp are the sweetness and wholesome character of the water, and the entire freedom of its few inhabitants from malarious diseases. This purity is ascribed to the influence of the juniper tree, which certainly colors if it does not improve the water, and possibly contributes an antiseptic property to the air.

\section{Trees as Shelter to Ground to the Leeward.}

As a mechanical obstruction, trees impede the passage of aircurrents over the ground, which, as is well known, is one of the most efficient agents in promoting evaporation and the refrigeration resulting from it. $\nmid$ In the forest, the air is almost quiescent,

* Except in the seething marshes of northern tropical and subtropical regions, where vegetable decay is extremely rapid, the uniformity of temperature and of atmospheric humidity renders all forests eminently healthful. See HoHexsterN's observations on this subject, Der Wald, p. 41 ; also A. MAdur, Les Forêts de la Gaule, p. 7.

The flat and marshy district of the Sologne in France was salubrious until its woods were felled. It then became pestilential, but within the last few years its healthfulness has been restored by forest plantation.-JuLEs Cuaré in Revue des Deux MFondes, for 1st March, 1866, p. 209.

There is no question that open squares and parks conduce to the salubrity of cities, and many observers are of opinion that the trees and other vegeta bles with which such grounds are planted contribute essentially to their beneficial influence. See an article in Aus der Natur, xxii., p. 813.

+ It is perhaps too much to say that the influence of trees upon the wind is strictly limited to the mechanical resistance of their trunks, branches and foliage. So far as the forest, by dead or by living action, raises or lowers the temperature of the air within it, so far it creates upward or downward currents in the atmosphere abore it, and, consequently, a flow of air towards or from itself. These air-streams have a certain, though doubtless a very small, influence on the force and direction of greater atmospheric movements. 
and moves only as local changes of temperature affect the specific gravity of its particles. Hence there is often a dead calm in the woods when a furious blast is raging in the open country at a few yards' distance. The denser the forest-as, for example, where it consists of spike-leaved trees, or is thickly intermixed with them-the more obvious is its effect, and no one can have passed from the field to the wood in cold, windy weather, without having remarked it.*

* As a familiar illustration of the influence of the forest in checking the movement of winds, I may mention the well-known fact, that the sensible cold is never extreme in thick woods, where the motion of the air is little felt. The lumbermen in Canada and the Northern United States labor in the woods, without inconrenience, when the mercury stands many degrees below the zero of Fahrenheit, while in the open grounds, with only a moderate breeze, the same temperature is almost insupportable. The engincers and firemen of locomotives, employed on railways rumning through forests of any considerable extent, observe that, in very cold weather, it is much easier to keep up the steam while the engine is passing through the woods than in the open ground. As soon as the train emerges from the shelter of the trees the steam-gauge falls, and the stoker is obliged to throw in a liberal supply of fuel to bring it up again.

Another less frequently noticed fact, due, no doubt, in a great measure to the immobility of the air, is that sounds are transmitted to incredible distances in the unbroken forest. Many instances of this have fallen under my own observation, and others, yet more striking, have been related to me by credible and competent witnesses familiar with a more primitive condition of the Anglo-American world. An acute observer of natural phenomena, whose childhood and youth were spent in the interior of one of the newer New England States, luas often told me that when lhe established his home in the forest, he always distinctly heard, in still weather, the plash of horses' feet when they forded a small brook nearly seven-eighths of a mile from his house, though a portion of the wood that intervened consisted of a ridge seventy or eighty feet higher than either the house or the ford.

I have no doubt that, in such cases, the stillness of the air is the most im. portant element in the extraordinary transmissibility of sound; but it must be admitted that the absence of the multiplied and confused noises, which accompany human industry in countries thickly peopled by man, contributes to the same result. We become, by habit, almost insensible to the familiar and never-resting voices of civilization in cities and towns; but the indistinguishable drone, which sometimes escapes even the ear of him who listens for it, deadens and often quite obstructs the transmission of sounds which would otherwise be clearly audible. An observer, who wishes to appreciate that hum of civic life which he can not analyze, will find an excellent opportunity 
The action of the forest, considered merely as a mechanical shelter to grounds lying to the leeward of it, might seem to be an influence of too restricted a character to deserve much notice; but many facts concur to show that it is a most importint element in local climate.

It is evident that the effect of the forest, as a mechanical impediment to the passage of the wind, would extend to a very considerable distance above its own height, and hence protect while standing, or lay open when felled, a much larger surfice than might at first thought be supposed. The atmosphere, movable as are its particles, and light and elastic as are its masses, is nevertheless held together as a continuous whole by the gravitation of its atoms and their consequent pressure on each other, if not by

by placing himself on the hill of Capo di JIonte at Naples, in the line of prolongation of the street called Spaccanapoli.

It is probably to the stillness of which I have spoken that we are to ascribe the transmission of sound to great distances at sea in calm weather. In June, 1853, I and my family were passenger's on board a ship-of-war bound up the Egean. On the evening of the 2ith of that month, as we were discussing, at the tea-table, some obserrations of Humboldt on this subject, the captain of the ship told us that he had once heard a single gun at sea at the distance of ninety nautical miles. The next morning, though a light breeze had sprung up from the north, the sea was of glassy smoothness when we went on deck. As we came up, an officer told us that he had heard a gun at suurise, and the conversation of the previous evening suggested the inquiry whether it could have been fired from the combined French and English fleet then lying at Beshika Bay. Upon examination of our position we were found to have been, at sunrise, ninety sea miles from that point. We continued beating up northwards, and between sunrise and twelve o'clock meridian of the 24 th, we had made twelve miles northing, reducing our distance from Beshika Bay to seventy-eight sea miles. At noou we heard weveral guns so distinctly that we were able to count the number. On the 29th we came up with the fleet, and learned from an officer who came on board that a royal salute had been fired at noon on the 28 th, in honor of the day as the anniversary of the Queen of England's coronation. The report at sunrise was evidently the morning gun, those at noon the salute.

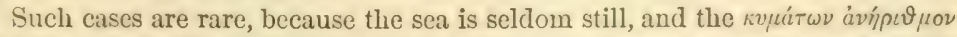
$\gamma^{\prime} \lambda(u \sigma u$ rarely silent, over so great a space as ninety or even seventy-eight nautical miles. I apply the epithet silent to yirarna advisedly. I am convinced that Eschylus meant the audible laugh of the waves, which is indeed of countless multiplicity, not the visible smile of the sea, which, belonging to the great expanse as one impersonation, is single, though, like the human smile, made up of the play of many features. 
attraction between them, and, therefore, an obstruction which mechanically impedes the movement of a given stratum of air will retard the passage of the strata above and below it. To this effect may often be added that of an ascending current from the forest itself, which must always exist when the atmosphere within the wood is warmer than the stratum of air above it, and must be of almost constant occurrence in the case of cold winds, from whatever quarter, because the still air in the forest is slow in taking up the temperature of the moving columns and currents around and above it. Experience, in fact, has shown that mere rows of trees, and even much lower obstructions, are of essential service in defending vegetation against the action of the wind. Hardy proposes planting, in Algeria, belts of trees at the distance of one hundred mètres from ench other, as a shelter which experience had proved to be useful in France." "In the valley of the Rhone," says Becquerel, "a simple hedge, two metres in height, is a sufficient protection for a distance of twenty-two mètres." + The mechanical shelter acts, no doubt, chiefly as a defence against the mechanical force of the wind, but its uses are by no means limited to this effect. If the current of air which it resists moves horizontally, it would prevent the access of cold or parching blasts to the ground for a great distance; and did the wind even descend at a large angle with the surface, still a considerable extent of ground would be protected by a forest to the windward of it.

In the report of a committee appointed in 1836 to examine an article of the forest code of France, Arago observes: "If a curtain of forest on the coast of Normandy and of Brittany were destroyed, these two provinces would become accessible to the winds from

* Becquerel, Des Climats, etc., p. 179.

$\uparrow$ Ibid., p. 116.

Becquerel's views have been amply confirmed by recent extensive experiments on the bleak, stony and desolate plain of the Crau in the Department of the Bouches-du-Rhone, which had remained a naked waste from the earliest ages of history. Belts of trees prove a secure protection even against the furious and chilly blasts of the Mistral, and in this shelter plantations of fruittrees and vegetables, fertilized by the waters and the slime of the Durance, which are conducted and distributed over the Crau, thrive with the greatest luxuriance.

SURELI, Étude sur les Torrents, 2 d edition, 1872, ii., p. 35. 
the west, to the mild breezes of the sea. Hence a decrease of the cold of winter. If a similar forest were to be cleared on the eastern border of France, the glacial east wind would prevail with greater strength, and the winters would become more severe. Thus the removal of a belt of wood would produce opposite effects in the two regions." *

This opinion receives confirmation from an observation of Dr. Dwight, who remarks in reference to the woods of New England: "Another effect of removing the forest will be the free passage of the winds, and among them of the southern winds, over the surface. This, I think, has been an increasing fact within my own remembrance. As the cultivation of the country has extended farther to the north, the winds from the south have reached distances more remote from the ocean, and imparted their warmth frequently, and in such degrees as, forty years since, were in the same places very little known. This fact, also, contributes to lengthen the summer and to shorten the winter half of the year." +

It is thought in Italy that the clearing of the Apennines has very materially affected the climate of the valley of the $\mathrm{Po}$. It is asserted in Le Alpi che cingono l' Italia that: "In consequence of the felling of the woods on the Apennines, the sirocco prevails greatly on the right bank of the $\mathrm{Po}$, in the Parmesan territory and in a part of Lombardy; it injures the harvests and the vineyards, and sometimes ruins the crops of the season. To the same cause many ascribe the meteorological changes in the precincts of Modena and of Reggio. In the communes of these districts, where formerly straw roofs resisted the force of the winds, tiles are now hardly sufficient; in others, where tiles answered for roofs, large slabs of stone are now ineffectual; and in many neighboring communes the grapes and the grain are swept off by the blasts of the south and south-west winds."

According to the same authority, the pinery of Porto, near Ravenna-which is twenty miles long, and is one of the oldest pine woods in Italy-having been replanted with resinous trees

* Becquerel, Des Climats, etc., Discours Prélim., vi.

+ Travels, i., p. 61. 
after it was unfortunately cut, has relieved the city from the sirocco to which it had become exposed, and in a great degree restored its ancient climate.*

The felling of the woods on the Atlantic coast of Jutland has exposed the soil not only to drifting sands, but to sharp seawinds, that have exerted a sensible deteriorating effect on the climate of that peninsula, which has no mountains to serve at once as a barrier to the force of the winds, and as a storehouse of moisture received by precipitation or condensed from atmospheric vapors. $†$

The local retardation of spring, so much complained of in Italy, France and Switzerland, and the increased frequency of late frosts at that season, appear to be ascribable to the admission of cold blasts to the surface, by the felling of the forests which formerly both screened it as by a wall, and communicated the warmth of their soil to the air and earth to the leeward. Caimi states that since the cutting down of the woods of the Apennines,

\section{* Le Alpi che cingono l'Italia, pp. 370, 371.}

The unusual severity of the winter of $1879-80$ proved very destructive to this valuable forest, the larger portion of the younger trees having been completely killed by the frosts.

† Bergsöe, Reventlovs Virtesomhed, ii., p. 125.

The following well-attested instance of a local change of climate is probably to be referred to the influence of the forest as a shelter against cold winds. To supply the extraordinary demand for Italian iron occasioned by the exclusion of English iron in the time of Napoleon I., the furnaces of the valleys of Bergamo were stimulated to great activity. "The ordinary production of charcoal not sufficing to feed the furnaces and the forges, the woods were felled, the copses cut before their time, and the whole economy of the forest was deranged. At Piazzatorre there was such a devastation of the moods, and consequently such an increased severity of climate, that maize no longer ripened. An association, formed for the purpose, effected the restoration of the forest, and maize flourishes again in the ficlds of Piazzatorre."-Report by G. RosA, in Il Politecnico, Dicembre, 1861, p. 614.

Similar ameliorations have been produced by plantations in Belgium. In an interesting series of articles by Baude, entitled, "Les Côtes de la MIanche," in the Revue des Deux IFondes, I find this statement: "A spectator, placed on the famous bell-tower of the cathedral of Antwerp, saw, not long since, on the opposite side of the Schelde, only a vast desert plain; now he sees a forest, the limits of which are confounded with the horizon. Let him enter within its shade. The supposed forest is but a system of regulir rows of trees, the 
the cold winds destroy or stunt the regetation, and that, in consequence of "the usurpation of winter on the domain of spring," the district of Mugello has lost all its mulberries, except the few which find in the lee of buildings a protection like that once furnished by the forest.*

The department of Ardèche, which now contains not a single considerable wood, has experienced within thirty years a climatic disturbance, of which the late frosts, formerly unknown in the country, are one of the most melancholy effects. Similar results have been observed in the plain of Alsace, in consequence of the denudation of several of the crests of the Vosges. $†$

Dussard, as quoted by Ribbe, $\neq$ maintains that even the mistral, or northwest wind, whose chilling blasts are so fatal to tender vegetation in the spring, "is the child of man, the result of his devastations." "Under the reign of Angustus," continues he, "the forests which protected the Cévennes were felled, or destroyed by fire, in mass. A vast comntry, before covered with impenetrable woods-powerful obstacles to the movement and even to the formation of hurricanes-was suddenly denuded, swept bare, stripped, and soon after, a scourge hitherto unknown struck

oldest of which is not forty years of age. These plantations have ameliorated the climate which had doomed to sterility the soil where they are planted. While the tempest is violently agitating their tops, the air a little below is still, and sands far more barren than the plateau of La Hague have been transformed, under their protection, into fertile fields."-Revue des Deux Mondes, January, 1859, p. 277.

* Cenni sulla Importanza e Coltura dei Boschi, p. 31.

† Clavé, Études, p. 44.

It has bcen observed in Sweden that the spring, in many districts where the forests have been cleared off, now comes on a fortnight later than in the last century.-Asijörnsen, Om Skovene $i$ Norge, p. 101.

$\ddagger$ La Provence au point de vue des Torrents et des Inondations, p. 19.

Dussard is doubtless historically inaccurate in making the origin of the mistrat. so late as the time of Augustus. Diodorus Siculus, who was a contemporary of Julius Cresar, describes the nortluwest winds in Gaul as violent enough to hurl along stones as large as the fist, with clouds of sand and sravel, to strip travellers of their arms and clothing, and to throw mounted men from their horses. - Biblinthese Histnrien, lib. r., c. xxri. Dindorms. it is true, is speaking of the climate of Gaul in general, hut his description can hardly refer to anything but the mistral of Southeastern France. 
terror over the land from Avignon to the Bouches-du-Phone, thence to Marseilles, and then extended its ravages, diminished indeed by a long career which had partially exhausted its force, over the whole maritime frontier. The people thought this wind a curse sent of God. They raised altar's to it and offered sacrifices to appease its rage." It seems, however, that this plagne was less destructive than at present, until the close of the sixteenth century, when further clearings had removed most of the remaining barriers to its course. Up to that time, the northwest wind appears not to have attained to the maximum of specific effect which now characterizes it as a local phenomenon. Extensive districts, from which the rigor of the seasons has now banished valuable crops, were not then exposed to the loss of their harvests by tempests, cold or drought. The deterioration was rapid in its progress. Under the Consulate, the clearings had exerted so injurious an effect upon the climate, that the cultivation of the olive had retreated several leagues, and since the winters and springs of 1820 and 1836, this branch of rural industry has been abandoned in a great number of localities where it was advantageously pursued before. The orange now flourishes only at a few sheltered points of the coast, and it is threatened even at Hyères, where the clearing of the hills near the town has proved very prejudicial to this valuable tree.

Marchand informs us that, since the felling of the woods, late spring frosts are more frequent in many localities north of the Alps; that fruit trees thrive no longer, and that it is difficult even to raise young fruit trees.*

\section{Influence of the Forest, considered as Inorganic MLatter, on Temperature.}

The evaporation of fluids, and the condensation and expansion of vapors and gases, are attended with changes of temperature;

* Ueber die Entwaldung der Gebirge, p. 28.

Interesting facts and observations on this point will be found in the valuable Report on the Effects of the Destruction of the Forests in Wisconsin, by LAPHAM and others, $\mathrm{pp} .6,18,20$. 
and the quantity of moisture which the air is capable of containing, and, of course, other things being equal, the evaporation, rise and fall with the thermometer. The hygroseopieal and the thermoscopical conditions of the atmosphere are, therefore, inseparably connected as reciprocally dependent quantities, and neither c:m be fully discussed without taking notice of the other. The leaves of living trees exhale enormous quantities of gas and of aqueous vapor, and they largely absorb gases, and, under certain conditions, probably also water. Hence they affect more or less powerfully the temperature as well as the humidity of the air. But the forest, regarded purely as inorganic matter, and without reference to its living processes of absorption and exhalation of gases and of water, has, as an absorbent, a radiator and a conductor of heat, and as a mere covering of the ground, an influence on the temperature of the air and the earth, which may be considered by itself.

\section{Absorbing and Emitting Sunface.}

A given area of ground, as estimated by the every-day rule of measurement in yards or acres, presents always the same apparent quantity of absorbing, radiating and reflecting surface; but the real extent of that surface is very variable, depending, as it does, upon its configuration and the bulk and form of the adventitious objects it bears upon it; and, besides, the true superficies remaining the same, its power of absorption, radiation, reflection and conduction of heat will be much affected by its consistence, its greater or less humidity, and its color, as well as by its inclination of plane and exposure. An acre of clay, rolled hard and smooth, would have great reflecting power, but its radiation would be much increased by breaking it up into clods, because the actually exposed surface would be greater, though the outline of the field remained the same. The inequalities, natural or artificial, which always occur in the surface of ordinary earth, affect in the same way its quantity of superficies acting upon the temperature of the atmosphere and acted on by it, though the amount of this action and reaction is not susceptible of measurement.

Analogous effects are produced by other objects, of whatever form or character, standing or lying upon the earth, and no solid 
can be placed upon a flat piece of ground, without itself exposing a greater surface than it covers. This applies, of course, to forest trees and their leaves, and indeed to all regetables, as well as to other prominent bodies. If we suppose forty trees to be planted on an acre, one being situated in the centre of every square of two rods the side, and to grow until their branches and leaves everywhere meet, it is evident that, when in full foliage, the trunks, branches and leaves would present an amount of thermoscopic surface much greater than that of an acre of bare earth; and besides this, the fallen leaves lying scattered on the ground, would somewhat angment the sum total.* On the other hand, the growing leaves of trees generally form a succession of stages, or, loosely speaking, layers, corresponding to the annual growth of the branches, and more or less overlying each other. This disposition of the foliage interferes with that free communication between sun and sky above and leaf-surface below, on which the amount of radiation and absorption of heat depends. From all these considerations, it appears that though the effective thermoscopic surface of a forest in full leaf does not exceed that of bare ground in the same proportion as does its measured superficies, yet the actual quantity of area capable of receiving and emitting heat must be greater in the former than in the latter case. $\nmid$

It must further be remembered that the form and texture of a given surface are important elements in determining its thermoscopic character. Leaves are porous, and admit air and light more or less freely into their substance; they are generally smooth and even glazed on one surface; they are usually covered on one or both sides with spiculæ, and they very commonly present one or more acuminated points in their outline-all circumstances which tend to angment their power of emitting heat by reflection or radiation. Direct experiment on growing trees

* "The Washington elm at Cambridge-a tree of no extraordinary sizewas some years ago estimated to produce a crop of seven millions of leaves, exposing a surface of two hundred thousand square feet, or about five acres of foliage."-Grar, First Lessons in Botany and Vegetable Physiology.

+ See, on this particular point, and on the general influence of the forest on temperature, HuмвоLDT, Ansichten der Natur, i., 158. 
is very difficult, nor is it in any case practicable to distinguish how far a reduction of temperature produced by vegetation is due to. radiation, and how far to exhalation of the gaseous and watery fluids of the plant; for both processes usually go on together. But the frigorific effect of leafy structure is well obselved in the deposit of dew and the occurrence of hoarfrost on the foliage of grasses and other small vegetables, and on other objects of similar form and consistence, when the temperature of the air a few feet above has not been brought down to the dewpoint, still less to $32^{\circ}$, the degree of cold required to congeal dew to frost.*

We are also to take into account the action of the forest as a conductor of heat between the atmosphere and the earth. In the most important countries of America and Europe, and especially in those which have suffered most from the destruction of the woods, the superficial strata of the earth are colder in winter, and warmer in summer, than those a few inches lower, and their shifting temperature approximates to the atmospheric mean of the respective seasons. The roots of large trees penetrate beneath the superficial strata, and reach earth of a nearly constant temperature, corresponding to the mean for the entire year. As conductors, they convey the heat of the atmosphere to the earth

* The leaves and twigs of plants may be reduced by radiation to a tempera. ture lower than that of the ambient atmosphere, and even be frozen when the air in contact with them is above $32^{\circ}$. Their temperature may be communi. cated to the dew deposited on them, and thus this dew be converted into frost when globules of watery fluid floating in the atmosphere near them, in the condition of fog or vapor, do not become congealed.

It has long been known that vegetables can be protected against frost by diffusing smoke through the atmosphere above them. This method has been lately practiced in France on a large scale: vineyards of forty or fifty acres have been protected by placing one or two rows of pots of burning coal-tar, or of naphtha, along the north side of the rineyard, and thus keeping up a cloud of smoke for two or three hours before and after sunrise. The expense is said to be small, and probably it might be reduced by mixing some less combustible substance, as earth, with the fluid, and thus checking its too rapid burning.

The radiating and refrigerating power of objects by no means depends on their form alone. MIelloni cut sheets of metal into the shape of leaves and grasses, and found that they produced little cooling effect, and were not moistened under atmospheric conditions, which determined a plentiful deposit of dew on the leaves of vegetables. 
when the earth is colder than the air, and transmit it in the contrary direction when the temperature of the earth is higher than that of the atmosphere. Of course, then, as conductors, they teud to equalize the temperature of the earth and the air.

In countries where the questions I an considering have the greatest practical importance, a very large proportion, if not a majority, of the trees are of deciluons foliage, and their radiating as well as their shading surface is very much greater in summer than in winter. In the latter season, they little obstruct the reception of heat by the ground or the radiation from it; whereas, in the former, they often interpose a complete camopy between the ground and the sky, and materially interfere with both processes.

\section{Dead Products of Trees.}

Besides this various action of standing trees considered as inorganic matter, the forest exercises, by the annual moulting of its foliage, still another influence on the temperature of the earth, and, consequently, of the atmosphere which rests upon it. If we examine the constitution of the superficial soil in a primitive or an old and undisturbed artificially planted wood, we find, first, a deposit of undecayed leaves, twigs and seeds, lying in loose layers on the surface; then, more compact beds of the same materials in incipient, and, as we descend, more and more advanced, stages of decomposition; then, a mass of black mould, in which traces of organic structure are hardly discoverable except by microscopic examination; then, a stratum of mineral soil, more or less mixed with vegetable matter carried down into it by water or resulting from the decay of roots ; and, finally, the inorganic earth or rock itself. Without this deposit of the dead products of trees, this latter would be the superficial stratum, and as its powers of absorption, radiation and conduction of heat would differ essentially from those of the layers with which it has been covered by the droppings of the forest, it would act upon the temperature of the atmosphere, and be acted on by it, in a very different way from the leaves and mould which rest upon it. Dead leaves, still entire, or partially decayed, are very indifferent conductors of heat, and, therefore, though they diminish the warming influence of 
the summer sun on the soil below them, they, on the other lianch, prevent the escape of heat from that soil in winter, and, consequently, in cold climates, even when the ground is not covererl by a protecting mantle of snow, the earth does not freeze to as great a depth in the wood as in the open field.

In the primitive forest the surface of the ground is so encumbered (often, indeed, half-covered) with trunks and branches of fillen trees, that there sometimes seems to be as much mood prostrate as growing, and the necessity of climbing over, or creeping under, the fallen trees, is the greatest difficulty in forest travelling. These decayed or wind-fallen trees intercept the water of precipitation and couvert the surface of the ground almost, sometimes altogether, into a bog.* The settler, for convenience, especially for cutting roads and paths, drags out these trunks, which he uses for firewood and other purposes, thereby at the same time partially draining the wood. A few years suffice to get rid of this material and convert a large area to the condition described above. The wood, though still native and self-propagating, soon acquires, to some extent, the character of an artificial forest. This process was gone through with long ago in most European countries, so that there is scarcely any truly original forest left in Central or Western Europe, in the condition in which Nature would have placed it. An experienced eye at once recognizes a modern wood as, in part at least, man's work. Especially is this the case in Tyrol and the other Southern Austrian provinces, occupied, as existing architectural remains still show, and at least partly cleared, hundreds, if not thousands of years ago. The woods have since grown up again, but always under Government supervision. The valley of the Drave, for instance, had, anciently, large tomns and of course adjacent fields, but the country is now almost completely wooded, and it is only since the opening of the railroad through the Pusterthal and thence to Austrian and Italian markets, that these new forests have been a little broken. Many inroads have now been made upon them for the sake of the timber, and slides and torrents have already begun their ravages. But not only do these forests differ from native woods in their general

* See Mruton and Cheadle's Travels, also Desor. 
pliysiognomy, but the individual trees have changed their habits, conifers, which largely prevail in that climate, sending up shoots from the roots as well as throwing them out laterally, and otherwise approximating in growth to broad-leaved trees.*

\section{Specific Heat.}

Trees, considered as organisms, produce in themselves or in the air, a certain amount of heat, by absorbing and condensing atmospheric gases, and they exert an opposite influence by absorbing water and exhaling it in the form of vapor; but there is still another mode by which their living processes may warm the air around them, independently of the thermometric effects of condensation and evaporation. The vital heat of a dozen persons raises the temperature of a room. If trees possess a specific temperature of their own, an organic power of generating heat like that with which the warm-blooded animals are gifted, though by a different process, a certain amount of weight is to be ascribed to this element in estimating the action of the forest upon atmospheric temperature.

Boussingault remarks: "In many flowers there has been observed a very considerable evolution of heat at the approach of fecundation. In certain arums the temperature rises to $40^{\circ}$ or $50^{\circ}$ Cent. $\left[-104^{\circ}\right.$ or $122^{\circ}$ Fahr. $]$ It is very probable that this phenomenon is general, and varies only in the intensity with which it is manifested." +

If we suppose the fecundation of the flowers of forest trees to be attended with a tenth only of this calorific power, they could not fail to exert an important influence on the warmth of the atmospheric strata in contact with them.

Experiments by Meguscher, in Lombardy, led that observer to conclude "that the wood of a living tree maintains a temperature of $+12^{\circ}$ or $13^{\circ}$ Cent. $\left[=54^{\circ}, 56^{\circ}\right.$ Fahr. $]$ when the temperature of the air stands at $3^{\circ}, 7^{\circ}$, and $8^{\circ}\left[=37^{\circ}, 46^{\circ}, 47^{\circ} \mathrm{F}.\right]$ above zero, and that the internal warmth of the tree does not rise and fall in proportion to that of the atmosphere. So long as the latter is below $18^{\circ}\left[=67^{\circ} \mathrm{Fahr}.\right]$, that of the tree is always the

* See note, p. 335-6, post.

† Économie Rurale, i., p. 22. 
highest; but if the temperature of the air rises to $18^{\circ}$, that of the vegretable growth is the lowest. Since, then, trees maintain at all seasons a constant mean temperature of $12^{\circ}\left[=54^{\circ}\right.$ Fahr.], it is easy to see why the air in contact with the forest must be warmer in winter, cooler in summer, than in situations where it is deprived of that influence." *

Professor Henry says: "As a general deduction from chemical and mechanical principles, we think no change of temperature is ever produced where the actions belonging to one or both of these principles are not present. Hence, in midwinter, when all vegetable functions are dormant, we do not believe that any heat is developed by a tree, or that its interior differs in temperature from its exterior further than it is protected from the external air. The experiments which have been made on this point, we think, have been directed by a false analogy. During the active circulation of the sap and the production of new tissue, variations of temperature belonging exclusively to the plant may be observed; but it is inconsistent with general principles that heat should be generated where no change is taking place." †

There can be no doubt that moisture is given out by trees and evaporated in extremely cold winter weather, and unless new fluid were supplied from the roots by the exercise of some vital function, the tree would be exhausted of its juices before winter was over. But this is not observed to be the fact, and, though the point is disputed, respectable authorities declare that " wood felled

\section{* Memoria sur Boschi della Lombardia, p. 45.}

The results of recent experiments by Becquerel do not accord with those obtained by Meguscher, and the former eminent physicist holds that " a tree is warmed in the air like any inert body." At the same time he asserts, as a fact well ascertained by experiment, that "vegetables possess in themselves the power of resisting extreme cold for a certain length of time, . . . . and lrence it is believed that there may exist in the organism of plants, a force, independent of the conduction of caloric, which resists a degree of cold above the freezing-point." In a following page he cites observations made by Bugeaud, under the parallel of $58^{\circ} \mathrm{N}$. L., between the months of November and June, during most of which time, of course, vegetable life was in its deepest lethargy. Bugeaud found that when the temperature of the air was at $-34^{\circ} .60$, that of a poplar was only at $-29^{\circ} .70$, which certainly confirms the doctrine that trees exercise a certain internal resistance against cold.

+ United States Patent Office Report for 1857, p. 504. 
in the depth of winter is the heaviest and fullest of sap." * Warm weather in winter, of too short continuance to affect the temper ature of the ground sensibly, stimulates a free flow of sap in the maple. Thus, in the last week of December, 1862, and the first wreek of Jamnary, 1863, sugar was made from that tree in various parts of New Eugland. "A single branch of a tree, admitted into a warm room in winter through an aperture in a window, opened its buds and developed its leaves, while the rest of the tree in the external air remained in its winter sleep." + Like facts are matter of every-day observation in graperies where the vine is often planted outside the wall, the stem passing through an aperture into the warm interior. The roots, of course, stand in ground of the ordinary winter temperature, but vegetation is developed in the branches at the pleasure of the gardener. The roots of forest trees in temperate climates remain, for the most part, in a moist soil, of a temperature not much below the annual mean, through the whole winter; and we can not account for the uninterrupted moisture of the tree, unless we suppose that the roots furnish a constant supply of water.

Atkinson describes a ravine in a valley in Siberia, which was filled with ice to the depth of twenty-five feet. Poplars were growing in this ice, which was thawed to the distance of some inches from the stem. But the surface of the soil beneath it must have remained still frozen, for the holes around the trees were full of water resulting from its melting, and this would have escaped below if the ground had been thawed. In this case, although the roots had not thawed the thick covering of earth above them, the trunks must have melted the ice in contact with them. The trees, when observed by Atkinson, were in full leaf, but it does not appear at what period the ice around their stems had melted.

From these facts, and others of the like sort, it would seem that "all vegetable functions are " not absolutely "dormant" in winter, and, therefore, that trees may give out some heat even at that season. $\neq$

* Rossmässler, Der Wald, p. 158.

† Ibid., p. 160.

$\ddagger$ All evergreens, even the broad-leaved trees, resist frosts of extraordinary severity better than the deciduous trees of the same climates. Is not this be 
It does not appear that observations have been made on the special point of the development of heat in forest trees during florification, or at any other period of intense vital action; and hence an important element in the argument remains undetermined. The "circulation of the sap" commences at a very early period in the spring, and the temperature of the air in contact with trees may then be sufficiently affected by lieat evolved in the vital processes of vegetation, to raise the thermoinctric mean of wooded countries for that season, and, of course, for the year. The determination of this point is of much greater importance to vegetable physiology than the question of the winter temperature of trees, because a slight increment of heat in the trees of a forest might so affect the atmosphere in contact with

cause the vital processes of trees of persistent foliage are less interrupted during winter than those of trees which annually shed their leaves, and that therefore more organic heat is developed ?

In crossing Mont Cenis in October, 1869, when the leaves of the larches on the northern slope and near the top of the mountain were entirely dead and turned brown, I observed that these trees were completely white with hoarfrost. It was a wonderful sight to see how every leaf was covered with a delicate deposit of frozen aqueous vapor, which gave the effect of the most brilliant silver. On the other hand, the evergreen coniferi, which were growing among the larches, and therefore in the same conditions of exposure, were almost entirely free from frost. The contrast between the verdure of the leaves of the evergreens and the crystalline splendor of those of the larches was strikingly beautiful. Was this fact due to a difference in the color and structure of the leaves, or rather is it a proof of a vital force of resistance to cold in the living foliage of the evergreen tree ?

The low temperature of air and soil at which, in the frigid zone, as well as in warmer latitudes under special circumstances, the processes of regretation go on, seems to necessitate the supposition that all the malnifestations of regetable life are attended with an evolution of heat. In the United States it is common to protect ice, in ice-houses, by a covering of straw, which naturally sometimes contains kernels of grain. These often sprout, and even throw out roots and leaves to a considerable length, in a temperature very little above the freezing-point. Several years since I saw a lump of very clear and apparently solid ice, about eight inches long by sis thick, on which a kernel of grain had sprouted in an ice-house, and sent half a dozen or more very slender roots into the pores of the ice and through the whole length of the lump. The young plant must have thrown out a considerable quantity of heat; for though the ice was, as I have said, otherwise solid, the pores through which the roots passed were enlarged to perhaps double the diameter of the fibres, but still not so much as to prevent the retention of water in them by capillary attraction. 
them as to make possible the growing of many plants in or near the wood which could not otherwise be reared in that climate.

The erilporation of the juices of trees and other plants is doult. less their most importunt thermoscopic function, and as recent ob. servations lead to the conclusion that the quantity of moisture exlialed by vegretables has been hitherto underrated, we must ascribe to this element a higher value than has been usually assigned to it as a meteorological influence.

The exhalation and evaporation of the juices of trees, by whatever process effected, take up atmospheric heat and produce a proportional refrigeration. This effect is not less real, though to common observation less sensible, in the forest than in meadow or pasture land, and it can not be doubted that the local temperature is considerably affected by it. But the evaporation that cools the air, diffuses through it, at the same time, a medium which powerfully resists the escape of heat from the earth by radiation. Visible vapors, fogs and elouds, it is well known, prevent frosts by obstructing radiation, or rather by reflecting back again the heat radiated by the earth, just as any mechanical screen wonld do. On the other hand, fogs and clonds intercept the rays of the sun also, and hinder its heat from reaching the earth. The invisible vapors given out by leaves impede the passage of heat reflected and radiated by the earth and by all terrestrial objects, but oppose much less resistance to the transmission of direct solar heat; and indeed the beams of the sun seem more scorching when received through clear air charged with uncondensed moisture than after passing through a dry atmosphere. Hence the reduction of temperature by the evaporation of moisture from vegetation, though sensible, is less than it would be if water in the gaseous state were as impervious to heat given ont by the sun as to that emitted by terrestrial objects.

\section{Total Influence of the Forest on Temperature.}

It has not yet been found practicable to measure, sum up, and equate the total influence of the forest, its processes and its products, dead and living, upon temperature, and investigators differ much in their conclusions on this subject. It seems probable that in every particular case the result is, if not determined, at 
least so much modified by local conditions which are infinitely varied, that no general formula is applicable to the question.

In the report to which I referred on page 161, Gay-Lussalc says: "In my opinion we have not yet any positive proof that the forest has, in itself, any real influence on the climate of a great country, or of a particular locality. By closely examining the effects of clearing off the woods, we should perhaps find that, far from being an evil, it is an adrantage; but these questions are so complicated when they are examined in a climatological point of view, that the solution of them is very difficult, not to say impossible."

Becquerel, on the other hand, considers it certain that in tropical climates the destruction of the forests is accompanied with an elevation of the mean temperature, and he thinks it highly probable that it has the same effect in the temperate zones. The following is the substance of his remarks on this subject:

"Forests act as frigorific causes in three ways:

"1. They shelter the ground against solar irradiation and maintain a greater humidity.

"2. They produce a cutaneous transpiration by the leaves.

"3. They multiply, by the expansion of their branches, the surfaces which are cooled by radiation.

"These three causes acting with greater or less force, we must, in the study of the climatology of a country, take into account the proportion between the area of the forests and the surface which is bared of trees and covered with herbs and grasses.

"We should be inclined to believe, $a$ priori, according to the foregoing considerations, that the clearing of the woods, by raising the temperature and increasing the dryness of the air, ought to react on climate. There is no doubt that, if the vast desert of the Sahara were to become wooded in the course of ages, the sands would cease to be heated as much as at the present epoch, when the mean temperature is twenty-nine degrees [Centigrade, $=85^{\circ}$ Fahr.]. In that case, the ascending currents of warm air would cease, or be less warm, and would not contribute, by descending in our latitudes, to soften the climate of Western Europe. Thus the clearing of a great country may react on the climates of regions more or less remote from it.

"The observations by Boussingault leave no doubt on this 
point. This writer determined the mean temperature of wooded and of cleared points, under the same latitude, and at the same elevation above the sea, in localities comprised between the eleventh degree of north and the fifth degree of south latitude, that is to say, in the portion of the tropies nearest to the equator, and where radiation tends powerfully during the night to lower the temperature under a sky without clouds." *

The result of these observations, which has been pretty generally adopted by physicists, is that the mean temperature of cleared land in the tropics appears to be about one degree Centigrade, or a little less than two degrees of Fahrenheit, above that of the forest. On page 147 of the volume just cited, Becquerel argues that, inasmuch as the same and sometimes a greater difference is found in favor of the open ground, at points within the tropies so elevated as to have a temperate or even a polar climate, we must conclude that the forests in Northern America exert a refrigerating influence equally powerful. But the conditions of the soil are so different in the two regions compared, that I think we can not, with entire confidence, reason from the one to the other, and it is much to be desired that observations be made on the summer and winter temperature of both the air and the ground in the depths of the North American forests, before it is too late.

Recent inquiries have introduced a new element into the problem of the influence of the forest on temperature, or rather into the question of the thermometrical effects of its destruction. I refer to the composition of the soil in respect to its hygroscopicity or aptitude to absorb humidity, whether in a liquid or a gaseous form, and to the conducting porver of the particles of which it is composed. $\dagger$

\footnotetext{
* Becquerel, Des Climats, etc., pp. 139-141.

$\uparrow$ Composition, texture and color of soil are important elements to be considered in estimating the effects of the removal of the forest upon its thermoscopic action. "Experience has proved," says Becquerel, "that when the soil is bared, it becomes more or less heated [by the rays of the sun] according to the nature and the color of the particles which compose it, and according to its humidity, and that, in the refrigeration resulting from radiation, we must take into the account the conducting power of those particles also. Other things being equal, silicious and calcareous sands, compared in equal volumes with different argillaceous earths, with calcareous porvder or dust,
} 
The hygroscopicity of humus or vegetable earth is much greater than that of any mineral soil, and consequently forest ground, where humus abounds, absorbs the moisture of the atmosphere more rapidly and in larger proportion than common earth. The condensation of vapor by absorption develops heat, and consequently elevates the temperature of the soil which absorbs it, together with that of air in contact with the surface. Von Babo found the temperature of sandy ground thus raised from $68^{\circ}$ to $80^{\circ} \mathrm{F}$., that of soil rich in humus from $68^{\circ}$ to $88^{\circ}$.

The question of the influence of the woods on temperature does not, in the present state of our knowledge, admit of precise solution, and, unhappily, the primitive forests are disappearing so rapidly before the axe of the woodman, that we shall never be able to estimate with accuracy the climatological action of the natural wood, though all the physical functions of artificial plantations will, doubtless, one day be approximately linown.

But the value of trees as a mechanical screen to the soil they cover, and often to ground far to the leeward of them, is most abundantly established, and this agency alone is important enough to justify extensive plantation in all countries which do not enjoy this indispensable protection.

\section{Influence of Forests, as Inorganic, onthe Humidity of the Air and the Earth.}

The most important hyrgroscopic as well as thermoscopic influence of the forest is, no doubt, that which it exercises on the hut-

with humus, with arable and with garden earth, are the soils which least conduct heat. It is for this reason that sandy ground, in summer, maintains a high temperature even during the night. TVe may hence conclude that when a sandy soil is stripped of wood, the local temperature will be raised. After the sands, follow successively argillaceous, arable and garden ground, then humus, which occupies the lowest rank.

"The retentive power of lumus is but half as great as that of calcareous sand. Te will add that the power of retainiug heat is proportional to the density. It has also a relation to the magnitude of the prarticles. It is for this reason that ground covered with silicious pebbles cools more slowly thim silicions sand, and that pebbly soils are best suited to the cultivation of the vine, because they advance the ripening of the grape more rapidly than chalky and cliyey earths, which cool quickly. Hence we see that in examining the caloritic effects of clearing forests, it is important to take into account the properties of the soil laid bare."-Becquenel, Des Climats et des Sols boisés, p. 137. 
midity of the air and the earth, and this climatic action it exerts partly as dead, partly as living matter. By its interposition as a curtain between the sky and the ground, it both checks evaporation from the earth, and mechanically intercepts a certain proportion of the dew and the lighter showers, which would otherwise moisten the surface of the soil, and restores it to the atmosphere by exhalation; * while in heavier rains, the large drops which fall upon the leaves and branches are broken into smaller ones, and consequently strike the ground with less mechanical force, or are perhaps even dispersed into vapor without reaching it. $†$

* Mengotti had observed, and described in his usual picturesque way, the retention of rain-water by the foliage and bark of trees, but I do not know that any attempts were made to measure the quantity thus intercepted before the experiments of Becquerel, communicated to the Acudemy of Sciences in 1866. These experiments embraced three series of observations continued respectively for periods of a year, a month, and two days. According to Becquerel's measurements, the quantity falling on bare and on wooded soil re spectively was as 1 to $0.67 ; 1$ to 0.5 ; and 1 to 0.6 , or, in other words, he found that only from five-tenths to sixty-seven hundredths of the precipitation reached the ground.-Comptes Rendus de l'Académie des Sciences, 1866.

It seems, indeed, improbable that in rain-storms which last not hours, but whole days in succession, so large a proportion of the downfall should continue to be intercepted by forest vegetation after the leaves, the bark, and the whole framework of the trees were thoroughly wet, but the conclusions of this eminent physicist appear to have been generally accepted until the very careful experiments of Mathieu at the Forest-School of Nancy were made known. The observations of Mathieu were made in a plantation of dedicuous trees fortytwo years old, and were continued through the entire years 1866, 1867 and 1865. The result was that the precipitation in the wood was to that in an open glade of several acres near the forest station as 913 to 1,000 , and the proportion in each of the three years was nearly identical. According to MIathieu, then, only 57 thousandths or 5.7 per cent. of the precipitation is intercepted by trees. -Sureli, Étude sur les Torrents, 2d ed., ii., p. 98.

By order of the Direction of the Forests of the Canton of Berne, a series of experiments on this subject was commenced at the beginning of the year 1869 . During the first seven months of the year (the reports for which alone I have seen), including, of course, the season when the foliage is most abundant, as well as that when it is thinnest, the pluviometers in the woods received only fifteen per cent. less than those in the open grounds in the vicinity.-RIsLER, in Revue des Eaux et Forêts, of 10th January, 1870.

+ We are not, indeed, to suppose that the condensation of vapor and the evaporation of water are going on in the same stratum of air at the same time, or, in other words, that vapor is condensed into rain-drops, and rain-drops evaporated, under the same conditions; but rain formed in one stratum may 
The regetable mould, resulting from the decomposition of leaves and of wood, serves as a perpetual mulch to forest-soil by carpeting the ground with a spongy corering which obstructs tho evaporation from the mineral earth below, * drinks up the rains and melting snows that would otherwise flow ralpidly over the surface and perhaps be conveyed to the distant sea, and then slowly gives out, by evaporation, infiltration and percolition, the moisture thus imbibed. The roots, too, penetrate far below the superficial soil, conduct water along their surface to the lower depths to which they reach, and thus by partially draining the superior strata, remove a certain quantity of moisture out of the reach of evaporation.

\section{The Forest as Organic.}

These are the principal modes in which the humidity of the atmosphere is affected by the forest regarded as lifeless matter. Let us inquire how its organic processes act upon this meteorological element.

The commonest observation shows that the wood and bark of living trees are always more or less pervaded with watery and other fluids, one of which, the sap, is very abundant in trees of deciduous foliage when the buds begin to swell and the leaves to develop themselves in the spring. This fluid is drawn principally, if not entirely, from the ground by the absorbent action of the roots; for though Schacht and some other eminent botanical physiologists have maintained that water is absorbed by the leaves and bark of trees, yet most experiments lead to the contrary re-

fall through another, where vapor would not be condensed. Two saturated strata of different temperatures may be brought into contact in the higher regions, and discharge large rain-drops, which, if not divided by some obstruction, will reach the ground, though passing through strata which would vaporize them if they were in a state of more minute division.

* The only direct experiments known to me on the evaporation from the surface of the forest are those of Mathieu.-Suneld, Etude sur les Torrents, 2d ed., ii., p. 99.

These experiments were continued from MIarch to December, inclusive, of the year 1868. It was found that during those months the eraporation from a recipient placed on the ground in a plantation of deciduous trees sixty-two years old, was less than one-fifth of that from a recipient of like form and di. mensions placed in the open country. 
sult, and it is now generally held that no water is taken in by the pores of vegretables. Late observations by Cailletet in France, however, tend to the establishment of a new doctrine on this subject which solves many difficulties and will probably be accepted by botanists as definitive. Cailletet finds that under normal conditions, that is, when the soil is humid enongh to supply sufficient moisture through the roots, no water is absorbed by the leaves, buds or bark of plants, but when the roots are unable to draw from the earth the requisite quantity of this fluid, the vegetable pores in contact with the atmosphere absorb it from that source.

Popular opinion, indeed, supposes that all the regetable fluids, during the entire period of growth, are drawn from the bosom of the earth, and that the wood and other products of the tree are wholly formed from matter held in solution in the water abstracted by the roots from the ground. This is an error, for the solid matter of the tree, in a certain proportion not important to our present inquiry, is received from the atmosphere in a gaseous form, through the pores of the leaves and of the young shoots, aud, as we have just seen, moisture is sometimes supplied to trees by the atmosphere. The amount of water taken up by the roots, however, is vastly greater than that imbibed through the leaves and bark, especially at the season when the sap is most abundant, and when the leaves are yet in embryo. The quantity of water thus received from the air and the earth, in a single year, even by a wood of only a hundred acres, is very great, though experiments are wanting to furnish the data for even an approximate estimate of its measure; for only the vaguest conclusions can be drawn from the observations which have been made on the imbibition and exhalation of water by trees and other plants reared in artificial conditions diverse from those of the natural forest.*

\section{Flow of Sap.}

The amount of sap which can be withdrawn from living trees furnishes, not indeed a measure of the quantity of water sucked

\footnotetext{
* The experiments of Hales and others on the absorption and exhalation of vegetibles are of high physiological interest; but observations on sunflowers, cabbages, hops, and single branches of isolated trees, growing in artificially prepared soils and under artificial conditions, furnish no trustworthy data for computing the quantity of water received and given off by the natural wood.
} 
up by their roots from the ground-for we can not extract from a tree its whole moisture-but numerical data which may airl the imagination to form a general notion of the powerful action of the forest ats an absorbent of humidity from the earth.

The only forest-tree known to Europe and North America, the sap of which is largely enough applied to economical uses to have made the amount of its flow a matter of practical importance and popular observation, is the sugar maple, Acer succharimum, of the Anglo-American Provinces and States. In the course of a single "sugar season," which lasts ordinarily from twenty-five to thirty days, a sugar maple two feet in diameter will yield not less than twenty gallons of sap, and sometimes much more.* This, however, is but a trifling proportion of the water abstracted from the earth by the roots during this season; for all this fluid runs from two or three incisions or auger-holes, so narrow as to intercept the current of comparatively few sap vessels, and besides, experience shows that large as is the quantity withdrawn from the circulation, it is relatively too small to affect very sensibly the growth of the tree.t The number of large maple-trees on an

* Emerson (Trees of MFassachusetts, p. 493) mentions a maple six feet in diameter, as having yielded a barrel, or thirty-one and a half gallons, of sap in twenty-four hours, and another, the dimensions of which are not stated, as having yielded one hundred and seventy-five gallons in the course of the season. The Cultivator, an American agricultural journal, for June, 18.12, states that twenty gallons of sap were drawn in eighteen hours from a single maple, two and a half feet in diameter, in the town of Warner, New Hampshire, and the truth of this account has been verified by personal inquiry made in my behalf. This tree was of the original forest growth, and had been left standing when the ground around it was cleared. It was tapped only every other year, and then with six or eight incisions. Dr. Williams (History of Fermont, i., p. 91) says: "A man much employed in making maple sugar, found that, for twenty-one days together, a maple-tree discharged seven and a half gallons per day."

An intelligent correspondent, of much experience in the manufacture of maple sugar, writes me that a second-growth maple, of about two feet in diameter, standing in open ground, tapped with four incisions, has, for several seasons, generally run eight gallons per day in fair weather. He speaks of a very large tree, from which sixty gallons were drawn in the course of a season, and of another, something more than three feet through, which made forty-two pounds of wet sugar, and must have yielded not less than one hun. dred and fifty gallons.

† Tapping does not check the growth, but does injure the quality of the wood of maples. The wood of trees often tapped is lighter and less dense 
acre is frequently not less than fifty, and of course the quantity of moisture abstracted from the soil by this tree alone is measured by thousands of gallons to the acre. The sugar orchards, as they are called, contain also many young maples too small for tapping, and numerous other trees-two of which, at least, the black birch, Betula lenta, and yellow birch, Betula excelsa, both very common in the same climate, are far more abundant in sap than the maple t-are scattered among the sugar-trees; for the North American native forests are remarkable for the mixture of their crops.

The sap of the maple, and of other trees with deciduous leaves which grow in the same climate, flows most freely in the early spring, and especially in clear weather, when the nights are frosty and the days warm; for it is then that the melting snows supply the earth with moisture in the justest proportion, and that the absorbent power of the roots is stimulated to its highest activity.

When the buds are ready to burst, and the green leaves begin to show themselves beneath their scaly covering, the ground has become drier, the absorption by the roots is diminished, and the sap, being immediately employed in the formation of the foliage, can be extracted from the stem in only small quantities.

than that of trees which have not been tapped, and gives less heat in burning. No difference has been observed in the bursting of the buds of tapped and untapped trees.

* Dr. Rush, in a letter to Jefferson, states the number of maples fit for tapping on an acre at from thirty to fifty. "This," observes my correspondent, " is correct with regard to the original growth, which is always more or less intermixed with other trees; but in second growth, composed of maples alone, the number greatly exceeds this. I have had the maples on a quarter of an acre, which I thought about an average of second-growth 'maple orchards,' counted. The number was found to be fifty-two, of which thirty-two were ten inches or more in diameter, and, of course, large enough to tap. This gives two hundred and eight trees to the acre, one hundred and twenty-eight of which were of proper size for tapping."

† The correspondent already referred to informs me that a black birch, tapped about noon with two incisions, was found the next morning to have yielded sixteen gallons. Dr. Williams (History of Vermont, i., p. 91) says: "A large birch, tapped in the spring, ran at the rate of five gallons an hour when first tapped. Eight or nine days after, it was found to run at the rate of about two and a half gallons an hour, and at the end of fifteen days the discharge continued in nearly the same quantity. The sap continued to flow for four or five weeks, and it was the opinion of the observers that it must have yielded as much as sixty barrels [1,890 gallons]." 


\section{Absorption and Exhalation by Fotiage.}

The leaves now commence the process of absorption, and im bibe both uncombined gases and an unascertained, but probably inconsiderable, quantity of aqueous vapor from the humid atmosphere of spring which bathes them.

The organic action of the tree, as thus far described, tends to the desiccation of air and earth; but when we consider what rolumes of water are daily absorbed by a large tree, and how small a proportion of the weight of this fluid consists of matter which, at the period when the flow of sap is freest, enters into new combinations and becomes a part of the solid framework of the vegetable or a component of its deciduous products, it is evident that the superfluous moisture must somehow be carried back again almost as rapidly as it flows into the tree. At the very commencement of vegetation in spring, some of this fluid certainly escapes through the buds, the nascent foliage, and the pores of the bark, and vegetable physiology tells us that there is a current of sap towards the roots as well as from them.* I do not know that the exudation of water into the earth, through the bark or at the extremities of these latter organs, has been proved, but the other known modes of carrying off the surplus do not seem adequate to dispose of it at the almost leafless period when it is most abundantly received, and it is possible that the roots may, to some extent, drain as well as flood the watercourses of their stem. Later in the season the roots absorb less, and the now developed leaves exhale an increased quantity of moisture into the air. In any event, all the water derived by the growing tree from the atmosphere and the ground is parted with by transpiration or exudation, after having surrendered to the plant the small proportion of matter required for vegetable growth which

* "The elaborated sap, passing out of the leaves, is received into the inner bark, . . . . and a part of what descends finds its way even to the ends of the roots, and is all along diffused laterally into the stem, where it meets and mingles with the ascending crude sap or raw material. So there is no separato circulation of the two kinds of sap; and no crude sap exists separately in any part of the plant. Even in the root, where it enters, this mingles at once with some elaborated sap already there."-GRAr, How Plants Grovo, §273. 
it held in solution or suspension.* The hygrometrical equilib rium is then restored, so far as this: the tree yields up again the moisture it had drawn from the earth and the air, though it does not return it each to each ; for the rapor carried off by transpiration greatly exceeds the quantity of water absorbed by the foliage from the atmosphere, and the amount, if any, carried back to the ground by the roots.

The present estimates of some eminent vegetable physiologists, in regard to the quantity of aqueous rapor exhaled by trees and taken up by the atmosphere, are much greater than those of former inquirers. Direct and satisfactory experiments on this point are wanting, and it is not easy to imagine how they could be made on a sufficiently extensive and comprehensive scale. Our conclusions must therefore be drawn from observations on small plants or separate branches of trees, and, of course, are subject to much uncertainty. Nerertheless, Schleiden, arguing from such aualogies, comes to the surprising result, that a wood evaporates ten times as much water as it receives from atmospheric precipitation. $\uparrow$ In the Northern and Eastern States of the Union, the

* Ward's tight glazed cases for raising and especially for transporting plants, go far to prove that water only circulates through vegetables, and is again and again absorbed and transpired by organs appropriated to these functions. Seeds, growing grasses, shrubs, or trees planted in proper earth, moderately watered and covered with a glass bell or close frame of glass, live for months, and even years, with only the original store of air and water. In one of Ward's early experiments, a spire of grass and a fern, which sprang up in a corked bottle containing a little moist earth introduced as a bed for a snail, lived and flourished for eighteen years without a new supply of either fluid. In these boxes the plants grow till the enclosed air is exhausted of the gaseous constituents of vegetation, and till the water has yielded up the assimilable matter it held in solution, and has dissolved and supplied to the roots the nutriment contained in the earth in which they are planted. After this, they continue for a long time in a state of vegetable sleep, but if fresh air and water be introduced into the cases, or the plants be transplanted into open ground, they rouse themselves to renewed life, and grow vigorously, without appearing to have suffered from their long imprisonment. The water transpired by the leaves is partly absorbed by the earth directly from the air, partly condensed on the glass, along which it trickles down to the earth, enters the roots again, and thus continually repeats the circuit. See Aus der Natur, 21, B. S. 537.

† Für Baum und Wald, pp. 46, 47, notes. Pfaff, too, experimenting on branches of a living oak, weighed immediately after being cut from the tree, 
mean precipitation during the period of forest growth-that is, from the swelling of the buds in the spring to the ripening of the fruit, the hardening of the young shoots, and the full perfection of the other anmual products of the tree-exceeds on the average twenty-four inches. Taking this estimate, the evaporation from the forest would be equal to a precipitation of two hundred and forty inches, or very nearly one hundred and fifty standard gallons to the square foot of surface.

The first questions which suggest themselves upon this statement are: what becomes of this immense quantity of water, and from what source does the tree derive it? We are told in reply that it is absorbed from the air by the humus and mineral soil of the wood, and supplied again to the tree through its roots, by a circulation analogous to that observed in Ward's air-tight cases.

When we recall the effect produced on the soil even of a thick wood by a rainfall of one inch, we find it hard to believe that two hundred and forty times that quantity, received by the ground between early spring and autumn, would not keep it in a state of perpetual saturation, and speedily convert the forest into a bog.

No such power of absorption of moisture by the earth from the atmosphere, or anything approaching it, has ever been shown by experiment, and all scientific observation contradicts the supposition. Schübler found that in seventy-two hours thoroughly dried humus, which is capable of taking up twice its own weight of water in the liquid state, absorbed from the atmosphere only twelre per cent. of its weight of humidity; garden-earth five and onefifth per cent. and ordinary cultivated soil two and one-third per cent. After seventy-two hours, and, in most of his experiments with thirteen different earths, after forty-eight hours no further absorption took place. Wilhelm, experimenting with air-dried field earth, exposed to air in contact with water and protected by a bell-glass, found that the absorption amounted in seventy-two hours to two per cent. and a very small fraction, nearly the whole of which was taken up in the first forty-eight hours. In other ex-

and again after an exposure to the air for three minutes, and computing the superficial measure of all the leaves of the tree, concludes that an oak tree evaporates, during the season of growth, eight and a half times the mean amount of rain fall on an area equal to that shaded by the tree. 
periments with carefully heat-dried field soil, the absorption was five per cent. in eighty-four hours, and when the water was first warmed to secure the complete saturation of the air, air-dried garden earth absorbed five and one-tenth per cent. in seventy. two hours.

In nature the conditions are never so favorable to the absorption of vapor as in these experiments. The ground is more compact and of course offers less surface to the air, and, especially in the wood, it is already in a state approaching saturation. Hence, both these pliysicists conclude that the quantity of aqueous vapor absorbed by the earth from the air is so inconsiderable "that we can ascribe to it no important influence on vegetation." *

Besides this, trees often grow luxuriantly on narrow ridges, on steep declivities, on partially decayed stumps many feet above the ground, on walls of high buildings, and on rocks, in situations where the earth within reach of their roots could not possibly contain the tenth part of the water which, according to Schleiden and Pfaff, they evaporate in a day. There are, too, forests of great extent on high bluffs and well-drained table-lands, where there can exist, neither in the subsoil nor in infiltration from neighboring regions, an adequate source of supply for such consumption. It must be remembered, also, that in the wood the leaves of the trees shade each other, and only the highest stratum of foliage receives the full influence of heat and light; and besides, the air in the forest is almost stagnant, while in the experiments of Unger, Marshal, Vaillant, Pfaff and others, the branches were freely exposed to light, sun and atmospheric currents. Such observations can authorize no conclusions respecting the quantitative action of leaves of forest trees in normal conditions.

Further, allowing two hundred days for the period of forest vital action, the wood must, according to Schleiden's position, exhale a quantity of moisture equal to an inch and one-fifth of precipitation per day, and it is hardly conceivable that so large a volume of aqueous vapor, in addition to the supply from other sources, could be diffused through the ambient atmosphere without manifesting its presence by ordinary hygrometrical tests much more energetically than it has been proved to do, and, in fact, the

* Writeum, Der Boden und das Wasser, pp. 14, 20. 
observations recorded by Ebermayer show that though the relu. tive humidity of the atmosphere is considerably greater in the cooler temperature of the wood, its absolute humidity does not sensibly differ from that of the air in open ground.* The daily discharge of a quantity of aqueous vapor correspouding to a rainfall of one inch and a fiftl into the cool air of the forest would produce a perpetual shower, or at least drizzle, unless, indeed, we suppose a rapidity of absorption and condensation by the ground, and of transmission through the soil to the roots and, through them and the ressels of the tree, to the leares, much greater than has been shown by direct observation. Notwithstanding the high authority of Schleiden, therefore, it seems impossible to reconcile his estimates with facts commonly observed and well established by competent investigators. Hence the important question of the supply, demand and expenditure of water by forest vegetation must remain undecider, until it can be determined by something approaching to satisfactory direct experiment. $\dagger$ Valualle observations, by Risler, on the evaporation from cultivated soils, and the exhalations and exudations of lummidity by field plants and forest trees, will be found in the Archives des Sciences, Bib. Ziothèque Universelle de Genère. His general conclusion, 1). 263 , is, that forests evaporate less than an equal extent of pisturage, and that if we suppose a mean precipitation of two and a half millimetres per day, of which two millimetres penetrate into the soil, the forest takes up less than one-half of this supply, the

* Ebermarer, Die Physikalischen Einoirhungen des Taldes, i., pp. 150 ct seq. It may be well here to guard my readers against the common error which supposes that a humid condition of the air is necessarily indicated by the presence of fog or visible vapor. The air is rendered humid by containing incisille vapor, and it becomes drier by the condensation of such vapor into fog, composed of solid globules or of hollow vesicles of water-for it is a disputed point whether the particles of fog are solid or vesicular. Hence, though the ambient atmosphere may hold in suspension, in the form of fog, water enough to obscure its transparency, and to produce the sensation of moisture on the skin, the air, in which the finely-divided water floats, may be charged with even less than an average proportion of humidity.

+ According to Cezanne, Suneli, Étude sur les Torrents, 2e édition, ii., p. 100, experiments reported in the Revue des Eaux et Forits for August, 1868, showed the evaporation from a living tree to be "almost insignificant." Do tails are not given. 
remainder descending into the sub soil and percolating through eartl and rock until it issues in the form of springs. He found an evaporation of one and one-tenth millimetres per day to be the maximum from a forest of firs, and this, too, under the exceptionally favorable conditions of a fertile and humid soil and abundance of sunlight.

Balance of Conflicting Influences of Forest on Atmospheric Heat and Humidity.

We have shown that the forest, considered as dead matter, tends to diminish the moisture of the air, by preventing the sun's rays from reaching the ground and evaporating the water that falls upon the surface, and also by spreading over the earth a spongy mantle which sucks up and retains the humidity it re. ceives from the atmosphere, while, at the same time, this covering acts in the contrary direction by accumulating, in a reservoir not wholly inaccessible to vaporizing influences, the water of precipitation which might otherwise suddenly sink deep into the bowels of the earth, or flow by superficial channels to other climatic regions. We now see that, as a living organism, it tends, on the one hand, to diminish the humidity of the air by sometimes ab. sorbing moisture from it, and, on the other, to increase that humidity by pouring out into the atmosphere, in a vaporous form, the water it draws up through its roots. This last operation, at the same time, lowers the temperature of the air in contact with or proximity to the wood, by the same law as in other cases of the conversion of water into vapor.

As I have repeatedly said, we can not measure the value of any one of these elements of climatic disturbance, raising or lowering of temperature, increase or diminution of humidity, nor can we say that in any one season, any one year, or any one fixed cycle, however long or short, they balance and compensate each other. They are sometimes, but certainly not always, contemporaneous in their action, whether their tendency is in the same or in opposite directions, and, therefore, their influence is sometimes cumulative, sometimes conflicting; but, upon the whole, their general effect is to mitigate extremes of atmospheric heat and cold, moisture and drought. They serve as equalizers of temperature and 
humidity, and it is highly probable that, in analogy with most other works and workings of nature, they, at certain or uncertain periods, restore the equilibrium which, whether as lifeless masses or as living organisms, they may have temporarily disturbed.*

When, therefore, man destroys these natural harmonizers of climatic discords, he sacrifices an important conservative power, though it is far from certain that he has thereby affected the meau, however much he may have exaggerated the extremes, of atmospheric temperature and humidity, or, in other words, may have increased the range and lengthened the scale of thermometric and hygrometric variation.

\section{Special Influence of Woods on Precipitation.}

With the question of the action of forests upon temperature and upon atmospheric humidity is intimately connected that of their influence upon precipitation, which they may affect by increasing or diminishing the warmth of the air and by absorbing or exhaling uncombined gas and aqueous vapor. The forest being a natural arrangement, the presumption is that it exercises a conservative action, or at least a compensating one, and consequently that its destruction must tend to produce pluviometrical disturbances as well as thermometrical variations. And this is

* There is one fact which I have nowhere seen noticed, but which seems to me to have an important bearing on the question whether forests tend to maintain an equilibrium between the various causes of hygroscopic action, and consequently to keep the air within their precincts in an approximately constant condition so far as this meteorological element is concerned. I refer to the comparative rarity of fog or visible vapor in thick woods in full leaf, even when the air of the neighboring open grounds is so heavily charged with condensed vapor as completely to obscure the sun. The temperature of the atmosphere in the forest is not subject to so sudden and extreme rariations as that of cleared ground, but at the same time it is far from constant, and so large a supply of vapor as is poured out by the foliage of the trees could not fail to be frequently condensed into fog, by the same causes as in the case of the adjacent meadows which are sometimes covered with a dense mist while the forest air remains clear, were there not some potent counteracting influence always in action. This influence, I believe, is to be found partly in the equalization of the temperature of the forest, and partly in the balance between the humidity exhaled by the trees and that absorbed and condensed invisibly by the earth. 
the opinion of perhaps the greatest number of observers. In deed, it is almost impossible to suppose that, under certain conditions of time and place, the quantity and the periods of rain should not depend, more or less, upon the presence or absence of forests; and without insisting that the removal of the forest las diminished the sum total of snow and rain, we may well admit that it has lessened the quantity which annually falls within particular limits. Various theoretical considerations make this probable, the most obvious argument, perhaps, being that drawn from the generally admitted fact, that the summer and even the mean temperature of the forest is below that of the open country in the same latitude. If the air in a wood is cooler than that around it, it must reduce the temperature of the atmospheric stratum immediately above it, and, of course, whenever a saturated current sweeps over it, it must produce precipitation which would fall upon it or at a greater or less distance from it.

We must here take into the account a very important consideration. It is not universally or even generally true, that the atmosphere returns its condensed humidity to the local source from which it receives it. The air is constantly in motion,

_- howling tempests scour amain

From sea to land, from land to sea; *

and, therefore, it is always probable that the evaporation drawn up by the atmosphere from a given river, or sea, or forest, or meadow, will be discharged by precipitation, not at or near the point where it rose, but at a distance of miles, leagnes, or even degrees. The currents of the upper air are invisible, and they leave behind them no landmark to record their track. We know not whence they come, or whither they go. We have a certain rapidly increasing acquaintance with the laws of general atmospheric motion, but of the origin and limits, the beginning and end, of that motion as it manifests itself at any particular time and place, we know nothing. We can not say where or when the vapor, exhaled to-day from the lake on which we float, will be

* Und Stürme brausen um die Wette

Vom Meer aufs Land, vom Land aufs Meer. GoETHE, Faust, Song of the Archangels. 
condensed and fall; whether it will waste itself on a barren des. ert, refresh upland pastures, deseend in snow on Alpine heights, or contribute to swell a distant torrent which shall lay waste square miles of fertile corn-land; nor do we linow whether the rain which feeds our brooklets is due to the transpiration from a meighboring forest, or to the evaporation from a farroff sea. If, therefore, it were proved that the annual quantity of rain and dew is nuw as great on the plaius of Castile, for example, as it was when they were covered with the native forest, it would by no meams follow that those woods did not angment the amount of precipitation elsewhere.

The whole problem of the pluriometrical influence of the forest, general or local, is so exceedingly complex and difficult that it can not, with our present means of knowledge, be decided upon ì priori grounds. It must now be regarded as a question of fact which would probably admit of scientific explanation, if it were once established what the artual fact is. Unfortunately, the evidence is conflicting in tendency, and sometimes equivocal in interpretation, but I believe that a majority of the foresters and physicists who have studied the question are of opinion that in many, if not in all cases, the destruction of the woods has been followed by a diminution in the annual quantity of rain and dew. Indeed, it has long been a popularly settled belief that vegetation and the condensation and fall of atmospheric moisture are reciprocally necessary to each other, and even the poets sing of,

Afric's barren sand,

Where nought can grow, because it raineth not,

And where no rain can fall to bless the land,

Because nought grows there.*

Before going further with the discussion, however, it is well to remark that the comparative rarity or frequency of inundations in earlier or later centuries is not necessarily, in most cases not probably, entitled to any weight whatever, as a proof that more

* —— Det golde Strög i Afrika,

Der Intet voxe kan, da ei det regner

$\mathrm{Og}$, omvendt, ingen Regn kan falde, da

Der Intet voxer.

Paludan-Müller, Adam Homo, ii., 408. 
or less rain fell formerly than now; because the accumulation of water in the channel of a river depends far less upon the quantity of precipitation in its valley, than upon the rapidity with which it is conducted, on or under the surface of the ground, to the central artery that drains the basin. But this point will be more fully discussed in a subsequent chapter.

In writers on the subject we are discussing, we find many positive assertions about the diminution of rain in countries which have been stripped of wood within the historic period, but these assertions very rarely rest upon any other proof than the doubtful recollection of unscientific observers, and I am unable to refer to a single instance where the records of the rain-gauge, for a considerable period before and after the felling or planting of extensive woods, can be appealed to in support of either side of the question. The scientific reputation of many writers who have maintained that precipitation has been diminished in particular localities by the destruction of forests, or augmented by planting them, has led the public to suppose that their assertions rested on sufficient proof. We can not affirm that in none of these cases did such proof exist, but I am not aware that it has ever been produced.*

* Among recent writers, Clavé, Schacht, Sir John F. W. Herschel, Hohenstein, Barth, Asbjörnsen, Boussiugault, and others, maintain that forests tend to produce rain and clearings to diminish it, and they refer to numerous facts of observation in support of this doctrine; but in none of these does it appear that these observations are supported by actual pluviometrical measure. So far as I know, the earliest expression of the opinion that forests promote precipitation is that attributed to Christopher Columbus in the Historio del S. D. Fernancto Colombo, Venetia, 1571, cap. 1viii., where it is said that the Admiral ascribed the daily showers which fell in the West Iudies about vespers to "the great forests and trees of those countries," and remarked that the same effect was formerly produced by the same cause in the Canary and Madeira islands and in the Azores, but that " now that the many woods and trees that covered them have been felled, there are not produced so many clouds and rains as before."

Mr. H. IIarrisse, in his very learned and able critical essay, Fernand Colomb, se Vie et ses Cucres, Paris, 1872, has made it at least extremely probable that the Historie is a spurious work. The compiler may have found this observation in some of the writings of Columbus now lost; but however that may be, the fact, which Humboldt mentions in Cosmos with much interest, still remains, that the doctrine in question was held, if not by the great discoverer himself, at least by one of his pretended biographers, as early as the year 1571 . 
The effect of the forest on precipitation, then, is by no means free from doubt, and we can not positively affirm that the total annual quantity of rain is even locally diminished or increaserl by the destruction of the woods, though both theoretical consicleritions and the balance of testimony strongly favor the opinion that more rain falls in wooded than in open countries. One important conchusion, at least, upon the meteorological influence of forests is certain and undisputed: the proposition, nanely, that, within their own limits, and near their own borders, they maintain a more uniform degree of humidity in the atmosphere than is observed in cleared grounds. Scarcely less can it be questioned that they tend to promote the frequency of showers, and, if they do not augment the amount of precipitation, they probably equalize its distribution through the different seasons.*

* The strongest direct evidence which I am able to refer to in support of the proposition that the woods produce even a local augmentation of precipitation is furnished by the observations of Mathieu, sub-director of the Forest-School at Nancy. His pluviometrical measurements, continued for three years, 18661868, show that during that period the annual mean of rainfall in the centre of the wooded district of Cinq-Tranchées, at Belle Fontaine on the borders of the forest, and at Amance, in an open cultivated territory in the same vicinity, was respectively as the numbers $1,000,95 \%$, and 858 . Fautrat and Sartiaut placed at an elevation of six metres above a grove of oaks and elms, of twenty years' growth and eight or nine metres height, in the forest domain of Hallete, pluviometers and other meteorological instruments, and like instruments at the same elevation in the open ground three hundred metres from the forest. In the months February to July inclusive, the rainfall above the trees was found to be $192.50^{\mathrm{mm}}$, and during the same period $177^{\mathrm{mm}}$ in the open ground. -Comptes Rendus, t. LXXIX., 409.

The alleged augmentation of rainfall in Lower Egypt, in consequence of large plantations by Mehemet $\mathrm{Ali}$, is very frequently appealed to as a proof of this influence of the forest, and this case has become a regular commonplace in all discussions of the question. It is, however, open to the same objection as the alleged instances of the diminution of precipitation in consequence of the felling of the forest.

This supposed increase in the frequency and quantity of rain in Lower Egypt is, I think, an error, or at least not an established fact. I have heard it disputed on the spot by intelligent Franks, whose residence in that country began before the plantations of Mehemet $A$ li aud Ibrahim Pacha, and I have been assured by them that meteorologrical observations, made at Alexandria about the beginuing of this century, show an annual fall of rain as great as is usual at this day. The mere fact that it did not rain during the French occupation is not conclusive. Having expericuced a gentle shower of nearly twenty-four hours' duration in Upper Egypt, I inquired of the local governor 
'The experience of observing persons confirms the common say ing, "All signs fail in dry times." This is partly an expression of the taw of probabilities, according to which, the longer a particular spell of weather has continued, the greater are the chances that it will continue yet longer; but there is a physical reason why, after a long drought, appearances, which, under ordinary circumstances, would almost certainly indicate an approaching rain-storm, prove delusive. It is this: After a drought of some days, which generally occurs only after a protracted continuance of hot weather, the surface of the ground is not only dry, but heated, and, like any other body of elevated temperature, throws off heat into the atmosphere. This heat tends to make the air capable of containing more humidity, and the rapor held in the atmosphere over an

in relation to the frequency of this phenomenon, and was told by him that not a drop of rain had fallen at that point for more than two years previous.

The belief in the increase of rain in Egrpt rests almost entirely on the observations of Marshal Marmont, and the evidence collected by him in 1836 . His conclusions have been disputed, if not confuted, by Jomard and others, and are probably erroneous. See Forssac, Météorologie, German translation, pp. 634-639.

It certainly sometimes rains briskly at Cairo, but evaporation is exceedingly rapid in Egypt-as any one who erer saw a Fellah woman wash a napkin in the Nile, and dry it by shaking it a fer moments in the air, can testify; and a heap of grain, wet a few inches below the surface, would probably dry again without injury. At any rate, the Egyptian Government often has vast quantities of wheat stored at Boulak in uncovered yards through the winter, though it must be admitted that the slorenliness and want of foresight in Oriental life, public and private, are such that we can not infer the safety of any practice followed in the East merely from its long continuance.

Grain, however, may be long kept in the open air in climates much less dry than that of Egypt, without injury except to the superficial layers ; for moisture does not penetrate to a great depth in a heap of grain once well dried and kept well aired. When Louis IX. was making his preparations for his campaign in the East, he had large quantities of wine and grain purchased in the Island of Cyprus, and stored up for two jears to await his arrival. "When we were come to Cyprus," says Joinville, Histoire de Saint Louis, §§ 72, 73, "we found there greate foison of the Kynge's purveyance. . . . . The wheate and the barley they had piled up in greate heapes in the feeldes, and to looke vpon, they were like vnto mountaynes; for the raine, the whyche hadde beaten vpon the wheate now a longe whyle, had made it to sproute on the toppe, so that it seemed as greene grasse. And whanne they were mynded to carrie it to Egypte, they brake that swarde of greene herbe, and dyd finde under the same the wheate and the barley, as freshe as yf menne hadde but nowe thrashed it." 
extent of heated ground, and which otherwise might be precipitated and form rain, is dissipated and carried of. Thus the clourls that gather round mountains are seen to ranish as they piss orel the plaius below. The forest dues not beeome heated by the sun, and therefore does not radiate heat enough to dissolve the vapor in the atmosphere above it, while the open ground is warmed by the sun and radiates heat into the air which drifts orer it. The lower limit of perpetual suow is said to be from two thousund to four thousand feet higher on the northern than on the southeru slope of the Himalayas. The explanation of this apparently anomalous fact is found partly in the condensation and congelation of the moisture with which the southern monsoon is charged, and its precipitation as snow on the southern scarp of this mighty chain. But the configuration of the earth's surface in this region furnishes another explanation to which physical geographers formerly ascribed even greater importance. This lofty chain is skirted on the north by the extensive, high plateau of Thibet which is without forests, and it mas believed that the naked surface of this plateau emitted, by reflection and radiation, heat enough to dissolve the moisture of the atmospheric strata above it, and thus to prevent the formation of rains and snows. Our vast Westem fields and plains, though lower by 10,000 feet, exercise a similar function, and probably materially modify the amount of precipitation in our climate. Whether the Russian steppes exert a like influence is a question which I have not seen discussed.

\section{Total Climatic Influence of the Forest.}

Aside from the question of local disturbances and their compensations, it does not seem probable that the forests sensibly affect the general mean of atmospheric temperature of the globe, or the total quantity of precipitation, or eren that they had this influence when their extent was vastly greater than at present. The waters cover about three-fourths of the face of the earth, and if we deduct the frozen zones, the peaks and crests of lofty mountains and their craggy slopes, the Sahara and other great African and Asiatic deserts, and all such other portions of the solid surface as are permanently untit for the growth of wood, we 
shall find that probably not one-tenth of the total superficies of our planet was ever, at any one time in the present geological period, covered with forests. Besides this, the distribution of forest land, of desert, and of water, is such as to reduce the possible influence of the woods to a low expression; for the forests are, in large proportion, situated in cold or temperate climates, where the action of the sun is comparatively feeble both in elevating temperature and in promoting evaporation; while, in the torrid zone, the desert and the sea-the latter of which always presents an evaporable surface-enormously preponderate. It is, upon the whole, not probable that so sinall an extent of forest, so situated, could produce a sensible influence on the general climate of the globe, though it might appreciably affect the local action of all climatic elements. The total annual amount of solar heat absorbed and radiated by the carth, and the sum of terrestrial evaporation and atmospheric precipitation, must be supposed constant; but the distribution of heat and of humidity is exposed to disturbance in both time and place by a multitude of local causes, among which the presence or absence of the forest is doubtless one.

So far as we are able to sum up the results, it would appear that, in countries in the temperate zone still chiefly covered with wood, the summers would be cooler, moister, shorter, the winters milder, drier, longer, than in the same regions after the removal of the forest, and that the condensation and precipitation of atmospheric moisture would be, if not greater in total quantity, more frequent and less violent in discharge. The slender historical evidence we possess seems to point to the same conclusion, though there is some conflict of testimony and of opinion on this point.

Among the many causes which, as we have seen, tend to influence the general result, the mechanical action of the forest, if not more important, is certainly more obvious and direct than the immediate effects of its organic processes. The felling of the woods involves the sacrifice of a valuable protection against the violence of chilling winds, and at the same time, the loss of the shelter afforded to the ground by the thick coating of leaves which the forest sheds upon it and by the snow which the woods prevent from blowing away, or from melting in the brief thaws of winter. I have already remarked that bare ground freezes much deeper than that which is 
covered by beds of leaves, and when the earth is thickly coated with snow, the strata frozen before it fell begin to thaw. It is not uncommon to find the ground in the woods, where the snow lies two or three feet deep, entirely free from frost, when the atmospheric temperature has been for several weeks below the freezing-point, and for some days even below zero of Falurenheit. When the ground is eleared and brought under cultivation, the leaves are ploughed into the soil and decomposed, and the snow, especially upon knolls and eminences, is blown off, or perhaps half thawed, several times during the winter. The water from the melting snow runs into the depressions, and when, after a day or two of warm sunshine or tepid rain, the cold returns, it is consolidated to ice, and the bared ridges and swells of earth are deeply frozen.* It requires many days of mild weather to raise the temperature of soil in this condition, and of the air in contact with it, to that of the earth in the forests of the same climatic region. Flora is already plaiting her sylvan wreath before the corn-flowers which are to deck the garland of Ceres have waked from their winter's sleep; and it is probably not a popular error to believe that, where man has substituted his artificial crops for the spontaneous harvest of nature, spring delays her coming. $\dagger$

* I have seen, in Northern New England, the surface of the open ground frozen to the depth of twenty-two inches, in the month of November, when in the forest-earth no frost was discoverable; and later in the winter, I have known an exposed sand-knoll to remain frozen six feet deep, after the ground in the woods was completely thawed.

t The conclusion arrived at by Noah Webster, in his very learned and able paper on the supposed change in the temperature of winter, read before the Connecticut Academy of Arts and Sciences in 1799, was as follows: "From a careful comparison of these facts, it appears that the weather, in modern win. ters, in the United States, is more inconstant than when the earth was covered with woods, at the first settlement of Europeans in the country; that the warm weather of autumn extends further into the winter months, and the cold weather of winter and spring encroaches upon the summer; that the wind being more variable, snow is less permanent, and perhaps the same remark may be applicable to the ice of the rivers. These effects seem to result necessarily from the greater quantity of heat accumulated in the earth in summer since the ground has been cleared of wood and exposed to the rays of the sun, and to the greater depth of frost in the earth in winter by the exposure of its un. covered surface to the cold atmosphere."-Collection of Papers by NOAп W Ев. STER, p. 162. 
There are, in the constitution and action of the forest, many forces, organic and inorganic, which unquestionably tend powerfully to produce meteorological effects, and it may, therefore, be assumed as certain that they must and do produce such effects, unless they compensate. and balance each other, and herein lies the dificulty of solving the question. To some of these elements late observations gire a new importance. For example, the exhalation of aqueous vapor by plants is now believed to be much greater, and the absorption of aqueous vapor by them much less, than was formerly supposed, and Tyndall's views on the relations of vapor to atmospheric heat give immense value to this factor in the problem. In like manner the low temperature of the surface of snow and the comparatively high temperature of its lower strata, and its consequent action on the soil beneath, and the great condensation of moisture by snow, are facts which seem to show that the forest, by protecting great surfaces of snow from melting, must inevitably exercise a great climatic influence. If to these influences we add the mechanical action of the woods in obstructing currents of wind, and diminishing the evaporation and refrigeration which such currents produce, we have an accumulation of forces which must manifest gręat climatic effects, unlesswhich is not proved and can not be presumed-they neutralize each other. These are points hitherto little considered in the discussion, and it seems difficult to deny that as a question of argument, the probabilities are strongly in favor of the meteorological influence of the woods. The evidence, indeed, is not satisfactory, or, to speak more accurately, it is non-existent, for there really is next to no trustworthy proof on the subject, but it appears to me a case where the burden of proof must be taken by those who maintain that, as a meteorological agent, the forest is inert.

The question of a change in the climate of the Northern American States is examined in the able Meteorological Report of Mr. Draper, Director of the New York Central Park Observatory, for 1871. The result arrived at by Mr. Draper is, that there is no satisfactory evidence of a diminution in the rainfall, or of any other climatic change in the winter season, in consequence of clearing of the forests or other human action. The proof from meteorological registers is certainly insufficient to establish the 
fact of a change of climate, but, on the other hand, it is equally insufficient to establish the contrary. Meteorological stations are too fer, their observations, in many cases, extend over a very short period, and, for reasons I have already given, the great majority of their records are entitled to little or no confidence.*

\section{Influence of the Forest on the Humidity of the Soit.}

I have hitherto confined myself to the influence of the forest on meteorological conditions, a subject, as has been seen, full of difficulty and uncertainty. Its comparative effects on the tem-

* Since these pages were written, the subject of forest meteorology has received the most important contribution ever made to it, in several series of observations at numerous stations in Bavaria, from the year 1866 to 1871 , published by Ebermayer, at Aschaffenburg, in 1873, under the title: Die Pliysilialischen Einairkungen des Waldes auf Luft und Boden, und seine Klimatologische und Hygienische Bedeutung. I. Band. So far as observations of only five years' duration can prove anything, the following propositions, not to speak of many collateral and subsidiary conclusions, seem to be established, at least for the localities where the observations were made:

1. The yearly mean temperature of wooded soils, at all depths, is lower than that of open grounds, p. 35 .

This conclusion, it may be remarked, is of doubtful applicability in regions of excessive climate like the Northern United States and Canada, where the snow keeps the temperature of the soil in the forest above the freezing-point, for a large part and sometimes the whole of the winter, while in unwooded ground the earth remains deeply frozen.

2. The yearly mean atmospheric temperature, other things being equal, is lower in the forest than in cleared grounds, p. 84.

3. Climates become excessive in consequence of extensive clearings, p. 117.

4. The absolute humidity of the air in the forest is about the same as in open ground, while the relative humidity is greater in the former than in the latter case, on account of the lower temperature of the atmosphere in the wood, p. 150 .

5. The evaporation from an exposed surface of water in the forest is sixty. four per cent. less than in unwooded grounds, pp. 159, 161.

6. About twenty-six per cent. of the precipitation is intercepted and prevented from reaching the ground by the foliage and branches of forest trees, p. 194.

7. In the interior of thick woods, the evaporation from water and from earth is much less than the precipitation, p. 210.

8. The loss of the water of precipitation intercepted by the trees in the forest is compensated by the smaller evaporation from the ground, p. 219.

9. In elevated regions and during the summer half of the year, woods tend to increase the precipitation, p. 202. 
perature, the humidity, the texture and consistence, the coufigu. ration and clistribution of the mould or arable soil, and very often of the mineral strata below, and on the permanence and resularity of springs and greater superficial watercourses, are much less disputalile as well as more ealsily estimated and more important, than its posible ralue as a cause of strictly climatic equilibrimm or clisturbance.

The action of the forest on the earth is chiefly mechanical, but the organic process of absorption of moisture by its roots affects the cuantity of water contained in the vegetable mould and in the mineral strata near the surface, and, eonsequently, the consistency of the soil. In treating of the effects of trees on the moisture of the atmosphere, I have said that the forest, by interposing a canopy between the sky and the ground, and by covering the surface with a thick mantle of fallen leares, at once obstructed insulation and prevented the radiation of heat from the earth. These influences go far to balance each other; but familiar observation shows that, in summer, the forest-soil is not raised to so high a temperature as are open grounds exposed to irradiation. For this reason, and in consequence of the mechanical resistance opposed by the bed of dead leares to the escape of moisture, we should expect that, except after recent rains, the superficial strata of woodland-soil wonld be more humid than that of cleared land. This agrees with experience. The soil of the natural forest is always moist, except in the extremest droughts, and it is exceedingly rare that a primitive wood suffers from want of humidity. How far this acemulation of water affects the condition of neighboring grounds by lateral infiltration, we do not know, but we shall see, in a subsequent chapter, that water is conveyed to great distances by this process, and we may hence infer that the influence in question is an important one.

It is undoubtedly true that loose soils, stripped of regetation and broken up by the plongh or other processes of cultiration, may, until again earpeted by grasses or other plants, absorb more rain and snow-water than when they were covered by a natural growth; but it is also true that the evaporation from such soils is augmented in a still greater proportion. Rain scarcely penetrates beneath the sod of grass-ground, but runs off over the surface; and after the heaviest showers a ploughed field will often be dried 
by eraporation before the water cin be carried off by infiltration, while the soil of a meighboring grove will remain half saturated for weeks together. Sandy soils frequently rest on a tenitcions subsoil, at a moderate depth, as is usually seen in the pine plains of the United States, where pools of rain-water collect in slight depresions on the surface of earth the upper stratum of which is as porous as a sponge. In the open grounds such pools are very scoun dried up by the sum and wind; in the woods they remain uncrilporated long enough for the water to diffuse itself litterally until it finds, in the sulsoil, erevices through which it may escape, or slopes which it may follow to their outerop or descend along them to lower strata.

\section{Drainage by Roots of Trees.}

Becquerel notices a special function of the forest to which I have already alluded, but to which sufficient importance has not, until very recently, been generally ascribed. I refer to the mechanical action of the roots as conductors of the superfluous humidity of the superficial earth to lower strata. The roots of trees often penetrate through subsoil almost impervious to water, and in such cases the moisture, which would otherwise remain above the subsoil and convert the surface-earth into a bog, follows the roots downwards and escapes into more porous strata or is received by subterranean canals or reservoirs.* When the forest is felled, the roots perish and decay, the orifices opened by them are soon obstructed, and the water, after having saturated the vegetable earth, stagnates on the surface and transforms it into ponds and morasses. Thus in La Brenne, a tract of 200,000 acres resting on an impermeable subsoil of argillaceous earth, which ten centuries ago was covered with forests interspersed with fertile and salubrious meadows and pastures, has been converted, by the destruction of the rroods, into a vast expanse of pestilential pools and marshes. In Sologne the same cause has withdrawn from culti-

* "The roots of vegetables," says d'Héricourt, "perform the office of drain. ing in a manner analogous to that artificially practised in parts of Holland and the British islands. This method consists in driving deeply down into the soil several hundred stakes to the acre; the water filters down along the stakes, and in some cases as favorable results have been obtained by this means as by hori. zontal drains."-Annales Frrestieres, 1857, p. 312. 
vation and human inhabitation not less than 1,100,000 acres of ground once well wooded, well drained and productive.

It is an important observation that the desiccating action of trees, by way of drainage or external conduction by the roots, is greater in the artificial than in the natural wood, and hence that the surface of the ground in the former is not characterized by that approach to a state of saturation which it so generally manifests in the latter. In the spontaneous wood, the leaves, fruits, bark, branches, and dead trumks, by their decayed material and by the conversion of rock into loose earth through the solvent power of the gases they develop in decomposition, cover the ground with an easily penetrable stratum of mixed regetable and mineral matter extremely favorable to the growth of trees, and at the same time too retentive of moisture to part with it readily to the capillary attraction of the roots. The trees, finding abundant nutriment near the surface, and so sheltered against the action of the wind by each other as not to need the support of deep and firmly fixed stays, send their roots but a moderate distance downwards, and indeed often spread them out like a horizontal network alınost on the surface of the ground. In the artificial wood, on the contrary, the spaces between the trees are greater; they are obliged to send their roots deeper both for mechanical support and in search of nutriment, and they consequently serve much more effectually as conduits for perpendicular drainage.*

It is only under special circumstances, however, that this function of the forest is so essential a conservative agent as in the two cases just cited. In a champaign region insufficiently provided with natural channels for the discharge of the waters, and with a subsoil which, though penetrable by the roots of trees, is otherwise impervious to water, it is of cardinal importance; but though trees everywhere tend to carry off the moisture of the superficial

* It has been remarked that with the planting of trees [on the Landes] the sheets of water on the surface have disappeared. This is attributed to the powerful tap-roots of the maritime pine, which, in time, pierce the pan and furnish an ingress for the surface waters into the porous strata beneath.French Forestry, etc.: Journal of Forestry, March, 1879, p. 771. The same Journal, p. 813, contains the account of a bog which was planted forty years ago with Italian black poplars. These trees, which grew rapidly, have drained the bog by their roots, these having penetrated, through many feet of bog and clay, into a porous underlying stratum. 
strati by this mode of conduction, yet the precise condition of soil which I have described is not of sufficiently frequent occurrence to have drawn much attention to this office of the wood. In fact, in most soils, there are counteracting influences which neutralize, more or less efiectually, the desiceative action of roots, and in general it is as true as it was in Seneca's time, that " the shadiest grounds are the moistest." *

It is always observed in the American States, that clearing the ground not only causes rumning springs to disappear, but dries up the stagnant pools and the spongy soils of the low grounds. The first roads in those States ran along the ridges, when practicable, because there only was the earth dry enough to allow of their construction, and, for the same reason, the cabins of the first settlers were perched upon the hills. As the forests have been from time to time removed, and the face of the earth laid open to the air and sun, the moisture has been evaporated, and the removal of the highways and of human habitations from the bleak hills to the sheltered valleys, is one of the most agreeable among the many improvements which later generations have witnessed in the interior of the Northern States. $†$

Recent observers in France affirm that evergreen trees exercise a special desiccating action on the soil, and cases are cited where large tracts of land lately planted with pines have been almost completely drained of moisture by some unknown action of the trees. It is argued that the alleged drainage is not due to the conducting power of the roots, inasmuch as the roots of the pine do not descend lower than those of the oak and other deciduous trees which produce no such effect, and it is suggested that the

* Seneca, Questiones Naturales, iii., 11, 2. See also Pliny, Nat. Hist., chap. 1xxx.

† The Tuscan poet Giusti, who had certainly had little opportunity of observing primitive conditions of nature and of man, was aware that such must have been the course of things in new countries. "You know," says he in a letter to a friend, " that the hills were first occupied by man, because stagnant waters, and afterwards continual wars, excluded men from the plains. But when tranquillity was established and means provided for the discharge of the wwaters, the low grounds were soon covered with human habitations."-Lettere, Firenze, 1864, p. 98. H. C. Carey, a distinguished American public economist, has, in his different works, made many important observations to the same effect. 
foliage of the pine continues to exhale through the winter a sufficient quantity of moisture to account for the drying up of the soil. This explanation is improbable, and I know nothing in American experience of the forest which accords with the alleged facts. It is true that the pines, the firs, the hemlock, and all the spike-leaved evergreens prefer a dry soil, but it has not been observed that such soils becone less dry after the felling of their trees. The cedars and other trees of allied families grow maturally in moist ground, and the white cedar of the Forthern States, Thuy occidentalis, is chiefly found in swamps. The roots of this tree do not penetrat deeply into the earth, but are spread out near the surface, and, of course, do not carry off the waters of the swamps by perpendicular conduction. On the contrary, by their shade, the trees prevent the evaporation of the superficial water; but when the cedars are felled, the swamp-which sometimes rather resembles a pool filled with aquatic trees than a grore upon solid ground-often dries up so completely as to be fit for cultivation without any other artificial clrainage than, in the ordinary course of cultiration, is giren to other new soils."

* A special desiccative influence has long been ascribed to the maritime pine, which has been extensively planted on the dunes and sand-plains of western France, and it is well established that, under certain conditions, all trees, whether evergreen or deciduous, exercise this function, but there is no convincing proof that in the cuses now referred to there is any difference in the mode of action of the two classes of trees. An article by D'Arbois de Jubainville in the Revue des Euux et Forits for April, 1869, ascribing the same action to the Pinus sylvestris, has excited much attention in Europe, and the facts stated by this writer constitute the strongest evidence known to me in support of the alleged influence of evergreen trees, as distinguished from the draining by downward conduction, which is a function exercised by all trees, under ordinary circumstances, in proportion to their penetration of a bibulous subsoil by tap or other descending roots. The question has been ably discussed by Beraud in the Revue des Deux MLondes for April, 18r0, the result being that the drying of the soil by trees is due simply to superficial conduction by the roots, whatever may be the foliage of the tree. See post: Influence of the Forest on Flow of Springs.

It is however certain, I believe, that evergreens exhale more moisture in winter than leafless deciduous trees, and consequently some weight is to be ascribed to this element.

The extraordinary rapidity of the growth of the eucalyptus has been ascribed to the supposed exceptional power of absorption of water from the earth by the roots of the tree, and the consequently increased supply of elements of vege table nutrition contained in the water thus absorbed. It is affirmed, indeed, 


\section{The Forest in Winter.}

The influence of the woods on the flow of springs, and consequeutly on the supply for the larger watercourses, naturally connects itself with the general question of the action of the forest on the humidity of the ground. But the special condition of the woodlinds, as affected by snow and frost in the winter of exeessive climates, like that of the United States, has not been so much studied as it deserves; and as it has a most important bearing on the superficial hydrology of the earth, I shall make some observations upon it before I proceed to the direct discussion of the influence of the forest on the flow of springs.

To estimate rightly the importance of the forest, in our climate, as a natural apparatus for accumulating the water that falls upon the surface and trausmitting it to the subjacent strata, we must compare the condition and properties of its soil with those of cleared and cultivated earth, and examine the consequently different action of these soils at different seasons of the year. 'The disparity between them is greatest in climates where, as in the Northern American States and in the extreme north of Europe, the open ground freezes and remains impervious to water during a considerable part of the winter; thongh, even in climates where the earth does not freeze at all, the woods have still an important influence of the same character. The difference is yet greater in countries which have regular wet and dry seasons, rain being very frequent in the former period, while, in the latter, it scarcely occurs at all. These countries lie chiefly in or near the tropies, but they are not wanting in higher latitudes; for a large part of Asiatic and even of European Turkey is almost wholly deprived

that this power is so great that a plantation of eucalyptus acts as a veritable drain on wet soils, but I do not linow that the alleged facts on which this theory rests have yet been verified by scientific observation. That there must exist some relation between nutrition and growth is too obvious to be doubted, and the character and measure of this relation constitute one of the most urgent and important of yet uusolved problems in vegetable physiology. In accordance with the ordinary economy of Nature, who does nothing in vain, we should presume that the absorbent powers of the roots of trees were limited to the supply of elements of accretion to the tree, but we are too ignorant on this subject to aftirm positively that the fluid absorbed may not subserve some other function independent of the growth of the tree. 
of summer rains. In the principal regions occupied by European cultivation, and where alone the questions discussed in this volume are recognized as having, at present, any practical inportance, more or less rain falls at all seasons, and it is to these regions that, on this point as well as others, I chiefly confine my attention.

\section{Importance of Snow.}

Recent observations in Switzerland give a new importance to the hygrometrical functions of snow, and of course to the forest as its accumulator and protector. I refer to statements of the condensation of atmospheric vapor by the snows and glaciers of the Rhone basin. Rendu, in 1844, estimated the condensation by snow and ice to be equal to a precipitation of thirty inches. Agassiz concluded that the evaporation and the condensation balanced each other,-a computation which allows to the latter a value perhaps not greatly inferior to that supposed by Rendu. In 1870, Professors Dufour and Forel of Morges made interesting experiments on the subject at Morges in March, and on the Rhine glacier in July and August. Of course the temperature and humidity of the atmosphere influenced the results, but in four experiments at Morges the condensation was found to be equal to a precipitation of 410 thousandths of a millimetre to the hour, or nearly a centimetre per day. On the glacier, in twentyseven observations between the 2ith of July and the $3 \mathrm{~d}$ of August, the hourly condensation ranged from fifty-one thousandths to twenty-six hundredths of a millimetre. Of course there are many hours, many days even, in the course of a year when, instead of a condensation on the surface of snow and ice, there is a very rapid evaporation, and while in some experiments Dufour and Forel found the evaporation during a period of eight favorable days to be equal only to the condensation during 67 hours of the following three, in others the evaporation amounted in 48 hours to four or five per cent. of the total weight of the ice or snow contained in the vessels exposed. They observe that the condensation is necessarily attended with a disengagement of heat which tends to melt the snow and ice, and it thus angments the flow of water from the glaciers both by depositing moisture and by thawing ice and snow, and at the same time exerts a marked 
and important influence on the atmosphere by diminishing its humidity.* How far similar results would be obtained by experiments continued through the year ean only be conjectured, but it is certain that the action of snow upon the atmosphere, even in our climate, is an element of great meteorological importance. Whenever the humidity of the atmosphere in contact with snow is above the point of saturation at the temperature to which the air is cooled by such contact, the superfluous moisture is absorbed by the snow or condensed and frozen upon its surface, and of course adds so much to the winter supply of water received from the snow by the ground. This quantity, in all probability, much exceeds the loss by evaporation, for during the period when the ground is covered with snow, the proportion of clear, dry weather favorable to evaporation is less than that of humid days with an atmosphere in a condition to yield up its moisture to any bibulous substance cold enough to condense it. $\dagger$ The cloud which so often caps snowy Alpine peaks is usually due to the condensation of atmospheric humidity by the snow, rather than to vapor borne up from below. The snow is at all times either giving off moisture by evaporation, or condensing and absorbing it. Thus the water of precipitation, which, if delivered by the cloud in the form of rain, would run off or be absorbed by the earth, when it takes the form of snow is saved and returned again to the atmosphere.

In our Northern States, irregular as is the climate, the first autumnal snows pretty constantly fall before the ground is frozen at all, or when the frost extends at most to the depth of only a fer inches. $f$ In the woods, especially those situated upon the

* The condensation of moisture is also an important agent in the conversion of flocculent snow into nevé. The heat disengaged in condensation partially melts the flakes, and, in freezing again, they contract and assume the globular form which characterizes nevé.

† The hard snow-crust, which in the early spring is a source of such keen enjoyment to the children and youth of the North-and to many older persons in whom the love of nature has kept awake a relish for the simple pleasures of rural life-is doulitless due to the congelation of the vapor condensed by the snow rather than to the thawing and freezing of the superficial stratum; for when the surface is melted by the sun, the water is taken up by the ab. sorbent mass beneath before the temperature falls low enough to freeze it.

$\ddagger$ The hard autumnal frosts are usually preceded by heary rains which 
elevated ridges, which supply the natural irrigation of the soil and feed the perennial fountains and streams, the ground remains corered with snow during the winter; for the trees protect the snow from blowing from the general surface into the depressions, and new accessions are received before the covering deposited by the first fall is melted. Snow is of a color unfavorable for radiation, but, even when it is of considerable thickness, it is not wholly impervious to the rays of the sun, and for this reason, as well as from the warmth of lower strata, the frozen crust of the soil, if one has been formed, is soon thawed, and does not again fall below the freezing-point during the winter.*

thoroughly moisten the soil, and it is a common saying in the North that "the ground will not freeze till the swamps are full."

* Dr. Williams, of Vermont, made some observations on the comparative temperature of the soil in open and in wooded ground in the years 1789 and 1791, but they generally belonged to the warmer months, and I do not know that auy extensive series of comparisous between the temperature of the ground in the woods and in the fields has been attempted in America. Dr. Williams's thermometer was sunk to the depth of ten inches, and gave the following results :

\begin{tabular}{|c|c|c|c|c|}
\hline & Time. & $\begin{array}{l}\text { Temperature } \\
\text { of ground in } \\
\text { pasture. }\end{array}$ & $\begin{array}{l}\text { Temperature } \\
\text { of ground in } \\
\text { vooods. }\end{array}$ & Difference. \\
\hline $\begin{array}{l}\text { May } \\
\text { June } \\
\text { July } \\
\text { Aug. } \\
\text { Sept. } \\
\text { Oct. } \\
\text { Nov. }\end{array}$ & 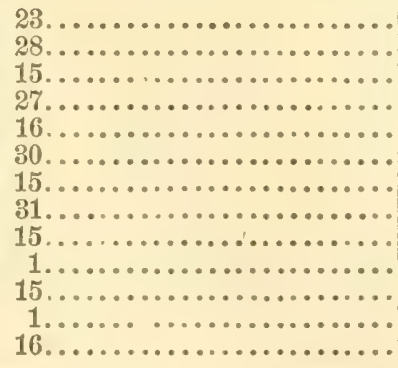 & $\begin{array}{l}52 \\
57 \\
64 \\
62 \\
62 \\
65 \frac{1}{2} \\
68 \\
59 \frac{1}{2} \\
59 \frac{1}{2} \\
59 \frac{1}{2} \\
49 \\
43 \\
43 \frac{1}{2}\end{array}$ & $\begin{array}{l}46 \\
48 \\
51 \\
51 \\
51 \\
55 \frac{1}{2} \\
58 \\
55 \\
55 \\
55 \\
49 \\
43 \\
43 \frac{1}{2}\end{array}$ & $\begin{array}{c}6 \\
9 \\
13 \\
11 \\
11 \\
10 \\
10 \\
4 \frac{1}{2} \\
4 \frac{1}{2} \\
4 \frac{1}{2} \\
0 \\
0 \\
0\end{array}$ \\
\hline
\end{tabular}

On the 14th of January, 1791, in a winter remarkable for its extreme severity, he found the ground, on a plain open field where the snow had been blown away, frozen to the depth of three feet and five inches; in the roods where the snow was three feet deep, and where the soil had frozen to the depth of six inches before the snow fell, the thermometer, at six inches below the surface of the ground, stood at $39^{\circ}$. In consequence of the covering of 
The snow in contact with the earth now begins to melt, with greater or less rapidity, according to the relative temperature of the earth and the air, while the water resulting from its dissolution is imbibed by the vegetable mould, and carried off by infiltration so fast that both the snow and the layers of leaves in contact with it often seem comparatively dry, when, in fact, the under surface of the former is in a state of perpetual thaw. No doubt a certain proportion of the snow is given off to the atmosphere by direct evaporation; but in the woods, the protection against the sun by even leafless trees prevents much loss in this way, and besides, the snow receives much moisture from the air by absorption and condensation. Very little water runs off in the winter by superficial watercourses, except in rare cases of sudden thaw, and there can be no question that much the greater part of the suow deposited in the forest is slowly melted and absorbed by the earth.

the snow, therefore, the previously frozen ground had been thawed and raised to seven degrees above the freezing-point. - Willians's Vermont, i., p. 74.

Boussingault's observations are important. Employing three thermometers, one with the bulb an inch below the surface of powdery snow; one on the surface of the ground beneath the suow, then four inches deep; and one in the open air, forty feet above the ground, on the north side of a building, he found, at 5 P.Mr., the first thermometer at $-1.5^{\circ}$ Centigrade, the seconl at $0^{\circ}$, and the third at $+2.5^{\circ}$; at 7 A.M., the next morning, the first stood at $-12^{3}$, the second at $-3.5^{\circ}$, and the third at $-3^{\circ}$; at 5.30 the same evening No. 1 stood at $-1.4^{\circ}$, No. 2 at $0^{\circ}$, and No. 3 at $+3^{\circ}$. Other experiments were tried, and though the temperature was affected by the radiation, which varied with the hour of the day and the state of the sky, the upper surface of the snow was uniformly colder than the lower, or than the open air.

According to the Report of the Department of Agriculture for May and June, 18\%, IIr. C. G. Priudle, of Vermont, in the preceding winter, found, for four successive days, the temperature immediately abore the snow at $13^{\circ}$ below zero; beneath the snow, which was but four inches deep, at $19^{\circ}$ above zero; and under a drift two feet deep, at $27^{\circ}$ above.

On the borders and in the glades of the American forest, violets and other small plants begin to vegetate as soon as the snow has thawed the soil around their roots, and they are not unfrequently found in full flower under two or three feet of snow.-American Naturalist, May, 1869, pp. 155, 156.

In very cold weather, when the ground is covered with light snow, flocks of the grouse of the Eastern States often plunge into the snow about sunset, and pass the night in this warm shelter. If the weather moderates before morning, a frozen crust is sometimes formed on the surface too strong to be broken by the birds, which consequently perish. 
The immense importance of the forest, as a reservoir of this stock of moisture, becomes apparent, when we consider that a large proportion of the summer rain either flows into the valleys and the rivers, because it falls faster than the ground can imbibe it; or, if absorbed by the warm superficial strata, is evaporated from them without sinking deep enough to reach wells and springs, which, of course, depend much on winter rains and snows for their entire supply. This observation, though specially true of cleared and cultivated grounds, is not wholly inapplicable to the forest, particularly when, as is too often the case in Europe, the underwood and the decaying leaves are removed.

The quantity of snow that falls in extensive forests, far from the open country, has seldom been ascertained by direct observation, because there are few meteorological stations in or near the forest. According to Thompson, * the proportion of water which falls in snow, in the Northern States, does not exceed one-fifth of the total precipitation, but the moisture derived from it is doubtless considerably increased by the atmospheric vapor absorbed by it, or condensed and frozen on its surface. I think I can say from experience-and I am confirmed in this opinion by the testimony of competent observer's whose attention has been directed specially to the point-that though much snow is intercepted by the trees, and the quantity on the ground in the woods is consequently less than in open land in the first part of the winter, yet most of what reaches the ground at that season remains under the protection of the wood until melted, and, as it occasionally receives new supplies, the depth of snow in the forest in the latter half of winter is considerably greater than in the cleared fields. Measurements in a snowy region in New England, in the month of February, gave a mean of 38 inches in the open ground and 44 inches in the woods, but the actual difference between the quantity of snow in the woods and that in open ground, in the latter part of winter, is greater than these measurements would seem to indicate. In the woods, the snow, which remains constant, is consolidated by pressure, while in the open ground, being blown off or thawed several times in the course of the winter, it seldom becomes as densely packed as in the woods, except in the

* Thompson's Vermont, Appendix, p. 8. 
bottom of valleys or other positions where it is sheltered both from wind and sun.*

The general effect of the forest in cold climates is to assimilite the winter state of the ground to that of wooded regions under softer skies; and it is a cireumstance well worth noting, that in Southern Europe, where Nature has denied to the earth a warm winter-garment of floceulent snow, she has, by one of those compensations in which her empire is so rich, clothed the hillsides with umbrella and other pines, ilexes, cork-oaks, bays, and other trees of persistent foliage, whose evergreen leaves afford to the soil a protection analogous to that which it derives from snow in more northern climates.

The water imbibed by the soil in winter sinks until it meets a

* As the loss of snow by evaporation has been probably exaggerated by popular opinion, an observation or two on the subject may not be amiss in this place. It is true that in the open grounds, in clear weather and with a dry atmosphere, snow and ice are evaporated with great rapidity even when the thermometer is much below the freezing-point; and Darwin informs us that the snow on the summit of Aconcagua, 22,400 feet high, and of course in a temperature of perpetual frost, is sometimes carried off by evaporation. The surface of the snow in our woods, however, does not indicate much loss in this way. Tery small deposits of snow-flakes remain unevaporated in the forest, for many days after snow which fell at the same time in the cleared field has disappeared without either a thaw to melt it or a wind powerful enough to drift it away. Even when bared of their leaves, the trees of a wood obstruct, in an important degree, both the direct action of the sun's rays on the snow and the movement of drying and thawing winds.

Dr. Piper (Trees of America, p. 48) records the following observations: "A body of snow, one foot in depth and sixteen feet square, was protected from the wind by a tight board fence about flve feet high, while another body of snow, much more sheltered from the sun than the first, six fect in depth, and about sixteen feet square, was fully exposed to the wind. When the thaw came on, which lasted about a fortnight, the larger body of snow was entirely dissolved in less than a week, while the smaller body was not wholly gone at the end of the second week.

"Equal quantities of snow were placed in ressels of the same kind and capacity, the temperature of the air being seventy degrees. In the one case, a constant current of air was kept passing over the open vessel, while the other was protected by a cover. The snow in the first was dissolved in sixteen minutes, while the latter had a small unthawed proportion remaining at the end of eighty-five minutes."

The snow in the woods is protected in the same way, though not literally to the same extent, as by the fence in one of these cases and the cover in the other. 
more or less impermeable or a saturated stratum, and then, by unseen conduits, slowly finds its way to the channels of springs, or oozes out of the ground in drops which unite in rills, and so all is conveyed to the larger streams, and by them finally to the sea. The water, in percolating through the vegetable and mineral layers, acquires their temperature, and is chemically affected by their action, but it carries very little matter in mechanical suspension.

The process I have described is a slow one, and the supply of moisture derived from the snow, angmented by the rains of the following seasons, keeps the forest-ground, where the surface is level or but moderately inclined, in a state of approximate saturation throughout almost the whole year.*

It may be proper to observe here that in Italy, and in many parts of Spain and France, the Alps, the Apennines, and the Pyrenees, not to speak of less important mountains, perform the functions which provident nature has in other regions assigned to the forest, that is, they act as reservoirs wherein is accumulated in winter a supply of moisture to nourish the parched plains during the droughts of summer. Hence, however enormous may be the erils which have accrued to the above-mentioned countries from the destruction of the woods, the absolute desolation which would otherwise have smitten them through the folly of man, has been partially prevented by those natural dispositions, by means of which there are stored up in the glaciers, in the snow-fields, and in the basins of mountains and valleys, vast deposits of condensed moisture which are afterwards distributed, in a liquid

* The statements I have made, here and elsewhere, respecting the humidity of the soil in natural forests, have been, I understand, denied by Mr. T. Meehan, a distinguished American naturalist, in a paper which I have not seen. He is quoted as maintaining, among other highly questionable propositions, that no ground is "so dry in its subsoil as that which sustains a forest on its surface." In open, artificially planted woods, with a smooth and regular surface, and especially in forests where the fallen leaves and branches are anmually burnt or carried off, both the superficial and the subjacent strata may, under certain circumstances, become dry, but this rarely, if ever, happens in a wood of spontaneous growth, undeprived of the protection afforded by its own droppings, and of the natural accidents of surface which tend to the retention of water. See, on this point, a very able article by MIr. Henry Stewart, in the New York Tribune of November 25, 1873. 
form, during the season in which the atmosphere furnishes a slender supply of the beneficent fluid so indispensable to vegetablu and animal life.*

\section{Importance of Summer Rains.}

Babinet quotes a French proverb: "Summer rain wets nothing," and explains it by saying that at that season the rain-water is "almost entirely carried off by evaporation." "The rains of summer," he adds, "however abundant they may be, do not penetrate the soil beyond the depth of six or eight inches. In summer the evaporating power of the heat is five or six times greater than in winter, and this force is exerted by an atmosphere capable of containing five or six times as much vapor as in winter." "A stratum of snow which prevents evaporation [from the ground], causes almost all the water that composes it to filter into the earth, and forms a provision for fountains, wells and streams which could not be furnished by any quantity whatever of summer rain. This latter, useful to vegetation like the dew, neither penetrates the soil nor accumulates a store to supply the springs and to be given out again into the open air." $†$

* The accumulation of snow and ice upon the Alps and other mountainswhich often fills up valleys to the height of hundreds of feet-is due not only to the fall of congealed and crystallized vapor in the form of snow, to the condensation of atmospheric vapor on the surface of snow-fields and glaciers, and to a temperature which prevents the rapid melting of snow, but also to the well-known fact that, at least up to the height of 10,000 feet, rain and snow are more abundant on the mountains than at lower levels.

But another reason may be suggested for the increase of atmospheric humidity, and consequently of the precipitation of aqueous vapor on mountain chains. In discussing the influence of mountains on precipitation, meteorologists have generally treated the popular belief, that mountains "attract" to them clouds floating within a certain distance from them, as an ignorant prejudice, and they ascribe the appearance of clouds about high peaks solely to the condensation of the humidity of the air carried by atmospheric currents up the slopes of the mountain to a colder temperature. But if mountains do not really draw clouds and invisible vapors to them, they are an exception to the universal law of attraction. The attraction of the small Mount Shehallien was found sufficient to deflect from the perpendicular, by a measurable quantity, a plummet weighing but a few ounces. Why, then, should not greater masses attract to them volumes of vapor weighing many tons, and floating freely in the atmosphere within moderate distances of the mountains ?

† Etudes et Lectures, vol. vi., p. 118. The experiments of Johnstrup in the 
This conclusion, however applicable to the climate and to the soil of France, is too broadly stated to be received as a general truth; and in countries like the United States, where rain is comparatively rare during the winter and abundant during the summer half of the year, common observation shows that the quantity of water furnished by deep wells and by natural springs depends almost as much upon the rains of summer as upon those of the rest of the year, and consequently that a large portion of the rain of that season must find its way into strata too deep for the water to be wasted by evaporation.*

vicinity of Copenhagen, where the mean annual precipitation is $23 \frac{1}{2}$ inches, and where the evaporation must be less than in the warmer and drier atmosphere of France, form one of the most careful series of observations on this subject which I have met with. Johnstrup found that at the depth of a metre and a half ( 59 inches) the effects of rain and evaporation were almost imperceptible, and became completely so at a depth of from two to three metres $\left(6 \frac{1}{2}\right.$ to 10 feet). During the summer half of the year the evaporation rather exceeded the rainfall ; during the winter half the entire precipitation was absorbed by the soil and transmitted to lower strata by infiltration. The stratum between one metre and a half ( 59 inches) and the three metres (10 feet) from the surface, was then permanently in the condition of a saturated sponge, neither gaining nor losing humidity during the summer half of the year, but receiving from superior, and giving off to lower, strata an equal amount of moisture during the winter half.-JoHnstrur, Om Fugtighedens Bevagelse $i$ den naturlige Jordbund. Kjöbenhavn, 1866.

Dalton's experiments in the years 1796,1797 and 1798 appeared to show that the mean absorption of the downfall by the earth in those years was twentynine per cent.

Dickinson, employing the same apparatus for eight years, found the absorption to vary widely in different years, the mean being forty-seven per cent.

Charnock's experiments in two years show an absorption of from seventeen to twenty-seven per cent.

Risler, in experiments referred to on p. 187, ante, found that no water escaped from a parcel of ground not far from Geneva, thoroughly underdrained to the depth of $1^{\mathrm{m}} 20$, in the months of July, August, September, November and December, 1867, and but a very trifling quantity in June and October of the same year; in 1868, very little in May and September, and none in June, July and August. In 1867 , the total precipitation was 1066.84 millimetres; the evaporation, as measured by the difference between rainfall and drainage, 733.44 millimetres; in 1868, these quantities were 1032.86 and 755.74 millimetres respectively.

* According to observations at one hundred military stations in the United States, the precipitation ranges from three and a quarter inches at Fort Yuma in California to about seventy-two inches at Fort Pike, Louisiana, the mean 
Besides, even admitting that the water from summer rains is so completely evaporated as to contribute nothing directly to the supply of springs, it at least tends indirectly to maintain their flow, because it saturates in part the atmosphere, and at the same time prevents the heat of the sun from drying the earth to still greater depths, and from bringing within the reach of evaporation the moisture of strita which ordinarily do not feel the effects of solar irradiation.

\section{Influence of the Forest on the Flow of Springs.}

It is an almost unirersal and, I believe, well-founded opinion, that the protection afforded by the forest against the escape of moisture from its soil by superficial flow and evaporation insures the permanence and regularity of natural springs, not only within the limits of the wood, but at some distance beyond its borders, and thus contributes to the supply of an element essential to both vegetable and animal life. As the forests are destroyed, the springs which flowed from the woods, and, consequently, the greater watercourses fed by them, diminish both in number and in volume. This fact is so familiar throughout the American

for the entire territory, not including Aliaska, being thirty-six inches. In the different sections of the Union it is as follows:

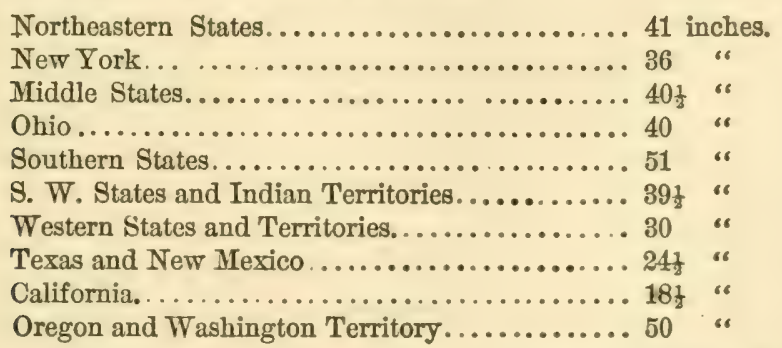

The mountainous regions, it appears, do not receive the greatest amount of precipitation. The average downfall of the Southern States bordering on the Atlantic and the Gulf of Mexico exceeds the mean of the whole United States, being no less than fifty-one inches, while on the Pacific coast it ranges from fifty to fifty-six inches.

As a general rule, it may be stated that at the stations on or near the seacoast the precipitation is greatest in the spring months, though there are several exceptions to this remark, and at a large majority of the stations the down. fall is considerably greater in the summer months than at any other season. 
States and the British Provinces, that there are few old residents of the interior of those districts who are not able to testify to its truth as a matter of personal observation. My own recollection suggests to me many instances of this sort, and I remember one case where a small mountain spring, which disappeared soon after the clearing of the ground where it rose, was recorered about trenty years ago, by simply allowing the bushes and young trees to grow up on a rocky knoll, not more than half an acre in extent, immediately above the spring. The ground was hardly shaded before the water reappeared, and it has ever since continued to flow without interruption. The hills in the Atlantic States formerly abounded in springs and brooks, but in many parts of these States which were cleared a generation or two ago, the hill pastures now suffer severely from drought, and in dry seasons furnish to cattle neither grass nor water.

Almost every treatise on the economy of the forest adduces facts in support of the rloctrine that the clearing of the woods tends to diminish the flow of springs and the humidity of the soil, and it might seem unnecessary to bring forward further evidence on this point.* But the subject is of too much practical importance and of too great philosophical interest to be summarily disposed of ; and it ought to be noticed that there is at least one case-that of some loose sandy soils which, as observed by Valles, $\dagger$ when bared of wood very rapidly absorb and transmit to lower strita the water they receive from the atmosphere-where the removal of the forest may increase the flow of springs at levels below it, by exposing to the rain and melted snow a surface

* "Why go so far for the proof of a phenomenon that is repeated every day under our own eyes, and of which every Parisian may convince himself, without venturing befond the Bois de Boulogne or the forest of Meudon ? Let him, after a few rainy days, pass along the Chevreuse road, which is bordered on the right by the wood, on the left by cultivated fields. The fall of water and the continuance of the rain have been the same on both sides; but the ditch on the side of the forest will remain filled with water proceeding from the infiltration through the wooded soil, long after the other, contiguous to the open ground, has performed its office of drainage and become dry. The ditch on the left will have discharged in a few hours a quantity of water, which the ditch on the right requires several days to receive and carry down to the valley."-Cuaví, Etudes, etc., pp. 53, 54.

† VALLìs, Études sur les Inondations, p. 472. 
more bibulous, and at the same time less retentive, than its original covering. Under such circumstances, the water of precipitation, which had formerly been absorbed by the vegetable mould? and retained until it was evaporated, might deseend through porous earth until it meets an impermeable stratnm, and then be conducted along it, until, finally, at the outcropping of this striatum, it bursts from a hillside as a running spring. But such instances are doubtless too rare to form a frequent or an important exception to the general law, because it is very seldom the case that such a soil as has just been supposed is covered by a layer of vegetable earth, thick enough to retain, until it is evaporated, all the rain that falls upon it, without imparting any water to the strata below it.

If we look at the point under discussion as purely a question of fact, to be determined by positive evidence and not by argument, the observations of Boussingault are, both in the circumstances they detail and in the weight to be attached to the testimony, among the most important yet recorded. The interest of the question will justify me in giving, nearly in Boussingault's orrue words, the facts and some of the remarks with which he accompanies the detail of them. "In many localities," he observes," "it has been thought that, within a certain number of years, a sensible diminution has been perceived in the volume of water of streams utilized as a motive-power; at other points, there are grounds for believing that rivers have become shallower, and the increasing breadth of the belt of pebbles along their banks seems to prove the loss of a part of their water; and, finally, abundant springs have almost dried up. These observations have been principally made in valleys bounded by high mountains, and it has been noticed that this diminution of the waters has immediately followed the epoch when the inhabitants have begun to destroy, unsparingly, the woods which were spread over the face of the land.

"And here lies the practical point of the question; for if it is once established that clearing diminishes the volume of streams, it is less important to know to what special cause this effect is due. The rivers which rise within the valley of Aragua, having

* Economie Rurale, t. ii., p. 730. 
no outlet to the ocean, form, by their anion, the Lake of Tacarigua or Valencia, having a length of about two leagues and a half [ $=7$ English miles].

"At the time of Humboldt's visit to the valley of Aragua, the inhabitants were struck by the gradual diminution which the lake had been undergoing for thirty year's. In fact, by comparing the descriptions given by historians with its actual condition, even making large allowance for exaggeration, it was easy to see that the level was considerably depressed. The facts spoke for themselves. Oriedo, who, towards the close of the sixteenth century, had often traversed the valley of Aragua, says positively that New Valencia was founded, in 1555 , at half a league from the Lake of Tacarigua; in 1800, Inmboldt found this city 5,260 mètres [ $=3 \frac{1}{2}$ English miles] from the shore.

"The aspect of the soil furnished new proofs. Many hillocks on the plain retain the name of islands, which they more justly bore when they were surrounded by water. The ground laid bare by the retreat of the lake was converted into admirable plantations; and buildings erected near the lake showed the sinking of the water from year to year. In 1796, new islands made their appearance. A fortress built in 1740 on the island of Cabrera, was now on a peninsula; and, finally, on two granitic islands, those of Cura and Cabo Blanco, Humboldt observed among the shrubs, some mètres above the water, fine sand filled with helicites.

"These clear and positive facts suggested numerous explanations, all assuming a subterranean outlet, which permitted the discharge of the water to the ocean. Humboldt disposed of these hypotheses, and did not hesitate to ascribe the diminution of the waters of the lake to the numerous clearings which had been made in the valley of Aragua within half a century."

Twenty-two years later, Boussingault explored the valley of Aragua. For some years previous, the inhabitants had observed that the waters of the lake were no longer retiring, but, on the contrary, were sensibly rising. Grounds, not long before occupied by plantations, were submerged. The islands of Nuevas A parecidas, which appeared above the surface in 1796, had again become shoals dangerous to navigation. Cabrera, a tongue of land on the north side of the valley, was so narrow that the least 
mse of the water completely inundated it. A protracted north wind sufficed to flood the road between Maracay and New Ta. lencia. The fears which the inhabitants of the shores had so long entertained wese reversed. Those who liad explained the dimimution of the lake by the supposition of subterramean channels were suspected of blocking them up, to prove themselves in the riglit.

I) uring the twenty-two years which had elitpsed, the valley of Aragual hat been the theatre of bloody struggles, and war had desolated these smiling lands and decimated their population. At the tirst cry of independence a great number of slaves found their liberty by enlisting under the banners of the new republic; the great plantations were abandoned, and the forest, which in the tropies so rapidly encroaches, had soon recovered a large proportion of the soil which man had wrested from it by more than a century of constant and painful labor.

Boussingault proceeds to state that two lakes near Ubate, in New Granada, had formed but one, a century before his risit; that the waters were gradually retiring, and the plantations extending over the abandoned bed; that, by inquiry of old hunters and by examination of parish records, he found that extensive clearings had been made and were still going on.

He found, also, that the length of the Lake of Fuquené, in the same valley, had, within two centuries, been reduced from ten leagues to one and a half, its brealth from three leagues to one. At the former period, the neighboring mountains were well wooded, but at the time of his visit they had been almost entirely stripped of their wood. Our author adds that other cases, similar to those already detailed, might be cited, and he proceeds to show, by several examples, that the waters of other lakes in the same regions, where the valleys had always been bare of wood or where the forests had not been disturbed, had undergone no change of level.

Boussingault further states that the lakes of Switzerland have sustained a depression of level since the too prevalent destruction of the woods, and arrives at the general conclusion that, "in countries where great clearings have been made, there has most probably been a diminution in the living waters which flow upon the surface of the ground." This conclusion he further supports by 
two examples: one, where a fine spring, at the foot of a wooded mountain in the Island of Ascension, dried up when the mountain was cleared, but reappeared when the wood was replanted; the other at Marmato, in the province of Popayan, where the streams employed to drive machinery were much diminished in volume, within two years after the clearing of the heights from which they derived their supplies. This latter is an interesting case, because, although the rain-ganges, established as soon as the decrease of water began to excite alarm, showed a greater fall of rain for the second year of observation than the first, yet there was no appreciable increase in the flow of the mill-streams. From these cases, the distinguished physicist infers that very restricted local clearings may diminish and even suppress springs and brooks, without any reduction in the total quantity of rain.

It will have been noticed that these observations, with the exception of the last two cases, do not bear directly upon the question of the diminution of springs by clearings, but they logically infer it from the subsidence of the natural reservoirs which springs once filled. There is, however, no want of positive evidence on this subject.

Marchand cites the following instances: "Before the felling of the woods within the last few years, in the valley of the Soulce, the Combe-ès-Mounin and the Little Valley, the Sorne furnished a regular and sufficient supply of water for the iron works of Unterwyl, which was almost unaffected by drought or by heary rains. The Sorne has now become a torrent, every shower occasions a flood, and after a few days of fine weather the current falls so low, that it has been necessary to change the water-wheels, because those of the old construction are no longer able to drive the machinery, and at last to introduce a steam-engine to prevent the stoppage of the works for want of water.

"When the factory of St. Ursanne was established, the river that furnished its power was abundant, and had, from time immemorial, sufficed for the machinery of a previous factory. Afterwards, the woods near its sources were cut. The supply of water fell off in consequence, the factory wanted water for half the year, and was at last obliged to stop altogether.

"The spring of Combefoulat, in the commune of Seleate, was 
well known as one of the best in the country; it was remarkably abundint, and sufficient, in the severest droughts, to supply all the fountains of the town; but as soon as considerable forests were felled in Combe-de-pré Martin and in the valley of Combefoulat, the fimous spring, which lies below these woods, has become a mere thread of water, and disappears altogether in times of drought.

"The spring of Varieux, which formerly supplied the castle of Pruntrut, lost more than half its water after the clearing of Varienx and Rougeoles. These woods have been replanted, the young trees are growing well, and, with the woods, the waters of the spring are increasing.

"The Dog Spring between Pruntrut and Bressancourt has entirely vanished since the surrounding forest-grounds were brought under cultivation.

"The Wolf Spring, in the commune of Soubey, furnishes a remarkable example of the influence of the woods upon fountains. A few years ago this spring did not exist. At the place where it now rises, a small thread of water was observed after very long rains, but the stream disappeared with the rain. The spot is in the middle of a very steep pasture inclining to the south. Eighty years ago, the owner of the land, perceiving that young firs were shooting up in the upper part of it, determined to let them grow, and they soon formed a flourishing grove. As soon as they were well grown, a fine spring appeared in place of the occasional rill, and furnished abundant water in the longest droughts. For forty or fifty years this spring was considered the best in the Clos du Doubs. A few years since, the grove was felled, and the ground turned again to a pasture. The spring disappeared with the wood, and is now as dry as it was ninety years ago." *

Siemoni gives the following very important and remarkable facts from his own personal observation:

"In a rocky nook near the crest of a mountain in the Tuscan Apennines, there flowed a clear, cool aud perennial fountain, uniting three distinct springs in a single current. The ancient beeches around and particularly above the springs were felled. On the disappearance of the rood, the spriugs ceased to flow, 
except in a thread of water in rainy weather, greatly inferior in quality to that of the old fountain. The beeches were succeeded by firs, and as soon as they had grom sufficiently to shade the soil, the springs began again to flow, and they gradually returned to their former abundance and quality." *

This and the next preceding case are of great importance both as to the action of the wood in maintaining springs, and particularly as tending to prove that erergreens do not exercise the desiccative influence ascribed to them in France. The latter instance shows, too, that the protective influence of the wood exteuds far below the surface, for the quality of the water was determined, no doubt, by the depth from which it was drawn. The slender occasional supply after the beches were cut, was rain-water which soaked through the superficial humus and oozed out at the old orifices, carrying the taste and temperature of the vegetable soil with it; the more abundant and grateful water which flowed before the becches were cut, and after the firs were well grown, came from a deeper source and had been purified, and cooled to the mean temperature of the locality, by filtering through strata of mineral earth.

"The influence of the forest on springs," says Hummel, "is strikingly shown by an instance at Heilbronn. The woods on the hills surrounding the town are cut in regular succession every twentieth year. As the amual cuttings approach a certain point, the springs yield less water, some of them none at all; but as the young growth shoots up, they flow more and more freely, and at length bubble up again in all their original abundance." +

Dr. Piper states the following case: "Within about half a mile of my residence there is a poud upon which mills have been standing for a long time, dating back, I believe, to the first settlement of the town. These have been kept in constant operation until within some twenty or thirty years, when the supply of water began to fail. The pond owes its existence to a stream that has it source in the hills which stretch some miles to the south. Within the time mentioned, these hills, which

* Manuale d' Arte Forestale, $2^{\text {da }}$ edizione, p. 492.

†Physiche Geographie, p. 32. 
were elothed with a dense forest, have been almost entirely stripped of trees; and to the wonder and loss of the mill-owners, the water in the pond has failed, except in the season of freshets; and, what was never heard of before, the stream itielf hats been entirely dry. Within the last ten yenrs a new growth of wood hats sprumg up on must of the land formerly occupied by the old forest; and now the water runs through the year, notwithstanding the great droughts of the last few years, going back from 1856."

Dr. Piper quotes from a letter of William C. Bryant the fol. lowing remarks: "It is a common observation that our summers are beeoning drier and our streams smaller. Take the Cuyahoga as an illustration. Fifty year's ago large barges loaded with goods went up and down that river, and one of the vessels engaged in the battle of Lake Erie, in which the gallant Perry was victorious, was built at Old Portage, six miles north of Albion, and floated down to the lake. Now, in an ordinary stage of the water, a canoe or skiff can hardly pass down the stream. Many a boat of fifty tons burden has been built and loaded in the Tuscaramas, at New Portage, and sailed to New Orleans without breaking bulk. Now, the river hardly affords a supply of water at New Portage for the canal. The same may be said of other streams-they are drying up. And from the same cause-the destruction of our forests-our summers are growing drier and our winters colder." *

No observer has more carefully studied the influence of the forest upon the flow of the waters, or reasoned more ably on the ascertained phenomena, than Cantegril. The facts presented in the following ease, communicated by him to the dini des Sciences for December, 1859, are as nearly conclusive as any single instance well can be:

"In the territory of the commune of Labruguiere there is a forest of $1,83 t$ hectares [ 4,530 acres], known by the name of the Forest of Montaut, and belonging to that commune. It extends along the northern slope of the Black Mountains. The soil is granitic, the maximum altitude 1,243 metres $[4,140$ feet], and the inclination ranges between 15 and 60 to 100 . 
"A small current of water, the brook of Caunan, takes its rise in this forest, and receives the waters of two-thirds of its surface At the lower extremity of the wood and on the stream are several fulleries, each requiring a force of eight horse-power to drive the water-wheels which work the stampers. The commune of Labruguière had been for a long time famous for its opposition to forest laws. Trespasses and abuses of the right of pasturage had converted the wood into an immense waste, so that this vast property now scarcely sufficed to pay the expense of protecting it, and to furnish the inhabitants with a meagre supply of fuel. While the forest was thus ruined, and the soil thus bared, the water, after every abundant rain, made an eruption into the valley, bringing down a great quantity of pebbles which still clog the current of the Caunan. The violence of the floods was sometimes such that they were obliged to stop the machinery for some time. During the summer another inconvenience was felt. If the dry weather continued a little longer than usual, the delivery of water became insignificant. Each fullery could for the most part only employ a single set of stampers, and it was not unusual to see the work entirely suspended.

"After 1840, the municipal anthority succeeded in enlightening the population as to their true interests. Protected by a more watchful supervision, aided by well-managed replantation, the forest has continued to improve to the present day. In proportion to the restoration of the forest, the condition of the manufactories has become less and less precarious, and the action of the water is completely modified. For example, sudden and violent floods, which formerly made it necessary to stop the machinery, no longer occur. There is no increase in the delivery until six or eight hours after the beginning of the rain; the floods follow a regular progression till they reach their maximum, and decrease in the same manner. Finally, the fulleries are no longer forced to suspend work in summer; the water is always sufficiently abundant to allow the employment of two sets of stampers at least, and often even of three.

"This example is remarkable in this respect, that, all other circumstances having remained the same, the changes in the action of the stream can be attributed only to the restoration of the forest-changes which may be thus summed up: diminu- 
tion of flood-water during rains-increase of delivery at other seasons."

Beequerel and other European writers adduce numerous other cases where the destruction of forests has caused the disappearance of springs, a diminution in the volume of rivers, and a lowering of the level of lakes; in fact, the evidence in support of the doctrine I lave been maintaining on this subject seems to be as conclusive as the nature of the case admits.* We can not, it is true, arrive at the same certainty and precision of result in these inquiries as in those branches of physical research where exact quantitative appreciation is possible, and we must content ourselves with probabilities and approximatious. We can not positively affirm that the precipitation in a given locality is increased by the presence, or lessened by the destruction, of the forest, and from our ignorance of the subterranean circulation of the waters, we can not predict, with certainty, the drying up of a particular spring as a consequence of the felling of the wood which shelters it; but the general truth, that the flow of springs and the normal volume of rivers rise and fall with the extension and the diminution of the woods where they originate and through which they run, is as well established as any proposition in the science of physical geography. $\dagger$

* See, in the Revue des Eaux et Forêts for April, 1867, an article entitled De l'influence des Forêts sur le R'́gime des Eaux, and the papers in previous numbers of the same journal therein referred to.

† Some years ago it was popularly believed that the volume of the Mississippi, like that of the Volga and other rivers of the Eastern Hemisphere, was diminished by the increased evaporation from its basin and the drying up of springs, in consequence of the felling of the forests in the vicinity of the sources of its eastern affluents. The boatmen of this great river and other intelligent observers now assure us, however, that the mean and normal level of the Mississippi has risen within a few years, and that in consequence the river is navigable at low water for boats of greater draught, and at higher points in its course, than was the case twenty-five years ago.

This supposed increase of volume has been attributed by some to the recent re-wooding of the prairies, but the plantations thus far made are not yet sufliciently extensive to produce an appreciable effect of this nature; and besides, while young trees have covered some of the prairies, the destruction of the forest has been continued perhaps in a greater proportion in other parts of the basin of the river. A more plausible opinion is that the substitution of ground that is cultivated, and consequently spongy and absorbent, for the 


\section{Of the converse proposition, namely, that the planting of new} forests gives rise to new springs and restores the regular flow of rivers, I find less of positive proof, however probable it may be that such effects would follow.* A reason for the want of evi-

natural soil of the prairies, has fumished a reservoir for the rains which are absorbed by the earth and carried gradually to the river by subterranean flow, instead of running off rapidly from the surface, or, as is more probable, instead of evapolating or being taken up by the vigorous herbaceous vegetation which covers the natural prairie.

A phenomenou so contrary to common experience, as would be a permanent increase in the waters of a great river, will not be accepted without the most convincing proofs. The present greater ficility of navigation may be attributed to improvements in the model of the boats, to the removing of sandbanks and other impediments to the flow of the waters, or to the confining of these waters in a narrower channel by extending the embankments of the river, or to yet other causes.

So remarkable a change could not have escaped the notice of Humphreys and Abbott, whose most able libors comprise the years 1850-1861, had it occurred during that period or at any former time within the linowledge of the many observers they consulted; but no such fact is noticed in their exhaustive report. Howerer, even if an increase in the volume of the Mississippi, for a period of ten or twenty years, were certain, it would still be premature to consider this increase as normal and coustant, since it might very well be produced by causes yet unknown and analogous to those which influence the mysterious advance and retreat of those $A$ lpine ice-rivers, the glaciers. Among such causes, we may suppose a long series of rainy seasous in regions where important tributaries have their far-off and almost unknown sources; and with no less probability, we may conceive of the opening of communications with great subterranean reservoirs, which may from jear to year empty large quantities of water into the bed of the stream ; or the closing up of orifices through which a considerable portion of the water of the river once made its way for the supply of such reservoirs.-See upon this point, Chap. IV., Of Subterranean Waters; post.

* According to the Report of the Department of Agriculture for February, 1872 , it is thought in the Far West that the young plantations have already influenced the watercourses in that region, and it is alleged that ancient riverbecls, never known to contain water since the settlement of the country, have begun to flow since these plantations were commenced. See also Harden, Report on Geological Surrey of Wyoming, 1870, pp. $10 t$ and 455 ; also HaxDEx, U. S. Survey of Colorado for 18\%4, p. 265 ; and BRyant, Forest Trees, 1871, chap. iv.

In the Toyage autour du Monde of the Comte de Beauvoir, chap. x., this passage occurs: Dr. Miuller, Director of the Botanic Garden at Melbourne, "has distributed through the interior of Australia millions of seedling trees from his nurseries. Small rivulets are soon formed under the young wood; the results are superb, and the observation of every successive year confirms 
dence on the subject may be, that, under ordinary circumstances, the process of conversion of bare ground to soil with a wellwooded surface is so gradual and slow, and the time required for a fair experiment is consequently so long, that many changes produced by the action of the new geographical element escape the notice and the memory of ordinary observers. The growth of a forest, inchuling the formation of a thick stratum of regetable mould beneath it, is the work of a generation, its restruction may be acemplished in a day; and hence, while the results of the one process may for a considerable time be doubtful, if not imperepptible, those of the other are immediate and readily apprecialle. Fortunately, the plantation of a wood produces other bencficial consequences which are both sooner realized and more easily estimated; and though he who drops the seed is sowing for a future generation as well as for his own, the planter of a grove may hope himself to reap a fair return for his expenditure and his labor.

\section{Influence of the Forest on Inundations and Torrents.}

Inasmuch as it is not jet proved that the forests augment or diminish the precipitation in the regions they principally cover, we can not positively affirm that their presence or absence increases or lessens the total volume of the water annually lelivered by great rivers or by mountain torrents. It is nevertheless certain that they exercise an action on the discharge of the water of rain and suow into the valleys, ravines and other depresions of the surface, where it is gathered into brooks and finally larger currents, and consequently they must influence the character of floods, both in rivers and in torrents. For this reason, river inundations and the devastations of torrents, and the geographical effects resulting from them, so far as they are occasioned or modified by the action of forests or of the destruction of the woods, may properly be discussed in this chapter, though they might scem otherwise to belong more appropriately to another division of this work.

them. On bare soils he has created, at more than a hundred points, forests and watercourses." Inquiring, however, of intelligent persons long rosident in Australia, I find no confirmation of this statement. 
Besides the climatic question, which I have already sufficiently discussed, and the obvious inconveniences of a scanty supply of charcoal, of fuel, and of timber for architectural and naval construction, and for the thousand other uses to which wood is applied in rural and domestic economy and in the various industrial processes of civilized life, the attention of European foresters and public economists has been specially drawn to three points, namely: the influence of the forests on the permanence and regular flow of springs or natural fountains; on inundations by the overflow of rivers; and on the abrasion of soil and the transportation of earth, gravel, pebbles, and even of considerable masses of rock, from higher to lower levels, by torrents. There are, however, connected with this general subject, several other topics of minor or strictly local interest, or of less certain character, which I shall have occasion more fully to speak of hereafter.

The first of these three principal subjects-the influence of the woods on springs and other living waters-has been already considered; and if the facts stated in that discussion are well established, and the conclusions I have drawn from them are logically sound, it would seem to follow, as a necessary corollary, that the action of the forest is as important in diminishing the frequency and violence of river-floods as in securing the permanence and equability of natural fountains; for any cause which promotes the absorption and accumulation of the water of precipitation by the superficial strata of the soil, to be slowly given out by infiltration and percolation, must, by preventing the rapid flow of surfacewater into the natural channels of drainage, tend to check the sudden rise of rivers, and, consequently, the overflow of their banks, which constitutes what is called inumdation.

The surface of a forest, in its natural condition, can never pour forth such deluges of water as flow from cultivated soil. Humus, or vegetable mould, is capable of absorbing almost twice its own weight of water. The soil in a forest of deciduous foliage is composed of humus, more or less unmixed, to the depth of sereral inches, sometimes even of feet, and this stratum is usually able to unbibe all the water possibly resulting from the snow which at any one time covers, or the rain which in any one shower falls upon it. But the regetable mould does not cease to absorb water when it becomes saturated, for it then gives off a portion of its 
moisture to the mineral earth below, and thus is ready to receiro a new supply; and, besides, the bed of leaves not yet converterl to monld takes up and retains a very considerable proportion of snow-water as well as of rain.

The stems of trees, too, and of underwood, the trunks and stumps and roots of fallen timber, the mosses and fungi and the numerous inequalities of the ground observed in all forests, oppose a mechanical resistance to the flow of water over the surface, which sensibly retards the rapidity of its descent down declivities, and diverts and divides streams which may have already aceumulated from smaller threads of water.*

* In a letter addressed to the Minister of Public Works, after the terrible in. undations of 1857 , the late Emperor of France thus happily expressed himself : "Before we seek the remedy for an evil, we inquire into its cause. Whence come the sudden floods of our rivers? From the water which falls on the mountains, not from that which falls on the plains. The waters which fall on our fields produce but few rivulets, but those which fall on our roofs and are collected in the gutters, form small streams at once. Now, the roofs are mountains-the gutters are valleys."

"To continue the comparison," observes D'Héricourt, "roofs are smooth and impermeable, and the rain-water pours rapidly off from their surfaces; but this rapidity of flow would be greatly diminished if the roofs were carpeted with mosses and grasses; more still, if they were covered with dry leaves, little shrubs, strewn branches, and other impediments-in short, if they were wooded."-Annales Forestieres, Dec., 1857, p. 311.

The mosses and fungi play a more important part in regulating the humidity of the air and of the soil than writers on the forest have usually assigned to them. They perish with the trees they grow on; but, in many situations, nature provides a compensation for the tree-mosses and fungi, in ground species, which, on cold soils, especially those with a northern exposure, spring up abundantly both before the woods are felled, and when the land is cleared and employed for pasturage or is deserted. These humble plants discharge a portion of the functions appropriated to the wood, and while they render the soil of improved lands much less fit for agricultural use, they, at the same time, prepare it for the growth of a new harvest of trees, when the infertility they produce shall have driven man to abandon it and suffer it to relapse into the hands of nature.

In flourishing natural forests, when the ground is not too moist to admit of a dense growth of trees, the soil is generally so thickly covered with leaves that there is little room for ground mosses and mushrooms. In the more open artificial woods of Europe these forms of vegetation, as well as many more attractive plants, are more frequent than in the native groves of Imerica. See, on cryptogamic and other wood plants, Rossmïsslen, Der Wall, pp. :3: et seq., and on the importance of such vegetables in checking the flow of water, MENcotтr, Idraulica Fisica e Sperimentale, chapters xvi. and xvii. No writer 
The value of the forest as a mechanical check to a too rapid discharge of rain-water was exemplified in numerous instances in the great floods of 1866 and 1868, in France and Switzerland, and I refer to the observations made on those occasions as of special importance, because no previous inundations in those countries had been so carefully wateheã and so well described by competent investigators. In the French Department of Lozère, which was anong those most severely injured by the inundation of 1866 -an inmulation caused by diluvial rains, not by melted snowit was everywhere remarked that "grounds covered with wood sustained no damage even on the steepest slopes, while in cleared and cultivated fields the very soil was washed away and the rocks laid bare by the pouring rain." *

The Italian journals of the day state that the province of Brescia and a part of that of Bergamo, which have heretofore been exposed to enorinous injury, after every heavy rain, from floods of the four principal streams which traverse them, in a great degree escaped damage in the terrible inundation of October, 1872 , and their immunity is ascribed to the forestal improvements exocuted by the former province, within ten or twelve years, in the $\mathrm{T}$ al Camonica and in the upper basins of the other rivers which drain that territory. Similar facts were noticed in the extraordinary floods of September and October, 1868, in the valley of the Upper Rhine, and Coaz makes the interesting observation that not even dense greensward was so efficient a protection to the earth as trees, because the water soaked through the sod and burst it up by hydrostatic pressure. $†$

known to me has so well illustrated this function of forest vegetation as Mengotti, though both he and Rossmässler ascribe to plants a power of absorbing water from the atmosphere which they do not possess, or rather can only rarely exercise.

* See, for other like observations, an article entitled Le Reboisement et les Inondations, in the Revue des Eaux et Forêts of September, 1868.

† Die Hochroasser in 1868 im Bündnerischen Rheingebiet, pp. 12, 68.

Observations of Forster, cited by Cézanne from the Annales Forestières for 1859 , p. 358, are not less important than those adduced in the text. The field of these observations was a slope of $45^{\circ}$ divided into three sections, one luxuriantly wooded from summit to base with oak and beech, one completely cleared through its whole extent, and one cleared in its upper portion, but retaining 
The importance of the mechanical resistance of the wood to the flow of water over the surface has, however, been exaggerated by some writers. Rain-water is generally absorled by the forest-soil as fast as it falls, and it is only in extreme cases that it gathers itself into a superficial sheet or current overflowing the ground. There is, nevertheless, besides the absorbent power of the soil, a very considerable mechanical resistance to the transmission of water beneuth the surface through and along the superior strata of the gromd. This resistance is exerted by the roots, which both convey the water along their surface downwirds, and oppose a closely wattled barrier to its descent along the slope of the permeable strata which have absorbed it.*

Rivers fed by springs and shaded by woods are comparatively uniform in volume, in temperature, and in chemical composition. $\nmid$

a wooded belt for a quarter of the height of the slope, which was from 1,300 to 1,800 feet above the brook at its foot.

In the first section, comprising six-sevenths of the whole surface, the rains had not produced a single ravine; in the second, occupying about a tenth of the ground, were three ravines, increasing in width from the summit to the valley beneath, where they had, all together, a cross-section of 600 square feet; in the third section, of about the same extent as the second, four ravines had been formed, widening from the crest of the slope to the belt of wood, where they gradually narrowed and finally disappeared.

For important observations to the same purpose, see Marchand, Les Torrents dès Alpes, in Revue des Eaux et Forêts for September, 1871.

* In a valuable report on a bill for compelling the sale of waste communal lands, now pending in the Parliament of Italy, Senator Torelli, an eminent man of science, calculates that four-fifths of the precipitation in the forest are absorbed by the soil, or detained by the obstructions of the surface, only onefifth being delivered to the rivers rapidly enough to create danger of floods, while in open grounds, in heavy rains, the proportions are reversed. Supposing a raiufall of four inches, an area measuring 100,000 acres, or a little more than four American townships, would receive 53, 777,777 cubic yards of water. Of this quantity it would retain, or rather detain, if wooded, 41,000,000 yards ; if bare, only $11,000,000$. The difference of discharge from wooded and unwooded soils is perhaps exaggerated in Col. Torelli's report, but there is no doubt that in very many cases it is great enough to prevent, or to cause, destructive inundations.

+ Dumont gives an interesting extract from the Misopogon of the Emperor Julian, showing that, in the fourth century, the Seine-the level of which now varies to the extent of thirty feet between extreme high and extreme low water mark-was almost wholly exempt from inundations, and flowed with a uniform current through the whole year. "Ego olim eram in hibernis apud ca- 
Their banks are little abraded, nor are their courses much ob. structed by fallen timber, or by earth and gravel washed down from the highlands. Their channels are subject only to slow and gradual changes, and they carry down to the lakes and the sea no accumulation of sand or silt to fill up their outlets, and, by raising their beds, to force them to spread over the low grounds near their mouth.*

\section{Causes of Inundations.}

The immediate cause of river inundations is the flow of superficial and subterranean waters into the beds of rivers faster than those channels can discharge them. The insufficiency of the channels is occasioned partly by their narrowness and partly by obstructions to their currents, the most frequent of which is the deposit of sand, gravel and pebbles in their beds by torrential tributaries during the floods. $\dagger$

ram Lutetiam, [sic] enim Galli Parisiorum oppidum appellant, qux insula est non magna, in fluvio sita, qui eam omni ex parte cingit. Pontes sublicii utrinque ad eam ferunt, raròque fluvius minuitur ac crescit ; sed qualis æstate, talis esse solet hyeme."-Des Tracaux Publics dans leur Rapports arec l'Agriculture, p. 361 , note.

As Julian was six years in Gaul, and his principal residence was at Paris, his testimony as to the habitual condition of the Seine, at a period when the provinces where its sources originate were well wooded, is very valuable.

* Forest rivers seldom if ever form large sedimentary deposits at their points of discharge into lakes or larger streams, such accumulations beginning, or at least advancing far more rapidly, after the valleys are cleared.

$\uparrow$ The extent of the overflow and the violence of the current in river-floods are much affected by the amount of sedimentary matter let fall in their channels by their affluents, which have usually a swifter flow than the main stream, and, consequently, deposit more or less of their transported material when they join its more slowly-moving waters. Such deposits constitute barriers which at first check the current and raise its level, and, of course, its violence at lower points is augmented, both by increased volume and by the solid material it carries with it, when it acquires force enough to sweep away the obstruction.-RIsLen, Sur l'Influence des Forêts sur les cours d'eau, in Reoue des Eaux et Forêts, 10th January, 1870.

In the flood of 1868 the torrent Illgraben, which had formerly spread its wa. ter and its sediment over the surface of a vast cone of dejection, having been forced, by the injudicious confinement of its current to a single channel, to discharge itself more directly into the Rhone, carried down a quantity of gravel, sand and mud, sufficient to dam that river for a whole hour, and in the same 
In accordance with the usual economy of nature, we should presume that she had everywhere provided the means of discharging, without disturbunee of her general arrangements or abnormal destruction of her products, the precipitation which she sheds upon the face of the earth. Observation confirms this presumption, at least in the countries to which I confine my inquiries; for, su far as we know the primitive conditions of the regions brought under human occupation within the historical period, it appear's that the overflow of river-banks was much less frequent and destructive than at the present day, or, at least, that rivers rose and fell less sudhenly, before man had removed the natural checks to the too rapid drainage of the basins in which their tributaries originate. The aflluents of rivers draining wooded basins generally transport, and of course let fall, little or no sediment, aud hence in such regions the special obstruction to the currents of watereourses to which I have just alluded does not occur. The banks of the rivers and smaller streams in the North American colonies were formerly little abraded by the currents.* Even now the trees come down almost to the water's edge along the rivers, in the larger forests of the United States, and the surface of the streams seems liable to no great change in level or in rapidity of current. $\uparrow$

great inundation the flow of the Rhine at Thusis was completely arrested for twenty minutes by a similar discharge from the Nolla. See p. 218, post, note. Of course, when the obstructions yielded to the pressure of the accumulated water, the damage to the country below was far greater than it would hare been had the currents of the rivers not been thus obstructed.-MARCHAND, Les Torrents des Alpes, in Revue des Eaux et Forêts, Sept. 1871.

* In primitive countries, running streams are very generally fringed by groves, for almost every river is, as Pliny, Nat. Hist., v. 10, says of the Upper Nile, an opifex silvarum, or, to use the quaint and picturesque language of Holland's translation, "makes shade of woods as he goeth."

$\dagger$ A valuable memoir by G. Doni, in the Rivista Forestale for October, 1865, p. 438 , is one of the best illustrations I can cite of the influence of forests in regulating and equalizing the flow of running water, and of the comparative action of watercourses which drain wooded valleys and valleys bared of trees, with regard to the erosion of their banks and the transportation of sediment.

"The Sestajone," remarks this writer, "and the Lima, are two considerable torrents which collect the waters of two great valleys of the Tuscan Apen. nines, and empty them into the Serchio. At the junction of these two tor. rents, from which point the combined current takes the name of Lima, a cu. 


\section{Inundations in Winter.}

In the Northern United States, although inundations are not very unfrequently produced by heary rains in the height of summer, it will be found generally true that the most rapid rise of the waters, and, of course, the most destructive "freshets," as they are called in America, are occasioned by the sudden dissolution of the snow before the open ground is thawed in the spring. It frequently happens that a powerful thaw sets in after a long period of frost, and the snow which had been months in accumulating is dissolved and carried off in a few hours. When the snow is deep, it, to use a popular expression, " takes the frost out of the ground" in the woods, and, if it lies long enough, in the fields also. But the heaviest suows usually fall after midwinter, and are succeeded by warm rains or sunshine, which dissolve the snow on the cleared land before it has had time to act upon the frost-bound soil beneath it. In this case, the snow in the woods is absorbed as fast as it melts, by the soil it has protected from

rious phenomenon is observed, which is in part easily explained. In rainy weather the waters of the Sestajone are in volume only about one-half those of the Lima, and while the current of the Lima is turbid and muddy, that of the Sestajone appears limpid and I might almost say drinkable. In clear weather, on the contrary, the waters of the Sestajone are abundant and about double those of the Lima. Now the extent of the two valleys is nearly equal, but the Sestajone winds down between banks clothed with firs and beeches, while the Lima flows through a valley that has been stripped of trees and in great part brought under cultivation."

The Sestajone and the Lima are neither of them what is technically termed a torrent-a name strictly applicable only to streams whose current is not derived from springs and perennial, but is the temporary effect of a sudden accumulation of water from heavy rains or from a rapid melting of the snows, while their beds are dry, or nearly so, at other times. The Lima, however, in a large proportion of its course, has the erosive character of a torrent, for the amount of sediment which it carries down, even when it is only moderately swollen by rains, surpasses almost everything of the kind which I have observed, under analogous circumstances, in Italy.

Still more striking is the contrast in the régine of the Saint-Phalez and the Combe-d'Yeuse in the department of Vaucluse, the latter of which became subject to the most violent torrential floods after the destruction of the woods of its basin between 1823 and 1833 , but has now been completely subdued, and its waters brought to a peaceful flow, by replanting its valley. See Labusstère, Revue Agric. et Forestiere de Provence, 1866, and Revue des Eaux et Forêts, 1866. 
freezing, and does not materially contribute to swell the current of the rivers. If the mild weather, in which great snow-storms usually oceur, does not continue and become a regular thaw, it is almost sure to be followed by drifting winds, and the inequality with which they distribute the snow over the eleared ground leaves the rilges of the surface-soil comparatively bare, while the depresions are often filled with drifts to the height of many feet. The knolls become frozen to a great depth ; succeeding partial thaws melt the surface-snow, and the water runs down into the furrows of ploughed fields, and other artificial and matural hollows, and then often freezes to solid ice. In this state of things, almost the entire surface of the cleared land is impervious to water, and from the absence of trees and the general smoothness of the ground, it offers little mechanical resistance to superficial currents. If, under these circumstances, warm weather accompanied by rain occurs, the rain and melted snow are swiftly hurried to the bottom of the valleys and gathered to raging torrents.

It ought further to be considered that, though the lighter ploughed soils readily imbibe a great deal of water, yet grass-lands, and all the heary and tenacious earths, absorb it in much smaller quantities, and less rapidly, than does the vegetable mould of the forest. Pasture, meadow, and clayey soils, taken together, greatly predominate over sandy ploughed fields, in all large agricultural districts, and hence, even if, in the case we are supposing, the open ground chance to have been thawed before the melting of the snow which covers it, it is already saturated with moisture, or very soon becomes so, and, of course, can not relieve the pressure by absorbing more water. The consequence is, that the face of the country is suddenly flooded with a quantity of melted snow and rain equivalent to a fall of six or eight inches of the latter, or even more. This runs unobstructed to rivers often still-bound with thick ice, and thus inundations of a fearfully devastating character are produced. The ice bursts, from the hydrostatic pressure from below, or is violently torn up by the current, and is swept by the impetuous stream, in large masses and with resistless fury, against banks, bridges, dams, and mills erected near them. The bark of the trees along the rivers is often abraded, at a height of many feet above the ordinary water-level, by cakes of floating ice, which are at last stranded by the receding flood on 
meadow or ploughland, to delay, by their chilling influence, the advent of the tardy spring.

Another important effect of the removal of the forest shelter in cold climates may be noticed here. We have observed that the ground in the woods either does not freeze at all, or that if frozen it is thawed by the first consilcrable snow-fill. On the contrary, the open ground is usually still frozen when the first spring freshet occurs, but is soon thatred by the warm rain and melting snow. Nothing more efrectually disintegrates a cohesive soil than freezing and thawing, and the surface of earth which has just undergone those processes is more subject to erosion by running water than under any other circumstances. Hence more vegetable mould is washed away from cultivated grounds, in such climates, by the spring floods than by the heaviest rain at other seasons.

In the warm climates of Southern Europe, as I have already said, the functions of the forest, so far as the disposal of the water of precipitation is concerned, are essentially the same at all seasons, and are analogous to those which it performs in the Northern United States in summer. Hence, in the former countries, the winter floods have not the characteristies which mark them in the latter, nor is the conservative influence of the woods in winter relatively so important, though it is equally unquestionable.

If the summer floods in the United States are attended with less pecuniary damage than those of the Loire and other rivers of France, the Po and its tributaries in Italy, the Emme and her sister torrents which devastate the valleys of Switzerland, it is partly because the banks of American rivers are not yet lined with towns, their shores and the bottoms which skirt them not yet covered with improvements whose cost is counted by millions, and, consequently, a smaller amount of property is exposed to injury by inundation. But the comparative exemption of the American people from the terrible calamities which the overflow of rivers has brought on some of the fairest portions of the Old World, is, in a still greater degree, to be ascribed to the fact that, with all our thoughtless improvidence, we have not yet bared all the sources of our streams, not yet overthrown all the barriers which nature has erected to restrain her own destructive energies. Let us be wise in time, and profit by the errors of our older brethren! The influence of the forest in preventing inundations has been 
very generally recognized, both as a theoretical inference and as a fact of observation; but the eminent engineer Belgrand and his commentator Vallès have deduced an opposite result from various facts of experience and from scientific considerations. They contend that the superficial drainage is more regular from cleared than from wooded ground, and that elenring diminishes rather than augments the intensity of inundations." Neither of these conclusions appear to be warranted by their data or their reasoning, and they rest partly upon facts, which, truly interpreted, are not inconsistent with the receired opinions on these subjects, partly upon assumptions which are contradicted by experience. Two of these latter are, first, that the fallen leaves in the forest constitute an impermeable covering of the soil over, not through, which the water of rains and of melting snows flows off, and secondly, that the roots of trees penetrate and choke up the fissures in the rocks, so as to imperle the passage of water through channels which nature has provided for its descent to lower strata.

As to the first of these, we may appeal to familiar facts within the personal knowledge of every man acquainted with the operations of sylvan nature. Rain-water never, except in very trifling quantities, flows over the leaves in the woods in summer or autumn. Water runs over them only in the spring, in the rare cases when they have been pressed down smoothly and compactly by the weight of the snow-a state in which they remain only until they are dry, when shrinkage and the action of the wind soon roughen the surface so as effectually to stop, by absorption, all flow of water. I have observed that when a sudden frost succeeds a thaw at the close of the winter, after the snow has principally disappeared, the water in and between the layers of leares sometimes freezes into a solid crust, which allows the flow of water over it. But this occurs only in depressions and on a very small scale; and the ice thus formed is so soon dissolved that no sensible effect is produced on the escape of water from the general surface.

As to the influence of roots upon drainage, we have seen that

* Belgrand's observations are confined to forests of deciduous trees, and, while he maintains the above opinions, he still adnuts the rast utility of the woods in preventing wvaste of earth.-La Seine, 1872, p. 405. 
there is no doubt that they, independently of their action as absorbents, mechanically promote it. Not only does the water of the soil follow them downwards, but their swelling growth powerfully tends to enlarge, not to obstruct, the crevices of rock into which they enter; and as the fissures in rocks are longitudinal, not mere circular orifices, every line of additional width gained by the growth of roots within them increases the area of the crevice in proportion to its lengtl. Consequently, the widening of a fissure to the extent of one inch might give an additional drainage equal to a square foot of open tubing.

The observations and reasonings of Belgrand and Vallès, though their conclusions have not been accepted by many, are very important in one point of view. These writers insist much on the necessity of taking account, in estimating the relations between precipitation and evaporation, of the abstraction of water from the surface and surface-currents, by absorption and infiltration-an element unquestionably of great value, but hitherto much neglected by meteorological inquirers, who have very often reasoned as if the surface-earth were either impermeable to water or already saturated with it; whereas, in fact, it is a sponge, always imbibing humidity and always giving it off, not by evaporation only, but by infiltration and percolation.

The remarkable historical notices of inundations in France in the Middle Ages, collected by Champion," are considered by many as furnishing proof, that when that country was much more generally covered with wood than it now is, destructive inundations of the French rivers were not less frequent than they are in modern days. But this evidence is subject to this among other objec. tions: we know, it is true, that the forests of certain departments of France were anciently much more extensive than at the present day; but we know also that in many portions of that country the soil has been bared of its forests, and then, in consequence of the depopulation of great provinces, left to reclothe itself spontaneously with trees, many times during the historic period; and our acquaintance with the forest topography of ancient Gaul

* Les Inondations en France depuis le VIe siècle jusqu'à nos jours. 6 vols. 8vo. Paris, 1858-64. See a very able review of this learned and important work by Prof. Messedaglia, read before the Academy of Agriculture at $\mathrm{Ve}$ rona in 1864 . 
or of medixval France is neither sufficiently extensive nor sufficiently miunte to permit us to say, with eertainty, that the sources of this or that particular river were more or less sheltered by wood at any given time, ancient or medixval, than at present.* I say the sources of the rivers, because the floods of great rivers are occasioned more by heary rains and snows which fall in the more elevated regions around the primal springs, than by precipitation in the main valleys or on the plains bordering on the lower course.

The destructive effects of inundations, considered simply as a mechanical power by which life is endangered, crops destroyed, and the artificial constructions of man overthrown, are very terrible. Thus far, however, the flood is a temporary and by no means an irreparable evil, for if its ravages end here, the prolific powers of nature and the industry of man soon restore what had been lost, and the face of the earth no longer shows traces of the deluge that had overwhelmed it. Inundations have even their compensations. The structures they destroy are replaced by better and more secure erections, and if they sweep off a crop of corn, they not unfrequently leave behind them, as they subside, a fertilizing deposit which enriches the exhausted field for a succession of seasons. $\dagger$ If, then, the too rapid flow of the surface-

\footnotetext{
* Alfred Maury has, nevertheless, collected, in his erudite and able work, Les Forêts de la Gaule et de l'ancienne France, Paris, 1867, an immense amount of statistical detail on the extent, the distribution, and the destruction of the forests of France, but it still remains true that we can very seldom pronounce on the forestal condition of the upper valley of a particular river at the time of a given inundation in the ancient or the mediæval period.

+ The productiveness of Egypt has been attributed too exclusively to the fertilizing effects of the slime deposited by the inundations of the Nile; for in that climate a liberal supply of water would produce good crops on almost any ordinary sand, while, without water, the richest soil would yield nothing. The sediment deposited annually is but a very small fraction of an inch in thickness. It is alleged that in quantity it would be hardly sufficient for a good top-dressing, and that in quality it is not chemically distinguishable from the soil inches or feet below the surface. But to deny, as some writers have done, that the slime has any fertilizing properties at all, is as great an error as the opposite one of ascribing all the agricultural wealth of Egypt to that single cause of productiveness. Fine soils deposited by water are almost uniformly rich in all climates; those brought down by rivers, carried out into salt water, and then returned again by the tide, seem to be more permanently fertile than any others. The polders of the Netherland coast are of this character, and the
} 
waters occasioned no other evil than to produce, once in ten years upon the arerage, an inundation which should destroy the harvest of the low grounds along the rivers, the damage would be too inconsiderable, and of too transitory a character, to warrant the inconveniences and the expense involved in the measures which the most competent judges, in many parts of Europe, believe the respective governments ought to take to obviate it.

\section{Destructive Action of Torrents.}

But the great, the irreparable, the appalling mischiefs which have already resulted, and which threaten to ensue on a still more extensive scale hereafter, from too rapid superficial drainage, are of a properly geographical, we may almost say geological, character, and consist primarily in erosion, displacement and transportation of the superficial strata, vegetable and mineral-of the integuments, so to speak, with which nature has clothed the skeleton framework of the globe. It is difficult to convey by description an idea of the desolation of the regions most exposed to the ravages of torrent and of flood; and the thousands who, in these days of swift travel, are whirled by steam near or even through the theatres of these calamities, have but rare and imperfect opportunities of observing the destructive eauses in action. Still more rarely can they compare the past with the actual

meadows in Lincolnshire, which have been covered with slime by warping, as it is called, or admitting water over them at high tide, are remarkably productive.

Recent analysis is said to have detected in the water of the Nile a quantity of organic matter-derived mainly, no doubt, from the decayed vegetation it bears down from its tropical course-sufficiently large to furnish an important supply of fertilizing ingredients to the soil.

It is computed that the Durauce- a river fed chiefly by torrents of great erosive powrer-carries down annually solid material enough to cover 272,000 acres of soil with a deposit of two-fifths of an inch in thickness, and that this deposit coutains, in the combination most favorable to vegetation, more azote than 110,000 tons of guano, and more carbon than 121,000 acres of woodland would assimilate in a year.-Eursée Reclus, La Terre, vol, i., p. 467. On the chemical composition, quantity and value of the solid matter transported by rivers, see Hervé Mangon, Sur l'Emploi des Eaux dans les Irrigations, 8vo. Paris, 1869, pp. 132 et seq. Duponcres, Traité d'Hydraulique et de Géologis Agricoles. Pari, 1868, chap. i., xii., and xiii. 
condition of the provinces in question, and trace the progress of their conversion from forest-crowned hills, luxuriant pasture grounds, and abundant corn-fields and vineyards well watered by springs and fertilizing rivulets, to bald mountain ridges, rocky declivities, and steep carth-banks furrowed by deep ravines with beds now dry, now filled by torrents of fluid mud and gravel hurrying down to spread themselves over the plain, and dooming to everlasting barrenness the once productive fields. In surveying such scenes, it is difficult to resist the impression that nature pronouneed a primal curse of perpetual sterility and desolation upon these sublime but fearful wastes, difficult to beliere that they were once, and but for the folly of man might still be, blessed with all the natural advantages which Providence has bestowed upon the most farored climes. But the historical eridence is conclusice as to the destructive changes occasioned by the agency of man upon the flanks of the Alps, the Apennines, the Pyrenees, and other mountain ranges in Central and Southern Europe, and the progress of physical deterioration has been so rapid that, in some localities, a single generation has witnessed the beginning and the end of the melancholy rerolution.

I have stated, in a general way, the nature of the evils in question, and of the processes by which they are produced; but I shall make their precise character and magnitude better understood by presenting some descriptive and statistical details of facts of actual occurrence. I select for this purpose the southeastern portion of France, not because that territory has suffered more sererely than some others, but because its deterioration is comparatively recent, and has been watched and described by very competent and trustworthy observers, whose reports are more easily accessible than those published in other countries.*

* Streflleur (Ueber die Natur und die Tirlunngen der Trilbbüche, p. 3) main. tains that all the observations and speculations of French authors on the nature of torrents had been anticipated by Austrian writers. In proof of this assertion he refers to the works of Franz von Zallinger, 17\%8; Von Arretin, 1808; Franz Duile, 1826, all published at Innsbruck, and IAGex's Beschreibung nenerer Wrasserbauzerlie, Kïnigsberg, 1826, none of which works are known to me. It is evident, howerer, that the conclusions of Surell and other French writers whom I cite, are original results of personal investigation, and not borrowed opinions. 
The provinces of Dauphiny and Provence comprise a territory of fourteen or fifteen thousand square miles, bounded northwest by the Isère, northeast and east by the Alps, south by the Mediterranean, west by the Rhone, and extending from $42^{\circ}$ to about $45^{\circ}$ of morth latitude. The surface is generally hilly and even mountainous, and several of the peaks in Dauphiny rise above the limit of perpetual snow. Except upon the mountain ridges, the climate, as compared with that of the United States in the same latitude, is extremely mild. Little snow falls except upon the higher mountains, the frosts are light, and the summers long, as might, indeed, be inferred from the regetation; for in the cultivated districts, the vine and the fig everywhere flourish, the olive thrives as far north as $431^{\circ}$, and upon the coast grow the orange, the lemon and the date-palm. The forest-trees, too, are of southern type, umbrella pines, various species of evergreen oaks, and many other trees and shrubs of persistent broad-leaved foliage, characterizing the landscape.

The rapid slope of the mountains naturally exposed these provinces to damage by torrents, and the Romans diminished their injurious effects by erecting, in the beds of ravines, barriers of rocks loosely piled up, which permitted a slow escape of the water, but compelled it to deposit above the dikes the earth and gravel with which it was charged.* At a later period the Crusaders brought home from Palestine, with much other knowledge gathered from the wiser MLoslems, the art of securing the hillsides and making them productive by terracing and irrigation. The forests which covered the mountains secured an abundant flow of

* Whether Palissy was acquainted with this ancient practice, or whether it was one of those original suggestions of which his works are so full, I know not; but in his treatise, Des Eaux ct Fontaines, he thus recommends it, by way of reply to the objections of "Thérique," who had expressed the fear that "the waters which rush violently down from the heights of the mountain would bring with them much earth, sand, and other things," and thus spoil the artificial fountain that "Practique" was teaching him to make: "And for hindrance of the mischiefs of great waters which may be gathered in few hours by great storms, when thou shalt have made ready thy parterre to receive the water, thou must lay great stones athwart the deep channels which lead to thy parterre. And so the force of the rushing currents shall be deadened, and thy water shall flow peacefully into his cisterns."-Frurres Complètes, p. 173. 
springs, and the procoss of clearing the soil went on so slowly that, for centuries, neither the want of timber and fuel, nor tho other evils about to be depicted, were seriously felt. Indered, thrunghout the Middle $A$ gres, these provinces were well wooded, and fimous for the fertility and abundance, not only of the low grounds, but of the hills.

Such was the state of things at the close of the fifteenth century. The statisties of the seventeenth show that while there hald been an increase of prosperity and population in Lower Provence, as well as in the correspondingly situated parts of the other two provinces I have mentioned, there was an alarming decrease both in the wealth and in the population of Upper Provence and Dauphiny, although, by the clearing of the forests, a great extent of ploughland and pasturage had been added to the soil before reduced to cuitivation. It was found, in fact, that the augmented violence of the torrents had swept away, or buried in sand and gravel, more land than had been reclaimed by clearing; and the taxes, computed by fires or habitations, underwent several successive reductions in consequence of the gradual abandonment of the wasted soil by its starving occupants. The growth of the large towns on and near the Phone and the coast, their advance in commerce and industry, and the consequently enlarged demand for agricultural products, ought naturally to have increased the rural population and the value of their lands; but the physical decay of the uplands was such that considerable tracts were deserted altogether, and in Upper Provence, the fires which in 1471 counted 897, were reduced to 747 in 1699 , to 728 in 1733 , and to 635 in $1776 . *$

Surell-whose admirable work, Etude sur les Torrents des Hautes Alpes, first published in 1811, $\uparrow$ presents a most appalling picture of the desolations of the torrent, and, at the same time, the most careful studies of the history and essential character of this great evil-in speaking of the valley of Dévoluy, on page 152, says: "Everything concurs to show that it was anciently

* These facts I take from the La Prorence au point de vue des Bois, des Torrents et des Inondations, of Charles de Ribbe, one of the highest authorities.

$\uparrow \mathrm{A}$ second edition of this work, with an additional volume of great value by Ernest Cézanne, was published at Paris, in two 8ro volumes, in 1871-7?. 
wooded. In its peat-bogs are found buried trunks of trees, monu ments of its former vegetation. In the framervork of old houses, one sees enormous timber, which is no longer to be found in the district. Many localities, now completely bare, still retain the name of 'wood,' and one of them is called, in old deeds, Comba nigra [Black Forest or dell], on account of its dense woods. These and many other proofs confirm the local traditions which are unanimous on this point.

"There, as everywhere in the Upler Alps, the clearings began on the flanks of the mountains, and were gradually extended into the valleys and then to the highest accessible peals. Then followed the Revolution, and caused the destruction of the remainder of the trees which had thus far escaped the woodman's axe."

In a note to this passage the writer says: "Several persons have told me that they lad lost flocks of sheep, by straying, in the forests of Mont Auroux, which covered the flanks of the mountain from La Cluse to Agnères. These declivities are now as bare as the palm of the hand."

The ground upon the steep mountains being once bared of trees, and the underwood killed by the grazing of horned cattle, sheep and goats, every depression becomes a watercourse. "Every storm," says Surell, page 153, "gires rise to a new torrent." Examples of such are shown, which, though not yet three yeurs old, have laid waste the finest fields of their valleys, and whole villages have narrowly escaped being swept into ravines formed in the course of a few hours. Sometimes the flood poturs in a sheet over the surface, without ravine or even bed, and ruins extensive grounds, which are abandoned forever."

I can not follow Surell in his description and classification of torrents, and I must refer the reader to his instructive work for a full exposition of the theory of the subject. In order, however, to show what a concentration of destructive energies may be effected by felling the woods that clothe and support the sides of mountain abysses, I cite his description of a valley descending

* No attentive observer can frequent the southern flank of the Piedmontese Alps or the French province of Dauphiny, for half a dozen years, without witnessing with his omn eyes the formation and increase of new torrents. I can bear personal testimony to the conversion of more than one grassy slope into the bed of a furious torrent by baring the hills above of their moods. 
from the Col Isoard, which he calls " a complete type of a basin of reception," that is, a gorge which serves as a common point of accumulation and discharge for the waters of several lateral torrents. "The aspect of the monstrous chamel," says he, "is frightful. Within a distance of less than two Euglish miles, more than sixty torrents hurl into the deptlis of the gorge the débris torn from its two flanks. The smallest of these secondary torrents, if transferred to a fertile valley, would be enough to ruin it."

The eminent political economist Blanqui, in a memoir read before the Academy of Mroral and Political Science on the 25th of November, 1843, thus expresses himself: "Important as are the causes of impoverishment already described they are not to be compared to the consequences which have followed from the two inveterate evils of the Alpine provinces of France, the extension of clearing and the ravages of torrents. . . . . The most important result of this destruction is this: that the agricultural capital, or rather the ground itself-which, in a rapidly increasing degree, is daily swept away by the waters-is totally lost. Signs of unparalleled destitution are visible in all the mountain zone, and the solitudes of those districts are assuming an indescribable character of sterility and desolation. The gradual destruction of the woods has, in a thousand localities, annililated at once the springs and the fuel. Between Grenoble and Briançon, in the valley of the Romanche, many villages are so destitute of wood that they are reduced to the necessity of baking their bread with sun-dried cow-dung, and even this they can afford to do but once a jear.

"Whoever has visited the valley of Barcelonette, those of Embrun, and of Verdun, and that Arabia Petræa of the department of the Upper Alps, called Dévoluy, knows that there is no time to lose-that in fifty years from this date France will be separated from Savoy, as Egypt from Syria, by a desert." *

It deserves to be specially noticed that the district here referred to, though now among the most hopelessly waste in France, was

* Ladoucette says the peasant of Déroluy "often goes a distance of five hours over rocks and precipices for a single [man's] load of rood"; and he remarks on another page, that "the justice of peace of that canton had, in the course of forty-three years, but once heard the voice of the nightingale." Histoire, etc., des Hautes Alpes, pp. 220, 434. 
very productive even down to so late a period as the commencement of the French Revolution. Arthur Young, writing in 1789, says: "About Barcelonette and in the highest parts of the mountains, the hill-pastures feed a million of sheep, besides large herds of other cattle"; and he adds: "With such a soil and in such a climate, we are not to suppose a country barren because it is mountainous. The valleys I have visited are, in general, beautitiful." * He ascribes the same character to the provinces of Dauphiny, Provence and Auvergne, aud, though he visited, with the cye of an attentive and practiced observer, many of the scenes since blasted with the wild desolation described by Blanqui, the Durance and a part of the course of the Loire are the only streams he mentions as inflicting serious injury by their floods. The ravages of the torrents had, indeed, as we have seen, commenced. earlier in some other localities, but we are authorized to infer that they were, in Young's time, too limited in range, and relatively too insignificant, to require notice in a general view of the provinces where they have now ruined so large a proportion of the soil.

But I resume my citations.

"I do not exaggerate," says Blanqui. "When I shall have finished my description and designated localities by their names, there will rise, I am sure, more than one voice from the spots themselves, to attest the rigorous exactness of this picture of their wretchedness. I have never seen its equal even in the Kabyle villages of the province of Constantine; for there you can travel on horseback, and you find grass in the spring, whereas in more than fifty communes in the Alps there is absolutely nothing.

"The clear, brilliant, Alpine sky of Embrun, of Gap, of Barce lonette, and of Digne, which for months is without a cloud, produces droughts interrupted only by diluvial rains like those of the tropics. The abuse of the right of pasturage and the felling of the woods have stripped the soil of all its grass and of all its trees,

* The valley of Embrun, now almost completely devastated, was once remarkable for its fertility. In 1806, Héricart de Thury said of it: "In this magnificent valley nature had been prodigal of her gifts. Its inhabitants have blindly revelled in her favors, and fallen asleep in the midst of her profu. sion."-BeCquerel, Des Climats, etc., p. 314. 
and the scorching sun bakes it to the consistence of porphyry. When moistened by the rain, as it has neither support nor colesion, it rolls down to the valleys, sometimes in floods resembling black, yellow, or reddish lava, sometimes in streams of pebbles, and even luge blocks of stone, which pour down with a frightful roar, and in their swift course exhibit the most convulsive movements. If you overlook from an eminence one of these landscapes furrowed with so many ravines, it presents only images of desolation and of death. Vast deposits of flinty pebbles, many feet in thickness, which have rolled down and spread far over the plain, surround large trees, bury even their tops, and rise above them, leaving to the husbandman no longer a ray of hope. One can imagine no sadder spectacle than the deep fissures in the flanks of the mountains, which seem to have burst forth in eruption to cover the plains with their ruins. These gorges, under the influence of the sun which cracks and shivers to fragments the very rocks, and of the rain which sweeps them down, penetrate deeper and deeper into the heart of the mountain, while the beds of the torrents issuing from them are sometimes raised several feet in a single year, by the débris, so that they reach the level of the bridges, which, of course, are then carried off. The torrent-beds are recognized at a great distance, as they issue from the mountains, and they spread themselves over the low grounds, in fan-shaped expansions, like a mantle of stone, sometimes ten thousand feet wide, rising high at the centre, and curving towards the circum ference till their lower edges meet the plain.

"Such is their aspect in dry weather. But no tongue can give an adequate description of their devastations in one of those sudden floods which resemble, in almost none of their phenomena, the action of ordinary river-water. They are now no longer overflowing brooks, but real seas, tumbling down in cataracts, and rolling before them blocks of stone, which are hurled forwards by the shock of the waves like balls shot out by the explosion of gunpowder. Sometimes ridges of pebbles are driven down when the transporting torrent does not rise high enough to show itself, and then the movement is accompanied with a roar louder than the crash of thunder. A furious wind precedes the rushing water and announces its approach. Then comes a violent eruption, followed by a flow of muddy waves, and after a few hours 
all returns to the dreary silence which at periods of rest marks these abodes of desolation.*

"The elements of destruction are increasing in violence. The devastation advances in geometrical progression as the higher slopes are bared of their wood, and 'the ruin from above,' to use the words of a peasant, 'helps to hasten the desolation below.'

"The Alps of Provence present a terrible aspect. In the more equable climate of Northern France, one can form no conception of those parched mountain gorges where not even a bush can be found to shelter a bird, where, at most, the wanderer sees in summer here and there a withered lavender, where all the springs are dried up, and where a dead silence, hardly broken by even the hum of an insect, prevails. But if a storm bursts forth, masses of water suddenly shoot from the mountain heights into the shattered gulfs, waste without irrigating, deluge without refreshing the soil they overflow in their swift descent, and leave it even more seared than it was from want of moisture. Man at last retires from the fearful desert, and I have, the present season, found not a living soul in districts where I remember to have enjoyed hospitality thirty years ago."

In 1553, ten years after the date of Blanqui's memoir, M. de Bonville, prefect of the Lower Alps, addressed to the Government a report in which the following passages occur:

"It is certain that the productive mould of the Alps, swept off by the increasing violence of that curse of the mountains, the torrents, is daily diminishing with fearful rapidity. All our Alps are wholly, or in large proportion, bared of wood. Their soil, scorched by the sun of Provence, cut up by the hoofs of the sheep, which, not finding on the surface the grass they require for their

* These explosive gushes of mud and rock appear to be occnsioned by the caving-in of large masses of earth from the bauks of the torrent, which dam up the stream and check its flow until it has acquired volume enough to burst the barrier and carry all before it. In 18:\%, such a suddeu eruption of a torrent, after the current had appeared to have ceased, swept off forty-two houses and drowned twenty-eight persons in the village of Goncelin, near Grenoble, and buried with rubbish a great part of the remainder of the village. See $p$. 232 , note.

'The French traveller, D'Abbadie, relates precisely similar occurrences as not unfrequent in the mountains of Abyssinia.-Surelu, Étules, etc., $2 \mathrm{~d}$ edition, pp. 224, 295. 
sustenance, guaw and scratch the ground in search of roots to satisfy their lunger, is periodically washed and carried off by melting snows and summer storms.

"I will not dwell on the effects of the torrents. For sixty years they have been too often depicted to require to be further discussed, but it is important to show that their ravages are daily extending the range of devastation. The bed of the Durance, which now in some places exceeds a mile and a quarter in width, and, at ordinary times, has a current of water less than eleven yards wide, shows something of the extent of the damage.* Where, ten year's ago, there were still woods and cultivated grounds to be seen, there is now but a vast torrent; there is not one of our mountains which has not at least one torrent, and new ones are daily forming.

"An indirect proof of the diminution of the soil is to be found in the depopulation of the country. In $1852 \mathrm{I}$ reported to the General Council that, according to the census of that year, the population of the department of the Lower Alps had fallen off no less than 5,000 souls in the five years between 1846 and 1851 .

"Unless prompt and energetic measures are taken, it is easy to fix the epoch when the French Alps will be but a desert. The interval between 1851 and 1856 will show a further decrease of population. In 1562 the ministry will announce a continued and progressive reduction in the number of acres devoted to agriculture; every year will aggravate the evil, and in half a century France will count more ruins, and a department the less."

Time has verified the predictions of De Bonville. The later census returns show a progressive diminution in the population of the departments of the Lower Alps, the Isère, Drome, Ariège, the Upper and the Lower Pyrenees, Lozère, the Ardennes, Doubs, the Vosges, and, in short, in all the provinces formerly remark

* In the days of the Roman Empire the Durance was a navigable, or at least a boatable, river, with a commerce so important that the boatmen upon it formed a distinct corporation.-LADOUCETTE, Histoire, etc., des Hautes Alpes, p. 354 .

Even as early as 1789 the Durance was computed to have already corered with gravel and pebbles not less than 130,000 acres, "which, but for its inundations, would have bren the finest land in the province."-ArTuUR YomNG, Travels in France, vol. i., ch. i. 
able for their forests. This diminution is not to be ascribed to a passion for foreign emigration, as in Ireland, and in parts of Germany and of Italy; it is simply a transfer of population from one part of the empire to another, from soils which human folly has rendered uninhabitable, by ruthlessly depriving them of their natural advantages and securities, to provinces where the face of the earth was so formed by nature as to need no such safeguards, and where, consequently, she preserves her outlines in spite of the wasteful improvidence of man.*

\section{Floods of the Ardèche.}

The River Ardèche, in the French department of that name, has a perennial current in a considerable part of its course, and therefore is not, technically speaking, a torrent; but the peculiar character and violence of its floods is due to the action of the torrents which discharge themselves into it in its upper valley, and to the rapidity of the flow of the water of precipitation from the surface of a basin now almost bared of its once luxuriant woods. $\dagger$ A notice of these floods may therefore not inappropriately be introduced in this place.

The floods of the Ardèche and other mountain streams are at-

* Between 1851 and 1856 the population of Languedoc and Provence had increased by 101,000 souls. The augmentation, however, was wholly in the provinces of the plains, where all the principal cities are found. In these provinces the increase was 204,000 , while in the mountain provinces there was a diminution of 103,000 . The reduction of the area of arable land is perlaps even more striking. In 1842 the department of the Lower Alps possessed 99,000 hectares, or nearly 245,000 acres, of cultivated soil. In 1852 it had but 74,000 hectares. In other words, in ten years 25,000 hectares, or 61,000 acres, had been washed away, or rendered worthless for cultivation, by torrents and the abuses of pasturage.-CLAví, Études, pp. 66, 67.

+ The original forests in which the basin of the Ardiche was rich have been rapidly disappearing for many years, and the terrific violence of the inundations which are now laying it waste is ascribed, by the ablest investigators, to that cause. In an article inserted in the Annales Forestieres for 1843, quoted by Hohenstein, Der Wald, p. 177 , it is said that about one-third of the area of the department had already become absolutely barren, in consequence of clearing, and that the destruction of the woods was still going on with great rapidity. New torrents were constantly forming, and they were estimated to have covered more than 70,000 acres of good land, or one-eighth of the surface of the department, with sand and gravel. 
tended with greater immediate danger to life and property than those of rivers of less rapid flow, because their currents are more impetuous, and they rise more suddenly and with less previous walrning. At the same time, their ravages are confined within narrower limits, the waters retire sooner to their accustomed channel, and the danger is more quickly over, than in the case of inmudations of larger rivers. The Ardeche drains a basin of 600,238 acres, or a little less than nine hundred and thirty-eight square miles. Its remotest source is about serenty-five miles, in a straight line, from its junction with the Rhone, and springs at an elevation of four thousand feet above that point. At the lowest stage of the river, the bed of the Chassezac, its largest and longest tributary, is in many places completely dry on the surface-the water being sufficient only to supply the subterranean channels of intiltration-and the Ardeche itself is almost everywhere fordable, even below the mouth of the Chassezac. But in floods, the river has sometimes risen more than sixty feet at the Pont d'Are, a natural arch of two hundred feet chord which spans the stream below its junction with all its important aftluents. At the height of the inundation of 1857 , the quantity of water passing this point-after deducting thirty per cent. for material transported with the current and for irregularity of flowwas estimated at $S, S+5$ cubic yards to the second, and betrreen twelve o'clock at noon on the 10th of September of that year and ten o'clock the next morning, the water discharged through the passage in question amounted to more than $450,000,000$ cubic yards. This quantity, distributed equally through the basin of the river, would cover its entire area to a depth of more than five inches.

The Ardeche rises so suddenly that, in the inundation of $18 \pm 6$, the women who were washing in the bed of the river had not time to save their linen, and barely escaped with their lives, though they instantly fled upon hearing the roar of the approaching flood. Its waters and those of its affuents fall almost as rapidly, for in less than twenty-four hours after the rain has ceased in the Cévennes, where it rises, the Ardèche returns within its ordinary channel, even at its junction with the Rhone. In the flood of 1772, the water at La Beaume de Ruoms, on the Beaume, a tributary of the Ardèche, rose thirty-five feet above 
low water, but the stream was again fordable on the evening of the same day. The inundation of 1827 was, in this respect, exceptional, for it continued three days, during which period the Ardèche poured into the Rhone 1,305,000,000 cubic yards of water.

The Nile delivers into the sea 101,000 cubic feet or 3,741 cubic yards per second, on an average of the whole year.* This is equal to $323,222,400$ cubic yards per day. In a single day of flood, then, the Ardeche, a river too insignificant to be known except in the local topography of France, contributed to the Rhone once and a half, and for three consecutive days once and one-third, as much as the average delivery of the Nile during the same periods, though the basin of the latter river probably contains $1,000,000$ square miles of surface, or more than one thousand times as much as that of the former.

The average annual precipitation in the basin of the Ardeche is not greater than in many other parts of Europe, but excessive quantities of rain frequently fall in that valley in the autumn. On the 9 th of October, 1827 , there fell at Joyeuse, on the Beaume, no less than thirty-one inches between three o'clock in the morning and midnight. Such facts as this explain the extraordinary suddenness and violence of the floods of the Ardèche, and the basins of many other tributaries of the Rhone exhibit meteorological phenomena not less remarkable.t The Rhone,

\footnotetext{
* Sir Jonv F. W. Herschel, citing Talabot as his authority, Physical Geography (24).

In an elaborate paper on "Irrigation," printed in the United States Patent Report for 1860 , p. 169 , it is stated that the volume of water poured into the Mediterranean by the Nile in twenty-four hours, at low water, is $150,566,392,-$ 368 cubic mètres; at high water, $705,514,667,440$ cubic metres. Taking the mean of these two numbers, the average daily delivery of the Nile would be $428,081,059,808$ cubic metres, or more than $550,000,000,000$ cubic yards. There is some enormous mistake, probably a typographical error, in this statement, which makes the delivery of the Nile seventeen hundred times as great as computed by Talabot, and more than physical geographers have estimated the quantity supplied by all the rivers on the face of the globe.

The estimates of physical geographers vary widely as to the total delivery of water by the rivers of the earth to the sea. Metcalfe calculated it at $135,000,000,000$ cubic metres per day; Keith Johnson at 175,000,000,000, and Elisée Reclus at 85,000,000,000.-RECLUs, La Terre, i., 516.

† The Drac, a torrent emptying into the Isère a little below Grenoble, has discharged 5,200, the Isere, which receives it, 7,800 cubic yards, and the
} 
therefore, is naturally subject to great and sudden inundatious, and the same remark may be applied to most of the principal rivers of France, because the geographical character of all of them is approximately the same.

The volume of water in the floods of most great rivers is determined by the degree in which the inundations of the different tributaries are coincident in time. Were all the aftuents of the Lower Rhone to pour their highest annual floods into its channel at once-as the smaller tributaries of the Upper Rhone sometimes do-were a dozen Niles to empty themselves into its bed at the same moment, its water would rise to a height and rush with an impetus that would sweep into the Mediterranean the entire population of its banks, and all the works that man has erected upon the plains which border it. But such a coincidence can never happen. The tributaries of this river run in very different directions, and some of them are swollen principally by the melting of the snows about their sources, others almost exclusively by heary rains. When a damp sontheast wind blows up the valley of the Ardèche, its moisture is condensed, and precipitated in a

Durance, above its junction with the Isère, an equal quantity, per second.Montluisant, Note sur les Desséchements, etc., Annales des Ponts et Chausées, 1833, 2me sémestre, p. 288.

The Upper Rhone, which drains a basin of about 1,900 square miles, including seventy-one glaciers, receives many torrential affluents, and rain-storms and thaws are sometimes extensive enough to affect the whole tributary Eystem of its narrow valley. In such cases its current swells to a great volume, but previously to the floods of the autumn of 1868 it was nerer known to reach a discharge of 2,600 cubic yards to the second. On the 28 th of September in that year, however, its delivery amounted to 3,700 cubic yards to the second, which is about equal to the mean discharge of the Nile. -Berichte der Experten-Commission über die Ueberschacemmungen im Jahr 1868 , pp. 174, 175 .

The floods of some other French rivers, which have a more or less torrential character, scarcely fall behind those of the Rhone. The Loire, above Roanne, has a basin of 2,471 square miles, or about twice and a half the area of that of the Ardeche. In some of its inundations it has delivered above 9,500 cubic yards per second, or 400 times its low-water discharge.-BELgraxd, De l'Influence des Forêts, etc., Annales des Ponts et Chausées, 185., 1er sémestre, p. 15, note.

The ordinary low-water discharge of the Seine at Paris is nearly 100 cubic yards per second. Belgrand gives a list of eight floods of that river within the last two centuries, in which it has delivered thirty times that quantity. 
deluge upon the mountains which embosom the headwaters of that stream, thus producing a flood, while a neighboring basin, the axis of which lies transversely or obliquely to that of the Ardèche, is not at all affected.*

It is easy to see that the damage occasioned by such floods as I have described must be almost incalculable, and it is by no means confined to the effects produced by orerflow and the mechanical force of the superficial currents. In treating of the devastations of torrents, I lave hitherto confined myself principally to the erosion of surface and the transportation of mineral matter to lower grounds by them. The general action of torrents, as thus far shown, tends to the ultimate elevation of their beds by the deposit of the earth, gravel and stone conveyed by them; but until they have thus raised their outlets so as sensibly to diminish the inclination of their channels-and sometimes when extraordinary floods give the torrents momentum enough to sweep away the accumulations which they have themselves heaped up-the swift flow of their currents, aided by the abrasion of the rolling rocks and gravel, scoops their beds constantly deeper, and they consequently not only undermine their banks, but frequently sap the most solid foundations which the art of man can build for the support of bridges and hydraulic structures. $\dagger$

" "There is no example of a coincidence between great floods of the Ardiche and of the Rhone, all the known iuundations of the former having taken place when the latter was very low."-IIARdianr, Limoire sur les Inondations des Rivières de l'Ardèche, p. 26.

The same observation may be applied to the tributaries of the Po, their floods being generally successive, not contemporancous. The swelling of the affluents of the Amazon, and indeed of most large rivers, is regulated by a similar law. See Messedaglis, Analisi dell' opera di Champion, etc., p. 103.

The floods of the affuents of the Tiber and the Seine form an exception to this law, being generally coincident, and this is one of the explanations of the frequency of destructive inundations in the former river.-LombardinI, Guida allo Studio dell' Idrologia, ff. 68; same author, Esame degli studi sul Tevere; Belgrand, La Seine, p. 388.

I take this occasion to acknowledge myself indebted to Mardigny's interesting memoir just quoted for all the statements 1 make respecting the floods of the Ardiche, except the comparison of the volume of its waters with that of the Nile.

† In some cases, where the bed of rapid Alpine streams is composed of very hard rock-as is the case in many of the valleys once filled by ancient glaciers 
In the inundation of 1857 , the Ardeche destroyed a stone bridge near La Beaume, which had been built about eighty years before. The resistance of the piers, which were erected on piles, the chamnel at that point being of grarel, produced an eddying current that washed away the bed of the river above them, and the foundation, thus deprived of lateral support, yiclded to the weight of the bridge, and the piles and piers fell up-stream.

By a curious law of compensation, the stream which, at flood, scoops out carities in its bed, often fills them up again as soon as the diminished relocity of the current allows it to let fall the sand and gravel with which it is charged, so that when the waters return to their usual channel, the bottom shows no sign of having been disturbed. In 1St6, during a flood of the Escontay, a tributary of the Rhone, piles, driven sixteen feet into its gravelly bed for the foundation of a pier, were torn up and carried off; and yet, when the river had fallen to low-water mark, the bottom at that point appeared to hare been raised, by new deposits of sand and gravel, higher than it was before the flood, while the cut stones of the half-built pier were found buried to a great depth in the excavation which the water had first washed out. The gravel with which rivers thus restore the level of their beds is principally derived from the crushing of the rocks brought down by the mountain torrents, and the destructive effects of inundations are immensely diminished by this reduction of large stones

-and especially where they are fed by glaciers not orerlumg by crumbling clifls, the channel may remain almost unchanged for centuries. This is observable in many of the tributaries of the Dora Baltea, which drains the valley of Aosta. Several of these small rivers are spanned by more or less perfect Roman bridges-one of which, that over the Lys at Pont St. Martin, is still in good repair and in constant use. An examination of the rocks on which the abutments of this and some other similar structures are founded, and of the channels of the rivers they cross, shows that the beds of the streams can not have been much elevated or depressed since the bridges were built. In other cases, as at the outlet of the Val Tournunche at Chatillon, where a single rib of a Roman bridge still remains, there is nothing to forbid the supposition that the deep excavation of the channel may have been partly effected at a much later period.

The Roman aqueduct known as the Pont du Gard, near Nismes, was built, in all probability, nineteen centuries ago. The bed of the river Gardon, a rather swift stream which flows beneath it, can have suffered but a slight depression since the piers of the aqueduct were founded. 
to minute fragments. If the blocks hurled down from the cliffs were transported unbroken to the channels of large rivers, the mechanical force of their movernent would be irresistible. They would overthrow the strongest barriers, spread themselves over a surface as wide as the flow of the waters, and convert the most smiling valleys into scenes of the wildest desolation.

As I have before remarked, I have taken my illustrations of the action of torrents and mountain streams principally from French authorities, because the facts recorded by them are chiefly of recent occurrence, and as they have been collected with much care and described with great fulness of detail, the information furnished by them is not only more trustworthy, but both more complete and more accessible than that which can be gathered from any other source. It is not to be supposed, however, that the countries adjacent to France have escaped the consequences of a like improvidence. The southern flanks of the Alps, and, in a less degree, the northern slope of these mountains and the whole chain of the Pyrenees, afford equally striking examples of the evils resulting from the wanton sacrifice of nature's safeguards. But I can afford space for few details, and as an illustration of the extent of these evils in Italy, I shall barely observe that it was calculated ten years ago that fourtenths of the area of the Ligurian provinces had been washed away or rendered incapable of cultivation in consequence of the felling of the woods.*

Highly colored as these pictures seem, they are not exaggerated, although the hasty tourist through Southern France, Switzerland, Tyrol, and Northern Italy, finding little in his high-road observations to justify them, might suppose them so. The lines of communication by locomotive train and diligence lead generally over safer ground, and it is only when they ascend the Alpine passes and traverse the mountain chains, that scenes somewhat

* Annati di Agricoltura, Industria e Commercio, vol. i., p. 77. Similar instances of the erosive power of running water might be collected by hundreds from the narratives of travellers in warm countries. The energy of the torrents of the Himalayas is such, that the brothers Schlagintweit believe they will cut gorges through that lofty chain wide enough to admit the passage of currents of warm wind from the south, and thereby modify the climate of the countries lying to the north of the mountains. 
resembling those just described fall under the eye of the ordinary traveller. But the extension of the sphere of devastation, by the degradation of the mountains and the transportation of their débris, is producing analogous effects upon the lower ridges of the Alps and the plains which slirt them; and even now one needs but an hour's departure from some great thoroughfares, to reach sites where the genius of destruction revels as wildly as in the most frightful of the abysses which Blanqui has painted.*

* The Skalitra-Tobel, for instance, near Coire. See the description of this and other like scenes in Berlepscr, Die Alpen, pp. 169 et seq., or in Stephen's English translation.

About an hour from Thusis, on the Splügen road, "opens the awful chasm of the Nolla, which a hundred years ago poured its peaceful waters through smiling meadows protected by the wooded slopes of the mountains. But the woods were cut down and with them departed the rich pastures, the pride of the valley, now covered with piles of rock and rubbish swept down from the mountains. This result is the more to be lamented as it was entirely compassed by the improvidence of man in thinning the forests."-MIoreLL, Scientific Guide to Sroitzerland, p. 100.

The recent change in the character of the Mella-a river anciently so remarkable for the gentleness of its current that it was specially noticed by Catullus as flowing molli flumine-deserves more than a passing remark. This river rises in the mountain chain east of Lake Iseo, and traversing the district of Brescia, empties into the Oglio after a course of about seventy miles. The iron-works in the upper valley of the Mella had long created a considerable demand for wood, but their operations were not so extensive as to occasion any very sudden or general destruction of the forests, and the only evil experienced from the clearings was the gradual diminution of the volume of the river. Within the last thirty years, the superior quality of the arms manufactured at Brescia has greatly enlarged the sale of them, and very naturally stimulated the activity of both the forges and of the colliers who supply them, and the hillsides have been rapidly stripped of their timber. Up to 1850 no destructive inundation of the Mella had been recorded. Buildings in great numbers had been erected upon its margin, and its valley was conspicuous for its rural beauty and its fertility. But when the denudation of the mountains had reached a certain point, avenging nature began the work of retribution. In the spring and suramer of 1850 several new torrents were suddenly formed in the upper tributary valleys, and on the 14th and 15th of August in that 5ear a fall of rain, not heavier than had been often experienced, produced a flood which not only inundated much ground never before overflowed, but destroyed a great number of bridges, dams, factories, and other valuable structures, and, what was a far more serious evil, swept off from the rocks an incredible extent of soil, and converted one of the most beautiful valleys of the Italian Alps into a ravine almost as bare and as barren as the savagest grorge of Southern France. The pecuniary damage was estimated at many millions of 
There is one effect of the action of torrents which few travel lers on the Continent are heedless enough to pass without notice. I refer to the elevation of the beds of mountain streams in consequence of the deposit of the débris with which they are charged. To prevent the spread of sand and gravel over the fields and the deluging overflow of the raging waters, the streams are confined by walls and embankments, which are gradually built higher and ligher as the bed of the torrent is raised, so that, to reach a river, you ascend from the fields beside it; and sometimes the ordinary level of the stream is above the streets and even the roofs of the towns through which it passes.*

The traveller who visits the depths of an Alpine ravine, observes the length and width of the gorge and the great height and apparent solidity of the precipitous walls which bound it, and calculates the mass of rock required to fill the vacancy, can hardly believe that the humble brooklet which purls at his feet has been the principal agent in accomplishing this tremendous erosion. Closer observation will often teach him, that the seemingly un-

franes, and the violence of the catastrophe was deemed so extraordinary, even in a country subject to similar visitatious, that the sympathy excited for the sufferers produced, in five months, voluntary contributions for their relief to the amount of nearly $\$ 200,000$. -Delle Inondazioni del Aclla, etc., nella notte del 14 al 15 Agosto, 1850.

The author of this pamphlet has chosen as a motto a passage from the Vulgate translation of Job, which is interesting as showing accurate observation of the action of the torrent: "MIons cadens definit, et saxum transfertur de loco suo; lapides cxcavant aquæ et alluvione paullatim terra consumitur." Job xiv. 18, 19.

The English version is much less striking, and gives a different sense.

The recent date of the change in the character of the Mella is contested, and it is possible that, though the extent of the revolution is not exaggerated, the rapidity with which it has taken place may have been.

* Streffleur quotos from Duile the following observations: "The channel of the Tyrolese brooks is often raised much above the valleys through which they flow. The bed of the Fersina is elevated high above the city of Trent, which lies near it. The Villerbach flows at a much more elevated level than that of the market-place of Neumarkt and Vill, and threatens to overwhelm both of them with its waters. The Talfer at Botzen is at least even with the roofs of the adjacent town, if not above them. The tower-steeples of the villagies of Schlanders, Kortsch, and Laas, are lower than the surface of the Gadribach. The Saldurbach at Schluderns menaces the far lower village with destruc tion, and the chief town, Schwaz, is in similar danger from the Lahnbach."Streffledr, Ueber die Wildbäche, etc., p. 7. 
broken rock which overhangs the valley is full of eracks and fiso sures, and really in such a state of disintegration that every frost must bring down tons of it. If he compute the area of the basin which finds here its only discharge, he will perceire that a sudden thaw of the winter's deposit of snow, or one of those terrible discharges of rain so common in the Alps, must send forth a deluge mighty enough to sweep down the largest mases of gravel and of rock. The simple measurement of the eulical contents of the semicircular hillock which he climbed before he entered the gorge, the structure and composition of which conclusively show that it must have been washed out of this latter by torrential action, will often account satisfactorily for the disposal of most of the matter which once filled the ravine.

When a torrent escilpes from the lateral confinement of its mountain walls and pours out of the gorge, it spreads and divides itself into numerous smaller streams which shoot out from the mouth of the ravine as from a centre, in different directions, like the ribs of a fan from the pivot, each carrying with it its quota of stones and gravel. The plain below the point of issue from the mountain is rapidly raised by newly-formed torrents, the eleration depending on the inclination of the bed and the form and weight of the matter transported. Every flood both increases the height of this central point and extends the entire circumference of the deposit.

Other things being equal, the transporting power of the water is greatest where its flow is most rapid. This is usually in the direction of the axis of the ravine. The stream retaining most nearly this direction moves with the greatest momentum, and consequently transports the solid matter with which it is charged to the greatest distance.

The untravelled reader will comprehend this the better when he is informed that the southern slope of the Alps generally rises suddenly out of the plain, with no interrening hill to break the abruptness of the transition, except those consisting of comparatively small heaps of its own débris brought down by ancient glaciers or recent torrents. The torrents do not wind down valleys gradually widening to the river's or the sea, but leap at once from the flanks of the mountains upon the plains below. This arrangement of surfaces naturally facilitates the formation of vast 
deposits at their points of emergence, and the centre of the acenmulation in the case of very small torrents is not unfrequently a humlred feet high, and sometimes rery much more.

The deposits of the torrent which has scooped out the Tantzen Thal, a couple of miles below Brieg in the Talais, have built up a semicireular hillock, which most travellers by the Simplon route pass orer without notice, though it is little inferior in dimensions to the great cones of dejection described by Blanqui. The principal course of the torrent having been-I know not whether spontaneously or artificially-direrted tomards the mest, the eastern part of the hill has been gralually brought under cultiration. and there are many trees, fields and houses upon it; but the larger mestern part is furrowed with channels direrging from the summit of the deposit at the outlet of the Nantzen Thal, which serve as the beds of the watercourses into which the torrent has dirided itself. All this portion of the hillock is subject to inumdation after long and heary rain, and when I saw it in the great flood of October, 1866, almost its whole surface seemed corered with an unbroken sheet of rushing water.

The semi-conical deposit of detritus at the moutl of the Litznerthal, a lateral branch of the valley of the Adige, at the point where the torrent pours out of the gurge, is a thousand feet high, and, measuring along the axis of the principal current, two and a half miles long." The solid material of this hillock-which it is hardly an exaggeration to call a mountain, the mork of a single insignificant torrent and its tributaries-including what the river which washes its base has carried off in a comparatirely few rears, probably surpasses the mass of the stupendous prramid of the Matterhorn.

In ralleys of ancient geological formation, which extend into the vers heart of the mountains, the streams, though rapid, hare often lost the true torrential character. if inteen they corer possessed it. Their hels have become apmroximately constant, and their walls no longer crumble and fall into the waters that wash their bases. The torrent-worn ravines, of which I hare spoken, are of later date, and belong more properly to what may be called the crust of the Alps, consisting of loose rocks, of grarel, and of 
earth, strewed along the surface of the great declivities of the centril ridge, and accumulated thickly between their solid buttresses. But it is on this crust that the mountaineer dwells. Here are his forests, here his pastures, and the ravages of the torrent both destroy his world, and convert it into a source of overwhelming desolation to the plains below.

I do not mean to assert that all the rocky valleys of the Alps hare been produced by the action of torrents resulting from the destruction of the forests. The greater, and many of the smaller, channels by which that chain is drained, owe their origin to higher causes. They are primitive fissures, ascribahle to disruption in uphearal or other geological convulsion, widened and scarped, and often eren polished, so to speak, by the action of glaciers during the ice period, and but little changed in form by running water in later eras.

It has been contended that all rivers which take their rise in mountains originated in torrents. These, it is said, have lowered the summits by gradual erosion, and, with the material thus derived, have formed shoals in the sea which once beat against the cliffs; then, by successive deposits, gradually raised them above the surface, and finally expanded them into broad plains traversed by gently flowing streams. If we could go back to earlier geological periods, we should find this theory often verified, and we can not fail to see that the torrents go on at the present hour, depressing still lower the ridges of the Alps and the Apennines, raising still higher the plains of Lombardy and Prorence, extending the coast still farther into the Adriatic and the Mediterranean, reducing the inclination of their own beds and the rapidity of their flow, and thus tending to become river-like in character.

We can not measure the share which human action has had in augmenting the intensity of causes of mountain degradation, and of the formation of plains and marshes below, but we know that the clearing of the woods has in some cases produced, within two or three generations, effects as blasting as those generally ascribed to geological convulsions, and has laid waste the face of the earth more hopelessly than if it had been buried by a current of lava or a shower of volcanic sand. New torrents are forming every year in the Alps. Tradition, written records and analogy concur to establish the belief that the ruin of most of the now 
desolate valleys in those mountains is to be ascribed to the same cause, and authentic descriptions of the irresistible force of the torrent show that, aided by frost and heat, it is adequate to level Mont Blanc and Monte Rosa themselves, unless new upheavals shall maintain their elevation.

There are cases where torrents cease their ravages of themselves, in consequence of some change in the condition of the basin where they originate, or of the face of the mountain at a higher level, while the plain or the sea below remains in substantially the same state as before. If a torrent rises in a small valley containing no great amount of earth and of disintegrated or loose rock, it may, in the course of a certain period, wash out all the transportable material, and if the valley is then left with solid walls, it will cease to furnish débris to be carried down by floods. If, in this state of things, a new channel be formed at an elevation above the head of the valley, it may divert a part or even the whole of the rain-water and melted snow which would otherwise have flowed into it, and the once furious torrent now sinks to the rank of a humble and harmless brooklet. "In traversing this department," says Surell, "one often sees, at the outlet of a gorge, a flattened hillock with a fan-shaped outline and regular slopes; it is the bed of dejection of an ancient torrent. It sometimes requires long and careful study to detect the primitive form, masked as it is by groves of trees, by cultivated fields, and often by houses, but, when examined closely, and from different points of view, its characteristic figure manifestly appears, and its true history can not be mistaken. Along the hillock flows a streamlet, issuing from the ravine, and quietly watering the fields. This was originally a torrent, and in the background may be discovered its mountain basin. Such extinguished torrents, if I may use the expression, are numerous." *

* Sutell, Les Torrents des Hautes Alpes, chap. xxiv. In such cases, the clearing of the ground, which, in consequence of a temporary diversion of the waters or from some other cause, has become rewooded, sometimes renews the ravages of the torrent. Thus, on the left bank of the Durance, a wooded declivity had been formed by the débris brought down by torrents, which had extinguished themselves after having swept off much of the superficial strata of the mountain of Morgon. "All this district was covered with woods, which have now been thinned out and are perishing from day to day; consequently, the torrents have recommenced their devastations, and if the clearings con. 
But for the intervention of man and domestic animals, these latter beneficent revolutions would occur more frequently, proceed more rapidly. The new scarped mountains, the hillocks of débris, the pliains elevated by sand and gravel spread over them, the shores freshly formed by fluriatile deposits, would clothe themselves with shrubs and trees, the intensity of the causes of degradation would be diminished, and nature would thus regain her ancient equilibrium. But these processes, under ordinary circumstances, demand, not years, generations, but centuries; * and man, who even now finds scarce breathing-room on this vast globe, can not retire from the Old World to some yet undiscorered continent, and wait for the slow action of such causes to replace, by a new ereation, the Eden he has wasted.

\section{Crushing Force of Torrents.}

I must here notice a mechanical effect of the rapid flow of the torrent, which is of much importance in relation to the desolating action it exercises by covering large tracts of cultivated ground with infertile material. The torrent, as we have seen, shoots or rolls forward, with great velocity, masses and fragments of rock, and sometimes rounded pebbles from more ancient formations. Every inch of this violent movement is accompanied with crushing concussion, or, at least, with great abrasion of the mineral material, and, as you follow it along the course of the waters which transport it, you find the stones gradually rounding off in form and diminishing in size, until they pass successively into gravel and, in the beds of the rivers to which the torrents convey it, into sand, and, lastly, into impalpable slime.

There are few operations of nature where the effect seems more disproportioned to the cause than in this crushing and comminu-

tinue, this declivity, now fertile, will be ruined, like so many others." - Ibid., p. 155.

* Where a torrent has not been long in operation, and earth still remains mixed with the rocks and gravel it heaps up at its point of eruption, vegetation soon starts up and prospers, if protected from encroachment. In Provence, "several communes determined, about ten years ago, to reserve the soils thus wasted, that is, to abandon them for a certain time, to spontaneous vegetation, which was not slow in making its appearance."-Becquener, Des Climuts p. 315. 
tion of rock in the channel of swift waters. Igneous rocks ares generally so hard as to be wrought with great difficulty, and they bear the weight of enormous superstructures without yielding to the pressure; but to the torrent they are as wheat to the millstone. The streams which pour down the southern scarp of the Mediterranean Alps along the Riviera di Ponente, near Genoa, have short courses, and a brisk walk of a couple of hours or even less takes you from the sea-beach to the headspring of many of them. In their heaviest floods, they bring rounded masses of serpentine quite down to the sea, but at ordinary ligh water their lower course is charged only with finely divided particles of that rock. Hence, while near their sources their channels are filled with pebbles and angular fragments, intermixed with a little gravel, the proportions are reversed near their mouths, and, just above the points where their outlets are partially choked by the rolling shingle of the beach, their beds are composed of sand and gravel to the almost total exclusion of pebbles.

Guglielmini argued that the gravel and sand of the beds of running streams were derived from the trituration of rocks by the action of the currents, and inferred that this action was generally sufficient to reduce hard rock to sand in its passage from the source to the outlet of rivers. Frisi controverted this opinion, and maintained that river-sand was of more ancient origin, and he inferred from experiments in artificially grinding stones that the concussion, friction and attrition of rock in the channel of running waters were inadequate to its comminution, though he admitted that these same causes might reduce silicious sand to a fine powder capable of transportation to the sea by the currents.* Frisi's experiments were tried upon rounded and polished riverpebbles, and prove nothing with regard to the action of torrents upon the irregular, more or less weathered, and often cracked and shattered rocks which lie loose in the ground at the head of mountain valleys. The fury of the waters and of the wind

\footnotetext{
* Frisr, Del modo di regolare $i$ Fiumi e $i$ Torrenti, pp. 4-19. See in LonBARDINI, Sulle Inondazioni in Francia, p. 87, notices of the action of currents transporting only fine material in wearing down hard rock. In the sluices for gold-washing in California having a grade of 1 to $14 \frac{1}{2}$, and paved with the hardest stones, the wear of the bottom is at the rate of two inches in three months.-RAYMoND, Mineral Statistics, 1870, p. 480.
} 
which accompanies them in the floods of the French $\Delta l_{\text {pine }}$ tor rents is such, that large blocks of stone are hurled out of the bed of the stream to the height of twelve or thirteen feet.* In the grent flood of 1S6S, the torrent at Giomica, in the Canton Ticino, carried rocks weighing many hundreds of pounds, and, it is silid, even tons, through the windows of houses, and at the sume time the Maggia conveyed liuge boulders into the streets and squares at Locarno.

The impulse of masses driven with such force overthrows the most solid masonry, and their concussion can not fail to be attended with the erishing of the roeks themselves. But the crushing power of torrents appears to be chiefly exerted on rocks while they are driven through narrow channels, where of course the compression and friction of the rolling mass are very great. When they are once thrown out of the bed, or the swift water current, they are subject to little abrasion.

The greatest depth of the basin of the Arddche is seventy-five miles, but most of its tributaries have a much shorter course. "These affluents," says Mardigny, "hurl into the bed of the Ardèche enormous blocks of rock, which this river, in its turn, bears onwards, and grinds down, at high water, so that its current rolls only gravel at its confluence with the Rhone." †

Duponchel makes the following remarkable statement: "The river Herault rises in a granitic region, but soon reaches caleareous formations, which it traverses for more than sixty lilomètres, rolling throngh deep and precipitous ravines, into which the torrents are constantly discharging enormous masses of pebbles belonging to the hardest rocks of the Jurassian period. These débris, continually renewed, compose, even below the exit of the gorge where the river enters into a regular channel cut in a tertiary deposit, broad beaches, prodigious accumulations of rolled

* Surell, Etude sur les Torrents, pp. 31-86.

† Mrémoire sur les Inondations des Rivìres de l'Ardiche, p. 16. "The terrific roar, the thunder of the raging torrents proceeds principally from the stones which are rolled along in the bed of the stream. This movement is attended with such powerful attrition that, in the Southern Alps, the atmosphere of valleys where the limestone contains bitumen, has, at the time of floods, the marked bituminous smell produced by rubbing pieces of such limestone to gether."-Wesselx, Die Oesterreichischen Alpenlënder, i., p. 113. 
pebbles, extending sereral kilomitres down the stream, but they diminish in size and weight so rapidly that above the mouth of the river, which is at a distance of thirty or thirty-five kilometres from the gorge, every trace of calcareous matter lias disappeared from the sands of the bottom, which are exclusively silicious." *

Similar effects of the rapid flow of water and the concussion of stones against each other in river-beds, may be observed in almost every Alpine gorge which serves as the channel of a swift stream. The tremendons eleft through which the well-known Tia Mala is carried receives, every year, from its own crumbling walls and from the Hinter Rhein and its wild tributaries, enormous quantities of rock, in blocks and boulders. $\dagger$ In fact, the masses hurled into it in a single flood like those of 1868 would probably fill it up, at its narrow points, to the level of the road 400 feet above its bottoin, were not the stones crushed and carried off by the force of the current. Yet below the outlet at Thusis only small rounded boulders, pebbles and gravel, not rock, are found in the bed of the river. The Swiss glaciers bring down thousands of cubic yards of hard rock every season. Where the glacier ends in a plain or wide valley, the rocks are accumulated in a terminal moraine, but in numerous instances the water which pours from the iceriver has force enough to carry down to larger streams the masses delivered by the glacier, and there they, with other stones washed out from the earth by the current, are ground down, so that few of the affluents of the Swiss lakes deliver into them anything but fine sand and slime.

Great rivers carry no boulders to the sea, and, in fact, receive none from their tributaries. Lombardini found, twenty years ago, that the mineral matter brought down to the Po by its tributaries was, in general, comminuted to about the same degree of fineness as the sands of its bed at their points of discharge. In the case of the Trebbia, which rises high in the Apennines and emp. ties into the $\mathrm{Po}$ at Piacenza, it was otherwise, that river rolling

\section{* Avant-projet pour la création d'un sol fertile, p. 20.}

$\uparrow$ At Riukenberg, on the right bank of the Vorder Rhein, in the flood of 1868 , a block of stone computed to weigh nearly $9,000 \mathrm{cwt}$. was carried bodily forwards, not rolled, by a torrent, a distance of three-quarters of a mile. CoAz, die Hochwasser im 1868, p. 54. 
pebbles and coarse gravel into the channel of the principal stream. The banks of the other aflluents-excepting some of those which discharge their waters into the great lakes-then either retained their woods, or had been so long clear of them that the torrents had remored most of the disintegrated and loose rock in their upper basins. The valley of the Trebbia had been recently cleared, and all the forces which tend to the degradation and transportation of rock were in full activity.*

\section{Transporting Power of Water.}

But the geographical effects of the action of torrents are not confined to erosion of earth and comminution of rock; for they, and the rivers to which they contribute, transport the débris of the mountains to lower levels and spread them out over the dry land and the bed of the sea, thus forming alluvial deposits, sometimes of a beneficial, sometimes of an injurious, character, and of vast extent. $\dagger$

A mountain rivulet swollen by rain or melted snow, when it escapes from its usual channel and floods the adjacent fields, naturally deposits pebbles and gravel upon them; but even at low water, if its course is long enough for its grinding action to have full scope, it transports the solid material with which it is charged to some larger stream, and there lets it fall in a state of minute division, and at last the spoil of the mountain is used to raise the level of the plains or is carried down to the sea.

An instance that fell under my own observation, in 1857, will serve to show something of the eroding and transporting power of streams which, in these respects, fall incalculably below the

* Since the date of Lombardini's observations, many Alpine valleys have been stripped of their woods. It would be interesting to know whether any sensible change has been produced in the character or quantity of the matter transported by the rivers to the Po.-Notice sur les Rivieres de la Lombardie, Annales des Ponts et Chaussées, 1847, 1er sémestre, p. 131.

†Lorentz, in an official report quoted by Marchand, says: "The felling of the woods produces torrents which cover the cultivated soil with pebbles and fragments of rock, and they do not confine their rarages to the vicinity of the mountains, but extend them into the fertile fields of Provence and other de. partments, to the distance of forty or fifty leagues."-Entwaldung der Gebirge, p. 17. 
torrents of the Alps. In a flood of the Ottaquechee, a smaL river which flows through Woodstock, Vermont, a mill-dam on that stream burst, and the sediment with which the pond was filied, estimated after careful measurement at 13,000 cubic yards, was carried down by the eurrent. Between this dam and the slackwater of another, four miles below it, the bed of the stream, which is composed of pebbles interspersed in a few places with larger stones, is about sixty-five feet wide, though at low water the breadth of the current is considerably less. The sand and fine gravel were smoothly and evenly distributed over the bed to a width of fifty-five or sixty feet, and, for a distance of about two miles, except at two or three intervening rapids, filled up all the interstices between the stones, covering them to the depth of nine or ten inches, so as to present a regularly formed concare channel, lined with sand, and reducing the depth of water, in some places, from five or six feet to fifteen or eighteen inches. Observing this deposit after the river had subsided and become so clear that the bottom could be seen, I supposed that the next flood would produce an extraordinary erosion of the banks and some permanent changes in the channel of the stream, in consequence of the elevation of the bed and the filling up of the spaces between the stones through which formerly much water had flowed; but no such result followed. The spring freshet of the next year entirely wașhed out the sand its predecessor had left, deposited some of it in ponds and still-water reaches below, carried the residue beyond the reach of observation, and left the bed of the river almost precisely in its former condition, though, of course, with the displacement of the pebbles which every flood produces in the channels of such streams. The pond, though often previously discharged by the breakage of the dam, had then been undisturbed for about twenty-five years, and its contents consisted almost entirely of sand, the rapidity of the current in floods being such that it would let fall little lighter sediment, even above an obstruction like a dam. The quantity I have mentioned evidently bears a very inconsiderable proportion to the total erosion of the stream during that period, because the wash of the banks consists chiefly of fine earth rather than of sand, and after the pond was once filled, or nearly so, even this material could no longer be deposited in it. The fact of the complete 
removal of the deposit I have described between the two dams is a single freshet, shows that, in spite of considerable obstruction from roughness of bed, large quantities of sand may be taken up and carried ofl by streams of no great rapidity of inclination; for the whole descent of the bed of the river between the two dams -a distance of four miles-is but sixty feet, or fifteen feet to the mile.*

The facts which I have adduced may aid us in forming an idea of the origin and mode of transportation of the prodigious deposits at the mouth of great rivers like the Mississippi, the Nile, the Ganges and the Hoang-Ho, the delta of which last river, composed entirely of river sediment, has a superficial extent of not less than 96,500 square miles. But we shall obtain a clearer conception of the character of this important geographical process by measuring, more in detail, the mass of earth and rock which a well-known river and its tributaries have washed from the mountains and transported to the plains or the sea, within the historic period.

\section{The $P_{0}$ and its Deposits.}

The current of the River Po, for a considerable distance after its volume of water is otherwise sufficient for continuous navigation, is too rapid for that purpose until near Cremona, where its velocity becomes too much reduced to transport great quantities of mineral matter, except in a state of minute division. Its southern affluents bring down from the Apennines a large quantity of fine earth from various geological formations, while its Alpine tributaries west of the Ticino are charged chiefly with rock ground down to sand or gravel. The bed of the river has been somewhat elerated by the deposits in its channel, though not by any means above the level of the adjacent plains, as has been so often represented. The dikes, which confine the current at high water, at the same time augment its velocity and compel

* In a sheet-iron siphon, 1,000 feet long, with a diameter of four inches, having the entrance 18 feet, the orifice of discharge 40 feet, below the summit of the curve, employed in draining a mine in California, the force of the current was such as to carry through the tube great quantities of sand and coarse gravel, some of the graius of which were as large as an English walnut.RAYMoND, Mfining Statistics, 1870, p. 602. 
it to carry most of its sediment to the Adriatic. It has, therefore, raised neither its own chamel nor its alluvial shores, as it would have done if it had remained unconfined. But, as the surface of the water in floods is above the general level of the plains through which it flows, the Po can, at that period, receive no contributions of earth from the washing of the fields of Lombardy, and there is no doubt that a large-proportion of the sediment it now deposits at its mouth descended from the Alps in the form of rock, though reduced by the grinding action of the waters, in its passage seaward, to the condition of fine sand, and often of silt.

We know little of the history of the $\mathrm{Po}$, or of the geography of the coast near the point where it enters the Adriatic, at any period more than twenty centuries before our own. Still less can we say how much of the plains of Lombardy had been formed by its action, combined with other causes, before man accelerated its levelling operations by felling the first woods on the mountains whence its waters are derived. But we know that since the Roman conquest of Northern Italy, its deposits have amounted to a quantity which, if recemented into rock, recombined into gravel, common earth, and vegetable mould, and restored to the situations where eruption or upheaval originally placed or vegetation deposited it, would fill up hundreds of deep ravines in the Alps and Apennines, change the plan and profile of their chains, and give their southern and northern faces respectively a geographical aspect very different from that they now present. Ravenna, forty miles south of the principal mouth of the Po, was built like Venice, in a lagoon, and the Adriatic still washed its walls at the commencement of the Christian era. The mud of the Po has filled up the lagoon, and Ravenna is now four miles from the sea. The town of Adria, which lies between the Po and the Adige, at the distance of some four or five miles from each, was once a harbor famous enough to have given its name to the Adriatic Sea, and it was still accessible to large vessels, if not by the open sea at least by lagoons, in the time of Augustus. The combined action of the two rivers has so advanced the coast-line that Adria is now more than fourteen miles inland, and, in other places, the deposits made within the same period by these and other neighboring streams have a width of twenty miles. 
What proportion of the earth with which they are charged these rivers have borne out into deep water, during the last two thonsand years, we do not know ; but as they still transport enolmous quantities, as the North Adriatic appears to have shoalerl rapidly, and as long islands, composed in great part of fluviatile deposits, have formed opposite their mouths, it must evidently have been very great. The floods of the Po occur but once, or sometimes twice, in a year.* At other times, its waters are comparatively limpid and seem to hold no great amount of mud or fine sand in mechanical suspension; but at high water it contains a large proportion of solid matter, and, according to Lombardini,

* In the earlier mediaval centuries, when the declivities of the mountains still retained a much larger proportion of their woods, the moderate annual floods of the Po were occasioned by the melting of the snows on the lower slopes, and, according to a passage of Tasso quoted by Castellani (Dell' Influenza dolle Selve, i., p. 58, note), they took place in IIay. The usually more violent inundations of later ages are due to rains, the waters of which are no longer retained by a forest-soil, but conveyed at once to the rivers-and they occur almost uniformly in the autumin or late summer. Castellani, on the page just quoted, says that even so late as about 1780 , the Po required a heavy rain of a week to overflow its banks, but that forty years later it was sometimes raised to full flood in a single day.

Pliny says: "The Po, which is inferior to no river in swiftness of current, is in flood about the rising of the dog-star, the snow then melting, and though so rapid in flow, it washes nothing from the soil, but leaves it increased in fertility."-Natural History, Book iii., 20.

The first terrible inundation of the Po in 1872 took place in May, and appears to have been occasioned by heavy rains on the southern flank of the Alps, and to have received little accession from snow. The snow on the higher Alps does not usually thaw so as to occasion floods before August, and often considerably later. The more destructive flood of October, 1872, was caused both by thaws in the high mountains and by an extraordinary fall of rain. See River Embankments; post.

The irregularity of the precipitation in many parts of Italy is extreme. Thus at Genoa, where the annual mean is 1285.98 millimetres, the rainfall in October, 1833 , was 16.18 millimetres; in the same month in $1860,18.15$ millimetres; in October, 1871, 24.62 millimetres, and in October, 18\%2, no less than 775.93 millimetres. Giurnale di Agricoltura, 30 November, 1873.

Pliny's remark as to enrichment of the soil by the floods appears to be verified in the case of that of October, 1872 , for it was found that the water left very extensively a thick deposit of slime on the fields.

See a list of the historically known great inundations of the Po by the engi neer Zuccholli in Tonelli, Progetto di Legge per la Vendita di Beni incolti Roma, 1872. 
it annually transports to the shores of the Adriatic not less than 42,760,000 cubic mètres, or very nearly 55,000,000 cubic yards, which carries the coast-line out into the sea at the rate of more than 200 feet in a year.* The depth of the annual deposit is stated at cighteen centimitres, or rather more than seven inches, and it would cover an area of not much less than ninety square miles with a layer of that thickness. The Adige, also, brings every Jear to the Adriatic many million cubic yards of Alpine detritus, and the contributions of the Brenta from the same source are far from inconsiderable. The Adriatic, however, receives but a small proportion of the soil and rock washed away from the Italian slope of the Alps and the northern declivity of the Apennines by torrents. Nearly the whole of the débris thus romoved from the southern face of the Alps between Monte Rosa and the sources of the Adda-a length of watershed $\uparrow$ not less than one hundred and fifty miles-is arrested by the still waters of the

* This change of coast-line can not be ascribed to upheaval, for a comparison of the level of old buildings-as, for instance, the church of San Vitale and the tomb of Theodoric at Ravenna-with that of the sea, tends to prove a depression rather than an elevation of their foundations.

A computation by a different method makes the deposits at the mouth of the Po 2,123,000 metres less; but as both of them omit the gravel and silt carried down at ordinary and low water, we are safe in assuming the larger quantity.

† Sir John F. W. Herschel (Physical Genfraphy, 137, and elsewhere) spells this word zater-sched, because he cousiders it a translation, or rather an adoption, of the German "Wasser-scheide, separition of the waters, not water-shed the slope donen vclich the waters run." As a point of historical etymology, it is probable that the word in question was sugrested to those who first used it by the German Wasserscheide; but the spelling water-sched, proposed by IIerschel, is objectionable, both because sch is a combination of letters wholly unknown to modern English orthograpliy and properly representing no sound recognized in English orthoepy, and for the still better reason that water-shed, in the sense of division-of-the-icaters, has a legitimate English etymology.

The Anglo-Saxom sceadan meant both to separate or divide, and to shade or shelter. It is the root of the English verbs to shed and to shacte, and in the former meaning is the A. S. equivalent of the German verb scheiden.

Shed in Old English had the meaning to separate or distinguish. It is so used in the Orrl and the Nightingale, v. 197. Palsgrave (Lesclarcissement, etc., p. 717) defines $I$ shede, I departe thinges asonder; and the word still means to divide in several English local dialects. Hence, vatershed, the division or separation of the waters, is good English both in etymology and in spelling.-Sec article WATERSHED, in Johnston's Cyclopadia. 
Lakes Magggiore and Como, and some smaller lacustrine reservoirs, and nerer reaches the sea. The $\mathrm{Po}$ is not continuously embanked except for the lower half of its course. Above Cremona, therefore, it spreads and deposits sediment over a wide surfice, and the witer withdrawn from it for irrigation at lower points, as well as its inundations in the occasional ruptures of its banks, carry over the aljacent soil a large amount of slime.*

If to the estimated annual deposits of the Po at its mouth, we add the carth and sand tramsported to the sea by the Adige, the Brenta, and other less important streams, the prodigious mass of detritus swept into Lago Marggiore by the Tosi, the Magrgia, and the Ticino, into the lake of Como by the Maira and the Adda, into the lakes of Garda, Lugano, Iseo, and Idro, by their aftuents, $\uparrow$ and the yet raster heaps of pebbles, gravel and earth permanently deposited by the torrents near their points of eruption from mountain gorges, or spread over the wide plains of lower levels, we may safely assume that we have an aggregate of not less than ten times the (1uantity curried to the Adriatic by the Po, or 550 ,000,000 cubic yards of solid matter, abstracted every year from the Italian Alps and the Apemines, and removed out of their domain by the force of running water. $\neq$

* The quantity of sediment deposited by the Po on the plains which border it, before the construction of the continuous dikes and in the floods which occasionally burst through them, is rast, and the consequent elevation of those plains is very considerable. I do not know that this latter point has been made a subject of special investigation, but vineyards, with the vines still attached to the elms which supported them, have been found two or three yards below the present surface at various points on the plains of Lombardy.

+ The Po receires about four-tenths of its maters from these lakes. See

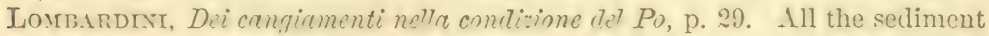
carried into the lakes by their tributaries is deposited in them, and the witer which flors ont of them is perfectly limpid. Fron their prosimits to the Alps and the number of torrents which empty into them, they no doubt receire vastly more transported matter than is contributed to the Po by the six-tenths of its waters received from other sources.

¥ Mencotti estimated the mass of solid matter annually "united to the waters of the Po" at $\$ 22,000,000$ cubic mitres, or nearly twenty times as much as, according to Lombardini, that river delivers into the Adriatic. Castellani supposes the computation of Mengotti to fall much below the truth, and there can he no doubt that a vastly larger quantity of earth and gravel is washed 
The present rate of deposit at the mouth of the $\mathrm{Po}$ has contin ued since the year 1600, the previous advance of the coast, after the year 1200, having been only one-third as rapid. The great increase of erosion and transport is ascribed by Lombardini chiefly to the destruction of the forests in the basin of that river and the valleys of its tributaries, since the beginning of the seventeenth century. "We have no data to show the rate of deposit in any given century before the year 1200, and it doubtless varied according to the progress of population and the consequent extension of clearing and cultivation. The transporting power of torrents is greatest soon after their formation, because at that time their points of delivery are lower, and, of course, their general slope and velocity more rapid, than after years of erosion above, and deposit below, have depressed the beds of their mountain valleys, and elevated the channels of their lower course. Their eroding action also is most powerful at the same period, both because their mechanical force is then greatest, and because the loose earth and stones of freshly cleared forest-ground are most easily removed. Many of the Alpine valleys west of the Ticino-that of the Dora Baltea, for instance-were nearly stripped of their forests in the days of the Roman Empire, others in the Middle Ages, and, of course, there must have been, at different periods before the year 1200, epochs when the erosion and transportation of solid matter from the Alps and the Apennines were at least as great as since the year 1600 .

Upon the whole, we shall not greatly err if we assume that, for a period of not less than two thousand years, the walls of the basin of the Po-the Italian slope of the Alps, and the northern and northeastern declivities of the Apennines-have annually sent down into the lakes, the plains, and the Adriatic, not less than $375,000,000$ cubic yards of earth and disintegrated rock. We have, then, an aggregate of 750,000,000,000 cubic yards of such matcrial, which, allowing to the mountain surface in question an area of 50,000,000,000 square yards, would cover the whole to

down from the Alps and the Apennines than is carried to the sea.-CASTEL. Lani, Dell' Immediata Influenza delle Selve sul corso delle Acque, i. pp. 42, 43.

I have contented myself with assuming less than one-half of Mengotti's estimate.

* Baudraarter, An. des Pontes et Chaussées, 1847, 1er sémestre, p. 175. 
the depth of fifteen yards.* There are very large portions of this area, where, as we know from ancient remains-roads, brilges, and the like-from other direct testimony, and from geological considerations, very little degradation has taken place within twenty centuries, and hence the quantity to be assigned to localities where the destructive causes have been most active is increased in proportion.

If this vast mass of pulrerized rock and earth were restored to the localities from which it was derived, it certainly would not obliterate valleys and gorges hollowed out by great geolorgical causes, but it would reduce the length and diminish the depth of ravines of later formation, modify the inclination of their walls, reclothe with earth many bare mountain ridges, essentially change the line of junction between plain and mountain, and carry back a long reach of the Adriatic coast many miles to the west. $\dagger$

* The total superficies of the basin of the Po, down to Ponte Lagoscuro [Ferrara]-a point where it has received all its affluents-is $6,938,200$ hectares, that is, 4,105,600 in mountain lands, 2,832,600 in plain lands.-DusrowT, Traraux Publics, etc., p. 272.

These latter two quantities are equal respectively to $10,145,318$, and 6,999 ,638 acres, or 15,852 and 10,937 square miles.

The valley of the Po is estimated to contain 58\%,916 hectares of rock and glacier, 1,131, 2S8 of forest often very thinly wooded, 789,999 bare of vegetation, and 209,107 capable of being wooded. Giornale ai Agricoltura, April, 1874 .

+ I do not use these quantities as factors the value of which is precisely ascertained; nor, for the purposes of the present argument, is quantitative exact. ness important. I employ numerical statements simply as a means of aiding the imagiuation to form a general and certainly not extravagant idea of the extent of geographical revolutions which man has done much to accelerate, if not, strictly speaking, to produce.

There is an old proverb, Dolus latet in generalibus, and Arthur Foung is not the only public economist who has warned his readers against the deceitfulness of round numbers. I think, ou the contrary, that vastly more error has been produced by the affectation of precision in cases where precision is impossible. In all the great operations of terrestrial nature, the elements are so numerous and so difficult of exact appreciation, that, until the means of scientific observation and measurement are much more perfected than they now are, we must content ourselves with general approximations. I say terrestrial nature, because in cosmical movements we have fewer elements to deal with, and may therefore arrive at much more rigorous proportional accuracy in determina. tion of time and place than we can in fixing and predicting the quantities and the epochs of variable natural phenomena on the earth's surface.

Travellers are often misled by local habits in the use of what may be called 
It is, indeed, not to be supposed that all the degradation of the mountains is due to the destruction of the forests-that the flanks of every Alpine valley in Central Europe below the snow-line were once covered with earth and green with woods, but there are not many particular cases in which we can, with certainty, or even with strong probability, affirm the contrary.

representative numbers, where a definite is put for an indefinite quantity. A Greek, who wished to express the notion of a great but undetermined number, used "myriad, or ten thousand"; a Roman, "six hundred"; an Oriental, "forty," or, at present, very commonly, "fifteen thousand." Many a tourist has gravely repeated, as an ascertained fact, the vague statement of the Arabs and the monks of Mount Sinai, that the ascent from the convent of St. Catherine to the summit of Gebel Moosa counts "tifteen thousand" steps, though the difference of level is ouly two thousind feet; and the "Forty" Thieves, the "forty" martyr-monks of the convent of El Arbain-not to speak of a similar use of this numeral in more important cases-have often been understood as expressions of a known number, when in fact they mean simply many. The number "fifteen thousand" has found its way to Rome, and De Quincey seriously informs us, on the authority of a lady who had been at much pains to ascertain the oxact truth, that, including closets large enough for a bed, the Vatican contains fifteen thousand rooms. Any one who has observed the vast dimensions of most of the apartments of that structure will admit that we make a very small allowance of space when we assign a square rod, sixteen and a half fect square, to each room upon the average. On an acre, there might be one hundred and sixty such rooms, including partition walls; and, to contain fifteen thousand of them, a building must cover more than nine acres, and be ten stories high, or possess other equivalent dimensions, which, as every traveller knows, many times exceeds the truth.

The value of a high standard of accuracy in scientific observation can hardly be overrated; but habits of rigorous exactness will never be formed by an investigator who allows himself to trust implicitly to the numerical precision of the results of a few experiments. The wonderful accuracy of geodetic measurements in modern times is, in general, attained by taking the mean of a great number of observations at every station, and this final precision is but the mutual balance and compensation of numerous errors.

But trustworthy general results can be obtained from means or averages only when the separate items are relatively numerous. The importance of this principle is well illustrated by the following fact. In an enumeration of the population of London, some years since, conducted with special reference to the effects of different industrial occupations on health, the mortality among manufacturers of children's toys was reported at fifty per cent. per annum. Upon inquiry into that surprising statement, it was found that in Loudon there were tico minufacturers of such toys, one of whom had died during the year, and this was the sole foundation for the conclusion that this manufacture was so destructive to human life.

The pretended exactness of statistical tables is too often little better than an 


\section{IIountain Slides.}

Terrible as are the ravages of the torrent and the rirer-flood, the destruction of the woorls exposes human life and industry to calamities even more appalling than those which I have yet deseribed. The slide in the Noteh of the White Momntains, by which the Willey family lost their lives, is an instance of the sort I refer to, though I am not able to say that in this particular case the slip of the earth and rock was produced by the denudation of the surface. It may have been occasioned by this cause, or by the construction of the road through the Notch, the excavations for which perhaps cut through the natural buttresses that supported the sloping strata above.

Not to speak of the fall of earth when the roots which held it together, and the bed of leaves and mould which sheltered it both from disintegrating frost and from sudden drenching and dissolution by heary showers, are gone, it is easy to see that, in a climate with severe winters, the removal of the forest, and consequently of the soil it had contributed to form, might cause the displacement and descent of great masses of rock. The woods, the regetable mould, and the soil beneath, protect the rocks they cover from the direct action of heat and cold and from the expansion and contraction which accompany them. Most rocks, while covered with earth, contain a considerable quantity of water.* A fragment of rock pervaded with moisture cracks and

imposture; and those founded, not on direct estimation by competent observers, but on the report of persons who have no particular interest in knowing the truth, are often a motive for distorting it, are commonly to be regarded as but vague guesses at the actual fact.

* Rock is permeable by water to a greater extent than is generally supposed. Marble, and even granite, as well as most other stones, when freshly quarried, are sensibly heavier, as well as softer and more easily wrought, than after they are dried and hardened by air-seasoning. Mlany sandstones are porous enough to serve as filters for liquids, and much of that of Upper Egypt and Nubia hisses audibly when thrown into water, from the escape of the air forced out of it by hydrostatic pressure and the capillary attraction of the pores for water. The purest water near London is that derived from precipitation and stored up by nature in the dense chalk formations of the interior of the country.

Even the denser silicious stones are penetrable by fluids and the coloring matter they contain, to such an extent that agates and other forms of silex 
splits if thrown into a furnace, and sometimes with a loud detonation; and it is a familiar observation that the fire, in burning over newly-cleared lands, breaks up and sometimes almost pulverizes the stones. This effect is due partly to the unequal expansion of the stone, partly to the action of heat on the water it contains in its pores. The sum, suddenly let in upon rock which had been covered with moist earth for centuries, produces more or less disintegration in the same way, and the stone is also exposed to chemical influences from which it was sheltered bofore. But in the climate of the United States as well as of the Alps, frost is a still more powerful agent in breaking up mountain masses. The soil that protects the lime and sandstone, the slate and the granite, from the influence of the sun, also prevents the water which filters into their crevices and between their strata from freezing in the hardest winters, so that the moisture descends, in a liquid form, until it escapes in springs or passes off by deep subterranean chamels. But when the ridges are laid bare, the water of the autumnal rains fills the minutest pores and veins and fissures and lines of separation of the rocks, then suddenly freezes, and bursts asunder huge and apparently solid blocks of adamantine stone.* Where the strata are inclined at a considerable angle, the freezing of a thin film of water over a

may be artificially stained through their substance. The colors of the stones cut at Oberstein are generally produced, or at least heightened, by art. This art was known to and practised by the ancient lapidaries, and it has been revived in recent times.

* Palissy had observed the action of frost in disintegrating rock, and he thus describes it, in his essay on the formation of ice: "I know that the stones of the mountains of Ardennes be harder than marble. Nevertheless, the people of that country do not quarry the said stones in winter, for that they be subject to frost; and many times the rocks have been seen to fall without being cut, by means whereof many people have been killed, when the said rocks were thawing." Palissy was ignorant of the expansion of water in freezing-in fact, he supposed that the mechanical force exerted by freezing-water was due to compression, not dilatation-and therefore he ascribes to thawing alone effects resulting not less from congelation.

Various forces combine to produce the stone avalanches of the higher Alps, the fall of which is one of the greatest dangers incurred by the adventurous explorers of those regions-the direct action of the sun upon the stone, the ex pansion of freezing-water, and the loosening of masses of rock by the thawing of the ice which supported them or held them together. 
large interstratal area might occasion a slide that should cover miles with its ruins; and similar results might be produced by the simple hyclrostatic pressure of a columm of water, admitted, by the removal of the covering of earth, to flow into a crevice faster than it could escape through orifices below.

Earth or rather mountain slides, compared to which the eatastrophe that buried the Willey family in New Hampshire was but a pinch of dust, have often occurred in the Swiss, Italian and French Alps. The land-slip which overwhelmed, and covered to the depth of seventy feet, the town of Plurs in the valley of the Maira, on the night of the 4th of September, 1618, sparing not a soul of a population of 2,430 inhabitants, is one of the most memorable of these catastrophes; and the fall of the Rossberg or Rufiberg, which destroyed the little town of Goldau in Switzerland, and 450 of its people, on the $2 d$ of September, 1806, is almost equally celebrated. In 1771, according to Wessely, the mountain-peak Piz, near Alleghe in the province of Belluno, slipped into the bed of the Cordevole, a tributary of the Piave, destroying in its fall three hamlets and sixty lives. The rubbish filled the valley for a distance of nearly two miles, and, by damming up the waters of the Cordevole, formed a lake about three miles long, and a hundred and fifty feet deep, which still subsists, though reduced to half its original length by the wearing down of its outlet and the filling up of its bed by deposits from streams which enter into it.*

* Wessely, Die Oesterreichischen Alpenländer und ihre Forste, pp. 125, 126. Wessely records several other more or less similar occurrences in the Austrian Alps. Some of them, certainly, are not to be ascribed to the removal of the woods, but in most cases they are clearly traceable to that cause. See Revue des Eaux et Forêts for 1869, pp. 182, 205.

Professor Filopanti gives in the Patria the history of a new lake in Italy, the formation of which dates from 1870. In the month of January of that year, in the mountainous Commune of Pian del Voglio, near the Apennine crest which separates the province of Florence from that of Bologna, occurred a great land-slip on the left of the Savena, bringing down earth, trees and houses, and obstructing the bed of the torrent to the height of 30 metres, and consequently forcing the waters to rise so far in order to surmount the new obstacle. There was thus formed a small lake on the mountain, measuring 30 mètres in greatest depth, 50 in breadth, and about a kilomètre long, running over into the valley by a rapid cascade. The waters of this little lake had the apparent immobility, the limpidity and the beautiful azure color of the large 
The important provincial town of Veleia, near Piacenza, where many interesting antiquities hare been discovered within a few yeare, was buried by a vast lancl-slip, probably about the time of Probus, but no historical record of the event has survived to us.

On the 1tth of February, 155 below the parish of San Stefano, in Tuscany, slid into the valley of the Tiber, which consequently flooded the village to the depth of fifty feet, and was finally drained off by a tunnel. The mass of dúbris is stated to have been about 3,500 feet long, 1,000 wide, and not less than 600 high.*

Occurrences of this sort have been so mumerous in the Alps and Apenuines, that almost erery Italian mountain commune has its tradition, its record, or its still visible traces of a great landslip within its own limits. The old chroniclers contain frequent notices of such calamities, and Giovanni Villani even records the destruction of fifty houses and the loss of many lives, by a slide of what seems to have been a spur of the hill of San Giorgio in the city of Florence, in the year 1284. $中$

Deficiency and excess of moisture are almost equally prejudicial to the stability of large masses of earth. During the extraordinarily dry summer of 1881 the winding surface of the chain of hills of which San Giorgio-a steep ridge almost overhauging

lakes. Few people knew anything about this new lake till Professor Filopanti gave an account of it in the Ionitore di Bologna, after a visit which he made to the place. Although the Professor has not been able to renew his visit, he has taken means to become acquainted with the present condition of the lakelet. He learns that its breadth and depth have considerably diminished, as might have been expected, on account of the quantity of earth and stone continually carried into the lake by the rains, and still more by the materials brought down by the torrent from above. Probably the lake in ten or twenty years, though much contracted, will still be recognizable; but in course of time geologists will scarcely be able to find its traces. Howerer this may be, the history of the little lake of Savena may well be regarded as in miniature that of most of the lakes formed thousands of years ago, and which are filled up only in the course of centuries.

* Bianciri, Appendix to the Italian translation of MIrs. SonerviLle's Physical Geography, p. xxxvi.

† Cronica di Grovannr Villanr, lib. vii., cap. 97. For descriptions of other slides in Italy, see same author, lib. xi., cap. 26 ; FANFANI, Antologia Italiana, parte ii., p. 95 ; Grolianr, Linguaggio vivente della Toscana, 1865, lettera, 63 . 
the left bank of the Arno at Florence-forms a part, was deeply fissured by cracks which seemed to threaten extensive slides; and similar observations were made in other parts of Tuscany. The joumals of Savoy ammounce that the forests of Joigny, at Combe, Mont-Granier, in that province, covering two sfuare kilomitres, has slid down the hill of Entremont, in the direction of the village, and its inhabitants have abandoned it. The heary rains had saturated the ground and then formed torrents which undermined the foot of the hill.

Such displacements of earth and rocky strata rise to the magnitude of geological convulsions, but they are of so rare occurrence in countries still covered by the primitive forest, so common where the mountains have been stripped of their native covering, and, in many cases, so easily explicable by the drenching of incohesive earth from rain, or the free admission of water between the strata of rocks-both of which a coating of regetation would have prevented-that we are justified in ascribing them for the most part to the same cause as that to which the destructive effects of mountain torrents are chiefly due-the felling of the woods. *

In nearly every case of this sort, the circumstances of which are known-except the rare instances attributable to earthquakes -the immediate cause of the slip has been the imbibition of water in large quantities by bare earth, or its introduction between or beneath solid strata. If water insinuates itself between the strata, it creates a sliding surface, or it may, by its expansion in freezing, separate beds of rock, which had been nearly contimuous before, widely enough to allow the gravitation of the superincumbent mass to overcome the resistance afforded by inequalities of face and by friction; if it finds its way beneath hard earth or rock reposing on clay, or on other bedding of similar prop-

* There is good reason for thinking that many of the earth and rock slides in the Alps occurred at an earlier period than the origin of the forest vegetation which, in later ages, covered the flanks of those mountains, - See Bericht über die Untersuchung der Schweizerischen Hochgebirgsualdungen, 1862, p. 61.

Where more recent slides have been again clothed with woods, the trees, shrubs and smaller plants which spontaneously grow upon them are usually of different species from those observed upon soil displaced at remote periods. This difference is so marked that the site of a slide can often be recognized at a great distance by the general color of the foliage of its regetation. 
erties, it converts the supporting layer into a semi-fluid mud, which opposes $n o$ obstacle to the sliding of the strata above.

The upper part of the mountain which buried Goldau was composed of a hard but brittle conglomerate, called nagelfue, resting on an unctuous clay, and inclining rapidly towards the village. Much earth remained upon the rock, in irregular masses, but the woods had been felled, and the water had free access to the surface, and to the crevices which sun and frost had already produced in the rock, and, of course, to the slimy stratum beneath. The whole summer of 1806 had been very wet, and an almost incessant deluge of rain had fallen the day preceding the catastrophe, as well as on that of its occurrence. All conditions, then, were favorable to the sliding of the rock, and, in obedience to the laws of gravitation, it precipitated itself into the valley as soon as its adhesion to the earth beneath it was destroyed by the conversion of the latter into a viscous paste. The mass that fell measured between two and a half and three miles in length by one thousand feet in width, and its arerage thickness is thought to have been about a hundred feet. The highest portion of the mountain was more than three thousand feet above the village, and the momentum acquired by the rocks and earth in their descent carried huge blocks of stone far up the opposite slope of the Rigi.

The Piz, which fell into the Cordevole, rested on a steeply inclined stratum of limestone, with a thin layer of calcareous marl intervening, which, by long exposure to frost and the infiltration of water, had lost its original consistence, and become a loose and slippery mass instead of a cohesive and tenacious bed.

\section{Protection against Avalanches.}

In Switzerland and other suowy and mountainous countries, forests render a most important service by preventing the formation and fall of destructive aralanches, and in many parts of the Alps exposed to this catastrophe, the woods are protected, though too often ineffectually, by law. No forest, indeed, could arrest a large avalanche once in full motion, but the mechanical resistance afforded by the trees prevents their formation, both by obstructing the wind, which gives to the dry snow of the Staub- 
Lawine, or dust-avalanche, its first impulse, and by checking the disposition of moist snow to gather itself into what is called the Rutsch-Luwine, or sliding avalanche. Marchand states that, the very first winter after the felling of the trees on the ligher part of a declivity between Samen and Gsteig where the snow had never been known to slide, an avalanche formed itself in the clearing, thundered down the mountain, and overthrew and carried with it a hitherto unviolated forest to the amount of nearly a million cubic feet of timber.* Elisée Reclus informs us in his remarkable work, La Terre, vol. i., p. 212, that a mountain, which rises to the south of the Pyrenzean village Araguanet in the upper valley of the Neste, having been partially stripped of its woods, a formidable aralanche rushed down from a platean above in $18+6$, and swept off more than 15,000 pine-trees. The path once opened down the flanks of the mountain, the eril is almost beyond remedy. The snow sometimes carries off the earth from the face of the rock, or, if the soil is left, fresh slides erery winter destroy the young plantations, and the restoration of the wood becomes impossible. The track widens with erery new avalanche. Drellings and their occupants are buried in the snow, or swept away by the rushing mass, or by the furious blasts it occasions through the displacement of the air; roads and bridges are destroyed; rivers blocked up, which swell till they orerflow the ralley abore, and then, bursting their snowy barrier, flood the fields below with all the horrors of a winter inundation. +

\section{* Entroaldung der Gebirge, p. 41.}

$f$ The importance of the wood in preventing avalanches is well illustrated by the fact that, where the forest is wanting, the inhabitants of localities exposed to snow-slides often supply the place of the trees by driving stakes through the snow into the ground, and thus checking its propensity to slip. The woods themselves are sometimes thus protected against avalanches originating on slopes above them, and as a further security, small trees are cut down along the upper line of the forest, and laid against the trunks of larger trees, transversely to the path of the slide, to serve as a fence or dam to the motion of an incipient avalanche, which may by this means be arrested before it acquires a destructive velocity and force.

In the volume cited in the text, Reclus informs us that " the village and the great thermal establishment of Barèges in the Pyrenees were threatened yearly by aralanches which precipitated themselves from a height of 1,200 mitres and at an angle of 35 degrees; so that the inhabitants had been obliged to 


\section{Minor Uses of the Forest.}

Besides the important conservative influences of the forest, and its value as the source of supply of a material indispensable to all the arts and industries of human life, it renders other services of a less obvious and less generally recognized character.

Woods often subserve a valuable purpose in preventing the fall of rocks, by mere mechanical resistance. Trees, as well as herbaceous vegetation, grow in the Alps upon declivities of surprising steepness of inclination, and the traveller sees both luxuriant grass and flourishing woods on slopes at which the soil, in the dry air of lower regions, would crumble and fall by the weight of its own particles. When loose rocks lie scattered on the face of these declivities, they are held in place by the trunks of the trees, and it is very common to observe a stone that weighs hundreds of pounds, perhaps even tons, resting against a tree which has stopped its progress just as it was beginning to slide down to a lower level. When a forest in such a position is cut, these blocks lose their support, and a single wet season is enough not only to bare the face of a considerable extent of rock, but to cover with earth and stone many acres of fertile soil below.*

In alluvial plains and on the banks of rivers trees are extremely useful as a check to the swift flow of the water in inundations, and the spread of the mineral material it transports; but this

leave large spaces between the different quarters of the town for the free pas sage of the descending masses. Attempts have been recently made to prevent these avalanches by means similar to those employed by the Swiss mountaineers. They cut terraces three or four yards in width across the mountain slopes and support these terraces by a row of iron piles. Wattled fences, with here and there a wall of stone, shelter the young shoots of trees, which grow up by degrees under the protection of these defences. Until natural trees are ready to arrest the snows, these artificial supports take their place and do their duty very well. The only avalanche which swept down the slope in the year 1860 , when these works were completed, did not amount to 350 cubic yards, while the masses which fell before this work was undertaken contained from 75,000 to 80,000 cubic yards." - La Terre, vol. i., p. 233.

* See in Korr, Alpenreisen, i., 120, an account of the ruin of fields and pastures, and even of the destruction of a broad belt of forest, by the fall of rocks in consequence of cutting a few large trees. Cattle are very often killed in Switzeriand by rock-avalanches, and their owners secure themselves from los by insurance against this risk as against damage by fire or hail. 
will be more appropriately considered in the chapter on the $\mathrm{Wa}$ ter's ; and another most important use of the woods, that of confining the loose sands of dunes and plains, will be treated of in the chapter on the Sands.

\section{Small Forest Plants, and Vitality of Seed.}

Another function of the woods, to which I have barely alluded, deserves a fuller notice than can be bestowed upon it in a treatise the scope of which is purely economical. The forest is the native habitat of a large number of humbler plants, to the growth and perpetuation of which its shade, its humidity, and its vegetable mould appear to be indispensable necessities.* We can not

* "A hundred and fifty paces from my house is a hill of drift-sand, on which stood a few scattered pines (Pinus sylcestris). Sempervivum tectorum in abundance, Statice armeria, immone vernalis, Dianthus carthusianorum, with other sand-plants, were growing there. I planted the hill with a few birches, and all the plants I have mentioned completely disappeared, though there were many naked spots of sand between the trees. It should be added, however, that the hillock is more thickly wooded than before. . . . It seems then that Sempervivum tectorum, etc., will not bear the neighborhood of the birch, though growing well near the Pinus syliestris. I have found the large red variety of Agaricus deliciosus only among the roots of the pine; the greenish-blue Agaricus deliciosus among alder roots, but not near any other tree. Birds have their partialities among trees and shrubs. The Sylvice prefer the Pinus Larix to other trees. In my garden this Pinus is never without them, but I never saw a bird perch on Thuja occidentalis or Juniperus sabina, although the thick foliage of these latter trees affords birds a better shelter than the loose leafage of other trees. Not even a wren ever finds its way to one of them. Perhaps the scent of the Thuja and the Juniperus is offensive to them. I have spoiled one of my meadows by cutting away the bushes. It formerly bore grass four feet high, because many umbelliferous plants, such as Heracleum sponclylium, Spirca ulmaria, Laserpitium latifolia, etc., grew in it. Under the shelter of the bushes these plants ripened and bore seed, but they gradually disappeared as the shrubs were extirpated, and the grass now does not grow to the height of more than two feet, because it is no longer obliged to keep pace with the umbellifera which flourished among it." See a paper by J. G. Büttwer, of Kurland, in BerGHaus's Geographisches Jahrbuch, 1852, No. 4, pp. 14, 15.

These facts are interesting as illustrating the multitude of often obscure conditions upon which the life or vigorous mrowth of smaller organisms de. pends. Particular species of truffles and of mushrooms are found associated with particular trees, without being, as is popularly supposed, parasites deriv ing their nutriment from the dying or dead roots of those trees. The success of Rousseau's experiments seem decisive on this point, for he obtains larger 
positively say that the felling of the woods in a given vegetable province Fould involve the final extinction of the smaller plants which are found only within their precincts. Some of these, though not naturally propagating themselves in the open ground, may perluaps germinate and grow under artificial stimulation and protection, and finally become hardy enough to maintain an independent existence in rery different circumstances from those which at present seem essential to their life.

Besides this, although the accounts of the growth of seeds, which have lain for ages in the ashy dryuess of Egyptian catacombs, are to be received with great cantion, or, more probably, to be rejected altogether, yet their vitality seems almost imperishable while they remain in the situations in which nature deposits them. When a forest old enough to have witnessed the mysteries of the Druids is felled, trees of other species spring up in its place; and when they, in their turn, fall before the axe, sometimes even as soon as they have spread their protecting shade over the surface, the germs which their predecessors had shed years,

crops of truffles from ground covered with young seedling onks than from that filled with roots of old trees. See an article on IIont Ventoux, by Charles Martins, in the Revue des Deux Mondes, Avril, 1863, p. 626.

It ought to be much more generally known than it is, that most if not all mushrooms, even of the species reputed poisonous, may be rendered harmless and healthful as food by soaking them for two hours in acidulated or salt water. The water requires two or three spoonfuls of vinegar or two spoonfuls of gray salt to the quart, aud a quart of water is enough for a pound of sliced mushrooms. After thus soaking, they are well washed in fresh water, thrown into cold water, which is raised to the boiling-point, and, after remaining half an hour, taken out and again washed. Gérard, to prove that "crumpets is wholesome," ate cue hundred and seventy-five pounds of the most poisonous mushrooms thus prepared, in a single month, fed his family ad libitum with the same, and finally administered them, in heroic doses, to the members of a committee appointed by the Council of Health of the city of Puris. See Frgurer, L'Annie Scientifique, 1862, pp. 358, 38.4. It should be observed that the venomous principle of poisonous mushrooms is not decomposed and rendered innocent by the process described in the note. It is merely extracted by the acidulated or saline water employed for soaking the plants, and care should be taken that this water be thrown away out of the reach of mischief.

It has long been known that the Russian peasantry eat, with impunity, mushrooms of species everywhere else regarded as very poisonous. Is it not probable that the secret of rendering them harmless-which was known to Pliny, though since forgotten in Italy-is possessed by the rustic Muscovites \& 
perhaps centuries, before, sprout up, and in due time, if not choked by other trees belonging to a later stage in the order of matural succession, restore again the original wood. In these easer, the seeds of the new crop may have been bronght by the wind, by birds, by (quadrupeds, or by other causes; but, in many instances, this explanation is not probable.

When newly cleared ground is burnt over in the United States, the ashes are hardly cold before they are covered with a crop of fire-weed, Senecio hierucifoliur, a tall, herbaceous plint, very seldom seen growing under other cireumstances, and often not to be found for a distance of many miles from the clearing. Its seeds, whether the fruit of an ancient vegetation or newly sown by winds or birds, require either a quickening by a heat which raises to a certain high point the temperature of the stratum where they lie buried, or a special pabulum furnished only by the combustion of the vegetable remains that cover the ground in the woods.

Earth brought up from wells or other excavations soon produces a harvest of plants often very unlike those of the local flora, and Hayden informs us that on our great Western desert plains, "whererer the earth is broken up, the wild sum-flower (Melianthus) and others of the taller-growing plants, thongh previously unknown in the vicinity, at once spring up, almost as if spontaneous generation had taken place." *

Moritz Waguer, as quoted by Wittwer, + remarks in his description of Mount Ararat: "A singular phenomenon to which my guide drew my attention is the appearance of several plants on the earth-heaps left by the last catastrophe [an earthiquake], which grow nowhere else on the mountain, and had nerer been observed in this region before. The seeds of these plants were probably brought by birds, and found in the loose, clayey soil remaining from the streams of mud, the conditions of growth which the other soil of the mountain refused them." This is probable enough, but it is hardly less so that the flowing mud brought them up to the influence of air and sun, from depths where a previous convulsion had buried them ages before. Seeds of

* Geological Survey of Wyoming, p. 455.

† Physitalische Geographie, p. 486. 
small sylvan plants, too deeply buried, by successive layers of forest foliage and the mould resulting from its decomposition, to be reached by the plough when the trees are gone and the ground brought under cultivation, may, if a wiser posterity replants the mood which sheltered their parent stems, germinate and grow, after lying for generations in a state of suspended animation.*

Darwin says: "On the estate of a relation there was a large and extremely barren heath, which had nerer been touched by the hand of man, but sereral hundred acres of exactly the same nature had been enclosed twenty-fire years previously and planted with Scotch fir. The change in the natire regetation of the planted part of the leath was most remarkable-more than is generally seen in passing from one quite different soil to another; not only the proportional numbers of the heath-plants were wholly changed, but twelve species of plants (not counting grasses and sedges) flourished in the plantation which could not be found on the heath." † Had the author informed us that these twelre plants belonged to species whose seeds enter into the nutriment of the birds which appeared with the young wood, we could easily account for their presence in the soil; but he says distinctly that the birds were of insectivorous species, and it therefore seems more probable that the seeds had been deposited when an ancient forest protected the growth of the plants which bore them, and that they sprang up to new life when a return of farorable conditions arraked them from a sleep of centuries. Darrin indeed says that the heath "had never been touched by the hand of man." Perhaps not,

* The mines of Laurium, which gave rise recently to such lively diplomatic discussion, are generally known to be larcely incumbered with scoriæ, proceeding from the working of the ancient Greeks, but still containing enough of silver to repay extraction by the improved modern methods. Prof. Hendreich relates, according to L'Union Miflicale, that under these scorixe, for at least 1,500 years, has slept the seed of a poppy of the species Glaucium. After the refuse had been removed to the furnaces, from the whole space which they had corered have sprung up and flowered the pretty yellow corollas of this flower, which was unknown to modern science, but is described by Pliny and Dioscorides. This flower had disappeared for fifteen to twenty centuries, and its reproduction at this interval is a fact parallel to the fertility of the famous "mummy wheat."-London Medical Record.

† Origin of Species, American ed., p. 69. 
after it became a heath; but what evidence is there to control the general presumption that this heath was preceded by a forest, in whose shade the vegetables which dropped the seeds in question might have grown? *

Although, therefore, the destruction of a wood and the reclaiming of the soil to agricultural uses suppose the death of its smaller dependent flora, these rerolutions do not exclude the possibility of its resurrection. In a practical view of the subject, however, we must admit that when the woodman fells a tree he sacrifices the colony of humbler growths which had regetated under its protection. Some wood-plants are known to possess valuable medicinal properties, and experiment may show that the number of these is greater than we now suppose. Few of them, however, have any other economical value than that of furnishing a slender pasturage to cattle allowed to roam in the woods;

* Writers on vegetable physiology record numerous instances where seeds have grown after lying dormant for ages. The following cases are mentioned by Dr. Dwight (Travels, ii., pp. 438, 439) :

"The lands [in Panton, Vermont], which have here been once cultivated, and again permitted to lie waste for several years, yield a rich and fine growth of hickory [Carya porcina]. Of this wood there is not, I believe, a single tree in any original forest within fifty miles from this spot. The native growth was here white pine, of which I did not see a single stem in a whole grove of hickory.".

The hickory is a walnut, bearing a fruit too heavy to be likely to be carried ffty miles by birds, and besides, I believe it is not eaten by any bird indigenous to Vermont. We have seen, however, on a former page, that birds transport the nutmeg, which when fresh is probably as heavy as the walnut, from one island of the Indian archipelago to another.

"A field, about five miles from Northampton, on an eminence called Rail Hill, was cultivated about a century ago. The native growth here, and in all the surrounding region, was wholly oak, chestnut, etc. As the field belonged to my grandfather, I had the best opportunity of learning its history. It colltained about five acres, in the form of an irregular parallelogram. As the savages reudered the cultivation dangerous, it was given up. On this ground there sprang up a grove of white pines covering the field and retaining its figure exactly. So far as T remember, there was not in it a single oak or chestnut tree. . . . There was not a single pine whose seeds were, or probably for ages had been, sufficientiy near to have been planted on this spot. The fact that these white pines covered this field exactly, so as to preserve both its extent and its figure, and that there were none in the neighborhood, are decisive proofs that cultivation brought up the seeds of a former forest within the limits of regetation, and gave them an opportunity to germinate."

See, on the Succession of the Forest, Tuonead, Excursions, p. 135 et seq. 
and even this small advantage is far more than compensated by the mischief done to the young trees by browsing animals. Upon the whole, the importance of this class of vegetables, as physic or as food, is not such as to furnish a very telling popular argument for the conservation of the forest as a necessary means of their perpetuation. More potent remedial agents may supply their place in the materia medica, and an acre of grass-land yields more nutriment for cattle than a range of a hundred acres of forest. But he whose sympathies with nature have taught him to feel that there is a fellowship between all God's creatures; to love the brilliant ore better than the dull ingot, iodic silver and crystallized red copper better than the shillings and the ponnies forged from them by the coiner's cunning; a venerable oak-tree than the brandy-cask whose staves are split out from its heartwood; a bed of anemones, hepaticas, or wood-violets than the leeks and onions which he may grow on the soil they have enriched and in the air they made fragrant-he who has enjoyed that special training of the heart and intellect which can be acquired only in the unviolated sanctuaries of nature, "where man is distant, but God is near" - -will not rashly assert his right to extirpate a tribe of harmless regetal,les, barely because their products neither tickle his palate nor fill his pocket; and his regret at the dwindling area of the forest solitude will be augmented by the reflection that the nurselings of the woodland perish with the pines, the oaks and the beeches that sheltered them.*

Nthough, as I have said in a former chapter, birds do not frequent the deeper recesses of the wood, yet a very large proportion of them build their nests in trees, and find, in their foliage and branches, a secure retreat from the inclemencies of the seasons and the pursuit of the reptiles and quadrupeds which prey upon them. The borders of the forests are vocal with song; and when

* Quaint old Valvasor had observed the subduing influence of nature's solitudes. In describing the lonely Canker-Thal, which, though rocky, was in his time well wooded with "fir, larches, beeches and other trees," he says • "Gladsomeness and beauty, which dwell in many valleys, may not be looked for there. The journey through it is cheerless, melawcholy, wearisome, and serveth to temper and mortify over-joyousness of thought. . . . . In sum it is a very desert, wherein the wildness of human pride doth grow tame."-Ehrs der Orain, i., p. 136, b. 
the gray and dewy moming calls the creeping things of the earth ont of their night-eells, it summons from the neighboring wood legions of their winged enemies, which swoop down "pon the fields to sare man's barrests by devouring the destroying worm, and surprising the lagging beetle in his tardy retreat to the dark cover where he lurks through the hours of daylight.

The insects most injurious to the rumal inclustry of the garren and the ploughland do not multiply in or near the woods. The locust, which ravages the East with its roracions armies, is bred in vast open plains which admit the full heat of the sun to hasten the hatching of the egrgs, gather no moisture to destroy them, and harbor no bird to feed upon the larve.* It is only since the felling of the forests of Asia Minor and Cyrene that the locust las become so fearfully destructive in those countries; and the grisshopper, which now threatens to be almost as great a pest to the agriculture of some North American soils, breeds in seriously injurious number's only where a wide extent of surface is bare of woods.

\section{General Functions of Forests.}

In the preceding pages we have seen that the electrical and chemical action of the forest, though obscure, exercises probably a beneficial, certainly not an injurious, influence on the composition and condition of the atmosphere; that it serves as a protection against the diffusion of miasmatic exhalations amd malarious poisons ; that it performs a most important function as a mechanical shelter from blasting winds to grounds and crops in the lee of it; that, as a conductor of heat, it teuds to equalize the temperature of the earth and the air; that its dead products form a mantle orer the surface, which protects the earth from excessive heat and cold; that the eraporation from the leaves of living

* Smela, in the government of Kiew, has, for some years, not suffered at all from the locusts, which formerly came erery year in vast swarms, and the curculio, so injurious to the turnip crops, is less destructive there than in other parts of the province. This improvement is owing partly to the more thorough cultivation of the soil, partly to the groves which are interspersed among the ploughlands. . . . . When in the midst of the plains woods shall be planted and filled with insectivorous birds, the locusts will cease to be a plague and a terror to the farmer.-Rextzscir, Dir Wald, pp. 45, 46. 
trees, while it cools the air around them, diffuses through the atmosphere a inedium which resists the escape of warmth from the earth by radiation, and hence that its general effect is to equilibrate caloric influences and moderate extremes of temperature.

We have seen, further, that the forest is equally useful as a regulator of terrestrial and of atmospheric humidity, preventing by its shade the drying up of the surface by parching winds and the scorching rays of the sun, intercepting a part of the precipitation, and pouring out a vast quantity of aqueous vapor into the atmosphere; that if it does not increase the amount of rain, it tends to equalize its distribution both in time and in place; that it preserves a hygrometric equilibrium in the superior strata of the earth's surface; that it maintains and regulates the flow of springs and rivulets; that it checks the superficial discharge of the waters of precipitation and consequently tends to prevent the sudden rise of rivers, the violence of floods, the formation of destructive torrents, and the abrasion of the surface by the action of running water; that it imperles the fall of avalanches and of rocks, and destructive slides of the superficial strata of mountains; that it is a safeguard against the breeding of locusts, and, finally, that it furnishes nutriment and shelter to many tribes of animal and of vegetable life which, if not necessary to man's existence, are conducive to his rational enjoyment. In fine, in well-wooded regions, and in inhabited countries where a due proportion of soil is devoted to the growth of judiciously distributed forests, natural destructive tendencies of all sorts are arrested or compensated, and man, bird, beast, fish and regetable alike find a constant uniformity of condition most favorable to the regular and harmonious coexistence of them all.

\section{General Consequences of the Destruction of the Forest.}

With the extirpation of the forest, all is changed. At one season, the earth parts with its warmth by radiation to an open sky-receives, at another, an immoderate heat from the unobstructed rays of the sun. Hence the climate becomes excessive, and the soil is alternately parched by the fervors of summer, and seared by the rigors of winter. Bleak winds sweep unresisted 
over its surface, drift away the snow that sheltered it from the frost, and dry up its scanty moisture. The precipitation becomes as irregular as the temperature; the melting snows and vernal rains, no longer absorbed by a loose and bibulons vegretable mould, rush over the frozen surface, and pour down the valleys seawards, insteat of filling a retentive bed of absorbent carth, and storing up a supply of moisture to feed perennial springs. The soil is bared of its covering of leaves, broken and loosened by the plough, deprived of the fibrous rootlets which held it together, dried and pulverized by sun and wind, and at last taken up by new combinations. The face of the earth is no longer a sponge, but a dustheap, and the floods which the waters of the sky pour over it hurry swiftly along its slopes, carrying in suspension vast quantities of earthy particles which increase the abrading power and mechanical force of the current, and, augmented by the sand and gravel of falling banks, fill the beds of the streams, divert them into new channels, and obstruct their outlets. The rivulets, wanting their former regularity of supply and deprived of the protecting shade of the woods, are heated, evaporated, and thus reduced in their summer currents, but swollen to raging torrents in autumn and in spring. From these causes there is a constant degradation of the uplands, and a consequent elevation of the beds of watercourses and of lakes, by the deposition of the mineral and vegetable matter carried down by the waters. The channels of great rivers become unnavigable, their estuaries are choked up, and harbors which once sheltered large navies are shoaled by dangerous sand-bars. The earth, stripped of its vegetable glebe, grows less and less productive, and, consequently, less able to protect itself by weaving a new network of roots to bind its particles together, a now carpeting of turf to shield it from wind and sun and scouring rain. Gradually it becomes altogether barren. The washing of the soil from the mountains leaves bare ridges of sterile rock, and the rich organic mould which covered them, now swept down into the dank low grounds, promotes a luxuriance of aquatic vegetation that breeds fever, and more insidious forms of mortal disease, by its decay, and thus the earth is rendered no longer fit for the habitation of man.*

* Almost every narrative of travel in those countries which were the earliest sorta of cf vilization, contains evidence of the truth of these general statements, 
To the general truth of this sad picture there are many exceptions, even in countries of excessive climates. Some of these are due to favorable conditions of surface, of geological structure, and of the distribution of rain; in many others, the evil consequences of man's improvidence have not yet been experienced, only because a sufficient time has not elapsed, since the felling of the forest, to allow them to develop themselves. But the vengeance of nature for the violation of her harmonies, though slow, is sure, and the gradual deterioration of soil and climate, in such exceptional regions, is as certain to result from the destruction of the woods as is any natural effect to follow its cause.

\section{Due Proportion of Woodland.}

The proportion of woodland that ought to be permanently maintained for its geographical and atmospheric influences varies according to the character of soil, surface and climate. In countries with a humid sky, or moderately undulating surface and an equable temperature, a small extent of forest, enough to serve as a mechanical screen against the action of the wind in localities where such protection is needed, suffices. But most of the territory occupied by civilized man is exposed, by the character of its surface and its climate, to a physical degradation which can not be averted except by devoting a large amount of soil to the growth of the woods.

From an economical point of view, the question of the due proportion of forest is not less complicated or less important than in its purely physical aspects. Of all the raw materials which nature supplies for elaboration by human art, wood is undoubtedly the most useful, and at the same time the most indispensable to social progress.*

and this evidence is presented with more or less detail in most of the special works on the forest which I have occasion to cite. I may refer particularly to Homenstein, Der Wald, 1860, as full of important facts on this subject. See also CAmi, Cenni sullu Importanza dei Boschi, for some statistics, not readily found elsewhere, on this and other topics counected with the forest.

* In an imaginary dialogue in the Recepte Véritable, the author, Palissy, having expressed his indignation at the folly of men in destroying the woods, Lis interlocutor defends the policy of felling them, by citing the example of "divers bishops, cardinals, priors, at bots, monkeries and chapters, which, by 
The demand for wood, and of course the quantity of forest re quired to furnish it, depend upon the supply of fucl from other sources, such as peat and coal, upon the extent to which stone, brick or metal can adrantageously be substituted for wood in building, upon the development of arts and industries employing wood and other forest products as materials, and upon the cost of oltaining them from other countries, or upon their commercial value as articles of export.

Upon the whole, taking civilized Europe and America torgether, it is probable that from twenty to twenty-five per cent. of well-wooded surface is indispensable for the maintenance of normal physical conditions, and for the supply of materials so essential to every branch of human industry and every form of social life as those which compose the harvest of the woods.

There is probably no country-there are few large farms even -where at least one-fourth of the soil is not either unfit for agricultural use, or so unproductive that, as pasture or ploughland, it yields less peeuniary return than a thrifty wood. Every Western prairie has its sloughs where willows and poplars would find a fitting soil, every Eastern farm its rocky nooks and its barren hillsides suited to the growth of some species from our rich forest flora, and everywhere belts of trees might advantageonsly be planted along the roadsides and the boundaries and dividing fences. In most cases, it will be found that trees may be made to grow well where cultivated crops will not repay the outlay of tillage, and it is a very plain dictate of sound economy that

cutting ther woods, have made three profits," the sale of the timber, the rent of the ground, and the "good portion" they received of the grain grown by the peasants upon it. To this argument Palissy replies: "I can not enough detest this thing, and I call it not an error, but a curse and a calamity to all France; for when forests shall be cut, all arts shall cease, and they which practise them shall be driven out to eat grass with Nebuchadnezzar and the beasts of the field. I have divers times thought to set down in writing the arts which shall perish when there shall be no more wood; but when I had written down a great number, I did perceive that there could be no end of my writing, and having diligently considered, I found there was not any which could be followed without wood." .... "And truly I could well allege to thee a thousand reasons, but 'tis so cheap a philosophy, that the rery chamberwenches, if they do but think, may see that without wood, it is not possible to exercise any manner of human art or cunning."-Euvres de BERNARI Pajdssy. Paris, 1844, p 89. 
if trees produce a better profit than the same ground would ro. turn if devoted to grass or grain, the wood should be substituted for the field.

\section{Woodland in European Countries.}

In 1862, Rentzsch calculated the proportions of woodland in different European countries as follows : *

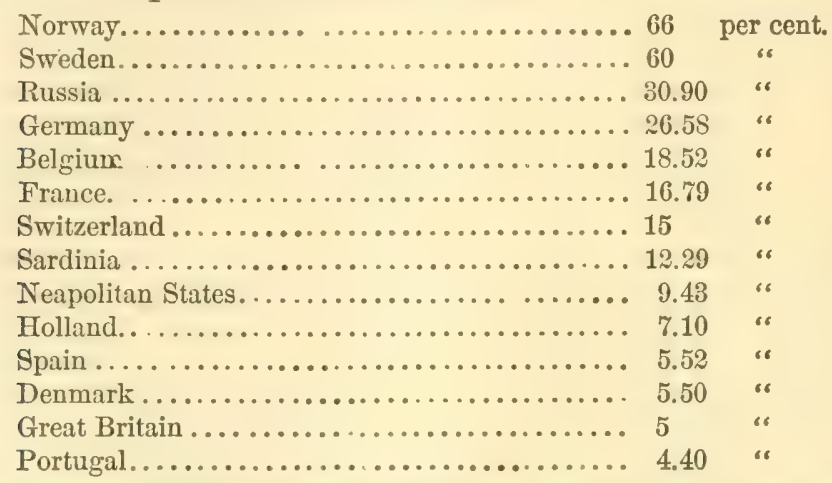

The large proportion of woodland in Norway and Sweden is in a great measure to be ascribed to the mountainous character of the surface, which renders the construction of roads difficult and expensive, and hence the forests are comparatively inaccessible, and transportation is too costly to tempt the inhabitants to sacrifice their woods for the sake of supplying distant markets.

The industries which employ wood as a material have only lately been much developed in these countries, and though the climate requires the consumption of much rood as a fuel, the population is not numerous enough to create, for this purpose, a demand exceeding the annually produced supply, or to need any great extension of cleared ground for agricultural purposes. Besides this, in many places peat is generally employed as domestic fuel. Hence, though Norway has long exported a considerable quantity of lumber, $\nmid$ and the iron and copper works of Sweden

* Der Wald, pp. 123, 124.

† Railway-ties, or, as they are called in England, sleepers, are largely exported from Norway to India, and sold at Calcutta at a lower price than timber of equal quality can be obtained from the native woods.-Reports on For. est Conservancy, vol. i., pt. ii., p. 1533.

From 1861 to 1870 Norway exported annually, on the average, more than 
consume eliareoal very largely, the forests have not diminished rapilly enough to produce very sensible climatic or even economical evils.

At the opposite end of the seale we find Holland, Demmark, Great Britain, Spain and Portugal. In the three first-named countries a cold and humid climate renders the almost constant maintenance of clomestic fires a necessity, while in Great Britain especially the demand of the various industries which depend on wood as a material, or on mechanical power derired from heat, are very great. Coal and peat serve as a combustible instead of wood in them all, and England imports an immense quantity of timber from her foreign possessions. Fortunately, the character of soil, surface and climate renders the forest of less importance, as a geographical agent, in these northern regions than in Spain and Portugal, where all physical conditions concur to make a large extent of forest an almost indispensable means of industrial progress and social advancement.

Rentzsch, in fact, ascribes the political decadence of Spain almost wholly to the destruction of the forest. "Spain," observes he, "seemed destined by her position to hold dominion over the world, and this in fact she once possessed. But she has lost her political ascendency, because, during the feeble administration of the successors of Philip II., her exhausted treasury could not furnish the means of creating new fleets, the destruction of the woods having raised the price of timber abore the means of the State."* On the other hand, the same writer argues

60,000,000 cubic feet of lumber.-Wulfsbeng, Norges Felstandstiller. Christiania, 1872.

Since 1872 the quantity of the annual exportation of timber from Norway and Sweden has steadily increased, and in 1881 it was so large that it might well excite the grave anxiety of all friends of the primeval forest.

* Der Wald, p. 63. Antonio Ponz (Viage de España, i., prólogo, p. Ixiii.) says : "Nor would this be so great an evil, were not some of them declaimers against trces, thereby proclaiming themselves, in some sort, enemies of the works of God, who gave us the leafy abode of Paradise to dwell in, where we should be even now sojourning, but for the first sin, which expelled us from it."

I do not know at what period the two Castiles were bared of their woods, but the Spaniard's proverbial "hatred of a tree" is of long standing. Herrera combats this foolish prejudice; and Ponz, in the prologue to the ninth volume of his journey, says that many carried it so far as wantonly to destroy the shade and ornamental trees planted by the municipal authorities. "Trees," 
that the wealth and prosperity of modern England are in great part due to the supply of lumber, as well as of other material for ship-building, which she imports from her colonies and other countries with which she maintains commercial relations.

\section{Forests of Great Britain.}

The proportion of forest is very small in Great Britain, where, as I have said, on the one haud, a prodigious industrial activity requires a vast supply of ligneous material, but where, on the other, the abundance of coal, which furnishes a sufficiency of fuel, the facility of importation of timber from abroad, and the conditions of climate and surface combine to reduce the necessary quantity of woodland to its lowest expression.

With the exception of Russia, Denmark, and parts of Germany, no European countries can so well dispense with the forests, in their capacity of conservative influences, as England and Ireland. Their insular position and latitude secure an abundance of atmospheric moisture; the general inclination of surface is not such as to expose it to special injury from torrents, and it is probable that the most important climatic action exercised by the forest in these portions of the British empire, is in its character of a mechanical screen against the effects of wind. The due proportion of woodland in England and Ireland is, therefore, a question not of geographical, but almost purely of economical, expediency, to be decided by the comparative direct pecuniary return from forest-growth, pasturage and ploughland.

Contrivances for economizing fuel came later into use in the British Islands than on the Continent. Before the introduction of a system of drainage, the soil, like the sky, was, in general, charged with humidity; its natural condition was unfavorable for the construction and maintenance of substantial common roads, and the transportation of so heavy a material as coal, by land, from the remote counties where alone it was mined in the

they contended, and still believe, "breed birds, and birds eat up the grain." Our author argues against the supposition of the "breeding of birds by trees," which, he says, is as absurd as to believe that an elm-tree can yield pears ; and he charitably suggests that the expression is, perhaps, a maniere de dire, a popular phrase, signifying simply that trees harbor birds. 
Middle Ages, was costly and difficult. For all these reasons, the consumption of wood was large, and apprehensions of the exhaus. tion of the forests were excited at an early period. Legislation there, as elsewhere, proved ineffectual to protect them, and many authors of the sixteenth century express fears of serious evils from the wasteful economy of the people in this respect. Harrison, in his curious clapter "Of Woods and Marishes" in Holinshed's compilation, complains of the rapid decrease of the forests, and adds: "Howbeit thus much I dare affirme, that if woods go so fast to decaie in the next hundred yeere of Grace, as they have doone and are like to doo in this, .... it is to be feared that the feunie bote, broome, turfe, gall, heath, firze, brakes, whinnes, ling, dies, hassacks, flags, straw, sedge, réed, rush, and also seacole, will be good merchandize enen in the citie of London, whereunto some of them enen now haue gotten readie passage, and taken vp their innes in the greatest merchants' parlours. . . . . I would wish that I might liue no longer than to sée foure things in this land reformed, that is: the want of discipline in the church: the couetous dealing of most of our merchants in the preferment of the commodities of other countries, and hinderance of their orme: the holding of faires and markets rpon the sundaie to be abolished and referred to the wednesdaies: and that enerie man, in whatsoeuer part of the champaine soile enioieth fortie acres of land, and vpwards, after that rate, either by fréc deed, copie hold, or fee farme, might plant one acre of wood, or sowe the same with oke mast, hasell, béech, and sufficient prouision be made that it may be cherished and kept. But I feare me that I should then live too long, and so long, that I should either be wearie of the world, or the world of me."*

\footnotetext{
* Holnsimed, reprint of 1807 , i., pp. 357 , 358. It is evident from this passage, and from anuther on page $39 \%$ of the same volume, that, though sea. coal was largely exported to the Continent, it had not yet come into general use in England. It is a question of much interest, when mineral coal was first employed in England for fuel. I can find no evidence that it was used as a combustible until more than a century after the Norman conquest. It has been said that it was known to the Anglo-Saxon population, but I am acquainted with $\mathrm{z} 0$ passage in the literature of that people which proves this. The dictionaries explain the Anglo-Saxon word grafa by sea-coal. I have met with this word in no Anglo-Saxon work, except in the Chronicle, A.D. 852, from a manuscript certainly not older than the 12 th century, and in two citations
} 
Evelyn's "Silva," the first edition of which appeared in 1664 , rendered an extremely important service to the cause of the woods, and there is no doubt that the ormamental plantations in which England far surpasses all other countries, are, in some

from Anglo-Sason charters, one published by Femble in Codex Diplomaticus, the other by Thorpe in Diplomaturium Anglimen, in all which passages it more probably means peat than mineral coal. According to Way, Promptorium Parrulorum, p. 506, note, the Catholicon Anglicanum has "A turfe grafte, turbarium." Grafte is here evidently the same word as the A.-S. grafa, and the Damish Töregraf, a turf-pit, confirms this opinion. Coal is not mentioned in King Alfred's Bede, in Nieckim, in Glanville or in Robert of Gloucester, though the two latter writers speak of the allied mineral, jet, and are very full in their enumeration of the mineral productions of the island.

In a Latin poem ascribed to Giraldus Cambrensis, who died after the year 12:0, but found also in the manuscripts of Walter Mapes (see Camden Society edition, pp, 131 and 3.50), and introrluced into Higden's Polychronicon (London, 1S65̃, pp. 39S, 399), carbo sub terre cortice, which can mean nothing but pit-coal, is enumerated among the natural commodities of England. Some of the translations of the 13 th and 14 th centuries render carbo by cool or col, some by gold, and some omit this line, as well as others unintelligible to the translators. Hence, although Giraldus wias acquainted with coal, it certainly was not generally known to English writers until at least a century after the time of that author.

Vegetius and Dion Cassius speak of jars of burning coal and brimstone as missiles employed in naval combats and other battles, but there is no reason to suppose that the coal referred to by them was other than charcoal. The Eongs-skugg-sio Sorös, 1768, page 391, enumerates, among like missiles, jardtol oli brennusteinn, er haufot-rapn, pessura allra, er nu hefi cle nefnt: ЕARTH-coal and brimstone are the most effective of these misxiles. Eurth-coal must of course mean mineral coal, but I know no other evidence that mineral coal was known to the Northmen so early as the 12th century, to which the Hongs-skugg-sio belongs. The new edition, Munich, 1881, has simply lol and brennusteinn, which is most likely the true reading, and the passage is probably taken from the ancient writers above referred to.

The earliest mediæral notice of mineral coal I have met with is in a passage cited by Ducange from a document of the year 1198, and it is an etymological observation of some interest, that carbones ferrei, as sea-coal is called in the document, are said by Ducange to have been known in France by the popular name of luulla, a word evidently identical with the modern French houille and the Cornish Huel, which in the form vcheal is an element in the name of many mining localities.

England was anciently remarkable for its forests, but Cæsar says it wanted the fagus and the abics.-B. G. V. 12. The late lamented Professor Rolleston, in a very interesting and instructive lecture on the influence of man in modifying the external aspects of nature, delivered before the Royal Geographical Fociety, observes that the Latin proter may mean besicles as well as except, and 
measure, the fruit of Evelyn's enthusiasm. In England, however, arboriculture, the planting and umsing of single trees, has, until comparatively recent times, been better understood than sylviculture, the sorring and training of the forest. But this

with characteristic modesty, deferring too readily to the authority of learned philologists, he adopts their interpretation of the passage in Casar as signifying that Britain possessed the same forest-trees as Gaul, besilles the fagus and the abries. I can by no means accept this view. We have abundant evidence that both the fugus and the abies were well known as indigenous to ancient Italy as well as Gaul, and Casiar must have been familiar with them both. Why, then, should he have made a sperial mention of these trees as common to Britain and Gaul, in describing the forestal growth of both countries as the sime? Professor Rolleston seems to have overlooked the observations of the Damish and German forestal botanists on the succession of species in the woods of their respective countries. The climate of Denmark and Britain are substantially alike, and it is well established that the fir tribe is not now found in the former country, where it was anciently abundant, but has been superseded in modern times by the beech. The forestal vegetation of the district of Cadore, in Southern Tyrol, is historically known to have changed in the Middle dyes from firs to beeches, and again from beeches to firs. See the authorities cited in this note, and especially De Beranger's most erudite Ginrisprudenza Forcotule. Partially fossilized remains of the palisades of ancient Roman entrenched camps are said to have been found not many years since in the neighborhood of Loudon. Of what wood those palisades were I have not seen it stated. If a microscopic examination of such remains should show that they were of a wood of spike-leaved trees, this may furnish important evidence as to the existence of firs in Britain in the time of the Romans. The Nuova Rivista Forestale di Fallambrosa, Anno iv., Dispensa iv., p. 153, has a review of an article in the Reeue des Deux. Mondes, by Broillard, from which it appears that beech-woods are spontaneously propagated by self-sowing, and are now supplanting the firs in the forests of France. There can be no doubt that fagus means the beech, which, as the remains in the Danish peat-mosses show, is a tree of late introduction into Denmark, where it succeeded the fir, a tree not now native to that country. The succession of forest crops seems to have been the same in England; for IIarrison, p. 359, speaks of the "great store of firre" found lying "at their whole lengths" in the "fens and marises" of Lancashire and other counties, where not even bushes grew in his time. Whe can not be sure what species of evergreen Cesar intended by abies. The popular designations of spike-leared trees are always more vague and uncertain in their application than those of broad-leaved trees. Pinus, pine, has been very loosely employed even in botanical nomenclature, and Fiefer, Fichte and Titnne are often confounded in German,-Rossmissier, Der Trald, pp. 256, 2\$9, 321. A similar confusion in the names of this family of trees exists in India. Dr. Cleghorn, Inspector-General of the Indian Forests, in forms us in his official Circular No. 2, that the name of dentur is applied in some provinces to a cypress, in some to a cedir, and in others to a juniper 
latter branch of rural improvement now receires great attention from private individuals, though, so far as I know, not from the National Government, except in the East Indian provinces, where the forestal department his assumed great importance."

and it is a curious etymological fact that in the earlier stages of many modern European languages the names of the oati and the fir were confounded. See Max MüLIER, Lectures, vol. ii.

If it were certain that the abies of Cæsar was the fir formerly and still found in peat-mosses, and that he Fas right in denying the existence of the beech in England in lis time, the olservation would be very important, because it would fix a date at which the fir had become extinct, and the beech had not yet appeared in the island.

From the valuable tomi relyuri delle principali piante di boseo, Annali del Ministero di Agrimlturu. etc., 14.:3, it apyears that the name abete is nowhere in Italy applied to any tree but the Pinus abies, except that in Tuscany the larch, Pinus larin, is sometimes called aluto larice, and the Pinus picea, abeto rosso or abeto di Moscoviu. The universality of the designation abete, as the name of the Pinus abies, in such a multitude of dialects, is a strong proof that the abies of ancient Latin writers was the Pinus abies.

The English oak, though strong and durable, was not considered generally suitable for finer work in the sixtcenth century. There were, howerer, exceptions. "Of all in Essex," observes Iarrison, Holinshed, i., p. 357, "that growing in Bardfield parke is the tinest for ioiners craft : for oftentimes haue I seene of their workes made of that oke so fine and faire, as most of the wainescot that is brought hither out of Danske [Dauzig] ; for our wainescot is not made in England. Yet diuerse haue assaied to deale with our okes to that end, but not with so good successe as they hame hoped, bicause the ab or iuice will not so soone be remoued and cleane drawne out, which some attrib. ute to want of time in the salt water."

This passage is also of interest as showing that soaking in salt-water, as a mode of seasoning, was practised in Harrison's time.

But the importation of wainscot, or boards for ceiling, panelling, and otherwise fuishing rooms, which was generally of oak, commenced at least three centuries before the time of Harrison. On page 204 of the Liber Albus mention is made of "squared oak timber," brought in from the country by carts, and of course of domestic growth, as free of city duty or octroi, and of "plauks of oak" coming in in the same way as paying one plank a cart-loar. But in the chapter on the "Customs of Billyngesgate," pp. 208, 209, relating to goods imported from foreign countries, an import duty of one halfpenny is imposed on every hundred of boards called "weynescotte"-a term formerly applied only to oak-and of one penny on every hundred of boards called "Rygholt." The editor explains "Rygholt" as "wood of Riga." This was doubtless pine or fir. The year in which these provisions were made does not appear, but they belong to the reign of Henry III.

* The improvidence of the population under the native and early foreign governments has produced great devastations in the forests of the British East 
In fact, England is, I believe, the only European country where private enterprise has pursued sylriculture on a really great scale, though admirable examples have been set in many others. In England the law of primogeniture, and other institutions and national customs which tend to keep large estates long undivided and in the same line of inheritance, the wealth of the landholders, the special adaptation of the climate to the growth of forest-trees, and the difficulty of finding safe and profitable investments of capital, combine to afford encouragements for the plantation of forests, which scarcely exist elsewhere in the same degree. Many laws for the protection of the forest, as a cover for game and for the preservation of ship timber, were enacted in England before the seventeenth century. The Statutes I Eliz. c. xv., XIII Eliz. c. $\nabla$. , and XXVII Eliz. c. xix., which have sometimes been understood as designed to discourage the manufacture of iron, were obviously intended to prevent the destruction of large and valuable timber, useful in ordinary and naval architecture, by burning it for charcoal. The injury to the forges was accidental, not the purpose of the laws.

In Scotland, where the country is for the most part broken and mountainous, the general destruction of the forests has been attended with very serious evils, and it is in Scotland that many of the most extensive British forest plantations have now been formed. But although the inclination of surface in Scotland is rapid, the geological constitution of the soil is not of a character to promote such destructive degradation by running water as in Southern France, and it has not to contend with the parching droughts by which the devastations of the torrents are rendered more injurious in those provinces.

It is difficult to understand how either law or public opinion, in a country occupied by a dense and intelligent population, and,

Indian provinces, and the demands of the railways for fuel and timber have greatly augmented the consumption of lumber, and of course contributed to the destruction of the woods. The forests of British India are now, and for several years have been, under the control of an efficient governmental organization, with great advantage both to the government and to the general private interests of the people.

The official Reports on Forest Conservancy from May, 1862, to August, 1871 , in 4 vols. folio, contain much statistical and practical information on all subjects connected with the administration of the forest. 
comparatively speaking, with an infertile soil, can tolerate the continued withdrawal of a great portion of the territory from the cultivation of trees and from other linds of rural economy, merely to allow wealthy individuals to amuse themselves with field-sports. In Scotland, 2,000,000 acres, as well suited to the growth of forests and for pasture as is the soil generally, are withheld from agriculture, that they may be given up to herds of deer protected by the game laws. A single nobleman, for ex ample, thus appropriates for his omn pleasures not less than 100,000 acres.* In this way one-tenth of all the land of Scotland is rendered valneless in an economical point of view-for the returns from the sale of the venison and other game scarcely suffice to pay the gamekeepers and other incidental expenses-and in these so-called forests there grows neither building timber nor firewood worth the cutting, as the animals destroy the young shoots.

\section{Forests of France.}

The preservation of the woods was one of the wise measures recommended to France by Sully, in the time of Henry IV., but the advice was little heeder, and the destruction of the forests went on with such alarming rapidity, that, two generations later, Colbert uttered the prediction: "France will perish for want of wood." Still, the extent of wooded soil was very great, and the evils attending its diminution were not so sensibly felt, that either the government or public opinion saw the necessity of authoritative interference, and in 1750 Mirahean estimated the remaining forests of the kingdom at seventeen millions of hectares $[42,000,000$ acres]. In 1860 they were reduced to cight millions [19,769,000 acres], or at the rate of 82,000 hectares [202,600 acres] per year.

* Robertson, Our Deer Forests. London, $186 \%$.

The Italie of April, 1877, says: "English oflicial documents furnish some curious information with regard to landed property in Scotland-a country in which, it is understood, such property is less divided than in most others. Of the three millions of inhabitants which Scotland contains, only 182,000 are landed proprietors, and of these there are only 19,000 who own more than a single English acre. The total superficies of the soil, which is $18,945,547$ acres, gives an average annual income of $18,688,065$ pounds sterling, that is, something less than one pound sterling per acre. MLre than one-quarter of the whole country is owued by ticenty-four proprietors, and the estate of one of these covers $1,326,453$ acres." 
Troy, from whose valuable pamphlet, Étude sur le Reboisement des 1 Lontagnes, I take these statistical details, supposes that Miriabeau's statement may have been an extravagant one, but it still remains certain that the waste has been enornous; for it is known that, in some departments, that of Ariege for instance, clearing has gone on during the last half century at the rate of three thousand acres a year, and in all parts of the empire trees lave been felled faster than they have grown." The total area of France in Mirabeau's time, excluding Savoy, but including Alsace and Lorraine, was about one hundred and thirty-one millions of acres. The extent of forest supposed by Mirabeau would be about thirtytwo per cent. of the whole territory. In a country and a climate where the conservative influences of the forest are so necessary as in France, trees must corer a large surface and be grouped in large masses, in order to discharge to the best advantage the rari ous functions assigned to them by nature. The consumption of

*Among the indirect proofs of the comparatively recent existence of exten sive forests in France, nay be mentioned the fact that wolves were abundant, not very long since, in parts of the empire where there are now neither wolves nor woods to shelter them. Arthur Young more than once speaks of the "innumerable multitudes" of these animals which infested France in 1789, and in the course of the winter of the year 5 of the French Republic the wolves of all ages killed in France were reported at 1,689. In the year 6 the number killed was 5,351 , of which 22 were said to be rabid. The premiums awarded by the Gorernment for the slaughter of wolves during that year amounted to 126,000 francs. George Sand states, in the Histoire de ma rie, that some years after the restoration of the Bourbons, they chased travellers on horseback in the southern prorinces, and literally knoclied at the doors of her father-in-law's country seat. Eugénie de Guérin, writing from Rayssac in Languedoc in 1881, speaks of hearing the wolves fighting with dogs in the night under her very windows. Lettres, 2d ed., p. 6. But, in 18s1, ofticial estimates gave the probable number of wolves in France as 5,000, and the damage done by them was calculated at a few hundred thousand francs.

There seems to have been a tendency to excessive clearing in Central and Western, earlier than in Southeastern, France. Beruard Palissy, in the Recepte Téritu'le, first printed in 1563, thus complains: "When I consider the value of the least clump of trees, or even of thorns, I much marvel at the crreat ignorance of men, who, as it seemeth, do nowadays study ouly to break down, fell, and waste the fair forests which their forefathers did guard so choicely. I would think no evil of them for cutting down the woods, did they but replant again some part of them; but they care nought for the time to come, neither reck they of the great damage they do to their children which shall come after them."- Eucris Complites de Berrand Palissr, 184t, p. 88. 
wood is rapidly increasing in that empire, and a large part of its territory is mountainous, sterile, and otherwise such in character or situation, that it can be more profitably devoted to the growth of wood than to any agricultural use. Hence it is erident that the proportion of forest in 1\%50, taking even Mirabeau's large estimate, was not very much too great for permanent maintenance, though doubtless the distribution was so unequal that it would have been sound policy to fell the woods and clear land in some provinces, while large forests should have been planted in others:* During the period in question France neither exported manufactured wood or rough timber, nor derived important collateral advantages of any sort from the destruction of her forests. She is consequently imporerished and crippled to the extent of the difference between what she actually possesses of wooded surface and what she ought to have retained. $†$

The force of the various considerations which have been suggested in regard to the importance of the forest has been gener-

* The view I have taken of this point is confirmed by the careful investigations of Rentzsch, who estimates the proper proportion of woodland to entire surface at twenty-three per cent. for the interior of Germany, and supposes that near the coast, where the air is supplied with humidity by evaporation from the sea, it might safely be reduced to twenty per cent. See Rentzsch's very valuable prize essay, Der Wald in Haushalt der NTatur und der Volkswirthschaft, cap. viii.

The due proportion in France would considerably exceed that for the German States, because France has relatively more surface unfit for any growth but that of wood, because the form and geological character of her mountains expose her territory to much greater injury from torrents, and because at least her southern provinces are more frequently visited both by extreme droughts and by deluging rains.

+ In 1863 , France imported lumber to the value of trventy-five and a half millions of dollars, and exported to the amount of six and a half millions of dollars. The annual consumption of France was estimated in 1866 at 212,000,000 cubic feet for building and manufacturing, and 1,588,500,000 for firewood and charcoal. The annual product of the forest-soil of France does not exceed $70,000,000$ cubic feet of wood fit for industrial use, and 1,300,000,000 cubic feet consumed as fuel. This estimate does not include the product of scattered trees on private grounds, but the consumption is estimated to exceed the production of the forests by the amount of about twenty millions of dollars. It is worth noticing that the timber for building and manufacturing produced in France comes almost wholly from the forests of the State or of the communes.-Jules Claví, in Revue des Deux Mondes for March 1, 1866, p. 207. 
ally felt in France, and the subject has been amply debated in special treatises, in scientitic journals, and by the public press, as well as in the legislative body of that country. Perhaps no one point has been more prominent in the discussions than the influence of the forest in equalizing and regulating the flow of the water of precipitation. Opinion is still somewhat divided on this subject, but the value of the woods as a safeguard against the ravares of torrents is universally acknowledged, and it is hardly disputed that the rise of river-floods is, even if as great, at least less sudden in streams having their sources in well-wooded territory.

Upon the whole, the conservative action of the woods in regard to torrents and to inundations has been generally recognized by the public of France as a matter of prime importance, and the Gorernment of the empire lias made this principle the basis of a special system of legislation for the protection of existing forests, and for the formation of new. The clearing of woodland, and the organization and functions of a police for its protection, are regulated by a law bearing date June 18th, 1859, and provision was made for promoting the restoration of private woods by a statute adopted on the 2Sth of July, 1S60. The former of these laws passed the legislative body by a vote of 246 against 4 , the latter with but a single negative voice. The influence of the Goverument, in a country where the throne was so potent as in France at that time, would account for a large majority, but when it is considered that both laws, the former especially, interfere very materially with the rights of private domain, the almost entire unanimity with which they were adopted is proof of a very general popular conviction, that the protection and extension of the forests is a measure more likely than any other to arrest the - devastations of the torrents and check the violence, if not to prevent the recurrence, of destructive river inundations. The law of July 28th, 1860, appropriated 10,000,000 francs, to be expended, at the rate of $1,000,000$ franes per year, in executing or aiding the replanting of woods. It is computed that this appropriation-which, considering the vast importance of the subject, does not seem extravagant for a nation rich enough to be able to expend annually six hundred times that sum in the maintenance of its military establishments in times of peace-will secure the creation of new forest to the extent of about 200,000 acres, or 
one-fourteenth part of the soil, where the restoration of the woods is thought feasible, and, at the same time, specially important as a security against the evils ascribed, in a great measure, to its destruction.*

In 1565 the Legislative Assembly passed a bill amendatory of the law of 1860, providing, among other things, for securing the soil in exposed localities by grading, and by promoting the growth of grass and the formation of greensward over the surface. This has proved a most beneficial measure, and its adoption under corresponding conditions in the United States is most highly to be recommended. The leading features of the system are:

1. Marking out, and securing from pasturage and all other encroachments, a zone along the banks and around the head of ravines.

2. Turfing this zone, which in France accomplishes itself, if not spontaneously, at least with little aid from art.

3. Consolidation of the scarps of the ravines by grading and wattling, and by establishing barriers, sometimes of solid masonry, but generally of fascines or any other simple materials at hand, across the bed of the stream.

4. Cutting banquettes or narrow terraces along the scarps, and planting upon them rows of small deciduous trees and arborescent shrubs, alternating with belts of grass obtained by turfing with sods or sowing grass-seeds. Planting the banquettes and slopes with bushes and other vegetables with tenacious roots is especially recommended. $\dagger$

* In 1848 the Government of the short-lived French Republic sold to the Bank of France 187,000 acres of public forests, and notwithstanding the zeal with which the Imperial Government had pressed the protective legislation of 1860 , it introduced into the Legislative $\mathrm{Assembly}$ in 1865 a bill for the sale, and consequently destruction, of the forests of the State to the amount of one hundred million fraucs. The question was much debated in the Assembly, and public opinion manifested itself so energeticully against the measure that the ministry felt itself compelled to withdraw it. See the discussions in L'Aliénation des Forêts de l'Êtat. Paris, 1865.

The late Imperial Government sold about 1\%0,000 acres of woodland between 18is: and 1866, both incluive. The other Governments, since the res. toration of the Bourbons in 1814, alienated more than 700,000 acres of the public forests, exclusive of sales between 1836 and 1857, which are not reported.-Annuaire des Eaux et Forêts, 1872, p. 9.

† See a description of similar processes recommended and adopted by Men. gotti, in his Idrautica, vol ii., chap. xvii. 


\section{Remedies against Torrents.}

The rural population, which in France is generally hostile to all forest laws, soon acquiesced in the adoption of this system, and its success has farr surpassed all expectation. At the end of the year 186 'S about 190,000 acres had been planted with trees," and nearly $\tau, 000$ acres well turfed over in the Department of the Hautes $A l$ pes. Many hundred ravines, several of which were the channels of formidable torrents, had been secured by barriers, grading and planting, and according to official reports the aspect of the mountains in the Department, wherever these methods were employed, had rapidly changed. The soil had acquired such stability that the violent rains of 1868 , so destructive elsewhere, produced no damage in the districts which had been subjected to these operations, and numerous growing torrents which threatened irreparable mischief had been completely extinguished, or at least rendered altogether harmless. $\dagger$

Besides the processes directed by the Government of France, various subsidiary measures of an easily and economically practicable character have been suggested. Among them is one which has long been favorably known in our Southern States under the name of circling, and the adoption of which in hilly regions in other States is to be strongly recommended.

It is simply a method of preventing the wash of surface by

* Travellers spending the winter at Nice may have a good opportunity of studying the methods of forming and conducting the rewooding of mountain slopes, under the most unfavorable conditions, by visiting MIont Boron, in the immediate vicinity of that city, and other coast plantations in that province, where great difficulties have been completely overcome by the skill and perseverance of French foresters. See Les Forîts des Maures, Rerue des Eaux et Forêts, January, 1869. Still more formidable difficulties have been vanquished in rewooding JIont Faron near Toulon, and it is hardly hyperbolical to say that this is a case of impossibilities conquered. See Revue des Eaux et Forêts, Feb., 1873.

Even in tropical and subtropical India experiments in rewooding bare and rocky soils have been tried with success. See Proccedings of the Forest Con. ference at Allahabad in Jan., 1874. Calcutta, 1874, p. 158, et seq.

$\uparrow$ For ample details of processes and results, see the second volume of SuRELL, Étude sur les Torrents, Paris, 18;2, and a Report by De LA GrYe, in the Revue des Eaux et Forêts for January, 1869. 
rains, and at the same time of providing a substitute for irriga. tion of steep pasture-grounds, consisting in little more than in rumning horizontal furrows along the hillsides, thus converting the scarp of the hills into a succession of small terraces which, when once turfed over, are very permanent. Experience is said to have demonstrated that this simple process at least partially checks the too rapid flow of surface-water into the valleys, and, consequently, in a great measure obriates one of the most prominent causes of inundations, and that it suffices to retain the water of rains, of snows, and of small springs, long enough for the irrigation of the soil, thus increasing its product of herbage in a fivefold proportion.*

As a further recommendation, it may be observed that this process is an admirable preparation of the ground for forest plantations, as young trees planted on the terraces would derive a useful protection from the form of the surface and the coating of turf, and would also find a soil moist enough to secure their growth.

\section{Forests of Italy.}

According to the most recent statistics, Italy has 17.64 per cent. of woodland, $\nmid$ a proportion which, considering the character of climate and surface, the great amount of soil which is fit for no other purpose than the growth of trees, and the fact that much of the land classed as forest is either very imperfectly wooded, or covered with groves badly administered, and not in a state of progressive improvement, might advantageously be doubled. Taking Italy as a whole, we may say that she is eminently fitted by climate, soil and superficial formation, to the growth of a varied and luxuriant arboreal vegetation, and that in the interests of self-protection, the promotion of forestal industry is among the first duties of her people. There are, in Western Piedmont, valleys where the felling of the woods has produced consequences geographically and economically as disastrous as in Southeastern France, and there are many other districts in the Alps and the Apennines where human improvidence has been almost equally

* Trox, Étude sur le Reboisement des Montagnes, §§ 6, 7, 21.

† Sienoni, Manuale d'Arte Forestale, 2 ediz., Firenze, 1872, p. 542. 
destructive. Some of these regions must be abandoned to absolute desolation, and for others the opportunity of physical restoration is rapidly passing away. But there are still millions of square miles which might profitably be planted with forest-trees, and thousands of acres of parched and barren hillside, within sight of almost erery Italian provincial capital, which might easily and shortly be reclothed with verdant woods.*

The denudation of the Central and Southern Apennines and of the Italian declivity of the Western Alps began at a period of unknown antiquity, but it does not seem to have been carried to a very dangerous length until the foreign conquests and extended commerce of Rome created a greatly increased demand for wood for the construction of ships and for military material. $\dagger$

* To one accustomed to the slow vegetation of less favored climes, the rapidity of growth in young plantations in Italy seems almost magical. The trees planted along the new drives and avenues in Florence have attained in three or four years a development which would require at least ten in our Northern States. This, it is true, is a special case, for the trees have been planted and tended with a skill and care which can not be bestowed upon a forest; but the growth of trees little cared for is still very rapid in Italy. According to Toscanelli, Economia rurale nella Provincia di Pisa, p. 8, note -one of the most complete, curious and instructive pictures of rustic life which exists in any literature-the white poplar, Populus alba, attains in the valley of the Serchio a great height, with a mean diameter of two feet, in twenty years. Selmi states in his Minsma Palustre, p. 115, that the linden reaches a diameter of sixteen inches in the same period. The growth of foreign trees is sometimes extremely luxuriant in Italy. Two Atlas cedars, at the well-known villa of Careggi, near Florence, grown from seed sown in 1850 , measure twenty inches in diameter, above the swell of the roots, with an estimated height of sixty feet.

$\nmid$ An interesting example of the collateral effects of the destruction of the forests in ancient Italy may be found in old Roman architecture. In the oldest brick constructions of Rome the bricks are very thin, and very thoroughly burnt. A few generations later the bricks were thicker and less well burnt. In the after ages of the Imperial period the bricks were still thicker, and generally soft-burnt. This fact, I think, is due to the abundance and cheapness of fuel in earlier, and its growing scarceness and dearness in later, ages. When wood cost little, constructors could afford to burn their brick thoroughly; but as the price of firewood advanced, they were able to consume less fuel in brick-kilns, and the quality and quantity of brick used in building were gradually reversed in proportion.

The multitude of geographical designations in Italy which indicate the former existence of forests, show that even in the Middle Ages there were woods where no forest-trees are now to be found. There are hundreds of 
The Eastern Alps, the WTestern Apennines, and the Maritime Alps retained their forests much later; but even here the want of wood, and the injury to the plains and the navigation of the river's by sediment brought down by the torrents, led to legislation for the protection of the forests, by the Republic of Venice, at rarious periods between the fifteenth and the nineteenth centuries, " by that of Genoa as early at least as the serenteenth; and both these Govermments, as well as several others, passed laws requiring the proprietors of mountain-lands to replant the roods. These, howerer, seem to hare been little observed, and it is generally true that the present condition of the forest, in Italy, is much less due to the want of wise legislation for its protection than to the laxity of the Governments in enforeing their laws.

It is very common in Italy to ascribe to the French occupation under the first Empire all the improrements and all the abuses of recent times, according to the political sympathies of the individual; and the French are often said to have prostrated erery forest which has disappeared within this century. However this may be, no energetic system of repression of abuses, or of restoration of the forests, was adopted by any of the Italian States after the downfall of the Empire, and the taxes on forest property, in some of them, were so burdensome that rural municipalities sometimes proposed to cede their common woods to the Government, without any other compensation than the remission of the taxes imposed on forest-lands.t Under such circum-

names of mediæval towns derived from abete, acero, carpino, castagno, faggio, frassino, noce, pino, quercia, and other names of trees.

* See A. de Berenger's Sagyio Storico della Legislazione Veneta Forestale, Venezia, 1863, and the same author's erudite Giurisprudena Forestale, Venezia, 1858. Indcx, Venezia, 1862, by far the most learned and exhaustive work which has ever appeared on the social history of the forest.

We do not find in the Venetian forestal legislation much evidence that geographical arguments were taken into account by the lawgivers.

According to Hummel, the desolation of the Karst, the high plateau lying north of Trieste, now one of the most parched and barren districts in Europe, is owing to the felling of its woods, centuries ago, to build the navies of Venice. "Where the miserable peasant of the Karst now sees nothing but bare rock swept and scoured by the raging Bora, the fury of this wind was once subdued by mighty firs, which Venice recklessly cut down to build her fleets." -Physische Geographie, p. 32.

+ See the Politecnico for the month of May, 1862, p. 234. 
stances, woodlands would soon become disafforested, and whero facilities of transportation and a good demand for timber have increased the inducements to fell it, as upon the borders of the M[editerranean, the destruction of the forest and all the evils which atteud it have gone on at a seriously alarming rate.

Gallenga gives a striking account of the wanton destruction of the forests in Northern Italy within his personal recollection,* and there are few Italians past middle life whose own memory will not supply similar reminiscences. The clearing of the mountain valleys of the provinces of Bergamo and of Brescia is recent, and Lombardini informs us that the felling of the woods in the Valtelline commenced little more than fifty years ago.

Although no country has produced more able writers on the value of the forest and the general consequences of its destruction than Italy, yet the specific geographical importance of the woods, except as a protection against inundations, has not been so clearly recognized in that country as in the States bordering it on the north and west. It is true that the face of nature has been as completely revolutionized by man, and that the action of torrents has created almost as wide and as hopeless devastation in Italy as in France; but in the French Empire the recent desolation produced by clearing the forests is more extensive, has been more suddenly effected, has occurred in less remote and obscure localities, and therefore excites a livelier and more general interest than in Italy, where public opinion does not so readily connect the effect with its true cause. Italy, too, from ancient habit, employs little wood in architectural construction; for generations she has maintained no military or commercial marine large enough to require exhaustive quantities of timber, $\nmid$ and the

* "Far away in the darkest recesses of the mountains a kind of universal conspiracy seems to have been got up among these Alpine people,-a destructive mania to hew and sweep down everything that stands on roots."-Country Life in Piednont, p. 134.

"There are huge pyramids of mountains now bare and bleak from base to summit, which men still living and still young remember seeing richly mantled with all but primeval forests."-Ibid., p. 135.

† The great naval and commercial marines of Venice and of Genoa must have occasioned an immense consumption of lumber in the MIiddle Ages, and in the centuries immediately succeeding those commonly embraced in that desig. nation. The marine construction of that period employed larger timbers than 
mildness of her climate makes small demands on the woods for fuel. Besides these circumstances, it must be remembered that the sciences of observation did not become knowledges of practical application till after the mischief was already mainly done, and even forgotten, in Alpine Italy; while its evils were just beginning to be sensibly felt in France when the claims of natural philosophy as a liberal study were first acknowledged in modern Europe. The former political condition of the Italian Peninsula would have effectually prerented the adoption of a general system of forest economy, howerer clearly the importance of a wise administration of this great public interest might have been understood. The woods which controlled and regulated the flow of the river-sources were very often in one jurisdiction; the plains to be irrigated, or to be inundated by floods and desolated by torrents, in another. Concert of action on such a subject, between a multitude of jealous petty sovereignties, was obviously impossible, and nothing but the permanent union of all the Italian States under a single government, can render practicable the establishment of such arrangements for the conservation and restoration of the forests, and for the regulation of the flow of the waters, as are necessary for the full development of the yet unexhausted resources of that fairest of lands, and even for the maintenance of the present condition of its physical geography.

\section{The Forests of Germany.}

Germany, including a considerable part of the Austrian Empire, from character of surface and climate, and from the attention which has long been paid in all the German States to sylviculture, is in a far better condition in this respect than its more southern neighbors; and though in the Alpine provinces of Bavaria and Austria the same improvidence which marks the rural economy of the corresponding districts of Switzerland,

does the modern naval architecture of most commercial countries, though apparently witnout a proportional increase of strength. The old modes of shipbuilding have been. to a considerable extent, handed down to very recent times in the Mediterranean, and though better models and modes of construction are now employed in Italian shipyards, an American or an Englishman looks with astonishment at the huge beams and thick planks so often employed in the construction of very small vessels nuvigating that sea, and not ret old enough to be broken up as unseaworthy. 
Italy and France, has produced effects hardly less disastrous," yet, as a whole, the German States, as Siemoni well observes, must be considered as in this respect the model countries of Europe. Not only is the forest area in general maintained without diminution, but new woods are planted where they are specially needed, + and, though the slow growth of forest-trees in those climates reduces the direct pecuniary returns of woodlands

* As an instance of the scarcity of fuel in some parts of the territory of Bavaria, where, not long since, wood abounded, I may mention the fact that the water of salt-springs is, in some instances, conveyed to the distance of sixty miles, in iron pipes, to reach a supply of fuel for boiling it down.

In France, the juice of the sugar-beet is sometimes carried three or four miles in pipes for the same reason.

Ilany of my readers may remember that it was not long ago proposed to manufacture the gas, for the supply of London, at the mouths of the coalmines, and convey it to the city in pipes, thus saving the transportation of the coal ; but as the coke and mineral tar would still have remained to be disposed of, the operation would probably not have proved advantageous.

Great economy in the production of petroleum has resulted from the application of cast-iron tubes to the wells, the oil being conveyed in this way over the various inequalities of surface for three or four miles to the tanks on the railroads, and forced into them by steam-engines. The price of transport is thus reduced one-fifth. But now, within less than twenty years after the first use of tubes for this short distance, we are told of the existence of many hundreds of miles of these iron arteries, which, starting from the generai reservoirs into whi h the oil is gathered from the different wells by the shorter tubes, convey this valuable fluid through hill and valley, mountain and river, and finally deposit it in receiving tanks at the sea-coast, from whence it is drawn out for domestic use or barreled for exportation. In the construction and laying of these conduits, which are fed by the wide oil districts of Ohio, Pennsylvania and New York, no doubt every advantage has been taken of all the known principles of hydrostatics, but it is impossible to suppose that it has not been necessary to employ steam-power, to a very considerable extent, in order to force the currents onward, and this is understood to be the fact.

+ The Austrian Government is making energetic efforts for the propagation of forests in Tyrol and on the desolate waste of the Karst. The diflieulties from drought and from the violence of the winds, which might prove fatal to young and even to somewhat advanced plantations, are very serious, but in 1866 upwards of 400,000 trees had been plinted on the Karst and great quantities of seeds sown. Thus far, the results of this important experiment are said to be encouraging. See the Chronique Forestiire in the Revue de's Eaux et Forêts, Feb., 1870.

Later accounts state that the Government nurseries of the Karst supplied between 1869-1872, 26,000,000 young forest-trees for planting, and that of 70,000 ash trees planted in the Karst, scarcely one failed to grow. 
to a minimum, the governments wisely persevere in encouraging this industry. The exportation of sawn lumber from Trieste is large, and in fact the Turkish and Egyptian markets are in great part supplied from this source.*

Forests of Russia.

Russia, which we habitually consider as substantially a forest country-which has in fact a large proportion of woodland-is beginning to suffer seriously for want of wood. Jourdier observes: "Instead of a vast territory with immense forests, which we expect to meet, one sees only scattered groves thinned by the wind or by the axe of the moujik, grounds cut over and more or less recently cleared for cultivation. There is probably not a single district in Russia which has not to deplore the ravages of man or of fire, those two great enemies of Muscovite sylviculture. This is so true, that clear-sighted men already foresee a crisis which will become terrible, unless the discovery of great deposits of some new combustible, as pit-coal or anthracite, shall diminish its evils." +

* For information respecting the forests of Germany, as well as other European countries, see, besides the works already cited, the very valuable MFanuale d'Arte Frostale of Siemoni, $2 d$ edizione, Firenze, 1872.

†Clavé, Études sur l'Économie Forestière, p. 261. Clavé adds (p. 262): "The Russian forests are very unequally distributed through the territory of this vast empire. In the north they form immense masses, and cover whole provinces, while in the south they are so completely wanting that the inhabitants have no other fuel than straw, dung, rushes, and heath." .... "At Moscow, firewood costs thirty per cent. more than at Paris, while, at the distance of a few leagues, it sells for a tenth of that price."

This state of things is partly due to the want of facilities of transportation, and some parts of the United States are in a similar condition. During a severe winter, ten or twelve years ago, the sudden freezing of the canals and rivers, before a large American town had received its winter supply of fuel, occasioned an enormous rise in the price of wood and coal, and the poor suffered severely for want of it. Within a few hours of the city were large forests and an abundant stock of firewood felled and prepared for burning. This might easily have been carried to town by the railroads which passed through the woods; but the managers of the roads refused to receive it as freight, because a rival market for wood might raise the price of the fuel required for their locomotives. Truly, our railways "want a master."

Hohenstein, who was long professionally employed as a forester in Russia, describes the consequences of the general war upon the woods in that country as already most disastrous, and as threatening still more ruinous evils. The 


\section{Forests of United States.}

I greatly doubt whether any one of the American States, except perhaps Oregon, has at this moment more woodland than it ought permanently to preserve, though, no doubt, a different distribution of the forests in all of them might be highly advantageous. It is, perhaps, a misfortune to the American Union that the State Governments have so generally disposed of their original domain to private citizens. It is true that public property is not sufficiently respected in the United States; and within the memory of almost every man of mature age, timber was of so little value in the northernmost States that the owners of private woodlands submitted, almost without complaint, to what would be regarded elsewhere as very aggravated trespasses upon them." Persons in want of timber helped themselves to it wher-

river Volga, the life artery of Russian internal commerce, is drying up from this cause, and the great IIuscovite plains are fast advancing to a desolation like that of Persia.-Der Wald, p. 223.

The level of the Caspian Sea is eighty-three feet lower than that of the Sea of Azoff, and the surface of Lake Aral is fast sinking. Von Baer maintains that the depression of the Caspian was produced by a sudden subsidence from geological causes, and not gradually by excess of evaporation over supply. See Kasprictie Studien, p. 25. But this subsidence diminished the area and consequently the evaporation of that sea, and the rivers which once maintained its ancient equilibrium ought to have raised it to its former level, if their own flow had not been diminished. It is, indeed, not yet proved that the laying bare of a wooded country diminishes the total annual precipitation upon it: but it is certain that the summer delivery of water from the surface of a champaign region, like that through which the Volga, its tributaries, and the feeders of Lake Aral, flow, is lessened by the removal of its woods. Hence, though as much rain may still fall in the valleys of those rivers as when their whole surface was covered with forests, more moisture may be carried off by evaporation, and a less quantity of water be discharged by the rivers since their basins were cleared, and therefore the present condition of the inland waters in question may be due to the removal of the forests in their valleys and the adjacent plains.

* According to the maxims of English jurisprudence, the common law consists of general customs so long established that " the memory of man runneth not to the contrary." In other words, long custom makes law. In new countries, the change of circumstances creates new customs, and, in time, new law, without the aid of legislation. Had the American colonists observed a more sparing economy in the treatment of their woods, a new code of customary forest law wonld have sprung up and acquired the force of a statute. Popular habit was fast elaborating the fundamental principles of such a code, when the rapid increase in the value of timber, in consequence of the reckless devas- 
ever they could find it, and a claim for damages, for so insignificant a wrong as cutting down and carrying off a few pine or oak trees, was regarded as a mean-spirited act in a proprietor. The habits formed at this period are not altogether obsolete, and even now the notion of a common right of property in the woods still lingers, if not as an opinion, at least as a sentiment. Under such circumstances it has been difficult to protect the forest, whether it belong to the State or to individuals. Property of this kind is subject to plunder, as well as to frequent damage by fire. The destruction from these causes would, indeed, considerably lessen, but would by no means wholly annililate, the climatic and geographical influences of the forest, or ruinously diminish its value as a regular source of supply of fuel and timber.

It is evidently a matter of the utmost importance that the public, and especially land-owners, be roused to a sense of the dangers to which the indiscriminate clearing of the woods may expose, not only future generations, but the very soil itself. Some of the American States, as well as the Governments of many European colonies, still retain the ownership of great tracts of primitive woodland. The State of New York, for example, has, in its northeastern counties, a vast extent of territory in which the lumberman has only here and there established his camp, and where the forest, though interspersed with permanent settlements, robbed of some of its finest pine groves, and often ravaged by devastating fires, still covers far the largest proportion of the surface. Through this territory the soil is generally poor, and even the new clearings have little of the luxuriance of harvest which distinguishes them elsewhere. The value of the land for agricultural uses is therefore very small, and few purchases are made for any other purpose than to strip the soil of its timber. It has been often proposed that the State should declare the remaining forest the inalienable property of the commonwealth, but I believe the motive of the suggestion has originated rather in poetical than in economical views of the subject. Both these classes

tation of the woodlands, made it the interest of the proprietors to interfere with this incipient system of forest jurisprudence, and appeal to the rules of English law for the protection of their woods. The courts have sustained these appeals, and forest property is now legally as inviolable as any othor, though common opinion still combats the course of judicial decision on such questions. 
of considerations have a real worth. It is desirable that some large and easily accessible region of American soil should remain, as far as possible, in its primitive condition, at once a museum for the instruction of the student, a garden for the recreation of the lover of nature, and an asylum where indigenous tree, and humble plant that loves the shade, and fish and fowl and fourfooted beast, may dwell and perpetuate their kind, in the enjoyment of such imperfect protection as the laws of a people jealous of restraint can afford them. The immediate loss to the public treasury from the adoption of this policy would be inconsiderable, for these lands are sold at low rates. The forest alone, economically managed, would, without injury, and even with benefit to its permanence and growth, soon yield a regular income larger than the present value of the fee.

The collateral advantages of the preservation of these forests would be far greater. Nature threw up those mountains and clothed them with leafy woods, that they might serve as a reservoir to supply with perennial waters the thousand rivers and rills that are fed by the rains and snows of the Adirondacks, and as a screen for the fertile plains of the central counties against the chilling blasts of the north wind, which meet no other barrier in their sweep from the Arctic pole. The climate of Northern New York even now presents greater extremes of temperature than that of Southern France. The long-continued cold of winter is more intense, the short heats of summer even fiercer than in Provence, and hence the preservation of erery influence that tends to maintain an equilibrium of temperature and humidity is of cardinal importance. The felling of the Adirondack woods would ultimately involve, for Northern and Central New York, consequences similar to those which have resulted from the laying bare of the southern and western declivities of the French Alps and the spurs, ridges and detached peaks in front of them.

It is true that the evils to be apprehended from the clearing of the mountains of New York may be less in degree than those which a similar cause has produced in Southern France, where the intensity of its action has been increased by the inclination of the mountain declivities, and by the peculiar geological constitution of the earth. The degradation of the soil is, perhaps, not equally promoted by a combination of the same circumstances, in 
any of the American Atlantic States, but still they have rapid slopes and loose and friable soils enough to render widespread desolation certain, if the further destruction of the woods is not soon arrested. The effects of clearing are already perceptible in the comparatively unviolated region of which I am speaking. The rivers which rise in it flow with diminished currents in dry seasons, and with augmented volumes of water after heavy rains. They bring down larger quantities of sediment, and the increasing obstructions to the navigation of the Hudson, which are extending themselves down the channel in proportion as the fields are encroaching upon the forest, give good grounds for the fear of irreparable injury to the commerce of the important towns on the upper waters of that river, unless measures are taken to prevent the expansion of "improvements" which have already been carried beyond the demands of a wise economy.*

In the Eastern United States the general character of the climate, soil and surface is such, that for the formation of very destructive torrents a much longer time is required than would be necessary in the mountainous provinces of Italy or of France. But the work of desolation has begun even there, and whereter a rapid mountain-slope has been stripped of wood, incipient ravines already plough the surface, and collect the precipitation in channels which threaten serious mischief in the future. There is a peculiar action of this sort on the sandy surface of pine-forests, and in other soils that unite readily with water, which has excited the attention of geographers and geologists. Soils of the first kind are found in all the Eastern States; those of the second are more frequent in the exhausted counties of Maryland, where tobacco is cultivated, and in the more southern territories of Georgia and Alabama. In these localities the ravines which appear after the cutting of the forest, through some accidental disturbance of the surface, or, in some formations, through the cracking of the soil in consequence of great drought or heat, enlarge and extend themselves with fearful rapidity.

* I learn with profound regret that, during the nineteen years that have passerl since the above was written, the forests of the Adirondacks have continued to be the scene of ever more and more rapidly encroaching inroads from the woodman's axe, and that there now seems little hope of averting the total destruction which must soon overtake them unless a wiser legislation or a sounder public opinion should interfere to save them. 
In Georgia and in Alabama, Lyell saw "the beginning of tho formation of hundreds of valleys in places where the primitive forest had been recently cut down." One of these, in Georgia, in a soil composed of clay and sand produced by the decomposition in situ of hornblendic gneiss with layers and veins of quartz, "and which did not exist before the felling of the forest twenty years previous," he describes as more than 55 feet in depth, 300 yards in length, and from 20 to 180 feet in breadth. Our author refers to other cases in the same States, "where the cutting down of the trees, which had prevented the rain from collecting into torrents and running off in sudden landfloods, has given rise to ravines from 70 to 80 feet deep." *

Similar results often follow in the Northeastern States from cutting the timber on the "pine plains," where the soil is usually of a sandy composition and loose texture.

\section{American Forest-Trees.}

The remaining forests of the Northern States and of Canada no longer boast the mighty pines which almost rivalled the gigantic sequoia and redwood of California; and the growth of the larger forest-trees is so slow, after they have attained to a certain size, that if every pine and oak were spared for two centuries, the largest now standing would not reach the stature of hundreds recorded to have been cut within two or three generations. $\nmid$ Dr. Williams, who wrote about sixty years ago, states

\footnotetext{
* LYeLL, Principles of Geology, 10th ed., vol. i., pp. 345-6.
}

$\dagger$ The growth of the white pine, on a good soil and in open ground, is rather rapid until it reaches the diameter of a couple of feet, after which it is much slower. The favorite habitat of this tree is light, sandy earth. On this soil, and in a dense wood, it requires a century to attain the diameter of a yard. Emerson (Trees of Mrassachusetts, p. 65) says that a pine of this species, near Paris, " thirty years planted, is eighty feet high, with a diameter of three feet." He also states that ten white pines planted at Cambridge, Massachusetts, in 1809 or 1810 , exhibited, in the winter of 1811 and 1812 , an average of twenty inches diameter at the ground, the two largest measuring, at the height of three feet, four feet eight inches in circumference; and he mentions another pine growing in a rocky swamp, which, at the age of thirty-two years, "gave seven feet in circumference at the butt, with a height of sixty-two feet six inches." This latter I suppose to be a seedling, the others transplented trees, which might have been some years old when placed where they finally grew.

The following case came under my own observation: In 1824 a white-pine $14^{*}$ 
the following as the dimensions of "such trees as are esteemed large ones of their kind in that part of America" [Vermont], qualifying his account with the remark that his measurements "do not denote the greatest which nature has produced of their particular species, but the greatest which are to be found in most of our towns."

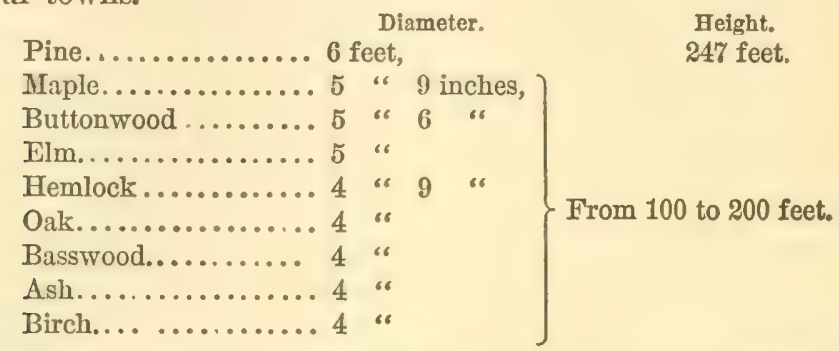

He adds a note saying that a white pine was cut in Dunstable, New Hampshire, in the year 1736, the diameter of which was seren feet and eight inches. Dr. Dwight says that a fallen pine in Connecticut was found to measure two hundred and fortyseven feet in height, and adds: "A few years since, such trees were in great numbers along the northern parts of Connecticut River." In another letter, he speaks of the white pine as "frequently six feet in diameter, and two hundred and fifty feet in height," and states that a pine had been cut in Lancaster, New Hampshire, which measured two hundred and sixty-four feet. Emerson wrote in 1816 : "Fifty years ago, several trees growing

tree, so small that a young lady, with the help of a lad, took it up from the ground and carried it a quarter of a mile, was planted near a house in a town in Vermont. It was occasionally watered, but received no other special treatment. I measured this tree in 1860, and found it, at four feet from the ground, and entirely above the spread of the roots, two feet and four inches in diameter. A new measurement in 1871 gave a diameter of two feet eight inches, being an increase of four inches in eleven years, a slower rate than that of preceding years. It could not have been more than two or at most three inches through when transplanted, and up to 1860 must have increased its diameter at the rate of about seven-tenths of an inch per year, almost double its later growth. In 1871 the crown had a diameter of 62 feet.

In the same neighborhood, elms transplanted in 1803, when they were not above three or four inches through, had attained, in 1871, a diameter of from four feet to four feet two inches, with a spread of crown of from 90 to 112 feet. Sugar-maples, transplanted in 1822, at about the same size, measured two feet three inches through. This growth undoubtedly considerably ex ccerls that of trees of the same species in the natural forest, though the trans. 
on rather dry land in Blandford, Massachusetts, measured, after they were felled, two hundred and twenty-threo feet." All these trees are surpassed by a pine felled at Hanover, New Hampshire, about a hundred years ago, and described as measuring two hundred and seventy-four feet.* These deseriptions, it will be noticed, apply to trees eut from seventy to one hundred and forty years since.

Persons, whom observation has rendered familiar with the present character of the American forest, will be struck with the smallness of the diameter which Dr. Williams and Dr. Dwight ascribe to trees of such extraordinary height. Individuals of the several species mentioned in Dr. Williams's table, are now hardly to be found, in the same climate, exceeding one-half or at most two-thirds of the height which he assigns to them; but, except in the case of the oak and the pine, the diameter stated by him would not be thought very extraordinary in trees of far less height now standing. Even in the species I have excepted, those diameters, with half the heights given by Dr. Williams, might perhaps be paralleled at the present time ; and many elms, transplanted, at a diameter of six inches, within the menory of persons still living, measure four and sometimes even five feet through. For this change in the growth of forest-trees there are two reasons: the one is, that the great commercial value of the pine and the oak has caused the destruction of all the best-that is, the tallest and straightest-specimens of both; the other, that the thinning of the woods by the axe of the lumberman has allowed the access of light and heat and air to trees of humbler worth and lower stature, which have survived their more towering brethren. These, consequently, have been able to expand their cromns and swell their stems to a degree not possible so long as they were overshadowed and stifled by the lordly oak and pine. While, therefore, the New England forester must search long before he finds a pine

fit to be the mast

Of some great ammiral,

planted trees had received no other fertilizing application than an unlimited supply of light and air.

* Williavs, History of Vermont, ii., p. 53. DWigrt's Travels, iv., p. 21, and iii., p. 36. Emensor, Trees of Massachusetts, p. 61. PArisir, Life of President Wheelock, p. 56. 


\section{beeches and elms and birches, as sturdy as the mightiest of their} progenitors, are still no rarity.*

California fortunately still preserves her magnificent sequoias, which rise to the height of three hundred feet, and sometimes, as we are assured, even to three hundred and sixty and four hundred feet, and she has also pines and cedars of scarcely inferior dimensions. The public being now convinced of the importance of preserving these colossal trees, it is very probable that the fear of their total destruction may prove groundless, and we may still hope that some of them may survive even till that distant future when the skill of the forester shall have raised from their seeds a progeny as lofty and as majestic as those which now exist. $\nmid$

* The forest-trees of the Northern States do not attain to extreme longevity in the dense woods. Dr. Williams found that none of the huge pines, the age of which he ascertained, exceeded three hundred and fifty or four hundred years, though he quotes a friend who thought he had noticed trees considerably older. The oak lives longer than the pine, and the hemlock-spruce is perhaps equally long-lived. A tree of this latter species, cut within my knowledge in a thick wood, counted four hundred and eighty-six, or, according to another observer, five hundred annual circles.

Great luxuriance of animal and vegetable production is not commonly accompanied by long duration of the individual. The oldest men are not found in the crowded city; and in the tropics, where life is prolific and precocious, it is also short. The most ancient forest-trees of which we have accounts havo not been those growing in thick woods, but isolated specimens, with no taller neighbor to intercept the light and heat and air, and no rival to share the nutriment afforded by the soil.

The more rapid growth and greater dimensions of trees standing near the boundary of the forest, are matters of familiar observation. "Long experience has shown that trees growing on the confines of the wood may be cut at sixty years of age as advantageously as others of the same species, reared in the depth of the forest, at a hundred and twenty. We have often remarked, in our Alps, that the trunk of trees upon the border of a grove is most developed or enlarged upon the outer or open side, where the branches extend themselves farthest, while the concentric circles of growth are most uniform in those entirely surrounded by other trees, or standing entirely alone."-A. and G. Villa, Necessita dei Boschi, pp. 17, 18.

+ California must surrender to Australia the glory of possessing the tallest trees. According to Dr. Mueller, Director of the Government Botanic Garden at MLlbourne, a Eucalyptus, near Healesville, measured 480 feet in height. Later accounts speak of trees of the same species fully 500 feet in height. Sce Schlemen, Für Baum und Wald, p. 21. The Journal of Frorestry, No. xx., p. 581, quotes from the Rivista de Nontes, a notice of a eucalyptus 


\section{European and American Trees compared.}

The woods of North Americaa are strikingly distinguished from those of Europe by the vastly greater variety of species they contain." According to Clavé, there are in "France and in most parts of Europe only about twenty forest-trees, five or six of which are spike-leaved and resinous, the remainder broadleaved." † Our author, however, doubtless means genera, though he uses the word espèces. Rossmässler enumerates fifty-seven species of forest-trees as found in Germany, but some of these are mere shrubs, some are fruit and properly garden trees, and some others are only varieties of familiar species. The valuable manual of Parade describes about the same number, including, however, two of American origin-the locust, Robinia pesuda cacia, and the Weymouth or white pine, Pinus strobus-and the cedar of Lebanon from Asia, which, or at least a very closely allied species, is indigenous in Algeria also. We may then safely say that Europe does not possess above forty or fifty native trees of such economical value as to be worth the special care of the forester, while the oak alone numbers more than thirty species in the United States, $\neq$ and some other North American genera are almost equally diversified. $\$$

plobulus $152 \mathrm{~m} .=506^{\prime}$ high, and of a eucalyptus amygdatinus $386^{\prime}$ to the lowest limb, with a total height of $137 \mathrm{~m},=460^{\prime}$.

If we may credit late reports, the growth of the eucalyptus is so rapid in California, that the child is perhaps now born who will see the tallest sequoig overtopped by this new vegetable emigrant from Australia.

* According to Scracrit, Les Arbres, p. 384, woods of a single species are always the product of an artificial planting, the spontaneous wood being more diversified in its composition. The few remnants of natural forest which still exist in the German States are composed of both evergreen conifers and deciduous trees.

\section{† Etudes Forestieres, p. 7.}

$\ddagger$ For catalogues of American forest-trees, and remarlss on their geographical distribution, consult papers on the subject by Dr. J. G. Cooper, in the Report of the Smithsonian Institution for 1858, and the Report of the United States Patent Office, Agricultural Division, for 1860.

$\S$ Although Spenser's catalogue of trees occurs in the first canto of the first book of the "Faery Queene"- the only canto of that exquisite poem actually. 
While the American forest flora has made large contributions to that of Europe, comparatively few European trees have been naturalized in the United States, and as a general rule the indig-

read by most students of English literature-it is not so generally familiar as to make the quotation altogether superfluous :

VII.

Enforst to seeke some covert nigh at hand, A shadie grove not farr away they spide, That promist ayde the tempest to withstand ; Whose loftie trees, yclad with sommers pride, Did spred so broad, that heavens light did hide, Not perceable with power of any starr: And all within were pathes and alleies wide, With footing worne, and leading inward farr ; Faire harbour that them seems; so in they entered ar.

VIII.

And foorth they passe, with pleasure forward led, Joying to heare the birdes sweete barmony, Which therein shrouded from the tempest dred, Seemd in their song to scorne the cruell sky. Much can they praise the trees so straight and hy, The sayling pine; the cedar stout and tall: The vine-propp elm; the poplar never dry; The builder oake, sole king of forrests all; The aspine good for staves; the cypresse funerall :

IX.

The lanrell, meed of mightie conquerours And poets sage; the firre that weepeth still; The willow, worne of forlorn paramours; The engh, obedient to the benders will; The birch for shaftes; the sallow for the mill; The mirrhe sweete-bleeding in the bitter wound; The warlike beech ; the ash for nothing ill ; The fruitfull olive; and the platane round; The carver holme; the maple seeldom inward sound.

Although the number of species of American forest-trees is much larger than of European, yet the distinguishable varieties are relatively more numerous in the Old World, even in the case of trees not generally receiving special care. This multiplication of varieties is no doubt a result, though not a foreseen or intended one, of human action; for the ordinary operations of European forest economy expose young trees to different conditions from those presented by nature, and new conditions produce new forms. All European woods, except in the remote North, even if not technically artificial forests, acquire a more or less artificial character from the governing hand of man, and the effect of this interference is seen in the constant deviation of trees from the original type. The holly, for example, even when growing as absolutely wild as any tree can ever grow in countries long occupied by man, produces numerous varieties, and twenty or thirty such, not to mention intermediate shades, are described and named as recognizably different, in treatises on the forest-trees of Europe. 
enous trees of Europe do not succeed well in our climate.* The European mountain-ash-which in beauty, dimensions and healthfulness of growth is superior to our ownt-the horse-chestnut, and the abele, or silver poplar, are valuable additions to the ornamental trees of North America. The Swiss arve, or zirbelkicfer, Pinus cembra, which yields a well-flavored edible seed and furnishes excellent wood for carving; the umbrella-pine, $\neq$ which also bears a seed agrecable to the taste, and which, from the color of its foliage and the beautiful form of its dome-like crown, is among the most elegant of trees; the white birch of Central Europe, with its pendulous branches almost rivalling those of the weeping willow in length, flexibility and gracefulness of fall; and, especially, the "cypresse funerall," might be introduced into the United States with great advantage to the landscape. The European beech and chestnut furnish timber of far better quality than that of their American congeners. The fruit of the European chestnut, though inferior to the American in sweetness and flavor, is larger, and is an important article of diet among the French and Italian peasantry. The walnut of Europe, though not equal to some of the American species in beauty of growth or of wood, or to others in strength and elasticity of fibre, is valuable for its timber and its oil.§ The maritime pine, which has proved of

* I am very courteously informed by my highly valued correspondent, Prof. C. S. Sargent, of the Botanic Garden, Harvard University, that the above statement, even with its qualification, is hardly borne out by his observationthat, in fact, a large proportion of the most valuable European trees are found, under favorable circumstances, to thrive extremely well in North America.

The same excellent authority assures me that the experiment, recommended on p. 328 , of introducing the maritime pine into the United States, has been tried-that this tree is not hardy enough to stand the climate of the New Eng. land coast, and that in the more southern Atlantic States the Pinus australis is believed to be more valuahle and, on the whole, to answer a better purpose.

† In Northern Tyrol mountain-ashes fifteen inches in diameter are not uncommon. The berries are distilled with grain to flavor the spirit.

$\ddagger$ The mountain ranges of our extreme West produce a pine closely resembling the European umbrella-pine.

$\S$ The walnut is a more valuable tree than is generally supposed. It yields one-third of the oil produced in France, and in this respect occupies an intermediate position between the olive of the south and the oleaginous seeds of the north. A hectare (ahout two and a half acres) will produce nuts to the value of five hundred francs a year, which cost nothing but the gathering. Unfor. 
such immense use in fixing drifting sands in France, may perhaps be better adapted to this purpose than any of the pines of the New World, and it is of great importance for its turpentine, resin and tar. The épicéa, or common fir, Abies picea, Abies excelsa, Picea excelsa, abundant in the mountains of France and the contiguous country, is known for its prodnct, Burgundy pitch, and, as it flourishes in a greater variety of soil and climate than almost any other spike-leaved tree, it might be well worth transplantation.* The cork oak has been introduced into California and

tumately, its maturity must be long waited for, and more nut-trees are felled than planted. The demaud for its wood in cabinet-worl is the principal cause of its destruction. See Laverane, Économie Rurale de la France, p. 253.

According to Cosimo Ridolfi (Lezioni Orali, ii., p. 42.1), France obtains three times as much oil from the walnut as from the olive, and nearly as much as from all oleaginous seeds together. He states that the walnut bears nuts at the age of twenty years, and yields its maximum product at seventy, and that a hectare of ground, with thirty trees, or twelve to the acre, is equal to a capital of twenty-five hundred francs.

The nut of this tree is known in the United States as the "English walnut." The fruit and the wood much resemble those of the American black-walnut, Juglans nigra, but for cabinet-work the American is the more beautiful material, especially when the large knots are employed. The timber of the European species, when straight-grained, and clear, or free from knots, is, for ordinary purposes, better than that of the American black-walnut, but bears no comparison with the wood of the hickory, when strength combined with elasticity is required, and its nut is very inferior in taste to that of the shagbark, as well as to the butternut, which it somewhat resembles.

The butternut, Juglans cinerea, was introduced into Finland, in lat. $60 \mathrm{~N}$., so long ago that the second generation of this hardy tree is now (1S82) growing thriftily from nuts of those first planted.-BLouroust, Catalogue Special d'Objets Forestiers, etc.

"The chestnut is more valuable still, for it produces on a sterile soil, which, without it, would yield only ferns and heaths, an abundant nutriment for man."-Laterane, Économie Rurale de la France, p. 253.

I believe the varieties developed by cultivation are less numerous in the walnut than in the chestnut, which latter tree is often grafted in Southern Europe.

The chestnut crop of France was estimated in 1848 at 3,478,000 hectolitres, or $9,877,520$ Winchester bushels, and valued at $13,528,000$ francs, or more than two million and a half dollars. In Tuscany the annual yield is computed at about $3,550,000$ bushels.

The Tuscan peasants think the flour of the dried chestnut not less nutritious than Indian cornmeal, and it sells at the same price, or about three cents per English pound, in the mountains, and four cents in the towns.

* This fir is remarkable for its tendency to cicatrize or heal over its stumps, 
some other parts of the United States, I believe, and would undoubtedly thrive in the Southern section of the Union.*

In the walnut, the chestnut, the cork oak, the mulberry, the olive, the orange, the lemon, the fig, and the multitude of other trees, which, by their fruit or by other products, yield an annual revenue, nature has provided Southern Europe with a partial compensation for the loss of the native forest. It is true that these trees, planted as most of them are at such distances as to

a property which it possesses in common with some other firs, the maritime pine, and the European larch. When these trees grow in thick clumps, their roots are apt to unite by a species of natural grafting, and if one of them be felled, although its own proper rootlets die, the stump may continue, sometimes for a century, to receive nourishment from the radicles of the surrounding trees, and a dome of wood and bark of considerable thickness be formed over it. The healing is, however, only apparent, for the entire stump, except the outside ring of annual growth, soon dies, and even decays within its coverings, without sending out new shoots. I have observed cases of Ucbericallung at Abetone or Bosco Lungo, but it is everywhere of rare occurrence, and I never saw an instance in the United States, and only a single one in the Austrian woods. In this case it was only partial, and occurred in a large stump in a fir forest near San Martino di Custozza in Tyrol.

Rossmässler, Der Waldt, p. 191, describes and figures a case in a Populus alba ten years old, but, p. 342, he says: "Der Lerche und der Tanne, der Fichte und der See-Kiefer ist die Ueberwallung eigen." See RosswässLER, p. 203. Schacht, Les Arbres, 1863, pp. 145, 387. GöpPERT, Das Ueberwallen der Tannenstocke. Bonn, 1842.

* At the age of twelve or fifteen years, the cork-tree is stripped of its outer bark for the first time. This first yield is of inferior quality, and is employed for floats for nets and buoys, or burnt for lampblack. After this, a new layer of cork, an inch or an inch and a quarter in thickness, is formed about once in ten years, and is removed in large sheets without injury to the tree, which lives a hundred and fifty years or more. According to Clave (p. 252), the annual product of a forest of cork oaks is calculated at about 660 kilogrammes, worth 150 francs to the hectare, which, deducting expenses, leaves a profit of 100 francs. This is about equal to 250 pounds weight, and eight dollars profit to the acre. The cork naks of the national domain in Algeria cover about 500,000 acres, and are let to individuals at rates which are expected, when the whole is rented, to yield to the state a revenue of about $\$ 2,000,000$.

George Sand, in the Histoire de ma Vie, speaks of the cork-forests in Southern France as among the most profitable of rural possessions, and states, what I do not remember to have seen noticed elsewhere, that Russia is the best customer for cork. The large sheets taken from the trees are slit into thin plates, and used to line the walls of apartments in that cold climate. On the cultiva. tion and management of the cork oak, see Des Incendies et de la cultrure du Ohenelïge, in Revue des Eaux et Forêts for February, 1869. 
admit of cultivation, or of the growth of grass among them, aro but an inadequate substitute for the thick and shady wood; but they perform to a certain extent the same offices of absorption and transpiration, they shade the surface of the ground, they serve to break the force of the wind, and on many a steep declivity, many a bleak and barren hillside, the chestnut binds the soil together with its roots, and prevents tons of earth and gravel from washing down upon the fields and the gardens. Fruittrees are not wanting, certainly, morth of the Alps. The apple, the pear, and the prune are important in the economy both of man and of nature, but they are far less numerous in Switzerland and Northern France than are the trees I have mentioned in Southern Europe, both because they are in general less remunerative, and because the climate, in higher latitudes, does not permit the free introduction of shade trees into grounds occupied for agricultural purposes.*

* The walnut, the chestnut, the apple, and the pear are common to the border between the countries I have mentioned, but the range of the other trees is bounded by the Alps, and by a well-defined and sharply drawn line to the west of those mountains. From some peculiarity in the sky of Europe, cultivated plants will thrive, in Northern Italy, in Southern France, and even in Switzerland, under a depth of shade where no crop, not even grass, worth harvesting, would grow in the United States with an equally high summer temperature. Hence the cultivation of all these trees is practicable in Europe to a greater extent than would be supposed reconcilable with the interests of agriculture. Some idea of the importance of the olive orchards may be formed from the fact that Sicily alone, an island scarcely exceeding 10,000 square miles in area, of which one-third at least is absolutely barren, has exported to the single port of Marseilles more than 2,000,000 pounds weight of olive-oil per year, for the last thirty years.

According to Cosimo Ridolfi, Lezioni Orali, vol. ii., p. 340, in a favorable soil and climate the average yield of oil from poorly manured trees, which compose the great majority, is six English pounds, while with the best cultivation it rises to twenty-three pounds. The annual production of olive-oil in the whole of Italy is estimated at upwards of $850,000,000$ pounds, and if we allow twelve pounds to the tree, we have something more than $70,000,000$ trees. The real number of trees is, however, much greater than this estimate, for in Tuscany and many other parts of Italy the average yield of oil per tree does not exceed two pounds, and there are many millions of young trees not yet in bearing. Probably we shall not exaggerate if we estimate the olive trees of Italy at $100,000,000$, and as there are about a hundred trees to the acre, the quantity of land devoted to the cultivation of the olive may be taken at a million acres. Indeed this estimate is far too low according to the Italia 
The multitude of species, intermixed as they are in their spontaneous growth, gives the American forest landscape a variety of aspect not often seen in the woods of Europe; the gorgeous tints which nature repeats from the dying dolphin to paint the falling leaf of the American maples, oaks, and ash trees, clothe the lillsiles and fringe the watercourses with a rainbow splendor of foliage unsurpassed by the brightest groupings of the tropieal flora. It must be confessed, however, that both the northern and the southern declivities of the Alps exhibit a nearer approximation to this rich and multifarious coloring of autumnal regetation than most American travellers in Europe are willing to allow; and, besides, the small deciduous shrubs which often carpet the forest-glades of these mountains are dyed with a ruddy and orange glow, which, in the distant landscape, is no mean sub. stitute for the scarlet and crimson and gold and amber of the transatlantic woodland.*

Agricola Forestale all' esposizione di Parigi, 1878, p. 204, where it is stated that the surface occupied by olive trees in Italy is 900,311 feet $=2,300,000$ acres, the total yield of oil 3,385,591 hectol.; and the average yield per hect. 1.38 in Lombardy, 2.39 in Tuscany, 4.04 in Liguria, 4.57 in the Southern Provinces, and 6.09 in Sardinia. Although olive-oil is much used in conkery in Italy, lard is preferred as more nutritious. Much American lard is exported to Southeastern Italy, and olive-oil is imported in return.

* The most gorgeous autumnal coloring I have observed in the regetation of Europe has been in the valleys of the Durance and its tributaries in Dau. phiny. I must admit that neither in variety nor in purity and brilliancy of tint, does this coloring fall much, if at all, short of that of the New England woods. But there is this difference : in Dauphiny it is only in small shrubs that this rich painting is seen, while in North America the foliage of large trees is dyed in full splendor. Hence the American woodland has fewer broken lights and more of what painters call breadth of coloring. Besides this, the arrangement of the leafage in large globular or conical masses affords a wider scale of light and shade, thus aiding now the gradation, now the contrast of tints, and gives the American October landscape a softer and more harmonious tone than marks the humble shrubbery of the forest hillsides of Dauphiny.

Thoreau-who was not, like some very celebrated landscape critics of the present day, an outside spectator of the action and products of natural forces, but, in the old religious sense, an observer of organic nature, living, more than almost any other descriptive writer, among and with her children-has a very eloquent paper on the "Autumnal Tints" of the New England landscape.See his Excursions, pp. 215 et seq.

Few men have personally noticed so many facts in natural history accessible to unscientific observation as Thoreau, and yet he had never seen that very 
I admit, though not without reluctance, that the forest-trees of Central and Southern Europe have a great advantage over our own in the corresponding latitudes, in density of foliage as well as in depth of color and persistence of the leaves in deciduous species. An American, who, after a long absence from the United States, returns in the full height of summer, is painfully surprised at the thinness and poverty of the leafage even of the trees which he had habitually regarded as specially umbrageous, and he must wait for the autumnal frosts before he can recover his partiality for the glories of his native woods.

None of our northeastern evergreens resemble the umbrellapine sufficiently to be a fair object of comparison with it. A cedar, very common above the Highlands on the Hudson, and elsewhere, is extremely like the cypress, straight, slender, with erect, compressed ramification, and feathered to the ground, but its foliage is neither so dark nor so dense, the tree does not attain the majestic height of the cypress, nor has it the lithe flexibility of that tree.* In mere shape, the Lombardy poplar nearly resembles this latter, but it is almost a profanation to compare the two, especially when they are agitated by the wind; for under such circumstances, the one is the most majestic, the other the most ungraceful, or-if I may apply such an expression to anything but human affectation of movement-the most awkward of trees. The poplar trembles before the blast, flutters, struggles wildly, dishevels its foliage, gropes around with its feeble branches, and hisses as in impotent passion. The cypress gathers its limbs still more closely to its stem, bows a gracious salute rather than an humble obeisance to the tempest, bends to the wind with an elasticity that assures you of its prompt return to its regal attitude, and sends from its thick leaflets a murmur like the roar of the far-off ocean.

common and striking spectacle, the phosphorescence of decaying wood, until, in the latter years of his life, it caught his attention in a bivouac in the forests of Maine. He seems to have been more excited by this phenomenon than by any other described in his works. It must be a capacious eye that takes in all the visible facts in the history of the most familiar natural objects. - The AFain Woods, p. 184.

* The cold winter, or rather spring, of 1872 proved fatal to many cypresses as well as olive trees in the Val d'Arno. The cypress, therefore, could be in. troduced only into California and our Southern States. 
The cypress and the umbrella-pine are not merely conventional types of the Italian landscape. They are essential elements in a field of rural beauty which ean be seen in perfection only in the basin of the Mediterranean, and they are as characteristic of this class of scenery as is the date-palm of the oases of the Eastern desert. There is, however, this difference: a single cypress or pine is often enough to shed benuty over a wide area; the palm is a social tree, and its beauty is not so much that of the individual as of the group.* The frequency of the cypress and the pine-combined with the fact that the other trees of Southern Europe which most interest a stranger from the north, the orange and the lemon, the cork oak, the ilex, the myrtle, and the laurel, are evergreens-goes far to explain the beauty of the winter scenery of Italy. Indeed, it is only in the winter that a tourist who confines himself to wheel-carriages and high-roads can acquire any notion of the face of the earth, and form any proper geographical image of that country. At other seasons, not high walls only, but equally impervious hedges, and now, unhappily, acacias thickly planted along the railway routes, confine the view so completely, that the arch of a tunnel, or a night-cap over the traveller's eyes, is scarcely a more effectual obstacle to the gratification of his curiosity. $\dagger$

\footnotetext{
* European poets, whose knowledge of the date-palm is not founded on personal observation, often describe its trunk as not only slender, but particu. larly straight. Nothing can be farther from the truth. When the Orientals compare the form of a beautiful girl to the stem of the palm, they do not represent it as rigidly straight, but on the contrary as made up of graceful curves, which seem less like permanent outlines than like flowing motion. In a palm grove, the trunks, so far from standing planted upright like the candles of a chandelier, bend in a vast variety of curves, now leaning towards, now diverging from, now crossing, each other, and among a hundred you will hardly see two whose axes are parallel.

+ Besides this, in a cuuntry so diversified in surface as Italy, with the exception of the champaign region drained by the Po, every new field of view recuuires either an extraordinary coup d'ait in the spectator, or a long study, in order to master its relief, its plans, its salient and retreating angles. In summer, except of course in the bare mountains, the universal greenery confounds light and shade, distance and foreground; and though the impression upon a traveller, who journeys for the sake of "sensations," may be strengthened by the mysterious annihilation of all standards for the measurement of space, yet the superior intelligibility of the winter scenery of Italy is more profitable to those who see with a view to analyze.
} 


\section{The Forest does not furnish Food for Man.}

In a region absolutely corered with trees, human life could not long be sustained, for want of animal and regetable food. The depths of the forest seldom furnish either bulb or fruit suited to the nourishment of man; and the fowls and beasts on which he feeds are scarcely seen except upon the margin of the wood, for here only grow the shrubs and grasses, and here only are found the seeds and insects, which form the sustenance of the noncarnivorous birds and quadrupeds.*

* Clavé, as well as many earlier writers, supposes that primitive man derived his nutriment from the spontaneous productions of the wood. "It is to the forests," says he, "that man was first indebted for the means of subsistence. Exposed alone, without defence, to the rigor of the seasons, as well as to the attacks of animals stronger and swifter than himself, he found in them his first shelter, drew from them his first weapons. In the first period of humanity, they provided for all his wants: they furnished him wood for warmth, fruits for food, garments to cover his nakedness, arms for his defencc."-Études sur l' Économie Forestière, p. 13.

But the history of savage life, as far as it is known to us, presents man in that condition as inhabiting only the borders of the forest and the open grounds that skirt the waters and the woods, and as finding only there the aliments which make up his daily bread. The villages of the North American Indians were upon the shores of rivers and lakes, and their weapons aud other relics are found only in the narrow open grounds which they had burned over and cultivated, or in the margin of the woods around their hamlets.

Except upon the banks of rivers or of lakes, the woods of the interior of North America, far from the habitations of man, are almost destitute of animal life. Dr. Newberry, describing the vast forests of the yellow pine of the West, Pinus ponderosa, remarks: "In the arid and desert regions of the interior basin, we made whole days' marches in forests of jellow pine, of which neither the monotony was broken by other forms of vegetation, nor its stillness by the flutter of a bird or the hum of an insect."-Pucific Railroad Report, vol. vi., 1857. Dr. NEWBERRY's Report on Botany, p. 37.

Cheadle and Milton's North-rcest Passage confirms these statements. Valvasor says, in a paragraph already quoted, "In my many journeys through this valley, I did never have sight of so much as a single bird."

The wild fruit and nut trees, the Canada plum, the cherry, the many species of walnut, the butternut, the hazel, yield very little, frequently nothing, so long as they grow in the woods; and it is only when the trees around them are cut down, or when they grow in pastures, that they become productire. The berries, too-the strawberry, the blackberry, the raspberry, the whortleberry-scarcely bear fruit at all except in cleared ground.

The rank forests of the tropics are as unproductive of human aliment as the less luxuriant woods of the temperate zone. In Strain's unfortunate cxpedi 


\section{First Removal of the Forest.}

When multiplying man had filled the open grounds along the margin of the rirers, the lakes, and the sea, and sufficiently peopled the natural meadows and savannas of the interior, where such existed, he could find room for expansion and further growth only by the removal of a portion of the forest that hemmed him in. The destruction of the woods, then, was man's first geographical conquest, his first violation of the harmonies of inanimate nature.

Primitive man had little occasion to fell trees for fuel, or for the construction of dwellings, boats, and the implements of his rude agriculture and handicraft. Windfalls would furnish a thin population with a sufficient supply of such material, and if occasionally a growing tree was cut, the injury to the forest would be too insignificant to be at all appreciable.

The accidental escape and spread of fire, or, possibly, the combustion of forests by lightning, must have first suggested the advantages to be derived from the removal of too abundant and extensive woods, and, at the same time, have pointed out a means by which a large tract of surface could readily be cleared of much of this natural incumbrance. As soon as agriculture had commenced at all, it would be observed that the growth of cultivated plants, as well as of many species of wild vegetation, was particularly rapid and luxuriant on soils which had been burned over, and thus a new stimulus would be given to the practice of destroying the woods by fire, as a means of both extending the open grounds and making the aequisition of a yet more productive soil. After a few harvests had exhausted the first rank fertility of the virgin mould, or when weeds and briers and the sprouting roots of the trees had begun to choke the crops of the half-subdued soil, the ground would be abandoned for new fields won from the forest by the same means, and the deserted plain or

tion across the great American isthmus, where the journey lay principally through thick woods, several of the party died of starvation, and for many days the survivors were forced to subsist on the scantiest supplies of innutritious regetables perhaps never before employed for food by man. See the interesting account of that expedition in Harper's Mragazine for March, Arril, and May, 1855. 
hillock would soon clothe itself anew with shrubs and trees, to be again subjected to the same destructive process, and again surrendered to the restorative powers of vegetable nature.* This rude economy would be continued for generations, and, wasteful as it is, is still largely pursued in Northern Sweden, Swedish Lapland, and sometimes even in France and the United States. $†$

\section{Principal Causes of the Destruction of the Forest.}

The needs of agriculture are the most familiar cause of the destruction of the forest in new countries; for not only does an increasing population demand additional acres to grow the vegetables which feed it and its domestic animals, but the slovenly

* In many parts of the North American States, the first white settlers found extensive tracts of thin woods, of a very park-like character, called "oakopenings," from the predominance of different species of that tree upon them. These were the semi-artificial pasture-grounds of the Indians, brought into that state, and so kept, by partial clearing, and by the annual burning of the grass. The object of this operation was to attract the deer to the fresh herbage which sprang up after the fire. The oaks bore the annual scorching at least for a certain time; but if it had been indefinitely continued, they would very probably have been destroyed at last. The soil would have then been much in the prairie condition, and would have needed nothing but grazing for a long succession of years to make the resemblance perfect. That the annual fires alone occasioned the peculiar character of the oak-openings, is proved by the fact that as soon as the Indians had left the country, young trees of many species sprang up and grew luxuriantly upon them. See a very interesting account of the oak-openings in DwrGHT's Tracels, iv., pp. 58-63.

+ The practice of burning over woodland, at once to clear and manure the ground, is called in Swedish svedjande, a participial noun from the verb att siedja, to burn over. Though used in Sweden as a preparation for crops of rye or other grain, it is employed in Lapland more frequently to secure an abundant growth of pasturage, which follows in two or three years after the fire; and it is sometimes resorted to as a mode of driving the Laplanders and their reindeer from the vicinity of the Swedish backwoodsman's grass-grounds and hay-stacks, to which they are dangerous neighbors. The forest, indeed, rapidly recovers itself, but it is a generation or more before the reindeer-moss grows again. When the forest consists of pine, tall, the ground, instead of being rendered fertile by this process, becomes hopelessly barren, and for a long time afterwards produces nothing but weeds and briers.-LEsTaDrus, Om Uppodlingar $i$ Lappmarken, p. 15. See also Scrüerт, Resa $i$ Sverge, ii., p. 375 .

In some parts of France this practice is so general that Clave says: "In the department of Ardennes it (le sartage) is the basis of agriculture." 
husbandry of the border settler soon exhausts the luxuriance of his first fields, and compels him to remove his household gods to a fresher soil. The extent of cleared ground required for agricultural use depends very much on the number and kinds of the cattle bred. We have seen, in a former chapter, that, in the United States, in 1870 , the domestic quadrupeds amounted to more than a hundred millions, or nearly three times the number of the human population of the Union at that time, and that the number greatly increased during the following ten years. In many of the Western States, the swine subsist more or less on acorns, nuts and other products of the woods, and the prairies, or natural meadows of the Mississippi valley, yield a large amount of food for beast, as well as for man. With these exceptions, all this vast army of quadrupeds is fed wholly on grass, grain, pulse and roots grown on soil reclaimed from the forest by European settlers. It is true that the flesh of domestic quadrupeds enters very largely into the aliment of the American people, and greatly reduces the quantity of vegetable nutriment which they would otherwise consume, so that a smaller amount of agricultural product is required for immediate human food, and, of course, a smaller extent of cleared land is needed for the growth of that product, than if no domestic animals existed. But the flesh of the horse, the ass, and the mule is not consumed by man, and the sheep is reared rather for its fleece than for food. Besides this, the ground required to produce the grass and grain consumed in rearing and fattening a grazing quadruped, would yield a far larger amount of nutriment, if devoted to the growing of breadstuffs, than is furnished by his flesh; and, upon the whole, whatever advantages may be reaped from the breeding of domestic cattle, it is plain that the cleared land devoted to their sustenance in the originally wooded part of the United States, after deducting a quantity sufficient to produce an amount of aliment equal to their flesh, still greatly exceeds that cultivated for vegetables, directly consumed by the people of the same regions; or, to express a nearly equivalent idea in other words, the meadow and the pasture, taken together, much exceed the ploughland.*

* The two ideas expressed in the text are not exactly equivalent, because, though the consumption of animal food diminishes the amount of vegretable aliment required for human use, yet the animals themselves consume a great 
Governments and military commanders have at different po. riods deliberately destroyed forests by fire or the axe, because they afforded a retreat to robbers, outlaws or enemies, and this was one of the hostile measures practiced by both Julius Cresar and the Gauls in the Roman war of conquest against that people. It was also resorted to in the Mediterranean provinces of France, then much infested by robbers and deserters, as late as the reign of Napoleon I., and is said to have been employed by the early American colonists in their exterminating wars with the native Indians.*

In the Middle Ages, as well as in earlier and later centuries, attempts have been made to protect the woods by law, $\uparrow$ as neces-

quantity of grain and roots grown on ground ploughed and cultivated as regularly and as laboriously as any other.

The 280,000,000 bushels of oats raised in the United States in 18\%0, and for the most part fed to the $7,000,000$ horses-as it is only since that date that so large a proportion of the oat-harvest has been used directly as food for manthe potatoes, the turnips, and the maize employed in fattening the oxen, the sheep, and the swine slaughtered the sime year, occupied an extent of ground which, cultivated by hand-labor and with Chinese industry and skill, would probably have produced a quantity of vegetable food equal in alimentary power to the flesh of the quadrupeds killed for domestic use. Hence, so far as the naked question of anount of aliment is concerned, the meadows and the pastures might as well have remained in the forest condition. It must, however, be borme in mind that animal labor, if not a necessary, is probably an economical, force in agricultural occupations, and that withont animal manure many branches of husbandry could hardly be carried on at all. At the same time, the introduction of machinery into rural industry, and of artificial, mineral and fossil manures, is working great revolutions, and we may find at some future day that the ox is no longer necessary as a help to the farmer.

* For many instances of this sort, see Madrr, Les Forêts de la Gaule, pp. 3-5, and Becquerex, Des Climats, etc., pp. 301-303.

In 1664 the Swedes made an excursion into Jutland and felled a considerable extent of forest. After they retired, a survey of the damage was had, and the report is still extant. The number of trees cut was found to be 120,000 , and as an account was taken of the numbers of each species of tree, the document is of much interest in the history of the forest, as showing the relative proportions between the different trees which at that time composed the wood. See VAUPELL, Bügens Indvandring, p. 35, and Notes, p. 55.

+ Stanley, quoting Selden, De Jure Naturali, lib. vi., and Fabricius, Cod. Pseudap., V. T., i. 874, mentions a noteworthy Hebrew tradition of uncertain date, but unquestionably very ancient, which is one of the oldest proofs of a public respect for the woods:

"A Hebrew tradition attributes to Joshua ten statutes, containing precise 
sary for the breeding of deer, wild boars, and other game, or for the more reasonable purpose of furnishing a supply of building timber and fuel for future generations. It was reserved for more advanced ages to appreciate the geographical importance of the woods, and it is only in the most recent times, only in a few countries of Europe, that the general destruction of the forests has been recognized as the most potent among the many causes of the physical deterioration of the earth.*

\section{Royal Forests and Game Laws.}

The French authors I have quoted, as well as many other mriters of the same nation, refer to the French Revolution as having given a new impulse to destructive causes which were already threatening the total extermination of the woods. $\dagger$ The general crusade against the forests, which accompanied that important event, is to be ascribed, in a considerable degree, to political resentments. The forest codes of the medireval kings, and

regulations for the protection of the property of every tribe and of every head of a family against irregular depredations. Small quadrupeds were allowed to pasture in dense woods, not in thin ones; but no auimal could feed in any forest without the consent of the proprietor of the soil. Every Hebrew might , pick up fallen boughs and twigs, but was not permitted to cut them. Trees might be pruned for the trimmings, with the exception of the olive and other fruit-trees, and provided there was sufficient shade in the place."-Lectures on the History of the Jevoish Church, part i., p. 271.

Alfred Maury mentions several provisions taken from the laws of the Indian legislator Manu, on the same subject.-Les Forêts de la Gaule, p. 9.

The very ancient tables of Heraclea contain provisions for the protection of woods, but whether these referred only to sacred groves, to public forests, or to leased lands, is not clear.

* We must perhaps make an exception in faror of the Emperor Constantine, who commenced the magnificent series of aqueducts and cisterns which still supply Constantinople with water, and enacted strict laws for the protection of the forest of Belgrade, in which rise the springs that feed the aqueducts. See an article by Mr. H. A. Homes on the Water-Supply of Constantinople in the Albany Argus of June 6, 1872.

+ Religious intolerance had produced similar effects in France at an earlier period. "The revocation of the edict of Nantes and the dragonnades occasioned the sale of the forests of the unhappy Protestants, who fled to seek in foreign lauds the liberty of conscience which was refused to them in France. The forests were soon felled by the purchasers, and the soil in part lrought under cultivation."-BecQuerel, Des Climats, etc., p. 303. 
the local "coutumes" of feudalism, contained many severe and even inhuman provisions, adopted rather for the preservation of game than from any enlightened views of the more important functions of the woods. Ordericus Vitalis informs us that William the Conqueror destroyed sixty parishes and drove out their inhabitants, in order that he might turn their lands into a forest, * to be reserved as a hunting-ground for himself and his posterity, and he punished with death the killing of a deer, wild boar, or even a hare. His successor, William Rufus, according to the Histoire des Ducs de Normandie et des Rois d'Angleterre, p. 67, "was hunting one day in a new forest, which he had caused to be made out of eighteen parishes that he had destroyed, when, by mischance, he was killed by an arrow wherewith Tyreus de Rois [Sir Walter Tyrell] thought to slay a beast, but missed the beast, and slew the king, who was beyond it. And in this very same forest, his brother Richard ran so hard against a tree that he died of it. And men commonly said that these things were because they had so laid waste and taken the said parishes."

These barbarous acts, as Bonnemère observes, $\nmid$ were simply the transfer of the customs of the French kings, of their vassals, and even of inferior gentlemen, to conquered England. "The death of a hare," says our author, "was a hanging matter, the murder of a plover a capital crime. Death was inflicted on those who spread nets for pigeons; wretches who had drawn a bow upon a stag were to be tied to the animal alive; and among the

* The American reader must be reminded that, in the language of the chase and of the English law, a "forest" is not necessarily a wood. Any large extent of ground, withdrawn from cultivation, reserved for the pleasures of the chase, and allowed to clothe itself with a spontaneous growth, serving as what is technically called "cover" for wild animals, is, in the dialects I have mentioned, a forest. When, therefore, the Norman kings afforested the grounds referred to in the text, it is not to be supposed that they planted them with trees, though the protection afforded to them by the game laws would, if cattle had been kept out, soon have converted them into real woods.

† Histoire des Paysans, ii., p. 190. The work of Bonnemère is of great value to those who study the history of medinval Europe from a desire to know its real character, and not in the hope of finding apparent facts to sustain a false and dangerous theory. Bonnemire is one of the few writers who, like Michelet, have been honest enough and bold enough to speak the truth with regard to the relations between the church and the people in the Middle Ages. 
seigniors it was a standing excuse for having killed game on forbidden ground, that they aimed at a serf." The fendal lords enforced these codes with unrelenting rigor, and not unfrequently took the law into their own hands. In the time of Louis IX., according to William of Nangis, "three noble children, born in Flanders, who were sojourning at the abbey of St. Nicholas in the IVood, to learn the speech of France, went out into the forest of the abbey, with their bows and iron-headed arrows, to disport them in shooting hares, chased the game, which they had started in the wood of the abbey, into the forest of Enguerrand, lord of Coucy, and were taken by the sergeants which kept the wood. When the fell and pitiless Sir Enguerrand knew this, he had the children straightway hanged without any manner of trial." * The matter being brought to the notice of good King Louis, Sir Enguerrand was summoned to appear, and, finally, after many feudal shifts and dilatory pleas, brought to trial before Louis himself and a special council. Notwithstanding the opposition of the other seigniors, who, it is needless to say, spared no efforts to save a peer, probably not a greater criminal than themselves, the king was much inclined to inflict the punishment of death on the proud baron. "If he believed," said he, "that our Lord would be as well content with hanging as with pardoning, he would hang Sir Enguerrand in spite of all his barons"; but noble and clerical interests unfortunately prevailed. The king was persuaded to inflict a milder retribution, and the murderer was condemned to pay ten thousand livres in coin, and to "build for the souls of the three children two chapels wherein mass should be said every day." + The hope of shortening the purga-

\footnotetext{
* It is painful to add that a similar outrage was perpetrated a very few years ago, in one of the European states, by a prince of a family now dethroned. In this case, however, the prince killed the trespasser with his own hand, his sergeants refusing to execute his mandate.

† Guilladme de Nangis, as quoted in the notes to Jornville, Nourelle Collection des Mémoires, etc., par Michaud et Poujoulat, première série, i., p. 335.

Persons acquainted with the character and influence of the mediæval clergy will hardly need to be informed that the ten thousand livres never found their way to the royal exchequer. It was easy to prove to the simple-minded king that, as the profits of sin were a monopoly of the church, he ought not to derive advantage from the commission of a crime by one of his subjects; and
} 
torial term of the young persous, by the religious rites to be cele brated in the chapels, was doubtless the consideration which operated most powerfully on the mind of the king; and Europe lost a great example for the sake of a mass.

The desolation and depopulation, resulting from the extension of the forest and the enforcement of the game laws, induced several of the French kings to consent to some relaxation of the severity of these latter. Francis I., however, revived their barbarous provisions, and, according to Bonnemère, even so good a monarch as Henry IV. re-enacted them, and "signed the sentence of death upon peasants guilty of having defended their fields against devastation by wild beasts." "A fine of twenty livres," he continues, "was imposed on every one shooting at pigeons, which, at that time, swooped down by thousands upon the newsown fields and devoured the seed. But let us count even this a progress, for we have seen that the murder of a pigeon had been a capital crime." *

Not only were the slightest trespasses on the forest domainthe cutting of an oxgoad, for instance-severely punished, but game animals were still sacred when they had wandered from their native precincts and were ravaging the fields of the peasantry. A herd of deer or of wild boars often consumed or trod down a harvest of grain, the sole hope of the year for a whole family; and the simple driving out of such animals from this costly pasturage brought dire vengeance on the head of the rustic who had endeavored to save his children's bread from their voracity. "At all times," says Panl Louis Courier, speaking in the name of the peasants of Chambord, in the "Simple Discours," "the game has made war upon us. Paris was blockaded eight hundred years by the deer, and its environs, now so rich, so fertile, did not yield bread enough to support the game-

the priests were dexterous enough both to secure to themselves the amount of the fine, and to extort from Louis large additional grants to carry out the purposes to which they devoted the money. "And though the king did take the moneys," says the chronicler, "he put them not into his treasury, but turned them into good works; for he builded therewith the maison-Dieu of Pontoise, and endowed the same with rents and lands; also the schools and the dormitory of the friars preachers of Paris, and the monastery of the Minorite friars."

* Histoire des Paysans, ii., p. 200. 
keepers." * The Tiers Etat declared, in 1789, "the most terrible scourge of agriculture is the abundance of wild game, a consequence of the privileges of the chase; the fields are wasted, the forests ruined, and the vines gnawed down to the roots."

\section{Effects of the French Revolution.}

The abrogation of the game laws and of the harsh provisions of the forestal code was one of the earliest measures of the revolutionary government; and the removal of the ancient restrictions on the chase, and of the severe penalties imposed on trespassers upon the public forests, was immediately followed by unbridled license in the enjoyment of the newly conceded rights.

In the popular mind the forest was associated with all the abuses of feudalism, and the evils the peasantry had suffered

* The following details from Bonnemère will serve to give a more complete idea of the vexatious and irritating nature of the game laws of France. The officers of the chase went so far as to forbid the pulling up of thistles and weeds, or the mowing of any unenclosed ground before St. John's day (24th June) in order that the nests of game birds might not be disturbed. It was unlawful to fence in any grounds in the plains where royal residences were situated; thorns were ordered to be planted in all fields of wheat, barley or oats, to prevent the use of ground-nets for catching the birds which consumed, or were believed to consume, the grain; and it was forbidden to cut or pull stubble before the first of October, lest the partridge and the quail might be deprived of their cover. For destroying the eggs of the quail a fine of one hundred lirres was imposed for the first offence, double that amount for the second, and for the third the culprit was flogged and banished for five jears to a distance of six leagues from the forest.-Histoire des Paysans, ii., p. 202, text and notes.

Neither these severe penalties, nor any provisions devised by the ingenuity of modern legislation, have been able effectually to repress poaching. "The game laws," says Clavé, "have not delivered us from the poachers, who kill twenty times as much game as the sportsman. In the forest of Fontainebleau, as in all those belonging to the state, poaching is a very common and a very profitable offence. It is in vain that the gamekeepers are on the alert night and day, they can not prevent it. Those who follow the trade begin by carefully studying the habits of the game. They will lie motionless on the ground, by the roadside or in thickets, for whole days, watching the paths most frequented by the animals," etc.-Revue des Deux IFondes, Mai, 1863, p. 160.

The writer adds many details on this subject, and it appears that, as thero are "beggars on horseback" in South America, there are poachers in carriages in France. 
from the legislation which protected both it and the game it sheltered, blinded them to the still greater physical mischiefs which its destruction was to entail upon them. No longer under the safeguard of the law, the crown forests and those of the great lords were attacked with relentless fury, unscrupulously plundered and wantonly laid waste, and even the rights of property in small private woods ceased to be respected.* Various alsurd theories, some of which are not even yet exploded, were propagated with regard to the economical advantages of converting the forest into pasture and ploughland, the injurious effects of the woods upon climate, health, facility of internal communication, and the like. Thus resentful memory of the wrongs associated with the forest, popular ignorance, and the cupidity of speculators cunning enough to turn these circumstances to profitable account, combined to hasten the sacrifice of the remaining woods, and a waste was produced which hundreds of years and millions of treasure will hardly repair.

In the era of savage anarchy which followed the beneficent reforms of 1789, economical science was neglected, and statistical details upon the amount of the destruction of woods during that period are wanting. But it is known to have been almost incalculably rapid, and the climatic and financial evils, which elsewhere have been a more gradual effect of this cause, began to make themselves felt in France within three or four years after that memorable epoch. $\dagger$

* "Whole trees were sacrificed for the most insignificant purposes; the peasants would cut down two firs to make a single pair of wooden shoes."Michelet, as quoted by ClavÉ, Études, p. 24.

A similar wastefulness formerly prevailed in Russia, though not from the same cause. In St. Pierre's time, the planks brought to St. Petersburg were not sawn, but hewn with the axe, and a tree furnished but a single plank.

† See Becquenel, Mémoire sur les Forêts, in the Mém. de l'Académie des Sciences, t. xxxv., p. 411 et seq.

Similar circumstances produced a like result, though on a far smaller scale, in Italy, at a very recent period. Gallenga says: "The destruction of the majestic timber [between the Vals Sesia and Sessera] dates no farther back than 1848, when, on the first proclamation of the Constitution, the ignorant boor had taken it for granted that all the old social ties would be loosened, and therefore the old forest-laws should be at once set at naught." -Country. Life in Piedmont, p. 136. 


\section{Increased Demand for Lumber.}

With increasing population and the development of new in. dustries, come new drains upon the forests from the many arts for which wood is the material. The demands of the near and the distant market for this product excite the eupidity of the harly forester, and a few years of that wild industry of which Springer's "Forest Life and Forest Trees" so vividly depicts the dangers and the triumphs, suffice to rob the most inaccessible glens of their fairest ornaments. The value of timber increases with its dimensions in almost geometrical proportion, and the tallest, most vigorous, and most symmetrical trees fall the first sacrifice. This is a fortunate circumstance for the remainder of the wood; for the impatient lumberman contents himself with felling a ferw of the best trees, and then hurries on to take his tithe of still virgin groves.

The vast extension of railroads, of manufactures and the mechanical arts, of military armaments, and especially of the commercial fleets and navies of Christendom, within the present century, has incredibly augmented the demand for wood,* and but

* Let us take the supply of timber for railroad-ties. According to Clavé (p. 248), France had, in 1862, 9,000 kilomètres of railway in operation, 7,000 in construction, half of which is built with a double track. Adding turn-outs and extra tracks at stations, the number of ties required for a single track is stated at 1,200 to the kilomètre, or, as Clavé computes, for the entire network of France, 58,000,000. This number is too large, for $16,000+8,000$ for the double track halfway $=24,000$, and $24,000 \times 1,200=28,500,000$. In an article in the Revue des Deux Mondes, July, 1863, Gandy states that 2,000,000 trees had been felled to furnish the ties for the French railroads, and as the ties must be occasionally renewed, and new railways have been constructed since 1863 , we may probably double this number.

The United States had in operation on the first of January, 1872, 61,000 miles, or about 97,000 kilometres, of railroad. Allowing the same proportion as in France, the American railroads required 116,400,000 ties. The Report of the Agricultural Department of the United States for November and Decem. ber, 1869 , estimates the number of ties annually required for our railways at $30,000,000$, and supposes that 150,000 acres of the best woodland must be felled to supply this number. This is evidently an error, perhaps a misprint for 15,000. The same authority calculates the annual expenditure of the American railroads for lumber for buildings, repairs and cars, at $\$ 38,000,000$, and for locomotive fuel, at the rate of 19,000 cords of wood per day, at $\$ 50,000,000$.

The walnut trees cut in Italy and France to furnish gunstocks to the American army, during our late civil war, would alone have formed a considerable 
for improvements in metallurgy and the working of iron, which have facilitated the substitution of that metal for wood, the last

forest. A single establishment in Northern Italy used twenty-eight thousand large walnut trees for that purpose in the years 1862 and 1863.

The consumption of wood for lucifer matches is enormous, and I have heard of several instances where tracts of pine forest, hundreds and even thousands of acres in extent, have been purchased and felled, solely to supply timber for this purpose. The United States Government tax, at one cent per hundred, produced $\$ 2,000,000$ per year, which shows a manufacture of $20,000,000,000$ matches. Allowing nothing for waste, there are about fifty matches to the cubic inch of wood, or 86,400 to the cubic foot, making in all upwards of 230 ,000 cubic feet, and, as only straight-grained wood, free from knots, can be used for this purpose, the sacrifice of not less than three or four thousand well-grown pines is required for this purpose.

If we add to all this the supply of wood for telegraph-posts, wooden pavements, wooden wall tapestry-paper, shoe-pegs, and even wooden nails, which have lately come into use-not to speak of numerous other recent applications of this material which American ingenuity has devised-we have an amount of consumption, for entirely new purposes, which is really appalling.

Wooden field and garden fences are very generally used in America, and some have estimated the consumption of wood for this purpose as not less than that for architectural uses.

Fully one-half our vast population is lodged in wooden houses; and barns and country out-houses of all descriptions are almost universally of the same material.

The consumption of wood in the United States as fuel for domestic purposes, for charcoal, for brick and lime kilns, for breweries and distilleries, for steam. boats, and many other uses, defies computation, and is vastly greater than is employed in Europe for the same ends. For instance, in rural Switzerland, cold as is the winter climate, the whole supply of wood for domestic fires, dairies, breweries, distilleries, brick and lime kilns, fences, furniture, tools, and even house-building and small smitheries, exclusive of the small quantity derived from the trimmings of fruit-trees, grape-vines, and hedges, and from decayed fences and buildings, does not exceed troo hundred and thirty cubic feet, or less than two cords a year, per household.-See Bericht über die Untersuchung der Schweiz Hochgebirgsicaldungen, pp. 85-89. In 1789, Arthur Young estimated the annual consumption of firewood by single families in France at from two and a half to ten Paris cords of 134 cubic feet.-Travels, vol. ii., chap. $\mathbf{x \nabla}$. See Wessely on Consumption of Wood in Austria.

The report of the Commissioners on the Forests of Wisconsin, 1867, allows three cords of wood to each person for household fires alone. Taking families at an average of five persons, we have eight times the amount consumed by an equal number of persons in Switzerland for this and all other purposes to which this material is ordinarily applicable. I do not think the consumption in the Northeastern States is at all less than the calculation for Wisconsin. It has been estimated that in the cold climate of Sweden, 144 solid, or 200 loose, cubic feet of pine or fir are required per head of the population. 
twenty-five years would have almost stripped Europe of her last remaining tree fit for these uses.*

The consumption in Norway is about the same.-Asizörnsen, Om et nidnet Skovbrug. Appendix, 1858.

Evergreen trees are thoughtlessly destroyed in immense numbers in the United States for the purpose of decoration of churches and on other festive occasions. The New York eity papers reported that 118,000 young everereen trees, besides 20,000 yards of small branches twisted into fectoons, were sold in the markets of that city, for this use, at Christmas, in 1869. At the Cincinnati Industrial Exhibition of $15 \% 2$, three miles of evergreen festoons were hung upon the beams and rafters of the "Floral IIall." I have known thrifty young aroves of evergreen of considerible extent completely destroyed in this reckless way.

Important statistics on the consumption and supply of wood in the United States will be found in a valuable paper by the Rev. Frederick Starr, Jr., in the Transactions of the Agricultural Society for -

of course, there is a vast consumption of ligneous material for all these uses in Europe, but it is greatly less than at earlier periods. The waste of wood in European carpentry was formerly enormous, the beams of houses being both larger and more numerous than permanence or stability required. In examining the construction of the houses occupied by the eighty fimilies which inhabit the village of Faucigny, in Savoy, in 1854, the forest inspector found that fifty thousand trees had been employed in building them. The builders " seemed," says Hudry-IIenos, "to have tried to solve the problem of piling upon the walls the largest quantity of timber possible without crushing them."-Revue des Deux Mondes, 1st June, 1864, p. 601.

European statistics present comparatively few facts on this subject, of special interest to American readers, but it is worth noting that France employs 1,500,00 cubic feet of oak per year for brandy and wine casks, which is about half her annual consumption of that material; and it is not a wholly insignificant fact that, according to Rentzsch, the quantity of wood used in parts of Germany for small carvings and for children's toys is so large, that the export of such objects from the town of Sonneberg alone, amounted, in 1853 , to 60,000 centner, or three thousand tons' weight.-Der Wald, p. 68.

In an article in the Revue des Eaux et Forets for November, 1868, it is stated that 200,000 dozens of drums for boys are manufactured per month in Paris. This is equivalent to $28,800,000$ per year, for which $56,000,000$ drumsticks are required, and the writer supposes that the annual growth of 50,000 acres of woodland would not more than supply the material. In the same article the consumption of matches in France is given at $7,200,000,000$, and the quautity of lumber annually required for this manufacture is computed at 80,000 stires, or cubic metres-evidently an erroneous calculation.

* Besides the substitution of iron for mood, a great saving of consumption of this latter material has been effected by the revival of ancient methods of increasing its durability, and the invention of new processes for the same purpose. The most effectual preservative yet discovered for wood employed on Iand, is sulphate of copper, a solution of which is introduced into the pores of 
I have spoken of the foreign demand for American agricultura. products as having occasioued an extension of cultivated ground, which had led to clearing land not required by the necessities of home consumption. But the forest itself has become, so to speak, an article of exportation. England, as we have seen, imported oak and pine from the Baltic ports more than six hundred jears ago. She has since drawn largely on the forests of Norway, and

the wood while green, by soaking, by forcing-pumps, or, most economically, by the simple pressure of a column of the fluid in a small pipe connected with the end of the piece of timber subjected to the treatment. Clavé (Études Forestiires, pp. 210-219) gives an interestiug account of the various processes employed for rendering Trood imperishable, and states that railroad-ties injected with sulphate of copper in 1816, were found absolutely unaltered in 1855; and telegraphic posts prepared two years earlier, are now in a state of perfect preservation.

For many purposes the method of injection is too expensive, and some simpler process is much to be desired. The question of the proper time of felling timber is not settled, and the best modes of air, water and steam seasoning are not yet fully ascertained. Experiments on these subjects, would be well worth the patronage of Governments in new countries, where they can be very easily made without the necessity of much waste of valuable material, and without expensive arrangements for observation.

The practice of stripping living trees of their bark some years before they are felled, is as old as the time of Vitruvius, but is much less followed than it deserves, partly because the timber of trees so treated inclines to crack and split, and partly because it becomes so hard as to be wrought with considerable difficulty.

In America, economy in the consumption of fuel has been much promoted by the substitution of coal for wood, the general use of stoves both for wood and coal, and recently by the employment of anthracite in the furnaces of stationary and locomotive steam-engines. All the objections to the use of anthracite for this latter purpose appear to have been overcome, and the improvements in its combustion have been attended with a great pecuniary saving, and with much advantage to the preservation of the woods.

The employment of coal has produced a great reduction in the consumption of firewood in Paris. In 1815, the supply of firewood for the city required $1,200,000$ stères, or cubic mètres ; in 1859 it had fallen to 501,805 , while, in the meantime, the consumption of coal had risen from 600,000 to $4,320,000$ metrical quintals. See Cuavé, Études, p. 212.

In 1869 Paris consumed 951,157 stires of firewood, 4,902,414 hectolitres, or more than 13,000,000 bushels, of charcoal, and 6,872,000 metrical quintals, or more than 7,000,000 tons, of mineral coal.-Annuaire de la Revue des Eaux et Forêts for 1872, p. 26.

The increase in the price of firewood at Paris, within a century, has been comparatively small, while that of timber and of sawed lumber has increased enormously. 
for many years has received vast quantities of lumber from her American possessions.

The unparalleled facilities for internal navigation, afforded by the numerous rivers of the present and former British colonial possessions in North America, lave proved very fatal to the forests of that continent. Quebec became many years ago a centre for a lumber trade, which, in the bulk of its material, and consequently, in the tonnage required for its transportation, rivalled the commerce of the greatest European cities. Immense rafts were collected at Quebec from the great Lakes, from the Ottawa, and from all the other tributaries which unite to swell the current of the St. Lawrence and help it to struggle against its mighty tides." Ships, of burden formerly undreamed of, have been built to convey the timber to the markets of Europe, and during the summer months the St. Lawrence is almost as crowded with shipping as the Thames. $†$

* The tide rises at Quebec to the height of twenty-five feet, and when it is aided by a northeast wind, it flows with almost irresistible violence. Rafts containing several hundred thousand cubic feet of timber are often caught by the flood-tide, torn to pieces, and dispersed for miles along the shores.

+ One of these, the Baron of Renfrew-so named from one of the titles of the kings of England-built forty or fifty years ago, measured 5,000 tons. They were little else than rafts, being almost solid masses of timber designed to be taken to pieces and sold as lumber on arriving at their port of destination.

The lumber trade at Quebec is still very large. According to an article in the Revue des Deux IFondes, that city exported, in 1860, 30,000,000 cubic feet of squared timber, and 400,000,000 square feet of "planches." The thickness of the boards is not stated, but I believe they are generally cut an inch and 3 quarter thick for the Quebec trade, and as they shrink somewhat in drying, we may estimate ten square for one cubic foot of boards. This gives a total of $70,000,000$ cubic feet. The specific gravity of white pine is .554 and the weight of this quantity of lumber, very little of which is thoroughly seasoned, would exceed a million of tons, even supposing it to consist wholly of wood as light as pine.

The London Times of October 10, 18\%1, states the exportation of lumber from Canada to Europe, in 1870 , at $200,000,000$ cubic fect, and adds that more than three times that quantity was sent from the same province to the United States. A rery large proportion of this latter quantity goes to Burlington, Vermont, whence it is distributed to other parts of the Union.

There must, I think, be some error or exaggeration in these figures. Per. laps instead of cubic feet we should read syuare feet. Two hundred millions 


\section{Effects of Forest Fires.}

The operations of the lumberman involve other dangers to the woods besides the loss of the trees felled by him. The narrow clearings around his shanties form openiugs which let in the wind, and thus sometimes occasion the overthrow of thousands of trees, the fall of which dams up small streams, and creates bogs by the spreading of the waters, while the decaying trunks facilitate the multiplication of the insects which breed in dead wood and are, some of them, injurious to living trees. The escape and spread of camp-fires, however, is the most devastating of all the causes of destruction that find their origin in the operations of the lumberman. The proportion of trees fit for industrial uses is small in all primitive woods. Only these fall before the forester's axe, but the fire destroys, almost indiscriminately, every age and every species of tree.* While, then, without fatal

of cubic feet of timber would require more than half the entire tonnage of England for its transportation.

I suppose the quantities in the following estimates, from a carefully prepared article in the St. Louis Republican, must be understood as meauing square or superficial feet, board measure, allowing a thickness of one inch :

"The lumber trade of Michigan, Wisconsin and Minnesota, for the year 1869 , shows the amount cut as being 2,029,372,255 feet for the State of Michigan, and $317,400,000$ feet for the State of Minnesota, and $964,600,000$ feet for the State of Wisconsin. This includes the lake shore and the whole State of Wisconsin, which heretofore has been difficult to get a report from. The total amount cut in these States was 3,311,372,255 feet, and to obtain this quantity there have been stripped 883,032 acres, or 1,380 square miles of pine woodland. It is calculated that $4,000,000$ acres of land still remain unstripped in Michigan, which will yield 15,000,000,000 feet of lumber ; while $3,000,000$ acres are still standing in $\mathrm{W}$ isconsin, which will yield $11,250,000,000$ feet, and that which remains in Minnesota, taking the estimate of a few years since of that which was surveyed and unexplored, after deducting the amount cut the past few yenrs, we find $3,630,000$ acres to be the proper estimate of trees now standing which will yield $32,362,500,000$ feet of lumber. This makes a total of $15,630,000$ acres of pine lands, which remain standing in the above States, that will yield $58,612,500,000$ feet of lumber, and it is thought that fifteen or twenty years will be required to cut and send to market the trees now standing."

See also Bryant, Forest Trees, chap. iv.

* Trees differ in their power of resisting the action of forest fires. Differ ent woods vary greatly in combustibility, and even when the bark is scarcely scorched, trees are, partly in consequence of physiological character, and 
injury tu the younger growths, the native forest will bear several "cuttings over" in a generation-for the increasing value of lumber brings into use, every four or five years, a quality of timber which had been before rejected as ummarketable-a fire may render the declivity of a mountain unproductive for a century.*

partly from the greater or less depth at which their roots habitually lie below the surface, differently affected by running fires. The white pine, Pinus stroGus, as it is the most valuable, is also perhaps the most delicate tree of the American forest, while its cougener, the Northern pitch-pine, Pinus rigulle, is Iess injured by fire than any other tree of our country. I have heard experienced lumbermen maintain that the growth of this pine was eren accelerated by a tire brisk enough to destroy all other trees, and I have myself seen it still flourishing after a conflagration which had left not a green leaf but its own in the wood, and actually throwing out fresh foliage, when the old had been quite burnt off and the bark almost converted into charcoal. The wood of the pitch-pine is of comparatively little value for the joiner, but it is useful for very many purposes. Its rapidity of growth in even poor soils, its hardihood, and its abundant yield of resinous products, entitle it to much more consideration, as a plantition tree, than it has hitherto received in Europe or America, though Prof. Sargent, of Cambridge, informs me that it is now very extensively used for that purpose in the United States. I quote from him: "There are in Barnstable County, Mass, especially about South Orleans, plantations of this tree, hundreds of acres in extent, raised directly from the seed. The seed of this species is not only more easily procured than that of the Thite Pine, but it germinates much more easily and surely, and is therefore preferred by the farmers to its more valuible congener. Unfortunately, howerer, several hundred acres of these artificially reared forests have lately been destroyed by fire."

* Between sixty and seventy years ago, a steep mountain with which I am familiar, composed of metamorphic rock, and at that time covered with $a$ thick coating of soil and a dense primeval forest, was accidentally burnt over. The fire took place in a very dry season, the slope of the mountain was too rapid to retain much water, and the conflagration was of an extraordinarily fierce character, consuming the wood almost entirely, burning the leaves and combustible portion of the mould, and in many places cracking and disintegrating the rock beneath. The rains of the following autumn carried off much of the remaining soil, and the mountain-side was nearly bare of wood for two or three years afterwards. At length a new crop of trees sprang up and grow vigorously, and the mountain is now thickly corered again. But the depth of mould and earth is too small to allow the trees to reach maturity. When they attain to the diameter of about six inches, they uniformly die, and this they will no doubt continue to do until the decay of leares and wood on the surface, and the decomposition of the subjacent rock, shall have formed, perhaps hundreds of years hence, a stratum of soil thick enough to support a full-grown forest. Under favorable conditions, howeter, as in the case of the fire of Miramichi, a burnt forest renews itself rapidly and permanently. 
Aside from the destruction of the trees and the laying bare of the soil, and consequently the freer admission of sun, rain and air to the ground, the fire of itself exerts an important influence on its texture and condition. It cracks and sometimes even pulverizes the rocks and stones upon and near the surface; * it consumes a portion of the half-decayed vegetable mould which served to hold its mineral particles together and to retain the water of precipitation, and thus loosens, pulverizes and dries the earth; it destroys reptiles, insects and worms, with their eggs, and the seeds of trees and of smaller plants; it supplies, in the ashes which it deposits on the surface, important elements for the growth of a new forest clothing, as well as of the usual objects of agricultural industry; and by the changes thus produced, it fits the ground for the reception of a vegetation different in character from that which had spontaneously covered it. These new conditions help to explain the natural succession of forest crops, so generally observed in all woods cleared by fire and then abandoned. There is no doubt, however, that other influences contribute to the same result, because effects more or less analogous follow when the trees are destroyed by other causes, as by high winds, by the woodman's axe, and even by natural decay. +

* In the burning over of a hill-forest in the Lower Engadine, in September, 1865 , the fire was so intense as to shatter and calcine the rocks on the slope, and their fragments were precipitated into the valley below.-Rivista Forestale del Regno d'Italia, Ottobre, 1865, p. 474.

t The remarkable mounds and other earthworks constructed in the valley of the Ohio and elsewhere in the territory of the United States, by a people apparently more advanced in culture than the modern Indian, were overgrown with a dense clothing of forest when first discovered by the whites. But though the ground where they were erected must have been occupied by a large population for a considerable length of time, and therefore entirely cleared, the trees which grew upon the ancient fortresses and the adjacent lands were not distinguishable in species, or even in dimensions and character of growth, from the neighboring forests, where the soil seemed never to have been disturbed. This apparent exception to the law of chauge of crop in natural forest growth was ingeniously explained by General Harrison's suggestion, that the lapse of time since the era of the mound-builders was so great as to have embraced several successive generations of trees, and occasioned, by their rotation, a return to the original vegetation.

The successive changes in the spontaneous growth of the forest, as proved by the character of the wood found in bogs, are such as to have suggested the theory of a considerable change of climate during the human period. But 
Another evil, sometimes of serious magnitude, which attends the operations of the lumberman, is the injury to the banks of rivers from the practice of floating. I do not here allude to rafts, which, being under the control of those who navigate them, may

this theory can not be admitted upon the evidence in question. In fact, the order of succession-for a rotation or alteration is neither proved nor probable-may be made to move in opposite directions in different countries with the same climate and at the same time. Thus in Denmark and in IIollind the spike-leaved firs have given place to the broad-leaved beech, while in Northern Germany the process has been reversed, and evergreens have supplanted the oaks and birches of deciduous foliage. The principal determining cause seems to be the influence of light upon the germination of the seeds and the growth of the young tree. In a forest of firs, for instance, the distribution of the light and shade, to the influence of which seeds and shoots are exposed, is by no means the same as in a wood of beeches or of oaks, and hence the growth of different species will be stimulated in the two forests.

When ground is laid bare both of trees and of vegetable mould, and left to the action of unaided and unobstructed nature, she first propagates trees which germinate and grow only under the influence of a full supply of light and air, and then, in succession, other species, according to their ability to bear the shade and their demand for more abundant nutriment. In Northern Europe the larch, the white birch, the aspen, first appear; then follow the raple, the alder, the ash, the fir; then the oak and the linden; and then the beech. The trees called by these respective names in the United States are not specifically the same as their European namesakes, nor are they always even the equivalents of these latter, and therefore the order of succession in America would not be precisely as indicated by the foregoing list, but so far as is known, it very nearly corresponds to it.

It is thought important to encourage the growth of the beech in Denmark and Northern Germany, because it upon the whole yields better returns than other trees, and does not exhaust, but on the contrary enriches, the soil ; for by shedding its leaves it returns to it most of the nutriment it has drawn from it, and at the same time furnishes a solvent which aids materially in the decomposition of its mineral constituents.

When the forest is left to itself, the order of succession is constant, and its occasional inversion is always explicable by some human interference. It is curious that the trees which require most light are content with the poorest soils, and vice verst. The trees which first appear are also those which propagate themselves farthest to the north. The birch, the larch, and the fir bear a severer climate than the oak, the oak than the becch. "These parallelisms," says Vaupell, "are very interesting, because, though they are entirely independent of each other, they all prescribe the same order of succession." Bögens Indiandring, p. 42. See also BEna, Das Terdrängen der Laubrïlder im Fordlichen Deutschland, 1841. MEser, Das Terhalten der Taldbäume gegen Licht und Schatten, 185:. Starra, De Bodem van Mederland, 18.56, L, pp. 120-200. VAUPELL, De Danske Skove, 1863. Kxonr, Studien über 
be so guided, as to aroid damage to the shore, but to masts, logs and other pieces of timber singly entrusted to the streams, to be conveyed by their currents to sawmill ponds, or to convenient places for collecting them into rafts. The lumbermen usually haul the timber to the banks of the rivers in the winter, and when the spring floods swell the streams and break up the ice, they roll the logs into the water, leaving them to float down to their destination. If the transporting stream is too small to furnish a sufficient channel for this rude navigation, it is sometimes dammed up, and the timber collected in the pond thus formed above the dam. When the pond is full, a sluice is opened, or the dam is blown up or otherwise suddenly broken, and the whole mass of lumber above it is hurried down with the rolling flood. Both of these modes of proceeding expose the banks of the rivers einployed as channels of flotation to abrasion,* and in some of the American States it has been found necessary to protect, by special legislation, the lands through which they flow from the serious injury sometimes received through the practices I have described. $\nmid$ Switzerland, as might be expected from the phys-

die Buchen-Wirthschaft, 1863. A. Maurx, Les Forêts de la Gaule, pp. 73, 74, 377,384 .

Within the last few years, the trunks of many well-grown oaks, in a partially decayed condition, have been extracted from bogs in Finland, in dis. tricts where the present spontaneous forest growth is composed wholly of spike-leaved trees.-BLomQuist, Catalogue, etc.

In the ancient forest of Valombrosa, the primitire beeches have been, to $\mathbf{3}$ great extent, superseded by firs and other trees of the same genera.

* Caimi states that "a single flotation in the Valtelline, in 1839, caused damages appraised at $\$ 250,000 . ”-C e n n i$ sulla Importanza e Coltura dei Boschi, p. 65 .

+ Many physicists who have investigated the laws of natural hydraulics maintain that, in consequence of direct obstruction and frictional resistance to the flow of the water of rivers along their banks, there is both an increased rapidity of current and an elevation of the water in the middle of the channel, so that a river presents always a convex surface. Others have thought that the acknowledged greater swiftness of the central current must produce a depression in that part of the stream. The lumbermen affirm that, while rivers are rising, the water is highest in the middle of the channel, and tends to throw floating objects shorewards; while they are falling, it is lowest in the middle, and floating objects incline towards the centre. Logs, they say, rolled into the water during the rise, are very apt to lodge on the banks, while thase set afloat during the falling of the waters keep in the current, and are carried 
ical configuration and climate of its territory, is especially exposed to all the evils resulting from the destruction of the forests, but it is only within a few years that the desolation thus produced has been so fully described as to bring it to the general notice of the European public. The methods of transporting timber employed by the lumbermen in the Alps are often more destructive than the baring of the soil. Forests frequently grow in Alpine glens or other mountain localities inaccessible to wheeled velicles and even to sledges. In such cases, the timber is sent down by slides, which, if long used, become the beds of new torrents, or is conveyed to larger streams by the method of flotation described on page 305. The Rapport au Conseil Fédéral sur les Torrents des Alpes Suisses inspectés en 1858-63, Lausanne, 1865, gives a great amount of information respecting this scourge and its causes, among which the practice of flotation is particularly noticed. The account of the damage to the Commune of Campo on the Rovana, a tributary of the Maggia in the Canton of Ticino, in great part from the effects of flotation, is most striking. Rapijort, i., p. 7, 13. The force of the torrent Rovana has been augmented to such a degree, by baring the soil and by suddenly

without hindrance to their destination, and this law, which has been a matter of familiar observation among woodmen for generations, is now admitted as a scientific truth.

Foresters and lumbermen, like sailors and other persons whose daily occupations bring them into contact, and often into conflict, with great natural forces, have many peculiar opinions, not to say superstitions. In one of these categories we must rank the universal belief of lumbermen, that with a given head of water, and in a given number of hours, a sawmill cuts more lumber by night than by day. Having been personally interested in several sawmills, I have frequently conversed with sawyers on this subject, and have always been assured by them that their uniform experience established the fact that, other things being equal, the action of the machinery of sawmills is more rapid by night than by day. I am sorry-perhaps I ought to be ashamed-to say that my skepticism has been too strong to allow me to avail myself of my opportunities of testing this question by passing a night, watch in hand, counting the strokes of a millsaw. More unprejudiced, and, I must add, very intelligent and credible, persons have informed me that they have done so, and found the report of the sawyers abundantly confirmed. A land surveyor, who was also an experienced lumberman, sawyer and machinist, a good mathematician and an accurate observer, has repeatedly told me that he had very often "timed" sawmills, and found the difference in favor of nightwork above thirty per cent. Sed quare. 
opening the dams near its sources, that in the course of four years it excavated below the village a new channel one hundred feet deeper than its ancient bed, and of course undermined the left bank, which was composed of comparatively loose materials, for a long distance. Deprived of its original support, the steeply inclined soil of the commune, to the extent of twenty-five hundred acres, including the village of Campo, began to slide downwards in a body. The movement still continues, many of the houses have heen carried off, some overthrown and the walls of most of the remainder dangerously cracked. Unless costly measures of protection are soon adopted, the whole of this vast moving mass will be washed by the Rovana into the Maggia, and by that river into Lago Maggiore. So insecure is the soil considered at Campo, that, as I was lately told on the spot, meadow and pasture grounds, which, if safe, would be worth a hundred dollars per acre, can not now be sold for ten.

\section{Restoration of the Forest.}

In most countries of Europe-and I fear in many parts of the United States-the woods are already so nearly extirpated, that the mere protection of those which now exist is by no means an adequate security against a great increase of the evils which have already resulted from the diminution of them. Besides this, experience has shown that where the destruction of the woods has been carried beyond a certain point, no coercive legislation can absolutely secure the permanence of the remainder, especially if it is held by private hands. The creation of new forests, therefore, is generally recognized, wherever the subject has received the attention it merits, as an indispensable measure of sound public economy. Enlightened individuals in some European states, the Governments in others, have made extensive plantations, and France, particularly, has now set herself energetically at work to restore the woods in her sonthern provinces, and thereby to prevent the utter depopulation and waste with which that once fertile soil and genial climate are threatened.

The objects of the restoration of the forest are as multifarious as the motives that have led to its destruction, and as the evils 
which that destruction has occasioned. It is hoped that the replanting of the mountain slopes, and of bleak and infertile plitins, will diminish the frequency and violence of river inundations, prevent the formation of new torrents and check the violence of those already existing, mitigate the extremes of atmospheric temperature, humidity and precipitation, restore dried-up springs, rivulets and sources of irrigation, shelter the fields from chilling and from parching winds, arrest the spread of miasmatic eftluvia, and, finally, furnish a self-renewing and inexhaustible supply of a material indispensable to so many purposes of domestic comfort, and to the successful exercise of every art of peace, every destructive energy of war.*

\section{The Economy of the Forest.}

The legislation of European states upon sylviculture, and the practice of that art, divide themselves into two great branches - the preservation of existing forests, and the creation of new. Although there are in Europe many forests neither planted nor regularly trained by man, yet from the long operation of causes already set forth, what is understood in America and other new countries by the "primitive forest," no longer exists in the territories which were the seats of ancient civilization and empire, except upon a small scale, and in remote and almost inaccessible glens quite out of the reach of ordinary observation. The oldest European woods are indeed native, that is, sprung from self-sown seed, or from the roots of trees which have been felled for human purposes; but their growth has been controlled, in a variety of ways, by man and by domestic animals, and they almost uniformly present more or less of an artificial character and arrangement. Both they and planted forests - which, though certainly not few, are of comparatively recent date in Europe-demand, as well for protection as for promotion of growth, a treatment different in some respects from that which would be suited to the character and wants of the virgin wood.

* The preservation of the woods on the former eastern frontier of France, as a kind of natural abattis, was recognized by the Government of that country as an important measure of military defence, though there havo been conflicting opinions on the subject. 
On this latter branch of the subject, the management of the primitive wood, experience and observation have not yet collected a sufficient stock of facts to serve for the construction of a complete system of this department of sylviculture; but the government of the forest as it exists in France-the different zones and climates of which country present many points of analogy with those of the United States and of some of the British colonieshas been carefully studied, and several manuals of practice have been prepared for the foresters of that empire. I believe the Cours Élémentaire de Culture des Bois créé à l'École Forestière de Nancy, par M. Lorentz, complété et publié par A. Parade, with a supplement under the title of Cours d'Aménagement des Forêts, par Henri Nanquette, has been generally considered the best of these. The Etudes sur l'Économie Forestière, par Jules Clavé, which I have often quoted, presents a great number of interesting views on this sulject, but it is not designed as a practical guide, and it does not profess to be sufficiently specific in its details to serve that purpose.* Notwithstanding the difference of conditions between the aboriginal and the trained forest, the judicious observer who aims at the preservation of the former will reap much instruction from the treatises I have cited, and I believe he will be convinced that the sooner a natural wood is brought into the state of an artificially regulated one, the better it is for all the multiplied interests which depend on the wise administration of this branch of public economy.

* Among more recent manuals may be mentioned: in French, Les Études de Naitre Pierre, Paris, 1864, 12mo; Bazelarre, Traité de Reboisement, ad edition, Paris, 1864; Paston, L'Aménagement des Forêts, Paris, 1867; in English, Gregor, Arboriculture, Edinburgh, 1868; in Italian, Sremonr's very valuable Manuale teorico-pratico d'Arte Forestale, 2d ediz., Firenze, 1872 ; the excellent work of CerrnI, Dei Vantaggi di Societi per l'Impianto e Conserrazione dei Boschi, Milano, 1844, 8vo; and the prize essay of Meguscher, Memoria sui Boschi, etc., 2d edizione, Milano, 1859, 8vo. Another very important treatise on the uses of the forest, though not a manual of sylviculture, is Schleiden, Für Baum und Wald, Leipzig, 1870 ; and Nutzhors, Skovog Land, Kjöbenhavn, 1873, is a valuable work of the same general character. Mich important and practically useful matter is also to be found in Reports on Forest Management, by Capt. Campbell Walker, 8vo, London, 1873, and in The Cultivation of Timber and the Preservation of Forests, a Report from the Committee on the Public Lands to the House of Representatives, March 17, 1874. 
One consideration bearing on this subject has received less attention than it merits, because most persons interested in such questions have not opportunities for the comparison I refer to. I mean the great general superiority of eultivated timber to that of strictly spontaneous growth. I say general superiority, because there are exceptions to the rule. The white pine, Pinus strobus, for instance, and other trees of similar character and uses, require, for their perfect growth and best ligneous texture, a density of forest vegetation around them, which protects them from too much agitation by wind, and from the persistence of the lateral branches which fill the wood with knots. A pine which has grown under those conditions possesses a tall, straight stem, admirably fitted for masts and spars, and, at the same time, its wood is almost wholly free from knots, is regular in aunular structure, soft and uniform in texture, and, consequently, superior to almost all other timber for joinery. If, while a large pine is spared, the broad-leaved or other smaller trees around it are felled, the swaying of the tree from the action of the wind mechanically produces separations between the layers of annual growth, and greatly diminishes the value of the timber. The same defect is often observed in pines which, from some accident of growth, have much overtopped their fellows in the virgin forest.

The white pine, growing in the fields, or in open glades in the woods, is totally different from the true forest-tree, both in general aspect and in quality of wood. Its stem is much shorter, its top less tapering, its foliage denser and more inclined to gather into tufts, its branches more numerous and of larger diameter, its wood shows much more distinctly the divisions of annual growth, is of coarser grain, harder and more difficult to work into mitrejoints. Intermixed with the most valuable pines in the American forests, are met many trees of the character I have just described. The lumbermen call them "saplings," and generally regard them as different in species from the true white pine, but botanists are unable to establish a distinction between them, and as they agree in almost all respects with trees grown in the open grounds from known white-pine seedlings, I believe their peculiar character is due to unfavorable circumstances in their early growth. The pine, then, is an exception to the general rule as to the inferiority of the forest to the open-ground tree. The pasture oak and pas- 
ture beach, on the contrary, are well known to produce far bet. ter timber than those grown in the woods, and there are few trees to which the remark is not equally applicable.*

Another advantage of the artificially regulated forest is, that it admits of such grading of the ground as to favor the retention or discharge of water at will, while the facilities it affords for selecting and duly proportioning, as well as properly spacing, and from

* It is often laid down as a universal law, that the wood of trees of slow vegetation is superior to that of quick growth. This is one of those commonplaces by which men love to shield themselves from the labor of painstaking observation. It has, in fact, so many exceptions, that it may be doubted whether it is in any sense true. Most of the cedars are slow of growth; but while the timber of some of them is firm and durable, that of others is light, brittle and perishable. The hemlock-spruce is slower of growth than the pines, but its wood is of very little value. The pasture oak and beech show a breadth of grain-and, of course, an annual increment-twice as great as trees of the same species grown in the woods, and furnish timber greatly superior in quality to that of forest-grown trees of the same kind. The American locust, Robinia pseudacacia, the wood of which is of extreme toughness and durability, is, of all trees indigenous to Northeastern America, by far the most rapid in growth. Some of the species of the Australian Eucalypt/s furnish wood of remarkable strength and durability, and yet the eucalyptus is surpassed by no known tree in rapidity of growth. "The American Catalpa," I quote again from Prof. Sargent, " is an excellent example of a fast-growing tree, producing durable wood. No American forest-tree grows faster than the Catalpa, while the power of its wood to resist decay is almost fabulous."

As an illustration of the mutual interdependence of the mechauic arts, I may mention that in Italy, where stone, brick and plaster are almost the only materials used in architecture, and where the "hollow ware" kitchen implements are of copper or of clay, the ordinary tools for working wood are of a very inferior description, and the locust timber is found too hard for their temper. At the same time the work of the Italian stipettai, or cabinet-makers and carvers in wood, who take pains to provide themselves with tools of better metal, is wholly unsurpassed in finish and in accuracy of adjustment as well as in taste. Southey states, in Espriella's Letters, that when a small quantity of mahogany was brought to England, early in the last century, the cabinetmakers were unable to use it, from the defective temper of their tools, until the demand for furniture from the new wood compelled them to improve the quality of their implements. In America, the cheapness of wood long made it the preferable material for almost all purposes to which it could by any possibility be applied. 'The mechanical cutlery and artisans' tools of the United States are of admirable temper, finish and convenience, and no wood is too hard, or otherwise too refractory, to be wrought with great facility, both by hand-tools and by the multitude of ingenious machines which the Americans have invented for this purpose. 
time to time felling and removing the trees which compose it, are too obvious to require to be more than hinted at. In conducting these operations, we must have a diligent eye to the requirenents of nature, and must remember that a wood is not an arbitrary assemblage of trees to be selected and disposed aceording to the caprice of its owner. "A forest," says Clavé, "is not, as is often supposed, a simple collection of trees succeeding each other" in long perspective, without bond of union, and capable of isolation from each other; it is, on the contrary, a whole, the different parts of which are interdependent upon each other, and it constitutes, so to speak, a true individuality. Every forest has a special character, determined by the form of the surface it grows upon, the kinds of trees that compose it, and the manner in which they are grouped."

The art, or, as the Continental foresters rather ambitiously call it, the science of sylviculture has been so little pursued in England and America, that its nomenclature has not been introduced into the English vocabulary, and it would not be possible to describe its processes with technical propriety of language, without occasionally borrowing a word from the forest literature of France and Germany. A full discussion of the methods of sylviculture would, indeed, be out of place in a work like the present, but the want of conveniently accessible means of information on the subject, in the United States, will justify me in presenting it with somewhat more of detail than would otherwise be pertinent.

The two best known methods of treating already existing forests are those distinguished as the taillis, copse, or coppice, treatment, ${ }^{*}$ and the futaie, for which I find no English equiralent, but which may not inappropriately be called the full-growth system. A taillis, copse, or coppice, is a wood composed of shoots from the roots of trees previously cut for fuel and timber. The shoots are thinned out from time to time, and finally cut, either after a fixed number of years, or after the young trees have attained to certain dimensions, their roots being then left to

* Copse, or coppice, from the French couper, to cut, means properly a wood the trees of which are cut at certain periods of immature growth, and allowed to shoot up again from the roots; but it has come to signify, very commonly, a young wood, grove, or thicket, without reference to its origin, or to its character of a forest crop. 
send out a new progeny as before. This is the cheapest method of management, and therefore the best wherever the price of labor and of eapital bears a high proportion to that of land and of timber; but it is essentially a wasteful economy.* If the woodland is, in the first place, completely cut over, as is found most convenient in practice, the young shoots have neither the sharle nor the protection from wind so important to forest growth, and their progress is comparatively slow, while, at the same time, the thick clumps they form choke the scedlings that may have sprouted near them. + The evergreens, once cut, do not shoot up again, $\neq$ and the mixed character of the forest-in many respects

* “In America," says Clavé (pp. 124, 125), "where there is a vast extent of land almost without pecuniary value, but where labor is dear and the rate of interest high, it is profitable to till a large surface at the least possible cost; extensice cultivation is there the most advantageous. In England, France and Germany, where every corner of soil is occupied, and the least bit of ground is sold at a high price, but where labor and capital are comparatively cheap, it is wisest to employ intensive cultivation. . . . . All the efforts of the cultivator ought to be directed to the obtaining of a given result with the least sacrifice, and there is equally a loss to the commonwealth if the application of improved agricultural processes be neglected where they are advantageous, or if they be employed where they are not required. . . . . In this point of view, sylviculture must follow the same laws as agriculture, and, like it, be modified according to the economical conditions of different states. In countries abounding in good forests, and thinly peopled, elementary and cheap methods must be pursued; in civilized regions, where a dense population requires that the soil shall be made to produce all it can yield, the regular artificial forest, with all the processes that science teaches, should be cultivated. It would be absurd to apply to the endless woods of Brazil and of Canada the method of the Spessart by 'double stages,' but not less so in our country, where every yard of ground has a high value, to leave to nature the task of propagating trees, and to content ourselves with cutting, every twenty or twenty-five years, the meagre growths that chance may have produced."

† In ordinary coppices, there are few or no seedlings, because the young shoots are cut before they are old enough to mature fertile seed, and this is one of the strongest objections to the system.

$\ddagger$ It was not long ago stated, upon the evidence of the Government foresters of Greece, and of the queen's gardener, that a large wood had been discovered in Arcadia, consisting of a fir which had the property of sending up both vertical and lateral shoots from the stump of felled trees and forming a new crown. It was at first supposed that this forest grew only on the "mom. tains," of which the hero of About's most amusing story, Le Roi des Montagnes, was "king"; but stumps, with the shoots attached, have been sent to Germany, and recognized by able botanists as true natural products, and the fact 
an important advantage, if not an indispensable condition of growth-is lost; * and besides this, large wood of any species can not be grown by this method, because trees which shoot from deeaying stumps and their dying roots, become hollow or otherwise unsomnd before they aequire their full dimensions. A more

must now be considered as established. Daubeny refers to Theophrastus as ascribing this faculty of reproduction to the $\dot{\varepsilon}>a^{-} \eta$ or fir, but he does not cite chapter and verse, and I have not been able to find the passige. The same writer mentions a case where an entire forest of the common tir in France had been renewed in this way.-Trecs and Shruls of the Ancients, 1865, pp. 27-28. The American Northern pitch-pine possesses the same power in a certain degree.

According to Charles Martins, the cedar of Mount Atlas-which, if not identiml with the cedar of Lebanon, is closely allied to it-possesses the same power.-lievue des Deux Mondes, July 15, 1864, p. 315.

Prof. Sargent states that: "The California 'Red Hood' (Sequoia sempervicens) sends from its stump suckers in immense numbers and of great vigor, a peculiarity not shared, however, by its near relation the 'Big Tree.' The genus Torreya has the same peculiarity. which is a very rare one among conifers, - at least the two American species of that genus sprout freely from the stump."

* Natural forests are rarely, if ever, composed of trees of a single species, and experience has shown that oaks and other broad-leaved trees, planted as artificial woods, require to be mixed, or associated with others of different habits.

In the forest of Fontainebleau, "oaks, mingled with beeches in due proportion," says Clavé, "may arrive at the age of five or six hundred years in full vigor, and attain dimensions which I have never seen surpassed; when, however, they are wholly unmixed with other trees, they begin to decay and die at the top, at the age of forty or fifty years, like men, old before their time, weary of the world, and longing only to quit it. This has been observed in most of the oak plantations of which I have spoken, and they have not been able to attain to full growth. When the vegetation was perceived to languish, they were cut, in the hope that this operation would restore their vigor, and that the new shoots would succeed better than the original trees; and, in fact, they seemed to be recovering for the first few years. But the shoots were soon attacked by the same decay, and the operation had to be renewed at shorter and shorter intervals, until at last it was found necessary to treat as coppices plintations originally designed for the full-growth system. Nor was this all: the soil, periodically bared by these cuttings, became imporerished, and less aud less suited to the growth of the oak. . . . It was then proposed to introduce the pine, and plant with it the vacancies and glades. . . . By this means, the forest was saved from the ruin which threatened it, and now more than 10,000 acres of pines, from tifteen to thirty years old, are disseminated at various points, sometimes intermixed with broad-leared trees, sometimes forming groves by themselves."-Revue des Deux IFondes, Mai, 1863, pp. 153, 154. 
fatal objection still, is, that the roots of trees will not bear more than two or three, or at most four cuttings of their shoots before their vitality is exhausted, and the wood can then be restored only by replanting entirely. The period of cutting coppices varies in Europe from fifteen to forty years, according to soil, species and rapidity of growth.

In the futaie, or full-growth system, the trees are allowed to stand as long as they continue in healthy and vigorous growth. This is a shorter period than would be at tirst supposed, when we consider the advanced age and great dimensions to which, under favorable circumstances, many forest-trees attain in temperate climates. But, as every observing person familiar with the forest is aware, these are exceptional cases, just as are instances of great longevity or of gigantic stature among men. Able vegetable physiologists have maintained that the tree, like most fish and reptiles, has no natural limit of life or of growth, and that the only reason why our oaks and our pines do not reach the age of twenty centuries and the height of a hundred fathoms, is, that in the multitude of accidents to which they are exposed, the chances of their attaining to such a length of years and to such dimensions of growth are millions to one against them. But another explanation of this fact is possible. In trees affected by no discoverable external cause of death, decay begins at the topmost branches, which seem to wither and die for want of nutriment. The mysterious force by which the sap is earried from the roots to the utmost twigs, can not be conceived to be unlimited in power, and it is probable that it differs in different species, so that while it may suffice to raise the fluid to the height of five hundred feet in the eucalyptus, it may not be able to carry it beyond one hundred and fifty in the oak. The limit may be different, too, in different trees of the same species, not from defective organization in those of inferior growth, but from more or less favorable conditions of soil, nourishment and exposure. Whenever a tree attains to the limit beyond which its circulating fluids can not rise, we may suppose that decay begins, and death follows from want of nutrition at the extremities, and from the same causes which bring about the same results in animals of limited size-such, for example, as the interruption of functions essential to life, in consequence of the clogging up of ducts by 
matter assimilable in the stage of growth, but no longer so when increment has ceased.

In the natural woods we observe that, though, among the myriads of trees which grow upon a square mile, there are sereral regetable giants, yet the great majority of them begin to decay long before they have attained their maximum of stature, and this seems to be still more emphatically true of the artificial forest. In France, according to Clavé, "oaks, in a suit. able soil, may stand, without exhibiting any sign of decay, for two or three hundred years; the pines hardly exceed one hundred and twenty, and the soft or white woods [bois blancs], in wet soils, languish and die before reaching the fiftieth year." * These ages are certainly below the average of those of American forest-trees, and are greatly exceeded in very numerous wellattested instances of isolated trees in Europe.

The former mode of treating the futaie, called the garden system, was to cut the trees individually as they arrived at maturity, but in the best regulated forests this practice has been abandoned for the German method, which embraces not only the securing of the largest immediate profit, but the replanting of the forest, and the care of the young growth. This is effected, in the case of a forest, whether natural or artificial, which is to be subjected to regular management, by three operations. The first of these consists in felling about one-third of the trees, in such way as to leave convenient spaces for the growth of seedlings. The remaining two-thirds are relied upon to replant the vacancies by natural sowing, which they seldom or never fail to do. The scedlings are watched, are thinned out when too dense, and the ill-formed and sickly, as well as those of species of inferior value, and the shrubs and thorns which might otherwise choke or too closely shade them, are pulled up. When they have attained sufficient strength and development of foliage to require, or at least to bear, more light and air, the second step is taken by remoring a suitable proportion of the old trees which had been spared at the first cutting; and when, finally, the younger trees are hardened enough to bear frost and sun without other protection than that which they mutually give to each other, the remain-

* Études Forestières, p. 89. 
der of the original forest is felled, and the wood now consists wholly of young and vigorous trees. This result is obtained after about twenty years. At convenient periods, the unhealthy stocks and those injured by wind or other accidents are removed, and in some instances the growth of the remainder is promoted by irrigation or by fertilizing applications.* When the forest

* The grounds which it is most important to clothe with wood as a couservative influence, and which also can best he spared from agricultural use, are steep hillsides. But the performance of all the offices of the forester to the tree-seeding, planting, thinning, trimming, and finally felling and removing for consumption-is more laborious upon a rapid declivity than on a level soil, and at the same time it is diflicult to apply irrigation or manures to trees so situated. Experience has shown that there is great advantage in terracing the face of a hill before plauting it, both as preventing the wash of the earth by checking the flow of water down its slope, and as presenting a surface favorable for irrigation, as well as for manuring and cultivating the trees. But even without so expensive a process, very important results have been obtained by simply ditching declivities. "In order to hasten the growth of wood on the flanks of a mountain, Mr. Eugine Chevandier divided the slope into zones forty or fifty feet wide, by horizontal ditches closed at both ends, and thereby obtained, from firs of different ages, shoots double the dimensions of those which grew on a dry soil of the same character, where the water was allowed to run off without olstruction."-Dumort, Des Traraux Publics, ete., pp. 94-96.

The ditches were about two feet and a half deep, and three feet and a half wide, and they cost about forty francs the hectare, or three dollars the acre. This extraordinary growth was produced wholly by the retention of the rainwater in the ditches, whence it filtered through the whole soil and supplied moisture to the roots of the trees. It may be doubted whether in a climate cold enough to freeze the entire contents of the ditches in winter, it would not be expedient to draw off the water in the autumn, as the presence of so large a quantity of ice in the soil might prove injurious to trees too young and small to shelter the ground effectually against frost.

Chevandier computes that, if the annual growth of the pine in the marshy and too humid soil of the Vosges be represented by one, it will equal two in ordinary dry ground, four or five on slopes so ditched or graded as to retain the water flowing upon them from roads or steep declivities, and six where the earth is kept sufficiently moist by infiltration from running brooks.Comptes Rendus à l'Académie des Sciences, t. xix., Juillet, Déc., 1844, p. 167.

The effect of accidental irrigation is well shown in the growth of the trees planted along the canals of irrigation which traverse the fields in many parte of Italy. They flourish most luxuriantly, in spite of continual lopping, and yield a very important contribution to the stock of fuel for domestic use; while trees, situated so far from canals as to be out of the reach of infiltration from them, are of much slower growth, under circumstances otherwise equally favorable.

In other experiments of Chevandier, under better conditions, the yield of 
is approaching to maturity, the original processes already described are repeated; and as, in different parts of an extensire forest, they would take place at different times in diflerent zones, it would afford indefinitely an anuual crop of small wood, fuel and timber.

The duties of the forester do not end here, for it sometimes liappens that the glades left by felling the older trees are not sufficiently seederl, or that the species, or essences, as the French oddly call them, are not duly proportioned in the new crop. In this case, seed must be artificially sown, or young trees planted in the racancies. Besides this, all trees, whether grown for fruit, for fuel, or for timber, require more or less training in order to yield the best returns. The experiments of the Vicomte de Courval in sylriculture throw much light on this subject, and show, in a most interesting way, the importance of pruning forest-trees. The principal feature of De Courval's rery successful method is a systematical mode of trimming which compels the tree to develop the stem, by reducing the lateral ramification. Beginning with young trees, the buds are rubbed off from the stems, and superfluous lateral shoots are pruned down to the trunk. When large trees are taken in hand, branches which can

wood was increased by judicious irrigation, in the ratio of seven to one, the profits in that of twelve to one. At the Exposition of 1855, Chambrelent exhibited young trees, which, in four years from the seed, had grown to the height of sixteen and twenty feet, and the circunference of ten and twelve inches. Chevandier experimented with various manures, and found that some of them might be profitably applied to young but not to old trees, the quantity required in the latter case being ton great. Wood-ashes and the refuse of soda factories are particularly recommended. See, on the manuring of trees, Chevavder, Recherches sur l'emploi de divers amendements, etc., Paris, 185̃̃, and KoDenLe, Grundsütze der Künstlichen Düngung im Forstculturuesen. Wien, 1865.

I have seen an extraordinary growth produced in fir-trees by the application of soapsuds; in a young and sickly cherry-tree, by heaping the chips and dust from a marble-quarry to the height of two or three feet over the roots and around the stem; and cases have come to my knowledge where like results followed the planting of vines and trees in holes half filled with fragments of plaster-castings and mortar from old buildings. Chevandier's experiments in the irrigation of the forest would not have been a "new thing under the sun" to wise King Solomon, for that monarch says: "I made me pools of water, to water therewith the wood that bringeth forth trees," Eccles, ii. 6. 
be spared, and whose removal is necessary to obtain a proper length of stem, are very smoothly cut off quite close to the trunk, and the exposed surface is immediately brushed over with mineral-coal tar. When thus treated, it is said that the healing of the wound is perfect, and without any decay of the tree. Trees trained by De Courval's method, which is now universally approved and much practiced in France, rapidly attain a great height. They grow with remarkable straightness of stem and of grain, and their timber commands the highest price.*

A system of plantation, specially though not exclusively suited to very moist soils, recommended by Duhamel a hundred years ago, has been revived in Germany, within about twenty years, with much success. It is called hill-planting, and consists in placing the young tree upright on the greensward with its roots properly spread out, and then covering the roots and supporting the trunk by thick sods cut so as to form a circular hillock around it. $\dagger$ By this method it is alleged trees can be grown advantageously both in dry ground and on humid soils, where they would not strike root if planted in holes after the usual manner. If there is any truth in the theory of a desiccating action in evergreen trees, plantations of this sort might have a value as drainers of lands not easily laid dry by other processes. There is much ground on the great prairies of the West, where experiments with this method of planting are strongly to be recommended.

It is common in Europe to permit the removal of the fallen leaves and fragments of bark and branches with which the forestsoil is covered, and sometimes the cutting of the lower twigs of evergreens. The leaves and twigs are principally used as litter for cattle, and finally as manure, the bark and wind-fallen branches as fuel. By long usage, sometimes by express grant, this privilege has become a vested right of the population in the neighbor-

* See De Courvat, Taille et conduite des Arbres forestiers, et autres arbres de grande dimension. Paris, 1861.

The most important part of Viscount de Courval's system will be found in L'Élagage des Arbres, par le Comte A. Des Cars, an admirable little treatise, of which numerous editions, at the price of one franc, have been printed since the first, of 1864, and which has been translated and published in the United States.

† See MIanteoffel, L'Art de Planter, traduit par Stumper. Paris, 1868. 
hood of many public and even large private forests; but it is generally regarded as a serious evil. To remove the leaves and fallen twigs is to withdraw much of the pabulum upon which the tree was destined to feed. The small branches and leaves are the parts of the tree which yield the largest proportion of ashes on combustion, and of course they supply a great amount of nutriment for the young shoots. "A cubic foot of twigs," says Vaupell, " yields four times as much ashes as a cubic foot of stem wood..... For every hundredweight of dried leaves carried off from a beech forest, we sacrifice a hundred and sixty cubic feet of wood. The leaves and the mosses are a substitute, not only for manure, but for ploughing. The carbonic acid given out by decaying leaves, when taken up by water, serves to dissolve the mineral constituents of the soil, and is particularly active in disintegrating feldspar and the clay derived from its decomposition. .... The leaves belong to the soil. Without them it can not preserve its fertility, and can not furnish nutriment to the beech. The trees languish, prodnce seed incapable of germination, and the spontaneous self-sowing, which is an indispensable element in the best systems of sylviculture, fails altogether in the bared and impoverished soil." *

Besides these evils, the removal of the leaves deprives the soil of much of that spongy character which gives it such immense value as a reservoir of moisture and a regulator of the flow of springs; and, finally, it exposes the surface-roots to the drying influence of sun and wind, to accidental mechanical injury from the tread of animals or men, and, in cold climates, to the destructive effects of frost.

* VAupell, Bägens Indrandring $i$ de Danstie Skore, pp. 29, 46. Vaupell further observes, on the page last quoted: "The removal of leaves is injurious to the forest, not only because it retards the growth of trees, but still more because it disqualifies the soil for the production of particular species. When the beech languishes, and the development of its branches is less vigorous and its crown less spreading, it becomes unable to resist the encroachments of the fir. This latter tree thrives in an inferior soil, and being no longer stifled by the thick foliage of the beech, it spreads gradually through the wood, while the beech retreats before it and finally perishes."

Schleiden confirms the opinion of Vaupell, and adds many important observations on this subject.-Für Baum und Wald, pp. 64, 65 . 


\section{Protection against Wild Animals.}

It is often necessary to take measures for the protection of young trees against the rabbit, the mole, and other rodent quadrupeds; and of older ones against the damage done by the larvæ of insects hatched upon the surface or in the tissues of the bark, or even in the wood itself. The much greater liability of the artificial than of the natural forest to injury from this cause, is perhaps the only point in which the superiority of the former to the latter is not as marked as that of any domesticated vegetable to its wild representative. But the better quality of the wood and the much more rapid growth of the trained and regulated forest are abundant compensations for the loss thus occasioned, and the progress of entomological science will, perhaps, suggest new methods of preventing the ravages of insects. Thus far, however, the collection and destruction of the eggs, by simple but expensive means, has proved the most effectual remedy.*

* I have remarked elsewhere that most insects which deposit and hatch their eggrs in the wood of the natural forest confine themselves to dead trees. Not only is this the fact, but it is also true that many of the borers attack only freshly-cut timber. Their season of labor is a short one, and unless the tree is cut during this period, it is safe from them. In summer you may hear them plying their augers in the wood of a young pine with soft, green bark, as you sit upon its trunk, within a week after it has been felled, but the windfulls of the winter lie uninjured by the worm and even undecayed for centuries. In the pine woods of New England, after the regular lumberman has removed the standing trees, these old trunks are bauled out from the mosses aud leaves which half cover them, aud often furnish excellent timber. The slow decay of such timber in the woods, it may be remarked, furnishes another proof of the uniformity of temperature aud humidity in the forest, for the trunk of a tree lying on grass or ploughland, and of course exposed to all the alteruations of climate, hardly resists complete decomposition for a generation. The forests of Europe exhibit similar facts. Wessely, in a description of the primitive wood of Neuwald in Lower Austria, says that the windfalls required from 150 to 200 years for entire decay.-Die Oesterreich ischen Alpenländer und ihre Forste, p. 312.

The comparative immunity of the American native forests from attacks by insects is perhaps in some degree due to the fact that the European destructiv tribes have not yet found their way across the ocean, and that our native specieare less injurious to living trees. On the European lignivorous insects, see Siemoni, Manuale d'Arte Forestale, 2d edizione, pp. 369-379. 


\section{Exchusion of Domestic Quadrupeds.}

But probably the most important of all rules for the government of the forest, whether natural or artificial, is that which prescribes the absolute exclusion of all domestic quadrupedis, exeept swine, from every wood which is not destined to be cleared. No growth of young trees is possible where horned cattle, sheep or goats, or even horses, are permitted to pasture at any season of the year, though they are doultless most destructive when trees are in leaf.* These animals browse upon

*Although the economy of the forest has receired little attention in the United States, no lover of American nature can have failed to observe a marked difference between a native wood from which cattle are excluded and one where they are permitted to browse. A few seasons suflice for the total extirpation of the "underbrusli," including the young trees on which alone the reproduction of the forest depends, and all the branches of those of larger growth which hang within reach of the cattle are stripped of their buds and leives, and soon wither and fall off. These effects are observable at a great distance, and a wood-pasture is recognized, almost as far as it can be seen, by the regularity with which its lower foliage terminates at what Ruskin somewhere calls the "cattle-line." This always runs parallel to the surface of the ground, and is determined by the height to which domestic quadrupeds can reach to feed upon the leaves. In describing a visit to the grand-ducal farm of San Rossore near Pisa, where a large herd of camels is kept, Chateauvieux says: "In passing through a wood of evergreen oaks, I observed that all the twigs and foliage of the trees were clipped up to the height of about twelve feet abcre the ground, without leaving a single spray below that level. I was informed that the browsing of the camels had trimmed the trees as high as they could reach,"-LULLIN DE CHATEAUVIEUx, Lettres sur l'Italie, p. 113.

Browsing auimals, and most of all the goat, are considered by foresters as more injurious to the growth of young trees, and, therefore, to the reproduction of the forest, than almost any other destructive cause. According to Beatson's Saint IIelena, introductory chapter, and Darwin's Journal of Reserreclies in Geology and Tatural History, pp. 582, 583, it was the goats which destroyed the beautiful forests that, three hundred and fifty years agro, covered a continuous surface of not less than two thousand acres in the interior of the island [St. Helena], not to mention scattered groups of trees. Darwin observes: "During our stay at Valparaiso, I was most positively assured that sandal-wood formerly grew in abundance on the island of Juan Fernandez, but that this tree had now become entirely extinct there, having been extirpated by the goats which early navigators had introduced. The neighboring islands, to which goats have not been carried, still abound in sandalwood."

In the winter, the deer tribe, especially the great American moose-deer, subsists much on the buds and young sprouts of trees; yet-though from the 


\section{the terminal buds and the tender branches, thereby stunting, if they do not kill, the young trees, and depriving them of all beauty and vigor of growth.}

destruction of the wolves or from some not easily explained cause, these latter animals have recently multiplied so rapidly in some parts of North America, that, not long since, four hundred of them are said to have been killed, in one season, on a territory in Maine not comprising more than one hundred and fifty square miles-the wild browsing quadrupeds are rarely, if ever, numerous enough in regions uninhabited by man to produce any sensible effect on the condition of the forest. A reason why they are less injurious than the goat to young trees may be that they resort to this nutriment only in the winter, when the grasses and shrubs are leafless or covered with snow, whereas the goat feeds upon buds and young shoots principally in the season of growth. However this may be, the natural law of consumption and supply keeps the forest growth, and the wild animals which live on its products, in such a state of equilibrium as to insure the indefinite continuance of both, and tho perpetuity of neither is endangered until man interferes and destroys the balance.

When, however, deer are bred and protected in parks, they multiply like domestic cattle, and become equally injurious to trees. "A few years ago," says Clavé, "there were not less than two thousand deer of different ages in the forest of Fontainebleau. For want of grass, they are driven to the trees, and they do not spare them. .... It is calculated that the browsing of these animals, and the consequent retardation of the growth of the wood, diminishes the anuual product of the forest to the amount of two hundred thousand cubic feet per year, . . . . and besides this, the trees thus mutilated are soon exhausted and die. The deer attack the pines, too, tearing off the bark in long strips, or rubbing their heads against them when shedding their horns; and sometines, in groves of more than a hundred hectares, not one pine is found uninjured by them."-Revue des Deu.x Mondes, Mai, 1863, p. 157.

Vaupell, though agreeing with other writers as to the injury done to the forest by most domestic animals and by half-tamed deer-which he illustrates in an interesting way in his posthumous work, The Inanish Woods-thinks, nevertheless, that at the season when the mast is falling, swine are rather useful than otherwise to forests of beech and oak, by trealing into the ground and thus sowing beechnuts and acorns, and by destroying moles and mice.-De Danske Sliove, p. 12. Meguscher is of the same opinion, and adds that swine destroy injurious insects and their larvæ.-Memoria, etc., p. 233.

Beckstein computes that a park of 2,500 acres, containing 250 acres of marsh, 250 of fields and meadows, and the remaining 2,000 of wood, may keep 364 deer of different species, 47 wild boars, 200 hares, 100 rabbits, and an indefinite number of pheasants. These animals would require, in winter, 123,000 pounds of hay, and 22,000 pounds of potatoes, besides what they would pick up themselves. The natural forest most thickly peopled with wild animals would not, in temperate climates, contain, upon the average, one-tenth of these numbers to the same extent of surface. 


\section{Forest Fires.}

The difficulty of protecting the woods against accidental or incendiary tires is one of the most discouraging circumstances attending the preservation of natural and the plantation of artificial forests." In the spontaneous wood the spreal of fire is somerhat retarded by the general humidity of the soil and of the beds of leaves which eover it. But in long droughts the superficial layer of leaves and the dry fallen branches become as intlammable as tinder, and the fire spreads with fearful rapidity, until its further progress is arrested by want of material, or more rarely, by heavy rains, sometimes caused, as many meteorologists suppose, by the conflagration itself.

In the artificial forest the annual removal of fallen or halfdried trees and the leaves and other droppings of the wood, though otherwise a very injurious practice, much diminishes the rapid spread of fires; and the absence of combustible underwood and the greater distance between the trees are additional safeguards. But, on the other haud, the comparative dryness of the

* The disappearance of the forests of ancient Gaul and of mediæval France has been ascribed by some writers as much to accidental fires as to the felling of the trees. All the treatises on sylviculture are full of narratives of forest fires. The woods of Corsica and Sardinia have suffered incalculable injury from this cause, and notwithstanding the resistance of the cork-tree to injury from common fires, the government forests of this valuable tree in Algeria have been lately often set on fire by the natives and have sustained immense damage.

See an article by Ysabeau in the Annales Forestiires, t. iii., p. 439 ; DeLLA Marmora, Foyage en Sardaigne, 2 d edition, t. i., p. 426 ; Rivista Forestale del Regno d'Italia, October, 1865, p. 474.

Five or six years ago I saw in Switzerland a considerable forest, chiefly of young trees, which had recently been burnt over. I was told that the poor of the commune had long enjoyed a customary privilege of carrying off dead wood and windfalls, and that they had set the forest on fire to kill the trees and so increase the supply of their lawful plunder. According to the Italia, ii., p. 193, the Italian Government claims, in some of the Southern provinces, all forest products as its exclusive right, though not claiming the soil. The peasintry set fire to the woods and destroy them in order to get possession of the ground they cover.

The customary rights of herdsmen, shepherds and peasants in European forests are often an insuperable obstacle to the success of attempts to preserve the woods or to improve their condition. See, on this subject, Alfred. Muorr, Les anciens Forêts de la Gaule, chap. xxix. 
soil, and of any leaves or twigs which may remain upon it, and the greater facility for the passage of wind-currents through a regularly planted and more open wood, are circumstances unfavorable to the security of the trees against this formidable danger. The natural forest, unless isolated and of small extent, can be protected from fire only by a vigilance too costly to be systematically practiced. But the artificial wood may be secured by a network of ditches and of paths or occasional open glades, which both check the rumming of the fire and furnish the means of approaching and combating it.*

The experience of 1871 ought not to be wholly without value as a lesson. It is not possible to estimate the damage by forest fires in that disastrous year, in what were lately the Northwestern States, and in Canada, but as the demand for lumber, and consequently its market price, are rising in a geometrical ratio at a rate higher than the interest on capital, one may almost say it is probable that ten years hence those fires will be thought to have diminished the national wealth by a larger amount than even the terrible conflagration at Chicago. $\dagger$

There is no good reason why insurance companies should not guarantee the proprietor of a wood as well as the owner of a house against damage by fire. In Europe there is no cunceivable liability to pecuniary loss which may not be insured against. The American companies might at first be embarrassed in estimating the risk, but the experience of a few years would suggest safe principles, and all parties would find advantage in this extension of security.

\section{Forest Legislation.}

I have alleged sufficient reasons for believing that a desolation, like that which has overwhelmed many once beautiful and fertile

* It is stated that in the pine woods of the Landes of Gascony a fire has never been known to cross a railway-track or a common road. See Des Incendies, etc., dans la Region des Maures in the Remee des Eaux et Forêts for February, 1869. Many other important articles on this subject will be found in other numbers of the same very valuable periodical.

+ The forest fires of 1881, in our Western States, were destructive almost beyond precedent, the damage being estimated by some as even greater than in 1871 . 
regions of Europe, awaits an important part of the territory of the United States, and of other comparatively new countries orer which European civilization is now extending its sway, unless prompt measures are taken to check the action of destructive causes already in operation. It is almost in vain to expect that mere restrictive legislation can do anything effectual to arrest the progress of the evil in those countries, except so far as the state is still the proprietor of extensive forests. Woodlands which lave passed into private hands will everywhere be managed, in spite of legal restrictions, upon the same economical principles as other possessions, and every proprietur will, as a general rule, fell his woods, unless he believes that it will be for his pecuniary interest to preserve them. Few of the new provinces which the last three centuries have brought under the control of the European race, would tolerate any interference by the law-making power with what they regard as the most sacred of civil rightsthe right, namely, of every man to do what he will with his own. In the Old World, even in France, whose people, of all Europeau nations, love best to be governed and are least annoyed by bureaucratic supervision, law has been found impotent to prevent the destruction, or wasteful economy, of private forests; and in many of the mountainous departments of that country, man is at this moment so fast laying waste the face of the earth, that the most serious fears are entertained, not only of the depopulation of those districts, but of enormous mischiefs to the provinces contiguous to them.* The only legal provisions from which

* "The laws against clearing have never been able to prevent these operations when the proprietor found his advantage in them, and the long series of royal ordinances and decrees of parliaments, proclaimed from the days of Charlemagne to our own, with a view of securing forest property against the improvidence of its owners, have served only to show the impotence of legislative action on this subject."-Clavé, Études sur l'Économie Forestière, p. 32.

"A proprietor can always contrive to clear his woods, whatever may be done to prevent him; it is a mere question of time, and a few imprudent cuttings, a few abuses of the right of pasturage, suffice to destroy a forest in spite of all regulations to the contrary."-Dunoren, De la Liberté du Tracail, ii., p. 452 , as quoted by Clavé, p. 353 .

Both authors agree that the preservation of the forests in France is practicable only by their transfer to the state, which alone can protect them and secure their proper treatment. It is much to be feared that even this measure would be inadequate to preserve the forests of the American Union. There is little respect for public property in America, and the Federal Government, 
anything is to be hoped, are such as shall make it a matter of private advantage to the landholder to spare the trees upon his grounds, and promote the growth of the young wood. Much may be done by exempting standing forests from taxation, and by imposing taxes on wood felled for fuel or for timber, something by more stringent provisions against trespasses on forest property, and something by premiums or honorary distinctions for judicious management of the woods; and, in short, in this matter rewards rather than punishments must be the incentives to obedience even to a policy of enlightened self-interest. It might be difficult to induce governments, general or local, to make the necessary appropriations for such purposes, but there can be no doubt that it would be sound economy in the end.

In countries where there exist municipalities endowed with an intelligent public spirit, the purchase and control of forests by such corporations would often prove advantageous; and in some of the provinces of Northern Lombardy, experience has shown that such operations may be conducted with great benefit to all the interests connected with the proper management of the woods. In Switzerland, on the other hand, except in some few cases where woods have been preserved as a defence against avalanches, the forests of the communes have been of little advantage to the public interests, and have very generally gone to decay.* The rights of pasturage, everywhere destructive to trees, combined with toleration of trespasses, have so reduced their value, that there is, too often, nothing left that is worth protecting. In the canton of Ticino, the peasants have very frequently voted to sell the town-woods and divide the proceeds among the corporators. The sometimes considerable sums thus received are squandered in wild revelry, and the sacrifice of the forests brings not even a momentary benefit to the proprietors. $\dagger$

certainly, would not be the proper agent of the nation for this purpose. It proved itself unable to protect the live-oak woods of Florida, which were intended to be preserved for the use of the navy, and it more than once paid contractors a high price for timber stolen from its own forests. The authorities of the individual States might be more efficient.

* A better economy has been of late introduced into the management of the forest in Switzerland. Excellent official reports on the subject have been pub lished, and important legal provisions adopted.

† See in Berlepsci, Die Alpen, chapter Holzschläger und Flösser, a lively account of the sale of a communal wood. 
Fortunately for the immense economical and sanitary interests involved in this branch of rural and industrial husbandry, public opinion in many parts of the United States is thoroughly rousced to the innportance of the subject. In the Eastern States, plantations of a certain extent have been made, and a wiser system is pursued in the treatment of the remaining native woods.* Im. portant experiments have been tried in Massachusetts on the propagation of forest-trees on seashore bluff's exposed to strong winds. This had been generally supposed to be impossille, but the experiments in question afford a gratifying proof that this is an erroneous opinion. Piper gives an interesting account of Mrr. Tudor's success in planting trees on the bleak and barren shore of Nahant. " Mrr. Tudor," observes he, "has planted more than ten thousand trees at Nahant, and, by the results of his experiments, has fully demonstrated that trees, properly cared for in the beginning, may be made to grow up to the very bounds of the ocean, exposed to the biting of the wind and the spray of the sea. The only shelter they require is, at first, some interruption to break the current of the wind, such as fences, houses, or other trees." +

Young trees protected against the wind by a fence mill somewhat overtop their shelter, and every tree will serve as a screen to a taller one behind it. Extensive groves have thus been formed in situations where an isolated tree would not grow at all.

The people of the Far West have thrown themselves into the work, we can not say of restoration, but rather of creation, of woodland, with much of the passionate energy which marks their action in reference to other modes of physical improvement. California has appointed a State Forester with a liberal salary, and made such legal provisions and appropriations as to render the discharge of his duties effectual. The hands that built the Pacific Railroad at the rate of miles in a day, are now busy in planting belts of trees to shelter the track from snow-drifts, and

* When the census of 1860 was taken, the States of Maine and New York produced and exported lumber in abundance. Neither of them now has timber enough for domestic use, and they are both compelled to draw much of their supply from Canada and the West.

+ Trees of America, p. 10 
to supply, at a future day, timber for ties and fuel for the locomotives. The settlers on the open plains, too, are not less actively engaged in the propagation of the woods, and if we can put faith in the official statistics on the subject, not thousands but millions of trees are annually planted on the prairies.

These experiments are of much scientific as well as economical interest. The prairies have never been wooded, so far as we know their history, and it has been contended that successful sylviculture would be impracticable in those regions from the want of rain But we are aequainted with no soil and climate which favor the production of herbage and forbid the rearing of trees, and, as Bryant well observes, "it seems certain that where grass will grow trees may be made to grow also." * It is true that

* The origin of our Western treeless prairies and plains, as of the Russian steppes, which much resemble them, is obscure, but the want of forests upon them seems to be due to climatic conditions and especially to a want of spring and summer rains, which prevents the spontaneous formation of forests upon them, though not necessarily the growth of trees artificially planted and cared for. Climatic conditions more or less resembling those of our Western territories produce analogous effects in India. Much valuable information on the relations between climate and forest vegetation will be found in an article by Dr. Brandis, On the Distribution of Forests in India, in Ocean Highuays for October, 1872.

In the more eastwardly prairie region, fires have done much to prevent the spread of the native groves, and throughout the whole woodless plains the pasturage of the buffalo alone would suflice to prevent a forest growth. The prairies were the proper feeding-grounds of the bison, and the vast number of those animals is connected, as cause or consequence, with the existence of these vast pastures. The bison, indeed, could not convert the forest into a pasture, but he would do much to prevent the pasture from becoming a forest.

There is positive evidence that some of the American tribes possessed large herds of domesticated bisons. See Humbold, Ansichten der Natur, i., pp. 71-73. What authorizes us to affirm that this was simply the wild bison reclaimed, and why may we not, with equal probability, believe that the migratory prairie-buffalo is the progeny of the domestic animal run wild?

There are, both on the prairies, as in Wisconsin, and in deep forests, as in Ohio, extensive remains of a primitive people, who must have been more numerous and more advanced in art than the present Indian tribes. There can be no doubt that the woods where such earthworks are found in Ohio were cleared by them, and that the vicinity of these fortresses or temples was inhabited by a large population. Nothing forbids the supposition that the prairies were cleared by the same or a similar people, and that the growth of trees upon them has been prevented by fires and grazing, while the restoration of the woods in Ohio may be due to the abandonment of that region by its 
Prof. J. D. Whitney, in two very important articles, entitled "Plain, Prairie and Forest," in the American Naturatist for October and November, 1576, expresses the belief that the origin of the treeless prairies is not dependent on climate, but on the character of the soil and of the geological formations from which it has been derived. The absence of forests, he thinks, is connected with "extreme fineness of soil," expecially if of a silicions character, and his opinions on this point appear to be contirmed by recent observations in Ceylon. I can not, however, adopt

original inhabitunts. The climatic conditions unfavorable to the spontaneous growth of trees on the prairies may possibly be an effect of too extensive clearings, rather than a cause of the want of woods.

It is disputed whether the steppes of Russia were ever wooded. They were certainly bare of forest growth at a very remote period; for Herodotus describes the country of the Scythians between the Ister and the Tanais as woodless, with the exception of the small province of Xyliea between the Dnieper and the Gulf of Perckop. They are known to have been occupied by a large nomade and pastoral population down to the sixteenth century, though these tribes are now much reduced in numbers. The habits of such races are scarcely less destructive to the forest than those of civilized life. Pastoral tribes do not employ much wood for fuel or for construction, but they carelessly or recklessly burn down the forests, and their cattle effectually check the growth of young trees wherever their range extends. Hommaire de Hell informs us that the Taurida was abundantly wooded when it passed into the hands of the Russians in 1774. The Russian peasants soon completely stripped the soil of its forests.

At present, the furious winds which sweep over the plains, the droughts of summer, and the rights and abuses of pasturage, constitute very formidable obstacles to the employment of measures which have been attended with so valuable results on the sand-wastes of France and Germany. The Russian Government has, however, attempted the wooding of the steppes, and there are thriving plantations in the neighborhood of Odessa, where the soil is of a particularly loose and sandy character. The tree best suited to this locality, and, as there is good reason to suppose, to sand plains in general, is the Ailenthus glandulosa, or Japan varnish-tree. The remarkable success which has crowned the experiments with the ailanthus at Odessa will, no doubt, stimulate to similar trials elsewhere, and it seems not improbable that the arundo and the maritime pine, which have fixed so many thousand acres of drifting sands in Western Europe, will be, partially at least, superseded by the tamarisk and the varnish-tree.

According to Homenstein, Der Wald, pp. 228, 229, an extensive plantation of pines-a tree new to Southern Russia-was commenced in 1812, on the barren and sandy banks of the Ingula, near Elisabethgrod, and has met with very flattering success. Other experiments in sylviculture at different points on the steppes promise valuable results. 
Prof. Whitney's discouraging views as to the propagation of arti ficial forests on the prairies. It is extravagant, doubtless, to suppose that prairies only require to be "let alone," in order to cover themselves spontaneously and speedily with woods. True, forests are not found on the natural prairie, but so neither are turnips, beets or carrots, and the want of the one no more proves the unfitness of the soil to produce them, than does the absence of the others prove that they can not be cultivated on that soil. Natural groves occur at many points on the prairies, and foresttrees have been successfully and extensively planted on them. Of course trees while young may require a different treatment from that suitable for them in other regions, but an artificial forest is everywhere the product of cultivation. As Cooper says, we can not assume "that any plant will not grow anywhere until it has been tried," - tried, that is, by judicious and persevering experiment. Nothing is to be inferred from the failure of hasty and careless trials, and I see no reason to doubt that, with proper care, trees will thrive on these plains as well as elsewhere. In any case the question will now he subjected to a practical test, and the plantations are so extensive, and, as is reported, so thrifty in growth, that one generation will suffice to determine with certainty and precision how far climate is affected by clothing with wood a vast territory naturally destitute of that protection.

I have thus far spoken only of the preservation and training of existing woods, not of the planting of new forests, because European experience, to which alone we can appeal, is convers. ant only with conditions so different from those of our own climate, soil and arboreal vegetation, that precedents drawn from it can not be relied upon as entirely safe rules for our guidance in that branch of rural economy.*

I apprehend that one rule, which is certainly alike applicable to both sides of the Atlantic-that, namely, of the absolute exclusion of domestic quadrupeds from all woods, old or young, not destined for the axe-would be least likely to be observed in our practice. The need of shade for cattle, and our inveterate habits in this respect, are much more serious obstacles

* Many valuable suggestions on this subject will be found in BryaNT, Forest Trees, chap. vi. et seq. 
to compliance with this precept than any inherent diffieulty in the thing itself ; for there is no good reason why our cattle may not be kept out of our woods as well as out of our wheat-fields. When forest-planting is earnestly and perseveringly practiced, means of overcoming this difficulty will be found, and our husbandry will be modified to meet the exigency.

The best general advice that can be offered, in the want of an experimental code, is to make every plantation consist of a great vitriety of trees, and this not only because nature favors a diversified forest-crop, but because the chances of success among a multitude of species are fir greater than if we confine ourselves to one or two.

It will doubtless be found that in our scorching summer, especially on bare plains, shade for young plants is even more necessary than in most parts of Europe, and hence a fair proportion of rapidly growing trees and shrubs, even if themselves of little intrinsic value, ought to be regarded as an indispensable feature in every young plantation. These trees should be of species which bear a full supply of air and light, and therefore, in the order of nature, precede those which are of greater value for the permanent wood; and it would be a prudent measure to seed the ground with a stock of such plants, a year or two before sowing or transplanting the more valuable varieties.

More specific rules than these can not at present well be given, but very brief experiments, even if not in all respects wisely conducted, will suffice to determine the main question: whether in a given locality this or that particular tree can advantageously be propagated or introduced. The special processes of arboriculture suited to the ends of the planter may be gathered partly from cautious imitation of European practice, and partly from an experience which, though not pronouncing definitively in a single season, will, nevertheless, suggest appropriate methods of planting and training the wood within a period not disproportioned to the importance of the object.*

The growth of arboreal vegetation is comparatively slow, and

* For rery judicious suggestions on experiments in sylviculture, see the Rev. Frederick Starr's remarkable paper on the American Forests in the Transao tions of the Agricultural Society for - 
we are often told that, though he who buries an acorn may hope to see it shoot up to a miniature resemblance of the majestic tree which shall shade his remote descendants, yet the longest life hardly embraces the seed-time and the harvest of a forest. The planter of a wood, it is said, must be actuated by higher motives than those of an investment, the profits of which consist in direct pecuniary gain to himself, or even to his posterity; for if, in rare cases, an artificial forest may, in a generation or two, more than repay its original cost, still, in general, the value of its timber will not return the capital expended and the interest accrued.*

But the modern improved methods of sylviculture show vastly more favorable financial results; and when we consider the immense collateral advantages derived from the presence of the forest, the terrible evils necessarily resulting from its destruction, we can not but admit that the preservation of existing woods, and the

* According to Clavé (Études, p. 159), the net revenue from the forests of the state in France, making no allowance for interest on the capital represented by the forest, is two dollars per acre. In Saxony it is about the same, though the cost of administration is twice as much as in Frawce; in Würtemberg it is about a dollar an acre; and in Prussia, where half the income is consumed in the expenses of administration, it sinks to less than half a dollar. This low rate in Prussia and other German states is partly explained by the fact that a considerable proportion of the annual product of the wood is either conceded to persons claiming prescriptive rights, or sold, at a very small price, to the poor. Taking into account the capital invested in forest-land, and adding interest upon it, Pressler calculates that a pine wood, managed with a view to felling it when eighty years old, would yield one-eighth of one per cent. annual profit; a fir wood, at one hundred years, one-sixth of one per cent.; a beech wood, at one hundred and twenty years, one-fourth of one per cent. The same author gives the net income of the New Forest in England, over and above expenses, interest not computed, at twenty-five cents per acre only. In America, where no expense is bestowed upon the woods, the value of the annual growth has generally been estimated much higher.

According to the tables in Capt. Walker's Reports on Forest Management, the annual "yield" of productive forests in Germany is from 20 to 84 cubic feet to the acre.

Forest-trees are often planted in Europe for what may be called an early crop. Thus in Germany acorns are sown and the younger seedlings cultivated like ordinary field-vegetables, and cut at the age of a very few years for the sake of the bark and the young twigs used by tanners. In England, trees are grown at the rate of two thousand to the acre, and cut for props in the mines at the diameter of a few inches. Plantations for hoop-poles, and other special purposes requiring small timber, would, no doubt, often prove highly remunerative. 
more costly extension and creation of them where they have been unduly reduced or have never existed, are among the plainest dictates of self-interest and most obvious of the duties which this age owes to those that are to come after it.

\section{Financial Results of Forest Plantation.}

Upon the whole, I am persuaded that the financial statisties which are found in French and German authors as the results of European experience in forest econony, present the question under a too unfavorable aspect; and therefore these calculations ought not to discourigge landed proprietors from making experiments on this subject. These statisties apply to woods whose present condition is, in an eninent degree, the effect of previous long-continued mismanagement; and there is much reason to believe that in the propitious climate of the United States new plantations, regulated substantially according to the methods of De Courval, Chambrelent, and Chevandier, and accompanied with the introduction of exotic trees, as, for example, the Australian casuarina and eucalyptus

*Although the cucalyptus thrives admirably in Algeria-where it attains a height of from fifty to sixty feet, and a diameter of fifteen or sisteen inches, in six years from the seed-and in some restricted localities in Southern Europe, it can not be expected to flourish in any part of the Lnited States except the extreme South and California. The writer of a somewhat enthusiastic article on this latter State, in Hurper's Monthly for July, 18\%2, affirms that he saw a eucalyptus " eight years from a small cutting, which was seventy-five feet in height, and two feet and a half in diameter at the base." On the cultivation of the eucalyptus, see LAMBErt, Eucalyptus Culture, etc., Puris, 1873. The growth of the eucalyptus in Italy, though rapid, is far less so than in Algeria and in California. It hardly flourishes at all north of the Apennines, being very frequently winter-killed. At Intra, however, on Lago Maggiore, which enjoys an exceptionally mild winter climate, Prince Trubetzkoy has established a large plantation comprising thirty or forty species of eucalyptus, which do not appear to suffer from frost. I can not learn from inquiries in respect to California, that any specific observations have been made there upon the supposed sanitary properties of this tree. On the Campagna of Rome, however, at the Abbey of the Le Fontane, where the Italian Gorernment has established a penal station for the employment of one hundred and fifty conricts in agricultural labor, plantations of eucalyptus were begun in 1869 with so favorable effects on the health of the Frati that the authorities were encouraged to extend its cultivation, and no less than twenty-five thousand eight hundred of these trees were planted there in the year 1851. Some of these trees, dating 
at least five, and, according to some, ten times more rapid than that of the oak-would prove good investments even in an eco. nomical aspect.*

There is no doubt that they would pay the expenses of their planting at no distant period, at least in every case where irrigation is possible, and in very many situations, terraces, ditches, or even horizontal furrows upon the hillsides, would answer as a substitute for more artificial irrigation. Large proprietors would receive important indirect benefits from the shelter and the moisture which forests furnish for the lands in their neighborhood, and eventually from the accumulation of vegetable mould in the woods.t The security of the investment, as in the case

back only to $18 \% 0$, have now a diameter of more than a foot. Their influence on the health of the establishment has been such that, though from 1869 to 1874 one-fourth of the frati were generally suffering from fever, and were obliged to leave the Abbey at evening in order to take refuge for the night within the walls of Rome, yet the latest report of the Superior states that the cases of fever do not at present exceed 5 to 100 of the inmates, and pernicious or congestive fevers have disappeared almost entirely.

The wood of the pauloronic, a tree which thrives in Northern Italy, is of little worth comparatively, though said to possess some very valuable qualities bosides its lightness, such as security against shrinkage, warping or splitting, and a capacity for receiving a fine polish. However this may be, this vigorous tree would serve well as a shelter for seedlings and young plants of more valuable species, and in other cases where a temporary shade is urgently needed. The young shoots, from a stem polled the previous season, almost surpass even the eucalyptus in rapidity of growth. Such a shoot from a tree not six inches in diameter, which I had an opportunity of daily observing, from the bursting out of the bud from the bark of the parent stem in April till November of the same year, acquired in that interval a diameter of between four and five inches and a height of above twenty feet.

* The economical statistics of Grigon, Arboriculture, Edinburgh, 1868, are very encouraging. In the preface to that work the author says: "Having formed several large plantations nearly forty years ago, which are still standing, in the Highlands of Scotland, I can refer to them as, after paying every expense, yielding a revenue equal to that of the finest arable land in the country, where the ground previously to these formations was not worth a shilling an acre." See also HAлтіG, Ueber den Wuchsthumsgang und Ertrag der Buche, Eiche und Fiefer, 1869, and especially Bryaxt, Furest Trees, chap. ix.

+ The fertility of newly cleared land is by no means due entirely to the accumulation of decayed vegetable matter on its surface, and to the decomposition of the mineral constituents of the soil by the gases emitted by the fallen leaves. Sachs has shown that the ronts of living plants exercise a most powerful solvent action on rocks, and hence stones are disintegrated and resolved 
of all real-estate, is a strong argument for undertaking such plantations, and a moderate amount of gorernment patronage and encouragement would be sufficient to render the creation of new forests an object of private interest as well as of public advantage, especially in a country where the necessity is so urgent and the climate so favorable as in the United States.

\section{Instability of American Life.}

All human institutions, associate arrangements, modes of life, have their characteristic imperfections. The natural, perhaps the necessary defect of ours, is their instability, their want of fixedness, not in form only, but eren in spirit. The face of physical nature in the United States shares this incessant fluctuation, and the landscape is as rariable as the habits of the population. It is time for some abatement in the restless love of change which characterizes us, and makes us almost a nomade rather than a sedentary people.* We have now felled forest enough everywhere, in many districts far too much. Let us restore this one element of material life to its normal proportions, and derise means of maintaining the permanence of its relations to the

into elements of vegetable nutrition, by the chemical agency of the forest, more rapidly than by frost, rain and other meteorological influences.

* It is rare that a middle-aged American dies in the house where he was born, or an old man even in that which he has built; and this is scarcely less true of the rural districts, where every man owns his habitation, than of the city, where the majority live in hired houses. This life of incessant flitting is unfavorable for the execution of permanent improvements of every sort, and especially of those which, like the forest, are slow in repaying any part of the capital expended in them. It requires a very generous spirit in a landholder to plant a wood on a farm he expects to sell, or which he knows will pass out of the hands of his descendants at his death. But the very fact of having berun a plantation would attach the proprietor more strongly to the soil for which he had made such a sacrifice; and the paternal acres would have a greater value in the eyes of a succeding generation, if thus improved and beatified by the labors of those from whom they were inherited. Landed property, therefore, the transfer of which is happily free from every legal impediment or restriction in the United Stites, would find, in the feelings thus prompted, a moral check against a too frequent change of omuers, and rould tend to remain long enough in one proprietor, or oue family, to admit of gradual improvements which would increase its value both to the possessor and to the state. 
fields, the meadows, and the pastures, to the rain and the dews of heaven, to the springs and rivulets with which it waters the earth. The establishment of an approximately fixed ratio between the two most broadly characterized distinctions of rural surfacewoodland and ploughland-would involve a certain persistence of character in all the branches of industry, all the occupations and habits of life, which depend upon or are immediately connected with either, without implying a rigidity that should exclude flexibility of accommodation to the many changes of external circumstance which human wisdom can neither prevent nor foresee, and would thus help us to become, more emphatically, a well-ordered and stable commonwealth, and, not less conspicu. ously, a people of progress. 


\title{
CHAPTER IV.
}

\author{
THE WATERS.
}

Land Artificially won from the Waters-Great Works of Material Improve. ment-Draining of Lincolnshire Fens-Incursions of the Sea in the Netherlands-Origin of Sea-dikes-Gain and Loss of Land in the Netherlands-Marine Deposits on the Coast of Netherlands-Draining of Iake of Haarlem-Draining of the Zuiderzee-Geographical Eflects of Improvements in the Netherlands-Ancient IIydraulic Works-Draining of Lake Celano by Priuce Torlonia-Incidental Consequences of draining Lakes-Draining of Marshes - Agricultural Draining-Meteorological Effects of Draining-Geographical Effects of Draining-Geographical Effects of Aqueducts and Canals-Antiquity of Irrigation-Irrigation in Palestine, India and Egypt-Irrigation in Europe-Meteorological Effects of Irrigation-Water withdrawn from Rivers for Irrigation-Injurious Effects of Rice-culture-Salts Deposited by Water of Irrigation-Subter. ranean Waters-Artesian Wells - Artificial Springs - Economizing Pre. cipitation-Inundations in France-Basins of Reception-Dirersion of Rivers-Glacier Lakes-River Embankments-Other Remedies against Inundations-Dikes of the Nile-Deposits of Tuscan Rivers-Improvements in Tuscan Maremma-Improvements in Val di Chiani-Coast of the Netherlands.

\section{Land artificially won from the Waters.}

MLAN, as we have seen, has done much to revolutionize the solid surface of the globe, and to change the distribution and proportions, if not the essential character, of the organisms which inhabit the land and even the waters. Besides the influence thus exerted upon the life which peoples the sea, his action upon the land has invoived a certain amount of indirect encroachment upon the territorial jurisdiction of the ocean. So far as he has increased the erosion of running waters by the destruction of the forest or by other operations which lessen the cohesion of the soil, he has promoted the deposit of solid matter in the sea, thus reducing the depth of marine estuaries, advancing the coast-line, and diminishing the area covered by the waters. He has gone. 
beyond this, and invaded the realm of the ocean by constructing within its borders wharves, piers, light-houses, breakwaters, fortresses, and other facilities for his commercial and military operations; and in some countries he has permanently rescued from tidal overflow, and even from the very bed of the deep, tracts of ground extensive enongh to constitute valuable additions to his agricultural domain. The quantity of soil gained from the sea by these different modes of acquisition is, indeed, too inconsiderable to form an appreciable element in the comparison of the general proportion between the two great forms of terrestrial surface, land and water; but the results of such operations, considered in their plyysical and their moral bearings, are sufficiently important to entitle them to special notice in every comprehensive view of the relations between man and nature.

There are cases, as on the western shores of the Baltic, where, in consequence of the secular elevation of the coast, the sea appears to be retiring; others, where, from the slow sinking of the land, it seems to be advancing. These movements depend upon geological causes wholly out of our reach, and man can neither advance nor retard them.*

* It is possible that the weight of the sediment let fall at the mouths of great rivers, like the Ganges, the Mississippi, and the Po, may cause the compression and consequently the depression of the strata on which they are deposited, and hence if man promotes the erosion and transport of earthy material by rivers, he augments the weight of the sediment they convey into their estuaries, and therefore his action tends to accelerate such depression. There are, however, cases where, in spite of great deposits of sediment by rivers, the coast is rising. Further, the manifestation of the internal heat of the earth at any given point is conditioned by the thickness of the crust at such point. The deposits of rivers tend to augment that thickness at their estuaries. The sediment of slowly-flowing rivers, emptying into shallow seas, is spread over so great a surface that we can hardly imagine the foot or two of slime they let fall over a wide area, in a century, to form an element amoug even the infinitesimal quantities which compose the terms of the equations of nature. But some swift rivers, rolling mountains of fine earth, discharge themselves into deeply scooped gulfs or bays, aud in such cases the deposit amounts, in the course of a few years, to a mass the transfer of which from the surface of a large basin, and its accumulation at a single point, may be supposed to produce other effects than those measurable by the sounding-line. Now, almost all the operations of rural life, as I have abundantly shown, increase the liability of the soil to erosion by water. Hence, the clearing of the valley of the Ganges, for example, by man, must have much augmented the quantity of earth transported by that river to the sea, aud of course have 
There are also cases where similar apparent effects are produced by local oceanic eurents, by river deposit or erosion, by tidal action, or by the influence of the wind, upon the waves and the sands of the seatheach. A regular current may drift suspended earth and seaweed along a coast mntil they are caught by an eddy and finally deposited out of the reach of further disturbance, or it may scoop out the bed of the sea and undermine promontories and headlands; a powerful river, as the wind changes the direction of its flow at its outlet, may wash away shores and sand-lonks at one point to deposit their material at another; the tide or waves, stirred to unusual depths by the wind, may gradually wear down the line of coast, or they may form shoals and coast-dunes by depositing the sand they have rolled up from the bottom of the ocean. These latter modes of action are slow in producing effects sufficiently important to be noticed in general geograply, or even to be visible in the representations of coast-line laid down in ordinary maps; but they nevertheless form conspicuous features in local topography, and they are attended with consequences of great moment to the material and the moral interests of men. The forces which produce these limited results are all in a considerable degree subject to control, or rather to direction and resistance, by human power, and it is in guiding, combating and compensating them that man has achieved some of his most remarkable and most honorable conquests over nature. The triumphs in question, or what we generally call harbor and coast improvements, whether we estimate their value by the money and labor expended upon them, or by their bearing upon the in-

strengthened the effects, whatever they may be, of thickening the crust of the earth in the Bay of Bengal. In such cases, then, human action must rank among geological influences. See Stoppant, Corso di Gcologia, i., p. 268.

To the geological effects of the thickening of the earth's crust in the Bay of Bengal, are to be added those of thinning it on the highlands where the Gauges rises. The same action may, as a learned friend suggests to me, even have a cosmical influence. The great rivers of the earth, taken as a whole, transport sediment from the polar regions in an equatorial direction, and hence tend to increase the equatorial diameter, and at the same time, by their inequality of action, to a continual displacement of the centre of sravity, of the earth. The motion of the globe, and of all bodies affected by its attraction, is modified by every change of its form, and in this case we are not authorized to say that such effects are in any way compensated. 
terests of commerce and the arts of civilization, must take a very high rank among the great works of man, and they are fast assuming a magnitude greatly exceeding their former relative importance. The extension of commerce and of the military marine, and especially the introduction of vessels of increased burden and deeper draught of water, have imposed upon engineer's tasks of a character which a century ago would have been pronounced, and in fact rould have been, impracticable; but necessity has stimulated an ingenuity which has contrived means of executing them, and which gives promise of yet greater performance in time to come.

Indeed, although man, detached from the solid earth, is almost powerless to strugghle against the sea, he is fast becoming invincible by it so long as his foot is planted on the shore, or even on the bottom of the rolling ocean; and though on some battle-fields between the waters and the land he is obliged slowly to yield his ground, yet he retreats still facing the foe, and will finally be able to say to the sea, "Thus far shalt thou come and no farther, and ere shall thy proud waves be stayed!" *

\section{Great Works of Material Improvement.}

Men have ceased to admire the vain exercise of power which heaped up the great pyramid to gratify the pride of a despot with a giant sepulchre; for many great harbors, many important lines of internal communication, in the civilized world, now exhibit works which in volume and weight of material surpass the vastest remains of ancient architectural art, and demand the exercise of far greater constructive skill, and involve a much heavier pe-

\footnotetext{
* It is, nevertheless, remarkable that in the particular branch of coast engineering where great improvements are most urgently needed, comparatively little has been accomplished. I refer to the creation of artificial harbors, and of facilities for loading and discharging ships. The coast of the Mediterranean Sea is, one may almost say, harborless and even wharfless, and there are many thousands of miles of coast in rich commercial countries in Europe, where vessels can neither lie in safety for a single day, nor, even in better protected havens, ship or land their passengers or cargoes except by the help of lighters and other not less clumsy contrivances. It is strange that such enormous inconveniences are borne with so little effort to remove them, and especi. ally that breakwaters are rarely constructed by Governments except for the ibenefit of the military marine.
} 
cuniary expenditure, than would now be required for the building of the tomb of Cheops. It is computed that the great pyramirl, the solid contents of which when complete were about $8,000,000$ cubic yards, could be erected for a million of pounds sterling. 'The breakwater at Cherbourg, founded in rough water sixty feet deep, at an arerage distance of more than two miles from the shore, contains double the mass of the pyramid, and many a comparatively unimportant canal has been constructed at twice the cost which would now build that stupendous monument.

The description of works of harbor and coast improvement which have only an economical value, not a true geographical importance, does not come within the plan of the present volume, and in treating this branch of my subject, I shall confine myself to such as are designed either to gain new soil by excluding the waters from grounds which they had permanently or occasionally covered, or to resist new encroachments of the sea upon the land.*

* Some notice of great works executed by man in foreign lands, and prob. ably not generally familiar to my readers, may, however, prove not uninteresting.

The desaguadero, or canal constructed by the Viceroy Revillagigedo to prevent the inundation of the City of Jexico by the lakes in its ricinity, besides subsidiary works of great extent, has a cutting half a mile long, 1,000 feet wide, and from 150 to 200 feet deep.-Hoffurax, Encyclopcedie, art. Mexico.

The adit which drains the mines of Gwennap in Cornwall, with its branches, is thirty miles long. Those of the silver mines of Saxony are scarcely less extensive, and the Ernst-August-Stollen, or great drain of the mines of the Harz, is fifteen miles long.

The excavations for the Suez Canal were computed at $\% 5,000,000$ cubic mitres, or about $100,000,000$ cubic yards, and those of the Ganges Canal, which, with its branches, has a length of 3,000 miles, amount to nearly the same quantity.

The quarries at Maestricht have undermined a space of sixteen miles by six, or more than two American townships, and the catacombs of Rome, in part at least originally quarries, have a lineal extent of five hundred and fifty miles. The catacombs of Paris required the excavation of $13,000,000$ cubic yards of stone, or more than four times the rolume of the great pyramid.

The excarations for the MIt. Cenis tunnel, eight miles in length, wholly through solid rock, amounted to more than 900,000 cubic yards, and 16,000 , 000 of brick were employed for the lining and backing. The St. Gothard tunnel, now (1882) just completed, is a still more surprising monument of human enterprise and perseverance. For cost and other details connected with this stupendous work, see the admirable Reports published by the Swiss Gorernment during its construction.

In an article on recent internal improrements in England, in the London 


\section{Draining of Lincolnshire Fens.}

The draining of the Lincolnshire fens in England, which has converted about 400,000 acres of marsh, pool, and tide-washed flat into ploughland and pasturage, is a work, or rather series of works, of great magnitude, and it possesses much economical, and indeed no trifling geographical, importance. Its plaus and methods were, at least in part, borrowed from the example of like improvements in Holland, and it is, in difficulty and extent, inferior to works executer for the same purpose on the opposite coast of the North Sea, by Dutch, Frisic and Low German engineers. The space I can devote to such operations will be better

Quarterly Revievo for January, 1858, it is stated that in a single rock-cutting on the Liverpool and Hanchester railway, 480,000 cubic yards of stone were removed; that the earth excavated in the construction of Euglish railways up to that date amounted to a hundred and fifty million cubic yards, and that at the Round Down Cliff, near Dover, a single blast of nineteen thousand pounds of powder blew down a thousand million tons of chalk, and covered fifteen acres of land with the fragments.

In 1869, a mass of marble equal to one and a half times the cubical contents of the Duomo at Florence, or about 450,000 cubic yards, was thrown down at Carrara by one blast, and two hours after, another equal mass, which had been loosened by the explosion, fell of itself.-Zolfanelit, La Lunigiana, p. 43.

The coal yearly extracted from the mines of England averages not less than $100,000,000$ tons. The specific gravity of British coal ranges from 1.20 to 1.35, and consequently we may allow a cubic yard to the ton. If we add the earth and rock removed in order to reach the coal, we shall have a yearly amount of excavation for this one object equal to more than thirty times the volume of the pyramid of Cheops. See p. 631, post.

The amount of coal yearly raised from British mines has rapidly increased since the above paragraph was written. The quantity extracted in 1881 is reported to exceed $150,000,000$ tons.

These are wonderful achievements of human industry: but the rebuilding of Chicago within a single year after the great fire-not to speak of the extraordinary material improvements previously executed at that city-in some respects surpasses them all, and it probably involved the expenditure of a sum of muscular and of moral energy which has never before been exerted, within a like period, in the accomplishment of a single material object.

In this connection it may not be amiss to mention an extraordinary labor of a single individual which was made the subject of a public commemoration, in 1880, at Susa, in Northern Italy. Early in the sixteenth century, a humble stone-cutter, named Colombano Romeau, spent eight years, entirely unaided, in the excavation of a long tunnel, through solid rock, to supply water to two small parcels of ground. 
employed in describing the latter, and I content myself with the simple statement I have already made of the quantity of worthless, and even pestilential, land which has been rendered both productive and salubrious in Lincolnshire, by diking ont the sea and the rivers which traverse the fens of that country.

The almost continued prevalence of west winds upon both coasts of the German Ocean occasions a constant set of the currents of that sea to the east, and both for this reason and on account of the greater violence of storms from the former quarter, the English shores of the North Sea are less exposed to invasion by the wares thim those of the Netherlands and the provinees contiguous to them on the north. The old Netherlandish chronicles are filled with the most startling accounts of the damage done by the irruptions of the ocean, from west winds or extraordinarily high tides, at times long before any considerable extent of sea-coast was diked. Several hundreds of these terrible inmdations are recorded, and in many of them the loss of human lives is estimated as high as one hundred thousand. It is impossible to doubt that there must be enormous exaggeration in these numbers; for, with all the reckless hardihood shown by men in braving the dangers and privations attached by nature to their birthplace, it is inconceivable that so dense a population as such wholesale destruction of life supposes could find the means of subsistence, or content itself to dwell, on a territory liable a dozen times in a century to such fearful devastation. There can be no doubt, however, that the low continental shores of the German Ocean very frequently suffered immense injury from inumdation by the sea, and it is natural, therefore, that the various arts of resistance to the encroachments of the ocean, and, finally, of aggressive warfare upon its domain and of permanent conquest of its territory, should have been earlier studied and carried to higher perfection in the latter countries, than in England, which had less to lose or to gain by the incursion or the retreat of the waters.

Indeed, although the confinement of swelling rivers by artificial embankments is of great antiquity, I do not know that the defence or acquisition of land from the sea by diking was ever practioed on a large scale, until systematically undertaken by the Netherlanders a few centuries after the commencement of the 
Christian era. The silence of the Roman historians affords a strong presumption that this art was unknown to the inhabitants of the Netherlands at the time of the Roman invasion, and the elder Pliny's description of the mode of life along the coast which has now been long diked in, applies precisely to the habits of the peopl. who live on the low islands and mainland flats lying ontside of the chain of dikes, and wholly unprotected by embankments of any sort.

\section{Origin of Sea-dikes.}

It has been conjecturer, and not without probability, that the causeways built by the Romans across the marshes of the Low Countries, in their campaigns against the Germanic tribes, gave the natives the first hint of the utility which might be derived from similar constructions applied to a different purpose.* If this is so, it is one of the most interesting among the many instances in which the arts and enginery of war have been so modified as to be eminently promotive of the blessings of peace, thereby in some measure compensating the wrongs and sufferings they have inflicted on hmmanity. ${ }^{\prime}$ The Lowlanders are believed to have secured some coast and bay islands by ring-dikes, and to

* It has often been alleged by eminent writers that a part of the fens in Lincolnshire was reclaimed by sea-dikes under the govermment of the Romans. I have found no ancient authority in support of this assertion, nor can I refer to any passige in Roman literature in which sea-dikes are expressly mentioned otherwise than as walls or piers, except that in Pliny (Hist. Nat., xxxvi. 24), where it is said that the Tyrrhenian Sea was excluded from the Lucrine Lake by dikes. Dugdale, whose enthusiasm for his subject led him to believe that recovering from the sea land subject to be flooded by it, was of divine appointment, because God said: "Let the waters under the heaven be gathered together unto one place and let the dry land appear," unhesitatingly ascribes the reclamation of the Lincolnshire fens to the Romans, though he is able to cite but one authority, a passage in Tacitus's Life of $\mathrm{Agricola}$, which certainly has no such meaning, in support of the assertion.-History of Embankment and Drainage, 2 d edition, 1772.

$+\mathrm{It}$ is worth mentioning, as an illustration of the applicability of military instrumentalities to pacific art, that the sale of gunpowder in the United States was smaller during the late rebellion than before, because the war caused the suspension of many public and private improvements, in the execution of which great quantities of powder were used for blasting.

The same observation was made in France during the Crimean war, and it 
have embanked some fresh-water channels, as early as the eightith or ninth century; but it does not appear that sea-dikes, importint enough to be noticed in historical records, were coustructed on the mainland before the thirteenth century. The practice of draining inland acemmulations of water, whether fresh or salt, for the purpose of bringing under cultivation the ground they cover, is of later origin, and is said not to have been adopted until after the middle of the fifteenth century.*

\section{Gain and Loss of Land in the Netherlands.}

The total amount of surface gained to the agriculture of the Netherlands by diking out the sea and by draining shallow bays

is alleged that, in general, not ten per cent. of the powder manufactured on either side of the Atlantic is employed for military purposes.

The blasting for the Mount Cenis tunnel consumed gunpowder enough to fill more than $200,000,000$ musket cartridges.

It is a fact not creditable to the moral sense of modern civilization, that very mary of the most important improvements in machinery and the working of metals have originated in the necessities of war, and that man's highest ingenuity has been shown, and many of his most remarkable triumphs over natural forces achieved, in the contrivance of engines for the destruction of his fellowman. The military miterial employed by the first Napoleon has become, in less than three generations, nearly as obsolete as the sling and stone of the shepherd, and attack and defence now begin at distances to which, half a century ago, military reconnoissances hardly extended. Upon a partial view of the subject, the human race seems destined to become its own executioner-on the one hand, exbausting the capacity of the earth to furnish sustenance to her taskmaster; on the other, compensating diminished production by inventing more efficient methods of exterminating the consumer. At the present mo. ment, at an epoch of universal peace, the whole civilized world, with the happy exception of our own country, is devoting its utmost energies, applying the highest exercise of inventive genius, to the production of new engines of war ; and the consumption of iron and copper in the fabrication of arms and of armed and armored vessels, has caused at least a temporary rise in the ralue of those metals in Europe. The simple substitution of sheet-copper for paper and other materials in the manufacture of cartridges has increased the market price of copper by a large percentage on its former cost.

But war develops great civil virtues, and brings into action a degree and kind of physical energy which seldom fails to awaken a new intellectual life in a people that achieves great moril and political results through great heroism and endurance and perseverance. Domestic corruption has destroyed more nations than foreign invasion, and a people is rarely conquered till it has deserved subjugation.

* Starivg, Voormaals en Thans, p. 150. 
and lakes, is estimated by Staring at three hundred and fifty-five thousand bunder or hectires, equal to eight hundred and seventyseven thousand two huudred and forty acres, which is one-tenth of the area of the kingdom.* In rery many instances the dikes have been partially, in some particularly exposed localities totally, destroyed by the violence of the sea, and the drained lands again flooded. In some cases the soil thus painfully won from the ocean has been entirely lost; in others it has been recovered by repairing or rebuilding the dikes and pumping out the water. Besides this, the weight of the dikes gradually sinks them into the soft soil beneath, and this loss of elevation must be compensated by raising the surface, while the increased burden thus added tends to sink them still lower. "Tetens declares," says Kohl, "that in somes places the dikes have gradually sumk to the depth of sixty or even a hundred feet." $\dagger$ For these reasons, the processes of dike-building have been almost everywhere again and again repeated, and thus the total expenditure of money and of labor, upon the works in question, is much greater than would appear from an estimate of the actual cost of diking-in a given extent of coastland and draining a given area of water-surface. $\neq$

* Staring, Toormaals en Thans, p. 163. Much the largest proportion of the lands so reclaimed, though for the most part lying above low-water tidemark, is at a lower level than the Lincolnshire fens, and more subject to inundation from the irruptions of the sea.

+Die Inseln und Marschen der Herzogthümer Schlescig und Holstein, iii., p. 151.

$\ddagger$ The purely agricultural island of Pelworm, off the coast of Schleswig, containing about 10,000 acres, annually expends for the maintenance of its dikes not less than $\$ 6,000$ sterling, or nearly $\$ 30,000$. -J. G. KomL, Inseln und Marschen Schleswoig's und Holstein's, ii., p. 394.

The original cost of the dikes of Pelworm is not stated.

"The greatest part of the province of Zeeland is protected by dikes measuring 250 miles in length, the maintenance of which costs, in ordinary years, more than a million guilders [above $\$ 400,000]$. . . . The annual expenditure for dikes and hydraulic works in Holland is from five to seven million guilders" $[\$ 2,000,000$ to $\$ 2,800,000]$. - WILD, Die Niederlande, i., p. 62 .

One is not sorry to learn that the Spanish tyranny in the Netherlands had some compensations. The great chain of ring-dikes which surrounds a large part of Zeeland is due to the energy of Caspar de Robles, the Spanish governor of that province, who in $\mathbf{1 5 7 0}$ ordered the construction of these works at the public expense, as a substitute for the private embankments which had 


\section{Loss of Land by Incursions of Sea.}

On the other hand, by crosion of the coast-line, the drifting of sand-dunes into the interior, and the drowning of fens and morasses by incursions of the sea-ail caused, or at least greatly aggravated, by human improvidence-the Netherlands have lost a far lirger area of land since the commencement of the Christian era than they have gained by diking and draining. Staring despuirs of the possibility of calculating the loss from the first-mentioned two causes of destruction, but he estimates that not less than six hundred and forty thousand bunder, or one million fire hundred and eighty-one thousand acres, of fen and marsh have been rrashed away, or rather deprived of their vegetable surface and covered by water; and thirty-seren thousand bunder, or ninetyone thousand four hundred acres, of recovered land, have been lost by the destruction of the dikes which protected them.* The average value of land gained from the sea is estimated at about nineteen pounds sterling, or ninety dollars, per acre; while the lost fen and morass was not worth more than one twenty-fifth part of the same price. The ground buried by the drifting of the dunes appenrs to have been almost entirely of this latter character, and, rupon the whole, there is no doubt that the soil added by human industry to the territory of the Netherlands, within the historical period, greatly exceeds in pecuniary valne that which has fallen a prey to the waves and the sands during the same era.

Upon most low and shelving coasts, like those of the Netherlands, the maritime currents are constantly changing, in consequence of the variability of the winds and the shifting of the sand-banks which the currents themselves now form and now displace. While, therefore, at one point the sea is advancing landward, and requiring great effort to prevent the undermining and washing away of the dikes, it is shoaling at another by its own deposits, and exposing, at low water, a gradually midening belt of sands and ooze. The coast-lands selected for diking-in are always at points where the sea is depositing productive soil. The Eider, the Elbe, the Weser, the Ems, the Rhine, the Maas

previously partially served the same purpose-W WLD, Die Niederlande, i. p. 62 .

* Staring, Voormaals en Thans, p. 163. 
and the Schelde bring down large quantities of fine earth. The. prevalence of west winds prevents the waters from carrying this material far out from the coast, and it is at last deposited northward or southward from the mouth of the rivers which contribute it, according to the varying drift of the currents.

\section{Marine Deposits.}

The process of natural deposit which prepares the coast for diking-in is thus described by Staring: "All sea-deposited soil is composed of the same constituents. First comes a stratum of sand, with marine shells, or the shells of mollusks living in brackish water. If there be tides, and, of course, flowing and ebbing currents, mud is let fall upon the sand only after the latter has been raised above low-water mark; for then only, at the change from flood to ebb, is the water still enough to form a deposit of so light a material. Where mud is found at great depths, as, for example, in a large proportion of the $\mathrm{Ij}$, it is a proof that at this point there was never any considerable tidal flow or other current. . . . . The powerful tidal currents, flowing and ebbing twice a day, drift sand with them. They scoop out the bottom at one point, raise it at another, and the sandbanks in the current are continually shifting. As soon as a bauk raises itself above low-water mark, flags and reeds establish themselves upon it. The mechanical resistance of these plants checks the retreat of the high water and farors the deposit of the earth suspended in it, and the formation of land goes on with surprising rapidity. When it has risen to high-water level, it is soon covered with grasses, and becomes what is called schor in Zeeland, kwelder in Friesland. Such grounds are the foundation or starting-point of the process of diking. When they are once elevated to the flood-tide level, no more mud is deposited upon them except by extraordinary high tides. Their further rise is accorlingly very slow, and it is seldom advantageous to delay longer the operation of diking." *

* Toormaals en Thans, pp. 150, 151. According to Reventlov, confervos first appear at the bottom in shoal water, then, after the deposit has risen above the surface, Salicornia herbacea. The Salicornin is followed by various sand-plants, and as the ground rises, by $P o a$ distans and Poa maritima and 


\section{Sew-dikes of the Netherlands.}

The formation of new banks by the sea is constantly going on at points farorable for the deposit of sand, and earth, and hence opportunity is continually afforded for enclosure of new land ontside of that alrearly diked in, the coast is fast advancing seaward, and erery new embankment increases the security of former enclosures. The province of Zeeland consists of islands washed by the sea on their western coasts, and separated by the many channels through which the Schelde and some other rivers find their way to the ocean. In the twelfth century these islands were much smaller and more numerous than at present. They have been gradually enlarged, and at least in several instances connected, by the extension of their system of dikes. Walcheren is formed of ten islets, united into one about the end of the fourteenth century. At the middle of the fifteenth century, Goeree and Overflakkee consisted of several separate islands, containing altogether about ten thousand acres; by means of above sixty snccessive advances of the dikes, they have been connected and brought to compose a single island whose area is not less than sixty thousand acres.*

In the Netherlands-which the first Napoleon characterized as a deposit of the Rhine, and as, therefore, by natural law, rightfully the property of him who controlled the sources of that great river-and on the adjacent Frisic, Low German and Danish shores and islands, sea and river dikes have been constructed on a grander and more imposing scale than in any other country. The whole economy of the art has been there most thoroughly studied, and the literature of the subject is very extensive. For my present aim, which is concerned with results rather than with processes, it is not worth while to refer to professional treatises, and I shall content myself with presenting such information as can be gathered from works of a more popular character.

finally common grasses establish themselves.-Om Marlictunnelsen paa Festhysten af Slesvig, pp. 7, 8.

* Staring, Foormaals en Thans, p. 152. Kohl states that the peninsula of Diksand on the coast of Holstein consisted, at the close of the last century, of several islands measuring togrether less than five thousand acres. In 1837 they had been connected with each other and with the mainland, and had nearly doubled in area.-Inseln u. Marschen Schlesio. Holst., iii., p. 262. 
The superior strata of the lowlands upon and near the coast are, as we have seen, principally composed of soil brought down by the great rivers I have mentioned, and either directly deposited by them upon the sands of the bottom, or carried out to sea by their currents, and then, after a shorter or longer exposure to the chemical and mechanical action of salt-water and marine currents, restored again to the land by tidal overflow and subsidence from the waters in which it was suspended. At a very remote period the coast-flats were, at many points, raised so high by successive alluvious or tidal deposits as to be above ordinary lighwater level, but they were still liable to occasional inundation from river-floods, and from the sea-water also, when heavy or long-contiuned west winds drove it landwards. The extraordinary fertility of this soil and its security as a retreat from hostile violence attracted to it a considerable population, while its want of protection against inundation exposed it to the devastations of which the chroniclers of the Middle Ages have left such highly colored pictures. The first permanent dwellings on the coastflats were erected upon artificial mounds, and many similar precarious habitations still exist on the unwalled islands and shores beyond the chain of dikes. River embaukments, which, as is familiarly known, have from the earliest antiquity been employed in many countries where sea-dikes are unknown, were probably the first works of this character constructed in the Low Countries, and when two neighboring streams of fresh water had been embanked, the next step in the process would maturally be to connect the river-walls together by a transverse dike or raised causeway, which would serve as a means of communication between different hamlets and at the same time secure the intermediate ground both against the backwater of river-floods and against overflow by the sea. The oldest true sea-dikes described in historical records, however, are those enclosing islands in the estuaries of the great rivers, and it is not impossible that the double character they possess as a security against maritime floods and as a military rampart, led to their adoption upon those islands before similar constructions had been attempted upon the mainland.

At some points of the coast, various contrivances, such as piers, piles, and, in fact, obstructions of all sorts to the ebb of the current, are employed to facilitate the deposit of slime, before a 
regular enclosure is commenced. Usually, howerer, the first step is to build low and cheap embankments, extending from an older dike or from high ground, around the parcel of tlat intended to be secured. These are called summer dikes. They are erected when a sufficient extent of ground to repay the cost has been elevated enough to be eovered with coarse vegetation fit for pasturage. They serve both to secure the ground from overflow by the ordinary flood-tides of mild weather, and to retain the slime deposited by very high water, which would otherwise be partly carried off by the retreating ebb. The elevation of the soil goes on slowly after this; but when it has at last been sufficiently enriched, and raised high enough to justify the necessary outlay, permanent dikes are constructed by which the water is excluded at all seasons. These embankments are constructed of sand from the coast-dunes or from sand-banks, and of earth from the mainland or from flats outside the dikes, bound and strengthened by fascines, and provided with sluices, which are generally founded on piles and of very expensive construction, for drainage at low water. The outward slope of the sea-dikes is gentle, experience having shown that this form is least exposed to injury both from the waves and from floating ice, and the most modem dikes are even more moderate in the inclination of the seaward scarp than the older ones.* The crown of the dike, howerer, for the last three or four feet of its height, is much steeper, being intended rather as a protection against the spray than against the waves, and the inner slope is always comparatively abrupt.

The height and thickness of dikes vary according to the elevation of the ground they enclose, the rise of the tides, the direetion of the prevailing winds, and other special causes of exposure, but it may be said that they are, in general, raised from fifteen to twenty feet above ordinary high-water mark. The waterslopes of river-dikes are protected by plantations of willows or strong semi-aquatic shrubs or grasses, lut as these will not grow upon banks exposed to salt-water, sea-dikes must be faced with stone, fascines, or some other revetement. $\dagger$ Upon the coast of

* The inclination varies from one foot rise in four of base to one foot in fourteen.-Korr, iii., p. 210.

$\uparrow$ The dikes are sometimes founded upon piles, and sometimes protected by one or more rows of piles driven deeply down into the bed of the sea in front 
Schleswig and Holstein, where the people have less capital at their command, they defend their embankments against ice and the waves by a coating of twisted straw or reeds, which must be renewed as often as once, sometimes twice, a year. The inhabitants of these coasts call the chain of dikes "the golden border," a name it well deserves, whether we suppose it to refer to its enormous cost, or, as is more probable, to its immense value as a protection to their fields and their firesides.

When outlying flats are enclosed by building new embankments, the old interior dikes are suffered to remain, both as an additional security against the waves, and because the removal of them would be expensive. They serve, also, as roads or causeways, a purpose for which the embankments nearest the sea are seldom employed, because the whole structure might be endangered from the breaking of the turf by wheels and the hoof of horses. Where successive rows of dikes have been thus constructed, it is observed that the ground defended by the more ancient embankments is lower than that embraced within the newer enclosures, and this depression of level has been ascribed to a general subsidence of the coast from geological causes; * lut the better opinion seems to be that it is, in most cases, due merely to the consolidation and settling of the earth from being more effectually dried, from the weight of the dikes, from the tread of

of them. "Triple rows of piles of Scandinavian pine," says Wild, "have been driven down along the coast of Friesland, where there are no dunes, for a distance of one hundred and fifty miles. The pile's are bound together by strong cross-timbers and iron clamps, and the interstices filled with stones. The ground adjacent to the piling is secured with fiscines, and at exposed points heary blocks of stone are heaped up as an additional protection. The earth-dike is built behind the mighty bulwark of this breakwater, and its foot also is fortified with stones." .... "The great Helder dike is about five miles long and forty feet wide at the top, along which runs a good road. It slopes down two hundred feet into the sea, at an angle of forty degrees. The highest waves do not reach the summit, the lowest always cover its base. At certain distances, immense buttresses, of a height and width proportioned to those of the dike, and even more strongly built, run several hundred feet out into the rolling sea. This gigantic artificial coast is entirely composed of Norwegian granite."-Wrid, Die Niederlande, i., pp. 61, 62.

* A similar subsidence of the surface is observed in the diked ground of the Lincolnshire fens, where there is no reason to suspect a general depression from geological causes. 
men and cattle, and from the movement of the lieary wagnons which carry off the crops." Notwithstanding this slow sinkinger,

* The shaking of the ground, even when loaded with large buildings, by the passage of heavy carriages or artillery, or by the march of a body of cavalry or even infantry, shows that such causes may produce inportant mechanical effects on the condition of the soil. The bogs in the Netherlands, as in most other countries, contain large numbers of fallen trees, huried to at certain depth by earth and vegetable mould. When the bogs are dry enough to serve as pastures, it is observed that trunks of these ancient treces rise of themselves to the surface. Staring ascribes this singular phenomenon to the aritation of the ground by the tread of cattle. "When road-beds," observes he, "are constructed of gravel and pebbles of different sizes, and these latter are placed at the bottom without being broken and rolled hard together, they are soon brought to the top by the effect of travel on the road. Lying loosely, they undergo some motion from the passage of every wagon-wheel and the tread of every horse that passes over them. This motion is an oscillation or partial rolling, and as one side of a pebble is raised, a little fine sand or earth is forced under it, and the frequent repetition of this process by cattle or carriages moving in opposite directions brings it at last to the surface. We may suppose that a similar effect is produced on the stems of trees in the bogs by the tread of animals."-De Bodem van Nederland, i., pp. 75, 76.

It is observed in the Northern United States, that when soils containing pebbles are cleared and cultivated and the stones removed from the surface, new pebbles, and even boulders of many pounds weight, continue to show themselves above the ground, every spring, for a loug series of years. In clayey soils the fence-posts are thrown up in a similar way, and it is not uncommon to see the lower rail of a fence thus gradually raised a foot or even two feet above the ground. This rising of stones and fences is popularly ascribed to the action of the severe frosts of that climate. The expausion of the ground, in freezing, it is said, raises its surface, and, with the surface, objects lying near or connected with it. When the soil thaws in the spring, it settles back again to its former level, while the pebbles and posts are prevented from sinking as low as before by loose earth which bas fallen under them. The fact that the elevation spoken of is observed only in the spring, gives counteuance to this theory, which is perhaps applicable also to the cases stated by Staring, and it is probable that the two causes above assigned concur in producing the effect. The rising of stones to the surface of fields is observed also in Norway, and is probably due to the same cause. A contrary action is observed in England, and is ascribed by Darwin to the covering of the stones by the casts of earth-20orms.

The question of the subsidence of the Netherlandish coast has been much discussed. Not to mention earlier geologists, Venema, in several essays, and particularly in Het Dalen ran de Noordelijte Fuststreken van ons Land, 185.t, adduces many facts and arguments to prove a slow sinking of the northern provinces of IIolland. Laveleye (Afficisement du sol ct encasement des fleures survenus dans les temps 7istnriques, 1859), upon a still fuller investiration, arrives at the same conclusion. The eminent greologist Staring, however, whe 
most of the land enclosed by dikes is still above low-water mark, and can, therefore, be wholly or partially freed from rain-mater, and from that received by infiltration from higher ground, by sluices opened at the ebb of the tide. For this purpose the land is carefully ditched, and advantage is taken of every favorable occasion for discharging the water throngh the sluices. But the ground can not be effectually drained by this means, unless it is elevated four or five feet, at least, above the level of the ebb-tide, because the ditches would not otherwise have a sufficient descent to carry the water off in the short interval between ebb and flow, and because the moisture of the saturated subsoil is always rising by capillary attraction. Whenever, therefore, the soil has sunk below the level I have mentioned, and in cases where its surface has never been raised above it, pumps, worked by wind or some other mechanical porrer, must be very frequently employed to keep the land dry enough for pasturage and cultivation.*

\section{Draining of the Lake of Haarlem.}

The substitution of steam-engines for the feeble and uncertain action of windmills, in driving pumps, has much facilitated the removal of water from the polders as well as the draining of lakes, marshes and shallow bays, and thus given such an jimpulse to these enterprises, that not less than one hundred and ten thousand acres were reclaimed from the waters, and added to the

briefly refers to the subject in De Bodem van Nederland, i., p. 356 et seq., does not consider the evidence sufficient to prove any thing more than the sinking of the surface of the polders from drying and consolidation.-See EliséE Reclus, La Terre, vol. i., pp. 730, 732.

* The elevation of the lands enclosed by dikes-or polders, as such lands are called in Holland-above low-water mark, depends upon the height of the tides, or, in other words, upon the difference between ebb and flood. The tide can not deposit earth higher than it flows, and after the ground is once enclosed, the decay of the vegetables grown upon it and the addition of manures do not compensate the depression occasioned by drying and consolidation. On the coast of Zeeland and the islands of South Holland, the tides, and of course the surface of the lands deposited by them, are so high that the polders cau be drained by ditching and sluices; but at other points, as in the enclosed grounds of North Holland on the Zuiderzee, where the tide rises but three feet or even less, pumping is necessary from the beginning.-STARING, Foormaals en Thans, p. 152. 
agrienltural domain of the Netherlands, between 1815 and 18:5. The most important of these undertakings was the draining of the Lilie of Haarlem, and for this purpose some of the nost powerful hydraulic engines ever constructed were designed and executerl.: "The origin of this lake is unknown. It is supposed by some geographers to be a part of an ancient bed of the lihine, the chamnel of which, as there is good reason to believe, has undergone great changes since the Roman invasion of the Netherlands; by others it is thonght to have once formed an inland marine channel, separated from the sea by a chain of low islands, which the sand washed up by the tides has since connected with the mainland and converted into a continuous line of coast. The best authorities, however, find geological evidence that the surface occupied by the lake was originally a marshy tract containing within its limits little solid ground, but many ponds and inlets, and much floating as well as fixed fen.

In consequence of the cutting of turf for fuel, and the destruction of the few trees and shrubs which held the loose soil together with their roots, the ponds are supposed to have gradually extended themselves, until the action of the wind upon their enlarged surface gave their waves sufficient force to overcome the resistance of the feeble barriers which separated them, and to unite them all into a single lake. Popular tradition, it is true, ascribes the formation of the Lake of Haarlem to a single irruption of the sea, at a remote period, and connects it with one or another of the destructive inundations of which the Netherland chronicles describe so many; but on a map of the year 1531, a chain of four smaller waters occupies nearly the ground afterwards covered by the Lake of Haarlem, and they have most probably been united by gradual encroachments resulting from the improvident practices above referred to, though no doubt the consummation may have been hastened by floods, and by the neglect to maintain dikes or by the intentional destruction of them in the long wars of the sixteenth century.

The Lake of Haarlem was a body of water not far from fifteen miles in length, by seven in greatest width, lying between the

* The principal engine, of 500 horse-power, drove eleven pumps with a tota]. delivery of 31,000 cubic yards per hour.-WrLD, Die Nederlande, i., p. 87 
cities of Amsterdam and Leyden, running parallel with the coast of Holland at the distance of about five miles from the sea, and covering an area of about 45,000 acres. By means of the $\mathrm{Ij}$, it communicated with the Zuiderzee, the Mediterranean of the Netherlands, and its surface was little above the mean elevation of that of the sea. Whenever, therefore, the waters of the Zuiderzee were acted upon by strong northwest winds, those of the Lake of Haarlem were raised proportionally and driven southwards, while winds from the south tended to create a flow in the opposite direction. The shores of the lake were everywhere low, and though between the years 1767 and 1848 more than $\$ 1,700,000$ had been expended in checking its encroachments, it often burst its barriers, and produced destructive inundations. In November, 1836, a south wind brought its waters to the very gates of Amsterdam, and in December of the same year, in a northwest gale, they overflowed twenty thousand acres of land at the southern extremity of the lake, and flooded a part of the city of Leyden. The depth of water in the lake did not in general exceed fourteen feet, but the bottom was a semi-fluid ooze or slime, which partook of the agitation of the waves, and added considerably to their mechanical force. Serious fears were entertained that the lake would form a junction with the inland waters of the Legmeer and Mijdrecht, swallow up a vast extent of valuable soil, and finally endanger the security of a large proportion of the land which the industry of Holland had gained in the course of centuries from the ocean.

For this reason, and for the sake of the large addition the bottom of the lake would make to the cultivable soil of the state, it was resolved to drain it, and the preliminary steps for that purpose were commenced in the year 1840. The first operation was to surround the entire lake with a ring-eanal and dike, in order to cut off the communication with the $\mathrm{Ij}$, and to exclude the water of the streams and morasses which discharged themselves into it from the land side. The dike was composed of different materials, according to the means of supply at different points, such as sand from the coast-dunes, earth and turf excavated from the line of the ring-canal, and floating turf, * fascines being every.

* In England and New England, where the marshes have been already drained or are of comparatively small extent, the existence of large floating 
where used to bind and compact the mass together. 'This operiltion was completed in 1845, and three steam-pumps were then employed for fire years in discharging the water. The whole enterprise was conducted at the expense of the stat, and in 185:3

islands seems incredible, and has sometimes been treated as a fable, but no

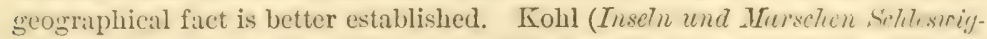
Ilolxteins, iii., p. 309 ) reminds us that Pliny mentions among the wonders of Germany the floating islands, covered with trees, which met the Roman tleets at the mouths of the Elbe and the Weser. Our author spenks also of having visited, in the territory of Bremen, floating moors, bearing not only houses but whole villages. At low stages of the water these moors rest upon a bed of sand, but are raised from six to ten feet by the high water of spring, and remain afloat until, in the course of the summer, the water beneath is exhausted by evaporation and drainage, when they sink down upon the sand again.

Staring explains, in an interesting way, the whole growth, formation and functions of floating fens or bogs, in his very valuable work, De Bodem van Nederlanc, i., pp. 36-43. The substance of his account is as follows: The first condition for the growth of the plants which compose the substance of turf and the surface of the fens, is stillness of the water. Hence they are not found in running streams, nor in pools so large as to be subject to frequent agitation by the wind. For example, not a single plant grew in the open part of the Lake of Haarlem, and fens cease to form in all pools as soon as, by the cutting of the turf for fuel or other purposes, their area is sufficiently enlarged to be much acted on by wind. When still water above a yard deep is left undisturbed, aquatic plants of various genera, such as Nuphar, Nymphra, Limnanthemum, Stratiotes, Polygonum, and Potamogeton, fill the botton with roots and cover the surface with leaves. Many of the plants die every year, and prepare at the bottom a soil fit for the growth of a higher order of vegetation, Phragmites, Acorus, Sparganium, Rumex, Lythrum, Pedicularis, Spiræa, Polystichum, Comarum, Caltha, etc., etc. In the course of twenty or thirty years the muddy bottom is filled with roots of aquatic and marsh plants, which are lighter than water, and if the depth is great enough to give room for detaching this vegetable network, a couple of yards for example, it rises to the surface, bearing with it, of course, the soil formed above it by decay of stems and leaves. New genera now appear upon the mass, such as Carex, Menyanthes, and others, and soon thickly cover it. The turf has now acquired a thickness of from two to four feet, and is called in Groningen, lad; in Friesland, til, tillanl, or drijftil; in Overijssel, drag; and in Holland, rietzod. It floats about as driven by the wind, gradually increasing in thickness by the decay of its annual crops of vegetation, and in about half a century reaches the bottom and becomes fixed. If it has not been invaded in the meantime by men or cattle, trees and arborescent plants, Alnus, Salix, Myrica, etc., appear, and these contribute to hasten the attachment of the turf to the bottom, both by their weight and by sending their roots quite through into the ground.

This is the regular method employed by nature for the gradual filling up of 
the recovered lands were offered for sale for its benefit. $\mathrm{U}_{\mathrm{p}}$ to 1858, forty-two thousand acres had been sold at not far from sixteen pounds sterling or seventy-secen dollars an acre, amounting altogether to $£ 661,000$ sterling or $\$ 3,200,000$. The unsold

shallow lakes and pools, and converting them first into morass and then into dry land. Whenever, therefore, man removes the peat or turf, he exerts an injurious geographical agency, and, as I have already said, there is no doubt that the inmense extension of the inland seas of Holland in modern times is owing to this and other human imprudences. "Hundreds of hectares of floating pastures," says our author, "which lave nothing in their appearance to distinguish them from grass-lands resting on solid bog, are found in Overijssel, in North Hollind, and near Ltrecht. In short, they occur in all deep bogs, and wherever deep water is left long undisturbed."

In one case a floating island, which had attached itself to the shore, continued to float about for a long time after it was torn off by a flood, and was solid enough to keep a pond of fresh water upon it sweet, though the water in which it was swimming had become brackish from the irruption of the sea. After the hay is cut, cattle are pastured, and occasionally root-crops grown upon these islands, and they sometimes have large trees growiug upon them.

When the turf or peat has been cut, leaving water less than a yard deep, Equisetum limosum grows at once, and is followed by the second class of marsh plants mentioned above. Their roots do not become detached from the bottom in such shallow water, but form ordinary turf or peat. These processes are so rapid that a thickness of from three to six feet of turf is formed in half a century, and many men have lived to mow grass where they had fished in their boyhood, and to cut turf twice in the same spot. In Ireland the growth of peat is said to be much more rapid. EliséE REClus, La Terre, i., 591, 592. But see AsbJönnsen, Torv og Torvdrift, ii., 29, 30. See Nature, Sept. 26, 1878, where it is stated, in an article on the Superficial Geology of S. W. Lancashire, that the turf-moss, in a certain peat-tract in Somersetshire, is growing at the rate of from four to six feet in fifteen years, so that the places where the peat is cut are filled up in that time.

Captain Gilliss says that before Lake Taguataga in Chili was drained, there were in it islands composed of dead plants matted together to a thickness of from four to six feet, and with trees of medium size growing upon them. These islands floated before the wind "with their trees and browsing cattle." - United States Naval Astronomical Expedition to the Southorn Hemisphere, i., pp. $16,17$.

Col. Yule, in his Mission to the Court of Ava, speaking of a lake in Burmah, says: "The surface of this lake presents the singular spectacle of a multitude of floating islands. They are composed of the interlaced roots of a coarse grass or reed, loaded with a little soil. The roots of the grass shoot down to the bottom of the lake in dry weather, but in the rains many of these entangled masses are buoyed up and separated from the ground, so as to be quite afloat. The inhabitants often occupy them as fishing stations, or even erect their cottages on them, anchoring the islands to the bottom by long bamboos. They 
lands were valued at more than $£ 6,000$ or nearly $\$ 30,000$, and as the total cost was $£ 764,500$ or about $\$ 3,700,000$, the direct los to the state, exclusive of interest on the capital expended, may be set at $£ 100,000$ or something less that $\$ 500,000$.

The suecess of this operation has encouraged others of like uature in Holland. The Zuid Plas, which covered 11,500 acres and was two feet deeper than the Lake of Haarlem, has been drained, and a similar work now in course of execution on an ar'm of the Schelde, will recover about 35,000 acres.

In a country like the United States, of almost boundless extent of sparsely inhabited territory, such an expenditure for such an object would be poor economy. But Holland has a narrow domain, great pecuniary resources, an excessively crowded population, and a consequent need of enlarged room and opportunity for the exercise of industry. Under such circumstances, and especially with an exposure to dangers so formidable, there is no question of the wisdom of the measure. It has already provided homes and occupation for more than five thousand citizens, and furnished a profitable investment for a private capital of not less than $£ 400,000$ sterling or $\$ 2,000,000$, which has been expended in improvements over and above the purchase money of the soil; and the greater part of this sum, as well as of the cost of drainage, has been paid as a compensation for labor. The excess of governmental expenditure over the receipts, if employed in constructing ships of war or fortifications, would have added little to the military strength of the kingdom; but the increase of territory, the multiplication of homes and firesides which the people have an interest in defending, and the augmentation of agricultural resources, constitute a stronger bulwark against foreign invasion than a ship of the line or a fortress armed with a hundred cannon.

\section{Draining of the Zuiderzee.}

I have referred to the draining of the Lake of Haarlem as an operation of great geographical as well as economical and mechanical interest. A much more gigantic project, of a similar

undulate at every step, and a man's house sometimes, during a squall, changes front to every point of the compass. Some of these islands are so large as to afford space for three or four cottages." 
character, is now engaging the attention of the Netherlandish engineers. It is proposed to drain the great salt-water basin called the Zuiderzee. This inland sea covers an area of not less than two thousand square miles, or about one million three hundred thousand acres. The seaward half, or that portion lying northwest of a line drawn from Enkhuizen to Stavoren, is believed to have been converted from a marsh to an open bay since the fifth century after Christ, and this change is ascribed, partly if not wholly, to the interference of man with the order of nature. The Zuiderzee communicates with the sea by at least six considerable channels, separated from each other by low islands, and the tide rises within the basin to the height of three feet. To drain the Zuiderzee, these channels must first be closed and the passage of the tidal flood through them cut off. If this be done, the coast currents will be restored approximately to the lines they followed fourteen or fifteen centuries ago, and there can be little doubt that an appreciable effect will thus be produced upon all the tidal phenomena of that coast, and, of course, upon the maritime geography of Holland.

A ring-dike and canal must then be constructed around the landward side of the basin, to exclude and carry off the freshwater streams which now empty into it. One of these, the Ijssel, a considerable river, has a course of eighty miles, and is, in fact, one of the outlets of the Rhine, though augmented by the waters of several independent tributaries. These preparations being made, and perhaps transverse dikes erected at convenient points for dividing the gulf into smaller portions, the water must be pumped out by machinery, in substantially the same way as in the case of the Lake of Haarlem.* No safe calculations can be made as to the expenditure of time and money required for the axecution of this stupendous enterprise, but I believe its practicability is not denied by competent judges, though doubts are entertained as to its financial expediency. $\dagger$ The geographical re-

* The dependence of man upon the aid of spontaneous nature, in his most arduous material works, is curiously illustrated by the fact that one of the most serious difficulties to be encountered, in executing this gigantic scheme, is that of procuring brushwood for the fascines to be employed in the $\mathrm{cm}$ bankments. See Diggelen's pamphlet, "Groote Werken in Nederland."

† The plan at present most in favor is that which proposes the drainage of only a portion of the southern half of the Zuiderzee, which covers not far 
sults of this improvement would be analogous to those of the draining of the Lake of Haarlem, but many times multiplied in extent, and its meteorological effects, though perhaps not perceptible on the coast, could hardly fail to be appreciable in the interior of Holland.

The bearing of the works I have noticed, and of others similar in character, upon the social and moral, as well as the purely economical, interests of the people of the Netherlands, has induced me to describe them more in detail than the general purpose of this volume may be thought to justify; but if we consider them simply from a geographical point of view, we shall find that they are possessed of no small importance as modifications of the natural condition of terrestrial surface. There is good reason to beliere that before the establishment of a partially civilized race upon the territory now occupied by Dutch, Frisic and Low German communities, the grounds not exposed to inundation were overgrown with dense woods; that the lowlands between these forests and the sea-coasts were marshes, covered and partially solidified by a thick matting of peat-plants and shrubs interspersed with trees; and that even the sand-dunes of the shore were protected by a vegetable growth which, in a great measure, prevented the drifting and translocation of them.

The present causes of river and coast erosion existed, indeed, at the period in question; but some of them must have acted with less intensity, there were strong natural safeguards against the influence of marine and fresh-water currents, and the conflicting tendencies had arrived at a condition of approximate equilibrium which permitted but slow and gradual changes in the face of nature. The destruction of the forests around the sources and along the valleys of the rivers, by man, gave them a more torrential character. The felling of the trees, and the extirpation of the shrubbery upon the fens by domestic cattle, deprived the surface of its cohesion and consistence; and the cutting of peat for fuel opened cavities in it, which, filling at once with

from 400,000 acres. The construction of the ship-canal directly from Amsterdam to the North Sea, lately executed, involved the draining of the $\mathbf{I j}, \mathbf{a}$ nearly land-locked basin communicating with the Zuiderzee and covering more than 12,000 acres. See official reports on this subject in Droogmaking ran het zuidelijk gedeelte der Zuiderzee, te s' Gravenhage, 1868, 4to. 
water, rapidly extended themselves by abrasion of their borders, and finally enlarged to pools, lakes and gulfs, like the Lake of Haarlem and the northern part of the Zuiderzee. The cutting of the wood and the depasturing of the grasses upon the sand-dunes, converted them from solid bulwarks against the ocean to loose accumulations of dust, which every sea-breeze drove farther landward, burying, perhaps, fertile soil and choling up watercourses on one side, and exposing the coast to erosion by the sea upon the other.

\section{Geographical Effect of Physical Improvements in the Netherlands.}

The changes which human action has produced within twenty centuries in the Netherlands and the neighboring provinces, are certainly of no small geographical importance, considered simply as a direct question of loss and gain of territory. They have also, as we shall see hereafter, undoubtedly been attended with some climatic consequences; they have exercised a great influence on the spontaneous animal and regetable life of this region, and they can not have failed to produce effects upon tidal and other oceanic currents, the range of which may be very extensive. The force of the tidal wave, the height to which it rises, the direction of its currents, and, in fact, all the phenomena which characterize it, as well as all the effects it produces, depend as much upon the con. figuration of the coast it washes, and the depth of water and form of bottom near the shore, as upon the attraction which occasions it. Every one of the terrestrial conditions which affect the character of tidal and other marine currents has been very sensibly modified by the operations I have described, and on this coast, at least, man has acted almost as powerfully on the physical geography of the sea as on that of the land.*

\section{Ancient Hydraulic Works.}

The hydraulic works of the Netherlands and of the neighboring states are of such magnitude that-with the exception of the dikes of the Mississippi-they quite throw into the shade all

* See, on the influence of the artificial modification of the coast-line on tides and other marine currents, StaniNG, De Bodem van Nederland, i., p. 279. 
other known artificial arrangements for defending the land against the encroachments of the rivers and the sea, and for reclaiming to the domain of agriculture and civilization soil long covered by the waters.* But although the recovery and protection of lands flooded by the sea seems to be an art wholly of Netherlandish origin, we have abundant evidence that, in ancient as well as in comparatively modern times, great enterprises more or less analogous in character have been successfully undertaken, both in inland Europe and in the less familiar countries of the East.

In many cases no historical record remains to inform us when or by whom such works were constructed. The Greeks and Romans, the latter especially, were more inclined to undertake and carry out stupendous material enterprises than to boast of them; and many of the grandest and most important constructions of those nations are absolutely unnoticed by contemporary annalists, and are first mentioned by writers living after all knowledge of the epochs of the projectors of these works had perished. Thus the aqueduct known as the Pont du Gard, near Nimes, which, though not surpassing in volume or in probable cost other analogous constructions of ancient and of modern ages, is yet among the most majestic and imposing remains of ancient civil architecture, is not so much as spoken of by any Roman author, $†$ and we are in absolute ignorance of the age or the construction of the remarkable tunnel cut to drain Lake Copais in Bœotia. This

* When the sluices of the great dike at Katwijk are opened at low tide for the escape of the accumulated waters of the Rhine, the discharge for some hours is equal to the average flow of the Nile, or 100,000 cubic feet per second.

† One reason for the silence of Roman writers in respect to great material improvements which had no immediate relation to military or political objects, is doubtless the contempt in which mechanical operations and mechanical contrivances were held by that nation of spoilers. Eren the engineer, upon whose skill the attack or defence of a great city depended, was only prafectus fubrum, the master-artisan, and had no military rank or command. This prejudice continued to a late period in the Middle Ages, and the chiefs of artillery were equally without grade or title as soldiers.

"The occupations of all artisans," says Cicero, "are base, and the shop can have nothing of the respectable."-De Officiis, 1. i., 42. The position of the surgeon relatively to the physician, in Englaud, is a remnant of the same prejudice, which still survives in full vigor in Italy, with regard to both trade and industry. See p. 6, ante. 
lake, now reduced by sedimentary deposit and the growth of aquatic and semi-aquatic vegetation to the condition of a marsh, was originally partially drained by natural subterranean outlets in the underlying limestone rock, many of which still exist. But these emissaries, or katavothra, as they are called in both ancient and modern Greek, were insufficient for the discharge of the water, and besides, they were constantly liable to be choked by earth and vegetables, and in such cases the lake rose to a height which produced much injury. To remedy this evil and secure a great accession of fertile soil, at some period anterior to the existence of a written literature in Greece and ages before the time of any prose author whose works have come down to us, two tunnels, one of them four miles long, and of course not inferior to the Torlonian emissary in length, were cut through the solid rock, and may still be followed throughout their whole extent. They were repaired in the time of Alexander the Great, in the fourth century before Christ, and their date was at that time traditionally referred to the reign of rulers who lived as early as the period of the Trojan war.

One of the best known hydraulic works of the Romans is the tunnel which serves to discharge the surplus waters of the Lake of Albano, about fourteen miles from Rome. This lake, about six miles in circuit, occupies one of the craters of an extinct volcanic range, and the surface of its waters is about nine hundred feet above the sea. It is fed by rivulets and subterranean springs originating in the Alban Mount, or Monte Cavo, the most elevated peak of the volcanic group just mentioned, which rises to the height of about three thousand feet. At present the lake has no discoverable natural outlet, and it is not known that the water ever stood at such a height as to flow regularly over the lip of the crater. It seems that, at the earliest period of which we have any authentic memorials, its level was usually kept, by evaporation or by discharge through subterranean channels, considerably below the rim of the basin which encompassed it; but in the year 397 в.с., the water, either from the obstruction of such channels or in consequence of increased supplies from unknown sources, rose to such a height as to flow over the edge of the crater, and threaten inundation to the country below by bursting through its walls. To obviate this danger, a tunnel for carrying off the water 
was pierced at a level much below the height to which it had risen. This gallery, eut entirely with the chisel through the rock for a distance of six thousand feet, or nearly a mile and one. seventh, is still in so good condition as to serve its original purpose. The fact that this work was contemporaneous with the siege of Veii, has given to ancient annalists occasion to connect the two events, but modern eritics are inclined to reject Livy's account of the matter, as one of the many improbable fables which disfigure the pages of that historian. It is, however, repeated by Cicero and by Dionysius of Halicarmassus, and it is by no means impossible, in an age when priests and soothsayers monopolized both the arts of natural magic and the little which yet existed of physical science, that the Government of Rome, by their aid, availed itself at once of the superstition and of the military ardor of its citizens to obtain their sanction to an enterprise which sounder arguments might not have induced them to approve.

Still more remarkable is the tunnel cut by the Emperor Claudius to drain the Lake Fucinus, now Lago di Celano, in the former Neapolitan territory, about fifty miles eastward of Rome. This lake, as far as its history is known, has varied very considerably in its dimensions at different periods, according to the character of the seasons. It lies 2,200 feet above the sea, and has no visible outlet, but was originally either drained by natural subterranean conduits, or kept within certain extreme limits by evaporation. In years of uncommon moisture it spread over the adjacent soil and destroyed the crops; in dry seasons it retreated, and produced epidemic disease by poisonous exhalations from the decay of regetable and animal matter upon its exposed bed. Julius Cæesar had proposed the construction of a tunnel to lower the bed of the lake and provide a regular discharge for its waters, but the enterprise was not actually undertaken until the reign of Claudius, when-after a temporary failure from errors in levelling by the engineers, as was pretended at the time, or, as now appears certain, in consequence of frauds by the contractors in the execution of the work-it was at least partially completed. From this imperfect construction, it soon got out of repair, but was restored by Hadrian, and is said to have auswered its design 
for some centuries.* In the barbarism which followed the downfall of the empire, it again fell into decay, and though numerous attempts were made to repair it during the Middle Ages, no tolerable success seems to have attended any of these efforts until the present generation.

\section{Draining of Lake Celano by Prince Torlonia.}

Works have been some years in progress and are now substantially completed, at a cost of about eight millions of dollars, for restoring, or rather enlarging and rebuilding, this ancient tunnel, upon a scale of grandeur which does infinite honor to the liberality and public spirit of the projectors; and with an ingenuity of design and a constructive skill which reflect the highest credit upon the professional ability of the engineers who have planned the works and directed their execution. The length of the Roman tunnel was 18,634 feet, or rather more than three miles and a half, but as the new emissary is designed to drain the lake to the bottom, it has been laid at a lower level and continued to the lowest part of the basin by an open canal. The new tunnel has a total length of about 21,000 feet, and, of course, is among the longest subterranean galleries in Europe. Many curious particulars in the design and execution of the original work have been observed in the course of the restoration, but these can not here be noticed. The difference between the lowest and highest known levels of the surface of the lake is rather more than forty feet, and the difference between the areas corered by water at these levels is not less than nine thousand acres. The complete drainage of the lake, including the ground occasionally flooded, will recover for agricultural occupation, and permanently secure from inundation, about forty-two thousand acres

* The fact alluded to in a note on p. 95 , ante, that since the opening of a communication between Lake Celano and the Garigliano by the works noticed in the text, fish, of species common in the lake, but not previously found in the river, have become naturalized in the Garigliano, is a circumstance of some weight as evidence that the emissary was not actually open in ancient times; for if the waters had been really connected, the fish of the lake would naturally have followed the descending current and established themselves in the river as they have done now. 
of soil as fertile as any in Italy.* The ground already dry enough for cultivation furnishes occupation and a livelihood for a population of many hundred persons, and it is thought that this number will be augmented to thousands when the drainage shall be completely effected.

The new tunnel follows the line of the Claudian emissarywhich though badly executed was admirably engineered-but its axis is at a somewhat lower level than that of the old gallery, and its cross-section is about two hundred and twelve square feet, while that of the Roman work was only one hundred and two square fect-a proportion which shows the possible delivery of water by the modern conduit to be far greater than that of its predecessor.

In consequence of the nature of the rock and of the soil, which had been loosened and shattered by the falling in of much of the crown and walls of the old tunnel-every stone of which it was necessary to remove in the progress of the work-and the great head of water in the lake from unusually wet seasons, the technical difficulties to be surmounted were most baffling and discouraging in character, and of such extreme gravity that it may well be doubted whether the art of engineering has anywhere triumphed over more serious obstacles.

It deserves to be mentioned, that at a most critical period in the work, when the risk to the laborers was very great, Prince Torlonia encouraged the men by his personal presence at the most exposed points. This great "victory of peace"-probably the grandest work of physical improvement ever effected by the means, the energy, and the munificence of a single inclividualis of no small geographical and economical, as well as sinitary,

* Springs rising in the bottom of the lake have materially impeded the process of drainage, and some engineers believe that they will render the complete discharge of the waters impossible. It appears that the earthy and rocky strata underlying the lake are extremely porous, and that the ground already laid dry on the surface absorbs an abnormally large proportion of the precipitation upon it. These strata, therefore, constitute a reservoir which contributes to maintain the springs fed chiefly, no doubt, by underground channels from the neighboring mountains. But it is highly probable that, after a certain time, the process of natural desiccation noticed in note to p. 19, ante, will drain this reservoir, and the entire removal of the surface-water will then bocome practicable. 
importance, but it has a still higher moral value as an almost unique example of the exercise of public spirit, courage and perseverance in the accomplishment of a noble and beneficent enterprise by a private citizen.*

The crater-lake of Nemi, in the same volcanic region as that of Albano, is also drained by a subterranean tunnel probably of very ancient construction, and the Valle-Riccia appears to have once been the basin of a lake long since laid dry, but whether by the bursting of its banks or by human art we are unable to say.

The success of the Lake Celano tunnel has suggested other like improvements in Italy. A gallery has been cut, under circumstances of great difficulty, to drain Lake Agnano near Naples, and a project for the execution of a similar operation on the Lake of Perugia, the ancient Trasimenus, which covers more than 40,000 acres, is under discussion.

Many similar enterprises have been conceived and executed in modern times, both for the purpose of reclaiming land covered by water and for sanitary reasons.t They are sometimes attended

* The draining of Lake Celano was undertaken by an incorporated company, but Prince Alessandro Torlonia of Rome bought up the interest of all the shareholders and has executed the entire work at his own private expense. Montricher, the celebrated constructor of the great aqueduct of Marseilles, was the engineer who designed and partly carried out the plans, and since his lamented death the work has been directed with equal ability by Bermont and Brisse.-See LeoN DE Rotrov, Prosciugamento del Lago Fucino, 8ro. Firenze, 1871. See also, The Draining of Lake Fucino, Rome, 1876, published and liberally distributed by the munificence of Prince Torlonia. I am sorry to be obliged to add that a hundred copies of this valuable work, destined by the Prince for the Centennial Exhibition of $18 \% 6$, were detained by the faithlessness of the agent entrusted with their transmission to the United States and failed to arrive there in time.

$\uparrow A$ considerable work of this character is mentioned by Captain Gilliss as having been executed in Chili, a country to which we should hardly have looked for an improvement of such a nature. The Lake Taguataga was partially drained by cutting through a narrow ridge of land, not at the natural outlet, but upon one side of the lake, and eight thousand acres of land cov. ered by it were gained for cultivation.-U. S. Naval Astronomical Expedition to the Southern Hemisphere, i., pp. 16, 17.

Lake Balaton and the Neusiedler See in Hungary have lately been, at least partially, drained.

The lakes of Neuchatel, Bienne and Morat, in Switzerland, have been con 
with wholly unexpected evils, as, for example, in the case of Barton Pond, in Vermont, and in that of a lalie near Ragunrla in Sweden, already mentioned on a former page. Another still less obvious consequence of the withdrawal of the waters has occasionally been observed in these operations. The hydrostatic foree with which the water, in virtue of its specific gravity, presses agrainst the banks that confine it, has a tendency to sustain them whenever their composition and texture are not such as to expose them to softening and dissolution by the infiltration of the water. If, then, the slope of the bamkis is considerable, or if the earth of which they are composed rests on a smooth and slippery stratum inclining towards the bed of the lake, they are liable to fall or slide forward when the mechanical support of the water is removed, and this sometimes happens on a considerable scale. A few years ago the surface of the Lake of Lungern, in the Canton of Unterwalden, in Switzerland, was lowered by driving a tunnel about a quarter of a mile long through the narrow ridge, called the Kaiserstuhl, which forms a barrier at the north end of the basin. When the water was drawn off, the banks, which are steep, cracked and burst, several acres of ground slid down as low as the water receded, and even the whole village of Lungern was thought to be in no small danger.*

nected and the common level of all of them lowered about four feet. The works in operation in 1871 were expected to produce, in the course of the year 18\%4, a further depression of four feet, and recover for agricultural use more than twelre thousand acres of fertile soil. A part of the plan of the works referred to is a canal for turning the river Aar into the Lake of Bienne, out of which it will flow again by a new channel cut at a depth which will considerably lower the surface of the Lake. In excavating the canal in the course of 1S74, the workman struck into an ancient Roman tunnel previously unknown, which was apparently constructed for the purpose of partially drain. ing the Lake of Bienne, the surface of which originally stood at a higher level than in modern times, into the Aar. The tunnel, which is about half a mile in length, lies almost exactly in the line of the new canal, and will be destroyed in the course of the excavations. Some suppose this tunnel to have been pierced to serve as a common road.

* In the course of the year 1864 there were slides of the banks of the Lake of Como, and in one case the grounds of a villa near the water suffered a considerable displacement. More important slips occurred at Feriolo on the shore of Lago Magrgiore in 1867 and 1869, and on the Lake of Orta in 1868. These occurrences excited some apprehensions in regard to the possible effects of projects then under discussion for lowering the level of some of the Italian 


\section{Mountain Lakes.}

Other incunveniences of a very serious character have often resulted from the natural wearing down, or, much more frequently, the imprudent destruction, of the barriers which confine mountain lakes. In their natural condition, such basins serve both to receive and retain the rocks and other detritus brought down by the torrents which empty into them, and to check the impetus of the rushing waters by bringing them to a temporary pause; but if the outlets are lowered so as to drain the reservoirs, the torrents continue their rapid flow through the ancient bed of the basins, and carry down with them the sand and gravel with which they are charged, instead of depositing their burden as before in the still waters of the lakes.

It is a common opinion in America that the river meadows, bottoms, or intervales, as they are popularly called, are generally the beds of ancient lakes which have burst their barriers and left running currents in their place. It was shown by Dr. Dwight, many years ago, that this is very far from being universally true; but there is no doubt that mountain lakes were of much more frequent occurrence in primitive than in modern geography, and there are many chains of such still existing in regions where man has yet little disturbed the original features of the earth. In the

lakes, to obtain an increased supply of water for irrigation and as a mechanical power, but as it was not proposed to depress the surface below the lowest natural low-water level, there seems to have been little ground for the fears expressed.

See, for important observations on the character and probable results of these projects, TAGLLaseccH, Notizie, etc., dei Canali dell' Alta Lombardia, Milano, 1871.

Jacini says : "A large proportion of the water of the lakes, instead of discharging itself by the Ticino, the Adda, the Oglio, the Mincio, filters through the silicious strata which underlie the hills, and follows subterranean channels to the plain, where it collects in the fontanili, and being thence conducted into the canals of irrigation, becomes a source of great fertility."-La Proprietd Fondiaria, etc., p. 144.

The quantity of water escaping from the lakes by infiltration depends much on the hydrostatic pressure on the bottom and the walls of the lake-basins, and consequently the depression of the lake surface, diminishing this pressure, would diminish the infiltration. Hence it is possible that the lowering of the level of these lakes would manifest itself in a decreased supply of water for the springs, fontanili and wells of Lombardy. 
long valleys of the Adirondack range in Northern New York, and in the mountainons parts of Maine, eight, ten and even more liakes and lakelets are sometimes found in succession, each empty. ing into the next lower pool, and so all at last into some considerable river. When the mountain slopes which supply these basins shall be stripped of their woods, the augmented swelling of the lakes will break down their barriers, their waters will run off, and the valleys will present successions of flats with rivers running through them, instead of chains of lakes connected by natural canals.

A similar state of things seems to have existed in the ancient geography of France. "Nature," says Lavergne, "has not excavated on the flanks of our Alps reservoirs as magnificent as those of Lombardy; she had, however, constructed smaller but more numerous lakes, which the improvidence of man has permitted to disappear. Auguste de Gasparin demonstrated more than thirty years ago that many natural dikes formerly existed in the mountain valleys, which have been swept away by the waters." *

Many Alpine valleys in Switzerland and Italy present unquestionable evidence of the former existence of chains of lakes in their basins, and this may be regarded as a general fact in regard to the primitive topography of mountainous regions. Where the forests have not been destroyed, the lakes remain as characteristic features of the geographical surface. But when the woods are felled, these reservoirs are sooner or later filled up by wash from the shores, and of course disappear. Geologists have calculated the period when the bottom of the Lake of Geneva will be levelled up and its outlet worn down.t The Rhone will then flow, in an unbroken current, from its source in the great Rhone glacier to the Mediterranean Sea.

\section{* Économie Rurale de la France, p. 289.}

$\uparrow$ Railway cuttings through the ancient deposits of the upper Rhone, at its entrance into the Lake of Geneva, have furnished data for important historical and chronological computations as to the geological agency of this river; and the later deposits of the same locality are very instructive in regard to the action of aquatic and semi-aquatic regetation in solidifying those deposits and converting them into dry land. 


\section{Draining of Swamps.}

The reclamation of bogs and swamps by draining off the surface water is doubtless much more ancient than the draining of lakes. The beneficial results of the former mode of improvement are more unequivocal, and balanced by fewer disadvantages, and, at the same time, the processes by which it is effected are much simpler and more obvious. It has accordingly been practiced through the whole historical period, and in recent times operations for this purpose have assumed a magnitude, and been attended with economical as well as sanitary and geographical effects, which entitle them to a high place in the efforts of man to ameliorate the natural conditions of the soil he occupies.

The methods by which the draining of marshes is ordinarily accomplished are too familiar, and examples of their successful employment too frequent, to require description, and I shall content myself, for the moment, with a brief notice of some recent operations of this sort which are less generally known than their importance merits.

Within the present century more than half a million acres of swamp-land have been drained and brought under cultivation in Hungary, and works are in progress which will ultimately recover a still larger area for human use. The most remarkable feature of these operations, and at the same time the process which has been most immediately successful and remunerative, is what is called in Europe the regulation of watercourses, and especially of the river Theiss, on the lower course of which stream alone not less than 250,000 acres of pestilential and wholly unproductive marsh have been converted into a healthful region of the most exuberant fertility.

The regulation of a river consists in straightening its channel by cutting off bends, securing its banks from erosion by floods, and, where necessary, constructing embankments to confine the waters and prevent them from overflowing and stagnating upon the low grounds which skirt their current. In the course of the Theiss about sixty bends, including some of considerable length, have been cut off, and dikes sufficient for securing the land along its banks against inundation have been constructed.

Many thousand acres of land have been recently permanently 
improved in Italy by the draining of swamps, and extensive operations have been projected and commenced on the lower Rhone, and elsewhere in France, with the same object.*

But there is probably no country where greater improvements of this sort have either been lately effected, or are now in course of accomplishment, than in our own. Not to speak of welllnown works on the New Jersey sea-coast and the shores of Lake Michigan, the people of the new State of California are engaging in this mode of subduing nature with as much enterprise and energy as they have shown in the search for gold. The Report of the Agricultural Department of the United States for January, 18 2, notices, with more or less detail, several highly successful experiments in California in the way of swamp-drainage and securing land from overflow, and it appears that not far from 200,000 acres have either very recently undergone or will soon be subjected to this method of improvement.

\section{Agricultural Draining.}

I have commenced this chapter with a description of the dikes and other hydraulic works of the Netherland engineers, because both the immediate and the remote results of such operations are more obvious and more easily measured, though certainly not more important, than those of much older and more widely dif-

* Very interesting and important experiments, on the practicability of washing out the salt from sea-coast lands too highly impregnated with that mineral to be fit for cultivation, are now in progress near the mouth of the Rhone, where millions of acres of marshy soil can easily be recovered, if these experiments are successful.

See Deponcmel, Traité d'Hydraulique et de Géologie agricoles. Paris, 1868, chaps. xi. and xii.

In the neighborhood of Ferrara are pools and marshes covering nearly two hundred square miles, or a surface more than equal to eight American townships. Centrifugal steam-pumps, of 2,000 horse-power, capable of discharging more than six hundred and fifty millions of gallons of water per day, have lately been constructed in England for draining these marshes. This discharge is equal to an area of 640 acres, or a mile square, with nearly three feet of water.

For a most striking and life-like picture of marsh-scenery in Italy, I would refer the reader to Fol. ii., p. 22, et seq., of the Head of Medusa, by our gifted young country-woman, Miss Fletcher. 
fused modes of resisting or directing the flow of waters, wlich have been practiced from remote antiquity in the interior of all civilized countries. Draining and irrigation are habitually regarded as purely agricultural processes, waving little or no relation to technical geography; but we shall find that they exert a powerful influence on soil, climate, and animal and vegetible life, and may, therefore, justly claim to be regarded as geographical elements.

Superficial draining is a necessity in all lands newly reclaimed from the forest. The face of the ground in the woods is never so regularly inclined as to permit water to flow freely orer it. There are, even on the hillsides, small ridges and depressions, partly belonging to the original distribution of the soil, and partly occasioned by irregularities in the growth and deposit of vegetable matter. These, in the husbandry of nature, serve as dams and reservoirs to collect a larger supply of moisture than the spongy earth can at once imbibe. Besides this, the vegetable mould is, even under the most favorable circumstances, slow in parting with the humidity it has accumulated under the protection of the woods, and the infiltration from neighboring forests contributes to keep the soil of small clearings too wet for the advantageous cultivation of artificial crops. For these reasons, surface draining must have commenced with agriculture itself, and there is probably no cultivated district, one may almost say no single field, which is not provided with artificial arrangements for facilitating the escape of superficial water, and thus carrying off moisture which, in the natural condition of the earth, would have been imbibed by the soil.

All these processes belong to the incipient civilization of the ante-historical periods, but the construction of subterranean channels for the removal of infiltrated water marks ages and countries distinguished by a great advance in agricultural theory and practice, a great accumulation of pecuniary capital, and a density of population which creates a ready demand and a ligh price for all products of rural industry. Under-draining, too, would be most advantageous in damp and cool climates, where evaporation is slow, and upon soils where the natural inclination of surface does not promote a very rapid flow of the surface-waters. All the conditions required to make this mode of rural improvement, if 
not absolutely necessary, at least profitable, exist in Great Britain, and it is, therefore, very natural that the wealthy and intelligent farmers of England should have carried this practice farther, and reaped a more abuudant pecuniary return from it, than those of any other country.

Besides superficial and subsoil drains, there is another method of disposing of superfluous surface-water, which, howerer, can rarely be practiced, beeause the necessary conditions for its employment are not of frequent occurrence. Whenever a tenacious Water-holding stratum rests on a loose, gravelly bed, so situated as to admit of a free discharge of water from or through it by means of the outeropping of the bed at a lower level, or of deeplying conduits leading to distant points of discharge, superficial waters may be carried off by opening a passage for them through the impervious into the permeable stratum. Thus, according to Bischof, as early as the time of King Réné, in the first half of the fifteenth century, when subsoil drainage was scarcely known, the plain of Paluns, near Marseilles, was laid dry by boring, and Wittwer informs us that drainage is effected at Munich by conducting the superfluous water into large excavations, from which it filters through into a lower stratum of pebble and gravel lying a little above the level of the river Isar.* So at $W$ ashington, in the western part of the city, which lies high above the rivers Potomac and Rock Creek, many houses are provided with dry wells for draining their cellars and foundations. These extend throngh hard, tenacious earth to the depth of thirty or forty feet, when

* Physitialische Geographie, p. 288. This method is now frequently err. ployed in France. Details as to the processes will be found in Mangon, Pratique du Drainage, p. 78, et seq. Draining by driving down stakes, mentioned in a note in the chapter on the Woods, ante, is a process of the same nature.

In the United States, large tracts of marshy ground, and even shallow lakes of considerable extent, have been sufficiently drained not only for pasturage but for cultivation, without resort to any special measures for effecting that end. The ordinary processes of rural improvement in the vicinity, such as felling woods upon and around such grounds, and the construction of roads, the side ditches of which act as drains, over or near them, aided now and then by the removal of a fallen tree or other accidental obstruction in the beds of small streams which flow from them, often suffice to reclaim miles square of unproductive swamp and water. Sce notes on p. 19, and on cedar swamps, p. 204, ante. 
they strike a stratum of gravel, through which the water readily passes off.

This practice has been extensively employed at Paris, not merely for carrying off ordinary surface-water, but for the discharge of offensive and deleterious fluids from chemical and manufacturing - establishments. A well of this sort received, in the winter of 1832-'33, twenty thousand gallons per day of the foul water from a starch factory, and the same process was largely used in other factories. The apprehension of injury to common and artesian wells and springs led to an investigation on this subject by Girard and Parent Duchatelet, in the latter year. The report of these gentlemen, published in the Annales des Ponts et Chaussées for 1833 , second half-year, is full of curious and instructive facts respecting the position and distribution of the subterranean waters under and near Paris; but it must suffice to say that the report came to the conclusion that, in consequence of the absolute immobility of these waters, and the relatively small quantity of noxious fluid to be conveyed to them, there was no danger of the diffusion of such fluid if discharged into them. This result will not surprise those who know that, in another work, Duchatelet maintains analogous opinions as to the effect of the discharge of the city sewers into the Seine or the waters of that river. The quantity of matter delivered by them he holds to be so nearly infinitesimal, as compared with the volume of water of the river, that it can not possibly affect it to a sensible degree, and therefore can not render the Seine water unfit for drinking. *

\section{Meteorological Effects of Draining.}

The draining of lakes diminishes the water-surface of the soil, and consequently, in many cases, the evaporation from it, as well as the refrigeration which attends all evaporation. $\nmid$ On the other

* Coste found, in his experiments on pisciculture, that the fermentation, which takes place in the water of the Seine in consequence of the discharge of the drains into the river, destroyed a large proportion of the eggs of fish in his breeding basins. Analysis of Seine water by Boussingault in 1855, detected a considerable quantity of ammonia.

$\uparrow$ The relative evaporating action of earth and water is a very complicated problem, and the results of observation on the subject are conflicting. Schübler found that at Geneva the evaporation from bare loose earth, in the months 
hand, if the volume of water abstracted is great, its removal de. prives its basin of an equalizing and moderating influence; for large bodies of water take very slowly the temperature of the air in contact with their surface, and are almost constantly either sending off heat into the atmosphere or absorbing heat from it. Besides, as we have seen, lakes in elevated positions discharge more or less water by infiltration, and contribute it by the same process to other lakes, to springs, and to rivulets, at lower levels. Hence the draining of lakes, on a considerable seale, must modify both the humidity and the temperature of the atmosphere of the neighboring regions, and the permanent supply of ground-water for the lands lying below them.

\section{Meteorological Action of Marshes.}

The shallow water of marshes, indeed, performs this latter function, though, under ordinary circumstances, marshes exercise in but a very small degree the compensating meteorological action which I have ascribed to large expansions of deeper water. The direct rays of the sun and the warmth of the atmosphere penetrate to the soil beneath, and raise the temperature of the water which covers it; and there is usually a much greater evaporation from marshes than from lakes in the same region, during the

of December, January and February, was from two and a half to nearly six times as great as from a like surface of water. In the other months, the evaporation from water was from about one and a half to six times as great as from earth. Taking the whole year together, the evaporation from the two surfaces was $199_{12}^{8}$ lines from earth and $536_{12}^{\frac{1}{12}}$ lines from water. Experiments by Van der Steer, at the Helder, in the years 1861 and 1862 , showed, for the former year, an evaporation of 602.9 millimitres from water, 1399.6 millimetres from ground covered with clover and other grasses; in 1862, the evaporation from water was 584.5 millimetres, from grass-ground, 875.5.-WILIEL, Der Boden und das Wasser, p. 57 ; KRECKE, Het Klimaat ran Nederland, ii., p. 111.

On the other hand, the evaporation from the Nile in Egypt and Nubia is stated to be three times as great as that from an equal surface of the soil which borders it.-LomBamdinr, Saggio Idrologico sul .Vilo, Milano, 1864, and Appendix. The rolative thermometrical conditions of land, air and water in the same vicinity are constantly varying, and the hysrometrical state of the two former is equally unstable. Consequently there is no general formula to rexpress the proportionate evaporation from fluid and solid geographical sur. faces. 
warmer half of the year. This evaporation implies refrigeration, and consequently the diminution of evaporation by the drainage of stramps tends to prevent the lowering of the atmospheric temperature, and to lessen the frequency and severity of frosts. Accordingly it is a fact of experience that, other things being equal, dry soils, and the air in contact with them, are perceptibly warmer during the season of vegetation, when evaporation is most rapid, than moist lands and the atmospheric stratum resting upon them. Instrumental observation on this special point has not yet been undertaken on a large scale, but still we have thermometric data sufficient to warrant the general conclusion, and the influence of drainage in diminishing the frequency of frost appears to be even better established than a direct increase of atmospheric temperature. The steep and dry uplands of the Green Mountain range in New England often escape frosts when the Indian-corn harvest on moister grounds, five hundred or even a thousand feet lower, is destroyed or greatly injured by them. The neighborhood of a marsh is sure to be exposed to late spring and early autumnal frosts, but they cease to be feared after it is drained, and this is particularly observable in very cold climates, as, for example, in Lapland.*

In England, under-drains are not generally laid below the reach of daily variations of temperature, or below a point from which moisture, if not carried off by the drains, might be brought to the surface by capillary attraction, and evaporated by the heat of the sun. They, therefore, like surface-drains, withdraw from local solar action much moisture which would otherwise be vaporized by it, and, at the same time, by drying the soil above them, they increase its effective hygroscopicity, and it consequently absorbs from the atmosphere a greater quantity of water than it did when, for want of under-drainage, the subsoil was always humid, if not

* "The simplest backwoodsman knows by experience that all cultivation is impossible in the neighborhood of bogs and marshes. Why is a crop near the borders of a marsh cut off by frost, while a field upon a hillock, a few stone's throws from it, is spared ?"-LaRs Levi Lestadrus, Om Uppodlingar i Lappmarken, pp. 69, 74 .

In the late spring frosts, which are sometimes so destructive to the crops in Northern Italy, it is generally observed that only the low grounds are affected, the high grounds very seldom suffering from that cause. 
saturated.* Under-drains, then, contribute to the dryness as well as to the warmth of the atmosphere, and, as dry ground is more readily heated by the rays of the sun than wet, they tend also to raise the mean, and especially the summer, temperature of the soil.

\section{Effects of Draining Lake of Haarlem.}

The meteorological influence of the draining of lakes and of humid soils has not, so far as I know, received much attention from experimental physicists; but we are not altogether without direct proof in support of theoretical and a priori conclusions. Thermometrical observations have been regularly made at Zwanenburg, near the northern extremity of the Lake of Haarlem, for more than a century; and since $\mathbf{1 8 4 5}$ a similar registry has been kept at the Helder, forty or fifty miles more to the north. In comparing these two series of observations, it is found that towards the end of 1852, when the draining of the lake was finished, and the following summer had completely dried the newly exposed soil-and of course greatly diminished the water-surface-a change took place in the relative temperature of those two stations. Taking the mean of each successive period of five days, from $18 \pm 5$ to 1852 , both inclusive, the temperature of Zwanenburg was thirty-three hundredths of a degree centigrade lower than at the Helder. From the end of 1852 the thermometer at Zwanenburg has stood, from the 11th of April to the 20th of September, twenty-two hundredths of a degree higher than that at Helder; but from the 1tth of October to the 17th of March, it has marked one-tenth of a degree lower than its mean between the same dates before $1853 . \dagger$

* Mangon thinks that the diminution of evaporation by agricultural drainage corresponds, in certain circumstances, to five per cent. of the heat received from the sun by the same surface in a year. He cites observations by Parkes, showing a difference in temperature of $5.5^{2}$ [centigrade ?] in favor of drained, as compared with undrained, ground in the same vicinity.-Instructions pratiques sur le Drainage, pp. 227, 228.

The diminution of evaporation is not the only mode in which under-draining affects the temperature. The increased effectire hygroscopicity of the soil increases its absorbent action, and the condensation of atmospheric vapor thus produced is attended with the manifestation of heat.

† KreChe, Het Klimaat van Nederland, ii., p. 64. 
There is no reason to doubt that these differences are due tc: the draining of the lake. In summer, solar irradiation has acted more powerfully on the now exposed earth and of course on the air in contact with it; and there is no longer a large expanse of water still retaining, and of course, imparting something of the winter temperature; in winter, the earth has lost more heat by radiation than when covered by water, and the influence of the lake, as a reservoir of warmth accumulated in summer and gradually given out in winter, was of course lost by its drainage. Doubtless the quantity of moisture contained in the atmosphere has been modified by the same cause, but it does not appear that observations have been made upon this point. Facts lately observed by Glaisher tend to prove an elevation of not far from two degrees in the mean temperature of England during the course of the last hundred years. For reasons which I have explained elsewhere, the early observations upon which these conclusions are founded do not deserve entire confidence; but admitting the fact of the alleged elevation, its most probable explanation would be found in the more thorough draining of the soil by superficial and subterranean conduits.

So far as respects the immediate improvement of soil and climate, and the increased abundance of the harvests, the English system of surface and subsoil drainage has fully justified the eulogiums of its advocates; but its extensive adoption appears to have been attended with some altogether unforeseen and undesirable consequences, very analogous to those which I have described as resulting from the clearing of the forests. The underdrains carry off very rapidly the water imbibed by the soil from precipitation, and through infiltration from neighboring springs or other sources of supply. Consequently, in wet seasons, or after heary rains, a river bordered by artificially drained lands receives in a few hours, from superficial and from subterranean conduits, an accession of water which, in the natural state of the earth, would have reached it only by small instalments after percolating through hidden paths for weeks or even months, and would have furnished perennial and comparatively regular contributions, instead of swelling deluges, to its channel. Thus, when human impatience rashly substitutes swiftly acting artificial contrivances for the slow methods by which nature drains the surface 
and superficial strata of a rirer-basin, the original equilibrium is disturbed, the waters of the heavens are no longer stored up in the earth to be gradually given out again, but are hurried out of man's domain with wasteful haste; and while the inundations of the river are sudden and disastrous, its current, when the drains have run dry, is reduced to a rivulet, it ceases to supply the power to drive the machinery for which it was once amply sufficient, and scarcely even waters the herds that pasture upon its margin.

The water of subterranean currents and reservoirs, as well as that of springs and common wells, is doubtless principally furnished by infiltration, and hence its quantity must vary with every change of natural surface which tends to accelerate or to retard the drainage of the surface-soil. The drainage of marshes, therefore, and all other methods of drying the superficial strata, whether by open ditches or by underground tubes or drains, has the same effect as clearing off the.forest in depriving the subterranean waters of accessions which they would otherwise receive by infiltration, and in proportion as the sphere of such operation is extended, their influence will make itself felt in the diminished supply of water in springs and wells.*

\section{Geographical and Meteorological Effects of Aqueducts, Reservoirs and Canals.}

Many of the great processes of internal improvement, such as aqueducts for the supply of great cities, railroad cuts and em-

* Babinet condemns the general draining of marshes. "Draining," says he, "has been much in vogue for some years, and it has been a special object to dry and fertilize marshy grounds. I believe that excessive dryness is thus produced, and that other soils in the neighborhood are sterilized in proportion." Etudes et Lectures, iv., p. 118.

"The extent of soil artificially dried by drainage is constantly increasing, and the water received by the surface from precipitation flows off by new chanuels, and is in general carried off more rapidly than before. Must not this fact exercise an influence on the régime of springs whose basin of supply thus undergoes a more or less complete transformation ?"-BERNKARD CoTTA, Preface to Paramelle, Quellenkunde, p. vii., viii.

The effects of agricultural drainage are perceptible at great depths. It has been observed in Cornwall that deep mines are more free from water in welldrained districts than in those where drainage is not generally practiced.Esquiros, Reme des Deux ICondes, 15 Nor., 1863, p. 430. The frequency of 
bankments, and the like, divert water from its natural channels, and effect its distribution and ultimate discharge. The collecting of the waters of a considerable district into reservoirs, to be thence carried off by means of aqueducts-as, for example, in the forest of Belgrade, near Constantinople-deprives the grounds, originally watered by the springs and rivulets, of the necessary moisture and reduces them to barrenness." Similar effects must have followed from the construction of the numerous aqueducts which supplied ancient Rome with such a profuse abundance of water + On the other hand, the filtration of water through the banks or walls of an aqueduct carried upon a high level across low ground, often injures the adjacent soil, and is prejudicial to the health of the neighboring population; and it has been observed in Switzerland and elsewhere, that fevers have been produced by the stagnation of the water in excavations from which earth had been taken to form embankments for railways.

If we consider only the influence of physical improvements on civilized life, we shall perhaps ascribe to navigable canals a higher importance, or at least a more diversified influence, than to aqueducts or to any other works of man designed to control the waters of the earth, and to affect their distribution. They bind distant regions together by social ties, through the agency of the commerce they promote; they facilitate the transportation of military stores and engines, and of other heavy material connected with the discharge of the functions of government; they encourage industry by giving marketable value to raw ma-

river inundations in England is, with great probability, now ascribed to excessive draining of the superficial strata of the soil.

See also Asbjörnsen, Torv og Torvdrift, p. 31.

* See the very interesting paper referred to in note to p. 339, ante, on the Water-Supply of Constantinople, by Mr. Homes, of the New York State Library, in the Albany Argus of June 6, 187\%. The system of aqueducts for the supply of water to that city was commenced by Constantine, and the great aqueduct, frequently ascribed to Justinian, which is 8.10 feet long and 112 feet high, is believed to have been constructed during the reign of the former emperor.

t The unhealthiness of the Roman Campagna is ascribed, by many mediæval as well as later writers, to the escape of water from the ancient aqueducts which had fallen out of repair from neglect, or been broken down by enemics in the sieges of Rome. 
terial and to objects of artificial elaboration which would otherwise be worthless on account of the cost of conveyance; they supply from their surplus waters means of irrigation and of mechanical power; and, in many other ways, they contribute much to adrance the prosperity and civilization of nations. Nor are they wholly without geographical importance. They somo times drain lands by conveying off water which would otherwise stagnate on the surface, and, on the other hand, like ayneducts, they render the neighboring soil cold and moist by the percolation of water through their embankments; * they dam up, eheck and divert the course of matural currents, and deliver them at points opposite to, or distant from, their original outlets; they often require extensive reservoirs to feed them, thus retain. ing through the year accumulations of water-which would otherwise run off, or evaporate in the dry season-and thereby enlarging the evaporable surface of the country; and we have already seen that they interchange the flora and the fauna of provinces widely separated by nature. All these modes of action certainly influence climate and the character of terrestrial surface, though our means of observation are not yet perfected enough to enable us to appreciate and measure their effects.

\section{Antiquity of Irrigation.}

We know little of the history of the extinct civilizations which preceded the culture of the classic ages, and no nation has, in

* Sismondi, speaking of the Tuscan canals, observes: "But inundations are not the only damage caused by the waters to the plains of Tuscany. Raised, as the canals are, above the soil, the water percolates through their bauks, penetrates every obstruction, and, in spite of all the efforts of industry, sterilizes aud turus to morasses fields which nature and the richness of the soil seemed to have designerl fur the most abuudant harvests. In ground thus porraded with moisture, or rendered cold, as the Tuscans express it, by the filtration of the canal-water, the vines and the mulberries, after having for at few years yiclded fruit of a saltish taste, rot and perish. The wheat decays in the ground, or dies as soon as it sprouts. Winter crops are given up, and summer cultivation tried for a time; but the increasing humidity, and the saline matter communicated to the earth-which affects the taste of all its products, even to the grasses, which the cattle refuse to touch-at last compel the husbandman to abandon his fields and leave uneultivated a soil that no longer repays his labor."-Tableau de l'Agriculture Toseane, pp. 11, 12. 
modern times, spontaneously emerged from barbarism, and cre. ated for itself the arts of social life.* The improvements of the savage races whose history we can distinctly trace are borrowed and imitative, and our theories as to the origin and natural development of industrial art are conjectural. Of course, the relative antiquity of particular branches of human industry depends much upon the natural character of soil, climate and spontaneous vegetable and auimal life in different countries; and while the geographical influence of man would, under given circumstances, be exerted in one direction, it would, under different conditions, act in an opposite or a diverging line. I have given some reasons for thinking that in the climates to which our attention has been chiefly directed, man's first interference with the natural arrangement and disposal of the water's was in the way of drainage of surface. But if we are to judge from existing remains alone, we should probably conclude that irrigation is older than drainage; for, in the regions regarded by general tradition as the cradle of the human race, we find traces of canals evidently constructed for the former purpose at a period long preceding the ages of which we have any written memorials. There are, in ancient Armenia, extensive districts which were already abandoned to desolation at the earliest historical epoch, but which, in a yet remoter antiquity, had been irrigated by a complicated and highly artificial system of canals, the lines of which can still be followed; and there are, in all the highlands where the sources of the Euphrates rise, in Persia, in Egypt, in India, and in China, works of this sort which must have been in existence before man had begun to record his own annals.

In warm countries, such as most of those just mentioned, the effects I have described as usually resulting from the clearing of

* I ought perhaps to except the MIexicans and the Peruvians, whose arts and institutions are not yet shown to be historically counected with those of any more ancient people. The lamentable destruction of so many memorials of these tribes, by the ignorance and bigotry of the so-called Christian barbarians who conquered them, has left us much in the dark as to many points of their civilization; but they seem to have reached that stage where continued progress in knowledge and in power over nature is secure, and a few more centuries of independence might have brought them to originate for themselves most of the great inventions which the last four centuries have bestowed upon man. 
the forests would very snon follow. In such climates, the rains are inclined to be periodieal; they are also violent, and for these reasons the soil would be parched in summer and lialble to wash in winter. In these countries, therefore, the necessity for irrigation must soon have been felt, and its introduction into mountainous regions like Armenia must have been immediately followed by a system of terracing, or at least scarping, the hillsides. Pasture and meadow, indeed, may be irrigated eren when the surface is both steep and irregular, as may be observed abundantly on the Swiss as well as on the Piedmontere slope of the $\mathrm{Al}_{\mathrm{l} \text { s; }}$ but in dry climates, ploughland and gardens on hilly grounds require terracing, both for supporting the soil and for administering water by irrigation, and it should be remembered that terracing, of itself, eren without special arrangements for controlling the distribution of water, prevents or at least checks the flow of rain-water, and gives it time to sink into the ground instead of running off over the surface.

The summers in Egypt, in Syria, and in Asia Minor and even Rumelia, are almost rainless. In such climates the necessity of irrigation is obvious, and the loss of the ancient means of furnishing it lielps to explain the diminished fertility of most of the countries in question.* The surface of Palestine, for example, is composed in a great measure of rounded limestone hills, once,

* In Egrpt, evaporation and absorption by the earth are so rapid, that all annual crops require irrigation during the whole period of their growth. As fast as the water retires by the subsidence of the anmual inundation, the seed is sown upon the still moist, uncovered soil, and irrigation begins at once. Lpon the Nile, you hear the creaking of the water-wheels, and sometimes the movement of steam-pumps, through the whole night, while the poorer cultivators unceasingly ply the simple shadoof, or bucket-and-streep, laboriously raising the water from trough to trough by as many as sir or seven stages when the river is low. The bucket is of flexible leather, with a stiff rim, and is emptied into the trough, not by inverting it like a wooden bucket, but by putting the hand beneath and pushing the bottom up till the water all runs over the brim, or, in other words, by turning the vessel inside out.

The quantity of water thus withdrawn from the Nile is enormous. Mfost of this is evaporated directly from the surface or the superficial struta, but some moisture percolates down and oozes through the banks into the river again, while a larger quantity sinks till it joins the slow current of infiltration by which the Nile water pervades the earth of the valley to the distance, at some points, of not less than fifty miles. 
no doubt, covered with forests. These were partially removed before the Jewish conquest.* When the soil began to suffer from drought, reservoirs to retain the waters of winter were hewn in the rock near the tops of the hills, and the declivities were terraced. So long as the cisterns were in good order, and the terraces kept up, the fertility of Palestine was unsurpassed, but when misgovernment and foreign and intestine war occasioned the neglect or destruction of these works-traces of which still meet the traveller's eye at every step,-when the reservoirs were broken and the terrace walls had fallen down, there was no longer water for irrigation in summer, the rains of winter soon washed away most of the thin layer of earth upon the rocks, and Palestine was reduced almost to the condition of a desert.

The course of events has been the same in Idumæa. The observing traveller discovers everywhere about Petra, particularly if he euters the city by the route of W Wadi Ksheibeh,extensive traces of ancient cultivation, and upon the neighboring ridges are the ruins of numerous cisterns evidently constructed to furnish a supply of water for irrigation. $\dagger$ In primitive ages, the precipitation of winter in these hilly countries was, in great part, retained for a time in the superficial soil, first by the vegetable mould of the forests, and then by the artificial arrangements I have described. The water imbibed by the earth was partly taken up by direct evap-

* "Forests," "woods" and "groves," are frequently mentioned in the Old Testament as existing at particular places, and they are often referred to by way of illustration, as familiar objects. See, for example, Joshua xvii. 15-18"Wood" is twice spoken of as a material in the New Testament, but other wise-at least according to Cruden-not one of the above words occurs in that volume. In like manner, while the box, the cedar, the fir, the oak, the pine, "beams" and "timber," are very frequently mentioned in the old Testament, not one of these words is found in the New, except the case of the "beam in the eye," in the parable in Matthew and Luke.

This interesting fact, were other evidence wanting, would go far to prove that a great change had taken place in this respect between the periods when the Old Testament and the New were respectively composed; for the Scriptural writers, and the speakers introduced into their narratives, are remarkable for their frequent allusions to the natural objects and the social and industrial habits which characterized their ages and their country.

† One of these on Mount Hor, two stories deep, is in such good preservation, although probably not repaired for many centuries, that I found ten feet of water in it in June, 1851. 
oration, partly absorbed by vegetation, and partly carried down by infiltration to subjacent strata which gave it out in springs at lower levels, and thus a fertility of soil and a condition of the atmosphere were maintained sufficient to adnit of the dense penulation that once inhabited those now arid wastes. At present, the rain-water runs immediately off from the surface and is carried down to the sea, or is drunk up by the sands of the wadis, and the hillsides which once teemed with plenty are bare of vegetation, and seared by the scorching winds of the desert.

In fact, climatic conditions render irrigation a necessity in all the oriental countries which have any importance in ancient or in modern history, and there can be no doubt that this diffusion of water over large surfaces has a certain reaction on climate. Some idea of the extent of artificially watered soil in India may be formed from the fact that in fourteen districts of the Presidency of Madras, not less than 43,000 reservoirs, constructed by the ancient native rulers for the purpose of irrigation, are now in use, and that there are in those districts at least 10,000 more which are in ruins and useless. These reservoirs are generally formed by damming the outlets of natural valleys; and the dams average half a mile in length, though some of them are thirty miles long and form ponds covering from 37,000 to 50,000 acres. The areas of these reservoirs alone considerably increase the water-surface, and each one of them irrigates an extent of cultivated ground much larger than itself. Hence there is a great augmentation of humid surface from these constructions.*

* The present government of India obtains the same result more economically and advantageously by constructing, in many provinces of that vast cmpire, canals of great length and capacity, which not only furnish a greater supply of water than the old reservoirs, but so distribute it as to irrigate a larger area than could be watered by any system of artificial basins. The excarations for the Ganges Canal were nearly equal to those for the Suez Cant, falling little short of $100,000,000$ cubic yards, without counting feeders and accessory lines amounting to a length of 3,000 miles. This canal, according to an article in the London Times, waters a tract of land 320 miles long by io broad. The Jumna Canal, 130 miles long, with 608 miles of distributing branches, waters a territory 120 miles long with a breadth of 15 miles.

Other statements estimate the amount of land actually under irrigation in British India at 6,000,000 acres, and add that canals now in construction will water as much more. The Indian irrigation canals are generally navigable 
The cultivable area of Egypt, or the space between desert and desert where cultivation would be possible, is now estimated at ten thousand square statute miles.* MLch of the surface, though not out of the reach of irrigation, lies too high to be economically watered, and irrigation and cultivation are therefore at present confined to an area of seven thonsand square miles, nearly the whole of which is regularly and constantly watered when not covered by the inundation, except in the short interval between the harvest and the rise of the waters. For nearly half of the year, then, irrigation adds seven thousand square miles to the humid surface of the Nile valley, or, in other words, more than decuples the area from which an appreciable quantity of moisture would otherwise be evaporated ; for after the Nile has retired within its banks, its waters by no means cover one-tenth of the space just mentioned.

The Nile receives not a single tributary in its course below Khartoum; there is not so much as one living spring in the whole land, $\uparrow$ and, with the exception of a narrow strip of coast, where the annual precipitation is said to amount to six inches,

some of them by boats of large tonnage, and the canals return a net revenue of from five to twenty per cent. on their cost.

* The area which the waters of the Nile, left to themselves, would now cover is greater than it would have been in ancient times, because the bed of the river has been elevated, and consequently the lateral spread of the inundation increased. See Surtu's Dictionary of Geography, article "Egyptus." But the industry of the Egyptians in the days of the Pharaohs and the Ptolemies carried the Nile-water to large provinces, which have now been long abandoned and have relapsed into the condition of desert. "Anciently," observes the writer of the article "Egypt" in Smith's Dictionary of the Bible, “2,735 square miles more [about 3,700 square statute miles] may have been cultivated. In the best days of Egypt, probably all the land was cultivated that could be made available for agricultural purposes, and hence we may estimate the ancient arable area of that country at not less than 11,000 square statute miles, or fully double its present extent."

According to an article in the Bollettino della Societi Geografica Italiana, vol. v., pt. iii., p. 219, the cultivated soil of Egypt in 1869 amounted to $4,500,000$ acres, and the remaining soil capable of cultivation was estimated at 2,000,000 acres. The extent of cultivation in Egypt is fast increasing. The tilled soil amounted to $4,744,298$ acres in 1873 . The increase since 1812 is stated at 1,500,000 acres.

+ The so-called spring at Heliopolis is only a thread of water infiltrated from the Nile or the canals. 
the fall of rain in the territory of the Pharaohs is not two inches in the year. The subsoil of the whole valley is pervaded with moisture by infiltration from the Nile, and water can everywhere be found at the depth of a few feet. Were irrigation suspended, and Egypt abandoned, as in that ease it must be, to the operatious of nature, there is no doubt that trees, the roots of which penctrate deeply, would in time establish themselves on the deserted soil, fill the valley with verdure, and perhaps at last temper the climate, and even call down abundant rain from the heavens.* But the immediate effect of discontinuing irrigation would be, first, an immense reduction of the evaporation from the ralley in the dry season, and then a greatly augmented dryness and heat of the atmosphere. Even the almost constant north wind-the strength of which would be increased in consequence of these changes-would little reduce the temperature of the narrow cleft between the burning mountains which hem in the channel of the Nile, so that a single year would transform the most fertile of soils to the most barren of deserts, and render uninhabitable a territory that irrigation makes capable of sustaining as dense a population as has ever existed in any part of the world. $\nmid$ Whether man found the valley of the Nile a forest, or such a waste as I have just described, we do not historically know. In either case, he has not simply converted a wilderness into a garden, but has unquestionably produced extensive climatic change. $\neq$

* The date and the doum palm, the sont and many other acacias, the caraub, the sycamore and other trees grow in Egypt without irrigation, and would doubtless spread through the entire valley in a lew years.

† Wilkinson states that the total population, which, two hundred years ago, was estimated at $4,000,000$, amounted till lately to only about $1,800,000$ souls, having been reduced since the year 1800 from $2,500,000$ to less than $2,000,000$. - Hundliool for Travellers in Egypt, p. 10. The population at the end of the year 1869 is computed at 5,215,000.-Bollettino della Soc. Geog. Ital., vol. v., pt. iii., p. 215. This estimate doubtless includes countries bordering on the upper Nile not embraced in Wilkinson's statistics.

$\ddagger$ Ritter supposes Egypt to have been a sandy desert when it was first occupied by man. "The first inhabitant of the sandy valley of the Nile was a desert-dweller, as his neighbors right and left, the Libyan, the nomade Arab, still are. But the civilized people of Erypt transformed, by canals, the waste into the richest granary of the world; they liberated themselves from the shackles of the rock and sand desert, in the midst of which, by a wise dis. tribution of the fluid through the solid geographical form, by irrigation in 
The fields of Eggpt are more regularly watered than those of any other country bordering on the Mediterranean, except the rice-grounds in Italy, and perhaps the marcite or winter meadows of Lombardy; but irrigation is nore or less employed throughout almost the entire basin of that sea, and is everywhere attended with effects which, if less in degree, are amalogous in char acter, to those resulting from it in Egypt.

There are few things in European husbandry which surprise English or American observers so much as the extent to which irrigation is employed in agriculture, and that, too, on soils, and with a temperature, where their own experience would have led them to suppose it would be injurious to vegetation rather than beneficial to it.* In Switzerland, for example, grass-grounds on

short, they created a region of culture most rich in historical monuments." Einleitung zur allgemeinen vergleichenden Geographie, pp. 165, 166.

This view seems to me highly improbable; for great rivers, in warm climates, are seldom if ever bordered by sandy plains. A small stream may be swallowed up by sands, but if the volume of water is too large to be carried off by evaporation or drunk up by absorption, it saturates its banks with moisture, and unless resisted by art, converts them into marshes covered with aquatic vegetation. By cauals and embankmeuts, man has done much to modify the natural distribution of the waters of the Nile; yet the annual inundation is not his work, and the river must have overflowed its banks and carried spontaneous vegetation with its waters, as well before as since Egypt was first occupied by the human family. There is, indeed, some reason to suppose that man lived upon the banks of the Nile when its channel was much lower, and the spread of its inundations much narrower, than at present; but wherever its flood reached, there the forest would propagate itself, and its shores would certainly have been morasses rather than sands.

The opinions of Ritter on this subject are not only improbable, but they are contradictory to the little historical testimony we possess. Herodotus informs us in Euterpe that except the province of Thebes, all Egypt, that is to say, the whole of the Delta and of middle Egypt extending to Hermopolis Magna in N. L. $27^{\circ} 45^{\prime}$, was originally a morass. This morass was doubtless in great part covered with trees, and hence, in the most ancient hieroglyphical records, a tree is the sign for the cultivable land between the desert and the channel of the Nile. In all probability, the real change effected by human art in the superficial geography of Egypt, is the conversion of pools and marshes into dry land, by a system of transverse dikes, which compelled the flood-water to deposit its sediment on the banks of the river instead of carrying it to the sea. The colmate of modern Italy were thus anticipated in ancient Egypt.

* For a remarkable case of successful irrigation, in Vermont, with water at little above the freezing point, see Report of $U$. S. Department of Agriculture: for 1868 , p. 580 . 
the very borders of glacier's are freely irrigated; in many parts of Norway water is applied to grass (partly as a protection against frost) both by flooding and flowing, and on the Italian slope of the $A l p$ s the meadows are irrigated at lieights exceeding 6,00n) feet. The summers in Northern Italy, though longer, are very often not warmer than in the Northern United States; and in ordinary years, the summer rains are as frequent and as abuntint in the former country as in the latter.* Yet in Piedmont and

* The me:m anmual precipitation in Lombardy is thirty-six inches, of which nearly two-thirds fall cluring the season of irrigation. The rainfall is about the same in Piedmont, though the number of days in the year classed as "rainy" is said to be but twenty-four in the former province while it is seventy in the latter.-Barmd Surrm, Italian Irrigation, vol. i., p. 196.

The necessity of irrigation in the great alluvial plain of Northern Italy is partly explained by the fact that the superficial stratum of fine earth and regetable mould is very extensively underlaid by beds of pebbles and gravel brought down by mountain torrents at a remote epoch. The water of the surface-soil drains rapidly down into these loose beds, and passes off by subterranean channels to some unknown point of discharge; but this circumstance alone is not a sufficient solution. Is it not possible that the habits of vegretibles, grown in countries where irrigation has been immemorially employed, have been so changed that they require water under conditions of soil and climate where their congeners, which have not been thus indulgently treated, do not? It is a remarkable fact that during the season of irrigation, when large tracts of surface are almost constantly saturated with water, there is an extraordinary dryness in the atmosphere of Lombardy, the hygrometer standing for days together a few degrees only above zero, while in winter the instrument indicates extreme humidity of the air, approaching to total saturation.-Bamp Sumte, Italian Irrigation, i., p. 189.

There are some atmospheric phenomena in Northern Italy, which an American finds it hard to reconcile with what he has observed in the United States. To an American eye, for instance, the sky of Piedmont, Lombardy, and the northern coast of the Mediterranean, is always whitish and curdled, and it never has the intensity and fathomless depth of the blue of his native heavens. Aud yet the heat of the sun's rays, as measured by sensation, and at the same time the evaporation, are greater than they would be with the thermometer at the same point in America. I have frequently felt in Italy, with the mercury below $60^{\circ}$ Fahrenheit, and with a mottled and almost opaque sky, a heat of solar irradiation which I can compare to nothing but the scorching sensation experienced in America at a temperature twenty degrees higher, during the intervals between showers, or before a rain, when the clear blue of the sky seems infinite in depth and transparency. Such circumstances may create a necessity for irrigation where it would otherwise be superfluous, if not absolutely injurious.

In speaking of the superior apparent clearness of the sky in America, I cou. 19* 
Lombardy irrigation is bestowed upon almost every crop, while in our Northern States it is never employed at all in farming husbandry, or indeed for any purpose except in kitchen-gardens, and possibly, in rare cases, in some other small branch of agricultural industry.*

In general, it may be said that irrigation is employed only in the seasons when the evaporating power of the sun and the capacity of the air for absorbing humidity are greatest, or, in other words, that the soil is nowhere artificially watered except when it is so dry that little moisture would be evaporated from it, and, consequently, every acre of irrigated ground is so much added to the evaporable surface of the country. $\nmid$ When the sup-

fine myself to the concave vault of the heavens, and do not mean to assert that terrestrial objects are generally visible at greater distances in the United States than in Italy. Indeed, I am rather disposed to maintain the contrary ; for though I know that the lower strata of the atmosphere in Europe never equal in transparency the air near the earth in New Mexico, Peru and Chili, yet $I$ think the accidents of the coast-line of the Riviera, as, for example, between Nice and La Spezia, and those of the incomparable Alpine panorama seen from Turin, are distinguishable at greater distances than they would be in most parts of the United States.

* In our comparatively rainless Western territory, irrigation is extensively and very beneficially employed. In the Salt Lake valley and in Califoruia, hundreds if not thousands of miles of irrigation canals have been constructed, and there is little doubt that artificially watering the soil will soon be largely resorted to in the older States. See valuable observations on this subject in Hayden, Preliminary Report on Geological Survy of Wyoming, 1870, pp. 194, $195,258,261$.

† The evaporative action of water in motion or at rest on the earth's surface, is affected by the temperature of the ground with which it is in contact; by the temperature of the water itself; by the hydroscopic condition of the air which rests upon it, and also by the movement of the air if not at rest. If all these conditions are favorable to evaporation,- as they generally are upon irrigated soil, especially with a ploughed surface,-the evaporation will pro ceed rapidly, and, of course, irrigation would have much importance as a meteorological or climatic influence. Large bodies of cold water, like that of the great American lakes, evaporate slowly, and, though they produce by conduction a certain amount of refrigeration, they do not sensibly affect the precipitation upon or near them. Milwaukee and Mackinaw, for instance, near the centre of the Great Lake system, are among the driest meteorologica] stations in the United States. I have often observed a striking phenomenon connected with this subject on Lake Champlain $\left(43^{\circ}\right.$ to $45^{\circ}$ N.L.). This lake does not usually freeze until February, sometimes not at all. A few hours wefore the ice closes over it, a great deal of fog is thrown off by it, and if the 
ply of water is mulimited, it is allowed, after serving its purpose on one field, to run into drains, canals or rivers. But in most regions where irrigation is regularly employed, it is necessury to economize the water; after passing over or through one parcel of ground, it is conducted to another; no more is usually withdrawn from the emals at any one point than is alsorberl by the soil it irrigates, or evaporated from it, and, conserpuently, it is not restored to lipuid circulation, except by infiltration or precipitation. We are safe, then, in saying that the humidity evaporated from any artificially watered soil is increased by a quantity bearing a large proportion to the whole amount distributed over it, for most even of that which is absorbed by the earth is immediately given out again either by regetables or by evaporation; and the hygrometrical and thermometrical condition of the atmosphere in irrigated comntries is modified proportionally to the extent of the practice.

It is not easy to ascertain precisely either the extent of surface thus watered, or the amount of water supplied, in any given country, because these quantities vary with the character of the season; but there are not many districts in Southern Europe where the management of the arrangements for irrigation is not one of the most important branches of agricultural labor. The eminent engineer Lombardini deseribes the system of irrigation in Lombardy as, "every day in summer, diffusing over 550,000 hectares $[1,375,000$ acres $]$ of land, 45,000,000 cubic mètres [nearly $60,000,000$ cubic yards] of water, which is equal to the entire volume of the Seine, at an ordinary flood, or a rise of three mètres above the hydrometer at the bridge of La Tournelle at

air is still, as it usually is in very cold weather, the surface of the lake, as far as the eye can reach, is dotted here and there with columns of fog, like the smoke from a chimney in clear, cold weather, rising to the height of three hundred feet or more, and then uniting into a long clond. How far the heat disengaged in the conversion of water iuto ice is an element in the production of this effect, I will not undertake to say. Though not exactly to the purpose, I may here notice the expansion of the ice in this lake with increased tenpera. ture. Two gentlemen well known to me, undertook, some fears since, to measure, on the ice of Lake Champlain, a lase line for ascertaining trigonometrically the height of a mountain peak, but every change of atmospheric temperature produced a change in the length of the line measured, and for this reason the experiment was abandoned. 
Paris." * Niel states the quantity of land irrigated in the former lkingdom of Sardinia, including Savoy, in 1856, at 240,000 hectures, or not much less than 600,000 acres. This is about fourthirteenths of the cultivable soil of the kingdom. According to the same author, the irrigated lands in France did not exceed 100,000 hectares, or 247,000 acres, while those in Lombardy anounted to 450,000 hectare, more than 1,100,000 acres. $\dagger$ In these three states alone, then, there were more than three thon sand square miles of artiticially watered land, and if we add the irrigated soils of the rest of Italy, + of the Mediterranean islands, of the Spanish peninsula, of Turkey in Europe and in Asia Minor, of Syria, of Egypt and the renainder of Northern Africa, we shall. see that irrigation increases the eraporable surface of the Mediterranean basin by a quantity bearing no inconsiderable proportion to the area naturally covered by water within it.

Arrangements are concluded, and new plans proposed, for an immense increase of the lands fertilized by irrigation in France and in Belgium, as well as in Spain and Italy, and there is every reason to believe that the artificially watered soil of the latter country will be doubled, that of France quadrupled, before the end of this century. There can be no doubt that by these operations man is exercising a powerful influence on the soil, on vegetable and animal life, and on climate, and lience that in this, as in many other fields of industry, he is truly a geographical agency. \$

* Memorie sui progetti per l'estensione dell' Irrigazione, etc., Il Politecnico, for January, 1863, p. 6.

+ NreL, L'Agriculture des États Sardes, p. 232. This estimate, it will be observed, is 275,000 acres less than that of Lombardini.

$\ddagger$ In 1865 the total quantity of irrigated lands in the kingdom of Italy was estimated at 1,357,677 hectares, or $2,000,000$ acres, of which one-half is supplied with water by artificial canals. The Canal Cavour adds 250,000 acres to the above amount. The extent of artificially watered ground in Italy is consequeutly equal to the entire area of the States of Delaware and Rhode Island.See the official report, Sulle Bonificazioni, Risaie, ed Irrigazioni, 1865, p. 269.

$\S$ It belongs rather to agriculture than to geography to discuss the quality of the crops obtained by irrigation, or the permanent effects produced by it on the productiveness of the soil. There is no doubt, however, that all crops which can be raised without watering are superior in flavor and in nutritive 
As near as can be ascertained, the amount of water applied to irrigated lands is scarcely anywhere less than the total precipita-

power to those grown by the aid of irrigation. Garden vegetables, particularly, profusely watered, are so insipid as to be hardly eatable.

Caule suburbano qui siccis crevit in agris

Dulcior, irriguo nihil est elutius horto.-Honaos, 5, 2, 4, 16.

Wherever irrigation is practiced there is an almost irresistible tendency, especially among ignorant cultivators, to carry it to excess; and in Piedmont and Lombardy, if the supply of water is abundant, it is so liberally applied as sometimes not only to injure the quality of the product, but to drown the plants and diminish the actual weight of the crop. Grass-lands are perhaps an exeeption to this remark, as it seems almost impossible to apply too much witer to them, provided it be kept in motion and not allowed to stagnate on the surface.

Professor Liebig, in his Modern Agriculture, says: "There is not to be found in chemistry a more wonderful phenomenon, one which more confounds all human wisdom, than is presented by the soil of a garden or field. By the simplest experiment, any one may satisfy himself that rain-water filtered through field or garden soil does not dissolve out a trace of potash, silicic acid, ammonia, or phosphoric acid. The soil does not gire up to the water one particle of the food of plants which it contains. The most continuous rains can not remove from the field, except mechanically, any of the essential constituents of its fertility."

"The soil not only retains firmly all the food of plants which is actually in it, but its power to preserve all that may be useful to them extends much farther. If rain or other water holding in solution ammonia, potash, and phosphoric and silicic acids, be brought in contact with soil, these substances disappear almost immediately from the solution; the soil withdraws them from the water. Only such substances are completely withdrawn by the soil as are indispensable articles of food for plants; all others remain wholly or in part in solution."

These opinions were confirmed, soon after their promulgation, by the experimental researches of other chemists, but are now questioned, and they are not strictly in accordance with the alleged experience of agriculturists in those parts of Italy where irrigation is most successfully applied. They believe that the constituents of regetable growth are washed out of the soil by exces. sive and long-continued watering. They consider it also established as a fact of observation, that witer which has flowed through or over rich ground is more valuable for irrigation than water from the same source, which has not been impremated with fertilizing substances by passing through soils containing them ; and, on the other hand, that water, rich in the clements of regetation, parts with them in serving to irrigate a poor soil, and is therefore less valuable as a fertilizer of lower grounds to which it may afterwarl be con-

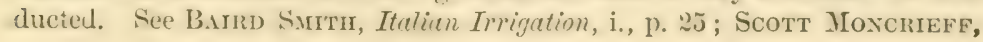




\section{tion during the season of regetable growth, and in general is much exceeds that quantity. In grass-grounds and in field-cul-}

Irrigation in Southern Europe, pp. 34 , 87, 89 ; Lourandri, Sulle Inondazioni, etc., p. 73 ; MANGoN, Les Irrigations, p. 48.

The practice of irrigition-except in mountainous countries where springs and rivulets are numerous-is attended with very serious ecomomical, social and political evils. The construction of canals and their immensely ramified branches, and the grading and scarping of the ground to be watered, are always expensive operations, and they very often require an amount of capital which can be commanded only by the stite, by moneyed corporatious, or by very wealthy proprietors; the calpacity of the canals must be calculated with reference to the area intended to be irrigated, and when they and their branches are once constructed, it is very difficult to extend them, or to accommodate any of their original arrangements to changes in the condition of the soil, or in the modes or objects of cultivation; the flow of the water being limited by the abundance of the source or the capacity of the canals, the indiridual proprietor can not be allowed to withdraw water at will, according to his own private interest or convenience, but both the time and the quantity of supply must be regulated by a general system applicable, as far as may be, to the whole area irrigated by the same canal, and every cultivator must conform his industry to a plan which may be quite at variance with his special objects or with his views of good husbandry. The clashing interests and the jealousies of proprietors depending on the same means of supply are a source of incessant contention and litigation, and the caprices or partialities of the oflicers who control, or of contractors who farm, the canals, lead not unfrequently to ruinous injustice toward individual landholders. These circumstances discourage the division of the soil into small properties, and there is a constant tendency to the accumulation of larre estates of irrigated land in the hands of great capitalists, and consequently to the dispossession of the small cultivators, who pass from the condition of owners of the land to that of hireling tillers. The farmers are no longer yeomen, but peasants. Iaving no interest in the soil which composes their country, they are virtually expatriated, and the middle class, which ought to constitute the real physical and moral strength of the land, ceases to exist as a rural estate, and is found only among the professional, the mercantile, and the iudustrial population of the cities.-See, on the difficulty of regulating irrigation by law, NeGrr, Iter su una Legge in materia di Acqua, 1864; and Armard, Irrigations du Midi de l'Europe, where curious and important remarks on the laws and usages of the Spanish Moors and the Spaniards, in respect to irrigation, will be found. The Moors were so careful in maintaining the details of their system, that they kept in public oflices bronze models of their dams and sluices, as guides for repairs and rebuilding. Some of these models are still preserved.-Ibidem, p1). 204, 205. For an account of recent irrigation works in Spain, see Spox, Dictionary of Engineering, article Irrigation. On the legal aspects of irrigation, see also the important work of CaLandra, IFanuale Iilraulico-Legale. 8ro, Sarigliano, 1871; PAssr, Étuche sur le Service Hydraulique, 8vo, Paris, 1868, and of less recent works, especially Rovagnosi, Trattato della Condotta 
ture it ranges from $2 \tau$ or $2 S$ to 60 inches, while in smaller crops, tilled by hand-labor, it is sometimes carried as high as 300 inches.*

delle Aeque, Firenze, 1813, 2 v. Svo, and Truttuto delle Ricyion Cieite delle Aeque, Firenze, 1s:it, Sro. Also, particularly on the economical question,

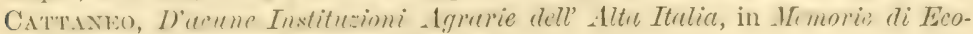
nomia Pubblica, vol. i., Miliano, 1860.

* Nres, Agriculture des États Sardes, p. 23\%. Lombardini's computation just given allows eighty-one cubic mètres per day to the hectare [two hundrent and sixty cubie yards to the acre], which, supposing the season of irrigation to be one hundred days, is equal to a precipitation of thirty-two inches. Ibut in I.ombardy, water is applied to some crops during a longer period than one humdred days; and in the mureite it flows over the ground even in winter. Acerding to Boussingant (Économie Rurale, ii., p. 246) grass-grounds ought to receive, in Germany, twenty-one centimetres of water per week, and with lese than half that (quantity it is not advisalle to incur the expense of supplying it. The ground is irrigated twenty-five or thirty times, and if the full yuantity of twenty-one centimitres is applied, it receives more than two hundred inches of water, or six times the total amount of precipitation. Puvis, (puoted by Boussingault, after much research comes to the conclusion that a proper quantity is trenty centimitres [eight inches] applied trenty-fire or thirty times, which corresponds with the estimate just stated. Puvis adds-and, as our author thinks, with reason-that this amount might be doubled without disadvantage. - Ibidcm, ii., pp. 248,249 . In some parts of France this quantity is immensely exceeded, and it is very important to observe, with reference to the employment of irrigation in our Northern States, that water is most freely supplied in the colder provinces. Thus, in the Vosges, meadows are literally tlooded for weeks together, and while in the department of Vaucluse a meadow may receive, in five waterings of six and a half hours each, twenty-one inches of water, in the Vosges it might be deluged for twenty. four hundred hours in six applications, the enormous quantity of thirteen hundred feet of water flowing over it. See the important work of Henvé Mangox, Sur l'emploi des eaux dans les Irrigations, chap. ix.

Boussingault observes that rain-water is vastly more fertilizing than the water of irrigating canals, and therefore the supply of the latter must be greater. This is explained partly by the different character of the substances held in solution or suspension by the waters of the earth and of the sky, partly by the hisher temperature of the latter, and, possibly, partly also by the mode of application-the rain being finely divided in its fall or by striking plants on the ground, river-water flowing in a continuous sheet.

The temperature of the water is thought even more important than its composition. The sources which irrigate the marcite of Lombardy-meadows so fertile that less than an acre furnishes grass for a cow the whole year-are very warm. The ground watered by them never freezes, and a first crop for soiling is eut from it in January or February. The Canal Cavour-which takes its supply chiefly from the Po at Chivasso, fourteen or fifteen miles below Turin-furnishes water of much higher fertilizing power than that de. 
The rice-grounds and the marcite of Lombardy are not included in these estimates of the amount of water applied.*

The meteorological effect of irrigation on a large scale, which would seem prima facie most probable, would be an increase of precipitation in the region watered. $\dagger$ Hitherto scientific observation has recorded no such increase, but in a question of so purely local a character, we must ascribe very great importance to a consideration which I have noticed elsewhere, but which has been frequently overlooked by meteorologists, namely, that vapors exhaled in one district may very probably be condensed and precipitated in another very distant from their source. If then it were proved that an extension of irrigated soil was not followed by an increase of rainfall in the same territory, the probability that the precipitation was augmented somewhere would not be in the least diminished.

But though we can not show that in the irrigated portions of

rived from the Dora Baltea and the Sesia, both because it is warmer, and because it transports a more abundant and a richer sediment than the latter streams, which are fed by Alpive ice-fields and melting snows, and which flow, for long distances, in cliannels ground smooth and bare by ancient glaciers and not now contributing much vegetable mould or fine slime to their waters.

* About one-seventh of the water which flows over the marcite is absorbed by the soil of those meadows or evaporated from their surface, and consequently six-sevenths of the supply remain for use on ground at lower levels.

$\dagger$ On the pluviometric effect of irrigation, see Lombardini, Sulle Inondazioni, etc., pp. 72, 74; the same author, Essai Hydrologique sur le Nil, p. 32 ; Messedagli, Analisi dell' opere di Champion, pp. 96, 97, note; and Bamd SmirH, Itatian Irrigation, i., pp. 189, 190.

In an article in Aus der Natur, vol. 57, p. 443, it is stated that the rain on the Isthmus of Suez has increased, since the opening of the canal has enlarged the evaporable surface of the country; but this can not be accepted as an establishod fact without further evidence. Nevertheless, although I an not able to adduce exact pluviometrical measurements, it appears now (1882) to be admitted that since the filling of the Bitter Lakes and other depressions on the Isthmus of Suez, by the opening of the canal, there has been a marlied increase in the quantity of precipitation falling there, and that rain, which was formerly a rare and exceptional phenomenon, now falls, at certain seasons, with considerable regularity. The Bitter Lakes are computed by Lesseps to coutain $2,000,000,000$ cubic metres of water, and the aunual evaporation from this surface is estimated at $200,000,000$ cubic mètres. It is also said that the rainfall has diminished in the old bed and the environs of the Lake of Haarlem since its drainage. But I am unable to refer to any competent authority in support of this assertion. 
Italy the summer rain is more abundant than it was before irrigation was practiced-for we know nothing of the meteorological conditions of that country at so remote a period-the fact that there is a very considerable precipitation in the summer months in Lombardy is a strong argument in favor of such increase. In the otherwise similar climate of Rumelia and of much of Asia Minor, irrigation is indeed practiced, but in a relatively small proportion. In those provinces there is little or no summer rain. Is it not highly probable that the difference between Italy and Turkey in this respect is to be ascribed, in part at least, to extensive irrigation in the former country, and the want of it in the latter? It is true that, in its accessible strata, the atmosphere of Lombardy is extremely dry during the period of irrigation, but it receires an immense quantity of moisture by the evaporation from the watered soil, and the rapidity with which the aqueous vapor is carried up to higher regions-where, if not driven elsewhere by the wind, it would be condensed by the cold into drops of rain or at least visible clourls-is the reason why it is so little perceptible in the air near the ground.*

But the question of an influence on temperature rests on a different ground; for though the condensation of vapor may not take place within days of time and degrees of distance from the hour and the place where it was exhaled from the surface, a local refrigeration must necessarily accompany a local evaporation. Hence, though the summer temperature of Lombardy is high, we are warranted in affirming that it must have been still higher before the introduction of irrigation, and would again become so if that practice were discontinued. $\nmid$

The quantity of water artificially withdrawn from running streams for the purpose of irrigation is such as very sensilily to affect their volume, and it is, therefore, an important element in the geography of rivers. Brooks of no trifling current are often

* Is not the mottled appearance of the upper atmosphere in Italy, which I lave already noticed, perhaps due in part to the condensation of the aqueous vapor exhaled by watered ground ?

f I do not know that observations have been made on the thermometric influence of irrigation, but I have often noticed that, on the irrigated plains of Piedmont ten miles south of Turin, the morning temperature in summer was several degrees below that marked at the Observatory in the city. 
wholly diverted from their natural channeks to supply the canals, and their entire mass of water is completely absorbed or evaporated, so that only such proportion as is transmitted by infiltration reaches the river they originally fed. Irrigation, therefore, diminishes great rivers in warm countries by cutting off their sonurces of supply, as well as lyy direct abstraction of water from their main chamnels. Te have just seen that the system of irrigation, in Lombardy, deprives the Po of a quantity of water erpual to the total delirery of the Seine at ordinary flood, or, in other words, of the equivalent of a trilsutary navigable for hmdreds of miles by vessels of considerable burden. The new canals, executed and projected, will greatly increase the loss. The water required for irrigation in Egypt is less than would be supposed from the exceeding rapidity of evaporation in that arid climate; for the soil is thoroughly saturated during the inundation, and infiltration from the Nile continues to supply a considerable amount of humidity in the driest season. Limant Bey computed that, in the Delta, fifteen and one-third cubic yards per day sufficed to irrigate an acre. If we suppose water to be applied for one hundred and fifty days during the season of growth, this would be equiralent to a total precipitation of about seventeen inches and one-third. Taking the area of actually cultivated soil in Egypt at the estimate of 4,500,000 acres, and the average amount of water daily applied in both Upper and Lower Egypt at twelve hundredths of an inch in depth, we have an abstraction of about 74,000,000 cubic yards, which-the mean daily delivery of the Nile being in round numbers $320,000,000$ cubic yardsis twenty-three per cent. of the average quantity of water contributed to the Mediterranean by that river.**

In estimating the effect of this abstraction of water upon the rolume of great rivers, especially in temperate climates and in countries with a hilly surface, we must remember that all the

* The proportion of the waters of the Nile withdrawn for irrigation is greater than this calculation makes it. The quantity required for an acre is less in the Delta than in Upper Egypt, both because the soil of the Delta, to which Linant Bey's estimate applies, lies little higher than the surface of the river, and is partly saturated by infiltration, and because near the sea, in N. L. $30^{\circ}$, evaporation is much less rapid than it is several degrees southwards and in the vicinity of a parched desert. 
water thus withdrawn-except that which is al)sorbed by vegetation, that which enters into new inorgamic eomponuds, and that which is carried off by evaporation-is finally restored to the original eurrent by superficial flow or by infiltration. It is generally estimated that from one-third to one-half of the water applied to the fields is absorbed by the earth, and this, with the deductions just given, is returned to the river by direct infiltration, or descends through invisible chammels to moisten lower grommls, and thence in part escapes again into the bed of the river, by similar conduits, or in the form of springs and rivulets. Interesting observations have lately been made on this suljject in France and important practical results arrived at. It was maintained that monntain irrigation is not ultimately injurious to that of the plains below, hecause lands liberally watered in the spring, when the supply is abundant, act as reservoirs, storing up by absorption water which afterwards filters down to lower grounds or escapes into the chanuel of the river and lieeps up its current in the dry summer months, so as to compensate for what, duriug those months, is withdrawn from it for upland irrigation. Carcful inrestigation showed that though this proposition is not miversally true, it is so in many cases, and there can be no doulit that the loss in the volume of rivers by the abstraction of water for irrigation is very considerably less than the measure of the quantity withdrawn.*

* See Vigax, Étude sur les Irrigations, Paris, 1867; and Scott MIoxcriefF, Irrigation in Southern Europe, pp. 89, 90.

The brook Ain Musa, which runs through the ruined city of Petra and finally disappears in the sands of Wadi el Araba, is a considerable stream in winter, and the inhabitants of that town were obliged to excavate a tunuel through the rock near the right bank, just above the upper entrance of the narrow Sik, to discharge a part of its swollen current. The sagacity of Dr. Pobinson detected the necessity of this measure, though the tumnel, the mouth of which was hidden by brushwood, was not discovered till some time after his visit. I even noticed, near the arch that crosses the Sik, unequivocal remains of a sluice by which the water was diverted to the tunnel. Immense labor was also expended in widening the natural channel at several points below the town, to prevent the damming up and setting back of the water-a fact, I believe, not hitherto noticed by travellers.

The Fellahheen above Petra still employ the waters of Ain Musa for irrigation, and in summer the superficial current is wholly diverted from its natural chamnel for that purpose. At this season the bed of the brook, which is com 
Irrigation, as employed for certain special purposes in Europe and America, is productive of very prejudicial climatic effects. I refer particularly to the cultivation of rice in the Southern States of the American Union and in Italy. The climate of the Southern States is in general not necessarily unhealthy for the white man, but he can scarcely sleep a single night in the vicinity of the rice-grounds without being attacked by a dangerons fever. The neighborhood of the rice-fields is possibly less pestilential in Lombardy and Piedmont than in South Carolina and Georgia, but still very insalubrious to both man and beast. "Not only does the population decrease where rice is gromn," says Escourrou-Milliago, "but even the flocks are attacked by typhus." In the rice-grounds the soil is divided into compartments rising in gradual succession to the level of the irrigating canal, in order that the water, after having flowed one field, may be drawn off to another, and thus a single current serve for several compartments, the lowest field, of course, still being higher than the ditch which at last drains both it and the adjacent soil. This arrangement gives a certain force of hydrostatic pressure to the water with which the rice is irrigated, and the infiltration from these fields is said to extend through neighboring grounds, sometimes to the distance of not less than a myriamètre, or six Eng-

posed of pebbles, gravel and sand, is dry in the Sik and through the town ; but the infiltration is such that water is generally found by digging to a small depth in the channel. Observing these facts in a visit to Petra in the summer, I was curious to know whether the subterramean waters escaped again to daylight, and I followed the ravine below the town for some distance. Not very far from the upper entrance of the ravine, arborescent vegetation appeared upon its bottom, and as soon as the ground was well shaded, a thread of water burst out. This was joined by others a little lower down, and at the distance of a mile from the town, a strong current was formed and ran down towards Wadi el Araba, where it was again swallowed up by the thirsty sands.

Similar facts are observed in all countries where the superficial current of watercourses is diverted from their bed for irrigation, but this case is of special interest because it shows the extent of absorption and infiltration even in the torrid climate of Arabia. See Burnd Surtr, Itctian Irrigation, vol, i., pp. 172,386 and 387 .

* According to Florence Nightingale, in India, fever rarely occurs in a village surrounded by rice swamps, as long as the water is moving-living, as the natives say. The fever time begins when the water falls and stagnates.Life and Death in India. 
lish miles, and to be destructive to crops and even to trees within its reach. Iand thus affected can no longer be employed for any purpose but growing rice, and when prepared for that crop, it lmopagates still further the evils under which it had itself suffered, and of course the mischief is a growing one." *

\section{Salts deposited by Water of Irrigation.}

The attentive traveller in Egypt and Nubia can not fail to notice many localities, generally of small extent, where the soil is rendered infertile by an excess of saline matter in its composition. In many cases, perhaps in all, these barren spots lie rather ahove the level usually flooded by the inundations of the Nile, and yet they exhibit traces of former cultivation. Observations in India suggest a possible explanation of this fact. A saline eftlorescence called "Reh" and "Kuller" is gradually invading

* Escotrrod-MIrliago, L'Italie à propos de l'Exposition de Paris, 1856, p. 92. According to an article in the Gazzetta d'Torino for the 17th of January, 1869, the deaths from malarious fever in the Canavese district-which is asserted to have been altogether free from this disease before the recent introduction of rice-culture-between the 1st of January and the 15th of October, 1868, were two thousand two hundred and fifty. The extent of the injurious influence of this very lucrative branch of rural industry in Italy is contested by the rice-growers. But see Secondo Ladra, Le Riscje, Torino, 1869 ; Selmi, Il Miasma Palustre, p. 89 ; and especially Carlo Lint, Delle coltirazione del Riso in Italia, in the Nuora Antologia for July, 1871, p. 599, et seq.

According to official statistics, the rice-grounds of Italy, including the islands, amounted in 1866 to 450,000 acres. It is an interesting fact iu relation to geographical and climatic conditions, that while little rice is cultivated south of N. L. $44^{\circ}$ in Italy, little is grown in the United States north of $35^{\circ}$. To the southward of the great alluvial plain of the Po, the surface is in general too much broken to admit of the formation of level fields of much extent, and where the ground is suitable the supply of water is often insufficient.

The Moors introduced the cultivation of rice into Spain at an early period of their dominion in that country. It appears to have been cultivated in Italy as early as the 13th century. Agrostino Gallo, the author of the curious vol. ume, Le Venti Giornate dell' Agricoltura, who died in 15\%0, is said to have first introduced rice into Lombardy. The Spaniards extended its cultivation in Lombardy and introduced it into the Neapolitan territory in the 16th century ; but besides the want of water and of level ground convenient for irrigation, rice-husbandry has proved so much more pestilential in Southern than in Northern Italy that it has long been discouraged by the Neapolitan government. 
many of the most fertile districts of Northern and Western India, and changing them into sterile deserts. It consists principally of sulpliate of soda (Glauber's salts), with varying proportions of common salt. These salts (which in small quantities are favorable to fertility of soil) are said to be the gradual result of concentration by evaporation of river and canal waters, which contain them in very minute quantitics, and with which the lands are either irrigated or occasionally orerflowed. The river inumdations in hot comntries usually take place but once in a year, and, though the banks remain submerged for days or even weeks, the water at that period, being derived principally from rains and snows, must be less highly charged with mineral matter than at lower stages, and besides, it is always in motion. The water of irrigation, on the other hand, is applied for many months in succession, it is drawn from rivers aud canals at the seasous when the proportion of salts is greatest, and it either sinks into the superficial soil, carrying with it the saline substances it holds in solution, or is evaporated from the surface, learing them upon it. Hence irrigation must impart to the soil more salts than natural inundation. The sterilized grounds in Egypt and Nubia lying above the reach of the floods, as I have said, we may suppose to have been first cultivated in that remote antiquity when the Nile valley received its earliest inhabitants, and when its lower grounds were in the condition of morasses. They must have been artificially irrigated from the beginning; they may have been under cultivation many centuries before the soil at a lower level was invaded by man, and hence it is natural that they should be more strongly impregnated with saline matter than fields which are exposed every year, for some weeks, to the action of rumning water so nearly pure that it would be more likely to dissolve salts than to deposit them.

\section{Subterranean Waters.}

I have frequently alluded to a branch of physical geography the importance of which is but recently adequately recognizedthe subterranean waters of the earth considered as stationary reservoirs, as flowing currents, ${ }^{*}$ and as filtrating fluids. The

\footnotetext{
* Among the anomalies of the geography of Australia, mention is often made of the fact that the rivers run the vorong way. In truth, a large portion
} 
earth drinks in moisture by direct absorption from the atmosphere, by the deposition of dew, by rain and snow, by percolation from rivers and other superficial bodies of water, and sometimes by currents flowing into eaves or smaller visible apertures.*

of this island continent is drained by streams emptying into a central depression of the surface where their waters are spread over a wide expanse. Here they are partly evaporated, and partly absorbed by deserts of sand beneath which they collect, and are ultimately conveyed to the sea by natural subterranean conduits.

Two large, underground rivers, flowing respectively east and west from the centre of the island to the sea, are said to have been encountered by minersor detected by artesian borings. This furnishes an explanation of the fresh, water currents which burst out from the bottom of the sea at a considerable distance from the Australian coast.

A somewhat analogous fact has been observed in Southeastern Africa. Here, according to Cooley, Phys. Geog., p. -, considerable streams, anciently flowing in argillaceous formations, have in comparatively recent times cut through their beds of tough clay, diffused their waters through the inferior more pervious strata, and left their original superficial channels quite dry.

For an interesting account of the flow of subterranean currents of water in Texas, see Academy, November 20, 1881, p. 370.

* The great limestone plateau of the Karst in Carniola is completely honeycombed by caves through which the drainage of that region is conducted. Rivers of considerable volume pour into some of these caves and can be traced underground to their exit. Thus the Recca has been satisfactorily identified with a stream flowing through the cave of Trebich, and with the Timavothe Timavus of Virgil and the ancient geographers-which empties through several mouths into the Adriatic between Trieste and Aquileia. The city of Trieste is very insufficiently supplied with fresh water. It has been thought practicable to supply this want by tunnelling through the wall of the plateau, which rises abruptly in the rear of the town, until some subterranean stream is encountered, the current of which can be conducted to the city. More visionary projectors have gone further, and imagined that advantage might be taken of the natural tunnels under the Karst for the passage of roads, railwilys, and even navigable canals. But however chimerical these latter schemes may seem, there is every reason to believe that art might avail itself of these all eries for improving the imperfect drainage of the champaign country bounded by the Karst, and that stopning or opening the natural chanuels might very much modify the hydrography of an extensive region. See in Aus der Nitur, xx., pp. 250-254, 263-266, two interesting articles founded on the researches of Schmidt.

The cases are certainly not numerous where marine currents are known to pour continuously into cavities beneath the surface of the earth, but there is at least one well-authenticated instance of this sort-that of the mill-streams at Argostoli in the island of Cephalonia. It had been long observed that the sea-water flowed into several rifts and carities in the limestone rocks of the 
Some of this humidity is exhaled again by the soil, some is taken up by organic growths and by inorganic compounds, some poured out upon the surface by springs and either immediately evaporated or carried down to larger streams and to the sea, some flows by subterranean courses into the bed of fresh-water rivers* or of

coast, but the phenomenon has excited little attention until very recently. In 1833 , three of the entrances were closed, and a regular chamel, sixteen feet long and three feet wide, with a fall of three feet, was cut into the mouth of a larger cavity. The sea-water flowed into this canal, and could be followed eighteen or twenty feet beyond its inner terminus, when it disappeared in holes and clefts in the rock.

In 1858 the canal had been enlarged to the width of five feet and a half, and a depth of a foot. The water pours rapidly through the canal into an irregular depression and forms a pool, the surface of which is three or four feet below the adjacent soil, and about two and a half or three feet below the level of the sea. From this pool it escapes through several holes and clefts in the rock, and has not yet been found to emerge elsewhere.

There is a tide at Argostoli of about six inches in still weather, but it is considerably higher with a south wind. I do not find it stated whether water flows through the canal into the cavity at low tide, but it distinctly appears that there is no refluent current, as of course there could not be from a basin so much below the sea. Mousson found the delivery through the canal to be at the rate of 24.88 cubic feet to the second; at what stage of the tide does not appear. Other mills of the same sort have been erected, and there appear to be several points on the coast where the sea flows into the land.

Virious hypotheses have been suggested to explain this phenomenon, some of which assume that the water descends to a great depth beneath the crust of the earth; but the supposition of a difference of level in the surface of the sea on the opposite sides of the island, which seems confirmed by other circumstances, is the most obvious method of explaining these singular facts. If we suppose the level of the water on one side of the island to be raised by the action of currents three or four feet higher than on the other, the existence of cavities and channels in the rock would easily account for a subterranean current beneath the island, and the apertures of escape miglit be so deep or so small as to elude observation. See Aus der Natur, vol. xix., pp. 129 , et seq. I have lately been informed by a resident of the Ionian Islands, who is familiar with the locality, that the sea flows uninterruptedly into the sub-insular cavities, at all stages of the tide.

* "The affluents received by the Seine below Rouen are so inconsiderable, that the augmentation of the volume of that river must be ascribed principally to springs rising in its bed. This is a point of which engineers now take notice, and M. Belgrand, the able officer charged with the improvement of the navigation of the Seine between Paris and Rouen, has devoted much attention to it."-BABINET, Études et Lectures, iii., p. 185.

On page 232 of the volume just quoted, the same author observes: "In the lower part of its course, from the falls of the Oise, the Seine receives so 
the ocean, and some remains, though even here not in ever motionless repose, to fill deep cavities and underground channels. In every case the aqueous vapors of the air are the ultimate source of suplyly, and all these hidden stores are again returned to the atmosphere by evaporation.

The proportion of the water of precipitation taken up by direct evaporation from the surface of the ground seems to have been generally exaggerated, sufficient allowance not being made for moisture carried downwards or in a lateral direction, by infiltratiun or by crevices in the superior rocky or earthy strata. According to Wittwer, Mariotte found that but one-sixth of the precipitation in the basin of the Seine was delivered into that sea by the river, "so that five-sixths remained for evaporation and consumption by the organic world." * Maury estimates the annmal amount of precipitation in the valley of the Mississippi at 620 cubic miles, the discharge of that river into the sea at 107 cubic miles, and concludes that "this would leave 513 cubic miles of water to be evaporated from this river-basin annually." + In

few important aftuents, that evaporation alone would suffice to exhaust all the water which passes under the bridges of Paris."

This supposes a much greater amount of evaporation than has been usually computed, but I believe it is well settled that the Seine conveys to the sea much more water than is discharged into it by all its superficial branches. Babinet states the evaporation from the surface of water at Paris to be twice as great as the precipitation.

Belgrand supposes that the floods of the Seine at Paris are not produced by the superficial flow of the water of precipitation into its channel, but from the augmented discharge of its remote mountain sources, when swollen by the rains and melted snows which percolate through the permeable strata in its upper course.-Annales des Ponts et Chaussées, 1851, vol. i.

* Physicalische Geographie, p. 286. It does not appear whether this inference is Mariotte's or Wittwer's. I suppose it is a conclusion of the latter.

According to Valle's, the Scine discharges into the sea thirty per cent. of the precipitation in its valley, while the Po delivers into the Adriatic two-thirds and perhaps even three-quarters of the total downfall of its basin. The differences between the tributaries of the Mississippi in this respect are remarkable, the Missouri discharging only fifteen per cent, , the Yazoo not less than ninety. The explanation of these facts is found in the geographical and geological character of the valleys of these rivers. The Missouri flows with a rapid cur. rent through an irregular country, the $Y$ azoo has a very slow flow through a low, alluvial region which is kept constantly almost saturated by infiltration.

t Pliysical Geography of the Sea. Tenth edition. London, 1861, § 274 . 
these and other like computations, the water carried down into the earth by capillary and larger conduits is wholly lost sight of, and no thought is bestowed upon the supply for springs, for common and artesian wells, and for underground rivers, like those in the great caves of Kentucky, which may gush up in fresh-water currents at the bottom of the Caribbean Sea, or rise to the light of day in the far-off peninsula of Florida.*

The progress of the emphatically modern science of geology has corrected these erroneous views, because the observations on which it depends have demonstrated not only the existence, but the movement, of water in mearly all geological formations, have collected evidence of the presence of large reservoirs at greater or less depths beneath surfaces of almost every character, and have investigated the rationale of the attendant phenomena. $\dagger$ The distribution of these waters has been minutely studied with reference to a great number of localities, and though the actual mode and rate of their vertical and horizontal transmission is still involved in much obscurity, the laws which determine their aggregation are so well understood, that, when the geology of a given district is known, it is not difficult to determine at what depth water will be reached by the borer, and to what height it will rise.

The same principles have been successfully applied to the dis-

* In the low peninsula of Florida, rivers, which must have their sources in mountains hundreds of miles distant, pour forth from the earth with a volume sufficient to permit steamboats to ascend to their basins of eruption. In January, 1857, a submarine fresh-water river burst from the bottom of the sea not far from the southern extremity of the peninsula, and for a whole month discharged a current not inferior in volume to the river Mississippi, or eleven times the mean delivery of the Po, and more than six times that of the Nile. We can explain this phenomenon only by supposing that the bed of the sea was suddenly burst up by the hydrostatic upward pressure of the water in a deep reservoir communicating with some great subterranean river or receptacle in the mountains of Georgia or of Cuba, or perhaps even in the valley of the Mississippi.-THoxassy, Essaisur l'Hydrologie.

Late Southern journals inform us that the creek under the Natural Bridge in Virginia has suddenly disappeared, being swallowed up by newiy formed fissures, of unknown depth, in its channel. It does not appear that an outlet for the waters thus absorbed has been discovered, and it is not improbable that they are filling some underground cavity like that which supplied the submarine river just mentioned.

t See especially StoppaNI, Corso di Geologia, i., pp. 270, et seq. 
covery of small subterranean collections or eurrents of water, and some persons have acquired, by a moderate knowledge of the superficial structure of the earth combined with long practice, a skill in the selection of favorable places for digging wells which seems to common observers little less than miraculous. The Abbé Paramelle-a French ecelesiastic who devoted himself for some years to this suloject and was extensively employed as a well-fincler-states, in his work on Fountains, that in the course of thirty-four years he had pointed out more than ten thousand subterranean springs, and though his geological speculations were often erroneous, high scientific authorities have testified to the great practical value of his methods, and to the general accuracy of his predictions.*

Hydrographical researches have demonstrated the existence of subterranean currents and reservoirs in many regions where superficial geology had not indicated their probable presence. Thus, a much larger proportion of the precipitation in the valley of the Tiber suddenly disappears than can be accounted for by eraporation and visible flow into the channel of the river. Castelli suspected that the excess was received by underground caverns, and slowly conducted by percolation to the bed of the Tiber. Lombardini-than whom there is no higher authorityconcludes that the quantity of water gradually discharged into the river by subterranean conduits, is not less than three-quarters of the total delivery of its basin. $\dagger$ According to Tucci, Campagna di Roma, the étiage or extreme low-water delivery of the Tiber does not fall below 70 per cent. of its mean delivery for the year.

What is true of the hydrology of the Tiber is doubtless more or less true of that of other rivers, and the immense value of natural arrangements which diminish the danger of sudden floods by retaining a large proportion of the precipitation, and of an excessive reduction of river currents in the droughts of summer, by slowly conducting into their beds water accumulated and

* Paramelle, Quellentunde, mit einem Vorzort ron B. Cotta, 1856.

† See Losrbardner, Importanza degli studi sulla Statistica dei Fiumi, p. 27; also, same author, Sulle Inondazioni avcenute in Francia, etc., p. 29.

For an experiment to show the escape of water from the Danube into the Aach, see Nature, Jan. 17th, 1878, p. 253. 
stored up in subterranean reservoirs in rainy seasons, is too obvious to require to be dwelt upon.

The readiness with which water not obstructed by impermeaable strata diffuses itself through the earth in all directions-and, consequently, the importance of keeping up the supply of subterranean reservoirs-find a familiar illustration in the effect of paving the ground about the stems of vines and trees. The surface-earth around the trunk of a tree may be made almost inpervious to water, by flagstones and cement, for a distance as great as the spread of the roots; and yet the tree will not suffer for want of moisture, except in droughts severe enough sensibly to affect the supply in deep wells and springs. Both forest and fruit trees attain a considerable age and size in cities where the streets and courts are closely paved, and where even the lateral ascess of water to the roots is more or less obstructed by deep cellars and foundation walls. The deep-lying veins and sheets of water, supplied by infiltration from often comparatively distant sources, send up moisture by capillary attraction, and the pavement prevents the soil beneath it from losing its humidity by evaporation. Hence, city-grown trees find moisture enough for their roots, and though plagued with smoke and dust, often retain their freshness, while those planted in the open fields, where sun and wind dry up the soil faster than the subterranean fountains can water it, are withering from dronght.* Without the help of artificial conduit or of water-carrier, the Thames and the Seine refresh the ornamental trees that shade the thoroughfares of London and of Paris, and beneath the hot and reeking mould of Egypt, the Nile sends currents to the extremest border of its valley. $†$

* The roots of trees planted in towns do not depend exclusively on infiltration for their supply of water, for they receive a certain amount of both moisture and air through the interstices between the paving-stones; but where wide surfaces of streets and courts are paved with air and water tight asphaltum, as in Paris, trees suffer from the diminished supply of these necessary elements.

† See the interesting observations of KRIEGK on this subject, Schriften zur allgemeinen Erdkunde, cap. iii., $§ 6$, and especially the passages in RITTER's Erdkunde, vol. i., there referred to.

The tenacity with which the parched soil of Egypt retains the supply of moisture it receives from the Nile is well illustrated by observations of Girard 


\section{Artesian Wells.}

The existence of artesian wells depends upon that of subterranean reservoirs and rivers, and the supply yielded by borings is regulated by the abundance of such sources. The waters of the earth are, in many cases, derived from superficial currents which

cited by Lombardini from the Mémoires de l'Académie des Scicnces, t. ii., 181\%. Girard dug wells at distances of $3,200,1,800$, and 1,200 mètres from the Nile, and after three months of low water in the river, found water in the most remote well, at $4 \mathrm{~m} .97$, in the next at $4 \mathrm{~m}$. 23 , and in that nearest the bank at $3 \mathrm{~m}$. 44 above the surface of the Nile. The fact that the water was highest in the most distaut well appears to show that it was derived from the inundation and not, by lateral infiltration, from the river. But water is found beneath the sands at points far above and beyond the reach of the inundations, and can be accounted for only by subterranean percolation from the current of the Nile at higher points of its course. At high flood, the hydrostatic pressure on the banks, combined with capillary attraction, sends water to great horizontal distances through the loose soil ; at low water the current is reversed, and the moisture received from the river is partly returned, and may often be seen oozing from the banks into the river.-Сцот BEx, Apercu sur l'Egypte, i., 128.

Laurent (Mémoires sur le Sallara Oriental, pp. 8, 9), in speaking of a river at El-Faid, "which, like all those of the desert, is, most of the time, without water," observes, that many wells are dug in the bed of the river in the dry season, and that the subterranean supply of water thus reached extends itself laterally, at about the same level, at least a kilometre from the river, as water is found by digging to the depth of twelve or fifteen mètres at a village situated at that distance from the bank.

Recent experiments, however, have shown that in the case of rivers flowing through thickly peopled regions, and especially where the refuse from industrial establishments is discharged into them, the finely comminuted material received from sewers and factories sometimes clogs up the interstices between the particles of sand and gravel which compose the bed and banks, and the water is consequently confined to the channel and no longer diffuses itself laterally through the adjacent soil. This obstruction of course acts in both directions, according to circumstances. In one case, it prevents the escape of river-water and tends to maintain a full flow of the current; in another it intercepts the supply the river might otherwise receive by infiltration from the land, and thus tends to reduce the volume of the stream. In some instances, pits have been sunk along the banks of large rivers and the water which filters into them pumped up to supply aqueducts. This method often succeeds, but where the bed of the stream has been rendered impervious by the discharge of impurities into it, it can not be depended upon.

The tubular wells generally known as the American wells furnish another proof of the free diffusion and circulation of water through the soil. I do not know the diate of the first employment of these tubes in the United States, but as early as 1861, the Chevalier Calandra used wooden tubes for this pur- 
are seen to pour into chasms opened, as it were, expressly for their reception; and in others, where no apertures in the crust of the earth have been detected, their existence is proved by the fact that artesian wells sometimes bring up, from great depths, seeds, leaves and even living fish, which must have been carried down through channels large enough to admit a considerable stream.* But in gencral, the sheets and currents of water reached

pose in Piedmont, with complete success. See the interesting pamphlet, Sulla Estrazione delle Acque Sotterranee, by C. Calandra. Torino, 1867. Also another pamphlet by the same author, Sui Pozzic Fontane Modenese, 1874.

The most remarkable case of infiltration known to me by personal observation is the occurrence of fresh water in the beach-sand on the eastern side of the Gulf of Akaba, the eastern arm of the Red Sea. If you dig a cavity in the beach near the sea-level, it soon fills with water so fresh as not to be undrinkable, though the sea-water two or three yards from it contains even more than the average quantity of salt. It can not be maintained that this is seawater freshened by filtration through a few feet or inches of sand, for saltwater can not be deprived of its salt by that process. It can only come from the highlands of Arabia, and it would seem that there must exist some large reservoir in the interior to furnish a supply which, in spite of evaporation, holds out for months after the last rains of winter, and perhaps even through the year. I observed the fact in the month of June. See Rosmson, Biblical Researches, 1857, vol. i., p. 167.

The precipitation in the mountains that border the Red Sea is not known by pluviometric measurement, but the mass of débris brought down the ravines by the torrents proves that their volume must be large. The proportion of surface covered by sand and absorbent earth, in Arabia Petræa and the neighboring countries, is small, and the mountains drain themselves rapidly into the wadies or ravines where the torrents are formed; but the beds of earth and disintegrated rock at the bottom of the valleys are of so loose and porous a texture, that a great quantity of water is absorbed in saturating them before a visible current is formed on their surface. In a heavy thunder-storm, accompanied by a deluging rain, which I witnessed at Mount Sinai in the month of May, a large stream of water poured, in an almost continuous cascade, down the steep ravine, north of the convent, by which travellers sometimes descend from the plateau between the two peals; but after reaching the foot of the mountain, it flowed but a few yards before it was swallowed up in the sands.

Fresh-water wells are not unfrequently found upon the borders of ocean beaches. In the dry summer of $18 \% 0$, drinkable water was procured in many places on the coast of Liguria by digging to the depth of a yard in the beachsands. Tubular wells reach fresh water at twelve or fifteen feet below the surface on the sandy plains of Cape Cod. In this latter case the supply is more probably derived directly from precipitation than from lateral infiltration.

* Charles Martins, Le Sahara, in Revue des Deux Mondes, September $\mathbf{1}_{\text {r }}$ 
by deep boring appear to be primarily due to infiltration from highlunds where the water is first collected in superficial or subterranean reservoirs. By means of channels conforming to the dip of the strata, these reservoirs communicate with the lower basins, and exert upon them a fluid pressure sufficient to raise a column to the surface, whenever an orifice is opened.* The water delivered by au artesian well is, therefore, often derived from distant sources, and may be wholly unaffected by geographical or meteorological changes in its immediate neighborhood, while the same changes may quite dry up common wells and springs which are fed only by the local infiltration of their own narrow basins.

In most cases, artesian wells have been bored for purely economical or industrial purposes, such as to obtain good water for domestic use or for driving light machinery, to reach saline or other mineral springs, and recently, in America, to open fountains of petroleum or rock-oil. The geographical and geological effects of such abstraction of fluids from the bowels of the earth are too remote and uncertain to be here noticed; $\dagger$ but artesian

1864, p. 619; Stoppani, Corso di Geologia, i., 281 ; Desor, Die Sahara, Basel, 1871, pp. 50, 51.

* It is conceivable that in shallow subterranean basins superincumbent mineral strata may rest upon the witer and be partly supported by it. In such case the weight of such strata would be an additional, if not the sole, cause of the ascent of the water through the tubes of artesian wells.

The ascent of petroleum in the artesian oil-mells in Pennsylrania, and, in many cases, of salt-water in similar tubes, can hardly be ascribed to hydrostatic pressure, and there is much difficulty in accounting for the rise of water in artesian wells in many parts of the African desert on that principle. Perhaps the elasticity of gases, which probably aids in forcing up petroleum and saline waters, may be, not unfrequently, an agency in causing the flow of water in common artesian borings. It is said that artesian wells lately bored in Chicago, some to the depth of 1,600 feet, raise water to the height of 100 feet above the surface. What is the source of the pressure?

t Many more or less probable conjectures have been made on this subject, but thus far I am not aware that any of the apprehended results are actually shown to have happened. In an article in the Annales des Ponts et Chaussées for July and August, 1839, p. 131, it was suggested that the sinking of the piers of a bridge at Tours in France was occasioned by the abstraction of water from the earth by artesian wells, and the consequent withdrawal of the mechanical support it had previously given to the strata containing it. 
wells have lately been employed in Algeria for a purpose which has even now a substantial, and may hereafter acquire a very great geographical, importance. It was observed by many earlier as well as recent travellers in the East, among whom Shaw deserves special mention, that the Libyan desert, bordering upon the cultivated shores of the Mediterranean, appeared in many places to rest upon a subterranean lake at an accessible distance below the surface. The Moors are vaguely said to bore artesian wells down to this reservoir, to obtain water for domestic use and irrigation, and there is evidence that this art was practiced in Northern Africa in the Middle Ages. But it had been lost by the modern Moors, and the universal astonishment and incredulity with which the native tribes viewed the operations of the French engineers sent into the desert for that purpose, are a sufficient proof that this mode of reaching the subterranean waters was new to them. They were, however, aware of the existence of water below the sands, and were dexterous in digging wellssquare shafts lined with a framework of palm-tree stems-to the level of the sheet. The wells so constructed, though not technically artesian wells, answer the same purpose; for the water rises to the surface and flows over it as from a spring.*

A reply to this article will be found in Vrollet, Théorie des Puits Artésiens, p. 217.

In some instances the water has rushed up with a force which seemed to threaten the inundation of the neighborhood, and even the washing away of much soil ; but in these cases the partial exhaustion of the supply, or the relief of hydrostatic or elastic pressure, has generally produced a diminution of the flow in a short time, and I do not know that any serious evil has ever been occasioned in this way.

In April, 1866, a case of this sort occurred in boring an artesian well near the church of St. Agnes at Venice. When the drill reached the depth of 160 feet, a jet of mud and water was shot up to the height of 130 feet above the surface, and continued to flow with gradually diminishing force for about cight hours. The removal of the sand brought up by the water undermined the superficial strata of the earth, and thus caused a subsidence which cracked the walls of houses.-OMвоNI, Le Nostre Alpi, 1879, p. 452.

* See a very interesting account of these wells, and of the workmen who clean them out when obstructed by sand brought up with the water, in Laurent's memoir on the artesian wells recently bored by the French Government in the Algerian desert, Mémoire sur le Sahara Oricntal, etc., p. 19, et seq. Some of the men remained under water from two minutes to two minutes and forty seconds. Several officers are quoted as having observed immersions of three minutes' duration, and MI. Berbrugger witnessed one of six 
These wells, however, are too few and too scanty in supply to serve any other purposes than the domestic wells of other countries, and it is but recently that the transformation of desert into cultivable land by this means has been seriously attempted.

minutes and five seconds and another of five minutes and fifty-five seconds. The shortest of these periods is longer than the best pearl-diver can remain below the surface of salt water. The wells of the Sahara are from twenty to eighty mètres deep.-Deson, La Forêt Vierge et Le Sahara.

The ancient Egyptians were acquainted with the art of boring artesian wells. Ayme, a French engineer in the service of the Pacha of Egypt, found several of these old wells, a few years ago, in the oases. They dillered little from modern artesian wells, but were provided with pear-shaped valves of stone for closing them when water was not needed. When freed from the sand and rubbish with which they were choked, they flowed freely and threw up fish large enough for the table. The fish were not blind, as cave-fish often are, but were provided with eyes, and belonged to species common in the Nile. The sand, too, brought up with them resembled that of the bed of that river. Hence it is probable that they were carried to the oases by subterranean channels from the Nile.-Deson, La Forît Vierge et Le Saluara; STopPani, Corso di Geolerjia, i., p. 281. Barth speaks of common wells in Northern Africa from 200 to 360 feet deep,-—Reisen in Africa, ii., p. 180.

It is certain that artesian wells have been common in China from a very remote antiquity, and the simple method used by the Chinese-where the drill is raised and let fall by a rope, instead of a rigid rod-has lately been employed in Europe with advantage. Some of the Chinese wells are said to be 3,000 feet deep; that of Neusalzwerk in Silesia is 2,300. A well was bored at St. Louis, in Missouri, a few years ago, to supply a sugar refinery, to the depth of 2,199 feet. This was executed by a private firm in three years, at the expense of only $\$ 10,000$. Some years since the boring was recommenced in this well and reached a depth of 3,150 feet, but without a satisfactory result. Another artesian well was sunk at Columbus, in Ohio, to the depth of 2,500 feet, but without obtaining the desired supply of water. Perhaps, however, the artesian well of the sreatest depth ever executed until very recently, is that bored within the last six or seven years, for the use of an Insane Asylum near St. Louis. This well descends to the depth of three thousand eight hundred and forty-three feet, but the water which it furnishes is small in quantity and of a quality that can not be used for ordinary domestic purposes. The bore has a diameter of six inches to the depth of 425 feet, and after that it is reduced to four inches. For about three thousand fect the strata penetrated were of carboniferous and magnesian limestone alternating with sandstone. The remainder of the well passes through igneous rock. It St. Louis the Missouri and Mississippi Rivers are not more than twenty miles distant from each other, and it is worthy of note that the waters of neither of these two rivers appear to have opened for themselves a cousiderable subterramean passage through the rocky strata of the peninsula which separates them.

Boring has been carried to a great depth at Sperenberg near Berlin, where 


\section{The French Government has bored a large number of artesian} wells in the Algerian desert within a few years, and the native sheikhs are beginning to avail themselves of the process. Every well becomes the nucleus of a settlement proportioned to the supply of water, and before the end of the year 1860, several nomade tribes had abandoned their wandering life, established themselves around the wells, and planted more than 30,000 palm trees, besides other perennial vegetables.* The water is found

in 1871 the drill had descended 5,500 feet below the surface, passing through a stratum of salt for the last 3,200 feet; but the drilling was still in progress, the whole thickness of the salt-bed not having been penetrated.-Aus der Natur, vol. 17., p. 208. According to other authorities the depth reached is 4,050 feet.

When in boring an artesian well water is not reached at a moderate depth, it is not always certain that it will be found by driving the drill still lower. In certain formations, water diminishes as we descend, and it seems probable that, except in case of caverns and deep fissures, the weight of the superincumbent mineral strita so compresses the underlying ones, at no very great distance below the surface, as to render them impermeable to water and consequently altogether dry. See London Quarterly Journal of Science, No, xvii., January, 1868, pp. 18, 19.

In the silver mines of Nevada water is scarcely found at depths below 1,000 feet, and at 1,200 feet from the surface the earth is quite dry.-American $A n$ nual of Scientific Discovery for 1870, p. 75.

Similar facts are observed in Australia. The Pleasant Creek Nencs writes: "A singular and unaccountable feature in connection with our deep quartz mines is being developed daily, which must surprise those well experienced in mining matters. It is the decrease of water as the greater depths are reached. In the Magdala shaft at 950 feet the water has decreased to a minimum; in the Crown Cross Reef Company's shaft, at 800 feet, notwithstanding the two reefs recently struck, no extra water has been met with; and in the long drive of the Extended Cross Reef Company, at a depth of over 800 feet, the water is lighter than it was nearer the surface."

The facts that there are mines extending two miles under the bed of the sea, which are not particularly subject to inconvenience from water, that little water was encountered in the Mt. Cenis tunnel, 5,200 feet below the surface, and that at Scarpa, not far from Tivoli, there is an ancient well 1,700 feet deep with but eighteen feet of water, may also be cited as proofs that water is not universally diffused at great distances beneath the surface.

* "In the anticipation of our success at Oum-Thiour, everything had been prepared to take advantage of this new source of wealth without a moment's delay. A division of the tribe of the Selmia, and their sheikh, Aissa ben Shâ, laid the foundation of a village as soon as the water flowed, and planted twelve hundred date-palms, renouncing their wandering life to attach them. selves to the soil. In this arid spot life had taken the place of solitude, and 
at a small depth, generally from 100 to 200 feet, and though containing too large a proportion of mineral matter to be acceptable to a European palate, it answers well for irrigation, and does not prove unwholesome to the natives.

The most obvious use of artesian wells in the desert at present is that of creating stations for the establishment of military posts and halting-places for the desert traveller; but if the supply of water shall prove adequate for the indefinite extension of the system, it is probably destined to produce a greater geographical trimsformation than has ever been effected by any scheme of human improvement.

The most striking contrast of landscape scenery that nature brings near together in time or place, is that between the greenery of the tropics, or of a northern summer, and the snowy pall of leafless winter. Next to this in startling novelty of effect, we must rank the sudden transition from the shady and verdant oasis of the desert to the bare and burning party-colored ocean of sand and rock which surrounds it.* The most sanguine believer in

presented itself, with its smiling images, to the astonished traveller. Young girls were drawing water at the fountain; the flocks, the great dromedaries with their slow pace, the horses led by the halter, were moving to the watering trough; the hounds and the falcons enlivened the group of party-colored tents, and living voices and animated movement had succeeded to silence and desolation."-LAurent, Mémoires sur le Sahara, p. 85.

Between 18.56 and 1864 the French engineers had bored 83 wells in the Hodna and the Sahara of the Province of Constantine, yielding, all together, 9,000 gallons a minute, and irrigating more than 125,000 date-palms. - REcLus, La Terre, i., p. 110.

* The variety of hues and tones in the local color of the desert is, I think, one of the phenomena which most surprise and interest a stranger to those regions. In England and the United States, rock is so generally covered with moss or earth, and earth with vegetation, that untravelled Englishmen and Americans are not very familiar with naked rock as a conspicuous element of landscape. IIence, in their conception of a bare cliff or precipice, they hardly ascribe definite color to it, but depict it to their imagination as wearing a neutral tint not assimilable to any of the hues with which nature tinges her atmospheric or paints her organic creations. There are certainly extensive desert ranges, chiefly limestone formations, where the surface is either white, or has weathered down to a dull uniformity of tone which can hardly be called color at all; and there are sand plains and drifting hills of wearisome monotony of tint. But the chemistry of the air, though it may tame the glitter of the limestone to a dusky gray, brings out the green and brown and purple of the igneous rocks, and the white and red and blue and violet and yellow of the 
indefinite human progress hardly expects that man's cunning will accomplish the universal fulfilment of the prophecy, "the desert shall blossom as the rose," in its literal sense; but sober geogra. phers have thought the future conversion of the sand plains of Northern Africa into fruitful gardens, by means of artesian wells, not an improbable expectation. They lave gone farther, and argued that, if the soil were covered with fields and forests, vegetation would call down moisture from the Libyan sky, and that the showers which are now wasted on the sea, or so often deluge Southern Europe with destructive inundation, would in part be condensed over the arid wastes of Africa, and thus, without further aid from man, bestow abundance on regions which nature seems to have condemned to perpetual desolation.

An equally bold speculation, founded on the well-known fact that the temperature of the earth and of its internal waters increases as we descend beneath the surface, has suggested that artesian wells might supply heat for industrial and domestic purposes, for hot-house cultivation, and even for the local amelioration of climate. The success with which Count Lardarel has employed natural hot springs * for the eraporation of water

sandstone. Many a cliff in Arabia Petrea is as manifold in color as the rainbow, and the veins are so variable in thickness and inclination, so contorted and involved in arrangement, as to bewilder the eye of the spectator like a disk of party-colored glass in rapid revolution.

In the narrower wadies the mirage is not common; but on broad expanses, as at many points between Cairo and Suez, and in Wadi el Araba, it mocks you with lakes and land-locked bays, studded with islands and fringed with trees, all painted with an illusory truth of representation absolutely indistinguishable from the reality. The checkered earth, too, is canopied with a heaven as variegated as itself. You see, high up in the sky, rosy clouds at noonday, colored probably by reflection from the ruddy mountains, while near the horizon float cumuli of a transparent, ethereal blue, seemingly balled up out of the clear cerulean substance of the firmament, and detached from the heavenly vault, not by color or consistence, but solely by the light and shade of their salient and retreating outlines.

* Although hot springs, sometimes of considerable volume, are numerous, yet the districts in which they occur are generally of swall extent, and the absolute quantity of water discharged by the hot springs of the earth may be treated as insignificant in comparison with that derived from springs of ordinary temperatures, by which most rivers are fed. The temperature of common gprings varies little from the mean atmospheric temperature of the locality, and hence it is clear that the rain which feeds these springs does not descend 
charged with boracic acil, and other fortunate applications of the heat of thermal sources, lend some countenance to the latter project; but both must, for the present, be ranked among the vague possibilities of science, not regarded as probable future triumphs of man over nature.

\section{Artificial Springs.}

A more plausible and inviting scheme is that of the creation of perennial springs by husbanding rain and snow water, storing it up in artificial reservoirs of earth, and filtering it through purifying strata, in analogy with the operations of nature. The sagacious Palissy-starting from the theory that all springs are primarily derived from precipitation, and reasoning justly on the accumulation and movement of water in the earth-proposed to reduce theory to practice, and to imitate the natural processes by which rain is absorbed by the earth and given out again in running fountains. "When I had long and diligently considered the cause of the springing of natural fountains and the places where they be wont to issue," says he, "I did plainly perceive, at last, that they do proceed and are engendered of nought but the rains. And it is this, look you, which hath moved me to enterprise the gathering together of rain-water after the manner of nature, and the most closely according to her fashion that I am able; and I am well assured that by following the formulary of the Supreme Contriver of fountains, I can make springs, the water whereof shall be as good and pure and clear as of such which be natural." * Palissy discusses the subject of the origin of springs at length and with much ability, dwelling specially on infiltration, and, among other things, thus explains the frequency of springs in mountainous regions: "Having well considered the which, thou mayest plainly see the reason why there

to a greater depth than the few yards at which we meet an invariable temperature corresponding with the atmospheric mean. Hot water, then, whether reached by artesian borings or rising from great depths in hot springs, is not derived from precipitation conveyed downwards to a heated stratum by ordinary filtration, but from lakes or rivers, by means of crevices or apertures in the superficial crust of the earth, and where such crevices do not exist, littlo water will be found far below the surface.

* Frurres de Palissy, Des Eaux et Fontaines, p. 157. 
be more springs and rivulets proceeding from the mountains than from the rest of the earth; which is for no other cause but that the rocks and mountains do retain the water of the rains like vessels of brass. And the said waters falling upon the said mountains descend continually through the earth, and through crevices, and stop not till they find some place that is bottomed with stone or close and thick rocks; and they rest upon such bottom until they find some channel or other manner of issue, and then they flow out in springs or brooks or rivers, according to the greatness of the reservoirs and of the outlets thereof." *

After a full exposition of his theory, Palissy proceeds to describe his method of creating springs, which is substantially the same as that lately proposed by Babinet in the following terms: "Choose a piece of ground containing four or five acres, with a sandy soil, and with a gentle slope to determine the flow of the water. Along its upper line, dig a trench five or six feet deep and six feet wide. Level the bottom of the trench, and make it impermeable by paving, by macadamizing, by bitumen, or, more simply and cheaply, by a layer of clay. By the side of this trench dig another, and throw the earth from it into the first, and so on until you have rendered the subsoil of the whole parcel impermeable to rain-water. Build a wall along the lower line with an aperture in the middle for the water, and plant fruit or other low trees upon the whole, to shade the ground and check the currents of air which promote evaporation. This will infallibly give you a good spring which will flow without intermission, and supply the wants of a whole hamlet or a large chateau." + Babinet states that the whole amount of precipitation on a reservoir of the proposed area, in the climate of Paris, would be about 13,000 cubic

* Euvres de Palissy, etc., p. 166. Palissy's method has recently been tried with good success in various parts of France.

+ BABINET, Études et Lectures sur les Sciences d'Observation, ii., p. 225. Our author precedes his account of his method with a complaint which most men who indulge in thinking have occasion to repeat many times in the course of their lives. "I will explain to my readers the construction of artificial fountains according to the plan of the famous Bernard de Palissy, who, a hundred and fifty [three hundred] years ago, came and took away from me, a humble academician of the nineteenth century, this discovery which I had taken a great deal of pains to make. It is enough to discourage all invention when one finds plagiarists in the past as well as in the future !" (P. 224.) 
yards, not above one-half of which, he thinks, would be lost, and, of course, the other half would remain available to supply the spring. I much doubt whether this expectation would be realized in practice, in its whole extent; for if Babinet is right in supposing that the summer rain is wholly evaporated, the winter rains, being much less in quantity, would hardly suffice to lieep the earth saturated and give off so large a surplus.

The method of Palissy, though, as I have said, similar in principle to that of Babinet, would be cheaper of execution, and, at the same time, more efficient. He proposes the construction of relatively small filtering receptacles, into which he would conduct the rain falling upon a large area of rocky hillside, or other sloping ground not readily absorbing water. This process would, in all probability, be a very successful, as well as an inexpensive, mode of economizing atmospheric precipitation, and of compelling the rain and snow to form perennial fountains at will.

\section{Economizing Precipitation.}

The methods suggested by Palissy and by Babinet are of limited application, and designed only to supply a sufficient quantity of water for the domestic use of small villages or large private establishments. Dumas has proposed a much more extensive system for collecting and retaining the whole precipitation in considerable valleys, and storing it in reservoirs, whence it is to be drawn for household and mechanical purposes, for irrigation, and, in short, for all the uses to which the water of natural springs and brooks is applicable. His plan consists in draining both surface and subsoil, by means of conduits differing in construction according to local circumstances, but in the main not unlike those employed in improved agriculture, collecting the water in a central channel, securing its proper filterage, checking its too rapid flow by barriers at convenient points, and finally receiving the whole in spacious, covered reservoirs, from which it may be discharged in a constant flow or at intervals as convenience may dictate.*

\footnotetext{
* M. G. Dumas, La Science des Fontaines, 185\%. - See article Pontrar MLARsHes, in Johnson's Cyclopadia.
} 
There is no reasonable doubt that a very wide employment of these various contrivances for economizing and supplying water is practicable, and the expediency of resorting to them is almost purely an economical question. There appears to be no serious reason to apprehend collateral evils from them, and in fact all of them, except artesian wells, are simply indirect methods of returning to the original arrangements of nature, or, in other words, of restoring the fluid circulation of the globe; for when the earth was covered with the forest, perennial springs gushed from the foot of every hill, brooks flowed down the bed of every valley. The partial recovery of the fountains and rivulets which once abundantly watered the face of the agricultural world seems practicable by such means, even without any general replanting of the forests; and the cost of one year's warfare-or in some countries of that armed peace which has been called "Platonic war" -if judiciously expended in a combination of both methods of improvement, would secure, to almost every country that man has exhausted, an amelioration of climate, a renovated fertility of soil, and a general physical improvement, which might almost be characterized as a new creation.

\section{Inundations and Torrents.}

In pointing out in a former chapter the evils which have resulted from the too extensive destruction of the forests, I dwelt at some length on the increased violence of river inundations, and especially on the devastations of torrents, in countries improvidently deprived of their woods, and I spoke of the replanting of the forests as probably the most effectual method of preventing the frequent recurrence of disastrous floods. There are many regions where, from the loss of the superficial soil, from financial considerations, and from other special causes, the general restoration of the woods is not, under present circumstances, either possible or desirable. In all inhabited countries, the necessities of agriculture and other considerations of human conven. ience will always require the occupation of much the largest proportion of the surface for purposes inconsistent with the growth of extensive forests. Even where large plantations are possible and in actual process of execution, many years must elapse before 
the action of the destructive causes in question can be arrested or perhaps even sensibly mitigated by their influence; and besides, floods will always oceur in years of excessive precipitation, whether the surface of the soil be generally cleared or generally wooded.*

* All the arrangements of rural husbandry, and we might say of civilized occupancy of the earth, are such as necessarily to increase the danger and the range of tloods by promoting the rapid discharge of the water's of precipitation. Superficial, if not subterranean, drainage is a necessary condition of all agriculture. There is no field which has not some artificial disposition for this purpose, and even the furrows of ploughed land, if the surface is inclined, and especially when it is frozen, serve rather to carry off than to retain water. As Becquerel has observed, common road and railway ditches are among the most efficient conduits for the discharge of surface-water which man has yet constructed, and of course they are powerful agents in causing river inundations. All these channels are, indeed, necessary for the convenience of man, but this convenience, like every other interference with the order of nature, must often be purchased at a heavy cost.

It has long been supposed that large towns, great aggregations of men living together under the artificial conditions of civic life, must exercise an appre ciable influence on climate. But such influence has hardly yet been shown by scientific observation. It is, however, at least certain that they intercept and divert from their proximate, if not from their ultimate, points of delivery into the common receptacle of the ocean, a large amount of precipitation. London, for example, after making a sufficient allowance for parks, gardens and other open spaces, has, within the jurisdiction of the Board of Works, at least 100 square miles of substantially impervious paved or roofed surfaces. Calculating the yearly rainfall at London at 24 inches, this city receives annually a quantity of water of precipitation about equal to the mean delivery of the Nile for forty minutes-a quantity not absolutely large, certainly, but relatively great enough to be attended with important geographical consequences; for though, as is above admitted, this water may, at least in part, finally reach the ocean, yet its channels, its rate of flow, and the amount of evaporation from it, must be very different from what they would have been had it fallen on an open tract of equal extent. Then again, this rast artin̂cially covered space may produce important meteorological effects. When we consider the heat of the domestic fires and lights required for the comfort and conrenience of so large a population, the forges and furnaces used for mechanical operations, the heat thrown off by the friction of machinery, of carriages and of the iron-shod hoofs of horses, the animal warmth disengaged by men and beasts, the solar heat absorbed, accumulated, and given off through radiation, by walls and other artificial constructions which greatly increase the area of exposed surface,- when we consider all these things, it would seem that a large city must be a source of heat potent enough to disperse overhanging clouds and to dissipate much of the aqueous vapor that composes them. 
Physical improvement in this respect, then, can not be confined to merely preventive measures, but, in countries subject to damage by inundation, means must be contrived to obviate dan gers and diminish injuries to which human life and all the works of human industry will occasionally be exposed, in spite of every effort to lessen the frequency of their recurrence by acting directly on the causes that produce them. As every civilized country is, in some degree, subject to inundation by the overflow of rivers, the evil is a familiar one and needs no general description. In discussing this branch of the subject, therefore, I may confine myself chiefly to the means that have been or may be employed to resist the force and limit the ravages of floods, which, left wholly unrestrained, would not only inflict immense injury upon the material interests of man, but produce geographical revolutions of no little magnitude.

\section{Inundations of 1856 in France.}

The month of May, 1856, was remarkable for violent and almost uninterrupted rains, and most of the river-basins of France were inundated to an extraordinary height. In the valleys of the Loire and its affluents, about a million of acres, including many towns and villages, were laid under water, and the amount of pecuniary damage was almost incalculable.* The flood was not less destructive in the valley of the Rhone, and in fact an invasion by a hostile army could hardly have been more disastrous to the inhabitants of the plains than was this terrible deluge. There had been a flood of this latter river in the year 1840, which, for height and quantity of water, was almost as remarkable as that of 1856 , but it took place in the month of November, when the crops had all been harvested, and the injury inflicted by it upon agriculturists was, therefore, of a character to be less severely and less immediately felt than the consequences of the inundation of $1856 . \dagger$

\footnotetext{
* Chamrion, Les Inondations en France, iii., p. 156, note.
}

+ Notwithstanding this favorable circumstance, the damage done by the great inundation of 1840 in the valley of the Rhone was estimated at seventy two millions of francs.-Champion, Les Inondations en France, iv., p. 124.

Several smaller floods of the Rhone, experienced at a somewhat earlier sea 
In the fifteen years between these two great floods, the population and the rural improvements of the river ralleys had much increased, common roads, bridges and railways had been multiplied and extended, telegraph lines had been constructed, all of which shared in the general ruin, and hence greater and more diversified interests were affected by the catastrophe of 1856 than by any former like calamity. The great flood of 1840 had excited the attention and roused the sympathies of the French people, and the subject was invested with new interest by the still more formidable character of the inundations of 1856 . It Wats felt that these scourges had ceased to be a matter of merely local concern, for, although they bore most hearily on those whose homes and fields were situated within the immediate reach of the swelling waters, yet they frequently destroyed harvests valuable enough to be a matter of national interest, endangered the personal security of the population of important political centres, interupted communication for days and even weeks together on great lines of traffic and travel-thus severing, as it were, all Sonthwestern France from the rest of the empire-and finally threatened to produce great and permanent geographical changes. The rell-being of the whole commonwealth was seen to be involved in preventing the recurrence and in limiting the range of such derastations. The Government encouraged scientific investigation of the phenomena and their laws. Their causes, their history, their immediate and remote consequences, and the possible safeguards to be employed against them, have been carefully studied by the most eminent physicists, as well as by the ablest theoretical and practical engineers of France. Many hitherto unobserved facts have been collected, many new hypotheses sug. gested, and many plans, more or less original in character, have been devised for combating the evil; but thus far, the most competent judges are not well agreed as to the mode, or even the possibility, of applying an effectual remedy.*

son of the year in 1846, occasioned a loss of forty-five millions of francs. "What if," says Dumont, " instead of happening in October, that is, between harrest and seedtime, these floods had occurred before the crops were secured f The damage would have been counted by hundreds of millions."-Des Travaux Publics, p. 99, note.

* The Telegraph has furnished a means, not indeed of preventing inunda. 
I have noticed in the next preceding chapter the recent legislation of France upon the preservation and restoration of the forests, with reference to their utility in subduing torrents and lessening the frequency and diminishing the violence of river inundations. The provisions of these laws are preventive rather than remedial, but most beneficial effects have already been experienced from the measures adopted in pursuance of them, though sufficient time has not yet elapsed for the complete execution of the greater operations of the system.

\section{Basins of Reception.}

Destructive inundations of large rivers are seldom, if ever, produced by precipitation within the limits of the principal valley, but almost uniformly by sudden thaws or excessive rains on the mountain ranges where the tributaries take their rise. It is therefore plain that any measures which shall check the flow of surface-waters into the channels of the affluents, or which shall retard the delivery of such waters into the principal stream by its tributaries, will diminish in the same proportion the dangers and the evils of inundation by great rivers. The retention of the surface-waters upon or in the soil can hardly be accomplished except by the methods already mentioned-replanting of forests and furrowing or terracing. The current of mountain streams zan be checked by various methods, among which the most familiar and obvious is the erection of barriers or dams across their channels, at points convenient for forming reservoirs large

tions, but of foreseeing them, and thus in some measure averting their evil consequences. On all considerable streams, observations are now regularly made, in rainy weather, at what may be called critical points along their course, where the rising of the water above its normal level, and the rate of its increment, have been found by experience to furnish trustworthy indications as to the time and measure of floods at important towns lower down the river. Notice can be given, long beforehand, as to the time when the flood-wave will reach such points. Thus, for example, it being known that the floodwave of the Tiber propagates itself from Orte-sixty miles above Rome, at the confluence of that river and the Nera-to Rome in from sixteen to seventeen hours, notice of an impending inundation can be communicated to the Capital in time for the removal of exposed objects alung the banks, for securing the entrances to cellars, and for other precautionary measures. 
enough to retain the superfluous waters of great rains and thaws.* Besides the utility of such basins in preventing floods, the construction of them is recommended by very strong considerations, such as the furnishing of a constant supply of water for agricultural and mechanical purposes, and, also, their value as ponds for breeding and rearing fish, and, perhaps, for cultivating aquatic vegretables. $†$

The objections to the general adoption of the system of reserroirs are these: the expense of their construction and maintenance; the reduction of cultivable area by the amount of surface they must cover; the interruption they would occasion to free communication; the probability that they would soon be filled up with sediment, and the obvious fact that when full of earth, or even water, they would no longer serve their principal purpose; the great danger to which they would expose the country below them in case of the bursting of their barriers ; $\neq$ the evil consequences they would occasion by prolonging the flow of inundations in proportion as they diminished their height; the injurious effects it is supposed they would produce upon the salubrity of the neighboring districts; and, lastly, the alleged impossibility. of constructing artificial basins sufficient in capacity to prevent, or in any considerable measure to mitigate, the evils they are intended to guard against.

The last argument is more easily reduced to a numerical question than the others. The mean and extreme annual precipitation of all the basins where the construction of such works would

* On the construction of temporary and more permanent barriers to the currents of torrents and rivulets, see MLARCHAND, Les Torrents des Alpes, in Revue des Eaux et Forêts for October and November, 1871.

t In reference to the utilization of artificial as well as natural reservoirs, see AckennoF, Die Nutzung der Teiche und Gevcisser, Quedlinburg, 1869.

$\ddagger$ For accounts of damage from the bursting of reservoirs, see VALLÉx, Mémoire sur les Reservoirs d'Alimentation des Canaux, Annales des Ponts et Chaussées, 1833, 1er sémestre, p. 261.

The dam of the reservoir of Puentes in Spain, which was one hundred and sixty feet high, after having discharged its functions for eleven years, burst, in 1802 , in consequence of a defect in its foundations, and the eruption of the water destroyed or seriously injured eight hundred houses, and produced damage to the amount of more than a million dollars,-Ararand, Irrigations du Midi de l'Europe, pp. 257-259. 
be seriously proposed is already approximately known by meto orological records, and the quantity of water delivered by the greatest floods which have occurred within the memory of man, may be roughly estimated from their visible traces. From these elements, or from meteorological tables, the capacity of the necessary reservoirs can be calculated. Let us take the case of the Ardeche. In the inundation of 1857 , that river poured into the Rhone 1,305,000,000 cubic yards of water in three days. If we suppose that half this quantity might have been suffered to flow down its channel without inconvenience, we shall have about $650,000,000$ cubic yards to provide for by reservoirs. The Ardèche and its principal affluent, the Chassezac, have, together, about twelve considerable tributaries rising near the crest of the mountains which bound the basin. If reservoirs of equal capacity were constructed upon all of them, each reservoir must be able to contain $54,000,000$ cubic yards, or, in other words, must be equal to a lake 3,000 yards long, 1,000 yards wide, and 18 yards deep, and besides, in order to render any effectual service, the reservoirs must all have been empty at the commencement of the rains which produced the inundation.

Thus far I have supposed the swelling of the waters to be uniform throughout the whole basin; but such was by no means the fact in the inundation of 1857 , for the rise of the Chassezac, which is as large as the Ardieche proper, did not exceed the limits of ordinary floods, and the dangrerous excess came solely from the headwaters of the latter stream. Hence reservoirs of double the capacity I have supposed would have been necessary upon the tributaries of that river, to prevent the injurious effects of the inundation. It is evident that the construction of reservoirs of such magnitude for such a purpose is financially, if not physically, impracticable, and when we take into account a point I have just suggested, namely, that the reservoirs must be empty at all times of apprehended flood, and, of course, their utility limited almost solely to the single object of preventing inundations, the total inapplicability of such a measure in this particular case becomes still more glaringly manifest.

Another not less conclusive fact is, that the valleys of all the upland tributaries of the Ardeche descend so rapidly, and have so little lateral expansion, as to render the construction of capa- 
cious reservoirs in them quite impracticable. Indeed, engineers have found but two points in the whole basin suitable for that purpose, and the reservoir's admissible at these would have only a joint eapacity of about $50,000,000$ cubic yards, or less than onewintl part of what I suppose to be required. The case of the Ardiche is no doult an extreme one, both in the topographical character of its basin and in its exposure to excessive rains; but all destructive inundations are, in a certain sense, extreme cases also, and this of the Ardeche serves to show that the construction of reservoirs is not by any means to be regarded as a miversal panacea against floods.

$\mathrm{Nor}$, on the other hand, is this measure to be summarily rejected. Nature has adopted it on a great scale, on both flanks of the Alps, and on a smaller, on those of the Adirondacks and of many lower chains. The quantity of water which, in great rains or sudden thaws, rushes down the steep declivities of the Alps, is so vast that the channels of the Swiss and Italian rivers would be totally incompetent to carry it off as rapidly as it would pour into them, were it not absorbed by the capacious basins which nature has scooped out for its reception, freed from the transported material which adds immensely both to the volume and to the force of its current, and then, after some reduction by evaporation and infiltration, gradually discharged into the beds of the rivers. In the inundation of 1829, the water discharged into Lake Como from the 15th to the 20th of September amounted to 2,600 cubic yards the second, while the outflow from the lake during the same period was only at the rate of about 1,050 cubic yards to the second. In those fire days, then, the lake accumulated $670,000,000$ cubic yards of superfluous water, and of course diminished by so much the quantity to be disposed of by the Po.* In the flood of October, 1568, the surface of Lago Maggiore was raised twenty-five feet above low-water mark in the course of a few hours. $\dagger$ There can be no doubt that without such detention of water by the Lakes Como, Maggiore, Garda, and other subalpine basins, almost the whole of Lombardy would have been irrecoverably desolated, or rather, its great plain would

* Bamp Sirtre, Italian Irrigation, i., p. 176.

+ Bollettino della Societd Geog. Italiana, iii., p. 466. 
never have become anything but a vast expanse of river-beds and marshes; for the annual floods would always have prevented the possibility of its improvement by man.*

Lake Bourget in Savoy, once much more extensive that it is at present, served, and indeed still serves, a similar purpose in the economy of nature. In a flood of the Rhone, in 1863, this lake received from the overflow of that river, which does not pass through it, $72,000,000$ cubic yards of water, and of course moderated, to that extent, the effects of the inundation below. $\dagger$

In fact, the alluvial plains which border the course of most considerable streams, and are overflowed in their inundations, either by the rise of the water to a higher level than that of their banks, or by the bursting of their dikes, serve as safety-valves for the escape of their superfluous waters. The current of the Po, spreading over the whole space between its widely separated embankments, takes up so much water in its inundations, that, while a little below the outlet of the Ticino the discharge of the channel is sometimes not less than 19,500 cubic yards to the second, it has never exceeded 6,730 yards at Ponte Lagoscuro, near Ferrara. The currents of the Mississippi, the Rhone, and of many other large rivers, are modified in the same way. In the flood of 1858, the delivery of the Mississippi, a little below the mouth of the Ohio, was 52,000 cubic yards to the second; but at Baton Rouge, though of course increased by the waters of the Arkansas, the Yazoo and other smaller tributaries, the discharge was reduced to 46,760 cubic yards. TVe rarely err when we cautiously imitate the processes of nature, and there are doubtless many cases where artificial basins of reception and lateral expansions of river-beds might be employed with advantage. Many upland streams present points where none of the objections usually urged against artificial reservoirs, except those of expense and of danger from the breaking of dams, could have any application. Reservoirs may be so constructed as to retain the entire precipitation of the heaviest thaws and rains, leaving only the ordinary quantity to flow along the channel; they may be raised

* See, as to the probable effects of certain proposed hydraulic works at the outlet of Lake IIaggiore on the action of the lake as a regulating reservoir, 'Tagliasecchr, Notizic sui Canali dell' Alta Lombardia, Milano, 1869.

† Elisée Reclus, La Terre, i., p. 460. 
to such a height as only partially to obstruct the surface drainage; or they may be provided with sluices by means of which their whole contents can be discharged in the dry season, and a summer crop be grown upon the ground they cover at high water. The expediency of employing them and the mode of construction depend on local conditions, and no rules of universal applicability can be laid down on the subject.*

It is remarkable that nations which we, in the inflated pride of our modern civilization, so generally regard as little less than barbarian, should have long preceded Christian Europe in the systematic employment of great artificial basins for the various purposes they are calculated to subserve. The ancient Peruvians built strong walls, of excellent workmanship, across the channels of the mountain sources of important streams, and the Arabs executed immense works of similar description, both in the great Arabian peninsula and in all the provinces of Spain which had the good fortune to fall under their sway. The Spaniards of the fifteenth and sixteenth centuries, who, in many points of true civilization and culture, were far inferior to the races they subdued, wantonly destroyed these noble monuments of social and political wisdom, or suffered them to perish, because they were too ignorant to appreciate their value, or too unskilful as practical engineers to be able to maintain them, and some of their most important territories were soon reduced to sterility and poverty in consequence.

\section{Diversion of Rivers.}

Another method of preventing or diminishing the evils of inundation by torrents and mountain rivers, analogous to that employed for the drainage of lakes, consists in the permanent or occasional diversion of their surplus waters, or of their entire currents, from their natural courses, by tunnels or open channels cut through their banks. Nature, in many cases, resorts to a similar process. Most great rivers divide themselves into several

* The insufficiency of artificial basins of reception as a means of averting the evils resulting from the floods of great rivers has been conclusively shown, in reference to a most important particular case-that of the Mississippi-by Iumphreys and Abbot, in their admirable monograph of that river. 
arms in their lower course, and enter the sea by different mouths. There are also cases where rivers send off lateral branches to convey a part of their waters into the channel of other streams.* The most remarkable of these is the junction between the Amazon and the Orinoco by the natural canal of the Cassiquiare and the Rio Negro. In India, the Cambodja and the Menam are connected by the Anam; the Saluen and the Irawaddi by the Panlaun. There are similar examples, though on a much smaller scale, in Europe. The Tornea and the Calix Rivers in Lapland communicate by the Tarando, and in Westphalia, the Else, an arm of the Haase, falls into the Weser.t

The change of bed in rivers by gradual erosion of their banks is familiar to all, but instances of the sudden abandonment of a primitive channel are by no means wanting. At a period of unknown antiquity, the Ardèche pierced a tunnel 200 feet wide and 100 high, through a rock, and sent its whole eurrent through it, deserting its former bed, which gradually filled up, though its course remained traceable. In the great inundation of 1827 , the tunnel proved insufficient for the discharge of the water, and the

* Some geographical writers apply the term bifurcation exclusively to this intercommunication of rivers; others, with more etymological propriety, use it to express the division of great rivers into branches at the head of their deltas. A technical word is wanting to designate the phenomenon mentioned in the text, and there is no valid objection to the employment of the anatomical term anastomosis for this purpose.

+ The division of the currents of rivers, as a means of preventing the overflow of their banks, is by no means a remedy capable of general application, even when local conditions are favorable to the construction of an emissary. The velocity of a stream, and consequently its delivery in a given time, are frequently diminished in proportion to the diminution of the volume by diversion; and on the other hand, the increase of volume by the admission of a new tributary increases proportionally the velocity and the quantity of water delivered. Emissaries may, nevertheless, often be useful in carrying off water which has already escaped from the channel, and which would otherwise become stagnant and prevent further lateral discharge from the main current, and it is upon this principle that Humphreys and Abbot think a canal of diversion at Lake Providence might be advisable. Emissaries serve an important purpose in the lower course of rivers where the bed is nearly a dead level, and where the water moves from previously acquired momentum and the pressure of the current above rather than by the force of gravitation; and it is, in general, only under such circumstances, as for example in the deltas at the mouths of great rivers, that nature employs them. 
river burst throngh the obstructions which had now choked up its ancient channel, and resumed its original course.*

It was probably such facts as these that suggrested to ancient engineers the possibility of like artificial operations, and there are numerous instances of the execution of works for this purpose in very remote ages. The Bahr Jusef, the great stream which supplies the Fayoum with water from the Nile, has been supposed, by some writers, to be a natural channel; but both it and the Bahr el Wady are almost certainly artificial canals constructed to water that basin, to regulate the level of Lake MLœris, and possibly, also, to diminish the dangers resulting from excessive inundations of the Nile, by serving as waste-weir's to discharge a part of its orerflowing waters. $\dagger$ Several of the seven ancient mouths of the Nile are believed to be artificial channels, and Herodotus even asserts that King Menes diverted the entire course of that river from the Libyan to the Arabian side of the valley. There are traces of an ancient river-bed along the western mountains, which give some countenance to this statement. But it is much more probable that the works of Menes were designed rather to prevent a natural, than to produce an artificial, change in the channel of the river.

Two of the most celebrated cascades in Europe, those of the Teverone at Tivoli and of the Velino at Terni, owe, if not their existence, at least their position and character, to the diversion of their waters from their natural beds into new channels, in order to obviate the evils produced by their frequent floods. Remarkable works of the same sort have been executed in Switzerland in very recent times. Until the year 1714, the Kander, which drains several large Alpine valleys, ran for a considerable distance parallel with the Lake of Thun, and a few miles below the city of that name emptied into the river Aar. It frequently flooded the flats along the lower part of its course, and it was determined to divert it into the Lake of Thun. For this purpose,

* Mrardiant, Mémoire sur les Inondations de l'Ardeche, p. 13.

+ The starting-points of these canals were far up the Nile, and of course at a comparatively high level, and it is probable that they received water only during the inundation. Linant Bey calculates the capacity of Lake MIœris at $3,686,667$ cubic yards and the water received by it at high Nile at 465 cubic yards the second. 
two parallel tunnels were cut through the intervening rock, and the river turned into them. The violence of the current burst up the roof of the tunnels, and, in a very short time, wore the new channel down not less than one hundred feet, and even deepened the former bed at least fifty feet, for a distance of two or three miles above the tunnel. The lake was two hundred feet deep at the point where the river was conducted into it, but the gravel and sand carried down by the Kander has formed at its mouth a delta containing more than a hundred acres, which is still advancing at the rate of several yards a year. The Linth, which formerly sent its waters directly to the Lake of Zurich, and often produced very destructive inundations, was turned into the Wallensee about fifty years ago, and in both these cases a great quantity of valuable land was rescued both from flood and from insalubrity.

\section{Glacier Lakes.}

In Switzerland, the most terrible inundations often result from the damming up of deep valleys by ice-slips or by the gradual advance of glaciers, and the accumulation of great masses of water above the obstructions. The ice is finally dissolved by the heat of summer or the flow of warm waters, and when it bursts, the lake formed above is discharged almost in an instant, and all below is swept down to certain destruction. In 1595, about a hundred and fifty lives and a great amount of property were lost by the eruption of a lake formed by the descent of a glacier into the valley of the Drance, and a similar calamity laid waste a considerable extent of soil in the year 1818. On this latter occasion, the barrier of ice and snow was 3,000 feet long, 600 thick and 400 high, and the lake which had formed above it contained not less than $800,000,000$ cubic feet. A tunnel was driven through the ice, and about $300,000,000$ cubic feet of water safely drawn off by it; but the thawing of the walls of the tunnel rapidly enlarged it, and before the lake was half drained, the barrier gave way and the remaining 500,000,000 cubic feet of water were discharged in half an hour. The recurrence of these floods has since been prevented by directing streams of water, warmed by the sun, upon the ice in the bed of the valley, and thus thaw. 
ing it before it accumulates in sufficient mass to form a new bar rier and threaten serious danger.*

In the eases of diversion of streams above mentioned, important geographical changes have been directly produced by those operations. By the rarer process of draining glacier lakes, natural eruptions of water, which would have occasioned not less important changes in the face of the earth, have been prevented by human agency.

\section{River Embankments.}

The most obvious and doubtless earliest method of preventing the escape of river-waters from their natural channels, and the overflow of fields and towns by their spread, is that of raised embankments along their course. $\dagger$ The necessity of such embankments usually arises from the gradual elevation of the bed of running streams, in consequence of the deposit of the earth and gravel they are charged with in high water; and, as we have seen, this elevation is rapidly accelerated when the highlands around the headwaters of rivers are cleared of their forests.

* In 1845 a similar lake was formed by the extension of the Vernagt glacier. When the ice barrier gave way, 3,000,000 cubic yards of water were discharged in an hour.-SonkI.AR, Die Oetzthaler Gebirgsgruppe, $§ 167$.

† Riparian embankments are a real, if not a conscious, imitation of a natural process. The waters of rivers which flow down planes of gentle inclination deposit, in their inundations, the largest proportion of their sediment as soon as, by overflowing their banks, they escape from the swift current of the channel. The immediate borders of such rivers consequently become higher than the grounds lying further from the stream, and constitute, of themselves, a sort of natural dike of small elevation. In the "intervales," or "bottoms" of the great North American rivers, the alluvial banks are elevated and dry; the flats more remote from the river, lower and swampy. This is generally observable in Egypt (see Figari Bex, Studi Scientifici sull' Egitto, i., p. 87), though less so than in the valley of the Mississippi, where the alluvial banks form natural glacis, descending as you recede from the river, and in some places, as below Cape Girardeau, at the rate of seven feet in the first mile.Hourmers AND Аввот, Report, pp. 96, 97.

In fact, rivers, like mountain torrents, often run for a long distance on the summit of a ridge built up by their own deposits. The delta of the Mississippi is a regular cone, or rather mountain, of dejection, extending far out into the Gulf of Mexico along the crest of which the river flows, sending off here and there, as it approaches the sea, a system of lateral streams resem. bling the fan-shaped discharge of a torrent. 
When a river is embanked at a given point, and consequently, the water of its floods, which would otherwise spread over a wide surface, is confined within narrow limits, the velocity of the current and its transporting power are augmented, and its burden of sand and gravel is deposited at some lower point, where the rapidity of its flow is checked by a dam or other artificial obstruction, by a diminution in the inclination of the bed, by a wider channel, or finally by a lacustrine or marine basin which receives its waters. Wherever it lets fall solid material, its channel is raised in consequence, and the declivity of the whole bed between the head of the embankment and the slack of the stream is reduced. Hence the current, at first accelerated by confinement, is afterwards checked by the mechanical resistance of the matter deposited and by the diminished inclination of its channel, and then begins again to let fall the earth it holds in suspension, and to raise its bed at the point where its overflow had been before prevented by embankment.* The bauk must now be raised in

* In proportion as the dikes are improved, and breaches and the escape of the water through them are less frequent, the height of the annual inundations is increased. Some towns on the bauks of the Po, and of course within the system of parallel embankments, were formerly secure from flood by the height of the artificial mounds on which they were built; but they have recently been obliged to construct ring-dikes for their protection.

Lombardini lays down the following general statement of the effects of river embankments :

"The immediate effect of embanking a river is generally an increase in the height of its floods, but, at the same time, a depression of its bed, by reason of the increased force, and consequently excavating action, of the current.

"It is true that coarser material may hence be carried further, and at the same time deposit itself on a reduced slope.

"The embankment of the upper branches of a river increases the volume, and therefore the height of the floods in the lower course, in consequence of the more rapid discharge of its affluents into it.

"When, in consequence of the flow of a river channel through an alluvial soil not yet regulated, or, in other words, which has not acquired its normal inclination, the course of the river has not become established, it is natural that its bed should rise more rapidly after its embankment. . . . .

"The embankment of the lower course of a river, near its discharge into the sea, causes the elevation of the bed of the next reach above, both because the swelling of the current, in consequence of its lateral confinement, occasions eddies, and of course deposits, and because the prolongation of the course of the stream, or the advance of its delta into the sea, is accelerated." -Die cangiamenti cui soggiacque l'idraulica condizione del Po, etc., pp. 41, 42.

Del Noce states that in the levellings for the proposed Leopolda railway, he 
proportion, and these processes would be repeated and repeated indefinitely, had not nature provided a remedy in floods, which sweep out recent deposits, burst the bonds of the river and overwhelm the adjacent country with final desolation, or divert the current into a new channel, destined to become, in its turn, the scene of a similar struggle between man and the waters.*

But here, as in so many other fields where nature is brought into conflict with man, she first resists his attempts at interference with her operations, then, finding him the stronger, quietly submits to his rule, and ends by contributing her aid to strengthen the walls and shackles by which he essays to confine her. If, by assiduons repair of his dikes, he, for a considerable time, restrains the floods of a river within new bounds, nature, by a series of ingenious compensations, brings the fluctuating bed of the stream to a substantially constant level, and when his ramparts have been, by his toil, raised to a certain height and widened to a certain thickness, she, by her laws of gravitation and cohesion, consolidates their material until it becomes almost as hard, as indissoluble, and as impervious as the rock.

But though man may press the forces of nature into his service, there is a limit to the extent of his dominion over them, and

found that the bed of the Sieve had been permanently elevated two yards between 1708 and 1841, and that of the Fosso di San Gaudenzio more than a yard and a half between 1752 and 1845. These, indeed, are not rivers of the rank of the Po; but neither are they what are technically called torrents or mountain streams, whose flow is only an occasional effect of heary rains or melting snow.-Trattato delle Macchie e Foreste di Toscana, Firenze, 1857, p. 29.

* The Hoang-ho has repeatedly burst its dikes and changed the channel of its lower course, sometimes delivering its waters into the sea to the north, sometimes to the south, of the peninsula of Chan-tung, thus varying its point of discharge by a distance of 220 miles.-Elisée Reclus, La Terre, t. i., p. 477 .

See interesting notices of the lower course of the Hoang-ho in Nature, Nor. $25,1869$.

The frequent changes of channel and mouth in the deltas of great rivers are by no means always an effect of diking. The mere accumulation of deposits in the beds of rivers which transport much sediment compels them continually to seek new outlets, and it is only by great effort that art can keep their points of discharge approximately constant. The common delta of the Ganges and the Brahmapootra is in a state of incessant change, and the latter rirer is said to have shifted its main channel 200 miles to the west since 1785 , the revolution having been principally accomplished between 1810 and 1830 . 
unless future generations shall discover new modes of controlling those forces, or new remedies against their action, he must at last succumb in the struggle. When the marine estuaries and other basins of reception shall be filled up with the sedimentary débris of the mountains, or when the lower course of the rivers shall be raised or prolonged, by their own deposits, until they have no longer such a descent that gravitation and the momentum of the current can overcome the frictional resistance of the bed and banks, the water will, in spite of all obstacles, diffuse itself laterally and for a time raise the level of the champaign land upon its borders, and at last convert it into morasses. It is for this reason that Lombardini advises that a considerable space along the lower course of rivers be left undiked, and the water allowed to spread itself over its banks and gradually raise them by its deposits.* This would, indeed, be a palliative, but only a palliative. For the present, however, we have nothing better, and here, as often in political economy, we must content ourselves with "après nous le déluge," allowing posterity to suffer the penalty of our improvidence and our ignorance, or to devise means for itself to ward off the consequences of them.

The deposit of slime by rivers upon the flats along their banks not only contributes greatly to the fertility of the soil thus flowed, but it subserves a still more important purpose in the general economy of nature. All running streams begin with excavating channels for themselves, or deepening the natural depressions in which they flow; + but in proportion as their outlets

* This method has been adopted on the lower course of the Lamone, and a considerable extent of low ground adjacent to that river has been raised by spontaneous deposit to a suflicient height to admit of profitable cultivation.

$\nmid I$ do not mean to say that all rivers excavate their own valleys, for I have no doubt that in the majority of cases such depressions of the surface originate in higher geological causes, such as the fissures and other irregularities of surface that could not fail to accompany upheaval, and hence the valley makes the river, not the river the valley. But even if we suppose a basin of the hardest rock to be elevated at once, completely formed, from the submarine abyss where it was fashioned, the first shower of rain that falls upon it, after it rises to the air, will discharge its waters along the lowest lines of the surface, and cut those lines deeper, and so on with every successive rain. The disintegrated rock from the upper part of the basin forms the lower by alluvial deposit, which is constantly transported farther and farther until the resistance of gravitation and cohesion balances the mechanical force of the 
are raised by the solid material transported by their currents, their relocity is diminished, they deposit gravel and sand at constantly higher and higher points, and so at last elevate, in the middle and lower part of their course, the beds they had previously scooped out." The raising of the channels is compensated in part by the simultaneous elevation of their banks and the flats adjoining them, from the deposit of the finer particles of earth and vegetable mould brought down from the mountains, without which elevation the low grounds bordering all rivers would be, as in many cases they in fact are, mere molasses.

All arrangements which tend to obstruct this process of raising

running water. Thus plains, more or less steeply inclined, are formed, in which the river is constantly changing its bed, according to the perpetually rarying force and direction of its currents, modified as they are by everfluctuating conditions. Thus the Po is said to have long inclined to move its chammel southwards, at certain points, in consequence of the mechanical force of its northern afluents. A diversion of these tributaries from their present beds, so that they should enter the main stream at other points and in different directions, might modify the whole course of that great river. But the mechanical force of the tributary is not the only element of its influence on the course of the principal stream. The deposits it lodges in the bed of the latter, acting as simple obstructions or causes of diversion, are not less important agents of change.

* The distance to which a new obstruction to the flow of a river, whether by a dam or by a deposit in its channel, will retard its current, or, in popular phrase, "set back the water," is a problem of more difficult practical solution than almost any other in hydraulics. The elements-such as straightness or crookedness of channel, character of bottom and banks, volume and previous velocity of current, mass of water far above the obstruction, extraordinary drought or humidity of seasons, relative extent to which the river may be affected by the precipitation in its own basin, and by supplies received through subterranean channels from sources so distant as to be exposed to very different meteorological influences, effects of clearing and other improvements always going on in new countries-are all extremely difficult, and some of them impossible, to be known and measured. In the American States, very numerous water-mills have been erected within a few years, and there is scarcely a stream in the settled portion of the country which has not several mill-dams upon it. When a dam is raised-a process which the gradual diminution of the summer currents renders frequently necessary-or when a new dam is built, it often happens that the meadows above are flowed, or that the retardation of the stream extends back to the dam next above. This leads to frequent law-suits. From the great uncertainty of the facts, the testimony is more conflicting in these than in any other class of cases, and the obstinacy with which "water causes" are disputed has become proverbial. 
the flats adjacent to the channel, whether consisting in dikes which confine the waters, and, at the same time, augment the velocity of the current, or in other means of producing the lastmentioned effect, interfere with the restorative economy of nature, and at last occasion the formation of marshes where, if left to herself, she might have accumulated inexhaustible stores of the richest soil, and spread them out in plains above the reach of ordinary floods.*

Dikes, which, as we have seen, are the means most frequently employed to prevent damage by inundation, are generally parallel to each other and separnted by a distance not very much greater than the natural width of the bed. $\dagger$ If such walls are high enough to confine the water and strong enough to resist its pressure, they secure the lands behind them from all the evils of inundation except those resulting from filtration; but such ramparts are enormously costly in original construction and in maintenance, and, as has been already shown, the filling up of the bed of the river in its lower course, by sand and gravel, often involves the necessity of incurring new expenditures in increasing the height of the banks. $\neq$ They are attended, too, with some

* The sediment of the Po has filled up some lagoons and swamps in its delta, and converted them into comparatively dry land; but, on the other hand, the retardation of the current from the lengthening of its course, and the diminution of its velocity by the deposits at its mouth, have forced its waters at some higher points to spread in spite of embankments, and thus fertile fields have been turned into unhealthy and unproductive marshes.-See BotTER, Sulla condizione dei Terreni Maremmani nel Ferrarese. Annali di Agricoltura, etc., Fasc. จ., 1863.

t In the case of rivers flowing through wide alluvial plains and much inclined to shift their beds, like the Po, the embankments often leave a very wide space between them. The dikes of the Po are sometimes three or four miles apart.

$\mp$ It appears from the investigations of Lombardini that the rate of elevation of the bed of the Po has been much exaggerated by earlier writers, and in some parts of its course the change is so slow that its level may be regarded as nearly constant. Observation has established a similar constancy in the bed of the Rhone and of many other important rivers, while, on the other hand, the beds of the Adige and the Brenta, streams of a more torrential character, are raised considerably above the level of the adjacent fields.

The length of the lower course of the Po having been considerably increased by the flling up of the Adriatic with its deposits, the velocity of the current ought, prima facie, to have been diminished and its bed raised in proportion. 
collateral disadvantages. They deprive the earth of the fertilizing deposits of the waters, which are powerful natural restoratives of soils exhausted by cultivation; they accelerate the rapidity and transporting power of the current at high water by confining it to a narrower channel, and it consequently conveys to the sea the

There are abundant grounds for believing that this has happened in the case of the Nile, and one reason why the same effect has not been more sensibly perceptible in the Po is, that the confinement of the current by continuous embankments gives it a high-water velocity suflicient to sweep out deposits let fall at lower stages and slower movements of the water. Torrential streams tent to excavate or to raise their beds according to the inclination, and to the character of the material they transport. No general law on this point can be laid down in relation to the middle and lower courses of rivers. The conditions which determine the question of the depression or elevation of a riverbed are too multifirious, variable and complex, to be subjected to formulæ, and they can scarcely even be enumerated.

The following observation, however, though apparently too unconditionally stated, is too important to be omitted:

Rivers which transport sand, gravel, pebbles, heavy mineral matter in short, tend to raise their own beds; those charged only with fine, light earth, to cut them deeper. The prairie rivers of the western United States have deep channels, because the mineral matter they carry down is not heavy enough to resist the impulse of even a moderate current, and those tributaries of the Po which deposit their sediment in the lakes-the Ticino, the Adda, the Oglio and the Mincio-flow in deep cuts, for the same reason.-BAUMGARTEN, p. 132.

In regard to the level of the bed of the Po, there is another weighty consideration that does not seem to have received the attention it deserves. I refer to the secular depression of the western coast of the Adriatic, which is computed at the rate of fifteen or twenty centimetres in a century, and which of course increases the inclination of the bed, and the velocity and transporting power of the current of the Po, unless we assume that the whole course of the river, from the sea to its sources, shares in the depression. Of this assumption there is no proof, and the probability is to the contrary. For the evidence, though not conclusive perhaps, tends to show an elevation of the Tuscan coast, and even of the Ligurian shore, at points lying farther west than the sources of the $\mathrm{P}$. The level of certain parts of the bed of the river referred to by Lombardini as constant, is not their elevation as compared with points nearer the sea, but relatively to the adjacent plains, and there is every reason to believe that the depression of the Adriatic coast, whether, as is conceirable, occasioned by the mere weight of the fluviatile deposits or by more general geological causes, has increased the slope of the bed of the river between the points in question and the sea. In this instance, then, the relative permanency of the river level at certain points may be, not the ordinary case of a natural equilibrium, but the negative effect of an increased velocity of current which prevents deposits where they would otherwise have happened. 
earthy matter it holds in suspension, and chokes up harbors with a deposit which it would otherwise have spread over a wider surface; they interfere with roads and the convenience of river navigation, and no amount of cost or care can secure them from occasional rupture, in case of which the rush of the waters through the breach is more destructive than the natural flow of the highest inundation.*

* To secure the city of Sacramento, in California, from the inundations to which it is subject, a dike or levee was built upon the bank of the river and raised to an elevation above that of the highest known floods, and it was connected, below the town, with grounds lying considerably above the river. On one occasion a breach in the dike occurred above the town at a very high stage of the flood. The water poured in behind it, and overflowed the lower part of the city, which remained submerged for some time after the river had retired to its ordinary level, because the dike, which had been built to keep the water out, now kept it in.

According to Arthur Young, on the lower Po, where the surface of the river at high water has been elevated considerably above the level of the adjacent fields by diking, the peasants in his time frequently endeavored to secure their grounds against threatened devastation through the bursting of the dikes, by crossing the river, when the danger became imminent, and opening a cut in the opposite bank, thus saving their own property by flooding their neighbors'. He adds, that at high water the navigation of the river was absolutely interdicted except to mail and passenger boats, and that the guards fired upon all others; the object of the prohibition being to prevent the peas ants from resorting to this measure of self-defence.-Travels in Italy and Spain, Nov. 7, 1789.

In a flood of the Po in 1839, a breach of the embankment took place at Bonizzo. The water poured through, and inundated 116,000 acres, or 181 square miles, of the plain to the depth of from twenty to twenty-three feet in the lower parts. In the inundation of MIay, 1872, a great breach occurred in the dike near Ferrara, 170,000 acres of cultivated land were overflowed, and a population of 30,000 souls driven from their homes. In the flood of October in the same year, in consequence of a breach of the dike at Revere, 250,000 acres of cultivated soil were overflowed, and 60,000 persons were made homeless. The dikes were seriously injured at more than forty points. See page 271 , ante. In the flood of 1856 , the Loire made seventy-three breaches in its dikes, and thus, instead of a comparatively gradual rise and gentle expansion of its waters, it created seventy-three impetuous torrents, which inflicted infinitely greater mischief than a simply natural overflow would have done. The dikes or levees of the Mississippi, being of more recent construction than those of the Po, are not yet well consolidated and fortified, and for this reason crevasses which occasion destructive inundations are of very frequent occurrence. The great flood of $1881-2$, in the valley of the Mississippi, which surpassed all former experience, is said to have overflowed 
For these reasons, many experienced engineers are of opinion that the system of longitudinal dikes is fundamentally wrong and it has been argued that if the Po, the Adige and the Brenta had been left unconfined, as the Nile formerly was, ard allowed to spread their muddy waters at will, according to the laws of nature, the sediment they have carried to the coast would have been chiefly distributed over the plains of Lombardy. Their banks, it is supposed, would have risen as fast as their beds, the coast-line would not have been extended so far into the Adriatic, and, the current of the streams being consequently shorter, the inclination of their channel and the rapidity of their flow would not have been so greatly diminished. Had man, too, spared a reasonable proportion of the forests of the Alps, and not attempted to control the natural drainage of the surface, the $\mathrm{Po}$, it has been said, .would resemble the Nile in all its essential characteristics, and, in spite of the difference of climate, perhaps be regarded as the friend and ally, not the enemy and the invader, of the population which dwells upon its banks.

But it has been shown by Humphreys and Abbot that the system of longitudinal dikes is the only one susceptible of advantageous application to the Mississippi, and if we knew the primitive geography and hydrography of the basin of the $\mathrm{Po}$ as well as we do those of the valley of the great American river, we should very probably find that the condemnation of the plan pursued by the ancient inhabitants of Lombardy is a too hasty generalization, and that the case of the Nile is an exception, not an example, of the normal régime and condition of a great river.*

no less than 80,000 square miles. Its current was computed as having a width of from thirty to forty miles. A large population was for months dependent for its daily food on rations distributed by the National Government.

* Embankments have been employed on the lower course of the Po for at least two thousand years, and for some centuries they have been connected in a continuous chain from the sea to the vicinity of Cremona. From early ages the Italian hydrographers have stood in the front rank of their profession, and the Italian literature of this branch of material improvement is exceedingly voluminous, exhaustive and complete.

"The science of rivers after the barbarous ages," says Mengotti, " may be said to hare been born and perfected in Italy." The eminent Italian engineer, Lombardini, published in 18\%0, under the title of Guida allo studio dell' idrolo- 
But in any event, these theoretical objections are counsels après coup. The dikes of the $\mathrm{Po}$, and probably of some of its. tributaries, were begun before we have any trustworthy physical or political annals of the provinces they water. The civilization of the valley has accommodated itself to these arrangements, and the interests which might be sacrificed by a change of system are too vast to be hazarded by what, in the present state of our knowledge, can be only considered as a doubtful experiment.*

The embankments of the Po, though they are of vast extent and have employed centuries in their construction, are inferior in magnitude to the dikes or levees of the Mississippi, which are the work of scarcely a hundred years and of a comparatively sparse population. On the right or western bank of the river, the levee extends, with only occasional interruptions from high bluffs and the mouths of rivers, for a distance of more than. 1,100 miles. The left bank is, in general, higher than the right, and upon that side a continuous embankment is not needed; but the total length of the dikes of the Mississippi, including those of the lower course of its tributaries and of its bayous or natural emissaries, is not less than 2,500 miles. They constitute, therefore, not only one of the greatest material achievements of the American people, but one of the most remarkable systems of physical improvement which has been anywhere accomplished in modern times.

Those who condemn the system of longitudinal embankments have often advised that, in cases where that system can not be

gia fluviale e dell' Idraulica pratica, a manual which serves both as a summary of the recent progress of that science and as an index to the literature of the subject. The professional student, therefore, as well as the geographer, will have very frequent occasion to consult Italian authorities, and in the very valuable Report of Humphreys and Abbot on the Mississippi, America has lately made a contribution to our potamological knowledge, which, in scientific interest and practical utility, does not fall short of the ablest European productions in the same branch of inquiry.

* Duponchel advises a resort to the "heroic remedy" of sacrificing, or con verting into cellars, the lower stories of houses in cities exposed to river inun dation, filling up the streets, and admitting the water of floods freely over the. adjacent country, and thus allowing it to raise the level of the soil to that of the highest inundations.-Traité d'Hydraulique et de Géologis Agricoles. Paris, 1868, p. 241. 
abandoned without involving too great a sacrifice of existing interests, the elevation of the dikes should be much reduced, so as to present no obstruction to the lateral spread of extraordinary floods, and that they should be provided with sluices to admit the water without riolence whenever they are likely to be overflowed. Where dikes have not been erected, or where they have been reduced in height, it is proposed to construct, at convenient intervals, transverse embankments of moderate height running from the banks of the river across the plains to the hills which bound them. These measures, it is argued, will diminish the violence of inundations by permitting the waters to extend themselves over a greater surface, and by thus retarding the flow of the river currents, will, at the same time, secure the deposit of fertilizing slime upon all the soil covered by the flood.*

Rozet, an eminent French engineer, has proposed a method of liminishing the ravages of inundations, which aims to combine the advantages of all other systems, and at the same time to obviate the objections to which they are all more or less liable. $\dagger$ The plan of Rozet is recommended by its simplicity and cheapness as well as its facility and rapidity of execution, and is looked upon with favor by many persons very competent to judge in such matters. It is, however, by no means capable of universal application, though it would often doubtless prove lighly useful in connection with the measures now eniployed in Southeastern France. He proposes to commence with the amphitheatres in which mountain torrents so often rise, by covering their slopes and filling their beds with loose blocks of rock, and by constructing at their outlets, and at other narrow points in the channels of the torrents, permeable barriers of the same material promiscuously heaped up, much according to the method employed by the ancient Rumans in their northern provinces for a similar purpose. By this means, he supposes, the rapidity of the current would be clecked, and the quantity of transported pebbles and

* The system described in the text is substantially the Egyptian method, the ancient Nile dikes having been constructed rather to retain than to exclude the water.

† Moyens de forcer les Torrents de rendre une partie du sol qu'ils ravagent, et đempêcher les grandes Inondations. 
gravel-mhich, by increasing the mechanical force of the water, greatly aggrarate the damage by floods-much diminished. When the stream has reached that part of its course where it is bordered by soil capable of cultivation, and worth the expense of protection, he proposes to place along one or both banks, according to circumstances, a line of cubical blocks of stone or pillars of masonry three or four feet high and wide, and at the distance of about eleven yards from each other. The space between the two lines, or between a line and the opposite high bank, would, of course, be determined by observation of the width of the swiftwater current at high floods. As an auxiliary measure, small ditches and banks, or low walls of pebbles, should be constructed from the line of blocks across the grounds to be protected, nearly at right angles to the current, but slightly inclining downwards, and at convenient distances from each other. Rozet thinks the proper interval would be 300 yards, and it is evident that, if he is right in his main principle, hedges, rows of trees, or even common fences, would in many cases answer as good a purpose as banks and trenches or low walls. The blocks or pillars of stone would, he contends, check the lateral currents so as to compel them to let fall all their pebbles and gravel in the main channel -where they would be rolled along until ground down to sand or silt-and the transverse obstructions would detain the water upon the soil long enough to secure the deposit of its fertilizing slime. Numerous facts are cited in support of the author's views, and I imagine there are few residents of rural districts whose own observation will not furnish testimony confirmatory of their soundness.*

\footnotetext{
* The effect of trees and other detached obstructions in checking the flow of water is particularly noticed by Palissy in his essay on Waters and Fount. ains, p. 173 , edition of 1844 . "There be," says he, "in divers parts of France, and specially at Nantes, wooden bridges, where, to break the force of the waters and of the floating ice, which might endamage the piers of the said bridges, they have driven upright timbers into the bed of the rivers above the said piers, without the which they should abide but little. And in likewise, the trees which be planted along the mountains do much deaden the violence of the waters that flow from them."

Lombardini attaches great importance to the planting of rows of trees transversely to the current on grounds subject to overflow.-Esame degli Studi sul Tevere, § 53, and Appendice, $\S \S 33,34$.
} 


\section{Removal of Obstructions.}

The removal of obstructions in the beds of rivers by dredging the bottom or blasting rocks, the washing out of deposits, and the local increase of the depth of water through narrowing the channel by means of spurs or other constructions projecting from the banks, and, finally, the eutting off of bends, thus shortening the course of the stream, diminishing the resistance of its shores and bottom and giving the bed a more rapid declivity, have all been employed not only to facilitate navigation, but as auxiliaries to more effectual modes of preventing inundations. But a bar removed from one point is almost sure to re-form at the same or another, spurs occasion injurious eddies and unforeseen diversions of the current, * and the cutting off of bends, though occasionally effected by nature herself, and sometimes advantageous in torrential streams whose banks are secured by solid walls of stone or other artificial constructions, seldom establishes a permanent channel; and besides, the increased rapidity of the flow through the new cut often injuriously affects the régime of the river for a considerable distance below. $\dagger$

* The introduction of a new system of spurs with parabolic curves has been attended with great advantage in France.-Annales du Génie Civil, Mai, 1863.

+ This practice has sometimes been resorted to on the Mississippi with advantage to navigation, but it is quite another question whether that advantage has not been too dearly purchased by the injury to the banks at lower points. If we suppose a river to have a navigable course of 1,600 miles as measured by its natural channel, with a descent of 800 feet, we shall have a fall of six inches to the mile. If the length of channel be reduced to 1,200 miles by cutting off bends, the fall is increased to eight inches per mile. The augmentation of velocity cousequent upon this increase of inclination is not computable without taking into account other elements, such as depth and volume of water, diminution of direct resistance, and the like; but in almost any supposable case, it would be sufficient to produce great effects on the height of floods, the deposit of sediment in the channel, on the shores, and at the outlet, the erosion of banks and other points of much geographical importance.

The $\mathrm{Po}$, in those parts of its course where the embankments leave a wide space between, often cuts off bends in its channel and straightens its course. These short cuts are called salti, or leaps, and sometimes abridge the distance between their termini by several miles. In 1777, the salto of Cottaro shortened a distance of 7,000 mitres by 5,000 , or, in other words, reduced the length of the river by five kilomitres, or about three miles, and in 1807 and 1810 the two salti of MIezzanone effected a still greater reduction. 


\section{Combination of Methods.}

Upon the whole, it is obvious that no one of the methods heretofore practiced or proposed for averting the evils resulting from river inundations is capable of universal application. Each of them is specially suited to a special case. But the hydrography of almost every considerable river and its tributaries will be found to embrace most special cases, most known forms of superficial fluid circulation. For rivers, in general, begin in the mountains, traverse the plains, and end in the sea; they are torrents at their sources, swelling streams in their middle course, placid currents, flowing molli flumine, at their termination. Hence in the different parts of this course the different methods of controlling and utilizing them may successively find application, and there is every reason to believe that by a judicious application of all, every great river may, in a considerable degree, be deprived of its powers of evil and rendered subservient to the use, the convenience, and the dominion of man.*

\section{Dikes of the Nile.}

"History tells us," says Mengotti, "that the Nile became terrible and destructive to ancient Egypt, in consequence of being confined within elevated dikes, from the borders of Nubia to the sea. It being impossible for these barriers to resist the pressure of its waters at such a height, its floods burst its ramparts, sometimes on one side, sometimes on the other, and deluged the plains, which lay far below the level of its current. . . . . In one of its formidable inundations the Nile overwhelmed and drowned a

* On the remedies against inundation, see the valuable paper of Lombar. DINI, Sulle Inondazioni avvenute in questi ultimi tempi in Francia. Milano, 1858.

There can be no doubt that, in the case of rivers which receive their supply in a large measure from mountain streams, the methods described in a former chapter as recently employed in Southeastern France to arrest the formation and lessen the force of torrents, would prove equally useful as a preventive remedy against inundations. They would both retard the delivery of surfacewater and diminish the discharge of sediment into rivers, thus operating at once against the two most efficient causes of destructive tloods. See Chapter III., ante, p. 308, et seq. 
large part of the population. The Egsptians then perceived that they were struggling against nature in vain, and they resolved to remove the dikes, and permit the river to expand itself laterally and raise by its deposits the surface of the fields which border its channel." *

The original texts of the passages cited by Mengotti, from Latin translations of Diodorus Siculus and Plutarch and from Pliny the Elder, do not by any means confirm this statement, though the most important of them, that from Diodorus Siculus, is, perhaps, not irreconcilable with it. Not one of them speaks of the removal of the dikes, and I understand them all as relating to the mixed system of embankments, reservoirs and canals which has been employed in Egypt through the whole period concerning which we have clear information. I suppose that the disastrous inundations, referred to by the authors in question, were simply extraordinary floods of the same character as those which have been frequent at later periods of Egyptian history, and I find nothing in support of the proposition that continuous embankments along the banks of the Nile ever existed until such were constructed by Mehemet Ali. $\dagger$

The object of the dikes of the Po, and, with few exceptions, of those of other European rivers, has always been to confine the waters of floods and the solid material transported by them within as narrow a channel as possible, and entirely to prevent them from flowing over the adjacent plains. The object of the Egyptian dikes and canals is the reverse, namely, to diffuse the swelling waters and their sediment over as wide a surface as possible, to store them up until the soil they cover has been thor-

\footnotetext{
* Idraulica Fisica e Sperimentale. 2d edizione, vol. i., pp. 131, 133.
}

$\uparrow$ The gradual elevation of the bed of the Nile from sedimentary deposit, from the prolongation of the Delta and consequent reduction of the inclination of the river-bed. or, as has been supposed by some, though without probability, from a secular rise of the coast, rendered necessary some change in the hydraulic arrangements of Egypt. IIehemet Ali was advised to adopt a system of longitudinal levees, and he embanked the river from Jebel silsileh to the sea with dikes six or seven feet high and twenty feet thick. Similar embankments were made around the Delta. These dikes are provided with iransverse embankments, with sluices for aldmitting and camals for distributing the water, and they serve rather to retain the water and contrul its flow than to exclude it.-CLOT BEY, A perşu sus l'Egypte, ii., 437. 
oughly saturated and enriched, and then to conduct them over other grounds requiring a longer or a second submersion, and, in general, to suffer none of the precious fluid to escape except by eraporation and infiltration.

Lake Mœris, whether wholly an artificial excavation, or a natural basin converted by embankments into a reservoir, was designed chiefly for the same purpose as the barrage built by Mougel Bey across the two great arms which enclose the Delta, namely, as a magazine to furnish a perennial supply of water to the thirsty soil. But such artificial arrangements alone did not suffice. Canals were dug to receive the water at lower stages of the river and conduct it far into the interior, and as all this was still not enough, hundreds of thousands of wells were sunk to bring up from the subsoil, and spread over the surface, the water which, by means of infiltration from the river-bed, pervades the inferior strata of the whole valley.*

If a system of lofty continuous dikes, like those of the $\mathrm{Po}$, had really been adopted in Egypt, in the early dynasties when the power and the will to undertake the most stupendous material enterprises were so eminently characteristic of the government of that country, and persevered in through later ages, and the waters of the annual inundation had thus been permanently prevented from flooding the land, it is conceivable that the productiveness of the small area of cultivable soil in the Nile valley might have been long kept up by artificial irrigation and the application of manures. But nature would have rebelled at last, and centuries before our time the mighty river would have burst the fetters by which impotent man had vainly striven to bind his swelling floods, the fertile fields of Egypt would have been converted into dank morasses, and then, perhaps, in some distant future, when the expulsion of man should have allowed the gradual restoration of the primitive equilibrium, would be again transformed into luxuriant garden and plough land. Fortunately, the sapientia Agyptiorum, the wisdom of the Egyptians, taught them better things. They invited and welcomed, not repulsed, the slimy embraces of Nilus, and his favors have been, from the

* It is said that in the Delta alone 50,000 wells are employed for irrigation 
hoariest antiquity, the greatest material blessing that nature ever bestowed upon a people.*

\section{Deposits of the Nile.}

The Nile is larger than all the rivers of Lombardy together ; $\uparrow$ it drains a basin fifty, possibly even a hundred, times as exten-

* Deep borings have not detected any essential difference in the quantity or quality of the deposits of the Nile for forty or fifty, or, as some compute, for a hundred centuries. From what vast store of rich earth does this river derive the three or four inches of fertilizing material which it spreads over the soil of Egypt every hundred years? Not from the White Nile, for that river drops nearly all its suspended matter in the broad expansions and slow current of its channel south of the tenth degree of north latitude. Nor does it appear that much sediment is contributed by the Bahr-el-Azrek, which flows through forests for a great part of its course. I have been informed by an old European resident of Egypt who is very familiar with the Upper Nile, that almost the whole of the earth with which its waters are charged is brought down by the Takazzé.

+ From daily measurements during a period of fourteen years-1827 to 1810 - the mean delivery of the Po at Ponte Lagoscuro, below the entrance of its last tributary, is found to be 1,720 cubic mètres, or 60,745 cubic feet, per second. Its smallest delivery is 186 cubic mètres, or 6,569 cubic feet, its greatest 5,156 cubic mètres, or 182,094 cubic feet. The average delivery of the Nile being 101,000 cubic feet per second, it follows that the Po contributes to the Adriatic rather more than six-tenths as much water as the Nile to the Jediterranean-a result which will surprise most readers. It must, however, be admitted that there is no small discrepancy among geographers with regard to such estimates. Duponcrel, Hydrologie Agricole, pp. 60, 61, states the mean delivery of the Rhone at 1,718 cubic mètres per second, that of the Rhine at 2,000 cubic mètres. Elisée Reclus, La Terre, i., p. 535, gives the delivery of the Rhone as 2,603 mètres per second, that of the Po as 1,785, and that of the Rhine as 1,975. I suspect a typographical error here in regard to the Rhone. Though the Po receives four-tenths of its water from lakes, in which the streams that empty into them let fall the solid material they bring down from the mountrins, its deposits in the Adriatic are at least sixty or seventy per cent. greater than those transported to the Mediterranean by the Rhone, which derives most of its supply from mountain and torrential tributaries. Those tributaries lodge much sediment in the Lake of Geneva and the Lac de Bourget, but the total erosion of the Po and its aftluents must be considerably greater than that of the Rhone system. The Rhine conveys to the sea much less sediment than either of the other two rivers.-LovBandivr, Cangiamenta nella condizione del Po, pp. 29, 39.

The mean discharge of the Mississippi is 675,000 cubic feet per second, and, accordingly, that river contributes to the sea about eleven times as much water as the $\mathrm{Po}$, and more than six and a half times as much as the Nile. The dis. 
sive; its banks have been occupied by man probably twice as long. But its geographical character has not been much changed in the whole period of recorded history, and, though its outlets have somewhat fluctuated in number and position, its historically known encroachments upon the sea are trifling compared with those of the Po and the neighboring streams. The deposits

charge of the Mississippi is estimated at one-fourth of the precipitation in its basin-certainly a very large proportion, when we consider the rapidity of evaporation in many parts of the basin, and the probable loss by infiltration. - Humphreys ANd AвBot's Report, p. 93.

The basin of the Mississippi has an area forty-six times as large as that of the Po, with a mean annual precipitation of thirty inches, while that of the Po, at least according to official statistics, has a precipitation of forty inches. Hence the down-fall in the former is one-fourth less than in the latter. Besides this, the Mississippi loses little or nothing by the diversion of its waters for irrigation. Consequently the measured discharge of the Mississippi is proportionally much less than that of the Po, and we are authorized to conclude that the difference is partly due to the escape of water from the bed, or at least the basin, of the Mississippi, by subterranean channels.

These comparisons are interesting in reference to the supply received by the sea directly from great rivers, but they fail to give a true idea of the real volume of the latter. To take the case of the Nile and the Po: we have reason to suppose that comparatively little water is diverted from the tributaries of the former for irrigation, but enormous quantities are drawn from its main trunk for that purpose, below the point where it receives its last affluent. This quantity is now increasing in so rapid a proportion, that Elisée Reclus foresees the day when the entire low-water current will be absorbed by new arrangements to meet the needs of extended and improved agriculture. On the other hand, while the affluents of the Po send off a great quantity of water into canals of irrigation, the main trunk loses little or nothing in that way except at Chivasso. Trustworthy data are wanting to enable us to estimate how far these different modes of utilizing the water balance each other in the case under consideration. Perhaps the Canal Cavour, and other irrigating canals now proposed, may one day intercept as large a proportion of the supply of the lower Po as Egyptian dikes, canals, shadoofs and steam-pumps do of that of the Nile.

Another circumstance is important to be considered in comparing the character of these three rivers. The Po runs nearly east and west, and it and its tributaries are exposed to no other difference of meteorological conditions than those which always subsist between the mountains and the plains. The course of the Nile and of the Mississippi is mainly north and south. The sources of the Nile are in a very humid region, its lower course for many hundred miles in almost rainless latitudes with enormous evaporating power, while the precipitation is large throughout the Mississippi system, except in the basins of some of its western affluents.-See Article Po, in Johnson's Cyclopoedia. 
of the Nile are naturally greater in Upper than in Lower Egypt. They are found to have raised the soil at Thebes about seven feet within the last seventeen hundred years, and in the Delta the rise has been certainly more than half as great.

We shall, therefore, probably not exceed the truth if we suppose the annually inundated surface of Egypt to have been elevated, upon an average, ten feet," within the last 5,000 years, or twice and a half the period during which the history of the Po is known to us. $\dagger$

\footnotetext{
* Fraas and Eyth maintain that we have no trustworthy data for calculating the annual or secular elevation of the soil of Egypt by the sediment of the Nile. The deposit, they say, is variable from irregularity of current, and especially from the interference of man with the operations of nature, to a degree which renders any probable computation of the amount quite impossible.-FraAs, Aus dem Orient, pp. 212, 213.
}

The sedimentary matter transported by the Nile might doubtless be estimated with approximate precision by careful observation of the proportion of suspended slime and water at different stations and seasons for a few successive years. Figari Bey states that at low stages the water of the Nile contains little or no sediment, and that the greatest proportion occurs about the end of July, and, of course, while the river is still rising. Experiments at Khartoum at that season showed solid matter in the proportion of one to a thousand by weight. The quantity is relatively greater at Cairo, a fact which shows that the river receives more earth from the erosion of its banks than it deposits at its own bottom, and it must consequently widen its channel unless we suppose a secular depression of the coast at the mouth of the Nile which produces an increased inclination of the bed of the river, and consequently an augmented velocity of flow sufficient to sweep out earth from the bottom and mix it with the current.

Herschell states the Nile sediment at 1 in 633 by weight, and computes the entire annual quantity at 140 millions of tons.-Physical Geography, p. 231.

The mean proportion of sedimentary material in the waters of the Mississippi is calculated at 1 to 1,500 by weight, and 1 to 2,900 in volume, and the total annual quantity at $812,500,000,000$ pounds, which would cover one square mile to the depth of 241 feet.-Huarpmens AND ABBOT, Report, p. 149.

+ We are quite safe in supposing that the valley of the Nile has been occupied by man at least 5,000 years. The dates of Egyptian chronology are uncertain, but I believe no inquirer estimates the age of the great pyramids at less than forty centuries, and the construction of such works implies an already ancient civilization.

It is an interesting fact that the old Egyptian system of embankments and canals is probably more ancient than the geological changes which have con. verted the Mississippi from a limpid to a turbid stream, and occasioned the formation of the vast delta at the mouth of that river. Humphreys and Abbot 
As I have observed, the area of cultivated soil is much less extensive now than under the dynasties of the Pharaohs and the Ptolemies; for-though, in consequence of the elevation of the river-bed, the inundations now have a wider natural spread-the industry of the ancient Egyptians conducted the Nile water over a great surface which it does not now reach.

Had the Nile been banked in, like the Po, all this deposit, except that contained in the water diverted by canals or otherwise drawn from the river for irrigation and other purposes, would have been carried out to sea. This would have been a considerable quantity; for the Nile holds some earth in suspension at all seasons except at the very lowest water, a much larger proportion during the flood, and irrigation must have been carried on during the whole year. The precise amount of sediment which would have been thus distributed over the soil is matter of conjecture, but though large, it would have been much less than the inundations have deposited, and continuous longitudinal embankments would have compelled the Nile to transport to the Mediterranean an immense quantity over and above what it has actually deposited in that sea. The Mediterranean is shoal for some miles out to sea along the whole coast of the Delta, and the large bays or lagoons within the coast-line, which communicate both with the river and the sea, have little depth of water. These lagoons the river deposits would have filled up, and there would still have been surplus earth enough to extend the Delta far into the Mediterranean.*

conclude that the delta of the Mississippi began its encroachments on the Gulf of Mexico not more than 4,400 years ago, before which period they supposo the Mississippi to have been "a comparatively clear stream," conveying very little sediment to the sea. The present rate of advance of the delta is 262 feet a year, and there are reasons for thinking that the amount of deposit has long been approximately constant.-Report, pp. $435,436$.

* The present annual extension of the Delta is, if perceptible, at all events very small. According to some authorities, a few hectares are added every year at each Nile mouth. Others, among whom I may mention Fraas, deny that there is any extension at all, the deposit being balanced by a secular depression of the coast.

Elisée Reclus states that the Delta advances about 40 inches per year. - Ia Terre, i., p. 500 . 


\section{Obstruction of River Mouths.}

The mouths of a large proportion of the streams known to ancient navigation are already blocked up by sand-bars or fluviatile deposits, and the maritime approaches to river harbors frequented by the ships of Phenicia and Carthage and Greece and Rime are shoaled to a considerable distance out to sea. The inclination of the lower course of almost every known river-bed has been considerably reduced within the historical period, and nothing but great volume of water, or exceptional rapidity of flow, now enables a few large streams like the Amazon, the La Plata, the Ganges, and, in a less degree, the Mississippi, to carry their own deposits far enough out into deep water to prevent the formation of serious obstructions to navigation. But the degradation of their banks, and the transportation of earthy matter to the sea by their currents, are gradually filling up the estuaries even of these mighty floods, and unless the threatened evil shall be averted by the action of geological forces, or by artificial contrivances more efficient than dredging-machines, the destruction of every harbor. in the world which receives a considerable river must inevitably take place at no very distant date.

This result would, perhaps, have followed in some incalculably distant future, if man had not come to inhabit the earth as soon as the natural forces, which had formed its surface, had arrived at such an approximate equilibrium that his existence on the globe was possible; but the general effect of his industrial operations has been to accelerate it immensely. Rivers, in countries planted by nature with forests and never inhabited by man, employ the little earth and gravel they transport chiefly to raise their own beds and to form plains in their basins. In their upper course, where the current is swiftest, they are most heavily charged with coarse rolled or suspended matter, and this, in floods, they deposit on their shores in the mountain valleys where they rise; in their middle course, a lighter earth is spread over the bottom of their widening basins, and forms plains of moder. ate extent; the fine silt which floats farther is deposited over a still broader area, or, if carried out to sea, is in great part quickly swept far off by marine currents and dropped at last in deep 
water. Man's "improvement" of the soil increases the erosion from its surface; his arrangements for confining the lateral spread of the water in floods compel the rivers to transport to their mouths the earth derived from that erosion even in their upper course: and, consequently, the sediment they deposit at their outlets is not only much larger in quantity, but composed of heavier materials, which sink more readily to the bottom of the sea and are less easily removed by marine currents.

The tidal movement of the ocean, deep-sea currents, and the agitation of inland waters by the wind, lift up the sands strewn over the bottom by diluvial streams or sent down by mountain torrents, and throw them up on dry land, or deposit them in sheltered bays and nooks of the coast-for the flowing is stronger than the ebbing tide, the affluent than the refluent wave. This cause of injury to harbors it is not in man's power to resist by any means at present available; but, as we have seen, something can be done to prevent the degradation of high grounds, and to diminish the quantity of earth which is annually abstracted from the mountains, from table-lands and from river-banks, to raise the bottom of the sea.

This latter cause of harbor obstruction, though an active agent, is, nevertheless, in many cases, the less powerful of the two. The earth suspended in the lower course of fluviatile currents is lighter than sea-sand, river water lighter than sea-water, and hence, if a land stream enters the sea with a considerable volume, its water flows over that of the sea, and bears its slime with it until it lets it fall far from shore, or, as is more frequently the ease, mingles with some marine current and transports its sediment to a remote point of deposit. The earth borne out of the mouths of the Nile is in part carried over the waves which throw up sea-sand on the beach, and deposited in deep water, in part drifted by the current, which sweeps east and north along the coasts of Egypt and Syria, and lodged in every nook along the shore-and among others, to the great detriment of the Suez Canal, in the artificial harbor at its northern terminus-and in part borne along until it finds a final resting-place in the northeastern angle of the Medi terranean.* Thus the earth loosened by the rude Abyssinian

\footnotetext{
* "The stream carries this mud, etc., at first farther to the east, and only lets it fall where the force of the current becomes weakened. This explains
} 
ploughshare, and washed down by the rain from the hills of Ethiopia which man has stripped of their protecting forests, contrilintes to raise the plains of Egypt, to shoal the maritime channels which lead to the city built by Alexander near the mouth of the Nile, to obstruct the artificial communication between the Merliterranean and the Red Sea, and to fill up the harbors made famous by Phenician commerce.

\section{Deposits of the Tuscan Rivers.}

The Arno and all the rivers rising on the western slopes and spurs of the Apennines, carry down immense quantities of mud to the Mediterranean. There can be no doubt that the volume of earth so transported is very much greater than it would have been had the soil about the headwaters of those rivers continued

the continual advance of the land seaward along the Syrian coast, in consequence of which Tyre and Sidon no longer lie on the shore, but some distance inland. That the Nile contributes to this deposit may easily be seen, even by the unscientific observer, from the stained and turbid character of the water for many.miles from its mouths. Ships often encounter floating masses of Nile mud, and Dr. Clarke thus describes a case of this sort:

"While we were at table, we heard the sailors who were throwing the lead suddenly cry out: 'Three and a half !' The ship slackened her way, and veered about. As she came round, the whole surface of the water was seen to be covered with thick, black mud, which extended so far that it appeared like an island. At the same time, actual land was nowhere to be seen-not even from the mast-head-nor was any notice of such a shoal to be found on any chart on board. The fact is, as we learned afterwards, that a stratum of mud, stretching from the mouths of the Nile for many miles out into the open sea, forms a movable deposit along the Egyptian coast. If this deposit is driven forwards by powerful currents, it sometimes rises to the surface, and disturbs the mariner by the sudden appearance of shoals where the charts lead him to expect a considerable depth of water. But these strata of mud are, in reality, not in the least dangerous. As soon as a ship strikes them they break up at once, and a frigate may hold her course in perfect safety where an inexperienced pilot, misled by his soundings, would every moment expect to be stranded."-BöTTGER, Das Mittelmeer, pp. 188, 189.

This phenomenon is not peculiar to the locality in question, and it is frequently observed in the Gulf of Bengal, and other great marine estuaries, where immense floating mud-banks are met with. These, like oil on the surface, still the waves, and ships lie-to quietly amongst them. See Nature, Decem. her 17, 1874, pp. 135, 136. 
to be protected from wash by forests; and there is as little ques. tion that the quantity borne out to sea by the rivers of Western Italy is much increased by artificial embankments, because they are thereby prevented from spreading over the surface the sedimentary matter with which they are charged. The western coast of Tuscany has advanced some miles seawards within a very few centuries. The bed of the sea, for a long distance, has been raised, and of course the relative elevation of the land above it lessened; harbors have been filled up and destroyed; long lines of coast-dunes have been formed, and the diminished inclination of the beds of the rivers near their ontlets has caused their waters to overflow their banks and convert them into pestilential marshes. The territorial extent of Western Italy has thus been considerabiy increased, but the amount of soil habitable and cultivable by man has been, in a still higher proportion, diminished. The coast of ancient Etruria was filled with great commercial towns, and their rural environs were occupied by a large and prosperous population. But maritime Tuscany has long been one of the most unhealthy districts in Christendom; the famous Etruscan mart of Populonia has scarcely an inhabitant; the coast is almost absolutely depopulated, and malarious fevers have extended their ravages far into the interior.

These results are certainly not to be ascribed wholly to human action. They are, in a large proportion, due to geological causes over which man has no control. The soil of much of Tuscany becomes pasty, almost fluid even, as soon as it is moistened, and when thoroughly saturated with water, it flows like a river. Such a soil as this would not be completely protected by woods, and, indeed, it would now be difficult to confine it long enongh to allow it to cover itself with forest vegetation. Nevertheless, it certainly was once chiefly wooded, and the rivers which flow through it must then have been much less charged with earthy matter than at present, and they must have carried into the sea a smaller proportion of their sediment when they were free to deposit it on their banks than since they have been confined by dikes.

It is, in general, true that the intervention of man has hitherto seemed to insure the final exhaustion, ruin and desolation of every province of nature which he has reduced to his dominion. Attila was only giving an energetic and picturesque expression 
to the tendencies of human action, as personified in himself, when he said that "no grass grew where his horse's hoofs had trod." The instances are few, where a second civilization has flourished upon the ruins of an ancient culture, and lands once rendered uninhabitable by human acts or neglect have generally been forerer abandoned as hopelessly irreclaimable. It is, as I have before remarked, a question of vast importance, how far it is practicable to restore the garden we have wasted, and it is a problem on which experience throws little light, because few deliberate attempts have yet been made at the work of physical regeneration, on a scale large enough to warrant general conclusions in any one class of cases.

The valleys and shores of Tuscany form, however, a striking exception to this remark. The suceess with which human guidance has made the operations of nature herself available for the restoration of her disturbed harmonies, in the Val di Chiana and the Tuscan Maremma, is among the noblest, if not the most brilliant achierements of modern engineering, and, regarded in all its bearings on the great question of which I have just spoken, it is, as an example, of more importance to the general interests of humanity than the proudest work of internal improvement that mechanical means have yet constructed. The operations in the Val di Chiana have consisted chiefly in so regulating the flow of the surface-waters into and through it, as to compel them to deposit their sedimentary matter at the will of the engineers, and thereby to raise grounds rendered insalubrious and unfit for agricultural use by stagnating water; the improvements in the Maremma have embraced both this method of elevating the level of the soil, and the prevention of the mixture of salt-water with fresh in the coast marshes and shallow bays, which is regarded as a very active cause of the development of malarious influences.*

* The fact that the mixing of salt and fresh water in coast marshes and lagoons is deleterious to the sanitary condition of the vicinity, has been generally admitted, though the precise reason why a mixture of both should be more injurious than either alone, is not altogether clear. It has been suggested that the admission of salt-water to the lagoons and rivers kills many fresh-water plants and animals, while the fresh water is equally fatal to many marine organisms, and that the decomposition of the remains originates 


\section{Improvements in the Tuscan Maremma.}

In the improvements of the Tusean Miaremma, formidable difficulties have been encumntered. The territory to be reclaimed was extensive; the salubrious places of retreat for laborers and inspectors were remote; the courses of the rivers to be controlled were long and their natural inclination not rapid; some of them, rising in wooded regions, transported comparatively little earthy matter,* and above all, the coast, which is a recent deposit of the waters, is little elevated above the sea, and admits into its lagoons and the mouths of its rivers floods of saltwater with every western wind, every rising tide. $\dagger$

poisonous miasmata. Other theories, however, have been proposed. The whole subject is fully and ably discussed by Dr. Salvagnoli Marchetti in the appendix to his valuable Rapprorto sul Bonificamento delle Mruremme Toscrne. See also the Tremorie Economico-stutistiche sulle 1Yuremme Toscane of the same author. A different view of this subject is taken by RAFFANINI and ORLANDINI in Analisi Storico-Fisico-Economica sull' insabubriti nelle ITaremme Tuscune, Firenze, 1869. See also the importiant memoir of D. Pantaleoni, Det Miasmu vegetrile e delle. Maluttie Mriesmatiche, in which the views of Sillvagnoli on this point are combated.

* This difficulty has been remedied-though with doubtful general advantage-as to one important river of the Maremmat, the Pecora, by clearings recently executed along its upper course. "The condition of this marsh and of its aftluents is now, November, 1859, much changed, and it is advisable to prosecute its improvement by deposits. In consequence of the extensive felling of the woods upon the plains, hills and mountains of the territory of Massa and Scarlino, within the last ten years, the Pecora and other affluents of the marsh receive, during the rains, water abundantly charged with slime, so that the deposits within the first division of the marsh are already considerable, and we may now hope to see the whole marsh and pond filled up in a much shorter time than we had a right to expect before 1850 . This circumstance totally changes the terms of the question, because the filling of the marsh and pond, which tnen seemed almost impossible on account of the small amount of sediment deposited by the Pecora, has now become practicable."-Salvagrour, Rapporto sul Bonifieamento delle Maremme Toscane, pp. li., lii.

Between 1830 and 1859 more than $36,000,000$ cubic yards of sediment were deposited in the marsh and shoal-water lake of Castiglione alone.-SALVAGNoLI, Raccolta di Documenti, pp. 74, 75.

$\uparrow$ The tide rises ten inches on the coast of Tuscany. See Mlemoir by FAr TON, in the appendix to SALvagnol, Rapporto, p. 189.

On the tides of the Mediterranean see Böttger, Das Mittelmeer, p. 190. 
The western const of Tuscany is not supposed to hare been an unhealthy recrion before the concuest of Etruria ly the Romans, but it certainly became si within a few centuries after that erent. This wats a natural consecpuence of the neglect or wanton destructim of the pullie improrements, especially the livilranlic works in which the Etruseans were so skilful, and of the felling of the upland forests, to satisfy the demand for wool at lome, for demestie, indu-trial and military purposes. After the downfall of the Roman empire, the incmrions of the barbarians, and then femtalimn, foreign domination, intestine wars, and temporal and spiritual tyramnies, acroravated still more ernelly the moral and physical erils which Tuscany and the other Italim States were domed to suffer, and from which they have enjoyed but brief respites during the whole period of modern history. The Maremma was already proverbially unhealthy in the time of Dante, who refers to the fact in several familiar passages, and the petty tyrants upon its borlers often sent criminals to places of confinement in its territory, as a slow but certain mode of execution. Ignorance of the causes of the insalubrity, and often the interference of private rights, ${ }^{*}$ prevented the adoption of measures to remore it, and the growing political and commercial importance of the large tomn in more healthful localities absorbed the attention of Govermment, and deprived the Maremma of its just share in the systems of physical improvement which were successfully adopted in interior and Northern Italy.

* In Catholic countries, the discipline of the church requires a meagre diet at certiin seasons, and as $\mathrm{i}, \mathrm{sh}$ is not flesh, there is a great demand for that article of food at those periods. For the convenience of monasteries and their patrons, and as a source of pecuniary emolument to ecclesiasticil establishments and sometimes to lay proprietors, great numbers of artificial fish-ponds were created during the Middle Ares. They were generally shallow pools formed by damming up the outlet of marshes, and they were among the most fruitful sources of endemic disease, and of the peculiar malignity of the epidemics whick so often ravaged Europe in those centuries. These ponds, in religions hands, were too sacred to be infringed upon for sanitary purposes, and when belonging to powerful lay lords they were almost as inviolable. The rights of fishery were a standing obstacle to every proposal of hydraulic improvement, and to this day large and fertile districts in Southern Europe remain sickly and amost unimproved and uninhabited, because the draining of the ponds upon them would reduce the income of proprietors who derive large profits by supplying the faithful, in Lent, with fish, and with various 
Before any serious attempts were made to drain or fill up the marshes of the Maremma, various other sanitary experiments were tried. It was generally beliered that the insalubrity of the province was the consequence, not the cause, of its depopulation, and that, if it were once densely inhabited, the ordinary operations of agriculture, and especially the maintenance of numerous domestic fires, would restore it to its ancient healthfulness.* In accordance with these views, settlers were invited from various parts of Italy, from Greece, and, after the accession of the Lorraine princes, from that country also, and colonized in the MIaremma. To strangers coming from soils and skies so unlike those of the Tuscan marshes, the climate was more fatal than to the inhabitants of the neighboring districts, whose constitutions had become in some degree inured to the local influences, or who at least knew better how to guard against them. The consequence very naturally was that the experiment totally failed to produce the desired effects, and was attended with a great sacrifice of life and a heavy loss to the treasury of the state.

The territory known as the Tuscan Maremma, ora maritima, or Maremme-for the plural form is most generally used-lies upon and near the western coast of Tuscany, and comprises about 1,900 square miles English, of which 500 square miles, or 320,000 acres, are plain and marsh, including 45,500 acres of water surface, and about 290,000 acres are forest. One of the mountain peaks, that of Mount Amiata, rises to the height of 5,780 feet. The mountains of the Maremma are healthy, the lower hills much less so, as the malaria is felt at some points at the height of 1,000 feet, and the plains, with the exception of a few localities favorably situated on the sea-coast, are in a high degree pestilential. The fixed population is about 80,000 , of whom one-sixth live on the plains in the winter and about one-tenth in the summer. Nine or ten thousand laborers come down from the mountains of the Maremma and the neighboring provinces into the plain, during the latter season, to cultivate and gather the crops.

species of waterfowl which, though very fat, are, ecclesiastically speaking, meagre.

* Macchiavelli advised the Government of Tuscany "to provide that men should restore the wholesomeness of the soil by cultivation, and purify the air by fires."-Salvacnoli, Memorie, p. 111. 
Out of this small number of inhabitants and strangers, 35,619 were ill enough to require medical treatment between the 1st of June, 1St0, and the 1st of June, 1841, and more than one-half the cases were of intermittent, malignant, gastric or catarrhal fever. Very few agricultural laborers escaped ferer, thongh the disease did not always manifest itself until they had returned to the mountains. In the province of Grosseto, which embraces nearly the whole of the Maremma, the annual mortality was 3.92 per cent., the average duration of life but 23.18 years, and 75 per cent. of the deaths rere among persons engaged in agriculture.

The filling up of the low grounds and the partial separation of the waters of the sea and the land, which had been in progress since the year 182 7 , now began to show very decided effects upon the sanitary condition of the population. In the year ending June 1, 1St2, the number of the sick was reduced by more than 2,000 , and the cases of fever by more than 4,000 . The next year the cases of fever fell to 10,500, and in that ending June 1, $18 \pm 4$, to 9,200 . The political events of 1848 , and the preceding and following years, occasioned the suspension of the works of improvement in the Maremma, but they were resumed after the revolution of 1859 .

I have spoken with some detail of the improvements in the Tuscan Maremma, because of their great relative importance, and because their history is well known; but like operations have been executed in the territory of Pisa and upon the coast of the duchy of Lucca. In the latter case they were confined principally to prevention of the intermixing of fresh water with that of the sea. In 1741 sluices or lock-gates were constructed for this purpose, and the following year the fevers, which had been destructire to the coast population for a long time previous, disappeared altogether. In 1768 and 1769 , the works having fallen to decay, the fevers returned in a very malignant form, but the rebuilding of the gates again restored the healthfulness of the shore. Similar facts recurred in 1784 and 1785 , and again from $180 t$ to 1821. This long and repeated experience has at last impressed upon the people the necessity of vigilant attention to the sluices, which are now kept in constant repair. The health of the coast is uninterrupted, and Viareggio, the capital town of the district, 
is now much frequented for its sea-baths aud its general salubrity, at a season when formerly it was justly shumned as the abode of disease and death.*

\section{Improvements in the Val di Chiana.}

For twenty miles or more after the remntest headwaters of the Arno have united to form a considerable stream, this river Hows southeastwards to the vicinity of Arezzo. It liere sweeps round to the northwest, and follows that course to near its junction with the Sieve, a few miles above Florence, from which point its general direction is westward to the sea. From the bend at Arezzo, a depression called the $\mathrm{Val}$ di Chiana rums sontheastwards mutil it strikes into the valley of the Paglia, a tributary of the Tiber, and thus connects the basin of the latter river with that of the Amo. In the Middle Ages, and down to the eighteenth century, the Val di Chiana was often overflowed and devastated by the torrents which poured down from the highlands, transporting great quantities of slime with their currents, stagnating upon its surface, and gradually converting it into a marshy and unhealthy district, which was at last very greatly reduced in population and productiveness. It had, in fact, become so desolate that even the swallow had deserted it. $\dagger$

* Gioranni, Sur les causes de l'Insalubrité de l'air dans le voisinage des marais, ctc., lue ì l'Atcaléribie des ściences à. Paris, le 12 Juillet, 18:5. Reprinted in Salvagnolr, Rapporto, etc., appendice, p. 5, et seq.

+ This curious fact is thus stated in the preface to Fossombroni (Memorie sopra la Fal di Chiana, edition of $18: 35$, p. xiii.), from which also I borrow most of the data hereafter given with respect to that valley: "It is perhaps not universally known, that the swallows, which come from the north [south] to spend the summer in our climate, do not frequent marshy districts with a malarious atmosphere. A proof of the restoration of salubrity in the Val di Chiana is furnished by these aerrial visitors, which had never before been seen in those low grounds, but which have appeared within a few years at Fojano and other points similarly situated."

Is the air of swamps destructive to the swallows, or is their absence in such Iocalities merely due to the want of human habitations, near which this halfdomestic bird loves to breed, perhaps because the house-fly and other insects which follow man are found only in the vicinity of his dwellings ?

In almost all European countries the swallow is protected, by popular opinion or superstition, from the persecution to which almost all other birds are subject. It is possible that this respect for the swallow is founded upon 
The bed of the Arno near Arezzo and that of the Paglia at the southern extremity of the Val di Chiana did not differ much in level. The general inclination of the ralley was therefore small ; it does not appear to have ever been diviled into opposite slopes by a true witershed, and the position of the summit seems to have shifted aceording to the varying amomit and place of deponit of the sediment brought down by the lateral streams which emptier into it. The length of its principal chammel of drainage, and even the direction of its flow at any given point, were therefore fluctuating. Hence, much difference of opinion Wils entertained at clifferent times with regard to the nommal course of this stream, and, consequently, to the question whether it was to be regarded as properly an affluent of the Tiber or of the Arno.

The bed of the latter river at the bend has been eroded to the depth of thirty or forty feet, and that, apparently, at no very remote period." If it were elevated to what was evidently its original height, the current of the Arno would be so much above that of the Paglia as to allow of a regular flow from its channel to the latter stream, through the Tal di Chiana, provided the bed of the ralley hat remained at the level which exeavations prove it to have had a few centuries ago, before it was raised by the deposits I have mentioned. These facts, together with the testimony of ancient geographers which scarcely admits of any other explanation, are thought to prove that all the waters of the Upper Arno were originally discharged throngh the Tal di Chiana into the Tiber, and that a part of them still continued to flow, at

ancient observation of the fict just stated on the authority of Fossombroni. Imnorance mistakes the effect for the cause, and the absence of this bird may have been supposed to be the ocension, not the consequence, of the unhealthiness of particular localities. This opiuion once adopted, the swallow would become a sicred bird, and in process of time fables and legends would be inrented to give additional sanction to the prejudices which protected it. The Romans considered the swallow as consecrated to the Penates, or household gods, and according to Peretti (Le Serate del Tillaygio, p. 168) the Lombard peasantry think it a sin to kill them, because they are le gallinelle del Signore, the chickens of the Lord.

* Able geologists infer from recent investigations, that, although the Arno fiowed to the south within the pliocenic period, the direction of its course was. changed at an earlier epoch than that supposed in the text. 
least occasionally, in that direction down to the days of the Roman empire, and perhaps for some time later. The depression of the bed of the Arno, and the raising of that of the valley by the deposits of the lateral torrents, finally cut off the branch of the river which had flowed to the Tiber, and all its waters were turned into its present channel, though the drainage of the principal part of the Val di Chiana appears to have been in a southeastwardly direction until within a comparatively recent period.

In the sixteenth century the elevation of the bed of the valley had become so considerable, that in 1551 , at a point about ten miles south of the Arno, it was found to be not less than one hundred and thirty feet above that river; then followed a level of ten miles, and then a continuous descent to the Paglia. Along the level portion of the valley was a boatable channel, and lakes, sometimes a mile or even two miles in breadth, had formed at various points farther south. At this period the drainage of the summit level might easily have been determined in either direction, and the opposite ascents of the valley made to culminate at the north or at the south end of the level. In the former case, the watershed would have been ten miles south of the Arno; in the latter, twenty miles, and the division of the valley into two opposite slopes would have been not very unequal.

Various schemes were suggested at this time for drawing off the stagnant waters, as well as for the future regular drainage of the ralley, and small operations for those purposes were undertaken with partial success; but it was feared that the discharge of the accumulated waters into the Tiber would produce a dangerous inundation, while the diversion of the drainage into the Arno would increase the violence of the floods to which that river was very subject, and no decisive steps were taken. In 1606 an engineer, whose name has not been preserved, proposed, as the only possible method of improvement, the piercing of a tunnel through the hills bounding the valley on the west to convey its waters to the Ombrone, but the expense and other objections prevented the adoption of this scheme.* The fears of the Roman Government for the safety of the basin of the Tiber had induced it to construct embankments across the portion of the

* Morozzi, Dello stato, etc., dell' Arno, ii., pp. 39, 40. 
valley lying within its territory, and these obstructions, though not specifically intended for that purpose, naturally promoted the deposit of sediment and the elevation of the bed of the valley in their neighborhood. The effect of this measure and of the contimued spontaneous action of the torrents was, that the northern slope, which in 1551 had commenced at the distance of ten miles from the Arno, was found in 1605 to begin nearly thirty miles south of that river, and in 1645 it had been removed about six miles farther in the same direction.*

In the seventeenth century the Tuscan and Papal Governments consulted Galileo, Torricelli, Castelli, Cassini, Viviani, and other distinguished philosophers and engineers, on the possibility of reclaiming the valley by a regular artificial drainage. Most of these eminent physicists were of opinion that the measure was impracticable, though not altogether for the same reasons; but they seem to have agreed in thinking that the opening of such channels, in either direction, as would give the current a flow sufficiently rapid to drain the lands properly, would dangerously augment the inundations of the river-whether the Tiber or the Arnointo which the waters should be turned. The general improvement of the valley was now for a long time abandoned, and the waters were allowed to spread and stagnate until carried off by partial drainage, infiltration and evaporation. Torricelli had contended that the slope of a large part of the valley was too small to allow it to be drained by ordinary methods, and that no practicable depth and width of canal would suffice for that purpose. It could be laid dry, he thought, only by converting its surface into an inclined plane, and he suggested that this might be accomplished by controlling the flow of the numerous torrents which pour into it, so as to force them to deposit their sediment at the pleasure of the engineer, and, consequently, to elevate the level of the area over which it should be spread. $\dagger$ This plan did

* Morozzr, Dello stato, etc., dell' Arno, ii., pp. 39, 40.

† Torricelli thus expressed himself on this point: "If we content ourselves with what nature has made practicable to human industry, we shall endeavor to control, as far as possible, the outlets of these streams, which, by raising the bed of the valley with their deposits, will realize the fable of the Tagus and the Pactolus, and truly roll golden sands for him that is wise enough to avail himself of them."-Fossommonr, Memorie sopra la Val di Chiana, p. 219. 
not meet with immediate general acceptance, but it was soon adopted for local purposes at some points in the southern part of the valley, and it gradually grew in public favor and was extended in application mutil its final triumph a hundred years later.

In spite of these encouraging successes, however, the fear of danger to the valley of the Amo and the Tiber, and the difficulty of an agreement between Tuscany and Rome-the boundary betreen which states crossed the Tal di Chiana not far from the half-way point between the two rivers-and of recouciling other conflicting interests, prevented the resumption of the projects for the general drainage of the ralley until after the middle of the eighteenth century. In the meantime the science of hydranlics had become better understood, and the establishment of the natural law according to which the velocity of a current of water, and of course the proportional quantity discharged by it in a given time, are increased by increasing its mass, had diminished if not dissipated the fear of exposing the banks of the Arno to greater danger from inuudations by draining the $\mathrm{Val}$ di Chiana into it.

The suggestion of Torricelli was finally adopted as the basis of a comprehensive system of improvement, and it was decided to continue and extend the inversion of the original flow of the waters, and to turn them into the Arno from a point as far to the south as should be found practicable. The conduct of the works was committed to a succession of able engineers who, for a long series of years, were under the general direction of the celebrated philosopher and statesman Fossombroni, and the success has fully justified the expectations of the most sanguine advocates of the scheme. The plan of improvement embraced two branches: the one, the removal of obstructions in the bed of the Arno, and, consequently, the further depression of the channel of that river, in certain places, with the view of increasing the rapidity of its current; the other, the gradual filling up of the pouds and swamps, and raising of the lower grounds of the Val di Chiana, by directing to convenient points the flow of the streams which pour down into it, and there confining their waters by temporary dams until the sediment was deposited where it was needed. The economical result of these operations has been, that in 1835 an area of more than four hundred and fifty 
square miles of pond, marsh, and damp, sickly lor grounds had been converted into fertile, healthy and well-drained soil, and, conserpuently, that so much territory has been added to the agricultural domain of Tuseany.

But in our present view of the subject, the geographical revolution which has been aceomplished is still more interesting. The climatic influence of the elevation and draining of the soil must have been considerable, though I do not know that an increase or a diminution of the mean temperature or precipitation in the ralley has been established by meteorologieal observation. There is, however, in the improvement of the sanitary condition of the Tal di Chiana, which was formerly extremely unhealthy, satisfactory proof of a beneficial climatic change. The fevers, which not only decimated the population of the low grounds but infested the adjacent hills, have ceased their ravages, and are now not more frequent than in other parts of Tuscany. The strictly topographical effect of the operations in question, besides the conrersion of marsh into dry surface, has been the inversion of the inclination of the valley for a distance of thirty-five miles, so that this great plain which, within a comparatively short period, sloped and drained its waters to the south, now inclines and sends its drainage to the north. The reversal of the currents of the valley has added to the Arno a new tributary equal to the largest of its former affluents, and a most important eireumstance commected with this latter fact is, that the increase of the volume of its waters has accelerated their velocity in a still greater proportion, and, instead of angmenting the danger from its inundations, has almost wholly obviated that source of apprehension.*

* Arrian observes that at the junction of the Hydaspes and the Acesines, both of which are described as wide streams, "one very narrow river is formed of two confluents, and its current is very swift."-Armis, Alex. Anab., vi., 4 .

1 like example is observed in the Anapus near Syracuse, which, below the junction of its two branches, is narrower, though swifter, than either of them, and such cases are by no means unfrequent. The immediate effect of the confluence of two rivers upon the current below depends upon local circumstances, and especially upon the angle of incidence. If the two nearly coincide in direction, so as to include a small angle, the joint current will have a greater velocity than the slower confluent, perhaps even than either of them. If the two rivers run in transverse, still more if they flow in more or less op. 
Between the beginning of the fifteenth century and the year 1761, thirty-one destructive floods of the Arno are recorded; between 1761, when the principal streams of the Val di Chiana were diverted into that river, and 1835 , not one.*

\section{Results of Operations.}

It is now a hundred years since the commencement of the improvements in the Val di Chiana. Those of the Maremma have been in more or less continued operation for above a generation. They have, as we have seen, produced important geographical changes in the surface of the earth and in the flow of considerable rivers, and their effects have been not less conspicuous in preventing other changes, of a more or less deleterious character, which would infallibly have taken place if they had not been arrested by the improvements in question.

posite, directions, the velocity of the principal branch will be retarded both above and below the junction, and at high water it may even set back the current of the aftluent.

On the other hand, the diversion of a considerable branch from a river retards its velocity below the point of separation, and here a deposit of earth in its channel immediately begins, which has a tendency to turn the whole stream into the new bed. "Theory and the authority of all hydrographical writers combine to show that the channels of rivers undergo an elevation of bed below a caual of diversion." -Letter of Fossombroni in SAlvagnoli, Racelta di Documenti, p. 32. See the early authorities and discussions on the principle stated in the text, in Frisi, Del modo di regolare $i$ Fiumi e $i$ Torrenti, libro iii., capit. i., and Mengotrt, Idraulica, ii., pp. 88 et seq., and see p. 486, note, ante.

In my account of these improvements I have chiefly followed Fossombroni, under whose direction they were principally executed. Many of Fossombroni's statements and opinions have been controverted, and in comparatively unimportant particulars they have been shown to be erroneous.-See LowBARDINr, Guida allo studio dell' Idrologia, cap. xviii., and same author, Esams degli Studi sul Tevere, §33.

* Fossombroni, Memorie Idraulico-storiche, Introduzione, p. xvi. Between the years 1700 and 1799 the chroniclers record seventeen floods of the Arno, and twenty between 1800 and 1870 , but none of these latter were of a properly destructive character except those of 1844, 1864 and 1870, and the ravages of that of 1870 were chiefly confined to Pisa, and were occasioned by the bursting of a dike or wall. They are all three generally ascribed to extraordinary, if not unprecedented, rains and snows; but many inquirers attribute them to the felling of the wcods in the valleys of the upper tributaries of the Arno since 1835. See a paper by GrmFrN, in the Italia Nuova, 18 Marzo, 1871. 
The sediment washed into the marshes of the MIaremma is not less than 12,000,000 cubic yards per annum. The escape of this quantity into the sea, which is now almost wholly prevented, would be sufficient to adrance the const-line fourteen yards per year, for a distance of forty miles, computing the mean depth of the sea near the shore at twelve yards. It is true that in this case, as well as in that of other rivers, the sedimentary matter would not be distributed equally along the shore, and much of it would be carried out into deep water, or perhaps transported by the currents to distant coasts. The immediate effects of the deposit in the sea, therefore, would not be so palpable as they appear in this numerical form; but they would be equally certain, and would infallibly manifest themselves, first, perhaps, at some remote point, and afterwards more energetically at or near the outlets of the rivers which produced them. The elevation of the bottom of the sea would diminish the inclination of the beds of the rivers discharging themselves into it on that coast, and of course their tendency to overflow their banks, and to extend still further the domain of the marshes which border them, would be increased in proportion.

It has been already stated that, in order to prevent the overflow of the valley of the Tiber by freely draining the Val di Chiana into it, the Papal authorities, long before the commencement of the Tuscan works, constructed strong barriers near the southern end of the valley, which detained the waters of the wet season until they could be gradually drawn off into the Paglia. They consequently deposited most of their sediment in the Val di Chiana, and carried down comparatively little earth to the Tiber. The lateral streams, contributing the largest quantities of sedimentary matter to the $\nabla$ al di Chiana, originally flowed into that valley near its northern end; and the change of their channels and outlets in a southern direction, so as to raise that part of the valley by their deposits and thereby reverse its drainage, was one of the principal steps in the process of improvement.

We have seen that the north end of the $V$ al di Chiana, near the Arno, had been raised by spontaneous deposit of sediment to such a height as to interpose a sufficient obstacle to all flow in that direction. If, then, the Roman dam had not been erected, or the works of the Tuscan Government undertaken, the whole 
of the earth, which has been arrested by those works and employed to raise the bed and reverse the declivity of the valley, would have been carried down to the Tiber and thence into the sea. The deposit thus created would, of course, have contributed to increase the advance of the shore at the mouth of that river, which has long been going on at the rate of three mitres and nine-tenths (twelve feet and nine inches) per annum.* It is evident that a quantity of earth, sufficient to effect the immense changes I have described in a wide valley more than thirty miles long, if deposited at the outlet of the Tiber, would have very considerably modified the outline of the coast, and have exerted no unimportant influence on the flow of that river, by raising its point of discharge and lengthening its channel.

\section{The Coast of the Netherlands.}

It has been shown in a former section that the dikes of the Netherlands and the adjacent states have protected a considerable extent of coast from the encroachments of the sea, and have won a large tract of cultivable land from the dominion of the ocean waters. The immense results obtained from the operations of the Tuscan engineers in the Val di Chiana and the Maremma have suggested the question, whether a different method of accomplishing these objects might not have been adopted with advantage. It has been argued, as in the case of the $\mathrm{Po}$, that a system of transverse inland dikes and canals, upon the principle of those which have been so successfully employed in the Val di Chiana and in Egypt, might have elevated the low grounds above the ocean tides, by spreading over them the sediment brought down by the Rhine, the Maes and the Schelde. If this process had been introduced in the Middle Ages, and constantly pursued to our times, the superficial and coast geography, as well as the hydrography of the countries in question, would undoubtedly have presented an aspect very different from their present condition; and by combining the process with a system of maritime dikes, which would have been necessary, both to resist the advance of the sea and to retain the slime deposited by river overflows, it

\footnotetext{
* See the careful estimates of RozwT, Moyens de forcer les Torrents, etc., pp. $42,44$.
} 
is, indeed, possible that the territory of those states would have been as extensive as it now is, and, at the same time, somewhat elevated above its natural level.

The argument in faror of that method rests on the assumption that all the sea-washed earth, which the tides lave let fall upon the shallow coast of the Netherlauds, has been brought down by the rivers which empty upon those shores, and could have been secured by allowing those rivers to spread over the flats and deposit their sediment in still-water pools formed by cross-dikes like those of Egypt.

But we are ignorant of the proportions in which the marine deposits that form the soil of the polders have been derived from materials brought down by these rivers, or from other more remote sources. Much of the river slime has, no donbt, been transported by marine currents quite beyond the reach of returning streams, and it is uncertain how far this loss has been balanced by earth washed by the sea from distant shores and let fall on the coasts of the Netherlands and other neighboring countries.

We know little or nothing of the quantity of solid matter brought down by the rivers of Western Europe in early ages, but, as the banks of those rivers are now generally better secured against wash and abrasion than in former centuries, the sediment transported by them must be less than at periods nearer the removal of the primitive forests of their valleys, though certainly greater than it was before those forests were felled. Klöden informs us that the sedimentary matter transported to the sea by the Rhine would amount to a cubic geographical mile in five thousand years.*

The proportion of this suspended matter which, with our present means, could be arrested and precipitated upon the ground, is almost infinitesimal, for only the surface-water, which carries much less sediment than that at the bottom of the channel, would flow over the banks, and as the movement of this water, if not checked altogether, would be greatly retarded by the proposed

* Erdkunde, vol. i., p. 384. The Mississippi-a. river "undercharged with sediment"-with a mean discharge of about ten times that of the Rhine, deposits a cubic geographical mile in thirty-three years. 
cross-dikes, the quantity of solid matter which would be conveyed to a given portion of land during a single inundation would be extremely small. Inundations of the Rhine occur but once or twice a year, and high water continues but a few days, or even hours; the flood-tide of the sea happens seven hundred times in a year, and at the turn of the tide the water is brought to almost absolute rest. Hence, small as is the proportion of suspended matter in the tide-water, the deposit probably amounts to far more in a year than would be let fall upon the same area by the Rhine.

This argument, except as to the comparison between river and tide water, applies to the Mississippi, the Po and most other great rivers. Hence, until that distant day when man shall devise means of extracting from rivers at flood, the whole volume of their suspended material and of depositing it at the same time on their banks, the system of cross-dikes and colmatage must be limited to torrential streams transporting large proportions of sediment, and to the rivers of hot countries, like the Nile, where the saturation of the soil with water, and the securing of a supply for irrigation afterwards, are the main objects, while raising the level of the banks is a secondary consideration. 


\title{
CHAPTER $\nabla$.
}

\author{
THE SANDS.
}

Origin of Sand - Sand now Carried to the Sea-Beach-Sands of Northern Africa-Sands of Egypt-Sand-Dunes and Sand-Plains-Coast-DunesSand-Banks-Character of Dune Sand-Interior Structure of DunesGeological Importance of Dunes - Dunes on American Coasts-Dunes of Western Europe-Age, Character and Permanence of Dunes-Dunes as a Barrier against the Sea-Encroachments of the Sea-LiimfjordCoasts of Schleswig-Holstein, Netherlands and France-Movement of Dunes-Control of Dunes by MIan-Inland Dunes-Inland Sand-Plains.

\section{Origin of Sand.}

$S_{\triangle N D}$, which is found in beds or strata at the bottom of the sea or in the channels of rivers, as well as in extensive deposits upon or beneath the surface of the dry land, appears to consist essentially of the detritus of rocks. It is not always by any means clear through what agency the solid rock has been reduced to a granular condition; for there are beds of quartzose sand, where the sharp, angular shape of the particles renders it highly improbable that they have been formed by gradual abrasion and attrition, and where the supposition of a crushing mechanical force seems equally inadmissible. In common sand, the quartz grains are the most numerous; but this is not a proof that the rocks from which these particles were derived were wholly, or even chiefly, quartzose in character; for, in many composite rocks, as for example in the granitic group, the mica, felspar and hornblende are more easily decomposed by chemical action, or disintegrated, comminuted and reduced to an impalpable state by mechanical force, than the quartz. In the destruction of such rocks, therefore, the quartz would survive the other ingredients, and remain unmixed, when they had been decomposed and recomposed into new mineralogical or chemical com- 
binations, or been ground to slime and washed away by water currents.

The greater or less specific gravity of the different constituents of rock doubtless aids in separating them into distinct masses when once disintegrated, though there are veined and stratified beds of sand where the difference between the upper and lower layers, in this respect, is too slight to be supposed capable of effecting a complete separation.* In cases where rock has been reduced to sandy fragments by heat, or by obscure chemical and other molecular forces, the sand-beds may remain undisturbed, and represent, in the series of geological strata, the solid formations from which they were derived. The large masses of sand not found in place have been transported and accumulated by water or by wind, the former being generally considered the most important of these agencies; for the extensive deposits of the Sahara, of the Arabian peninsulas, of the Llano Estacado and other North and South American deserts, of the deserts of Persia, and of that of Gobi, are supposed to have been swept together or distributed by marine currents, and to have been elevated above the ocean by the same means as other upheaved strata. $\nmid$

Meteoric and mechanical influences are still active in the reduction of rocks to a fragmentary state; $\neq$ but the quantity of sand now transported to the sea seems to be comparatively inconsiderable, because-not to speak of the absence of diluvial ac-

* In the curiously variegated sandstone of Arabia Petræa-which is certainly a reaggregation of loose sand derived from disaggregation of older rocksthe contiguous veins frequently differ very widely in color, but not sensibly in specific gravity or in texture; and the singular way in which they are now alternated, now confusedly intermixed, must be explained otherwise than by the weight of the respective grains which compose them. They seem, in fact, to have been let fall by water in violent ebullition or tumultuous mechanical agitation, or deposited by a succession of sudden aquatic or aerial currents flowing in different directions and charged with differently colored matter.

† KuEn, Physische Geographie, p. 371.

$\ddagger$ A good account of the agencies now operative in the reduction of rock to sand will be found in WrNkLer, Zand en Duinen, Dockum, 1865, pp. 4-20. I take this occasion to acknowledge my obligations to this author for assuming the responsibility of many of the errors I may have committed in this chapter, by translating a large part of it from a former edition of the present work and publishing it as his own. 
tion-the number of torrents emptying directly into the sea is much less than it was at earlier periods. The formation of alluvial plains in maritime bays, by the sedimentary matter brought down from the mountains, has lengthened the flow of such streams and converted them very generally into rivers, or rather affluents of rivers, of later geographical origin than themselves. The filling mp of the estuaries has so reduced the slope of all large and many small rivers, and consequently so checked the current of what the Germans call their Unterlanf, or lower course, that they are much less able to transport heavy material than at earlier epochs. The slime deposited by rivers at their junction with the sea, is usually found to be composed of material too finely ground and too light to be denominated sand, and it can be abundantly shown that the sand-banks at the outlet of most large streams are of tidal, not of fluviatile, accumulation, or, in lakes and tideless seas, a result of the concurrent action of waves and of wind.

Large deposits of sand, therefore, must in general be considered as of ancient, not of recent formation, and many eminent geologists ascribe them to diluvial action. Staring has discussed this question very fully, with special reference to the sands of the North Sea, the Zuiderzee, and the bays and channels of the Dutch coast.* His general conclusion is, that the rivers of the Netherlands "move sand only by a very slow displacement of sand-banks, and do not carry it with them as a suspended or floating material." The sands of the German Ocean he holds

* De Bodem van Nederland, i., pp. 243, 246-377, et seq. See also the arguments of Brémontier as to the origin of the dune sands of Gascony, Annales des Ponts et Chaussées, 1833, 1er sémestre, pp. 158, 161. Brémontier estimates the sand annually thrown up on that coast at five cubic toises and two feet to the running toise ( $u$ hi supra, p. 162), or rather more than two hundred and twenty cubic feet to the running foot. Laval, upon observations continued through seven years, found the quantity to be twenty-five metres per running metre, which is equal to two hundred and sixty-eight cubic feet to the running foot.-Annales des Ponts et Chaussées, 1842, 2me sémestre, p. 229. These computations make the proportion of sand deposited on the coast of Gascony three or four times as great as that observed by Andresen on the shores of Jutland. Laval estimates the total quantity of sand annually thrown up on the coast of Gascony at $6,000,000$ cubic metres, or more than 7,800,000 cubic yards. 


\section{to be a product of the "great North German drift," deposited} where they now lie before the commencement of the present geological period, and he maintains similar opinions with regard to the sands thrown up by the Mediterranean at the mouths of the Nile and on the Barbary coast.*

\section{Sand now carried to the Sea.}

There are, however, cases where mountain streams still bear to the sea perhaps relatively small, but certainly absolutely large, amounts of disintegrated rock.t The quantity of sand

\footnotetext{
* De Bodem van Nederland, i., p. 339.
}

+ The conditions favorable to the production of sand from disintegrated rock, by causes now in action, are perhaps nowhere more perfectly realized than in the Sinaitic Peninsula. The mountains are steep and lofty, unprotected by vegetation or even by a coating of earth, and the rocks which compose them are in a shattered and fragmentary condition. They are furrowed by deep and precipitous ravines, with beds sufficiently inclined for the rapid flow of water, and generally without basins in which the larger blocks of stone rolled by the torrents can be dropped and left in repose; there are severe frosts and much snow on the higher summits and ridges, and the winter rains are abundant and heavy. The mountains are principally of igneous formation, but many of the less elerated peals are capped with sandstone, and on the eastern slope of the peninsula jou may sometimes see, at a single glance, several lofty pyramids of granite, separated by considerable intervals, and all surmounted by horizontally stratified deposits of sandstone often only a few yards square, which correspond to each other in height, are evidently contemporancous in origin, and were once comnected in continuous beds. The degradation of the rock ou which this formation rests is constantly bringing down masses of it, and mingling them with the basaltic, porphyritic, granitic and calcareous fragments which the torrents carry down to the valleys, and, through them, in a state of greater or less disintegration to the sea. The quantity of sand annually washed into the Red Sea by the larger torrents of the Lesser Peniusula, is probably at least equal to that contributed to the ocean by any streams draining basins of no greater extent. Absolutely considered, then, the mass may be said to be large, but it is apparently very small as compared with the sand thrown up by the German Ocean and the Atlantic on the coasts of Denmark and of France. There are, indeed, in Arabia Petræa, many torrents with very short courses, for the sea-waves in many parts of the peninsular coast wash the base of the mountains. In these cases the débris of the rocks do not reach the sea in a sufficiently comminuted condition to be entitled to the appellation of sand, or even in the form of well-rounded pebbles. The fragments retain their angular shape, and, at some points on the coast, they become cemented together by lime or other binding substances held in solution or mechanical suspension in the sea-water, and are so rapidly converted 
and gravel carried into the Mediterranean by the torrents of the Maritime Alps, the Ligurian Apennines, the islands of Corsica, Sardinia and Sicily, and the mountains of Calabria, is apparently great. In mere mass, it is possible, if not probable, that as much rocky material, more or less comminuted, is contributed to the basin of the Mediterranean by Europe, even excluding the shores of the Adriatic and the Euxine, as is washed up from it upon the coasts of Northern Africa and Syria. A great part of this material is thrown out again by the waves on the Europeaz shores of that sea. The harbors of Luni, Albenga, San Remo, and Savona west of Genoa, and of Porto Fino on the other side, are filling up, and the coast near Carrara and Massa is said to have advanced upon the sea to a distance of 475 feet in thirty. three years.* Besides this, we have no evidence of the existence of deep-water currents, in the Mediterranean, extensive enough and strong enough to transport quartzose sand across the sea. It may be added that much of the rock from which the torrent sands of Southern Europe are derived contains little quartz, and hence the general character of these sands is such that they must be decomposed, or ground down to an impalpable slime, long before they could be swept over to the African shore.

\section{Sands of Northern Africa.}

The torrents of Europe, then, do not at present furnish the material which composes the beach-sands of Northern Africa,

into a singularly heterogeneous conglomerate, that one deposit seems to be consolidated into a breccia before the next winter's torrents cover it with another.

In the northern part of the peninsula there are extensive deposits of sand intermingled with agate pebbles and petrified wood, but these are evidently neither derived from the Sinaitic group, nor products of local causes known to be now in action.

I may here notice the often repeated but mistaken assertion, that the petrified wood of the Western Arabian desert consists wholly of the stems of palms, or at least of endogenous regetables. This is an error. I have myself picked up in that desert, within the space of a very few square yards, fragments apparently of fossil palms, and of at least two petrified trees distinctly marked as of exogenous growth both by annular structure and by knots. In ligneous character, one of these almost precisely resembles the grain of the extant beech, and this specimen was worm-eaten before it was converted into silex.

* Bõttatar, Das Miftelmeer, p. 128. 
and it is equally certain that those sands are not brought down by the rivers of the latter continent. They belong to a remote geological period, and have been accumulated by causes which we can not at present assign. The wind does not stir water to great depths with sufficient force to disturb the bottom,* and the sand throrn upon the coast in question must be derired from a narrow belt of sea. It must hence, in time, become exhausted, and the formation of new sand-banks and dunes upon the southern shores of the Mediterranean will cease at last for want of material. $\dagger$

* The testimony of divers and of other observers on this point is conflicting, as might be expected from the infinite variety of conditions by which the morement of water is effected. It is generally believed that the action of the wind upon the water is not perceptible at greater depths than from fifteen feet in ordinary to eighty or ninety in extreme cases; but these estimates are probably very considerably below the truth. Andresen quotes Brémontier as stating that the morement of the wares sometimes extends to the depth of five hundred feet, and he adds that others think it may reach to six or even seren hundred feet below the surface.-Ardreses, Om Klitfornationen, p. 20.

Jany physicists now suppose that the undulations of great bodies of water reach even deeper. But a morement of undulation is not necessarily a movement of translation, and besides, there is very frequently an undertow, which tends to carry suspended bodies out to sea as powerfully as the superficial waves to throw them on shore. Sand-banks sometimes recede from the coast, instead of rolling towards it. Reclus informs us that the MIauvaise, a sandbank near the Point de Grave, on the Atlantic coast of France, has moved five miles to the west in less than a century.-Revue des Deux Mondes for December, 1862, p. 905 .

The action of currents may, in some cases, have been confounded with that of the waves. Sea-currents, strong enough, possibly, to transport sand for some distance, flow far below the surface in parts of the open ocean, and in narrow straits they have great force and velocity. The divers employed at Constantinople in 1853 found in the Bosphorus, at the depth of twenty-five fathoms and at a point much exposed to the wash from Galata and Pera, a number of bronze guns supposed to have belonged to a ship-of-war blown up about a hundred and fifty years before. These guns were not covered by sand or slime, though a crust of earthy matter, an inch in thickness, adhered to their upper surfaces, and the bottom of the strait appeared to be wholly free from sediment. The current was so powerful at this depth that the divers were hardly able to stand, and a keg of nails, purposely dropped into the water, in order that its movements might serve as a guide in the search for a bag of coin accidentally lost overboard from a ship in the harbor, was rolled by the stream several hundred yards before it stopped.

$\nmid$ Few seas have thrown up so much sand as the shallow German Ocean; but there is some reason to think that the amount of this material now cast 
But even in the cases where the accumulations of sand in ex. tensive deserts appear to be of marine formation, or rather aggre. gation, and to liave been brought to their present position by upheaval, they are not wholly composed of material collected or distributed by the eurrents of the sea; for, in all such regions, they continue to receive some small contributions from the disintegration of the rocks which underlie, or crop out through, the superficial deposits.* In some instances, too, as in Northern Africa, alditions are constantly made to the mass by the prevalence of sea-winds, which transport, or, to speak more precisely, roll the finer beach-sand to considerable distances into the interior. But this is a very slow process, and the exaggerations of travellers have diffused a vast deal of popular error on the subject.

\section{Sands of Egypt.}

In the narrow valley of the Nile-which, above its bifurcation near Cairo, is, throughout Egypt and Nubia, generally bounded

upon its northern shores is less than at some former periods, though no extensive series of observations on this subject has been recorded. On the Spit of Agger, at the present outlet of the Liimfjord, Andresen found the quantity during ten years, on a beach about five hundred and seventy feet broad, equal to an annual deposit of an inch and a half over the whole surface. $-O m$ Kitformationen, p. 56.

This gives seventy-one and a quarter cubic feet to the running foot-a quantity certainly much smaller than that cast up by the same sea on the shores of the Dano-German duchies and of Holland, and, as we have seen, scarcely one-fourth of that deposited by the Atlantic on the coast of Gascony.

* See, on this subject, an article in Aus der Natur, vol. xxx., p. 590.

The Florentine Frescobaldi, who visited the Sinaitic peninsula five hundred years ago, observed the powerful action of the solar heat in the disintegration of the desert rocks. "This place," says he, "was a ridge of rocks burnt to powder by the sun, and this powder is blown away from the rock by the wind and is the sand of the desert; and there be many hills which are pure bare rock, and when the sun parcheth them, the wind carries off the dust, and other sand is there none in that land."-Viaggio, pp. 69, 70.

In Arabia Petrea, when a wind, powerful enough to scour down below the ordinary surface of the desert and lay bare a fresh bed of stones, is followed by a sudden burst of sunshine, the dark agate pebbles are often cracked and broken by the heat; and this is the true explanation of the occurrence of the fragments in situations where the action of fire is not probable. If the fragments are small enough to be rolled by the winds, they are in time ground down to sand and contribute to the stock of that material which covers the face of the desert, though the sand thus formed is but an infinitesimal proportion of the whole. 
by precipitous cliffs- - herever a ravine or other considerable de. pression occurs in the wall of rock, one sees what seems a stream of desert sand pouring down, and common observers have hence concluded that the whole valley is in danger of being buried under a stratum of infertile soil. The ancient Egyptians apprehended this, and erected walls, often of unburnt brick, across the outlet of gorges and lateral valleys, to check the flow of the sandstreams. In later ages, these walls have mostly fallen into decay, and no preventive measures against such encroachments are now resorted to. The extent of the mischief to the soil of Egypt, and the future danger from this source, have been much overrated.* The sand on the borders of the Nile is neither elevated so high by the wind, nor transported by that agency in so great masses, as is popularly supposed; and of that which is actually lifted or rolled and finally deposited by air-currents, a considerable proportion is either calcareous, and therefore readily decomposable, or in the state of a very fine dust, and so in neither case injurious to the soil. There are, indeed, both in Africa and in Arabia, considerable tracts of fine, silicious sand, which may be carried far by high winds; but these are exceptional cases, and in general the progress of the desert sand is by a rolling motion along the surface. $\dagger$ So little is it lifted, and so inconsiderable is

* KLen, Physische Geographie, p. 371.

† Sand heaps, three and even six hundred feet high, are indeed formed by the wind, but this is effected by driving the particles up an inclined plane, not by lifting them. Brémontier, speaking of the sand-hills on the western coast of France, says: "The particles of sand composing them are not large enough to resist wind of a certain force, nor small enough to be taken up by it, like dust; they only roll along the surface from which they are detached, and, though moving with great velocity, they rarely rise to a greater height than three or four inches."-Mémoire sur les Dunes, Annales des Ponts et Chaussées, 1883, 1er sémestre, p. 148.

Andresen says that a wind, laving a velocity of forty feet per second, is strong enough to raise particles of sand as high as the face and eyes of a man, but that, in general, it rolls along the ground, and is scarcely ever thrown more than to the height of a couple of yards from the surface. Even in these cases, it is carried forward by a hopping, not a continuous, motion; for a very narrow sheet or channel of water stops the drift entirely, all the sand dropping into it until it is filled up.

Blake observes, Pacific Railroad Report, vol. v., p. 242, that the sand of the Colorado desert does not rise high in the air, but bounds along on the surface or only a few inches above it.

The character of the motion of sand drifts is well illustrated by an inter 
the quantity yet remaining on the borders of Egypt, that a wall four or five feet high suffices for centuries to check its encroachments. This is obvious to the eye of every olserver who prefers the true to the marvellous; but the old-world fable of the overwhelming of caravans by the fearful simoom-which even the Arabs no longer repeat, if indeed they are the authors of it-is so thoroughly rooted in the imagination of Christendom that most desert travellers, of the tourist class, think they shall disappoint the readers of their journals if they do not recount the particulars of their escape from being buried alive by a sandstorm, and the popular demand for a "sensation" must be gratified accordingly.*

Another circumstance is necessary to be considered in estimating the danger to which the arable lands of Egypt are exposed. The prevailing wind in the valley of the Nile and its borders is

esting fact not much noticed hitherto by travellers in the East. In situations where the sand is driven through depressions in rock-beds, or over deposits of silicious pebbles, the surface of the stone is worn and smoothed much more effectually than it could be by running water, and I have picked up, in such localities, rounded, irregularly broken fragments of agate, which had received from the attrition of the sand as fine a polish as could be given them by the wheel of the lapidary. The polish of the granite rocks at the First Cataract of the Nile is due to the silicious slime transported by the water, and it must have required countless ages to effect it. The smoothness of river pebbles is due to a similar cause, combined with the attrition of the pebbles against each other.

Very interesting observations, by Blake, on the polishing of hard stones by drifting sand will be found in the Pacific Railroad Report, vol. v., pp. 92, $230,231$.

The grinding and polishing power of sand has lately received a new and most ingenious application in America. Jets of sand, and even of small particles of softer substances, thrown with a certain force, are found capable of cutting the hardest minerals and metals. A block of corundum, some inches thick, has been bored through in a few minutes by this process, and it promises to be highly useful in glass-cutting and other similar operations.

* Wilkinson says that, in much experience in the most sandy parts of the Libyan desert, and much inquiry of the best native sources, he never saw or heard of any instance of danger to man or beast from the mere accumulation of sand transported by the wind. Chesney's observations in Arabia, and tho testimony of the Bedouins he consulted, are to the same purpose. The dangers of the simoom are of a different character, though they are certainly aggravated by the blinding effects of the light particles of dust and sand borne along by it, and by that of the inhalation of them upon the respiration. 
from the north, and it may be said without exaggeration that the north wind blows for three-quarters of the year.* The effect of winds blowing up the valley is to drive the sands of the desert plateau which borders it, in a direction parallel with the axis of the valley, not transversely to it; and if it ran in a straight line, the north wind would carry no desert sand into it. There are, however, both curves and angles in its course, and hence, wherever its direction deviates from that of the wind, it might receive sand drifts from the desert plain through which it runs. But, in the course of ages, the winds have in a great measure bared the projecting points of their ancient deposits, and no great accumulations remain in situations from which either a north or a south wind would carry them into the valley. $\dagger$

The sand let fall in Egypt by the north wind is derived, not from the desert, but from a very different source-the sea. Considerable quantities of sand are thrown up by the Mediterranean, at and between the mouths of the Nile, and indeed along

* In the narrow valley of the Nile, bounded as it is above the Delta by high cliffs, all air-currents from the northern quarter become north winds, though, of course, varying in partial direction, in conformity with the sinuosities of the valley. Upon the desert plateau they incline westwards, and have already borne into the valley the sands of the eastern banks, and driven those of the western quite out of the Egyptian portion of the Nile basin.

$\uparrow$ These considerations apply, with equal force, to the supposed danger of the obstruction of the Suez Canal by the drifting of the desert sands. The winds across the isthmus are almost uniformly from the north, and they swept it comparatively clean of flying sands long ages since. The traces of the ancient canal between the Red Sea and the Nile are easily followed for a considerable distance from Suez. Had the drifts upon the isthmus been as formidable as some have feared and others have hoped, those traces would have been obliterated, and Lake Timsah and the Bitter Lakes filled up many centuries ago. The few particles driven by the rare east and west winds towards the line of the canal, will easily be arrested by plantations or other simple methods, or removed by dredging. The real dangers and difficulties of this magnificent enterprise-and they have been great-consisted in the nature of the soil to be removed in order to form the line, and especially in the constantly increasing accumulation of sea-sand at the southern terminus by the tides of the Red Sea, and of sand and Nile slime at the northern, by the action of the winds and currents. Both seas are shallow for miles from the shore, and the excavation and maintenance of deep channels, and of capacious harbors with casy and secure entrances, in such localities, is doubtless one of the hardest problems offered to modern engineers for practical solution. See post, Gea logical Importance of Dunes, note. 
alınost the whole southern coast of that sea, and drifted into the interior to distances varying according to the force of the wind and the abundance and quality of the material. The sand so transported contributes to the gradual elevation of the Delta, and of the banks and bed of the river itself. But just in proportion as the bed of the stream is elevated, the height of the water in the annual inundations is increased also, and as the inclination of the chammel is diminished, the rapidity of the current is checked, and the deposition of the slime it holds in suspension consequently promoted. Thus the winds and the water, moving in contrary directions, join in producing a common effect.

The saud, blown over the Delta and the cultivated land higher up the stream during the inundation, is covered or mixed with the fertile earth brought down by the river, and no serious injury is sustained from it. That spread over the same ground after the water has subsided, and during the short period when the soil is not stirred by cultivation or covered by the flood, forms a thin pellicle over the surface as far as it extends, and serves to divide and distinguish the successive layers of slime deposited by the annual inundations. The particles taken up by the wind on the sea-bench are borne onward, by a hopping motion, or rolled along the surface, until they are arrested by the temporary cessation of the wind, by vegetation, or by some other obstruction; and they may, in process of time, accumulate in large masses, under the lee of rocky projections, buildings, or other barriers which break the force of the wind.

In these facts we find an important element in the explanation of the sand drifts, which have half buried the Sphinx and so many other ancient monuments in that part of Egypt. These drifts, as I have said, are not wholly from the desert, but in large proportion from the sea; and, as might be supposed from the distance they have travelled, they have been long in gathering. While Egypt was a great and flourishing kingdom, measures were taken to protect its territory against the encroachment of sand, whether from the desert or from the Mediterranean; but the foreign conquerors, who destroyed so many of its religious monuments, did not spare its public works, and the process of physical degradation undoubtedly began as early as the Persian invasion. The urgent necessity, which has compelled all the suo 
cessive tyrannies of Egypt to keep up some of the canals and other arrangements for irrigation, was not felt with respect to the advancement of the sands; for their progress was so slow as hardly to be perceptible in the course of a single reign, and long experience has shown that, from the natural effect of the inumdations, the cultivable soil of the valley is, on the whole, trenching upon the domain of the desert, not retreating before it.

The oases of the Libyan, as well as of many Asiatic deserts, have no such safeguards. The sands are fast encroaching upon them, and threaten soon to engulf them, unless man shall resort to artesian wells and plantations, or to some other efficient means of checking the advance of this formidable enemy, in time to save these islands of the waste from final destruction.

Accumulations of sand are, in certain cases, beneficial as a protection against the ravages of the sea; but, in general, the vicinity, and especially the shifting of bodies of this material, are destructive to human industry, and hence, in civilized countries, measures are taken to prevent its spread. This, however, can be done only where the population is large and enlightened, and the value of the soil, or of the artificial erections and improvements upon it, is considerable. Hence in the deserts of Africa and of Asia, and the inhabited lands which border on them, no pains are usually taken to check the drifts, and when once the fields, the houses, the springs, or the canals of irrigation are covered or choked, the district is abandoned without a struggle, and surrendered to perpetual desolation.*

\section{Sand-Dunes and Sand-Plains.}

Two forms of sand deposit are specially important in European and American geography. The one is that of dune or

* In parts of the Algerian desert, some efforts are made to retard the advance of sand-dunes which threaten to overwhelm villages. "At Debila," says Laurent, "the lower parts of the lofty dunes are planted with palms, ... but they are constantly menaced with burial by the sands. The only remedy employed by the natives consists in little dry walls of crystallized gypsum, built on the crests of the dunes, together with hedges of dead palmleaves. These defensive measures are aided by incessant labor; for every day the people take up in baskets the sand blown over to them the night before and carry it back to the other side of the dune."-Mémoires sur le Sahara, p. 14. 
shifting hillock upon the coast, the other that of barren plain in the interior. The coast-dunes are composed of sand washed up from the depths of the sea by the waves, and heaped in more or less rounded knolls and undulating ridges by the winds. The sand with which many plains are covered appears sometimes to have been deposited upon them while they were yet sulmmerged beneath the sea, sometimes to have been drifted from the sea-coast, and scittered over them by wind-currents, sometimes to have been washed upon them by running water. In these latter cases, the deposit, thongh in itself considerable, is comparatively narrow in extent and irregular in distribution, while, in the former, it is often evenly spread over a very wide surface. In all great bodies of either sort, the silicious grains are the principal constituent, though, when not resulting from the disintegration of silicious rock and still remaining in place, they are generally accompanied with a greater or less admixture of other mineral particles, and of animal and vegetable remains, " and they are, also, usually somewhat changed in consistence by the ever-varying conditions of temperature and moisture to which they have been exposed since their deposit. Unless the proportion of these latter ingredients is so large as to create a considerable adhesiveness in the massin which case it can no longer properly be called sand-it is infertile, and, if not charged with water partially agglutinated by iron, lime or other cement, or confined by alluvion resting upon it, it is much inclined to drift whenever, by any chance, the

* Organic constituents, such as comminuted shells, and silicious and calcareous exuvir of infusorial animals and plants, are sometimes found mingled in considerable quantities with mineral sands. These are usually the remains of aquatic vegetables or animals, but not uniformly so, for the microscopic organisms, whose flinty cases enter so largely into the sand-beds of the MIark of Brandenburg, are still living and prolific in the dry earth. See WITTWER, Physikalische Geographie, p. 142.

The desert on both sides of the Nile is inhabited by a land-snail-of which I have counted eighty, in estivation, on a single shrub barely a foot high-and thousands of its shells are swept along and finally buried in the drifts by every wind. Every handful of the sand contains fragments of them. FoncHinam. MER, in LEONHARD und BRoNn's Jahrbuch, 1841, p. 8, says of the sand-hills of the Danish coast: "It is not rare to find, high in the knolls, marine shells, and especially those of the oyster. They are due to the oyster-eater [Homalopus ostralegus], which carries his prey to the top of the dunes to devour it." See also Staring, De Bodem van Nederland, i., p. 321. 
vegetable network, which in most cases thinly clothes and at the same time confines it, is broken.

Human industry has not only fixed the flying dunes by plantations, but, by mixing clay and other tenacious earths with the superficial stratum of extensive sand-plains, and by the application of fertilizing substances, it has made them abundantly productive of regetable life. These latter processes belong to agriculture and not to geography, and therefore are not embraced within the scope of the present subject. But the preliminary steps whereby wastes of loose, drifting, barren sands are transformed into wooded knolls and plains, and finally, through the accumulation of vegetable mould, into arable ground, constitute a conquest orer nature which precedes agriculture-a geographical revolution-and, therefore, an account of the means by which the change has been effected belongs properly to the history of man's influence on the great features of terrestrial surface. I proceed, then, to examine the structure of dunes, and to describe the warfare man wages with the sand-hills, striving on the one hand to maintain and even extend them, as a natural barrier against encroachments of the sea, and, on the other, to check their moving and wandering propensities, and prevent them from trespassing upon the fields he has planted and the habitations in which he dwells.

\section{Coast-Dunes.}

Coast-dunes are oblong ridges or round hillocks, formed by the action of the wind upon sands thrown up by the waves on the low beaches of seas, and sometimes of fresh-water lakes. On most coasts, the supply of sand for the formation of dunes is derived from tidal waves. The flow of the tide is more rapid, and consequently its transporting power greater, than that of the ebb; the momentum, acquired by the heavy particles in rolling in with the water, tends to carry them even beyond the flow of the waves; and at the turn of the tide, the water is in a state of repose long enough to allow it to let fall much of the solid matter it holds in suspension. Hence, on all low, tide-washed coasts of seas with sandy bottoms, there exist several conditions favorable to the formation of sand deposits along high-water mark. If the land-

* There are various reasons why the formation of dunes is confined to low 
winds are of greater frequency, duration or strength than the seawinds, the sands left by the retreating wave will be constantly blown back into the water; but if the prevailing air-eurrents are in the opposite direction, the sands will soon be carried out of the reach of the highest waves, and transported continually farther and farther into the interior of the land, unless obstructed by high grounds, regetation or other obstacles.

The laws which govern the formation of dunes are substantially these. We have seen that, under certain conditions, sand is accumulated above high-water mark on low sea and lake shores. So long as the sand is kept wet by the spray or by capillary attraction, it is not disturbed by air-currents, but as soon as the wares retire sufficiently to allow it to dry, it becomes the sport of the wind, and is driven up the gently sloping beach until it is arrested by stones, vegetables or other obstructions, and thus an accumulation is formed which constitutes the foundation of a dune. However slight the elevation thus created, it serves to stop or retard the progress of the sand-grains which are driven against its

shores, and this Iaw is so universal, that when bluffs are surmounted by them, there is always cause to suspect upheavel, or the removal of a sloping-beach in front of the bluff, after the dunes were formed. Bold shores are usually without a sufficient beach for the accumulation of large deposits; they are commonly washed by a sea too deep to bring up sand from its bottom; their abrupt elevation, even if moderate in amount, would still be too great to allow ordinary winds to lift the sand above them; and their influence in deadening the wind which blows towards them would even more effectually prevent the raising of sand from the beach at their foot.

Forchhammer, describing the coast of Jutland, says that, in high winds, "one can hardly stand upon the dunes, except when they are near the water line and have been cut down perpendicularly by the waves. Then the wind is little or not at all felt-a fact of experience very common on our coasts, observed on all the steep shore bluffs of 200 feet height, and, in the Faroe Islands, on precipices 2,000 feet high. In heavy gales in those islands, the cattle fly to the very edge of the cliffs for shelter, and frequently fall over. The wind, impinging against the vertical wall, creates an ascending current which shoots somewhat past the crest of the rock, and thus the observer or the animal is protected against the tempest by a barricr of air."-LEONHAnD und BRons, Jahrbuch, 1841, p. 3.

The calming, or rather diversion, of the wind by cliffs extends to a considerable distance in front of them, and no wind would have sufficient force to raise the sand vertically, parallel to the face of a bluff, even to the height of twenty feet. 
seaward face, and to protect from the further influence of the wind the particles which are borne beyond it, or rolled over its crest, and fall down behind it. If the shore above the beach line were perfectly level and straight, the grass or bushes upon it of equal height, the sand thrown up by the waves uniform in size and weight of particles as well as in distribution, and if the action of the wind were steady and regular, a continuous bank would be formed, everywhere alike in height and cross section. But no such constant conditions anywhere exist. The banks are curved, broken, unequal in elevation; they are sometimes bare, sometimes clothed with vegetables of different structure and dimensions; the sand thrown up is variable in quantity and character; and the winds are shifting, gusty, vortical, and often blowing in very narrow currents. From all these causes, instead of uniform hills, there rise irregular rows of sand heaps, and these, as would naturally be expected, are of a pyramidal, or rather conical shape, and connected at bottom by more or less continuous ridges of the same material.

Elisée Reclus, in describing the coast-dunes of Gascony, observes that when, as sometimes happens, the sands are not heaped in a continuous, irregular bulwark, but deposited in isolated hillocks, they have a tendency to assume a crescent shape, the convexity being turned seawards, or towards the direction from which the prevailing winds proceed. This fact, the geological bearing of which is obvious, is not noticed by previous French writers or even by Andresen, though a semi-lunar outline has been long generally ascribed to inland dunes. It is, however, evident that such a form would naturally be produced by the action of a wind blowing long in a given direction upon a mass of loose sand with a fixed centre--such as is constituted by the shrub or stone around which the sand is first deposited-and free extremities.

On a receding coast, dunes will not attain so great a height as on more secure shores, because they are undermined and carried off before they have time to reach their greatest dimensions. Hence, while at sheltered points in Southwestern France there are dunes three hundred feet or more in height, those on the Frisic Islands and the exposed parts of the coast of Schleswig. Holstein range only from twenty to one hundred feet. On the western shores of Africa, it is said that they sometimes attain an 
elevation of six hundred feet. This is one of the very few points known to geographers where desert sands are advancing seawards," and here they rise to the greatest altitude to which sandgrains can be carried by the wind.

The hillocks, once deposited, are held together and kept in shape, partly by mere gravity, and partly by the slight cohesion of the lime, clay and organic matter mixed with the sand; and it is observed that, from capillary attraction, evaporation from lower strata and retention of rain-water, they are always moist a little below the surface. $\dagger$ By successive accumulations, they

* "On the west coast of Africa the dunes are drifting seawards, and always receiving new accessions from the Sahara. They are constantly advancing out into the sea."-NaUmann, Geognosie, ii., p. 1172.

+ "Dunes are always full of water, from the action of capillary attraction. Upon the summits, one seldom needs to dig more than a foot to find the sand moist, and in the depressions, fresh water is met with near the surface."Forchinanier, in Leonhard und Bronn, for 1841, p. 5, note.

On the other hand, Andresen, who has very carefully investigated this as well as all other dune phenomena, maintains that the humidity of the sand ridges can not be derived from capillary attraction. He found by experiment that a heap of drift-sand was not moistened to a greater height than eight and a half inches, after standing with its base a whole night in water. He states the minimum of water contained by the sand of the dunes, one foot below the surface, after a long drought, at two per cent., the maximum, after a rainy month, at four per cent. At greater depths the quantity is larger. The hygroscopicity of the sand of the coast of Jutland he found to be thirty-three per cent. by mensure, or 21.5 by weight. The annual precipitation on that coast is twenty-seven inches, and, as the evaporation is about the same, he argues that rain-water does not penetrate far beneath the surface of the dunes, and concludes that their humidity can be explained only by evaporation from below.-Om Klitformationen, pp. 106-110.

In the dunes of Algeria, water is so abundant that wells are constantly dug in them at high points on their surface. They are sunk to the depth of three or four mitres only, and the water rises to the height of a metre in them.LAURExt, Mimoire sur le Sahara, pp. 11, 12, 13. The dunes of the Sahara, in some places, supply pasturage for the caravans. See interesting notice of Pomel's observations in L'Année Geographique, January, 1873, p. 258, seq.

Laurent also observes (p. 14) that the hollows in the dunes are planted with palms which find moisture enough a little below the surface. It would hence seem that the proposal to fix the dunes which are supposed to threaten the Suez Canal, by planting the maritime pine and other trees upon them, is not altogether so absurd as it has been thought to be by some of those disinterested plilanthropists of other nations who were distressed with fears that 
gradually rise to the height of thirty, fifty, sixty or a hundred feet, and sometimes even much higher. Strong winds, instead of adding to their elevation, sweep off loose particles from their surface, and these, with others blown over or between them, build up a second row of dunes, and so on according to the character of the wind, the supply and consistence of the sand, and the face of the country. In this way is formed a belt of sand-dumes, irregularly dispersed, varying much in height and dimensions, and sometimes many miles in breadth. On the Island of Sylt, in the German Sea, where there are several rows, the width of the belt is from half a mile to a mile. There are similar ranges on the coast of Holland, exceeding two miles in breadth, while at the mouths of the Nile they form a zone not less than ten miles wide.

The base of some of the dunes in the Delta of the Nile is reached by the river during the annual inundation, and the infiltration of the water, which contains lime, has converted the lower strata into a silicious limestone, or rather a calcareous sandstone, and thus afforded an opportunity of studying the structure of that rock in a locality where its origin and mode of aggregation and solidification are known.

The tide, though a usual, is by no means a necessary, condition for the accumulations of sand out of which dunes are formed. The Baltic and the Mediterranean are almost tideless seas, but there are vast ranges of dunes on the Russian and Prussian coasts of the Baltic, and at the mouths of the Nile and many other points on the shores of the Mediterranean. The vast shoals in the latter sea, known to the ancients as the Greater and Lesser Syrtis, are of marine origin. They are still filling up with sand, washed up from greater depths or sometimes drifted from the coast in small quantities, and will probably be converted, at some future period, into dry land covered with sand-hills. There are

French capitalists would lose the money they had invested in that great undertaking.

Ponds of water are often found in the depressions between the sand-hills of the dune chains in the North American desert.

The best water supplied to the city of Amsterdam is rain-water absorbed by the coast-dunes and purified by those natural filters, from which large quantities are conveyed to the city. 
also extensive ranges of dunes upon the eastern shores of the Caspian, and at the southern, or rather southeastern, extremity of Lalie Michigan.* There is no doubt that this latter lake formerly extended much farther in that direction, but its southern portion has gradually shoaled, and at last been converted into solid land, in consequence of the prevalence of the northwest winds. These blow over the lake a large part of the year, and create a southwardly set of the eurrents which wash up sand from the bed of the lake and throw it on shore. Sand is taken mp from the beach at Michigan city by every wind from that quarter, and, after a heavy blow of some hours' duration, sand ridges may be observed on the north side of the fences, like the snow wreaths deposited by a drifting wind in winter. Some of the particles are carried back by contrary wiuds, but most of them lodge on or behind the dunes, or in the moist soil near the lake, or are entangled by vegetables, and tend permanently to elevate the level. Like effects are produced by constant sea-winds, and dunes will generally be formed on all low coasts where such prevail, whether in tideless or in tidal waters.

Jobard thus describes the modus operandi, under ordinary circumstainces, at the mouths of the Nile, where a tide can scarcely be detected: "Then a wave breaks, it deposits an almost imperceptible line of fine sand. The next wave brings also its contribution, and shoves the preceding line a little higher. As soon as the particles are fairly out of the reach of the water they are dried by the heat of the burning sun, and immediately seized by the wind and rolled or borne farther inland. The gravel is not thrown out by the waves, but rolls backwards and forwards until it is worn down to the state of fine sand, when it, in its turn, is cast upon the land and taken up by the wind." + This description applies only to the common every-day action of wind and water; but just in proportion to the increasing force of the wind and the waves, there is an increase in the quantity of sand, and

* The careful observations of Colonel J. D. Graham, of the United States Army, show a tide of about three inches in Lake Michigan. See "A Lunar Tidal Wave in the North American Lakes," demonstrated by Lieut.-Colonel J. D. Graham, in the fourteenth volume of the Proceedings of the American Association for the Advancement of Science.

+ Starnig, De Bodem van Nederland, i., p. 327, note. 
in the niagnitude of the particles carried off from the beach by it, and, of course, every storm in a landward direction adds sensibly to the accumulation upon the shore.

\section{Sand-Banks.}

Although dunes, properly so called, are found only on dry land and above ordinary high-water mark, and owe their elevation and structure to the action of the wind, yet, upon many shelving coasts, accumulations of sand much resembling dunes are formed under water at some distance from the shore by the oscillations of the waves, and are well known by the name of sand-banks. They are usually rather ridges than banks, of moderate inclination, and with the steepest slope seawards, ${ }^{*}$ and their form differs little from that of dunes except in this last particular and in being lower and more continuous. Upon the western coast of the island of Amrum, for example, there are three rows of such banks, the summits of which are at a distance of perhaps a couple of miles from each other; so that, including the width of the banks themselves, the spaces between them, and the breadth of the zone of dunes upon the land, the belt of moving sands on that coast is probably not less than eight miles wide.

Under ordinary circumstances, sand-banks are always rolling landwards, and they compose the magazine from which the material for the dunes is derived. $\dagger$ The dunes, in fact, are but aquatic sand-banks transferred to dry land. The laws of their formation are closely analogous, because the action of the two fluids, by which they are respectively accumulated and built up,

* Koml, Inseln und Marschen Schleswig Holsteins, ii., p. 33. From a drawing in ANDIESEN, Om Klitformationen, p. 24, it would appear that on the Schleswig coast the surf-formed banks have the steepest slope landwards, those farther from the shore, as stated in the text.

+ Sand-banks sometimes connect themselves with the coast at both ends, and thus cut off a portion of the sea. In this case, as well as when salt water is enclosed by sea-dikes, the water thus separated from the ocean gradually becomes fresh, or at least brackish. The Haffs, or large expanses of fresh water in Eastern Prussia-which are divided from the Baltic by narrow sandbanks called Nehrungen, or, at sheltered points of the coast, by fluviatile deposits called Werders-all have one or more open passages, through which the water of the rivers that supply them at last finds its way to the sea. 
is very similar when brought to bear upon loose particles of solid matter. It would, indeed, seem that the slow and comparatively regular movements of the heavy, inelastic water ought to affect such particles very differently from the sudden and fitful impulses of the light and elastic air. But the velocity of the wind currents gires them a mechanical force approximating to that of the slower wares, and, however difficult it may be to explain all the phenomena that characterize the structure of the dunes, observation has proved that it is nearly identical with that of submerged sand-banks.* The differences of form are generally ascribable to the greater number and variety of surface accidents of the ground on which the sand-hills of the land are built up, and to the more frequent changes, and wider variety of direction, in the courses of the wind.

\section{Character of Dune Sand.}

"Dune sand," says Staring, "consists of well-rounded grains of quartz, more or less colored by iron, and often mingled with fragments of shells, small indeed, but still visible to the naked eje. $\downarrow$ These fragments are not constant constituents of dune

* Forchinammer ascribes the resemblance between the furrowing of the dune sands and the beach ripples, not to the similarity of the effect of wind and water upon sand, but wholly to the action of the wind; in the first instance, directly; in the latter, through the water. "The wind-ripples on the surface of the dunes precisely resemble the water-ripples of sand-flats occasionally orerflowed by the sea; and with the closest scrutiny, I have never been able to detect the slightest difference between them. This is easily explained by the fact, that the water-ripples are produced by the action of light wind on the water which only transmits the air-waves to the sand."-LEoNHARD und BRONN, 1841, pp. 7, 8.

+ According to French authorities, the dunes of France are not always composed of quartzose sand. "The dune sands" of different characters, says Bremontier, "partake of the nature of the different materials which compose them. At certain points on the coast of Normandy they are found to be purely calcareous; they are of mixed composition on the shores of Brittany and Saintonge, and generally quartzose between the mouth of the Gironde and that of the Adour."-MÉmoire sur les Dunes, Annales des Ponts et Chaussées, t. vii., 1833, 1er sémestre, p. 146.

In the dunes of Long Island and of Jutland, there are considerable veins composed almost wholly of garnet. For a very full examination of the mechanical and chemical composition of the dune sands of Jutland, see ANDRE SEN, Om Klitformationen, p. 110.

Fraas informs us, Auз dem Orient, pp. 176, 177, that the dune sands of the 
sand. They are sometimes found at the very summits of the hillocks, as at Overveen; in the King's Dune, near Egmond, they form a coarse, calcareous gravel ver'y largely distributed through the sand, while the interior dunes between Haarlem and Warmond exhibit no trace of them. It is yet undecided whether the presence or absence of these fragments is determined by the period of the formation of the dunes, or whether it depends on a difference in the process by which different dumes have been accumulated. Land shells, such as snails, for example, are found on the surface of the dunes in abundance, and many of the shelly fragments in the interior of the hillocks may be derived from the same source." *

Sand concretions form within the dunes, and especially in the depressions between them. These are sometimes so extensive and impervious as to retain a sufficient supply of water to feed perennial springs, and to form small permanent ponds, and they are a great impediment to the penetration of roots, and consequently to the growth of trees planted, or germinating from selfsown seeds, upon the dunes.

Egyptian coast arise from the disintegration of the calcareous sandstone of the same region. This sandstone, composed in a large proportion of detritus of both land and sea shells mingled with quartz sand, appears to have been consolidated under water during an ancient period of subsidence. A later upheaval brought it to or near the surface, when it was more or less disintegrated by the action of the waves and by meteoric influences-a process still going on-and it is now again subsiding with the coast it rests on.

The calcareous sand arising from the comminution of corals forms dunes on some of the West India Islands.-AGAssiz, Bulletin of the Mruseum of Comparartive Zoölogy, vol. i.

* De Bodem van Nederland, i., p. 323.

+ Starna, De Bodem van Nederland, i., p. 317. See also Bergsöe, Rc. ventlov's Tirksomhed, ii., p. 11.

"In the sand-hill ponds mentioned in the text, there is a vigorous growth of bog plants accompanied with the formation of peat, which goes on regularly as long as the dune sand does not drift. But if the surface of the dunes is broken, the sand blows into the ponds, covers the peat, and puts an end to its formation. When, in the course of time, marine currents cut away the coast, the dunes move landwards and fill up the ponds, and thus are formed the remarkable strata of fossil peat called Martörv, which appears to be un. known to the geologists of other parts of Europe."-FoncriHAMnER, in LEoNIIARD und BronN, 1841, p. 13. Martörv has a specific gravity thrice as great as that of ordinary peat in consequence of the pressure of the sand.AsBJörnsen, Torv og Torvdrift, p. 26. 


\section{Interior Structure of Dunes.}

The interior structure of the dunes, the arrangement of their particles, is not, as might be expected, that of an unorganized, confused heap, but they show a strong tendency to stratification. This is a point of much geological interest, because it inclicates that sandstone may owe its stratified character to the action of other forces as well as of water. The origin and peculiar charac. ter of these layers are due to a variety of causes.

For example, a sonthwest wind and current may deposit upon a dune a stratum of a given color and mineral composition, and this may be succeeded by a northwest wind and current, bringing with them particles of a different hue, constitution and origin. Again, if we suppose a violent tempest to strew the beach with sand-grains very different in magnitude and specific gravity, and, after the sand is dry, to be succeeded by a gentle breeze, it is evident that only the lighter particles will be taken up and carried to the dunes. If, after some time, the wind freshens, heavier grains will be transported and deposited on the former, and a still stronger succeeding gale will roll up yet larger kernels. Each of these deposits will form a stratum. If we suppose the tempest to be followed, after the sand is dry, not by a gentle breeze, but by a wind powerful enough to lift at the same time particles of very various magnitudes and weights, the heaviest will often lodge on the dune while the lighter will be carried farther. This would produce a stratum of coarse sand, and the same effect might result from the blowing array of light particles out of a mixed layer, while the heavier remained undisturbed.* Still another cause of apparent stratification may be found in the occasional interposition of a thin layer of leaves or other vegeta-

* The lower strata must be older than the superficial layers, and the particles which compose them may in time become more disintegrated, and therefore finer than those deposited later and above them.

Hull ingeniously suggests that, besides other changes, fine sand intermixed with or deposited above a coarser stratum, as well as the minute particles resulting from the disintegration of the grains of the latter, may be carried by rain in the case of dunes, or by the ordinary action of sea-water in that of sand-banks, down through the interstices in the coarser layer, and thus the relative position of sand and gravel may be changed.-Oorsprong der Holland. sche Duinen, p. 103. 
ble remains between successive deposits, and this I imagine to be more frequent than has been generally supposed. Some geologists have thought that the sand strata of dunes are of annual formation; * but the autumnal deposit of foliage from neighboring trees and shrubs furnishes a more probable explanation of the division of the sand-heaps into regular layers.

A late distinguished American admiral communicated to me an interesting observation made by him at San Francisco, which has an important bearing on the arrangement of the particles of sand in dunes and other irregular accumulations of that substance. In laying out a navy-yard at that port, a large quantity of earthy material was removed from the dunes and other hillocks and carted to a low piece of ground which required filling up. Sand of various characters, fine and coarse gravel, and common earth were dropped promiscuously by the carts as accident or convenience dictated, and of course they were all confusedly intermixed. Some time after, when the new ground was consolidated, various excavations were made in it, and the different materials of which the filling was composed were found to be stratified with considerable regularity, according to their specific gravity.

Two explanations of this remarkable fact suggest themselves to me, which, however, do not perhaps exclude others. San Francisco is subject to earthquakes, and though violent or even sensible shocks are not very frequent, it is highly probable that, as is shown to be the case in many other cuuntries by late seismological observations, there are, in the course of the year, a great number of slight shocks which escape unscientific observation. A frequent repetition of slight tremblings of the earth would, like any other moderate mechanical agitation, probably produce the separation of a miscellaneous mass, like that described, into distinct layers. Again, the Pacific coast, like all others upon an open sea, is exposed to incessant concussion from the shock of the waves, which is repeated many thousand times a day. This concussion is often sensibly felt by the observer, and it seems not in the least improbable that the agitation may lave tended to produce a stratified arrangement in the case at

\footnotetext{
* Scromann, Geologische Wanderungen durch die Preussischen Ost-See Pra vinzen, 1869, p. 81.
} 
San Francisco, as well as in all coast-dunes and other accumulations of loose mineral material in similar situations. Kohl observes that the shore on the landward side of the files of dunes often trembles from the shock of the waves on the beach,* and Tilleneure established by careful experiment that at Dunkerque the ground is sensibly agitated by the same cause, in storny weather, to a distance of more than a mile from the sea.

The eddies of strong winds between the hillocks must also occasion disturbances and rearrangements of the sand layers, and it seems possible that the irregular thickness and the strange contortions of the strata of the sandstone at Petra may be due to some such cause. A curious observation of Professor Forchhammer suggests an explanation of another peculiarity in the structure of the sandstone of Mount Seir. He describes dunes in Jutland, composed of yellow quartzose sand intermixed with black titanian iron. When the wind blows over the surface of the dunes, it furrows the sand with alternate ridges and depressions, ripples, in short, like those of water. The swells, the dividing ridges of the system of sand ripples, are composed of the light grains of quartz, while the heavier iron rolls into the depressions between, and thus the whole surface of the dune appears as if covered with a fine black network.

The sea side of dunes, being more exposed to the caprices of the wind, is more irregular in form than the lee or land side, where the arrangement of the particles is affected by fewer disturbing and conflicting influences. Hence, the stratification of the windward slope is somewhat confused, while the sand on the lee side is found to be disposed in more regular beds, inclining landwards, and with the largest particles lowest, where their greater weight would naturally carry them. The lee side of the dunes, being thus formed of sand deposited according to the laws of gravity, is very uniform in its slope, which, according to Forchhammer, varies little from an angle of $30^{\circ}$ with the horizon, while the more exposed and irregular weather side lies at an inclination of from $5^{\circ}$ to $10^{\circ}$. When, however, the outer tier of dunes is formed so near the water line as to be exposed to the immediate action of the waves, it is undermined, and the face of the hill is very steep and sometimes nearly perpendicular.

* Inseln und Marschen, etc., ii., p. 34. 


\section{Geological Importance of Dunes.}

These observations, and other facts which a more attentive study on the spot would detect, might furmish the means of determining interesting aud important questions concerning geological formations in localities very unlike those where dunes are now thrown up. For example, Sturler supposes that the drifting sandhills of the African desert were origimally coast-lunes, and that they have been trausported to their present position, far in the interior, by the rolling and shifting leewird movement to which all dunes not covered with vegretation are subject. The present general drift of the sauds of that desert appears to be to the southwest and west, the prevailing winds blowing from the northeast and east; but it has been doubted whether the shoals of the western coast of Northern Africa, and the sinds upon that shore, are derived from the bottom of the Atlantic, in the usual manner, or, by an inverse process, from those of the Sahara. The latter, as has been before remarked, is probably the truth, though observations are wanting to decide the question.* There would be nothing violently improbable in the a priori supposition that they may have been in part first thrown up by the Mediterranean on its Libyan coast, and thence blown south and west over the vast space they now cover. But inasmuch as it is now geologically certain that the Sahara is an uplifted bed of an ancient sea, we may suppose that, while submerged, it was, like other sea-bot toms, strewn with sand, and that its present supply of that ma terial was, in great proportion, brought up with it. Laurent observed, some years ago, that marine shells of still extant species were found in the Sahara, far from the sea, and even at consideable depths below the surface. $\uparrow$ These observations have been co. firmed past all question by Desor, Martins and others, and the facts and the obvious conclusion they suggest are at present not disputed.

* "The North African desert falls into two divisions : the Sahel, or western, and the Sahar, or eastern. The sands of the Sahar were, at a remote period, drifted to the west. In the Sahel, the prevailing east winds drive the sandocean with a progressive westward motion. The eastern half of the desert is swept clean."-NAUMANN, Geognosie, ii., p. 1173.

† Mémoires sur le Sahara Oriental, p. 62. 
But whatever have been the source and movement of these sands, they can hardly fail to have left on their route some sandstone monuments to mark their progress, such, for example, as we have seen are formed from the dune sand at the mouth of the Nile; and it is conceivable that the character of the drifting sands themselves, and of the conglomerates and sandstones to whose formation they have contributed, might furnish satisfactory evidence as to their origin, their starting-point, and the course by which they have wandered so far from the sea.*

If the sand of coast-dunes is, as Staring describes it, composed chiefly of well-rounded quartzose grains, fragments of shells, and other constant ingredients, it would often be recognizable as coast sand, in its agglutinate state of sandstone. The texture of this rock varies from an almost imperceptible fineness of grain to great coarseness, and affords good facilities for microscopic ob-

* Forchhammer, after pointing out the coincidence between the inclined stratification of dunes and the structure of ancient tilted rocks, says: "But I am not able to point out a sandstone formation corresponding to the dunes. Probably most ancient dunes have been destroyed by submersion before the loose sand became cemented to solid stone, but we may suppose that circum. stances have existed somewhere which have preserved the characteristics of this formation."-LEONHARD und BRoNN, 1841, pp. 8, 9.

Such formations, however, certainly exist. Laurent tells us that in the Algerian desert there are "sandstone formations" not only " corresponding to the dunes," but actually consolidated within them. "A place called El-MouiaTadjer presents a repetition of what we saw at El-Baya; one of the funnels formed in the middle of the dunes contains wells from two metres to two and a half in depth, dug in a sand which pressure, and probably the presence of certain salts, have cemented so as to form true sandstone, soft indeed, but which does not yield except to the pickaxe. These sandstones exhibit an inclination which seems to be the effect of wind; for they conform to the direa tion of the sands which roll down a scarp occasioned by the primitive obstacle."-LaUnent, Mémoire sur le Sahara, etc., p. 12.

" $\Delta t \mathrm{New}$ Quay, the dune sands are converted to stone by an oxide of iron held in solution by the water which pervades them. This stone, which is formed, so to speak, under our eye, has been found solid enough to be employed for building."-Esquiros, L'Angleterre, etc., in Revue des Deux Mondes, 1864, pp. $44,45$.

The dunes near the mouth of the Nile, the lower sands of which have been cemented together by the infiltration of Nile water, would probably show a similar stratification in the sandstone which now forms their base.

Dana describes a laminated rock often formed by the infiltration of water into the sand-dunes on the Hawaian islands.-Corals and Coral Islands, 1872, p. 155 . 
servation of its structure. There are sandstones, such, for example, as are used for grindstones, where the grit, as it is called, is of exceeding sharpness; others where the angles of the grains are so obtuse that they scarcely act at all on hard metals. The former may be composed of grains of rock, disintegrated indeed, and recemented together, but not, in the meanwhile, much rolled; the latter, of sands long washed by the sea, and drifted by land-winds. There is, indeed, so much resemblance between the effects of driving winds and of rolling water upon light bodies, that there might be difficulty in distinguishing them; but after all, it is not probable that sandstone, composed of grains thrown up from the salt sea and long tossed by the winds, would be identical in its structure with that formed from fragments of rock crushed by mechanical force, or disintegrated by heat, and again agglutinated without much exposure to the action of moving water.

\section{Dunes of American Coasts.}

Upon the Atlantic coast of the United States, the prevalence of western or off-shore winds is unfavorable to the formation of dunes, and, though marine currents lodge vast quantities of sand in the form of banks on that coast, its shores are proportionally more free from sand-hills than some others of lesser extent. There are, however, very important exceptions. The action of the tide throws much sand upon some points of the New England coast, as well as upon the beaches of Long Island and other more southern shores, and here dunes resembling those of Europe are formed. There are also extensive ranges of dunes on the Pacific coast of the United States, and at San Francisco they border some of the streets of the city.

The dunes of America are far older than her civilization, and the soil they threaten or protect possesses, in general, too little value to justify any great expenditure in measures for arresting their progress or preventing their destruction. Hence, great as is their extent and their geographical importance, they have, at present, no such intimate relations to human life as to render them objects of special interest in the point of view I am taking, and I do not know that the laws of their formation and motion have been made a subject of original investigation by any American observer. 


\section{Dunes of Western Europe.}

Upon the western coast of Europe, on the contrary, the ravages occasioned by the morement of sand-dunes, and the serious consequences often resulting from the destruction of them, have long engaged the earnest attention of Governments and of scientific men, and for nearly a century persevering and systematic eflort has been made to bring them under human control. The sulject has been carefully studied in Demmark and the adjacent duchies, in Western Prussia, in the Netherlands, and in France; and the experiments in the way of arresting the drifting of the dumes, and of securing them, and the lands they shelter, from the encroachments of the sea, have resulted in the adoption of a system of coast improvement substantially the same in all these countries. The sands, like the forests, have now their special literature, and the volumes and memoirs, which describe them and the processes employed to subdue them, are full of scientific interest and of practical instruction.

\section{Dunes: on the Baltic and Atlantic Shores of Europe.}

In the small kingdom of Denmark, inclusive of the duchies of Schleswig and Holstein, the dunes cover an area of more than two hundred and sixty square miles. The breadth of the chain is very various, and in some places it consists only of a single row of sandhills, while in others it is more than six miles wide. $t^{\text {The dunes }}$ of the Prussian coast are vaguely estimated to cover from eightyfive to one hundred and ten thousand acres; those of Holland one hundred and forty thousand acres; and those of Gascony more than two hundred thousand acres. I do not find any estimate of their extent in other provinces of France, or in the Baltic prov-

\footnotetext{
* The Icelandic or Old Northern, the ancient common language of the countries peopled by the Scandinavian race, rich as it was in terms descriptive of natural scenery, had no name for dune. The modern Icelanders call the dune sand-melr, or simply melr,-melr being properly the designation of a species of bent-grass, or wild oats, with which dunes are often more or less covered. Icelandic geographers, however, apply to the dune-ranges of Jutland the name of klettr, a cliff, or rocky hill-in modern Danish, Hlitt.
}

†ANDRESEN, Om Klitformationen, pp. 78, 262, 275. 
inces of Russia, but it is probable that the entire quantity of dune land upon the Atlantic and Baltic shores of Europe does not fall much short of a million of acres.* This vast deposit of sea-sand extends along the coasts for a distance of several hundred miles, and from the time of the destruction of the forests which covered it, to the year 1789 , the whole line was rolling inwards and burying the soil beneath it, or rendering the fields unproductive by the sand which drifted from it. At the same time, as the sandhills moved landwards, the ocean was closely following their retreat and swallowing up the ground they had covered, as fast as their movement left it bare.

\section{Age, Character and Permanence of Dunes.}

The origin of many great lines of dunes goes back past all written history of the lands where they occur. There are, on many coasts, several distinct ranges of sand-hills which seem to be of very different ages, and to have been formed under different relative conditions of land and water. $\dagger$ In some cases there has been

* In an article on the dunes of Europe, in vol. 29 (1864) of Aus der Natur, p. 590 , the dunes are estimated to cover, on the islands and coasts of Schleswig-Holstein, in Northwest Germany, Denmark, Holland and France, one hundred and eighty-one German, or nearly four thousand English square miles; in Scotland, about ten German, or two hundred and ten English miles; in Ireland, twenty German, or four hundred and twenty English miles; and in England, one hundred and twenty German, or more than twenty-five hundred English miles. Pannewitz (Anleitung zum Anbau der Sandflüchen), as cited by Andresen (Om Klitformationen, p. 45), states that the drifting" sands of Europe, including of course sand plains as well as dunes, cover an extent of 21,000 square miles. This is perhaps an exaggeration, though there is, undoubtedly, much more desert-land of this description on the European continent than has been generally supposed. There is no question that most of this waste is capable of reclamation by simple planting, and no mode of physical improvement is better worth the attention of civilized Governments than this.

There are often serious objections to extensive forest-planting on soils capable of being otherwise made productive, but they do not apply to sand wastes, which, until covered by woods, are not only a useless incumbrance, but a source of serious danger to all human improvements in the neighborhood of them.

+Krause, speaking of the dunes on the coast of Prussia, says: "Their origin belongs to three different periods, in which important changes in the relative level of sea and land have unquestionably taken place. . . . Except 
an upheaval of the coast line since the formation of the oldest hillocks, and these have become inland dunes, while younger rows have been thrown up on the new beach laid bare by elevation of the sea-bed. Our knowledge of the mode of their first accumulation is derived from observation of the action of wind and water in the few instances where, with or without the aid of man, new const-dumes have been accumulated, and of the influence of wind alone in elevating new sand-heaps inland of the coast tier, when the outer rows are destroyed by the sea, as also when the sodded surface of ancient sands has been broken, and the subjacent strata laid open to the air.

It is a question of much interest, in what degree the naked condition of most dunes is to be ascribed to the improvidence and indiscretion of man. There are, in Western France, extensive ranges of dunes covered with ancient and dense forests, while the recently formed sand-hills between them and the sea are bare of vegetation, and in some cases are rapidly advancing upon the wooded dunes, which they threaten to bury beneath their drifts. Between the old dunes and the new there is no discoverable difference in material or in structure; but the modern sand-hills are naked and shifting, the ancient, clothed with vegetation and fixed. It has been conjectured that artificial methods of confinement and plantation were employed by the primitive inhabitants of Gaul; and Laval, basing his calculations on the rate of annual movement of the shifting dunes, assigns the fifth century of the Christian era as the period when these processes were abandoned.*

There is no historical evidence that the Gauls were acquainted with artificial methods of fixing the sands of the coast, and we

in the deep depressions between them, the dunes are everywhere sprinkled, to a considerable height, with brown oxidulated iron, which has penetrated into the sand to the depth of from three to eighteen inches, and colored it red. .... Above the iron is a stratum of sand differing in composition from ordinary sea-sand, and on this, growing woods are always found. . . . The gradually accumulated forest soil occurs in beds of from one to three feet thick, and changes, proceeding upward, from gray sand to black humus." Even on the third or seaward range, the sand grasses appear and thrive luxuriantly, at least on the west coast, though Krause doubts whether the dunes of the east coast were ever thus protected.-Der Dünenbau, pp. 8, 11.

* Latal, Mémoire sur les Dunes de Gascogne, Annales des Ponts et Chaussées, 1847, 2me sémestre, p. 231. The same opinion had been expressed by BRf́. arontrer, Annales des Ponts et Chaussées, 1833, 1er sémestre, p. 185. 
have little reason tu suppose that they were advanced enough in civilization to be likely to resort to such processes, especially at a period when land could have had but a moderate value.

In other countries, dunes have spontaneously clothed themselves with forests, and the rapidity with which their surface is covered by various species of sand-plants and finally by trees, where man and cattle and burrowing animals are excluded from them, renders it highly probable that they would, as a general rule, protect themselves if left to the undisturbed action of natural causes. The sand-hills of the Frische Nehrung, on the coast of Prussia, were formerly wooded down to the water's edge, and it was only in the last century that, in consequence of the destruction of their forests, they became moving sands." There is every reason to believe that the dunes of the Netherlands were clothed with trees until after the Roman invasion. The old geographers, in describing these countries, speak of vast forests extending to the very brink of the sea; but drifting coast-dunes are first mentioned by the chroniclers of the Middle Ages, and so far as we know they have assumed a destructive character in consequence of the improvidence of man. The history of the dunes of Michi-

* "In the Middle Ages," says Willibald Alexis, as quoted by Müller, Das Buch der Pfanzenwelt, i., p. 16, "the Nehrung was extending itself further, and the narrow opening near Lochstadt had filled itself up with sand. A great pine forest bound with its roots the dune sand and the heath uninterruptedly from Danzig to Pillau. King Frederick William I. was once in want of money. A certain Herr von Korff promised to procure it for him, without loan or taxes, if he could be allowed to remove something quite useless. He thinned out the forests of Prussia, which then indeed possessed little pecuniary value; but he felled the entire woods of the Frische Nehrung, so far as they lay within the Prussian territory. The financial operation was a success. The king had money, but in the material effects which resulted from it, the state receired irreparable injury. The sea-winds rush over the bared hills; the Frische Haff is half choked with sand; the channel between Elbing, the sea, and Königsberg is endangered, and the fisheries in the Haff injured. The operation of Herr von Korff brought the king 200,000 thalers. The state would now willingly expend millions to restore the forests again."

† STARING, Voormaals en Thans, p. 231. Had the dunes of the Netherlandish and French coasts, at the period of the Roman invasion, resembled the moving sand-hills of the present day, it is inconceivable that they could have escaped the notice of so acute a physical geographer as Strabo; and the absolute silence of Cresar, Ptolemy, and the encyclopædic Pliny, respecting them, would be not less inexplicable. 
gan, so far as I have been able to learn from my orwn observation or that of others, is the same. Thirty years ago, when that region was scarcely inhabited, they were generally covered with a thick growth of trees, chicfly pines and underwood, and there was little appearance of undermining and wash on the lake side, or of shifting of the sands, except where the trees had been cut or turned up by the roots.*

Nature, as she builds up dunes for the protection of the seashore, provides, with similar conservatism, for the preservation of the dunes themselves; so that, without the interference of man, these hillocks would be, not perhaps absolutely perpetual, but very lasting in duration, and very slowly altered in form or position. Then once covered with the trees, shrubs and herbaceous growths adapted to such localities, dunes undergo no apparent chimge, except from the slow occasional undermining of the outer tier, and from the accidental exposure of their interior, through the burrowing of animals or the upturning of trees with their roots; and all these causes of displacement are very much less destructive when a vegetable covering exists in the immediate neighborhood of the breach.

\section{Protection of Dunes.}

Before the occupation of the coasts by man, dunes, at all points where they have been observed, seem to have been protected in their rear by forests, which served to break the force of the winds in both directions, $\nmid$ and to have spontaneously clothed themselves

*The sinds of Cape Cod were partially, if not completely, covered with vegetation by nature. Dr. Dwight, describing the dunes as they were in 1800 , says: "Some of them are covered with beach grass; some fringed with whortleberry bushes; and some tufted with a small and singular growth of oaks. ... The parts of this barrier which are covered with whortleberry bushes and with oaks, have been either not at all or very little blown. The oaks, particularly, appear to be the continuation of the forests originally formed on this spot. ... . They wore all the marks of extreme age ; were, in some instances, already decayed, and in others decaying; were hoary with moss, and were deformed by branches, broken and wasted, not by violence, but by time."Iravels, iii., p. 91.

+ Bergsöe (Reventlovs Firksomhed, ii., 3) states that the dunes on the west coast of Jutland were stationary before the destruction of the forests to the east of them. The felling of the tall trees removed the resistance to the lower currentis of the westerly winds, and the sands have since buried a great extent of fertile soil. See also same work, ii., p. 124. 
with a dense growth of the various plants, grasses, shrubs and trees which nature has assigned to such soils. It is observed in Europe that dunes, though now without the shelter of a forest country behind them, begin to protect themselves as soon as human trespassers are excluded, and grazing animals denied access to them. Herbaceous and arborescent plants spring up almost at once, first in the depressions, and then upon the surface of the sand-hills. Every seed that sprouts, binds together a certain amount of sand by its roots, shades a little ground with its leaves, and furnishes food and shelter for still younger or smaller growths. A succession of a very few favorable seasons suffices to bind the whole surface together with a vegetable network, and the power of resistance possessed by the dunes themselves, and the protection they afford to the fields behind them, are just in proportion to the abundance and density of the plants they support.

The growth of the vegetable covering can, of course, be much accelerated by judicious planting and watchful care, and this species of improvement is now carried on upon a vast scale on the sandy coasts of Western Europe, wherever the value of land is considerable and the population dense.

\section{Use of Dunes as a Barrier against the Sea.}

Although the sea throws up large quantities of sand on flat leeshores, there are many cases where it continually encroaches on those same shores and washes them away. At all points of the shallow North Sea where the agitation of the waves extends to the bottom, banks are forming and rolling eastwards. Hence the sea-sand tends to accumulate upon the coast of Schleswig-Holstein and Jutland, and were there no conflicting influences, the shore would rapidly extend itself westwards. But the same waves which wash the sand to the coast undermine the beach they cover, and still more rapidly degrade the shore at points where it is too high to receive partial protection by the formation of dunes upon it. The earth of the coast is generally composed of particles finer, lighter and more transportable by water than the sea-sand. While, therefore, the billows raised by a heary west wind may roll up and deposit along the beach thousands of tons of sand, the same. waves may swallow up even a larger quantity of fine shore-earth. 
This earth, with a portion of the sand, is swept off by northwardly and southwardly currents, and let fall at other points of the coast, or carried off altogether out of the reach of causes which might bring it back to its former position.

Although, then, the eastern shore of the German Ocean here and there advances into the sea, it in general retreats before it, and but for the protection afforded it by natural arrangements seconded by the art and industry of man, whole provinces would soon be engulfed by the waters. This protection consists in an almost unbroken chain of sand banks and dunes, extending from the northernmost point of Jutland to the Elbe, a distance of not much less than three hundred miles, and from the Elbe again, though with more frequent and wider interruptions, to the Atlantic borders of France and Spain. So long as the dunes are maintained by nature or by human art, they serve, like any other embankment or dike, as a partial or a complete protection against the encroachments of the sea; and on the other hand, when their drifts are not checked by natural processes or by the industry of man, they become a cause of as certain, if not of as sudden, destruction as the ocean itself whose advance they retard. On the whole, the dunes on the const of the German Sea, notwithstanding the great quantity of often fertile land they cover, and the evils which result from their movement, are a protective and beneficial agent, and their maintenance is an object of solicitude with the Governments and people of the shores they defend."

The eastward progress of the sea on the Danish, Netherlandish and French coasts depends so much on local geological structure, on the force and direction of tidal and other marine currents, on the volume and rapidity of coast rivers, on the contingencies of

* "We must, therefore, not be surprised to see the people here deal as gingerly with their dunes as if treading among eggs. He who is lucky enough to own a molehill of dune pets it affectionately, and spends his substance in cherishing and fattening it. That fair, fertile, rich province, the peninsula of Eiderstidd in the south of Friesland, has, on the point towards the sea, only a tiny row of dunes, some six miles long or so ; but the people talk of their fringe of sand-hills, as if it were a border set with pearls. They look upon it as their best defence against Neptune. They have connected it with their system of dikes, and for years have kept sentries posted to protect it against wanton in jury."-J. G. KошL, Die Inseln u. Marschen Schleswig-Holsteins, ii., p. 115. 
the weather and on other varying circumstances, that no general rate can be assigned to it.

At Agger, near the western end of the Liimfjord, in Jutland, the coast was washed away, between the years 1815 and 1839, at the rate of more than eighteen feet a year. The advance of the sea appears to have been something less rapid for a century before; but from 1810 to 1857 , it gained upon the land no less than thirty feet a year. At other points of the shore of Jutland the loss is smaller, but the sea is encroaching generally upon the whole line of the coast.*

\section{The Liimfjord.}

The irruption of the sea into the fresh-water lagoon of Liimfjord in Jutland, in 1825-one of the most remarkable encroachments of the ocean in modern times-is expressly ascribed to "mismanagement of the dunes" on the narrow neck of land which separated the fjord from the North Sea. At earlier periods the sea had swept across the isthmus, and even burst through it, but the channel had been filled up again, sometimes by artificial means, sometimes by the operation of natural causes, and on all these occasions effects were produced very similar to those resulting from the formation of the new channel in 1825, which still remains open. Within comparatively recent historical ages, the Liimfjord has thus been several times alternately filled with fresh and with salt water, and man has produced, by neglecting the dunes, or at least might have prevented by maintaining them, changes identical with those which are usually ascribed to the action of great geological causes, and sometimes supposed to have required vast periods of time for their accomplishment.

"This breach," says Forchhammer, "which converted the Liimfjord into a sound, and the northern part of Jutland into an island, occasioned remarkable changes. The first and most striking phenomenon was the sudden destruction of almost all the

* ANdresen, Om Klitformationen, pp. 68-72.

† Id., pp. 231, 232. Andresen's work, though printed in 1861, was finished in 1859. Lyell (Antiquity of Man, 1863, p. 14) says: "Even in the course of the present century, the salt-waters have made one irruption into the Baltic by the Liimfjord, although they have been now again excluded." 
fresh-water fish previously inhabiting this lagoon, which was famous for its abundant fisheries. Millions of fresh-water fish were thrown on shore, partly dead and partly dying, and were carted off by the people. A few only survived, and still frequent the shores at the mouth of the brooks. The eel, however, has gradually accommodated itself to the change of circumstances, and is found in all parts of the fjord, while to all other freshwater fish the salt-water of the ocean seems to have been fatal. It is more than probable that the sand washed in by the irruption covers, in many places, a layer of dead fish, and has thus prepared the way for a petrified stratum similar to those observed in so many older formations.

"As it seems to be a law of nature that animals whose life is suddenly extinguished wbile yet in full vigor, are the most likely to be preserved by petrification, we find here one of the conditions farorable to the formation of such a petrified stratum. The bottorn of the Liinfjord was covered with a vigorous growth of aquatic plants, belonging both to fresh and to salt-water, especially Zostera marina. This vegetation totally disappeared after the irruption, and in some instances was buried by the sand; and here again we have a familiar phenomenon often observed in ancient strata-the indication of a given formation by a particular regetable species-and when the strata deposited at the time of the breach shall be accessible by upheaval, the period of irruption will be marked by a stratum of Zostera, and probably by impressions of fresh-water fishes.

"It is very remarkable that the Zostera marina, a sea-plant, was destroyed even where no sand was deposited. This was probably in consequence of the sudden change from brackish to salt-water. . . . . It is well established that the Liimfjord communicated with the German Ocean at some former period. To that era belong the deep beds of oyster-shells and Cardirum edule, which are still found at the bottom of the fjord. And now, after an interval of centuries during which the lagoon contained no salt-water shell-fish, it again produces great numbers of MYytilus edulis. Could we obtain a deep section of the bottom, we should find beds of Ostrea edulis and Cardium edule, then a layer of Zostera marina with fresh-water fish, and then a bed of IIytilus edulis. If in course of time the new channel should be closed, 
the brooks would fill the lagoon again with fresh water; fresh water fish and shell-fish would reappear, and thus we should have a repeated alternation of organic inhabitants of the sea and of the waters of the land.

"These events have been accompanied with but a comparatively insignificant change of land surface, while the formations in the bed of this inland sea have been totally revolutionized in character." *

\section{Coasts of Schleswig-Holstein, Holland and France.}

On the islands on the coast of Schleswig-Holstein, the advance of the sea has been more unequivocal and more rapid. Near the beginning of the last century, the dunes which had protected the western coast of the island of Sylt began to roll to the east, and the sea followed closely as they retired. In 1757, the church of Rantum, a village upon that island, was obliged to be taken down in consequence of the advance of the sand-hills; in 1791, these hills had passed beyond its site, the waves had swallowed up its foundations, and the sea gained so rapidly, that, fifty years later, the spot where they lay was seven hundred feet from the shore. $t$

The most prominent geological landmark on the coast of HolIand is the Huis te Britten, Arx Britannica, a fortress built by the Romans, in the time of Caligula, on the mainland near the mouth of the Rhine. At the close of the seventeenth century, the sea had advanced sixteen hundred paces beyond it. The older Dutch annalists record, with much parade of numerical accuracy, frequent encroachments of the sea upon many parts of the Netherlandish coast. But though the general fact of an advance of the ocean upon the land is established beyond dispute, the precision of the measurements which have been given is open to question. Staring, however, who thinks the erosion of the coast much exaggerated by popular geographers, admits a loss of more than a million and a half acres, chiefly worthless morass; $\ddagger$ and it is certain that but for the resistance of man, but for his

\footnotetext{
* Forchinammer, Geognostische Studien am Meeres-Ufer, Leonmand und Brows, Jahrbuch, 1841, pp. 11, 13.

† ANDRESEN, Om Klitformationen, pp. 68, 72.

‡ Voormaals en Thans, pp. 126, 170.
} 
erection of dikes and protection of dunes, there would now be left of Holland little but the name. It is, as has been already seen, still a debated question among geologists whether the coast of Holland now is, and for centuries has been, subsiding. I believe most investigators maintain the affirmative; and if the fact is so, the advance of sea upon the land is, in part, due to this cause. But the rate of subsidence is at all events very small, and therefore the encroachments of the ocean upon the coast are mainly to be ascribed to the erosion and transportation of the soil by marine waves and currents.

The sea is fast advancing at several points of the western coast of France, and unknown causes have given a new impulse to its ravages since the commencement of the present century. Between 1830 and 1812, the Point de Grave, on the north side of the Gironde, retreated one hundred and eighty mètres, or fifty feet, per year ; from the latter year to 1846 , the rate was increased to more than three times that quantity, and the loss in those four years was about six hundred feet. All the buildings at the extremity of the peninsula have been taken down and rebuilt farther landwards, and the lighthouse of the Grave now occupies its third position. The sea attacked the base of the peninsula also, and the Point de Grave and the adjacent coasts have been for thirty years the scene of one of the most obstinately contested struggles between man and the ocean recorded in the annals of modern engineering.

\section{Movement of Dunes.}

Besides their importance as a barrier against the inroads of the ocean, dunes are useful by sheltering the cultivated ground behind them from the violence of the sea-wind, from salt spray, and from the drifts of beach sand which would otherwise overwhelm them. But the dunes themselves, unless their surface sands are kept moist, and confined by the growth of plants, or at least by a crust of vegetable earth, are constantly rolling inwards, and thus, while, on one side, they lay bare the traces of ancient human habitations or other evidences of the social life of primitive man, they are, on the other, burying fields, houses, churches, and converting populous districts into barren and deserted wastes.

Especially destructive are they when, by any accident, a cavity 
is opened into them to a considerable depth, thereby giving the wind access to the interior, where the sand is thus first dried, and then scooped out and scattered far over the neighboring soil. The dune is now a magazine of sand, no longer a rampart acrainst it, and mischief from this source seems more difficult to resist than from almost any other drift, because the supply of material at the command of the wind is more abundant and more concentrated than in its original thin and widespread deposits on the beach. The burrowing of conies in the dunes is, in this way, not unfrequently a cause of their destruction and of great injury to the fields behind them. Drifts, and even inland sand-hills, sometimes result from breaking the surface of more level sand deposits, far within the range of the coast-dunes. Thus we learn from Staring, that one of the highest inland dunes in Friesland owes its origin to the opening of the drift sand by the uprooting of a large oak.*

Great as are the ravages produced by the encroachment of the sea upon the western shores of continental Europe, they have been in some degree compensated by spontaneous marine deposits at other points of the coast, and we have seen in a former chapter that the industry of man has reclaimed a large territory from the bosom of the ocean. These latter triumphs are not of recent origin, and the incipient victories which paved the way for them date back perhaps as far as ten centuries. In the meantime, the dunes had been left to the operation of the laws of nature, or rather freed by human imprudence from the fetters with which nature had bound them, and it is scarcely three generations since man first attempted to check their destructive movements. As they advanced, he unresistingly yielded and retreated before them, and they have buried under their sandy billows many hundreds of square miles of luxuriant corn-fields and vineyards and forests.

On the west coast of France a belt of dumes, varying in width from a quarter of a mile to five miles, extends from the Adour to the estuary of the Gironde, and covers an area of nine hundred and seventy square kilomètres, or two hundred and forty thousand acres. When not fixed by regetable growths, these dunes advance enstwards at a mean rate of about one rod, or six- 
teen and a half feet, a year. We do not know historically when they began to drift, but if we suppose their motion to have been always the same as at present, they would have passed over the space between the sea-coast and their present eastern border, and covered the large area above inentioned, in fourteen hundred years. We know, from written records, that they have buried extensive fields and forests and thriving villages, and changed the comrses of rivers, and that the lighter particles carried from them by the winds, even where not transported in sufficient quantities to form sand-hills, have rendered sterile much land formerly fertile.* They have also injuriously obstrueted the natural drainage of the maritime districts by choking up the beds of the streams, and forming lakes and pestilential swamps of no inconsiderable extent. In fact, so completely do they embank the coast, that between the Gironde and the village of Mimizan, a distance of one hundred miles, there are but two outlets for the discharge of all the waters which flow from the land to the sea; and the eastern front of the dunes is bordered by a succession of stagnant pools, some of which are more than six miles in length and breadth. $†$

* The movement of the dunes has been hardly less destructive on the north side of the Gironde. See the valuable articles of Élisée Reclos in the Re. vue des Deux Mondes for December, 1862, and several later numbers, entitled "Le Littoral de la Frrance."

+ Laval, Mémoire sur les Dunes du Golfe de Gascogne, Annales des Ponts et Chaussécs, 1847, p. 223. The author adds, as a curious and unexplained fact, that some of these pools, though evidently not original formations, but mere accumulations of water dammed up by the dunes, have, along their western shore, near the base of the sand-hills, a depth of more than one hun dred and thirty feet, and hence their bottoms are not less than eighty feet below the level of the lowest tides. Their western banks descend steeply, conforming nearly to the slope of the dunes, while on the northeast and south the inclination of their beds is very gradual. The grentest depth of these pools corresponds to that of the sea ten miles from the shore. Is it possible that the weight of the sands has pressed together the soil on which they rest, and thus occasioned a subsidence of the surface extending beyond their base ?

A more probable explanation of the fact stated in the note is suggested by Elisée Recsus, in an article entitled Le Littoral de la France, in the Reoue des Deus, Mondes for September 1, 1864, pp. 193, 194. This able writer believes such pools to be the remains of ancient maritime bays, which have been cut off from the ocean by gradually accumulated sand-banks raised by the waves. and winds to the character of dunes. 
A range of dunes extends along the whole western coast of Jutland and Schleswig-Holstein, and the movement of these sand-hills was formerly, and at some points still is, very destructive. The rate of eastward movement of the drifting dunes varies from three to twenty-four feet per annum. If we adopt the mean of thirteen feet and a half for the annual motion, these dunes have traversed the widest part of the belt in about twentyfive hundred years. Historical data are wanting as to the period of the formation of these dunes and of the commencement of their drifting; but there is recorded evidence that they have buried a vast extent of valuable land within three or four centuries, and further proof is found in the fact that the movement of the sands is constantly uncovering ruins of ancient buildings, and other evidences of human occupation, at points far within the present limits of the uninhabitable desert. Andresen estimates the average depth of the sand deposited over this area at thirty feet, which would give a cubic mile and a half for the total quantity.*

The drifting of the dunes on the coast of Prussia commenced not much more than a hundred years ago. The Frische Nehrung is separated from the mainland by the Frische Haff, and there is but a narrow strip of arable land along its eastern borders. Hence its rolling sands have covered a comparatively small extent of dry land, but fields and villages have been buried and valuable forests laid waste by them. The loose coast-row has drifted over the inland ranges, which, as was noticed in the description of these dunes on a former page, were protected by a surface of different composition, and the sand has thus been raised to a height which it could not have reached upon level ground. This elevation has enabled it to advance upon and overwhelm woods, which, upon a plain, would have checked its progress, and in one instance a forest of many hundred acres of tall pines was destroyed by the drifts between 1804 and 1827. $\dagger$

* ANdresen, Om Klitformationen, pp. 56, 79, 82.

† Stoprant, Corso di Geologia, i., ff. 154, says there are dunes 100 metres high. at the mouth of the —_, and they have advanced a mile in twenty years. 


\section{Control of Dunes by Man.}

There are three principal modes in which the industry of man is brought to bear upon the dunes. First, the creation of them at points where, from changes in the currents or other causes, new encroachments of the sea are threatened; second, the maintenance and protection of them where they have been naturally formed; and third, the removal of the inner rows where the belt is so broad that no danger is to be apprehended from the loss of them.

In describing the natural formation of dunes, it was said that they began with an accumulation of sand around some vegetable or other accidental obstruction to the drifting of the particles. A high, perpendicular cliff, which deadens the wind altogether, prevents all accumulation of sand; but, up to a certain point, the higher and broader the obstruction, the more sand will heap up in front of it, and the more will that which falls behind it be protected from drifting farther. This familiar observation has taught the inhabitants of the coast that an artificial wall or dike will, in many situations, give rise to a broad belt of dunes. Thus a sand-dike or wall, of three or four miles in length, thrown in 1610 across the Koegras, a tide-washed flat between the Zuiderzee and the North Sea, has occasioned the formation of rows of dunes a mile in breadth, and thus excluded the sea altogether from the Koegras. A similar dike, called the Zijperzeedijk, has produced another scarcely less extensive belt in the course of two centuries.

A few years since, the sea was threatening to cut through the island of Ameland, and, by encroachment on the southern side and the blowing off of the sand from a low flat which connected the two higher parts of the island, it had made such progress, that in heavy storms the waves sometimes rolled quite across the isthmus. The construction of a breakwater and a sand-dike have already checked the advance of the sea, and a large number of sandhills has been formed, the rapid growth of which promises complete future security against both wind and wave. Similar effects have been produced by the erection of plank fences, and even of simple screens of wattling and reeds.*

* Staring, De Bodem ran Nederland, i., pp. 329-331. Id., Voormaals en Thans, p. 163. ANDREsen, Om Klitformationen, pp. 280, 295.

The creation of new dunes, by the processes mentioned in the text, seems 
The dunes of Holland are sometimes protected from the dashing of the wares by a revêtement of stone, or by piles; and the lateral high-water currents, which wash away their base, are occasionally checked by transverse walls running from the foot of the dunes to low-water mark; but the great expense of such constructions has prevented their adoption on a large scale.* The principal means relied on for the protection of the sand-hills are the planting of their surfaces and the exclusion of burrowing and grazing animals. There are grasses, creeping plants and shrubs of spontaneous growth which flourish in loose sand, and, if protected, spread over considerable tracts, and finally convert their face into a soil capable of cultivation, or at least of producing forest trees. Krause enumerates one hundred and seventy-one plants as native to the coast sands of Prussia, and the observations of Andresen in Jutland carry the number of these vegetables up to two hundred and thirty-four.

Some of these plants, especially the Arundo arenaria or arenosa, or Psamma or Psammophita arenaria-Klittetag, or Hjelme in Danish, helm in Dutch, Dünenhalm, Sandschilf or Hügelrohr in German, gourbet in French, and marram in English-are exclusively confined to sandy soils, and thrive well only in a saline atmosphere. $\dagger$ The arundo grows to the height of about twenty-four inches, but sends its strong roots with their many rootlets to a distance of forty or fifty feet. It has the peculiar property of flourishing best in the loosest soil, and a sand-shower seems to refresh it as the rain revives the thirsty plants of the common earth. Its roots bind together the dunes,

to be much older in Europe than the adoption of measures for securing them by planting. Dr. Dwight mentions a case in Massachusetts where a beach was restored, and new dunes formed, by planting beach grass. "Within the memory of my informant, the sea broke over the beach which connects Truro with Province Town, and swept the body of it away for some distance. The beach grass was immediately planted on the spot; in consequence of which the beach was again raised to a sufficient height, and in various places into bills."一Travels, iii., p. 93.

* Starnig, i., pp. 310, 332.

+ There is some confusion in the popular use of these names, and in the scieutific designations of sand-plants, and they are possibly applied to different. plants in different places. Some writers style the gourbet Calamagrostis arenaria, and distinguish it from the Danish Klittetag or Hjelme. 
and its leaves protect their surface. When the sand ceases to drift, the arundo dies, its decaying roots fertilizing the sand, and the decomposition of its leaves forming a layer of vegetable earth over it. Then follows a succession of other plants which gradually fit the sand-hills, by growth and decay, for forest planting, for pasturage, and sometimes for ordinary agricultural use.

But the protection and gradual transformation of the dumes is not the only service rendered by this valuable plant. Its leaves are nutritious food for sheep and cattle, its seeds for poultry; * cordage and netting twine are manufactured from its fibres, it makes a good material for thatching, and its dried roots furnish excellent fuel. These useful qualities, unfortunately, are too often prejudicial to its growth. The peasants feed it down with their cattle, cut it for rope-making, or dig it up for fuel, and it has been found necessary to resort to severe legislation to prevent them from bringing ruin upon themselves by thus improvidently sacrificing their most effectual safeguard against the drifting of the sands. $†$

In 1539 a decree of Christian III., king of Denmark, imposed a fine upon persons convicted of destroying certain species of sand-plants upon the west coast of Jutland. This ordinance was renewed and made more comprehensive in 1558, and in 1569 the inhabitants of several districts were required, by royal rescript, to do their best to check the sand-drifts, though the specific measures to be adopted for that purpose are not indicated. Various laws against stripping the dunes of their vegetation were enacted in the following century, but no active measures were taken for the subjugation of the sand-drifts until 1779, when a preliminary system of operation for that purpose was adopted. This consisted in little more than the planting of the Arundo arenaria and other sand-plants, and the exclusion of animals destructive to these vegetables. $\neq$ Ten years later, plantations of

* Bread, not indeed very palatable, has been made of the seeds of the arundo, but the quantity which can be gathered is not sufficient to form an important economical resource.-ANDRESEN, Om Klitformationen, p. 160.

† BergsôE, Reventlovs Firksomhed, ii., p. 4.

$\ddagger$ Measures were taken for the protection of the dunes of Cape Cod, in Massachusetts, during the colonial period, though I believe they are now sub. 
forests trees, which have since proved so valuable a means of fixing the dunes and rendering them productive, were commenced, and have been continued erer since.* During this latter period, Brémontier, without any knowledge of what was doing in Denmark, experimented upon the cultivation of forest trees on the dunes of Gascony, and perfected a system, wheh, with some improvements in matters of detail, is still largely pursued on those shores. The example of Denmark was soon followed in the neighboring kinglom of Prussia, and in the Netherlands; aud, as we shall see hereafter, these improvements have been everywhere crowned with most flattering success.

Under the administration of Reventlov, a little before the close of the last century, the Danish Government organized a regular system of improvement in the economy of the dunes. They were planted with the arundo and other vegetables of similar habits, protected against trespassers, and at last partly covered with forest trees. By these means much waste soil has been converted into arable ground, a large growth of valuable timber obtained, and the further spread of the drifts, which threatened to lay waste the whole peninsula of Jutland, to a considerable extent arrested.

In France, the operations for fixing and reclaiming the duneswhich began under the direction of Brémontier about the same

stantially abandoned. A hundred years ago, before the valley of the Mississippi or even the rich plains of Central and Western New York were opened to the white settler, the value of land was relatively much greater in New England than it is at present, and consequently some rural improvements were then worth making, which would not now yield sufficient returns to tempt the investment of capital. The money and the time required to subdue and render productive twenty acres of sea-sand on Cape Cod, would buy a "section" and rear a family in Illinois. The son of the Pilgrim, therefore, abandons the sand-hills, and seeks a better fortune on the fertile prairies of the West. See Dwigrt, Travels, i, pp. 92, 93.

* Andresen, Om Klitformationen, pp. 237, 240. In the article Dune, in Professor Boccardo's valuable Dizionario dell' Economia Politica, it is said that Cassini adopted successful processes for checking the advance of the dunes at Boulogne sur Mer, and that his methods of plantation are still followed. According to Nutzhorn, Skov og Land, p. 7, a German named Röhl, employed by the Danish Government, introduced into Northern and Western Seeland methods analogous to those of Brémontier as early as 1730. 
time as in Deumark, and which are, in principle and in many of their details, similar to those employed in the latter kingdomlawe been conducted on a far larger scale, and with greater suc(es, than in any other country. This is partly owing to a climate more farorable to the growth of suitable forest trees than that of Northern Europe, and partly to the liberality of the Govermment, which, having more important landed interests to protect, has put linrger means at the disposal of the engineers than Denmark and Prussia have found it convenient to appropriate to that purpose. The area of the dunes already secured from drifting, and planted by the processes invented by Brémontier and perfected ly his successors, is about 100,000 acres.* This amount of productive soil, then, has been added to the resomrees of France, and a still greater quantity of valuable land has been thereby resened from the otherwise certain destruction with which it was threatened by the advance of the rolling sand-hills.

The improrements of the dunes on the coast of West Prussia began in 1795, under Sören Björen, a native of Denmark, and, with the exception of the ten years between 1807 and 1817, they have been prosecuted ever since. The methods do not differ essentially from those employed in Denmark and France, though they are modified by local circumstances, and, with respect to the trees selected for planting, by climate. In 1850, between the mouth of the Vistula and Kahlberg, 6,300 acres, including about 1,900 acres planted with pines and birches, had been secured from drifting; between Kahlberg and the eastern boundary of West Prussia, 8,000 acres; and important preliminary operations had been carried on for subduing the dunes on the west coast. $\dagger$

The tree which has been found to thrive best upon the sandhills of the French coast, and at the same time to confine the sand most firmly and yield the largest pecuniary returns, is the maritime pine, Pinus maritima, a species valuable both for its

* These plantations, perseveringly continued from the time of Brémontier, now cover more than 40,000 hectares, and compose forests which are not only the salvation of the department, but constitute its wealth."-Cravé, Etudes Forestieres, p. 254.

Other authors have stated the plantations of the French dunes to be much more extensive.

† KraUse, Dünenbau, pp. 34, 38, 40 . 
timber and for its resinous products. It is always grown from seed, and the young shoots require to be protected for several seasons, by the branches of other trees, planted in rows, or spread over the surface and staked down, by the growth of the Arundo arenaria and other small sand-plants, or by wattled hedges. The beach from which the sand is derived has been generally planted with the arundo, because the pine does not thrive well so near the sea; but it is thought that a species of tamarisk is likely to succeed in that latitude even better than the arindo. The shade and the protection offered by the branching top of the pine are favorable to the growth of deciduous trees, and, while still young, of shrubs and smaller plants which contribute more rapidly to the formation of vegetable mould; and thus, when the pine has once taken root, the redemption of the waste is considered as effectually secured.

In France, the maritime pine is planted on the sands of the interior as well as on the dunes of the sea-coast, and with equal advantage. This tree resembles the pitch-pine of the Southern American States in its habits, and is applied to the same uses. The extraction of turpentine from it begins at the age of about twenty years, or when it has attained a diameter of from nine to twelve inches. Incisions are made up and down the trunk, to the depth of about half an inch in the wood, and it is insisted that if not more than two such slits are cut, the tree is not sensibly injured by the process. The growth indeed is somewhat checked, but the wood becomes superior to that of trees from which the turpentine is not extracted. Thus treated, the pine continues to flourish to the age of one hundred or one hundred and twenty years, and up to this age the trees on an acre yield annually 300 pounds of essence of turpentine, and 250 pounds of resin, worth together not far from ten dollars. The expense of extraction and distillation is calculated at about four dollars, and a clear profit of more than five dollars per acre is left.* This

* These processes are substantially similar to those employed in the pineries of the Carolinas, but they are better systematized and more economically conducted in France. In the latter country, all the products of the pine, even to the cones, find a remunerating market, while, in America, the price of resin is so low, that in the fierce steamboat races on the great rivers, large quantities of it are thrown into the furnaces to increase the intensity of the fircs. 
is exclusive of the value of the timber, when finally cut, which of course amounts to a very considerable sum.

In Denmark, where the climate is much colder, hardier conifers, as well as the birch and other northern trees, are found to answer a better purpose than the maritime pine, and it is doubtful whether this tree would be able to resist the winter on the dunes of Massachusetts. Probably the pitch-pine of the Northern States, in conjunction with some of the American oaks, birches and poplars, and especially the robinia or locust, would prove very suitable to be employed on the sand-hills of Cape Cod and Long Island. The ailanthus, now coming into notice as a sand-loving tree, some species of tamarisk, and perhaps the $C u-$ pressus macrocarpa, alreaty found useful on the dunes in California, may prove valuable auxiliaries in resisting the encroachment of drifting sands, whether in America or in Europe, and the intermixing of different species would doubtless be attended with as valuable results in this as in other branches of forest economy.

It can not, indeed, be affirmed that human power is able to arrest altogether the incursions of the waves on sandy coasts, by planting. the beach and elothing the dunes with wood. On the contrary, both in Holland and on the French coast, it has been found necessary to protect the dunes themselves by piling and by piers and sea-walls of heavy masonary. But experience has amply shown that the processes referred to are entirely successful in preventing the movement of the dunes, and the drifting of their sands over cultivated lands behind them; and that, at the same time, the plantations very much retard the landward progress of the waters.*

In a carefully prepared article on the Southern pineries published in an American magazine-I think Harper's-a few years ago, it was stated that the resin from the turpentine distilleries was sometimes allowed to run to waste; and the writer, in one instance, observed a mass, thus rejected as rubbish, which was estimated to amount to two thousand barrels. Olmsted saw, near a distillery which had been in operation but a single year, a pool of resin estimated to contain three thousand barrels, which had been allowed to run off as waste.-A Journey in the seaboard Slave States, 1863, p. 345.

* See a very interesting article entitled "Le Littoral de la France," by Érisée Reclus, in the Revue des Deux Mondes for December, 1862, pp. 901, 936. 
Besides the special office of dune plantations already notical, these forests have the same general uses as other woods, and they hare sometimes formed, by their droppings, so thick a layer of regetable mould that the sand beneath has become sufficiently secured to allow the wood to be felled, and the surface to be ploughed and cultivated with ordinary field crops.

In some cases it has been found possible to confine and cultivate coast sand-hills, even without preliminary forestal plantation. Thus, in the vicinity of Cap Breton in France, a peculiar process is successfully employed, both for preventing the drifting of dunes, and for rendering the sands themselves immediately productive; but this method is applicable only in exceptional cases of farorable climate and exposure. It consists in planting vineyards upon the dunes, and protecting them by hedges of broom, Erica scoparia, so disposed as to form rectangles about thirty feet by forty. The vines planted in these enclosures thrive admirably, and the grapes produced by them are among the best grown in France. The dmes are so far from being an unfarorable soil for the vine, that fresh sea-sand is regularly employed as a fertilizer for it, alternating every other season with ordinary manure. The quantity of sand thus applied every second year, raises the surface of the vineyard about four or five inches. The vines are cut down every year to three or four shoots, and the raising of the soil rapidly covers the old stocks. As fast as buried, they send out new roots near the surface, and thus the vineyard is constantly renewed, and has always a youthful appearance, though it may have been already planted a couple of generations. This practice is ascertained to have been followed for two centuries, and is amoug the oldest well-authenticated attempts of man to resist and vanquish the dunes.*

The artificial removal of dunes no longer necessary as a protection, does not appear to have been practiced upon a large scale except in the Netherlands, where the numerous canals furnish an easy and economical means of transporting the sand, and where the construction and maintenance of sea and river dikes, and of causeways and other embankments and fillings, create a great demand for that material. Sand is also employed in Holland, in

* Bortel, Mfise en valeur des Terres pauvres, pp. 212, 218. 
large quantities, for improving the consistence of the tough clay bordering upon or underlying diluvial deposits, and for forming an artificial soil for the growth of certain garden and ornamental regetables. When the dunes are removed, the grround they covered is restored to the domain of industry; and the quantity of land recovered in the Netherlands by the removal of the barren sunds which encumbered it, amounts to hundreds and perhaps thousands of acres.

\section{Inland Dunes.}

Tast deposits of sand, both in the form of dunes and of plains, are found far in the interior of contineuts, in the Old World and in the New. The deserts of Gobi, of Arabia, and of $A$ frica have been rendered familiar by the narratives of travellers, but the sandy wildernesses of America, and even of Europe, have not yet been geuerally recognized as important elements in the geography of the regions where they oceur. There are immense wastes of drifting sands in Poland and other interior parts of Europe, in Peru, and in the less known regions of our own Western territory, where their extent is greater than that of all the coast-dunes together which have hitherto been described by European and American geographers.*

The inland sand-hills of both hemispheres are composed of substantially the same material, and aggregated by the action of the same natural forees as the dunes of the coast. There is therefore a general resemblance between them, but they appear, nevertheless, to be distinguished by certain differences which a more attentive study may perhaps enable geologists to recognize in the sandstone formed by them. $\dagger$ The sand of which they are com-

* On the Niobrara river alone, the dunes cover a surface of twenty thousand square miles.-HArDen, Report on Geological Survey of Wyoming, 1870, p. 108.

+ American observers do not agree in their descriptions of the form and character of the sand-grains which compose the interior dunes of the North American desert. C. C. Parry, geologist to the Mexican Boundary Commission, in describing the dunes near the station at a spring thirty-two miles west from the Rio Grande at El Paso, says : "The separate grains of the sand composing the sand-hills are seen under a lens to be angular, and not rounded, as would be the case in regular beach deposits."-U. S. Hexican Boundary Survey, Report of, vol. i., Geological Report of O. O. Parry, p. 10.

In the general description of the country traversed, same volume, p. 47 
posed comes in both principally from the bed of the sea being brought to the surface in one case by the action of the wind and the waves, in the other by geological upheaval. The sand of the coast-dunes is rendered, to a certain extent, cohesive by moisture and by the saline and other binding ingredients of sea-water, while long exposure to meteoric influences has in a great measure deprived the inland sands of these constituents, though there are not wanting examples of large accumulations of sand far from the sea and yet agglutinated by saline material. Hence, as might be expected, inland dunes, when not confined by a fixed nucleus, are generally more movable than those of the coast, and the form of such dunes is more or less modified by their want of consistence. Thus, the crescent or falciform shape is described by all observers as more constant and conspicuous in these sand-hills than in those of littoral origin; they tend less to unite in continuous ridges, and they rarely attain the height or other dimensions of the dunes of the seashore.

Meyer describes the sand-hills of the Peruvian desert as perfectly falciform in shape and from seven to fifteen feet high, the chord of their are measuring from twenty to seventy paces. The slope of the convex face is described as very small, that of the concave as high as $70^{\circ}$ or $80^{\circ}$, and their surfaces were rippled. No smaller dunes were observed, nor any in the process of formation. The concave side uniformly faced the northwest, execpt towards the centre of the desert, where, for a distance of one or two hundred paces, they gradually opened to the west, and then again gradually resumed the former position.

Colonel Emory says that on an "examination of the sand with a microscope of sufficient power," the grains are seen to be angular, not rounded by rolling in water.

On the other hand, Blake, in Geological Report, Pacific Railroad Rep., vol. v., p. 119 , observes that the grains of the dune sand, consisting of quartz, chalcedony, carnelian, agate, rose quartz, and probably chrysolite, were much rounded ; and on page 241, he says that many of the sand grains of the Colorado desert are perfect spheres.

On page 20 of a report in vol. ii. of the Pacific Railroad Report, by the same observer, it is said that an examination of dune sands brought from the Llano Estacado by Captain Pope, showed the grains to be "much rounded by attrition."

The sands described by Mr. Parry and Colonel Emory are not from the 
Tschudi observed, in the same desert, two species of dunes, fixed and morable, and he ascribes a falciform shape to the movable, a conical to the fixed dunes, or medanos. "The medanos," he obserres, "are hillock-like elevations of sand, some having a firm, others a loose base. The former [latter], which are always crescent-shaped, are from ten to twenty feet high, and have an acute crest. The inner side is perpendicular, and the outer or bow side forms an angle with a steep inclination downwards.* When driven by violent winds, the medanos pass rapidly over the plains. The smaller and lighter ones move quickly forward, before the larger; but the latter soon overtake and crush them, whilst they are themselves shivered by the collision. These medanos assume all sorts of extraordinary figures, and sometimes move along the plain in rows forming most intricate labyrinths. . . . A plain often appears to be covered with a row of medanos, and some days afterwards it is again restored to its level and uniform aspect. . . . .

"The medanos with immovable bases are formed on the blocks of rocks which are scattered about the plain. The sand is driven against them by the wind, and as soon as it reaches the top point, it descends on the other side until that is likewise covered; thus gradually arises a conical-formed hill. $\nmid$ Entire hillock chains with acnte crests are formed in a similar manner. . . . On their southern declivities are found vast masses of sand, drifted thither by the mid-day gales. The northern declivity, though not steeper than the southern, is only sparingly covered with sand. If a hillock chain somewhat distant from the sea extends in a line parallel with the Andes, namely, from S.S.E. to N.N.W., the western

same localities as those examined by Mr. Blake, and the difference in their character may be due to a difference of origin or of age.

In New Mexico, sixty miles south of Fort Stanton, there are inland dunes composed of finely granulated gypsum.-American Naturalist, Jan. 1871, p. 695 .

* The dunes of the plains between Bolshara and the Oxus are all horseshoe shaped, convex towards the north, from which the prevailing wind blows. On this side they are sloping, inside precipitous, and from fifteen to twenty feet aigh.-Bunnes, Journal in Bokhara, ii., pp. 1, 2.

t The sand-hills observed by Desor in the Algerian desert were fixed, changIng their form only on the surface as sand was blown to and from them.Sahara und Atlas, 1865, p. 21. 
declivity is almost entirely free of sand, as it is driven to the plain below by the southeast wind, which constantly alternates with the wind from the south." *

It is difficult to reconcile this description with that of Meyer, but if confidence is to be reposed in the accuracy of either observer, the formation of the sand-lills in question must be governed by very different laws from those which determine the structure of coast-dunes. Captain Gilliss, of the American navy, found the sand-hills of the Perurian desert to be in general crescent-shaped, as described by Neyer, and a similar structure is said to charncterize the inland dunes of the Llano Estacado and other plateaus of the North American desert, thuugh these latter are of greater height and other dimensions than those described by Meyer. There is no very obvious explanation of this difference in form between maritime and inland sand-hills, and the subject merits investigation. It is, however, probable that the great mobility of the flying dunes of the Peruvian desert is an effect of their dryness, no rain falling in that desert, and of the want of salt or other binding material to hold their particles together.

\section{Inland Sand-Plains.}

The inland sand-plains of Europe are either derived from the drifting of dunes or other beach sands, or cousists of diluvial deposits, or are ancient sea-beds uplifted by geological upheaval. As we have seen, when once the interior of a dune is laid open to the wind, its contents are soon scattered far and wide over the adjacent country, and the beach sands, no longer checked by the rampart which nature had constrained them to build against their own encroachments, are also carried to considerable distances from the coast. Few regions have suffered so much from this cause, in proportion to their extent, as the peninsula of Jutland. So long as the woods, with which nature had planted the Danish dunes, were spared, they seem to have been stationary, and we have no historical evidence of an earlier date than the sixteenth century, that they had become in any way injurious. From that period there are frequent notices of the invasions of cultivated grounds

* Travels in Peru, New York, 1848, chap. ix. 
by the sands; and excarations are constantly bringing to light prof of human habitation and of agrieultural industry, in former ages, on soils now buried beneath deep drifts from the dunes and beaches of the sea-coast.*

Extensive tracts of valuable plain-land, in the Netherlands and in France, have been covered in the same way with a layer of sand deep enough to render them infertile, and they cin be restored to cultivation only by processes analogous to those employed for fixing and improving the dunes. Diluvial sund-plains, also, have been rechaned by these methods in the Duehy of Anstria, between Vienna and the Semmering ridge, in Jutland, and in the great champaign country of Northern Germany, especially the Mark Bradenburg, where artificial forests can be propagated with ease, and where, consequently, this branch of inclustry has been pursued on a great scale, and with highly beneficial results, both as respects the supply of forest products and the preparation of the soil for agricultural use, as well as with much advantage to local climate.

As has been already observed, inland sands are generally looser, dryer and more inclined to drift, than those of the sea-coast, where the moist and saline atmospliere of the ocean keeps them always more or less humid and cohesive. The sands of the valley of the Lower Euphrates-themselves probably of submarine origin, and not derived from dunes-are advancing to the northwest with a rapidity which seems falunlous when compared with the slow movement of the sand-hills of Gascony and the Low German coasts. Loftus, speaking of Niliyya, an old Aral) tomn a few miles east of the ruins of Babylon, says that, "in 18 18 , the sand began to accumulate around it, and in six years the desert, within a ralius of six miles, was covered with little, undulating domes, while the ruins of the city were so buried that it is now impossible to trace their original form or extent." + Loftus considers this

* For details, consult Axdresex, Om I litformationen, pp. 2283, 236.

$\uparrow$ When the deposit is not very deep, and the adjacent land lying to the leeward of the prevailing winds is covered with water or otherwise worthless, the surface is sometimes freed from the drifts by repeated harrowings, which loosen the sand, so that the wind takes it up and transports it to grounds where accumulations of it are less injurious.

$\ddagger$ Travels and Researches in Chaldaa, chap. ix.

Dwight mentions (Traecls, vol. iii., p. 101) an instance of great mischiet from the depasturing of the beach grass which had been planted on a sand 
sand-flood as the "vanguard of those vast drifts which, advancing from the southeast, threaten eventually to overwhelm Babylon and Baghdad."

An observation of Layard, cited by Loftus, appears to me to furnish a possible explanation of this irruption. He "passed two or three places where the sand, issuing from the earth like water, is called 'Aioun-er-rummal,' sand springs." These "springs" are very probably merely the drifting of sand from the ancient subsoil, where the protecting crust of aquatic deposit and vegetable earth has been broken through, as in the case of the drift which arose from the upturning of an oak mentioned on a former page. When the valley of the Euphrates was regularly irrigated and cultivated, the underlying sands were bound by moisture, alluvial slime, and vegetation; but now that all improvement is neglected, and the surface, no longer watered, has become parched, powdery and naked, a mere accidental fissure in the superficial stratum may soon be enlarged to a wide opening, that will let in loose sand enough to overwhelm a province.

\section{The Landes of Gascony.}

The most remarkable sand-plain of France lies at the southwestern extremity of the empire, and is generally known as the Landes, or heaths, of Gascony. Clavé thus describes it: "Composed of pure sand, resting on an impermeable stratum called alios, the soil of the Landes was, for centuries, considered incapable of cultivation.* Parched in summer, drowned in winter,

plain in Cape Cod: "Here, about one thousand acres were entirely blown away to the depth, in many places, of ten feet. . . . Not a green thing was visible except the whortleberries, which tufted a few lonely hillocks rising to the height of the original surface and prevented by this defence from being blown away also. These, although they varied the prospect, added to the gloom by their strongly picturesque appearance, by marking exactly the original level of the plain, and by showing us in this manner the immensity of the mass which had been thus carried away by the wind. The beach grass had been planted here, and the ground had been formerly enclosed; but the gates had been left open, and the cattle had destroyed this invaluable plant."

* The alios, which from its color and consistence was supposed to be a ferruginous formation, appears from recent observations to contain little iron and to owe most of its peculiar properties to vegetable elements carried down into the soil by the percolation of rain-water. See Revue des Eaux et Forêts for 1870, p. 301 . 
it produced only ferns, rushes and heath, and scarcely furnished pasturage for a few half-starved flocks. To crown its miseries, this plain was continually threatened by the encroachments of the dunes. Vast ridges of sand, thrown up by the waves for a distance of more than fifty leagues along the coast, and continually renewed, were driven inland by the west wind, and, as they rolled over the plain, they buried the soil and the hamlets, overcame all resistance, and advanced with fearful regularity. The whole province seemed devoted to certain destruction, when Brémontier invented his method of fixing the dunes by plantations of the maritime pine." *

Although the Landes had been almost abandoned for ages, they show numerous traces of ancient cultivation and prosperity, and it is principally by means of the encroachments of the sands that they have become reduced to their present desolate condition. The destruction of the coast towns and harbors, which furnished markets for the products of the plains, the damming up of the rivers, and the obstruction of the smaller channels of natural drainage by the advance of the dunes, were no doubt very influential causes; and if we add the drifting of the sea-sand over the soil, we have at least a partial explanation of the decayed agriculture and diminished population of this great waste. When the dunes were once arrested, and the soil to the east of them was felt to be secure against invasion by them, experiments, in the way of agricultural improvement by drainage and plantation, were commenced, and they have been attended with such signal success, that the complete recovery of one of the dreariest and most extensive wastes in Europe may be considered as both a probable and a near event. $\uparrow$

* Etudes Forestieres, p. 250. See, also, Reouds, La Terre, 1., 105, 106.

† Lavergne, Economie Rurale de la France, p. 300, estimates the area of the Landes of Gascony at 700,000 hectares, or about 1,700,000 acres. The same author states (p. 301), that when the Moors were driven from Spain by the blind cupidity and brutal intolerance of the age, they demanded permission to establish themselves in this desert; but political and religious prejudices prevented the granting of this liberty. At this period the Moors were a far more cultivated people than their Christian persecutors, and they had carried many arts, that of agriculture especially, to a higher pitch than any other European nation. But France was not wise enough to accept what 
In the northern part of Belgium, and extending across the confines of Holland, is another very similar heath-plain, called the Campine. This is a vast sand-flat, interspersed with marshes and inland dunes, and, until recently, considered almost wholly incapable of cultivation. Enormous sums had been expended in reclaiming it by draining and other familiar agricultural processes, but without results at all proportional to the capital invested. In 1849, the unimproved portion of the Campine was estimated at little less than three humdred and fifty thousand acres. The cxample of France prompted experiments in the planting of trees, especially the maritime pine, upon this barren waste, and the results have now been such as to show that its sands may both be fixed and made productive, not only without loss, but with positive pecuniary advantage.*

There are still unsubdued sand wastes in many parts of interior Europe not familiarly known to tourists or even geographers. "Olknez and Schiewier in Poland," says Naumann, "lie in true sand deserts, and a boundless plain of sand stretches around Czenstockau, on which there grows neither tree nor shrub. In heavy winds, this plain resembles a rolling sea, and the sand-hills rise and disappear like the waves of the ocean. The heaps of waste from the Olkucz mines are covered with sand to the depth of four

Spain had cast out, and the Landes remained a waste for three centuries longer.

For a brilliant account of the improvement of the Landes, see Edmond About, Le Progrès, chap. vii.

The forest of Fontainebleau, which contains above 40,000 acres, is not a plain, but its soil is composed almost wholly of sand, interspersed with ledges of rock. The sand forms not less than ninety-eight per cent. of the earth, and, as it is almost without water, it would be a drifting desert but for the artificial propagation of forest trees upon it.

The Landes of Sologne and of Brenne are less known than those of Gascony, because they are not upon the old great lines of communication. They once composed a forest of $1,200,000$ acres, but by clearing the woods, have relapsed into their primitive condition of a barren sand waste. Active efforts are now in progress to reclaim them.

* Économie Rurale de la Belgique, par Emre de Lavelexe, Revue des Deux Mondes, Juin, 1861, pp. 617-644. The quantity of land annually reclaimed on the Campine is stated at about 4,000 acres. Canals for navigation and irrigation have been constructed through the Campine, and it is said that its barren sands, improved at an expense of one hundred dollars per acre, vield, from the second year, a return of twenty-five dollars to the acre. 
fathoms." * No attempts have yet been made to subdue the sands of Poland, but when peace and prosperity shall be restored to that unhappy country, there is no reasonable doubt that the measures, which have proved so successful on similar formations in Germany and near Odessa, may be employed with advantage in the Polish deserts. $†$

* Geognosic, ii., p. 1173.

+ "Sixtcen years ago," says an Odessa landholder, "I attempted to fix the sand of thesteppes, which covers the rocky ground to the depth of a foot, and forms moving hillocks with every change of wind. I tried acacias and pines in vain; nothing would grow in such a soil. At length I planted the varnish tree, or ailanthus, which succeeded completely in binding the sand." This result encouraged the proprietor to extend his plantations over both dunes and sand steppes, and in the course of sixteen years this rapidly growing tree had formed real forests. Other landholders have imitated his example with great advantage.-ReNrsch, Der Wald, pp. 44, 45. 


\section{CHAF'TER VI.}

\section{GREAT PROJECTS OF PHYSICAL CHANGE ACCOMIPLISHED OR PROPOSED BY MAN.}

Gutting of Isthmuses-Canal of Suez-Maritime Canals in Greece-Canals to Dead Sea-Canals to Libyan Desert-Maritime Canals in Europe-Cape Cod Canal-Changes in Caspian-Diversion of the Nile-Diversion of the Rhine-Improvements in North American Hydrography-Soil below Rock-Covering Rock with Earth-Desert Valleys-Effects of MiningDuponchel's Plans of Improvement-Action of Man on the WeatherResistance to Great Natural Forces-Incidental Effects of Human Action -Nothing small in Nature.

Is a former chapter I spoke of the influence of human action on the surface of the globe as immensely superior in degree to that exerted by brute animals, if not essentially different from it in kind. The eminent Italian geologist, Stoppani, goes further than I had ventured to do, and treats the action of man as a new physical element altogether sui generis. According to him, the existence of man constitutes a geological period which he designates as the anthropozoic era. "The creation of man," says he, "was the introduction of a new element into nature, of a force wholly unknown to earlier periods." "It is a new telluric force which in power and universality may be compared to the greater forces of the earth." * It has already been abundantly shown that, though the undesigned and unforeseen results of man's action on the geographical conditions of che earth have perhaps been hitherto greater and more revolutionary than the effects specially aimed at by him, yet there is scarcely any assignable limit to his present and prospective voluntary controlling power over terrestrial nature.

* Corso di Geologia, Milano, 1873, vol. ii., cap. xxxi., §1827 (584) 


\section{Cutting of Irarine Isthmuses.}

Besides the great enterprises of physical transformation of which I have already spoken, other works of internal improvement or change have been projected in ancient and modern times, the execution of which would produce considerable, and, in some cases, extremely important, revolutions in the face of the earth. Some of the schemes to which I refer are evidently chimerical; others are difficult indeed, but can not be said to be impracticable, though discouraged by the apprehension of disastrous consequences from the disturbance of existing natural or artificial arrangements; and there are still others, the accomplishment of which is ultimately certain, though for the present forbidden by economical considerations.

Nature sometimes mocks the cunning and the power of man by spontaneously performing, for his benefit, works which he shrinks from undertaking, and the execution of which by him she would resist with unconquerable obstinacy. A dangerous sand-bank, that all the enginery of the world could not dredge out in a generation, may be carried off in a night by a strong river-flood, or by a current impelled by a violent wind from an unusual quarter, and a passage searcely navigable by fishing-boats may be thus converted into a commodious channel for the largest ship that floats upon the ocean. In the remarkable gulf of Liimfjord in Jutland, referred to in the preceding chapter, nature has given a singular example of a canal which she alternately opens as a marine strait, and, by shutting again, converts into a freshwater lagoon. The Liimfjord was doubtless originally an open channel from the Atlantic to the Baltic between two islands, but the sand washed up by the sea blocked up the western entrance, and built a wall of dunes to close it more firmly. This natural dike, as we have seen, has been more than once broken through, and it is perhaps in the power of man, either permanently to maintain the barrier, or to remove it and keep a navigable channel constantly open. If the Liimfjord becomes an open strait, the washing of sea-sand through it would perhaps block some of the belts and small channels now important for the navigation of the Baltic, and the direct introduction of a tidal current 
might produce very perceptible effects on the hydrography of the Cattegat.

When we consider the number of narrow necks or isthmuses which separate gulfs and bays of the sea from each other or from the main ocean, and take into account the time and cost and risks of navigation which would be saved by executing channels to connect such waters, thus avoiding the necessity of doubling long capes and promontories, and even continents, it seems strange that more of the enterprise and money, which have been so lavishly expended in forming artificial rivers for internal navigation, should not have been bestowed upon the construction of maritime canals. Many such have been projected in early and in recent ages, and some trifling cuts between marine waters had been actually made; but before the construction of the Suez Canal, no work of this sort, possessing real geographical or even commersial importance, had been effected.

These enterprises are attended with difficulties and open to objections which are not, at first sight, obvious. Nature guards well the chains by which she connects promontories with mainlands, and binds continents together. Isthmuses are usually composed of adamantine rock or of shifting sands-the latter being: much the more refractory material to deal with. In all such works there is a necessity for deep excavation below low-water mark-always a matter of great difficulty; the dimensions of channels for sea-going ships must be much greater than those of canals of inland navigation; the height of the masts or smokepipes of that class of vessels would often render bridging impossible, and thus a ship-canal might obstruct a communication more important than that which it was intended to promote; the securing of the entrances of marine canals and the construction of ports at their termini would in general be difficult and expensive, and the harbors and the channel which connected them would be extremely liable to fill up by deposits washed in from sea and shore. Besides all this there is, in many cases, an alarming uncertainty as to the effects of joining together witers which nature has put asunder. A new channel may deflect strong currents from safe courses, and thus occasion destructive erosion of shores otherwise secure, or promote the transportation of sand or slime to block up important harbors, or it may furnish 
a powerful enemy with dangerous facilities for hostile operations along the coast.

The most colossal project of canalization ever suggested, whether we consider the physical difficulties of its execution, the magnitude and importance of the waters proposed to be united, or the distance which would be saved in navigation, is that of a channel between the Gulf of Mexico and the Pacific, across the Isthmus of Darien. I do not now speak of a lock-canal, by way of the Lake of Nicaragua or any other route-for such a work would not differ essentially from other canals, and would scarcely possess a geographical character-but of an open cut between the two seas. The survey by Captain Selfridge, giving the lowest point on the dividing ridge as several hundred feet above the sealevel, had been considered as determining in the negative the question of the possibility of such a cut, by any means now at the control of man; and both the sanguine expectations of benefits, and the dreary suggestions of danger, from the realization of this great dream, were dismissed as equally chimerical. Recent surveys, however, are said to have found a more practicable route across the Isthmus, and a company has been formed in France by Lesseps for the construction of an open ship-canal between the Atlantic and the Pacific at the common level of the two oceans. But the details of the plan have not yet been publicly subjected to professional criticism, and for the present the possibility of the execution of such a work must be regarded as problematical.

\section{Suez Canal.}

The cutting of the Isthmus of Suez-the grandest and most truly cosmopolite physical improvement ever undertaken by man-threatens none of these dangers, and its only immediate geographical effect will probably be that interchange between the aquatic animal and regetable life of two seas and two zones to which $I$ alluded in a former chapter.*

* According to an article by Ascherson, in Petermann's Mittheilungen, vol. xvii., p. 247, the sea-grass floras of the opposite sides of the Isthmus of Suez were as different as possible. It does not appear whether they have yet in. termixed. See Nature, May 11, 1882, for interesting observations of Kellez on the interchange of marine species now slowly taking place along the line of the Suez Canal, between the Mediterranean and Red Seas. 
A collateral feature of this great enterprise deserves notice as possessing no inconsiderable geographical importance. I refer to the conduit or conduits constructed from the Nile to the isthmus, primarily to supply fresh water to the laborers on the great canal, and ultimately to serve as aqueducts for the city of Suez and other towns on the line of the canal, and for the irrigation and reclamation of a large extent of desert soil. In the flourishing days of the Egyptian empire, the waters of the Nile were carried over important districts east of the river. In later ages most of this territory relapsed into a desert, from the decay of the canals which once fertilized it. There is no difficulty in restoring the ancient channels, or in constructing new, and thus watering, not only all the soil that the wisdom of the Pharaohs had improved, but much additional land. Hundreds of square miles of arid sand waste would thus be converted into fields of perennial verdure, and the geography of Lower Egypt would be thereby sensibly changed. Considerable towns are growing up at both ends of the chanuel and at intermediate points, all depending on the maintenance of aqueducts from the Nile, both for water and for the irrigation of the neighboring fields which are to supply them with bread. Important interests will thus be created, which will secure the permanence of the hydraulic works and of the geographical changes produced by them, and Suez, or Port Said, or Ismailich, may become the capital of the government which has been so long established at Cairo.

\section{Maritime Canals in Greece.}

A maritime canal executed and another projected in ancient times, the latter of which is again beginning to excite attention, deserve some notice, though their importance is of a commercial rather than a geographical character. The first of these is the cut made by Xerxes through the rock which connects the promontory of Mount Athos with the mainland; the other, a navigable canal through the Isthmus of Corinth. In spite of the testimony of Herodotus and Thucydides, the Romans classed the canal of Xerxes among the fables of "mendacious Greece," and yet traces of it are perfectly distinct at the present day through its whole extent, except at a single point where, after it had become so 
choked as to be no longer navigable, it was probably filled up to facilitate communication by land between the promontory and the country in the rear of it.

The emperor Nero commenced the construction of a canal across the Isthmus of Corinth, solely to facilitate the importation of grain from the East for distribution among the citizens of Rome -for the encouragement of general commerce was no part of the policy either of the republic or the empire, and though the avidity of traders, chiefly foreigners, secured to the luxury of the imperial city an abundant supply of far-fetched wares, yet Rome bad nothing to export in return. The line of Nero's excavations is still traceable for three-quarters of a mile, or more than a fifth of the total distance between gulf and gulf.

If the fancy kingdom of Greece shall ever become a sober reality, escape from its tutelage and acquire such a moral as well as political status that its own capitalists-who now prefer to establish themselves and employ their funds anywhere else rather than in their native land-have any confidence in the permanency of its institutions, a navigable channel may be opened between the gulfs of Lepanto and Egina. The annexation of the Ionian Istands to Greece will make such a work almost a political necessity, and it would not only furnish valuable facilities for domestic intercourse, but become an important channel of communication between the Levant and the countries bordering on the Adriatic, and of conducting their trade through that sea.

Short as is the distance, the work would be a somewhat formidable undertaking, for the lowest point of the summit ridge of the isthmus is stated to be 246 feet above the water, and consequently the depth of excavation must be not less than 275 feet.*

As I have said, the importance of this latter canal and of a navigable channel between Mount Athos and the continent would be chiefly commercial, but both of them would be conspicuous instances of the control of man over nature in a field where he has thus far done little to interfere with her spontaneous arrangements. If they were constructed upon such a scale as to admit

* Recent journals (MIay, 1882) announce the completion of arrangements for the construction of this canal, and work is stated to have actually commenced upon it. 
of the free passage of the water through them, in either direction, as the prevailing winds should impel it, they would exercise a certain influence on the coast currents, which are important as hydrographical elements, and also as producing abrasion of the coast and a drift at the bottom of seas, and hence they would be entitled to rank higher than simply as artificial means of transit.

It has been thought practicable to cut a canal across the peninsula of Gallipoli from the outlet of the Sea of Marmora into the Gulf of Saros. It may be doubted whether the mechanical difficulties of such a work would not be found insuperable; but when Constantinople shall recover the important political and commercial rank which naturally belongs to her, the execution of such a canal will be recommended by strong reasons of military expediency, as well as by the interests of trade. An open channel across the peninsula would divert a portion of the water which now flows through the Dardanelles, diminishing the rapidity of that powerful current, and thus in part remove the difficulties which obstruct the navigation of the strait. It would considerably abridge the distance by water between Constantinople and the northern coast of the Egean, and it would have the important advantage of obliging an enemy to maintain two blockading fleets instead of one.

\section{Canals communicating with Dead Sea.}

The project of Captain Allen for opening a new route to India by cuts between the Mediterranean and the Dead Sea, and between the Dead Sea and the Red Sea, presents many interesting considerations.* The hypsometrical observations of Bertou, Roth and others, render it highly probable, if not certain, that the watershed in the Wadi-el-Araba between the Dead Sea and the Red Sea is not less than three hundred feet above the mean level of the latter, and if this is so, the execution of a canal from the one sea to the other is quite out of the question. But the summit level between the Mediterranean and the Jordan, near Jezreel, is believed to be little, if at all, more than one hundred feet above the sea, and the distance is so short that the cutting of a channel through the dividing ridge would probably be found by no means

* The Dead Sea a new Route to India. 2 vols. 12mo, London, 1855. 
an impracticable undertaking. Although, therefore, we have nc reason to believe it possible to open a navigable channel to India by way of the Dead Sea, there is not much doubt that the basin of the latter might be made accessible from the Mediterranean.

The level of the Dead Sea lies 1,316.7 feet below that of the ocean. It is bounded east and west by mountain ridges, rising to the height of from 2,000 to 4,000 feet above the ocean. From its southern end, a depression called the Wadi-el-Araba extends to the Gulf of Akaba, the eastern arm of the Red Sea. The Jordan empties into the northern extremity of the Dead Sea, after having passed through the Lake of Tiberias at an elevation of 663.4 feet above the Dead Sea, or 653.3 below the Mediterranean, and drains a considerable valley north of the lake, as well as the plain of Jericho, which lies between the lake and the sea. If the waters of the Mediterranean were admitted freely into the basin of the Dead Sea, they would raise its surface to the general level of the ocean, and consequently flood all the dry land below that level within the basin.

I do not know that accurate levels have been taken in the valley of the Jordan above the Lake of Tiberias, and our information is very vague as to the hypsometry of the northern part of the Wadi-el-Araba. As little do we know where a contour line, carried around the basin of the Dead Sea, at the level of the Mediterranean, would strike its eastern and western borders. We can not, therefore, accurately compute the extent of now dry land which would be covered by the admission of the waters of the Mediterranean, or the area of the inland sea which would be thus created. Its length, however, would certainly exceed one hundred and fifty miles, and its mean breadth, including its gulfs and bays, could scarcely be less than fifteen, perhaps even twenty. It would cover very little ground now occupied by civilized or even uncivilized man, though some of the soil which would be submerged-for instance, that watered by the Fountain of Elisha and other neighboring sources-is of great fertility, and, under a wiser government and better civil institutions, might rise to importance, because, from its depression, it possesses a very warm climate, and might supply Southeastern Europe with tropical products more readily than they can be obtained from any other cource. Such a canal and sea would be of no present commerciai 
importance, because they would give access to no new markets or sources of supply; but when the fertile valleys and the deserted plains east of the Jordan shall be reclaimed to agriculture and civilization, these waters would furnish a channel of communication which might become the medium of a very extensive trade.

Whatever might be the economical results of the opening and filling of the Dead Sea basin, the creation of a new evaporable area, adding not less than 2,000 or perhaps 3,000 square miles to the present fluid surface of Syria, could not fail to produce important meteorological effects. The climate of Syria would probably be tempered, its precipitation and its fertility increased, the courses of its winds and the electrical condition of its atmosphere modified. The present organic life of the valley would be extinguished, and many tribes of plants and animals would emigrate from the Mediterranean to the new home which human art had prepared for them. It is possible, too, that the addition of 1,300 feet, or forty atmospheres, of lydrostatic pressure upon the bottom of the basin might disturb the equilibrium between the internal and the external forces acting on the crust of the earth at this point of abnormal configuration, and thus produce geological convulsions the intensity of which can not be even conjectured.

It is now established by the observations of Rohlf and others that Strabo was right in asserting that a considerable part of the Libyan desert, or Sahara, lay below the level of the Mediterranean. At some points the depression exceeds 325 feet, and at Siwah, in the oasis of Jupiter Ammon, it is not less than 130 feet. It has been proposed to cut a canal through the coast-dunes, on the shore south of the Syrtis Major, or Dschun el Kebrit of the Arabs, and another project* is to reopen the communication

* The project referred to in the text has been at least partially studied, has been entertained by the French Chambers, and has become a subject of much discussion. The most careful estimates $I$ have seen allow to the new internal sea a length of 350 kilometres, a width of 60 , and a depth of from 40 to 60 mètres. There has been much wild conjecture in regard both to the ameliorating effects of such an expanse of water on the climate of Northern Africa, and the injurious consequences to Europe of the large addition of moisture to the atmospheric currents, which it is argued might increase the rain and snow on the Alps to a very prejudicial extent. The possibility of the scheme is by no means yet established, and the doubt whether it would be practicable to keep open, through the sandy isthmus, a channel wide enough to furnish a 
which appears to have once existed between the Palus Tritonis, or Sebcha el Nandid, and the Syrtis Parva. As we do not know the southern or eastern limits of this depression, we can not determine the area which would thus be covered with water, but it would certainly be many thousands of square miles in extent, and the climatic effects would doubtless be sensible through a considerable part of Northern Africa, and possibly even in Europe. The rapid evaporation would require a constant influx of water from the current through the Straits of Gibraltar.

\section{Maritime Canals in Europe.}

A great navigable cut across the peninsula of Jutland, forming a new and short route between the North Sea and the Baltic, has been proposed, but will not probably be attempted. The motives for opening such a communication are perhaps rather to be found in political than in geographical or even commercial considerations, but it would not be without an important bearing on the material interests of all the countries to whose peoples it would furnish new facilities for communication and traffic.

The North Holland canal between the Helder and the port of Amsterdam, a distance of fifty miles, executed a few years since at a cost of $\$ 5,000,000$, and with dimensions admitting the passage of a frigate, was a magnificent enterprise, but it is thrown quite into the shade by the shorter channel lately constructed for bringing that important city into almost direct communication with the North Sea, and thus restoring to it something at least of

sufficient supply of water to counterbalance the evaporation, deserves consideration.

Since the above paragraph was written, this project, generally called the Rondaire scheme, from the name of one of its most distinguished advocates, has been examined at considerable length by Desor-La Forêt Vierge et Le Sahara, p. 131. It is now receiving the serious attention of the French Government. We run no risk in predicting that, if new surveys shall show it to be practicable, it will almost certainly be carried into effect. As a means of communicating with and controlling the unruly tribes of the desert its value can hardly be over-estimated, and as a harbor of refuge for the commercial marine of France, and, more especially, as a naval station and port of construction not less unassailable than Gibraltar itself, its importance is incalcular ble. It will indeed go far towards realizing the idea of the first Napoleon La Mediterranée est un lac français. 
its ancient commercial importance. The work involved some of the heaviest hydraulic operations yet undertaken, including the construction of an artificial harbor of great dams, locks, dikes, embankments, and the execution of draining-works and deep cuttings under circumstances of extreme difficulty. In the course of these labors many novel problems presented themselves for practical solution by the ingenuity of modern engineers, and the new inventions and processes thus necessitated are valuable contributions to our means of physical improvement.

\section{Cape Cod Canal.}

The opening of a navigable cut through the narrow neck which separates the southern part of Cape Cod Bay in Massachusetts from the Atlantic, was long ago suggested, and there are few coast improvements on the Atlantic shores of the United States which are recommended by higher considerations of utility. It would save the most important coasting trade of the United States the long and dangerous navigation around Cape Cod, afford a new and safer entrance to Boston harbor for vessels from Southern ports, secure a choice of passages, thus permitting arrivals upon the coast and departures from it at periods when wind and weather might otherwise prevent them, and furnish a most valuable internal communication in case of coast blockade by foreign power. The difficulties of the undertaking are no doubt formidable, but the expense of maintenance and the uncertainty of the effects of currents setting through the new strait are still more serious objections.*

* The opening of a channel across Cape Cod would have, though perhaps to a smaller extent, the same effects in interchanging the animal life of the southern and northern shores of the isthmus, as in the case of the Suez Canal ; for although the breadth of Cape Cod does not anywhere exceed twenty miles, and is in some places reduced to one, it appears from the official reports on the Natural History of Massachusetts, that the population of the opposite waters differs widely in species.

Not having the original documents at hand, I quote an extract from the $R$ port on the Invertebrate Animals of MFass., given by Thoreau, Excursions, p. 69: "The distribution of the marine shells is well worthy of notice as a geo. logical fact. Cape Cod, the right arm of the Commonwealth, reaches out into the ocean some fifty or sixty miles. It is nowhere many miles wide; but this narrow point of land has hitherto proved a barrier to the migration of many 


\section{Changes in the Caspian.}

The Russian Government has contemplated the establishment of a nearly direet water communication between the Caspian Sea and the Sea of Azoff, partly by natural and partly by artificial channels, and there are now navigable canals between the Don and the Volga; but these works, though not wanting in commercial and political interest, do not possess any geographical importance. It is, however, very possible to produce appreciable geographical changes in the basin of the Caspian by the diversion of the great rivers which flow from Central Russia. The surface of the Caspian is eighty-three feet below the level of the Sea of Azoff, and its depression has been explained upon the hypothesis that the evaporation exceeds the supply derived, directly and indirectly, from precipitation, though able physicists now maintain that the sinking of this sea is due to a subsidence of its bottom from geological causes. At Tsaritsin, the Don, which empties into the Sea of Azoff, and the Volga, which pours into the Caspian, approach each other within ten miles. Near this point, by means of open or subterranean canals, the Don might be turned into the Volga, or the Volga into the Don. If we suppose the whole or a large proportion of the waters of the Don to be thus

species of mollusca. Several genera and numerous species, which are separated by the intervention of only a few miles of land, are effectually prevented from mingling by the Cape, and do not pass from one side to the other. . . . . Of the one hundred and ninety-seven marine species, eighty-three do not pass to the south shore, and fifty are not found on the north shore of the Cape."

Probably the distribution of the species of mollusks is affected by unknown local conditions, and therefore an open canal across the Cape might not make every species that inhabits the waters on one side common to those of the other ; but there can be no doubt that there would be a considerable migration in both directions.

The fact stated in the repurt may suggest an important caution in drawing conclusions upon the relative age of formations from the character of their fossils. Had a geological movement or movements upheaved to different levels the bottoms of waters thus separated by a narrow isthmus, and dislocated the connection between those bottoms, naturalists, in after ages, reasoning from the character of the fossil faunas, might have assigned them to different, and perhaps very widely distant, periods.

I learn that since the above suggestions were made with regard to the cutting of a canal across Cape Cod, this important work has been actually begun, and is now (June, 1882,) far advanced towards completion. 
diverted from their natural outlet and sent down to the Caspian, the equilibrium between the evaporation from that sea and its supply of water might be restored, or its level even raised above its ancient limits. If the Volga were turned into the Sea of Azoff, the Caspian would be reduced in dimensions until the balance between loss and gain should be re-established, and it would occupy a much smaller area than at present. Such changes in the proportion of solid and fluid surface would have some climatic effects in the territory which drains into the Caspian, and on the other hand, the introduction of a greater quantity of fresh water into the Sea of Azoff would render that gulf less saline, affect the character and numbers of its fish, and perhaps be not wholly without sensible influence on the water of the Black Sea.*

Perhaps the most remarkable project of great physical change, proposed or threatened in earlier ages, is that of the diversion of the Nile from its natural channel, and the turning of its current into either the Libyan Desert or the Red Sea. The Ethiopian or Abyssinian princes more than once menaced the Memlouk sultans with the execution of this alarming project, and the fear of so serious an evil is said to have induced the Moslems to conciliate the Abyssinian kings by large presents, and by some concessions to the oppressed Christians of Egypt. Indeed, Arabian historians affirm that in the tenth century the Ethiopians dammed the river, and, for a whole year, cut off its waters from Egypt. $\nmid$

* Mr. Spalding, an eminent American engineer, has recently submitted to the Russian Government a detailed plan for opening a navigable canal, by a new route, between the Black Sea and the Caspian. It is proposed that this canal should be deep enough for vessels of any draught, and wide enough for vessels of any width to pass each other in safety, and it is supposed that, owing to the difference in level between these two seas, the area of the Caspian would be extended by nearly one-half. This, it is suggested, would increase the rainfall in that region which now suffers so much from drought, would tend to mitigate the severity of the winters, and eventually restore to fertility vast tracts already relapsed or fast relapsing into barren deserts. The facilities which such a "New MIediterranean" would offer to commerce are too evident to require exposition, but the material difficulties of such a work seem almost too great to be overcome even in imagination.

$\nmid$ "Some haue writte, that by certain kings inhabiting aboue, the Nilus should there be stopped; \& at a time prefixt, let loose vpon a certaine tribute payd them by the Aegyptians. The error springing perhaps frō a truth (as all wandring reports for the most part doe) in that the Sultan doth pay a 
The prohable explanation of this story is to be found in a season of extreme drough., such as have sometimes occurred in the valley of the Nile.

The Libyan Desert, above the junction of the two principal branches of the Nile at Khartoum, is so much higher than the level of the river below that point, that there is no reason to beliove a new channel for the united waters of the two streans could be found in that direction; but the Bahr-el-Abiad flows through, if it does not rise in, a great table-land, and some of its tributaries are supposed to communicate in the rainy season with branches of great rivers flowing in quite another direction. Hence it is probable that a portion at least of the waters of this great arm of the Nile-and perhaps a quantity the abstraction of which would be sensibly felt in Egypt-might be sent to the Atlantic by the Congo or Niger, lost in inland lakes and' marshes in Central Africa, or employed to fertilize the Libyan sandwastes.

About the beginning of the sixteenth century, Albuquerque the "Terrible" revived the scheme of turning the Nile into the Red Sea, with the hope of destroying the transit trade through Egypt by way of Kosseir. In 1525 the King of Portugal was requested by the Emperor of Abyssinia to send him engineers for that purpose; a successor of that prince threatened to attempt the project about the year 1700, and even as late as the French occupation of Egypt, the possibility of driving out the intruder by this means was suggested in England.

It can not be positively affirmed that the diversion of the waters of the Nile to the Red Sea is impossible. In the chain of mountains which separates the two valleys, Brown found a deep depression or wadi, extending from the one to the other, apparently at no great elevation above the bed of the river, but the height of the summit level was not measured.

Admitting the possibility of turning the whole river into the Red Sea, let us consider the probable effect of the change. First and most obvious is the total destruction of the fertility of Mid-

certaine annuall summe to the Abissin Emperour for not diuerting the course of the Riuer which (they say) he may, or impouerish it at the least."-Georas Sandrs, A Relation of a Journey, etc., p. 98. See, also, Vansleb, Voyage en. Egypte, p. 61. 
dle and Lower Egypt, the conversion of that part of the valley into a desert, and the extinction of its imperfect civilization, if not the absolute extirpation of its inhabitants. This is the calamity threatened by the Abyssinian princes and the ferocious Portuguese warrior, and feared by the Sultans of Egypt. Beyond these immediate and palpable consequences neither party then looked; but a far wider geographical area, and far more extensive and various human interests, would be affected by the measure. The spread of the Nile during the annual inundation covers, for many weeks, several thousand square miles with water, and at other seasons of the year pervades the same and even a larger area with moisture by infiltration. The abstraction of so large an eraporating surface from the southern shores of the Mediterranean could not but produce important effects on many meteorological phenomena, and the humidity, the temperature, the electrical condition and the atmospheric currents of Northeastern Africa might be modified to a degree that would sensibly affect the climate of Europe.

The Mediterranean, deprived of the contributions of the Nile, would require a larger supply, and of course a stronger current, of water from the Atlantic through the Straits of Gibraltar; the proportion of salt it contains would be increased, and the animal life of at least its southern borders would be consequently modified; the current which winds along its southern, eastern and northeastern shores would be diminished in force and volume, if not destroyed altogether, and its basin and its harbors would be shoaled by no new deposits from the highlands of inner Africa.

In the much smaller Red Sea, more immediately perceptible, if not greater, effects would be produced. The deposits of slime would reduce its depth, and perhaps, in the course of ages, divide it into a northern inland and a southern open sea, the former of which, receiving no supply from rivers, would, as in the case of the northern part of the Gulf of California, soon be dried up by evaporation, and its whole area added to the Africo-Arabian desert; the waters of the latter would be more or less freshened, and their immensely rich marine fauna and flora changed in character and proportion, and, near the mouth of the river, perhaps even destroyed altogether; its navigable channels would be 
altered in position and often quite obstructed; the flow of its tides would be modified by the new geographical conditions; the sediment of the river would form new coast-lines and lowlands, which would be covered with vegetation, and probably thereby produce sensible climatic changes.

\section{Diversion of the Rhine.}

The interference of physical improvements with vested rights and ancient arrangements, is a more formidable obstacle in old countries than in new, to enterprises involving anything approaching to a geographical revolution. Hence such projects meet with stronger opposition in Europe than in America, and the number of probable changes in the face of nature in the former continent is proportionally less. I have noticed some important hydraulic improvements as already executed or in progress in Europe, and I may refer to some others as contemplated or suggested. One of these is the diversion of the Rhine from its present channel below Ragatz, by a cut through the narrow ridge near Sargans, and the consequent turning of its current into the Lake of Wallenstadt. . This would be an extremely easy undertaking, for the ridge is but twenty feet above the level of the Rhine, and hardly two hundred yards wide at its crest. There is no present adequate motive for this diversion, but it is easy to suppose that it may become advisable within no long period. The navigation of the Lake of Constance is rapidly increasing in importance, and the shoaling of the eastern end of that lake by the deposits of the Rhine may require a remedy which can be found by no other so ready means as the discharge of that river into the Lake of Wallenstadt. The navigation of this latter lake is not important, nor is it ever likely to become so, because the rocky and precipitous character of its shores renders their cultivation impossible. It is of great depth, and its basin is capacious enough to receive and retain all the sediment which the Rhine would carry into it for thousands of years.*

* Many geographers suppose that the dividing ridge between the Lake of Wallenstadt and the bed of the Rhine at Sargans is a fluviatile deposit, which has closed a channel through which the Rhine anciently discharged a part or the whole of its waters into the lake. In the flood of 1868 , the water of the 


\section{Improvements in North American Hydrography.}

We are not yet well enough acquainted with the geography of Central Africa, or of the interior of South America, to conjecture what hydrographical revolutions might there be wrought; but from the fact that many important rivers in both continents drain extensive table-lands of moderate elevation and inclination, there is reason to suppose that important changes in the course of those rivers might be accomplished. Our knowledge of the drainage of North America is much more complete, and it is certain that there are numerous points within our territory where the courses of great rivers, or the discharge of considerable lakes, might be completely diverted, or at least partially directed into different channels.

The surface of Lake Erie is 565 feet above that of the Hudson at Albany, and it is so near the level of the great plain lying east of it, that it was found practicable to supply the western section of the canal, which unites it with the Hudson, with water from the lake, or rather from the Niagara which flows out of it. The greatest depth of water yet sounded in Lake Erie is but two hundred and seventy feet, the mean depth one hundred and twenty. Open canals parallel with the Niagara, or directly towards the Genesee, might be executed upon a scale which wonld exercise an important influence on the drainage of the lake, if there were any adequate motive for such an undertaking. Still easier would it be to enlarge the outlet for the waters of Lake Superior at the Sault St. Mary-where the river which drains the lake descends twenty-two feet in a single mile-and thus to produce incalculable effects, both upon that lake and upon the great chain of inland waters which communicate with it.

The summit level between the surface of Lake Michigan at its mean height and that of the river Des Plaines, a tributary of the Illinois, at a point some ten miles west of Chicago, is but ten and a half feet above the lake. The lake once discharged a part or the whole of its waters into the valley of the Des Plaines. A

Rhine rose to the level of the railway station at Sargans, and for some days there was fear of the giving way of the barrier and the diversion of the current of the river into the lake. 
slight upheaval, at an unknown period, elevated the bed of tho Des Plaines and the prairie between it and the lake, to their present level, and the ontflow of the lake was turned into a new direction. The bed of the Des Plaines is higher than the surface of the lake, and in recent times the Des Plaines, when at flood, has sent more or less of its waters across the ridge into the bed of the South Branch of Chicago River, and so into Lake Michigan.

A navigalsle chammel has now been cut, admitting a constant flow of water from the lake, by the valley of the Des Plaines, into the Illinois. The mean discharge by this channel does not much exceed 23,000 cubic feet per minute, but it would be quite practicable to enlarge its cross-section indefinitely, and the flow through it might be so regulated as to keep the Illinois and the Jississippi at flood at all seasons of the year. The increase in the rolume of these rivers would augment their velocity and their transporting power, and, consequently, the erosion of their banks and the deposit of slime in the Gulf of Mexico, while the opening of a communication between the lake and the affluents of the Mississippi, unobstructed except by locks, and the introduction of a large body of colder water into the latter would very probably produce a considerable effect on the animal life that peoples them. The diversion of water from the common basin of the great lakes through a new channel, in a direction opposite to their present discharge, would not be absolutely without influence on the St. Lawrence, though probably this effect might be too small to be readily perceptible.*

* From Reports of the Canal Commissioners of the State of Illinois, and especially from a very interesting private letter from William Gooding, Esq., an eminent engineer, (which I regret I have not space to print in full), I learn that the length of the present canal, from the lake to the River Illinois, is 101 miles, with a total descent of a trifle more than 145 feet, and that it is proposed to enlarge this channel to the width of one hundred and sixty feet, with a minimum depth of seven, and to create a slack-water navigation in the Illinois by the construction of five dams, one of which is already completed. The descent from the outlet of the canal at La Salle on the Illinois to the Mississippi is twenty-eight feet, the distance being 230 miles. The canal thus enlarged would cost about $\$ 16,000,000$, and it would establish a navigation for vessels of 1,200 to 1,500 tons burden between Lake Michigan and the Mis. sissippi, and consequently, by means of the great lakes and the Welland Canal, between the St. Lawrence and the Gulf of Mexico. 
In an able and interesting article in a California magazine, Dr. Widney has suggested a probable cause and a possible remedy for the desiccation of Southeastern California referred to in a former chapter. The Colorado Desert, which lies considerably below the level of the waters of the Gulf of California, and has an area of about 4,000 square miles, evidently once formed a part of that gulf. This northern extension of the gulf appears to have been cut off from the main body by deposits brought down by the great river Colorado, at no very distant period. These deposits at the same time turned the course of the river to the south, and it now enters the gulf at a point twenty miles distant from its original outlet.

When this northern arm of the gulf was cut off from the sea, and the river which once discharged itself into it was diverted, it was speedily laid dry by evaporation, and now yields no vapor to be condensed into fog, rain and snow on the neighboring mountains, which are now parched and almost bare of vegetation.

The ancient bed of the river may still be traced, and in floods the Colorado still sends a part of its overflowing supply into its old channel, and for a time waters a portion of the desert. It is believed that the river might easily be turned back into its original course, and indeed nature herself seems to be now tending, by various spontaneous processes, to accomplish that object. The waters of the Colorado, though perhaps not sufficient to fill the basin and keep it at the sea-level in spite of the rapid evaporation in that climate, * would at least create a permanent lake in the lower part of the depression, the evaporation from which, Dr. Widney suggests, might sensibly increase the humidity and lower the temperature of an extensive region which is now an arid and desolate wilderness.

\section{Soil below Rock.}

One of the most singular changes of natural surface effected by man is that observed by Beechey and by Barth at Lîn, Tefla, and near Gebel Genûnes, in the district of Ben Gâsi, in Northern Africa. In this region the superficial stratum originally con

* The thermometer sometimes rises to $120^{\circ}$ F. at Fort Yuma, at the S.E. angle of California in N. L. $33^{\circ}$. 
sisted of a thin sheet of rock covering a layer of fertile earth. This rock has been broken up, and, when not practicable to find use for it in fences, fortresses or dwellings, heaped together in high piles, and the soil, thus bared of its stony shell, has been employed for agricultural purposes.* If we remember that gunpowder was unknown at the period when these remarkable improvements were executed, and of course that the rock could have been broken only with the chisel and wedge, we must infer that land had at that time a very great pecuniary value, and of course that the province, though now exhausted and almost entirely deserted by man, had once a dense population. The monks at the Abbey of Tre Fontane, near Rome, now gain ground for agricultural production by blasting the thin layer of tufaceous rock lying near the surface and beneath which they find a fertile soil.

\section{Covering Rock with Earth.}

If man has, in some cases, broken up rock to reach productive ground beneath, he has, in many other instances, covered bare ledges, and sometimes extensive surfaces of solid stone, with fruitful earth brought from no inconsiderable distance. Not to speak of the Campo Santo at Pisa, filled, or at least coated, with earth from the Holy Land, for quite a different purpose, it is affirmed that the garden of the monastery of St. Catherine at Mount Sinai is composed of Nile mud, transported on the backs of camels from the banks of that river. Parthey and older authors state that all the productive soil of the Island of Malta was brought over from Sicily. $t$ The accuracy of the information may be questioned in both cases, but similar practices, on a smaller scale, are matter of daily observation in many parts of Southern Europe. Much of the wine of the Moselle is derived from grapes grown on earth carried high up the cliffs on the shoulders of men, and the steep terraced slopes of the Island of Teneriffe are

* Barth, Wanderungen durch die Kusten des Mittelmeeres, i., p. 353 . In a note on page 380 , of the same volume, Barth cites Strabo as asserting that $\mathbf{8}$ similar practice prevailed in Iapygia; but the epithet $\tau \rho a \chi \varepsilon i a$, applied by Strabo to the original surface, does not necessarily imply that it was covered with a continuous stratum of rock.

f Parther, Wanderungen durch Sicilien und die Levante, i., p. 404. 
covered with soil painfully scooped out from fissures in and botween the rocks which have been laid bare by the destruction of the native forests.* In China, too, rock has been artificially covered with earth to an extent which gives such operations a real geographical importance, and the accounts of the importation of earth at Malta, and the fertilization of the rocks on Mount Sinai with slime from the Nile, may be not wholly without foundation.

\section{Valleys in Deserts.}

In the latter case, indeed, river sediment might be very useful as a manure, but it could hardly be needed as a soil; for the growth of regetation in the wadies of the Sinaitic Peninsula shows that the disintegrated rock of its mountains requires only water to stimulate it to considerable productiveness. The wadies not unfrequently present narrow gorges which might easily be closed, and thus accumulations of earth, and reservoirs of water to irrigate it, might be formed which would convert many a square mile of desert into flourishing date-gardens and corn-fields. For example, not far from Wadi Feiran, on the most direct route to Wadi Esh-Sheikh, is a very narrow pass called by the Arabs El Bueb (El Bab) or, The Gate, which might be securely closed to a very considerable height, with little labor or expense. A bove this pass is a wide and nearly level expanse, filled up to a certain regular level with deposits brought down by torrents before the Gate, or Bueb, was broken through, and they have now worn down a channel in the deposits to the bed of the wadi. If a dam were constructed at the pass, and reservoirs built to retain the winter rains, a great extent of valley might be rendered cultivable.

\section{Effects of Mining.}

The excavations made by man, for mining and other purposes, may occasion disturbance of the surface by the subsidence of the strata above them, as in the case of the mine of Fablun, in Sweden, but such accidents have generally been too inconsiderable in

* Maftegazza, Rio de la Plata, e Teneriffa, p. 567. 
extent to deserve notice in a geographical point of view.* It is saic, however, that in many places in the mining regions of England alarming indications of a tendency to a wide dislocation of the superficial strata have manifested themselves. Indeed, when we consider the measure of the underground cavities which miners have excarated, we can not but be surprised that grave catastrophes have not often resulted from the removal of the foundations on which the crust of our earth is laid. $\dagger$ The 100,000,000 tons of cual yearly extracted from British mines require the withdrawal of subterranean strata equal to an area of 20,000 acres one yard deep, or 2,000 acres ten yards deep. $\neq$ These excarations have gone on for several years at this rate, and in smaller proportions for centuries. Hence, it can not be doubted that by these and other like operations the earth has been undermined and honeycombed in many countries to an extent that may well excite serious apprehensions as to the stability of the surface.§ In any event

* In March, 18\%3, the imprudent extension of the excavations in a slate mine near MIorzine, in Savoy, occasioned the fall of a mass of rock measuring more than 700,000 yards in cubical contents. A forest of firs was destroyed, and a hamlet of twelve houses crushed and buried by the slide.

† The public journals in mining districts on both sides the Atlantic have, within the last few years, contained frequent notices of extensive subsidences in consequence of the removal of acres of coal from underlying veins. Several casis are recorded as having occurred in Pennsylvania and in Belgium, in which latter locality injurious effects have been augmented by injudiciously depositing above the cavities huge heaps of stones and other waste from the mines. Alineral springs, too, bring to the surface vast quantities of common and other salts dissolved by the subterraneous flowing of the waters; and, of course, thus produce cavities in the earth. Tschihacheff describes a saline spring in Asia Minor, which throws out a current of brine a foot in cross section, no attempt being made to utilize the salt. Several English towns in the neighborhood of salt mines seem exposed to danger of serious injury from the removal of subterraneous strata by running water. Many persons have supposed that the earthquake in Ischia, in 1881, which destroyed Casa Hieciola, was occasioned by the action of mineral springs in washing out the deposits on which the superficial strata rested.

$\ddagger$ See page 392 , ante.

$\S$ It is now thought highly probable that extensive coal beds underlie the city of London at accessible depths, and it is proposed to attempt to raise from those beds the supply for the British Capital, but the risk of undermining a town with such a vast population will probably be considered too great to bo incurred at present. 
such excavations may interfere materially with the course of subterranean waters, and it has even been conjectured that the removal of large bodies of metallic ore from their original deposits might, at least locally, affect in a sensible degree the magnetic and electrical condition of the earth's crust.*

\section{Hydrautic Mining.}

What is called hydraulic mining-a system substantially identical with that described in an interesting way by Pliny the elder, in Book XXXV. of his Natural History, as practiced in his time in the gold mines of Spain $†$-is producing important geographical effects in California. Artificially directed currents of water have been long employed for washing down and removing masses of earth, but in the Californian mining the process is resorted to on a vastly greater scale than in any other modern engineering operations, and with results proportioned to the means. Brooks of considerable volume are diverted from their natural channels and conducted to great distances in canals or wooden aqueducts, $\neq$ and then directed against hills and large level surfaces of ground

* The exhaustion of the more accessible deposits of coal and other minerals has compelled the miners in Belgium, England and other countries, to carry their operations to great depths below the surface. At the colliery Des Viviers, at Cilly near Charleroi, in Belgium, coal is worked at the depth of 2,820 feet, and one pit has been sunk to the depth of 3,411 feet. It is supposed that the internal heat of the earth will render mining impossible below 4,000 feet. At Clifford Amalgamated Mines, in Cornwall, the temperature at 1,590 feet stood at $100^{\circ}$, but after the shaft had remained a year open it fell to $83^{\circ}$. In another Cornish mine men work at from $110^{\circ}$ to $120^{\circ}$, but only twenty minutes at a time, and with cold water thrown frequently over them. $-T$ the Last Thirty Years in Mining Districts, p. 95.

Stoppani mentions an abandoned mine at Huttenberg, in Bohemia, of the depth of 3,775 feet.-Corso di Geologia, i., p. 258.

f I have little doubt that the hydraulic mining in Gaul, alluded to by Diodorus Siculus, Bibliotheca Historica, v. 27, as merely a mode of utilizing the effects of water flowing in its natural channels, was really the artificial method described by Pliny.

$\ddagger$ In 1867 there were 6,000 miles (including branches) of artificial watercourses employed for mining purposes in California. The flumes of these canals are often of sheet-iron, and in some places are carried considerable distances at a height of 250 feet above the ground.-RAYMond, Mineral Statistics voest of the Rocky Mountains, 1870, p. 476. 
which it is necessary to remove to reach the gold-bearing strata, or which themselves contain deposits of the precious mineral.* Naked hills and fertile soils are alike washed away by the artificial torrent, and the material removed - vegetable mould, sand, gravel, pebbles and gold-dust-is carried down by the current and often spread over ground lying quite out of the reach of natural inundations, and burying it to the depth sometimes of twenty-five feet. $\mathrm{An}$ orchard valued at $\$ 60,000$, and another estimated at not less than $\$ 200,000$, are stated to have been thus sacrificed, and a report from the Agricultural Bureau at Washington computes the annual damage done by this mode of mining at the incredible sum of $\$ 12,000,000$.

Accidental fires in mines of coal or lignite sometimes lead to consequences not only destructive to large quantities of valuable material, but which may, directly or indirectly, produce results important in geography. The coal is occasionally ignited by the miners' lights or other fires used by them, and certain kinds of this mineral, if long exposed to air in deserted galleries, may be spontaneously kindled. Under favorable circumstances, a stratum of coal will burn until it is exhausted, and a cavity may be burnt out in a few months which human labor could not excavate in many years. Wittwer informs us that a coal mine at St. Etienne in Dauphiny has been burning ever since the fourteenth century, and that a mine near Duttweiler, another near Epterode, and a third at Zwickau, have been on fire for two hundred years. Such conflagrations not only produce cavities in the earth, but communicate a perceptible degree of heat to the surface, and the author just quoted cites cases where this heat has been advantageously employed in forcing vegetation.

\section{Projects of Agricultural Improvements by Duponchel.}

Duponchel's schemes of agricultural improvement are so grandiose in their nature, so vast in their sphere of operation,

* The water is sometimes driven through iron tubes under a hydrostatic pressure of several hundred feet, with a force which cuts away rock of considerable solidity almost as easily as hard earth. In this way of using water, the cutting force might, doubtless, be greatly augmented by introducing sand or gravel into the current. 
and so important in their possible effects upon immense tracts of the earth's surface, that they must be considered as projects of geographical revolution, and they therefore merit more than a passing notice. In a memoir already quoted, and in a later work, * this engineer proposes to construct artificial torrents for the purpose of grinding up calcareous rock, by rolling and attrition along their beds, and thus reducing it into a fine slime; and at the same time these torrents are to transport an argillaceous deposit which is to be mingled with the calcareous slime, and distributed over the Landes by watercourses constructed for the purpose. By this means he supposes that a very fertile soil may be formed, and so graded in depositing as to secure for it a good drainage.

In order that nothing may be wanting to recommend the project, Duponchel suggests that, as some rivers of Western France are gold-bearing, it is probable that gold enough may be collected by washing the sands to defray in part the expense of such operations.

In the Landes of Gascony alone, he believes that 3,000,000 acres, now barren, might be made productive at a moderate expense, and that similar methods might be advantageously employed in France over an extent of not less than 30,000,000 acres now almost wholly valueless.

The successful execution of the plan would increase the fertile territory of France by an area of four or five times the extent of Sicily or of Sardinia.

There seems to be no reason why the same method, applied for such different purposes, should necessarily be destructive in the one case while it is so advantageous in the other. A wiser economy might bring about a harmony of action between the miners and the agriculturists of California, and the soil which is removed by the former as an incumbrance, judiciously deposited, might become for the latter a source of wealth more solid and enduring than the gold now obtained by such a sacrifice of agricultural interests.

\section{Action of Man on the Weather}

Espy's well-known suggestion of the possibility of causing rain artificially, by kindling great fires, is not likely to be turned to

* Traité d'Hydraulique et de Géologie Agricoles, 1868. 
practical account, but the speculations of this able meteorologist are not, for that reason, to be rejected as worthless. His labors exhibit great industry in the collection of facts, much ingenuity in dealing with them, remarkable insight into the laws of nature, and a ready perception of analogies and relations not obvious to minds less philosophically constituted. They have unquestionably contributed essentially to the advancement of meteorological science.

The possibility that the distribution and action of electricity may be considerably modified by long lines of iron railways and telegraph wires, is a kindred thought, and in fact rests much on the same foundation as the belief in the utility of lightning-rods, but such influence is too obscure and too uncertain to have been yet demonstrated, though many intelligent observers believe that sensible meteorological effects have been produced by it.

It is affirmed that battles and heavy cannonades are generally followed by rain and thunder-storms, and Powers has collected much evidence on this subject, * but the proposition does not seem to be by any means established.

\section{Resistance to Great Natural Fiorces.}

I have often spoken of the greater and more subtile natural forces, and especially of geological agencies, as powers beyond human guidance or resistance. This is no doubt at present true in the main, but man has shown that he is not altogether impotent to struggle with even these mighty servants of nature, and his unconscious as well as his deliberate action may in some cases have increased or diminished the intensity of their energies. It is a very ancient belief that earthquakes are more destructive in districts where the crust of the earth is solid and homogeneous, than where it is of a looser and more interrupted structure. Aristotle, Pliny the elder, and Seneca believed that not only nat-

* War and the Weather, or the Artificial Production of Rain, Chicago, 1871. Paifer proposed, as early as 1814, arrangements for producing rain by firing cannon and exploding shells in the air.-Ein wounderbarer Traum die Fruchtbarkeit durch willkürlichen Regen zu befördern, Metz, 1814. See, on the question of the possibility of influencing the weather by artificial means, London Quarterly Journal of Science, xxix., p. 126, and Nature, Feb. 16, 1871, p. 306. 
ural ravines and caves, but quarries, wells, and other human excavations, which break the continuity of the terrestrial strata and facilitate the escape of elastic vapors, have a sensible influence in diminishing the violence and preventing the propagation of the earth-waves. In all countries subject to earthquakes this opinion is still maintained, and it is asserted that, both in ancient and in modern times, buildings protected by deep wells under or near them have suffered less from earthquakes than those the architects of which have neglected this precaution.*

If the commonly received theory of the cause of earthquakes is true-that, namely, which ascribes them to the elastic force of gases accumulated or generated in subterranean reservoirs-it is evident that open channels of communication between such reservoirs and the atmospliere might serve as a harmless discharge of gases that would otherwise acquire destructive energy. The doubt is whether artificial excavations can be carried deep enough to reach the laboratory where the elastic fluids are distilled. There are, in many places, small natural crevices through which such fluids escape, and the source of them sometimes lies at so moderate a depth that they pervade the superficial soil and, as it were, transpire from it, over a considerable area. When the borer of an ordinary artesian well strikes into a cavity in the earth, imprisoned air often rushes out with great violence, and this has been still more frequently observed in sinking mineraloil wells. In this latter case, the discharge of a vehement current of inflammable fluid sometimes continues for hours and even longer periods. These facts seem to render it not wholly improbable that the popular belief of the efficacy of deep wells in mitigating the violence of earthquakes is well founded.

In general, light, wooden buildings are less injured by earthquakes than more solid structures of stone or brick, and it is commonly supposed that the power put forth by the earth-wave is too great to be resisted by any amount of weight or solidity of mass that man can pile upon the surface. But the fact that in countries subject to earthquakes many very large and strongly constructed palaces, temples and other monuments have stood for centuries, comparatively uninjured, suggests a doubt whether

* Landarebe, Geschichte der Vulkane, ii., pp. 19, 20. 
this opinion is sound. The earthquake of the first of November, 1755 , which is asserted, though upon doubtful evidence, to have been felt over a twelfth part of the earth's surface, was among the most violent of which we have any clear and distinct account, and it seems to have exerted its most destructive force at Lisbon. It has often been noticed as a remarkable fact, that the mint, a building of great solidity, was almost wholly unaffected by the shock which shattered every house and church in the city, and its escape from the common ruin can hardly be accounted for except upon the supposition that its weight, compactness and strength of material enabled it to resist an agitation of the earth which overthrew all weaker structures. On the other hand, a stone pier in the harbor of Lisbon, on which thousands of people had taken refuge, sank with its foundations to a great depth during the same earthquake; and it is plain that where subterranean cavities exist at moderate depths, the erection of heavy masses upon them would tend to promote the breaking down of the strata which roof them over.

No physicist, I believe, has supposed that man can avert the eruption of a volcano or diminish the quantity of melted rock which it pours out of the bowels of the earth; but it is not always impossible to divert the course of even a large current of lava. "The smaller streams of lava near Catania," says Ferrara, in describing the great eruption of 1669, "were turned from their course by building dry walls of stone as a barrier against them. .... It was proposed to divert the main current from Catania, and fifty men, protected by hides, were sent with hooks and iron bars to break the flank of the stream near Belpasso.*

* Soon after the current issues from the volcano, it is covered above and at its sides, and finally in front, with scoriæ, formed by the cooling of the exposed surface, which bury and conceal the fluid mass. The stream rolls on under the coating and between the walls of scorix, and it was the lateral crust which was broken through by the workmen mentioned in the text.

The distance to which lava flows, before its surface begins to solidify, depends on its volume, its composition, its temperature and that of the air, the foree with which it is ejected, and the inclination of the declivity over which it runs. In most cases it is difficult to approach the current at points where it is still entirely fluid, and hence opportunities of observing it in that condition are not very frequent. In the eruption of February, 1850, on the east side of Vesuvius, I went quite up to one of the outlets. The lara shot out of 
When the opening was made, fluid lava poured forth and flowed rapidly towards Paterno; but the inhabitants of that place, not caring to sacrifice their own town to save Catania, rushed out in arms and put a stop to the operation." * In the eruption of Vesuvius in 1794, the viceroy saved from impending destruction the town of Portici, and the valuable collection of antiquities then deposited there, but since removed to Naples, by employing several thousand men to dig a ditch above the town, by which the lava current was carried off in another direction. $\dagger$

\section{Incidental Effects of Human Action.}

I have more than once alluded to the collateral and unsought consequences of human action as being often more momentous than the direct and desired results. There are cases where such incidental, or, in popular speech, accidental, consequences, though of minor importance in themselves, serve to illustrate natural processes; others, where, by the magnitude and character of the material traces they leave behind them, they prove that man, in

the orifice upwards with great velocity, like the water from a fountain, in a stream eight or ten feet in diameter, throwing up occasionally volcanic bombs three or four feet in diameter, which exploded at the height of eight or ten yards, but it immediately spread out on the declivity down which it flowed, to the width of several yards. It continued red-hot in broad daylight, and without a particle of scoriæ on its surface, for a course of at least one hundred yards. At this distance, the suffocating, sulphurous vapors became so dense that I could follow the current no farther. The undulations of the surface were like those of a brook swollen by rain. I estimated the height of the waves at five or six inches by a breadth of eighteen or twenty. To the eye, the fluidity of the lava seemed as perfect as that of water, but masses of cold lava weighing ten or fifteen pounds floated upon it like cork.

The heat emitted by lava currents seems extremely small when we consider the temperature required to fuse such materials and the great length of time they take in cooling. I saw at Nicolosi ancient oil-jars, holding a hundred gallons or more, which had been dug out from under a stream of old lava above that town. They had been very slightly covered with volcanic ashes before the lava flowed over them, but the lead with which holes in them had been plugged was not melted. The current that buried Mompiliere in 1669 was thirty-five feet thick, but marble statues, in a church over which the lava formed an arch, were found uncalcined and uninjured in 1704 See Scrope, Volcanoes, chap. vi., \$6.

* Ferrara, Descrizione dell 'Etna, p. 108.

† LANDGREBE, Naturgeschichte der Vulkane, ii., p. 82. 
primary or in more advanced stages of social life, must have occupied particular districts for a longer period than has been supposed by popular chronology. "On the coast of Jutland," says Forchlhammer, "wherever a bolt from a wreck or any other fragment of iron is deposited in the beach sand, the particles are cemented together, and form a very solid mass around the iron. A remarkable formation of this sort was observed a few years ago in constructing the sea-wall of the harbor of Elsineur. This stratum, which seldom exceeded a foot in thickness, rested upon common beach sand, and was found at various depths, less near the shore, greater at some distance from it. It was composed of pebbles and sand, and contained a great quantity of pins, and some coins of the reign of Christian IV., between the beginning and the middle of the seventeenth century. Here and there a coating of metallic copper had been deposited by galvanic action, and the presence of completely oxidized metallic iron was often detected. Investigation made it in the highest degree probable that this formation owed its origin to the street sweepings of the town, which had been thrown upon the beach, and earried off and distributed by the waves over the bottom of the harbor." * These and other familiar observations of the like sort show that a sandstone reef, of no inconsiderable magnitude, might originate from the stranding of a ship with a cargo of iron, $\nmid$ or from throwing the waste of an establishment for working metals into running water which might carry it to the sea.

Parthey records a singular instance of unforeseen mischief from an interference with the arrangements of nature. A land-owner at Malta possessed a rocky plateau sloping gradually towards the sea, and terminating in a precipice forty or fifty feet high, through natural openings in which the sea-water flowed into a large cave under the rock. The proprietor attempted to establish salt-works on the surface, and cut shallow pools in the rock for the evaporation of the water. In order to fill the salt-pans more readily, he sank a well down to the cave beneath, through which he drew up water by a windlass and buckets. The speculation proved a fail-

\footnotetext{
* Geognostische Studien am Meeres Ufer, Leonrard und Brown, Jahrbuch. 1841, pp. 25, 26.

† Kонш, Schleswig-Holstein, ii., p. 45
} 
ure, because the water filtered through the porous bottom of the pans, leaving little salt behind. But this was a small evil, compared with other destructive consequences that followed. When the sea was driven into the cave by violent west or northwest winds, it shot a jet d'eau through the well to the height of sixty feet, the spray of which was scattered far and wide over the neighboring gardens and blasted the crops. The well was now, closed with stones, but the next winter's storms hurled them out again, and spread the salt spray over the grounds in the vicinity as be. fore. Repeated attempts were made to stop the orifice, but at the time of Parthey's visit the sea had thrice burst through, and it was feared that the evil was without remedy."

I have mentioned the great extent of the heaps of oyster and other shells left by the American Indians on the Atlantic coast of the United States. Some of the Danish kitchen-middens, which closely resemble them, are a thousand feet long, from one hundred and fifty to two hundred wide, and from six to ten high. These piles have an importance as geological witnesses, independent of their bearing upon human history. Wherever the coast line appears, from other evidence, to have remained unchanged in outline and elevation since they were accumulated, they are found near the sea, and not more than about ten feet above its level. In some cases they are at a considerable distance from the beach, and in these instances, so far as yet examined, there are proofs that the coast has advanced in consequence of upheaval or of fluviatile or marine deposit. Where they are altogether wanting, the coast seems to have sunk or been washed away by the sea. The constancy of these observations justifies geologists in arguing where other evidence is wanting, the advance of land or sea respectively, or the elevation or depression of the former, from the position or the absence of these heaps alone.

Every traveller in Italy is familiar with Monte Testaccio, the mountain of potsherds, at Rome; $\nmid$ but this deposit, large as it is,

* Wanderungen durch Sicilien und die Levante, i., p. 406.

tUntil recently this hillock was supposed to consist of sherds of household pottery broken in using, but it now appears to be ascertained that it is composed chiefly of fragments of earthenware broken in transportation from the place of manufacture to the emporium on the Tiber where such articles were landed. 
shrinks into insignificance when compared with masses of similar origin in the neighborhood of older cities. The castaway pottery of ancient towns in Magna Grrecia composes strata of such extent and thickness that they have been dignified by geologists with the appellation of the ceramic formation. The Nile, as it slowly elanges its bed, exposes in its banks masses of the same material, so vast that the population of the world during the whole historical period would seem to have chosen this valley as a general deposit for its broken vessels.

The fertility imparted to the banks of the Nile by the water and the slime of the inundations, is such that manures are little employed. Hence much domestic waste, which would elsewhere be employed to enrich the soil, is thrown out into vacant places near the town. Hills of rubbish are thus piled up which astonish the traveller almost as much as the solid pyramids themselves. The heaps of ashes and other household refuse collected on the borders and within the limits of Cairo were so large, that the removal of them by Ibrahim Pacha has been looked upon as one of the great works of the age.

These heaps formed almost a complete rampart around the city, and inpeded both the circulation of the air and the communication between Cairo and its suburbs. At two points these accumulations are said to have risen to the incredible height of between six and seven hundred feet; and these two heaps covered two hundred and fifty acres.* During the occupation of Cairo by the French, the invaders constructed redoubts on these hillocks which commanded the city. They were removed by Mehemet Ali, and the material was employed in raising the level of low grounds in the environs. $\dagger$

In European and American cities, street sweepings and other town refuse are used as manure and spread over the neighboring fields, the surface of which is perceptibly raised by them, by vegetable deposit, and by other effects of human industry, and in spite of all efforts to remove the waste, the level of the ground on which large towns stand is constantly elevated. The present streets of Rome are twenty feet, and in many places much more, above those of the ancient city. The Appian Way between Rome

* Clot Ber, Égypte, i., p. 277.

†Egypt manufactures annually about 1,200,000 pounds of nitre, by lixiviating the ancient and modern rubbish-heaps around the towns. 
and Albano, when cleared out a few years ago, was found buried four or five feet deep, and the fields along the road were elevated nearly or quite as much. The floors of many churches in Italy, not more than six or seven centuries old, are now three or four feet below the adjacent streets, though it is proved by excavations that they were built as many feet above them.*

\section{Nothing Small in Nature.}

It is a legal maxim that "the law concerneth not itself with trifles," de minimis non curat lex; but in the vocabulary of nature, little and great are terms of comparison only; she knows no trifles, and her laws are as inflexible in dealing with an atom as with a continent or a planet. $\dagger$ The human operations men-

* Rafinesque maintained many years ago that there was a continual deposition of dust on the surface of the earth from the atmosphere, or from cosmical space, sufficient in quantity to explain no small part of the elevation referred to in the text. Observations during the eclipse of Dec. 22, 1870, led some astronomers to believe that the appearance of the corona was dependent upon or modified by cosmical dust or matter in a very attenuated form diffused through space.

Tyndall has shown by optical tests that the proportion of solid matter suspended or floating in common air is very considerable, and there is abundant other evidence to the same purpose. Ehrenberg has found African and even American infusoria in dust transported by winds and let fall in Europe, and Schliemann asserts that the quantity of dust brought by the sirocco from Africa is so great, that by cutting holes in the naked rocks of Malta enough of Libyan transported earth can be caught and retained, in the course of fourteen years, to form a soil fit for cultivation.-Beilage zur Allgemeinen Zoitung, March 24, 1870.

+ Cosmic forces of little comparative energy may, by long continued or often repeated action, produce sensible effects of great magnitude. Thus the course of rivers flowing north or south is gradually deflected by the earth's rotation and that rotation is itself retarded by the tidal action of the sea. In these cases the ultimate effect produced may be considered as the sum of an almost infinite number of infinitesimal impulses. Mran, from his limitations in time and space, can not imitate this mode of action as manifested in nature, but each of the supposed impulses must exert a definite force, though we can neither compute nor express its measure. Analogous individual impulses, however, may be produced by forces put in action or set at liberty by man. The discharge of heavy ordnance by the recoil of the piece and by the impinging of its projectile, either coincides with or opposes the rotary force of the earth according to the direction in which the guns are pointed, and of course tends to accelerate or retard the rotation of the earth, or even it may be to deviate the globe itself from her orbit. The same may be said of the explosion of mines for military or industrial purposes. The immediate effects. 
tioned in the last few paragraphs, therefore, do act in the ways ascribed to them, though our limited faculties are at present, perhaps forever, incapable of weighing their immediate, still more their ultimate, consequences. But our inability to assign definite values to these causes of the disturbance of natural arrangements is not a reason for ignoring the existence of such causes in any general view of the relations between man and nature, and we are never justified in assuming a force to be insignificant because its measure is unknown, or even because no physical effect can now be traced to it as its origin. The collection of phenomena must precede the analysis of them, and every new fact, illustrative of the action and reaction between humanity and the material world around it, is another step towards the determination of the great question, whether man is of material nature or above her.

in such cases now elude human understanding, but who shall say that the mathematics of the future may not compute the measure of such agency and calculate even these small cosmical results of human action?

One of the sublimest, and at the same time most fearful suggestions that have been prompted by the researches of modern science, was made by Babbage in the ninth chapter of his Ninth Bridgewater Treatise. I have not the volume at hand, but the following explanation will recall to the reader, if it does not otherwise make intelligible, the suggestion I refer to:

No atom can be disturbed in place, or undergo any change of temperature, of electrical state, or other material condition, without affecting, by attraction or repulsion or other communication, the surrounding atoms. These again, by the same law, transmit the influence to other atoms, and the impulse thus given extends through the whole material universe. Every human movement, every organic act, every volition, passion or emotion, every intellectual process, is accompanied with atomic disturbance, and hence every such movement, every such act or process, affects all the atoms of universal matter. Though action and reaction are equal, yet reaction does not restore disturbed atoms to their former place and condition, and consequently the effects of the least material change are never cancelled, but in some way perpetuated, so that no action can take place in physical, moral or intellectual nature, without leaving all matter in a different state from what it would have been if such action had not occurred. Hence, to use language which $I$ have employed on another occasion: there exists, not alone in the human conscience or in the omniscience of the Creator, but in external nature, an ineffaceable, imperishable record, possibly legible even to created intelligence, of every act done, every word uttered, nay, of every wish and purpose and thought conceived by mortal man, from the birth of our first parent to the final extinction of our race; so that the physical traces of our most secret sins shall last until time shall be merged in that eternity of which not science, but religion alone, assumes to take cognizance. 



\section{INDEX.}

A AR River, plan for turning the course of, 419 , note.

Absorption of molsture by earth, amount of, uncertain, 21.

Adirondacks, forest, geographical importunce of, 318 ; injudicious clearing of, 320 ; lakes of, 421 .

Africa, Northern, artesian wells in, 463467: desert of, atmospaere and scenery in, 572 .

Agriculture of the United States, products of, 72 .

Akaba, fresh water on sea-beach at, 462 , note.

Alaska, protection of the seal in, 104.

Albano, lake of, artificial lowering of, 414 .

America, North, primitive physical condition of, 16 ; scientitic observation of its physical changes, 43 ; forests of, 317 et seq.; forest trees of, compared with European, 325-333; dunes of, 552; hydrographical improvements in, 600 602.

Amsterdam, water supply of, 542 , note.

Animalculæ, or infusorial life, importance of, 14 et seq.

Animal life, as geographical agener, 78 ; remains of, volume of, 79 , note ; extirpation of, by man, 89 , note.

Avimals, wild, sympathy of ruder races witb, 38, note; wild, instinct, modification of, 39, note; large marine, uniuportant in geography, 94 ; extinction of, 103 ; dowestic, origin aud trunsfer of, 85 .

Apennines, effects of felling woods of, 151

Appian Way, the level of, raised, 615 et seq.

Aquatic plants, action of, in raising level of marshes, 30 , note.

$\Delta q u e d u c t s$, seographical and climatic effects of, 431.

Arabia Petræa, sandstone of, 468, note: 526 , note; sands and petritied wood of, 528 , note.

Aragua, valley of, 217

Ardèche River, floods of, 250-255.

Argostali, subterranean marine currents at, 455 , note.

Armies, introduction of forelgn vegetables by, 67 .

Arno, tluods of, 520 , note.
Artesian wells, ascent of fluids in, 461 t seq. ; ancient, 465 , note; in Algeria, $464-466$; at St. Louis, 465 , note ; deepest, 465 , note.

Auk, the wingless, extirpation of, 120 .

Australia, as a field of physical observation, 50 ; direction of rivers in, 454 , note; underground rivers in, 455 , note. Avalanches, trees as protection against, 282.

Averages, untrustworthy results obtained from, 276, note.

\section{BABINET'S plan for artificial springs,} 470,471 .

Baird, Prof. S. F., on the oyster, 98, note. Bavaria, scarcity of fuel in, 315 , note.

Beaver, action of, in produciny bags, 81 ; constructs canals, 83 , note; caust: of increased numbers of, 90 .

Beech-tree, discussion concerning, 300, note.

Bee-honey, introduction of, into the United States, 134

Bee-husbandry in Italy, 134, note.

Belgrand, on drainage, 237, note.

Bergamo, change of climate in the vicinity of, 162 , note.

Bienne, lake of, proposed partial draining of, 419 , note.

Birds, geographical importance of, 109 ; iutroduction of foreign, 111 ; society for feeding in winter, 112 , note; destruction of, 113-123; how far useful or injurious by preying on insects, 117 , note; migration of, 118 ; fushion's war on, 120 ; seek shelter from cold under snow, 209 , note.

Bison, domestication of, 86,378 , note ; numbers of, in the United States, 88 , note; numbers of, anuually destroyed,93.

Bitter Lakes, their effect on rainfall, 448 , note.

Black Sea, plan to open a canal between Caspian und, 596 , note.

Blasts, powder, remarkable, 392, note.

Bogs, floating, 29 ; quautity of, 28, rote ; how formed, 29 ; formation of, by beavers, 81.

Bourget Lake, importance of, as a basin of reception, 480 .

Brémontier's system of dune plantations, 5 ro. 
Breton, Cape, dune vineyards of, 574 .

Butfulo, the, its introduction into Italy, 86 Busbequius's letters, value of, 64 .

CAMEL, introduction of, into Europe and America, 85, 86; injurious to vegetation in desert, 149 .

Campine in Belgium, 582.

Canada thistle, 68.

Canale della Pleve, nature's efforts at reclotbing the rocks of, 148 , note.

Canals, effects of, in interchanging organic life, 95, 587, note; excavations for, 391 , note; 419 , note; and aqueducts, climatic and geographical effects of, 431; of Tuscany, injurious effects of, 433 , note; of the Ganges, 437 , note; marine, 585 : across Isthmus of Darien, 587 ; Suez, 95, 587 ; across Isthmus of Corinth, 588; between Mediterranean, Red Sea, and Dead Sea, 590 ; between North Sea and Baltic, 593 ; between North Sea and Zuiderzee, 593 ; across Cape Cod, 594 ; between Don and Volga, 595; between Erie and Genesee, 600 ; between Lake Michigan and the Illinois, 600 .

Cape Cod, sand-dunes of, 557, note.

Cappercailzie, extinction and reintroduction of, in Great Britain, 122 ; habits of, 122 , note.

Caprification, whether useful, 128, note.

Carniola, caves of, 455 , note.

Caspian, natural and artificial changes in, 317 , note; 595,596 , note.

Catalpa, the American, 360 , note.

Catania, lava streams at, 611.

Cauliflowers, fresh, supplied by Algeria to Northern Germany, 63, note.

Celano, Lake, draining of, by Prince Torlovia, 416.

Census returns of 1880,73 , note : 79 , note; 88 , note; 101 , note; 103 , note ; 106.

Cereals, self-propagating in California, 59 , note.

Cevennes, effects of clearing the, 163.

Chalk formations, pure water held in, 277 , note.

Chamois, numbers of killed, 92 ; their number increasing, 93.

Champlain, Lake, phenomenon on, 442, note.

Charcoal as inissiles, 300, note.

Cherbourg, breakwater at, 391.

Chestaut crop in France and Tuscany, value of, 328 , nole.

Chiana, Val di, character of, 514; improvements iu, 516-519.

Chicago, unwarrantable exposure for sale of quail and grouse at, 137 , note.

Cicero, his opinion of merchants, 6 , note; his opinion of the mechanical arts, 413, note.

Cinchona, introduction of, into India, 59, note; improved by cultivation, 59 , note. Cirio, freight cars of, 63, note.

Climates, ancient, character of, ancer- tain, 14; causes producing change in New England, 19, note.

Coal, early use of, for fuel, 299, note ; increased use of, in Paris, 348, note; ex tracted in England, quantity of, 392 , 605.

Cosst-line, change of, from natural causes, 388 ; subject to human guidance, 389.

Cochineal insect transferred to Spain, 134.

Cod, Cape, 594, note, et seq.

Commerce, discouraged and despised by ancient Romans, 6,63 , note; 589 ; modern, objects of, 61 .

Como, Lake of, proposed lowering of, 419 , note; effect of lowering on stability of shores and percolation, 420 ; percolation of water from, 420, note; im. portance of, as basin of reception, 479.

Constance, Lake of, diversion of Rhine from, 599.

Constantinople, water supply of, 339 , note; 432 , note.

Copais Lake, draining of, 413.

Cork tree, yield of, 329 , note.

Corporations, iudustrial and flnancial, corruption and demoralizing effects of, 52 , note.

Cotton-seed, value of, 35 , note ; introduction of, into U. S., 73, note.

Crau, reclamation of, 160 , note.

Cypress tree, its beauty, 332, 333 .

DANUBE, the, escape of water from, 459 , note.

Darieu, Isthmus, proposed canal across, 587.

Dead Sea, projected canal to, 590 .

Deer, tame, injurious to trees, 371 , note: number of, in the United States, 89.

Delta, of the Mississippi, 487, note; of the Ganges, 487, note; of the Hoang-ho, 487 , note.

Denmark, peat mosses of, 30 , note.

Deposits of rivers, geological importance of, 389 ; marine, on the coast of Netherlands, 398; of rivers of Tuscany, 507.

Desert trees, propagation of, 149 ; Ara. bian, scenery of, 467 , note.

Desiccation, secular, of soil, 19 , note.

Despotism a cause of physical decay, 4 .

Dikes, Sea, origin of, 394 ; of Netherlands, 395 ; construction of, 400 et seq. : in Egypt, 440; of Mississippi, 494. See Embankments.

Dinornis or Moa, recent extirpation of, in New Zealand, 121.

Discoveries, recent and future, 46.

Diseases, contagious, propagation of, by germs, 145 , note.

Dismal Swamp in North Carolina and Virginia, 157.

Dodo, extirpation of, 120.

Don River, proposed diversion of, 595.

Drainage by roots of trees, $201 \mathrm{et}$ seq.

Drainage of Lakes, 404 ; of Lake of Haarlem, 405 ; of Lake of Albano, 414 ; of 
Lake of Fuclnus or Celano, 415 ; of Lake of Copais, 413 ; of Lake of Lungern, 419 ; of Lake of Bienue, 419 , nole; of bogs and swamps, 422 et scq.; its necessity in lands nerwly reclaimed from forest, 424 ; surface and subterranean, and their effects, 434 ; by boring, 425 ; of surface waters, climatic effects of, 426 ; unforeseen effects of, 430 ; effect of, on iuundations, 474 .

Drance, glacier lake of, 484.

Drought accounted for, 191.

Dugdale on sea-dikes, 394 , note.

Dunes, coast, how formed, 538 et seq.; height of, 540 et seq.; 566, note; sands of, character and composition of, 545 ; 575 , note; interior structure of, 547 ; stratification of, 547 ; geological importance of, 550 ; of American coasts, 552; of Western Europe, 553; age, charucter, and permanence of, 554 ; naturally wooded, 556 ; protection of, 557, 568 ; uses of ns a barrier against the sea, 558 : movement of, 563,566 , note; control of, by man, 567 ; artificial, 567 ; plantation of, 569 et seq.; vineyards upon, 5\%4; artiticial removal of, $\mathbf{5 7 4}$; inland, 575; of North American Desert, 575 ; of South American Desert, 576.

Duponchel, proposals for agricultural iupprovement, 607.

Durance, fertilizing slime of, 240 , note.

Dust, cosmical, deposit of, 616 , note.

Dwight, Dr., travels in the United States characterized, 50 , note.

FARTH, hygroscopicity of, increased $\mathcal{C}$ by heat, 25 , note; habitable, generally wonded, 146 ; displacement of, in engineering, 391 , note; transported to cover rocky surfice, 603.

Earthquakes, resistance to, 609.

Earthworms, utility of, 128-130.

Economies, many recent, 35 , note, et seq.

Eels, destruction of, 105 , note.

Egypt, introduction of foreign plants and auimals into, 65 , note; catacombs of, 80, note; papyrus and water-lily of, 75 , note; poisonous snakes of, 125 , note; supposed increase of rain in, 193, note; productiveness of, 239 , nole; original condition of, 434; amount of water used for irrigation, 435 , note; cultivated soil of, 438 ; populatiun of, 439 ; originally morass, 440 , note; saline deposits of, 453 ; sands of, 531 ; their prevalence and extent, 534, note; action on the Delta and cnltivated land, 535 ; source of sunds, 334 ; etfect of diversion of the Nile upon, 596 ; refuse heaps near Cairo, 614, note.

Elaud, an African species, 91, note.

Elephaut, numbers of, killed, 92.

Elsineur, artiticial formation in harbor, of, 613 .

Embankments, river uses and evils of, 485 et seq. ; imitation of nature, 485 , note; Lorobardini's views of, 486 , note, of Misslesippi, magnitude of, 494 .

Engineers and Artisans not respected by ancients, or in Middle Ages, 413 .

England, forest economy of, 298 ; forests of, described by Cæsar, 300, note; large exteut of ornamental plantation, 301; private enterprises in sylviculture, 303 .

Enguerrand te Coucy, cruelty of, $3 \pm 1$.

Etna, eruptive matter of, infertile, 148.

Eucalyptus, rapid growth of, 201, note ; growth and height of, 324, note; 383, note.

Euphrates, sand-plains in the valley of, 579.

Evaporation, amount of, uncertain, 24; from forest earth, 174 ; relative, from meadow and forest, 187 ; relative, from earth and water, 436 , note.

Everyreen trees, properties of, 172, note; $203,204$.

Eye, cultivation of, 11 ; sympathy between, and other organs, 11, note.

FASHION, its war on birds, 120 , note, et seq.

Fens of Lincolnshire, drainage of, 392.

Feudalism, sbuses of, 5 , note.

Filopanti's, account of the lake of Savena, 279 , note.

Fire, action of, on woodland, 350, 351; protection of woods against, 373 ; forest, of 1871,374 ; measures agaiust, 375.

Fire-weed in hurnt forests of the United States, $28 \%$.

Fir-tree, doubts as to its existence in ancient Britain, 300 , note; cicatrization of stump, 328, note.

Fish, introduction and breeding of, 91 99 ; naturalization of, 94,95 ; destruction of, 99 el seq.; spawn consumed by water-fowl, inferiority of artificially fattened, 106 ; fresh water, growing scarcity of, in United States, 107, note; shell, extensive beaps of remains of, in United States, 94; shell, extensive heaps of remains of, Indian origin, 94 ; effect on, by the discharge of factory refuse, 108.

Fisheries of the world, annual yield of, 101 , note.

Fish ponds, in Catholic countries, 511, note.

Flotation of trees.

Fog rive in woods, 189 , note.

Fontainebleau, forest of, Its renovation, 363 , note; soil of, 582 , note.

Forces, natural, accumulation of, 37 .

Forest laws, Jewish, 338, note; severity of, in France and England, 340 ; under Louis IX., 341 ; medireval character of, 375 ; of America, created by circumstauces, 377.

Forests, clearing of, its effect on fruittrees, 20 , note.

Forests, royal, 339-343. See Woods.

France, the peasantry of, described by 
La Bruyère, 5 , note; the peasantry of, described by Arthur Young, 6 , note; forests of, 304 ; imports timber largely, 306 , note; sale of forest lands by, 308 , note; recent forest legislation of, highly useful, 309 ; royal forests and forest laws, 339 ; inundations of, 474 ; remedies against inundations, 475 .

Frescobaldi, on sands of desert, 531, note.

Friesland, sand-dunes of, 564 .

Frost, action of, on soil, 403 , note.

Fucinus, draining of Lake of, by Prince Torlonia, 415, et seq.

Fur animals, destruction of, 103, note.

GAME Laws, effects of, 94, note; 115, 303,342 .

Ganges, effect of clearing valley of, 388 , note; canal, 437, note.

Gascony, coast-sunds of, 553 ; dunes, 553 ; dunes, extent and advance of, 553 ; lands of, 580 ; their reclamation, 581 ; their area, 581, note.

Geographers, new school of, 7.

Geography, modern, embraces organic life, 55.

German Ocean, sands of, 528, note.

Glacier lakes in Switzeriand, 484.

Goat, Angora, habits of, 87 , note; introduction of, into America, 87, note.

Goldau, Switzerland, mountain-slide at, 279.

Gold-fish, the introduction of, from China, 95.

Groode, Prof. G. B., on the Osster, 98, note; on Fisheries, 101 , note; 105 , note.

Grape disease, its economic effects in France, Italy, Sicily, 77, note.

Grasshopper, increase of, on account of wholesale slaughter of birds, 137 , note.

Grass-land, meteorological action of, 26.

Grave-digger beetle, habits of, 130 .

Greece, subterranean waters of, 455 , note; proposed canal through Isthmus of Corintb, 588; proposed canal across Mt. Athos, 599.

Gulls, sea, habits of, 112, note.

Gunpowder, chiefly used for industrial purposes, 394 , note.

HAARLEM, Lake of, drained, 405; climatic effect of drainage, 429 .

Hail, damage done by, 152 , note; whether prevented by woods, 153, note.

Harbors, artificial, rarity of, 390 , note.

Hauran, the productions of its soil, 59 , note.

Hearing, faculty of, 12, note.

Heat, solar, utilization of, 45 , note; action of, on rock, 531, note.

Heilbronn, springs of, 222 .

Herring, fishery of, 104, note.

Hessian fly, introduction of, into the United States, 133.

Himalayas, the, snow limit of, 195.
Hoang - ho, delta of, 277; change of mouth of, 487, note.

Honey, spurious, 134 , note.

Human action, incidental effects of, 612 ; cosmical results of, 616 , note.

Humphreys \& Abbot's Report on the Mississippi, value of, 491, note.

Hydrography of North America, 600.

Hygroscopicity of earth, increased by heat, 25 , note.

IBEX, the Alpine, 9.

Ice, expansion of, 443 , note.

Ijssel River, 410.

Improvement, works of, remarkable for volume and difficulty, 391 , note.

Indestructibility of man's work, 49 , note.

India, human victims to beasts and snakes in, 125 , note; devastation of forests in, 302 , note.

Indian corn, acclimation of, 17 , note.

Indians on Amazon, their skill in the use of the bow, 12, note.

Individual labor, 392 , note.

Infiltration of water from lakes, 420 , note; of fresh water in Gulf of Ákaba, 462 , note; of Nile water, 460 , note.

Infusoriæ, importance of, 139-145.

Inoculation, suggestions concerning, $\mathbf{1 4 5}$, note.

Insects, destruction of property by, 114, note.

Insects and worms, utility of, 126 ; useful in fertilization of plants, $127 \mathrm{et} \mathrm{seq.:}$ influence of, on vegetation, $130-136$; carnivorous, useful to man, 130; how far injurious to forest trees, 131 ; introduction of, 133-136 : ravagres of, 133 ; tenacity of life in, 135 et seq. ; destruction of, by fish, 136 ; abundance of, in Northern Europe, 137, note; destruction of, uy birds, 112; quadrupeds, 139 ; confine themselves to dead trees, 138,370 , note; do not multiply in the forest, 334 .

Instinct, animal, modification of, 39 , note. Insurance agaiust fall of rocks, 284 , note; forest fires, 374 ; hail.

Inundations, recent measures against, 493 ; aggravated by deposits in bed of streams, 23:; occasioned by thaws, 234 ; in France, history of, 238, note; economical evils of, 239 ; action of, on river bed, 254; in Netherlands, 393 ; and torrents, 474 et seq.; of 18.76 in France, 474; measures against, in France, 475 ; where they originate, 476 ; remedies against, 475 ; from ice-barriers, 481 ; of bunks of River $\mathrm{Po}, 492$, note; of the Mississippi, 492, note; Rozet's remedy against, 495.

Irrigation, antiquity of, 433 ; among Nexicans and Peruvians, 434 , note; its necessity in hot climates, 434 ; in Northern Italy, 441, note; in Turkish Empire, 435 ; in India, 437 ; in Egypt, 438 ; in the United States, 448, note; in 
Italy, 444, note; in Spain, 444 ; quantity of water used in, 441,450 , note; difficulties of, 416 , note; effects of, on vegetable crops, 444, note; climatic effects of, 448,452 ; recovery of water employed in, 450 ; effects of, on river supply, 451 ; deposit of salt by, 453 .

Islands, floating, 407, note, et seq.

Italy, beauty of its winter scenery, 212 ; effect of the denudations of its forests, 256 ; legislation in, concerning forests, 373 , nole ; extent of irrigation in, 441, note; sks of, 441 , note; 419 , note.

$J^{\circ}$ OHNSTRUP'S observation on absorption of moisture by earth, 214, note. Juniper tree, antiseptic properties of, 157.

Jutland, destruction of forests in, 338 , note; encroachments of the sea on, 560.

Jupiter, satellites of, visible to the naked oye, 13, note.

T ANDER River, artificial course of, 483.

Karst, plantations on, 315 , note; subterranean waters of, 455 , note.

Kjökkenmöddinger, heaps of kitchen refuse, 15.

Kock's investigations into tubercular diseases, 145, note.

TESTADIUS, account of Swedish L Laplanders, 12:, note.

Lakes, history of, 279 , note; draining of, 404; natural process of flling up, by aquatic vegetation, 407 , note; lowering of, in ancient and modern times, 414 et seq. ; draining of, in Switzerland, 418. note; effects of, 419 ; mountain, their disappearance, 420 et seq. ; their utility, 421.

Land won from waters, 387 et seq.

Life, American, instability of, 385 ; balance of animal and vegetable, 143.

Liimfjord, irruption of sea into, 560 et seq.; aquatic regetation of, 361 ; original atate of, 585 .

Lima and Sestajone Rivers compared, 233, note.

Lion, an inhabitant of Europe, 90, note.

Lisbon, earthquake of, 611 .

Locust, swarms of, avenge the slaughter of birds, 137, note; does not hreed in woods, 291.

Lombardini on precipitation 448 , note; ou 'Tiber, 459 ; on river embankments, 486 , note; on elevation of bed of $\mathrm{Po}$, 490 , note; Guido allo Studio dell' Idrologia, 493, note; on inundations, 498, note; on Val di Chiana, 515.

Lombardy, climate of, 441 ; statistics of irrigation in, 444.

London, the meteorologica] effect of, 473 , note; coal beds under, 605 , note.
Louls IX. of France, misguided clemencs of, 841.

Lumber trade of Quebec, 349, note; the United States, 350, nole; augmented cousumption of, 345 .

Lungern, Lake of, lowering, 419.

I $\triangle D A G A S C A R$, gigantic bird of, 121. Madder, cultivation of, in France, 18 , note.

Maggiore, Lake of, importance of, as basin of reception, 479 .

Magnitude, unit of, nature has none, 144 Maize, acclimation of, 18 , note.

Malta, trunsported soil of, 603 .

Man, reaction of, on nature, 8 ; action of on organic life, 9 , note; measurement of influence of uncertain, 14 ; destructireness of, 33 et seq., $35-40$; first conquests over nature, 38 , note; geographical action of, compared with that of brutes, 40 ; physical improvement by, 43 ; limits of his physical power, 44 ; remains of, contemporary with mammoth, 80 , note; agency of, in extirpation of fish, 99 ; of aquatic animals, 103 ; of birds, 114-123 ; possible control of minute organisms bj, 139 et seq. ; possible geographical changes by, 584 et seq. ; incidental effects of his action, 612 et seq. ; action of, illimitable and never-ending effects of, 616,617 .

Mango, the, its introduction into the West Indies, 64, note.

Marcite of Lombardy, 447 , note.

Maremma, Tuscan, improvements in, 509 et seq.

Marshes, how far unhealthy, 156, note; draining of, in Italy, 423; United States, 422 ; climatic action of, 426 ; insalubrity of mixture of salt and fresh water in, 509, note.

Matches, lucifer, 346 , note.

Meat, fresh, transportation of, 35 , note.

Mechavic arts, illustration of their mutual interdependence, 360 , note; despised by ancient Romans and in Middle Áges, 413 , note; not respected in modern Italy, 413 , note.

Medanos or dunes of the South American Desert, 576, 577.

Mediterranean Sea, not rich in organic life, 96 ; sands of, 528 ; tides of, 512 .

Mella River, change in character of, 257 , note.

Mengotti on Nile, 498.

Menhaden fisheries, 105 , note.

Meteorology, uncertainty of this science, 21 ; nomenclatare of, vague and equirocal, 23, note.

Metrical System, French, objections to, 144, note.

Mexico, Desaguadero at, 391 , note.

Michigan, Lake, sand-dunes of, $\mathbf{5}+3$; sand-dunes of, originally wooded, 556 , et seq.; diversion of its waters, 600 et seg. 
Migration of birds, 119 , note.

Mines, auits of, 391, note; excavations for, 601 ; depth of, grentest, 606 , note; fires in, 607 .

Mining, effects of, 604 ; hydraulic, 606 ; practiced by ancients, 606 .

Mint, British, value of its sweepings, 36 , note.

Miramichi, great fire of, 27, note.

Mississippi, alleged increase in volume of, 225, note; discharge of, 457,501 , note; delta of, 485 , note; great flood of, in 1881-2, 492, note; levees of, 494 : cut-offs and their effects, 497; sediment of, 503, note; 523 , note; precipitation in the valley of, 502 , note.

Mistral, noticed by Diodorus Siculus, 163 , note.

Moisture, effect on the stability of large masses of earth, 280 .

Monasteries, evil effects of, $\mathbf{5}$, note.

Monte Testaccio, 614.

Moose deer, the American, rapid multiplication of, 371 , note.

Morgan, L. H., on the American beaver, 83 , note.

Mosses and fungi, uses of, 229 , note.

Mountains as reservoirs of water, 212.

Mountain slides, their cause, 277; caused by deticiency and excess of moisture, 280 ; woods as protection agaiust, 282.

Mt. Cenis tunnel, excavations for, 391, note; gunpowder used in, 395, note.

Mud-banks, floating, 507, note.

Mushrooms, poisonous, how rendered harmless, 286 , note.

NATURAL Bridge in Virginia, disappearance of river at, 458 , note.

Natural forces, accumulation of, 42 ; resistance to, 609 .

Nature, its action on man, 6 ; man's reaction on, 8 ; observation of, 11 ; geographical stability of, 26-31; restoration of disturbed harmonies of, 47 ; nothing insignificant in, 616 .

Netherlands, ancient inundations of, 393 ; recovery of land by diking in, 393 ; extent of land gained from sea, 395 ; lost by incursion of sea, 397 ; character of land gaiued by, 398; natural process of recovery, 398-100; method of construction of dikes, 400 et seq. ; modes of protection of coasts in, 401, note; effect of diking on the level of the land, 402; drainage, 410; effects on social, moril, and economic interests of the people, 411 ; coast improre. ments in, 522; sand-dunes of, 558 ; encroachments of the sea on, 559 ; artiticial dunes in, 567 ; removal of dunes in, 563,574 .

New school of geographers, 7 .

Nightingale, Florence, on fevers, 452, note.

Nile, its ancient state, 438, 439, 498; iufiltration of water of, 460,461 , note; artificial mouths of, 483 ; inundations of, 498; embankments of, 499 ; mudbanks caused by its deposits, 499 et seg. discharge of, 501, note; sediment of, 499 , note; 501, note; 503, note; sanddunes at its mouth, 542 ; proposed diversion of, 596 ; effects of, 597 et seq. : ceramic bauks of, 615 .

Nolla torrent, 257.

Norway, exports lumber to India, 296, note.

Numbers, misleading effects of too deflnite statement of, 275 , note.

Nutmeg transported by birds, 110, note.

( $)$ AK, the English, early uses in the arts, 302 , note; openings in North America, 336, note; in Finland, 354, note.

Observation, power of, cultivated, 11-13.

Ohio, mounds of, 17 ; remains of a primitive people in, 352 , note.

Oils, importance of, in modern commerce, 62

Old World, physical decay of, 2 ; former populousness of, 3 ; present desolation of, 3 ; its causes, 4 ; ancient climate of, 14 ; physical restoration of, 47 et seq.

Olive tree, the wild, 59 , note; importance of, 330 , nole; cultivation of, in Italy, 330 , note.

Orange, when first known in Europe, 64. Orehids, fertilization of, by insects, 127.

Organic life embraced in modern geography, 55 et seq. ; its geological agency, 78 et seq. ; geographical importance of, 81.

Organisms, minute, importance of, 139 143.

Ostrich, the, diminution of its numbers, 122.

Ottaquechee River, Vermont, transporting power of, 268 .

Otter, the American, vorucity of, 104.

Oyster, the, transplantation of, 97 ; danger of the extirpation of, 98 , note.

DALESTINE, ancient terrace culture, and irrigation of, 435 ; disastrous effects of its neglect, 436 .

Palissy on artiticial springs, 469 et seq.

Paragrandini, of Lombardy, 152.

Paramelle, the Abbé of, on fountains, 459.

Paulownia, rapid growth of, 384 , note.

Peat, unknown as fuel to Greeks, Romans, and High-German tribes, 29, note; used anciently by Low-German tribes, 29, note; rapid growth of, 408, note.

Peat mosses of North Sjælland, fassil wood in, 30, note, et seq.

Pecora, river of the Maremma, its de posits, 510 , note.

Penguin, destruction of, 123 , note. 
Pera, anclent progress in the arts, 434, note; basins of reception in, 481.

Petra, water at, 451 , note.

Petroleum, quantity of, 62,815 ; ascent of, in artesiun wells, 463, note.

Phosphorescence of the sea, not noticed by ancients, $10 \%$.

Phylloxera, the American vine withstands the effects of, 69 , note.

Physical decay of the earth's surface, 2 et seq. ; its causes, 4 ; forms and formations predisposing to, 30 ; arrest of, in new countries, 43 .

Physical geography, study of, recommended, 12 ; effect of the introduction of mathematical method into, 13 , note.

Physical improvements, important, chapter on, 581-616.

Physical restoration of disturbed harmonies, 31 ; of the earth, 43 et seq. ; of the Old World, 43.

Pigeon-roost, in Michigan, 111.

Pine, the American, former ordinary dimensions of, 321 ; the white, rapidity of its growth, 321 , note; umbrella, the most elegant of trees, 327 ; the maritime, on dune sands in France, 337, 571, 581; the pitch, 351, note; bow affected by accidents of its growth, 359 .

Pinus cembra of Switzerland, 327.

Pisciculture, its valuable results, 97. See Fish.

Plants, cultivated, uncertain identity of ancient and modern, 18; changes of habits of, by domestication, 20 ; geographical influences of, 55 ; domestic, origin of, 57,58 ; modes of introduction of, 64 ; accidental introduction of, 66,67 ; how aftected by transfer, 67 ; tenacity of life in wild species, 70 ; power of accommodation of, 68 ; foreign, grown in United States, 69; American, grown in Europe, 69, 74; extirpation of, 75 ; wild Americac, extirpation of, 77 , note.

Po, sediment of, 269-276; floods of, in 1872,271 , note; valley of, 275 , note; embankments of, 490 et seq. ; geographical character of, 490 , note; inundations of, 492, note: discharge of, 501, note.

Ponds, objections to draining, in Catholic countries, 511, note.

Pools of Solomon, vipers about, 125, note.

Poppy, its disappearauce and reproduction, 288, note.

Powder, consumption and uses of, 391, note.

Prairies, character and origin of, 378, note; artificial forests in, 379.

Precipitation, absorption of, by earth, 20,212 , note ; in the United States, 214, note; in Lombardy, 441, note; extraordinary, at Genoa in October, 1872, 271, note; how affected by the great American lakes, 442, note; how much loss by evaporation, 457 ; plans for economizing, 471.
DADRUPEDS, domestic, origin and transfer of, 85,86 ; domestic, number of, in the United States, 80 ; wild, number of, in the United States, 88, 89 ; extirpation of, 89-94.

Quarries, extent of, 391 , note.

Quebec, high tides at, 349 , note; lumber trade of, 349 , note.

RABBIT, injurious in Australia, 87, note; skins of, 93.

Railways, scientific uses of, 52, note, consumption of timber by, 345 .

Rain, summer, bow far lost by evaporation, 213.

Rainfall, varies at different elevations, 22 , note, et seq. ; 193 , note ; irregularity of, 271 , note.

Raiu-water, supply of, near London, 277 , note; its absorption and infiltration, 460 ; economizing its precipitation, 471; Amsterdam supplied with, 542 , note.

Rattlesnake, enemies of, 124, note.

Ravenna, cathedral of, 61 , note.

Red Hood, the California, 363, note.

Red Sea, richness in organic life, 95 ; diversion of the Nile to, its effect, 596.

Reptiles, utility and destruction of, 123.

Reservoirs, natural subterranean, 459 ; as remedies against inundations, 477 , 478 ; natural, 479 .

Reveutlov's organization of dune economy in Denmark, 570.

Revolution, French, influence of, on woods, 343.

Rewooding of mountains and rocky soil, 148 , note; 309 , note.

Rhine, discharge of, in flood, 233 , note, 413 , note; ordinary discharge of, 501 , note; sediment of, 523 ; diversion of, 599.

Rhone, geological agency of, 421 , note; discharge of, 501, note.

Rice, cultiration of, unhealthy, 452 ; Climatic limits of, 453, note ; introduced into Europe by Moors, 453 , note.

Risler, on evaporation, 187, 214, note.

Ritter's opinion on Egspt erroneous, 440 , note.

River beds, natural change of, 482 ; artificial change of, 483 ; in Egypt, 483 ; in Italy, 483; in Switzerland, 483.

River deposits, 488 ; of the Po, 273, 490, note; of the Nile, $50 \%$, note; of the Tuscan rivers, 507 .

River embankments, 485 ; their effects, 486.

River months, obstructions of, 505 ; accelerated by man's influence, 505 ; effect of tidal movements, 506 .

Rivers, fertilizing slime of, 239 , note; estimated delivery of, 252 , note; origin of, 261,488 , note; transporting power of, 266 et seq. ; sediment of, its extent, 265 ; injury to their bauks by lumbermen, 353 ; underground and submarine, 
458, note; intercommunication of, 482 , note; diversion of water from, effects of, 482 , note; effect of obstructions in, 489 , note; confluence of, effect on the current below, 489, note; great proposed diversion of, 597 et seq.

Robin, the American, voracity of, 113, note.

Rock, gencrally permeable by water, 277 , note; cuttings in England, 392, note; soil beneath, 602 ; covering with eartb, 603.

Rolleston's interpretation of Cæsar, 300, note.

Roman campagna, insalubrity of, 432 , note.

Ruman Empire, physical advantages of its territory, 1 ; physical decay of its territory, 2-4; causes of this decay, 5,6 .

Roman landmarks, 49, note.

Romans and Grecks, great material works of, 413 ; contempt for artisans and engineers, 413.

Rome, commerce of, passive, 63 , note; objects of, 63 , note; insalubrity of, 156 , note.

Roots of trees, influence of, on drainage, 202 , note; 237.

Rozet's plan for diminishing inundations, 495 .

Rubbish heaps in Egypt, 615 ; of Monte Testaccio, 614 .

Rude tribes, continuity of arts among, 16 ; commerce of, 17 ; relations to organic life and nature, 38 , note.

Russia, diminution of forests in, 316 ; diminution of forests in, effect of, on rivers and lakes, 316 , note; attempts to reclaim the sands, 583, note.

SACRAMENTO City, effect of river dike at, 492 , note.

Sahara, Largeau's views concerning, 150 , note; dunes of, 541 , note; project to flood, 592, note.

St. Gothard tunnel, 391, note.

St. Helena, flora of, 65 ; destruction of its forests, 371, note.

Salmon, of Europe, United States, and Norway, 106.

Salt, waste of, 36 , note : 605 , note : possibllity of washing out from land, 423 , note; subsidences caused by removal of, 605 , note.

Sand, chapter on, 545-580; quartz grains most abundant in, 545 ; of desert, generally derived from upheaval of seabottom, 526; how formed at present, 526 ; generally of ancient formation, 527 ; of coast of France and Denmark, 547 , note; 530, note; how carried to the sea, 528; of Sinaitic Peninsula, 528, note; of Northern Africa, 529 ; of Egypt, 531; drifting movement of, 532 , note; polishing action of, 533, note; storms, exaggerations respecting,
533 ; dunes and sand-plains, 536 ; plains, inland, 578; of Belgium, 582 of Eastern Europe, 582.

Sandal-wood, extirpation of, in Juan Fernandez, 371, note.

Sand-banks, structure of, 544; marine, 543.

Sand-springs, 580.

Sandstone of Arabia Petræa, 526, note: originating in dunes, 551 , note.

Sansa, or pulp of the olive, 35 , note.

Sap of maple and birch, 181 .

Saros, projected canal of, 590.

Savage tribes, arts of, 16 ; commerce of, 18 ; interfere little with nature, 38 , note; first domesticate wild animals, 38 , nole; sympathy of, with animals, 38 , note.

Savena, lake of, 279 , note.

Sawmills, whether action of their machinery more rapid by night, 355 , note.

Schelk, the extirpation of, 91 .

Schleiden, on exhalation of aqueous vapor by trees, 184.

Schleswig-Holstein, encroachments of sea on, 562.

Scotland, real property in, 304, note.

Sea, exclusion of, by dikes in Lincoln. shire, 392; encroachments of, 559 et seq.; the Lilimfjord, 560 ; in Schleswig. Holstein, Holland, and France, 562.

Sea-cow, Steller's extirpation of, 103.

Seal, found far from sea, 97 ; voracity of, 104.

Sediment, river, geological importance of, 388 , note.

Seeds, transportation of, by birds, 109 ; vitality of, $285-288$.

Seine, ancient uniformity of volume of, 231, note; ordinary and flood discharge of, 231, note; aftluents of, 456 , note, supply and discharge of, 457 , note.

Serpents, multiplication of, in France, 125 , note; human lives destroyed by, in India, 125 , note.

Shark, fishery of, 102 , note.

Shelter afforded by forests, 158-164.

Shipbuilding of the middle ages, 311.

Siberia, ice ravines in, 172 .

Sicily, sulphur mines of, 77 , note; olive oil, crop of, 330, note.

Siemoni, on action of woods on springs, 221.

Silicious slime, polishing action of, 533 , note.

Silkworm, new, introduction into America, 134.

Silphium, extirpation of, 75 , note.

Sinai, Mount, rain torrents at, 462 , note; production of sand in peninsula of, 528 , note; garden of monastery at, 604 .

Slides, mouvtain, 277-282.

Slime, river, fertilizing qualities of, 239 ; silicious, polishing action of, 533, note.

Smith, Baird, on irrigation, 445 , note; 448 , note.

Snakes, destructive to insects, 124; to- 
nacity of species, 124; number of, 125, note; human victims of, 125 , note.

Snow in the wnods in winter, 205, 212, 213 ; and ice, condensation of moisture by, 206 et seq. ; crust of, how formed, 207 , note; thaws the ground beneath it, 209 ; plants grow under, 209, note; temperaturo of, 209 , note; quantity of, in woods, 210; and ice, accumulation of, in mountains, 213 , note.

Soil, secular desiccation of, 19, note; new, favorable to growtb, 20 , note; amonnt of thermoscopic action on various, 165; mechanical effect of shaking, in Netherlands, 403, note; effect of frost on, in United States, 403 , note.

Solar heat, utilization of, 45 , note ; action of, on stoue, 5i31, note.

Sound, transmissibility of, 158, note.

Spuin, neglect of forest culture in, 297.

Springs, bot, 468, note; artificial, 469.

Squirrel, destructiveness of, in forests, 83, note.

Starling, habits of, in Piedmout, 124, note.

Stone implements, modern use of, 16.

Stones, rising of, in tields, 403, note.

Stork, aneedote of a, 112 , note; geographical range of, 117 , note.

Subterranean waters, their origin, 454 ; of the Karst, 455, note; of Greece, 455, note; sources of supply, 457 ; reservoirs and currents of, 459 ; diffusion of, in soil, 460 .

Suez Canal, effect of, on the Mediterrinean and Red Sei, 95 ; excavations for, 391, note; effect on the rainfall, 448, note; danger from sand-drifts, 531, note.

Sugar-cane, introduction of, into Europe and America, 74, note.

Sucar-maple tree, produce of, 181.

Sunflower, effect of plantation of, $\mathbf{1 5 5}$.

Swallow, popular superstition respecting, 514, note.

Sweepings, valuable, 36 , note.

Switzerland, ancient lacustrine habitations, 15,75 ; floating of timber in, 354 et seq.

Sylt Island, sand-dunes of, 512; encroachment of the sea upon, 542.

Sylviculture, best manuals of practice of 358 , note; its methods, 361 ; the taillis treatment, 361 ; the futaie treatment, 361 ; beneficiul effects of irrigation in, 366 ; removal of leaves in, 368 ; exclusion of animals, 371 , note.

TAGUATAGa Lake, Chili, draining of, 1418 , note.

Telegraph averts the evil consequences of $1100 \mathrm{ds}, 475$, note.

Temperature, how affected by elevation, 51 , note.

Teredo, the general diffusion of, 136.
Termite, or white ant, ravages of, 130.

Threshing machines, saving by, 36 , note.

Tiber, subterranean reservoirs in valley of, 459 .

Tick, wood, disappearance of, in Northeastern States, 132, note.

Timber, exportition of, from Norway and Sweden, 297, note; increased demand for, 345 ; tloating of, 354 et seq. ; of natural growth, inferiority of, 359 .

Torrents, destructive action of, 240 ; in Southeastern France, 2t1-250; deposits of, in beds of rivers, 232 , note; in the Himalayas, 256, note; excivations by, 256 ; action of in elevating the bed of streams, 258 ; of the Nant zenthal, 260 ; of the Litznerthal, 260 . whether origin of rivers, 261 ; extinguished, 261 ; crushing force of, 263267 ; danger of, in the United States, 319.

Towns, meteorological effects of, 473 , note.

Toys, children's, consumption of wood for, 347 , note.

Transportation, facilities of, effect of, on commerce, 63 , note.

Trees, forest, succession of species in, 20 , note, et seq.; how far injured by small animals, 82 , notc; 371 , note; improvement of, by cultivation, 58, note; decayed, or wind-fallen, 169 ; evergreen, power of resisting frost, 172 , note; how far they interrupt precipitation, 169, 178, note; absorption of vapor by, 183 ; absorption of moisture from the earth by, 183; exhalation of moisture by, 185; drainage of soil by roots of, 200 ; evergreen, alleged desiccatory action of, 203, 20t, note; names of, vaguely applied, 299 , note; rapid growth of, in Italy, 310 ; forest, Anerican, 321-324; their dimensions, 32\%; change in relative proportion of height and diameter, 322; comparative longevity of, 324, note; American compared with Europe:un, 325-332; destruction of evergreen, for decorative purposes, 347, note; hill plantations of, 369 ; powers of resisting action of fire, 373 , note; planting of, on sea-coast, 377.

Trieste, proposed supply of water to, 455 , note.

Trout, the American, 96, 106, 107, note.

Tubes, oil conveyed great distances in, 315 , note.

Tunnel of Mt. Cenis, statistics of, 391, note; 395 , note; of Lake Copais, 413.

Turtles' eggs, destruction of, 106, note.

Tuscany, rivers of, their deposits, 507; physical restoration in, 509 ; improve. ments in the Maremma, 510; Val di Claiana, 514.

Tyrolese rivers, elevation of, their beds 258 , note. 
TTDULATIONS of water, 530 .

United States, foreign plants grown in, 66 ; weight of annual harvest in, 72 , 73; number of quadrupeds in, 88; birds in, 110 ; forests of, 317 ; instability of life in, 385 .

Urus or auerochs, domesticated by man, 91 ; extirpation of, 91.

VAL DI CHIANA, improvements in, 514 et seq.

Vapor prevents escape of heat by radiation, 170 ; condensation of, by snow and ice, 206 ; and cloud attracted by mountains, 213 , note.

Vegetable life, how affected by animals, 81.

Vegetables, cultivated European, not indigenous, 2 ; acclimation of, 16 ; geographical importance of, 41,43 ; meteorological action of, 56 ; domestic origin of, 57, 58, note; modification of $5 \mathrm{~S}$, note ; improvement of, by cultivation, 58, note; early garden, sent from Algeria and Naples, to Northern Europe, 63 , note; transfer of, 62 , note; foreign, how introduced, $64-68$; power of accommodation, 68-71; American, grown in Europe, 74 ; extirpation of, 75 ; indigenous, dying out in America, 78.

Vesuvius crater, wooded inside, 149.

Vine, in what countries indigenous, 68 ; dimensions of, 69, note; European, introduction of, into America, 69 ; American, resists the phylloxera, 69, note; injury to,by parasites, not economically injurious to vine-grower, 77 , note.

Viper, multiplication of, in France, 125, note.

Vision, extraordinary powers of, in Arabs, 11, note.

Volcanoes, eruptive matter of, not infertile, 148 ; resistance to action of, 611.

Volga, proposed diversion of, 595 .

WALCHEREN, formation of the island of, 399 .

Wallenstadt, lake of, diversion of Rhine into, 599.

Walnut tree, oil yielded by, 327 , note; consumption of, for gunstucks, 345 , note.

War, instrumentalities of, applied to social and civil purposes, 394 , note.

Ward's cases for plants, 184, note.

Waste, modern mode of economizing, 31, note.

Water, chapter on, 387 et seq. ; land won from, 387 ; evaporative action of, 442 , note; subterranean, $45 \pm$ et seq.; infiltration of, 460 ; fresh on sea-beaches, 462 , note; not found at great depth in boring, 465 , note.

Weather, action of man upon, 608.

Weeds, common to Old and New World,
70,72 , note; bencficial mission of, 70 , note; extirpation of, in China, 77.

Wells. See Artesian Wells, tubular, 461, note.

Wild animals, numbers of, 81 ; human victims of, 125 , note.

Whale, food of, 100 ; destruction of, 101. Whale-fishery, when first practiced. 99, note: American, 101, note.

Wheat, its asserted origin, 58; how introduced into America, 66.

Whitney, Prof. J. D., on prairies, 379.

Wild organic life, superior hardiness of, 71.

Winkler, work on dunes, 526, note.

Winter of $1879-80,162$, note.

Wolf, increase of the, 90 ; prevalence of, in forests of France, 305, note.

Woodpecker, red-headed, disappearance of, from Eastern States, 139 ; destruction of insects by, 138 .

Woods, native American, permanent character of, 26 ; generally, Chap. III., 146 ; general meteorological action of, 150: electrical influence of, 151: whether preventive of bail, 151; chemical influence of, 153; of Australia and New Zealand, 153, note; as protection against malaria, 154; in Southern Hemisphere evergreen, 156, note; as a shelter to the ground to the leeward, 157 ; as inorganic matter, influence of, on temperature, 161-168; specific temperature of, 170-174; evaporation from earth of, 178, note; exhalation of vapor by, 174; intercepting rain by foliage of, 178 ; organic action of, 179 ; balance of conflicting influences of, 188; influence on precipitation, 169 , $189-195$; on humidity of soil, 169,199 ; in winter, 205-212; influence of, on flow of springs, 215 ; on inundations and torrents, $2: 7-232$; mechanical resistance of, to flow of water 169,231 effect of, in disintegration of soil, 236 ; influence of, on drainage, 237 ; protection against avalanches, 282; minor uses of, 284 ; utility of, in preserving small plants, 285 ; protection against locusts, 291; summary of influences of, 291 ; general consequences of destruction of, 292 ; proper proportion of, 294; in different countries, 296 et seq.; in Great Britain, 298-304; in France, $304-308$; in Scotland and India, 303; Southern France, 305, wote; legislation on, in France, 308 ; in Italy, 310-314; in Russia, 316; in American States, 317; diversity of species in, spontaneous, 325 , note; do not furnish food for man, 334; first removal of, 335 ; burning over for agricultural purposes, 335 ; principal causes for destruction of, 336 ; affected by game laws and French revolution, 339-342; restoration of, $356^{\circ}$; management of, 357 ; cultivation of, $360-368$; injured 
by removal of leaves from ground, 369 ; growth, 360 , note ; faclities for workdestructive action of cattle on, 371 , ing, 360 , note.

note; fires in, 373,374 ; plantation of, Worms, earth, useful to agriculturists, in Ưnited States, 376 ; legislation on, 128.

374378 ; rules for planting in, 380 ; economical results of, 382 ; profits of, YEW tree, geographical range of, 76 ; 33: et seq.; inereased demand for, 345 ; 1 contradictory reports concerning, consumption of, as fuel, 346 , note; re- 76 , note.

placed by iron in the arts, 316 ; means of increasing its durability, 3it, note: ZULERZEE, proposed drainlng of quality of, how affected by rapld 2409 ; geographical results, 412 




\section{Date Due}

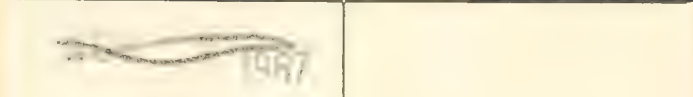

JUL 311992

DEG 11992

MA广) $31-1995$ 






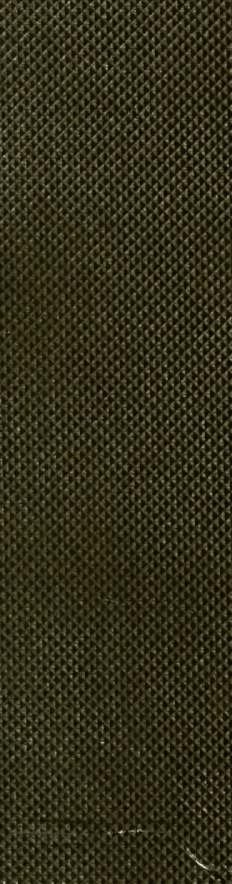

